\title{
Canada's Disarmers: The Complicated Struggle Against Nuclear Weapons, 1959-1963
}

\author{
by
}

Nicole Marion

A thesis submitted to the Faculty of Graduate and Postdoctoral Affairs in partial fulfillment of the requirements for the degree of

\author{
Doctor of Philosophy \\ in
}

History

Carleton University

Ottawa, Ontario

(C) 2017, Nicole Marion 


\begin{abstract}
$\underline{\text { Abstract }}$
This dissertation investigates the motivations, messages, and methods of Canadians who organized in opposition to nuclear weapons between 1959 and 1963. The efforts of Canadian anti-nuclear movements have been undervalued in histories of disarmament activism. Canadian disarmers have been dismissed as quiet in comparison to better-known movements in the United States and in Great Britain. This dissertation demonstrates that there were in fact complex and vigorous expressions of anti-nuclear sentiment in Cold War Canada. Canadian disarmers may have been few in number, and may have been conservative in their protest methods, but they were committed participants in an international struggle to protect humanity from the threat of nuclear war.
\end{abstract}

There were many Canadian movements in opposition to the Bomb, both organized and disorganized, which were shaped by the diverse relationships that disarmers had to the world around them. Disarmers' endeavours were informed by engagements with feminisms, Western ideals of masculinity, parents' desires to protect their children, young people's hopes to inherit a world of peace and prosperity, longstanding ideas about social protest, concerns over domestic politics, and enthusiasm for international cooperation. Focusing on the various ways in which Canadians worked for disarmament in the early 1960s, this study demonstrates how much often divided and sometimes isolated disarmament organizations shared.

This dissertation is the first extended historical analysis of anti-nuclear efforts in Canada in the late 1950s and early 1960s. It is also a necessary revision of the existing historiography on disarmament activism. This dissertation brings together diverse 
literatures on Canada's Sixties; American, British, and Western European disarmament and peace movements; connected social movements such as the New Left, feminist movements, and environmental movements; and histories of children and childhood. The thesis offers a reassessment of these movements and their importance to an understanding of Cold War social and political dynamics. 


\section{Acknowledgements}

This dissertation would never have been completed without the support of many wonderful people and organizations. I am extremely grateful for funding from the Social Sciences and Humanities Research Council of Canada and the Ontario Graduate Scholarship Program. Carleton University also extended financial assistance that was critical to allowing me to complete my studies.

I appreciate the efforts of those working at the University of British Columbia Rare Books and Special Collections, the University of Saskatchewan University Archives and Special Collections, the William Ready Division of Archives and Research Collections at McMaster University, and those in the Access to Information and Privacy Section at Library and Archives Canada. Their knowledge, diligence, efficiency, and kindness all served to accelerate my research and to make those long days in the archive less lonesome. I must also thank those who responded to my call for interviews and shared their experiences with me. Their insight and passion helped to point me into new directions and led me to ask questions of the archives that I had never thought of.

The History Department at Carleton University has been a home to me since well before I began this journey. My intellectual development owes much to the generous and passionate individuals who traverse the halls of Paterson Hall. Some departmental members who have been particularly influential to me include Dominique Marshall, James Opp, Joanna Dean, John Walsh, Jennifer Evans, Deborah Gorham, Andrew Burtch, and Danielle Kinsey. The department's administrative staff, Regina Aulinskas, Irene Sanna, and especially Joan White kindly dealt with my questions and requests, and helped to ensure that I met deadlines and filled out paperwork properly. 
I would like to extend a special thank you to Aleksandra Bennett. Dr. Bennett has always offered her unwavering support. She is a dearly cherished advisor and friend, who nurtured my casual interests in History and teaching into passions. I am only on this path because of her confidence in me.

I owe the most thanks to my supervisors Norman Hillmer and Susan Whitney. They have challenged me to be a better scholar, writer, and teacher than I ever thought I could be. Their combined editorial skills are without equal. Their commentary and inquiry helped to clarify and condense my often convoluted and tangled thoughts and prose. I thank them for their mentorship, unceasing encouragement, and untiring academic, professional, and personal support.

I extend my gratitude to my Canadianist cohort, Sarah Hogenbirk and Will Tait, and to my colleagues Ian Wereley and Nick Hyrynk. Our common interests made for stimulating conversations that helped me to get the most out of our shared course work. They helped me immeasurably in learning how to navigate academe.

To my kindred spirit, Casey Hurrell, I owe immense thanks. We embarked on this journey together, and she has been there throughout to commiserate with me, to challenge me, and to inspire me. This dissertation would never have been completed were it not for her friendship and her keen and ruthless editorial skills.

My parents and siblings have always been a wellspring of support. My mother's example of hard work and determination has always inspired me. Her unshakable confidence calmed me and fuelled me when I needed it most. I would like to thank my family and my in-laws for motivating me to work and for recognizing when it was time for a break. The laughter that they all bring to my life was always a welcome distraction. 
Last, but certainly not least, I would like to acknowledge my partner Aaron. He has been supportive, understanding, and patient since the very early stages of this journey. He whisked me away for holidays as soon as I showed signs of becoming too overwhelmed, and has always made sure that I took time to eat and rest. I will forever be grateful that he put life on hold to allow me to complete this project. I cannot wait to see what adventures lie ahead for us! 
Abstract__ ii

Acknowledgements___ iv

Table of Contents___ vii

List of Illustrations___ viii

List of Abbreviations___ix

Introduction

\section{Chapter One}

"Surely a mother has a right:" Canadian Feminism and Disarmament Activism

\section{Chapter Two}

Rational, Professional Fathers: Masculinities and Disarmament Activism

\section{Chapter Three}

"For the sake of our children:" "The Child" in Anti-Nuclear Activism

\section{Chapter Four}

"We simply have too much at stake:" The Combined Universities Campaign for

Nuclear Disarmament and Canadian Youth Disarmament Activism

\section{Chapter Five}

Canadian Disarmers and the End of "Proper Politics"

\section{Chapter Six}

Finding Meaning Through International Cooperation: "National Internationalist" Canadians and Transnational Disarmament Advocacy Networks

Conclusion

Bibliography

Appendix

Ethics Clearance 


\section{List of Illustrations}

Image 1: Voice of Women executive meets with Prime Minister John Diefenbaker, 26

September 1961. Photo credit: Chaplain Marcil, Le Droit. 85

Image 2: Voice of Women women and children outside the British Columbia legislative buildings, October 1961. Photo credit: Victoria Daily Times.

Image 3: Dr. J. Gordin Kaplan at his lab at Dalhousie University. Photo credit: Louis Jacques, 1958.

Image 4: "Dr. Kaplan with his two children, Michael, four and Elizabeth, eight, on the steps of his home in Halifax." Photo credit: Louis Jacques, 1958. 


\section{List of Abbreviations}

\begin{tabular}{|c|c|}
\hline $\mathrm{CBC}$ & Canadian Broadcasting Corporation \\
\hline $\mathrm{CCCRH}$ & Canadian Committee for the Control of Radiation Hazards (later CCND) \\
\hline $\mathrm{CCF}$ & Cooperative Commonwealth Federation \\
\hline CCND & Canadian Campaign for Nuclear Disarmament (formerly CCCRH) \\
\hline CND & Campaign for Nuclear Disarmament (Great Britain) \\
\hline $\mathrm{CPC}$ & Canadian Peace Congress \\
\hline CPRI & Canadian Peace Research Institute \\
\hline CUCND & Combined Universities Campaign for Nuclear Disarmament \\
\hline HUAC & House Un-American Activities Committee \\
\hline ICDP & International Confederation for Disarmament and Peace \\
\hline MDN & Mouvement pour le désarmement nucléaire \\
\hline NAC & National Ad Hoc Action Committee on the Status of Women \\
\hline NATO & North Atlantic Treaty Organization \\
\hline NDP & New Democratic Party \\
\hline NORAD & North American Air Defence Command \\
\hline RCMP & Royal Canadian Mounted Police \\
\hline SANE & National Committee for a Sane Nuclear Policy \\
\hline SCM & Student Christian Movement \\
\hline SDS & Students for a Democratic Society \\
\hline SNCC & Student Nonviolent Coordinating Committee \\
\hline SUPA & Student Union for Peace Action \\
\hline TAP & Toronto Association for Peace \\
\hline
\end{tabular}


UNA United Nations Association in Canada

UNICEF United Nations Children's Fund

VOW Voice of Women

WILPF Women's International League for Peace and Freedom

WPC World Peace Council (also known as the World Council of Peace)

WSP Women Strike for Peace

YCND Youth Campaign for Nuclear Disarmament

YMCA Young Men's Christian Association 


\section{Introduction}

From 1959 to 1963 a group of determined, frustrated, and anxious Canadians fought against the testing and proliferation of nuclear arms. Early Cold War disarmament efforts in Canada became a point of convergence for pacifists, conscientious objectors, leftists, feminists, students, intellectuals, unions, religious groups, and community organizations. ${ }^{1}$ Though they came from a variety of backgrounds and were attracted to activism for an array of reasons, anti-nuclear activists shared an abhorrence of nuclear weapons development, the accumulation of nuclear arms by states as a strategy to deter aggression, nuclear weapons testing, and nuclear war. ${ }^{2}$

In spite of a determined effort by disarmers to keep nuclear arms out of Canada, they were stationed on Canadian soil on New Year's Eve 1963. ${ }^{3}$ Nevertheless, Canadian disarmers inspired a public discussion about the safety of and need for nuclear arms, and actively contributed to a significant international effort to bring an end to nuclear weapons testing. In the fall of 1963, disarmers across the globe took heart from the signing of the Limited Test Ban Treaty by existing and potential nuclear powers, with the exception of China, France, and North Korea. The treaty prohibited the testing of nuclear arms in the atmosphere, in outer space, and under water. ${ }^{4}$

\footnotetext{
${ }^{1}$ Lawrence S. Wittner, The Struggle Against the Bomb, vol. 2 (Stanford: Stanford University Press, 1997), 59.

${ }^{2}$ Wittner, The Struggle Against the Bomb, vol. 2, 41.

${ }^{3}$ Wittner, The Struggle Against the Bomb, vol. 2, 202; Manitoba Conference for a Non-Nuclear Canada, "Only Disarmament Guarantees Survival! Brief presented to members of Manitoba Provincial Legislature," 16 March 1964, Library and Archives Canada (LAC), James G. Endicott and Family fonds, MG30-C130, vol. 19 , file $362,2$.

${ }^{4}$ Wittner, The Struggle Against the Bomb, vol. 2, 415; Frances Early, "Canadian Women and the International Arena in the Sixties: The Voice of Women/La voix des femmes and the Opposition to the Vietnam War," in The Sixties: Passion, Politics and Style, ed. Dimitry Anastakis (Montreal: McGillQueen's University Press, 2008), 28; “Two Memos Regarding the International Confederation for Disarmament and Peace," 19 July 1963, The William Ready Division of Archives and Research Collections, McMaster University Library (MUL), CCND fonds, SW571, box 2, file 3, 3.
} 
In 1961, British pacifist leader Bertrand Russell praised Canadian anti-nuclear efforts, declaring "The movement for nuclear disarmament in Canada has already shown itself vigorous and forthright, and has roused the admiration of those of us in Britain who are engaged in the same task." 5 Yet these "vigorous" efforts have received little scholarly attention. Furthermore, when they have been considered, historians have often dismissed disarmament efforts as part of a larger tradition of "quiet" “unpoliticized" Canadians. ${ }^{7}$ Lawrence S. Wittner, the preeminent scholar of global disarmament activism, classified Canadian efforts as "minimal" and "small" in his classic three-volume history of Cold War international anti-nuclear protest movements. ${ }^{8}$ From the earliest days of disarmament activity in Canada, disarmers have been all but ignored because of comparisons to larger American and British movements and public misconceptions that there was "no protest in Canada."9

Though Canadian anti-nuclear disarmers were fewer in number than their compatriots in the United States and Great Britain, Canadians who worked to prevent a nuclear war and who challenged the logic behind nuclear deterrence were far from quiet.

\footnotetext{
${ }^{5}$ Bertrand Russell, "Preface to First Issue," Our Generation Against Nuclear War 1(1) (Fall 1961), accessed 19 November 2015, http://s3.amazonaws.com/xlsuite_production/assets/9271675/Vol_1_part_1.pdf, 3 .

${ }^{6}$ Peter Brock and Nigel Young, Pacifism in the Twentieth Century (Syracuse: Syracuse University Press, 1999), 249.

${ }^{7}$ Gary Moffatt, History of the Peace Movement in Canada (Ottawa: Grapevine Press, 1982), 28.

${ }^{8}$ Lawrence S. Wittner, The Struggle Against the Bomb, vol. 1 (Stanford: Stanford University Press, 1993), 99; Wittner, The Struggle Against the Bomb, vol. 2, 78. Regarding Wittner's reputation and critical praise for his work see: Karthika Sasikumar, "Documenting Disarmament," review Confronting the Bomb: A Short History of the World Nuclear Disarmament Movement by Lawrence S. Wittner, Peace and Conflict 17 (2011): 104; Ronald E. Powaski, Review The Struggle Against the Bomb, Volume 3, A History of the World Disarmament Movement, 1971 to the Present by Lawrence S. Wittner, The American Historical Review 109(4) (October 2004): 1207; Lawrence Badash, Review The Struggle Against the Bomb, Volume 2, Resisting the Bomb: A History of the World Nuclear Disarmament Movement, 1954-1970 by Lawrence S. Wittner, Isis 93(3) (September 2002): 539; Maurice Isserman, Review Resisting the Bomb: A History of the World Nuclear Disarmament Movement, 1954-1970 by Lawrence S. Wittner, Political Science Quarterly 114(3) (Autumn 1999): 528.

${ }^{9}$ Patricia Wiley to the Editor Toronto Daily Star, 8 April 1959, LAC, James G. Endicott and Family fonds, MG30-C130, vol. 18, file 349, 1.
} 
As Toronto Daily Star columnist Lotta Dempsey put it in the spring of 1960, Canadian disarmers did not go "down without a fight." ${ }^{10}$ In fact, they waged a vibrant and complex battle against nuclear arms in the early Cold War. This dissertation is the first extended historical analysis of these Canadian efforts to ban nuclear arms.

There were many Canadian movements in opposition to the Bomb, both organized and disorganized, which were shaped by the diverse relationships that disarmers had to the world around them. Disarmers were women, men, parents, professionals, students, teenagers, conservatives, liberals, leftists, and communists, all united in the effort to ensure a future "without despair and hopelessness." 11 Their endeavours were informed by engagements with feminisms, Western ideals of masculinity, parents' desires to protect their children, young people's hopes to inherit a world of peace and prosperity, traditional ideas about social protest, concerns over domestic politics, and enthusiasm for international cooperation.

Despite the experiences, values, and politics that separated them, as one Canadian disarmament organizer optimistically declared in 1962, "It is not labels but what you do for peace that counts." 12 What mattered was that disarmers were "united on the one issue of peace." ${ }^{13}$ Canadian Peace Congress supporter Edith Holtom explained that, while facing what may at times have seemed like an impossible task, disarmers took solace in the knowledge that "we are not alone." 14 Their primary aim of protecting the world from nuclear war transcended linguistic, political, religious, provincial and national

\footnotetext{
${ }^{10}$ Lotta Dempsey, "Private Line,” The Toronto Daily Star, 21 May 1960, 62.

${ }^{11}$ Mrs. C. Steinberg, 23 September 1961, MUL, CCND fonds, SW573, box 17, file 4, 1-2.

12 Jacqueline Dineen to Louise Harvey, 15 April 1962, LAC, James G. Endicott and Family fonds, MG30C130, vol. 8, file 142, 1.

13 "Forgery for War," 1950, LAC, James G. Endicott and Family fonds, MG30-C130, vol. 63, file 1320, 2.

${ }^{14}$ Edith Holtom to James Endicott, 10 September 1959, LAC, James G. Endicott and Family fonds, MG30C130, vol. 7, file 122, 1 .
} 
boundaries, and this allowed disarmers across Canada and the world to join voices in the belief that "Disarmament will open the way for a new and different and better world."15 Labels did, however, matter to most Canadians outside and inside anti-nuclear efforts. Under the title of "ban-the-bombers," which they did not choose for themselves and was tainted by associations to communism and radicalism, disarmers had a common public identity. ${ }^{16}$ Yet, few disarmers embraced the shared identity as "ban-the-bombers," even as they shared so much. Political differences often resulted in conflict between autonomous disarmament organizations.

In his transnational comparison of Cold War British and West German disarmament efforts, historian Holger Nehring identified shared understandings of and responses to the Cold War by geographically and politically distinct movements. Nehring was interested in uncovering the "cognitive frames" activists developed that allowed them to think of themselves as members of a common movement in spite of differences in views, experiences, and historical contexts. ${ }^{17}$ While this dissertation has been influenced by Nehring's work, it takes a different starting point in that it does not seek to understand a single concerted disarmament effort.

\footnotetext{
${ }^{15}$ James G. Endicott quoted in "Report of the Proceedings of the National Council of the Canadian Peace Congress," 3-4 December 1960, LAC, James G. Endicott and Family fonds, MG30-C130, vol. 8, file 134, 7.

${ }^{16}$ On the question of the "ban-the-bomber" title see: Hanna Newcombe to Mrs. Davis, 1 December 1962, LAC, Voice of Women fonds, MG28-I218, vol. 1, file: correspondence Josephine Davis 1962, 1; Shirley McNaughton to Mme. Casgrain, 15 January 1963, LAC, Voice of Women fonds, MG28-I218, vol. 1, file: correspondence Josephine Davis, 2; Arthur Pape to Viv Nelles, 28 May 1963, MUL, CCND fonds, SW571, box 5, file 8, 1; Olive Johnson to K. C. Woodsworth, 2 May 1963, MUL, CCND fonds, SW571, box 5, file 17, 1; C. J. Creedon to Lester B. Pearson, 15 January 1963, LAC, Lester B. Pearson fonds, MG26-N2, vol. 52, file 806.2 part 11, 1; R. L. Garrett to L. B. Pearson, 14 January 1963, LAC, Lester B. Pearson fonds, MG26-N2, vol. 52, file 806.2 part 11, 1. One VOW member took particular offense to the use of term "banthe-bombers" in my call for interview participants (Anonymous to VOW, "Re: Banning the Bomb: your help with research," email forwarded to author, 30 October 2013).

${ }^{17}$ Holger Nehring, Politics of Security: British and West German Protest Movements and the Early Cold

War, 1945-1970 (Oxford: Oxford University Press, 2013), 6, 7.
} 
Some Canadian disarmers did claim to represent "The Peace Movement."18 But this singular terminology erroneously suggests that there was a united endeavour and fails to respect the diversity that always existed among disarmers. To remain faithful to the heterogeneity of Canadian anti-nuclear weapons efforts of the late 1950s and early 1960s, the dissertation will always refer to many movements. However, by focusing on the various ways in which Canadians worked for disarmament in the early 1960s, this study will also demonstrate how much often divided and sometimes isolated disarmament organizations shared.

\section{Early Cold War Canadian disarmament activism}

After recovering from significant weaknesses during the Second World War, peace movements in Canada began to experience a revival fed by fears over nuclear weapons. ${ }^{19}$ Religious groups with a history of peace activism in Canada, including the Society of Friends, Jehovah's Witnesses, Mennonites, and the Christian peace organization, the Fellowship of Reconciliation, established during the First World War, integrated anti-Bomb activism into their wider denunciation of violence following the atomic bombings of Hiroshima and Nagasaki. ${ }^{20}$ Though dissident in their own ways, these traditional peace groups remained isolated from secular Cold War peace and anti-

\footnotetext{
18 The Provisional Committee for a Canadian National Peace Congress, "Statement of Purpose," n.d., LAC, James G. Endicott and Family fonds, MG30-C130, vol. 1, file 1, 1; "The Nature and Purpose of the Canadian Peace Congress," 1950, LAC, James G. Endicott and Family fonds, MG30-C130, vol. 1, file 6, 1; Mary Jennison, "The Growth of the Peace Movement in Canada," n.d., LAC, James G. Endicott and Family fonds, MG30-C130, vol. 1, file 1, 1-2; James G. Endicott, “Christmas Appeal," 1956, LAC, James G. Endicott and Family fonds, MG30-C130, vol. 2, file 21, 1.

19 Thomas Socknat, Witness Against War: Pacifism in Canada, 1900-1945 (Toronto: University of Toronto Press, 1987), 10-11, 44-45, 285; Lawrence S. Wittner, Rebels Against War: The American Peace Movement, 1933-1983 (Philadelphia: Temple University Press, 1984), 240; Charles Chatfield, The American Peace Movement (New York: Twayne Publishers, 1992), 100.

${ }^{20}$ Wittner, The Struggle Against the Bomb, vol. 1, 71.
} 
nuclear weapons groups, largely because of their religiously-based and conservative pacifism. $^{21}$

Born out of the 1915 International Congress of Women at The Hague, which sought a peaceful resolution to the First World War, the Women's International League for Peace and Freedom (WILPF) was one of the oldest international peace organizations. ${ }^{22}$ Inspired by the notion that women have a particular interest in the maintenance of peace, the WILPF was founded as both a pacifist and women's suffrage organization. ${ }^{23}$ The League was among the first organizations to speak out against nuclear arms in $1945 .^{24}$ However, by the mid-1950s, the Canadian League had lost most of its membership because of its leftist focus on the economic causes of conflict, with the Vancouver branch remaining as the lone voice of the WILPF in Canada by $1960 .^{25}$

Many WILPF members became enthusiastic participants in the newly-formed and state-sanctioned United Nations Association in Canada (UNA) in the late-1940s, further weakening the WILPF. ${ }^{26}$ While the UNA offered a safe space for anti-nuclear and peace

\footnotetext{
${ }^{21}$ Socknat, Witness Against War, 289.

${ }^{22}$ Chatfield, The American Peace Movement, 48; Harriet Hyman Alonso, Peace as a Women's Issue: A History of the U.S. Movement for World Peace and Women's Rights (Syracuse: Syracuse University Press, 1999), 14; Catherine Foster, Women for all Seasons: The Story of the Women's International League for Peace and Freedom (Athens, Georgia: University of Georgia Press, 1989), 17.

${ }^{23}$ Melissa Anne Hensley, "Feminine Virtue and Feminist Fervor: The Impact of the Women's International League for Peace and Freedom in the 1930s," Affilia: Journal of Women and Social Work 21 (2) (Summer 2006): 148.

${ }^{24}$ Alonso, Peace as a Women's Issue, 155-156.

${ }^{25}$ Chatfield, The American Peace Movement, 48; Alonso, Peace as a Women's Issue, 14, 155-156; Foster, Women for all Seasons, 17; Tarah Brookfield, Cold War Comforts: Canadian Women, Child Safety, and Global Insecurity, 1945-1975 (Waterloo: Wilfrid Laurier University Press, 2012), 77-78, 117; Christine Ball, "The History of the Voice of Women/La Voix des Femmes: The Early Years, 1960-1963," (PhD diss., University of Toronto, 1994), 64; Victor Huard, "The Canadian Peace Congress and the Challenge to Postwar Consensus, 1948-1953," Peace \& Change 19(1) (January 1994): 28; Veronica Strong-Boag, "Peace-Making Women: Canada 1919-1939," in Women and Peace: Theoretical, Historical, and Practical Perspectives, eds. Ruth Roach Pierson, with Joanne Thompson, Somer Bodribb, and Paula Bourne (London: Croom Helm, 1987), 182, 184; Barbara Roberts, "Women's Peace Activism in Canada," in Beyond the Vote: Canadian Women and Politics, eds. Linda Kealey and Joan Sangster (Toronto: University of Toronto Press, 1989), 287-288.

${ }^{26}$ Huard, "The Canadian Peace Congress," 28; Brookfield, Cold War Comforts, 117.
} 
activists, the association's formal relationships with the Department of External Affairs

and the United Nations limited its ability to engage in public criticism of either body. The UNA was never strong in Canada, and struggled particularly after the formation of more radical peace and disarmament organizations in the late $1950 \mathrm{~s}^{27}$

The Canadian Peace Congress (CPC), founded in the spring of 1949, therefore stood virtually alone as a secular peace organization in Canada promoting nuclear disarmament. Because of its formal association to the communist-led World Peace Council (WPC), the CPC always struggled against charges that it was allied with communism. ${ }^{28}$ The organization had some success, collecting an impressive 300,000 Canadian signatures against atomic weapons for the WPC's Stockholm Peace Appeal in $1950 .{ }^{29}$ However, the Liberal government of Louis St. Laurent dismissed the petition as a collection of signatures of "communists and fellow travellers" and "dupes." 30 Hamstrung by the association with communism, the CPC managed few significant efforts to increase Canadian popular concern over nuclear weapons during the 1950s after the Stockholm Appeal.

\footnotetext{
${ }^{27}$ Brookfield, Cold War Comforts, 120; Eric W. Morse, "Report of the National Secretary," 21 May 1948, LAC, United Nations Association in Canada fonds, MG28-I202, vol. 44, file: annual meeting report 1948, 1, 5; William Woodside, “Annual report of the national director 1962-63," 15 May 1963, LAC, United Nations Association in Canada fonds, MG28-I202, vol. 45, file: annual meeting 1963, 2-3.

28 "Carte de delegue," 1949, LAC, James G. Endicott and Family fonds, MG30-C130, vol. 20, file 396; Wittner, The Struggle Against the Bomb, vol. 1, 175, 177, 211; S. H. Morrison to Hon L. B. Pearson, 3 May 1950, LAC, James Endicott and Family fonds, MG30-C130, vol. 20, file 386, 1; Reg Whitaker and Gary Marcuse, Cold War Canada: The Making of a National Insecurity State, 1945-1957 (Toronto: University of Toronto Press, 1994), 372-373; Stephen Endicott, James G. Endicott: Rebel out of China (Toronto: University of Toronto Press, 1980), 271; Moffatt, History of the Peace Movement, 18; Huard, "The Canadian Peace Congress," 33-34.

29 "Petitions for peace," 1949, LAC, James G. Endicott and Family fonds, MG30 C 130, vol. 1, file 3; Information Bulletin, "Press Release," 8 August 1950, LAC, James G. Endicott and Family fonds, MG30C130, vol. 20, file 402; Huard, "The Canadian Peace Congress," 26; Whitaker and Marcuse, Cold War Canada, 364; "The Stockholm Appeal Campaign in Canada," Information Bulletin, Special Bulletin no. 2, 29 August 1950, LAC, James G. Endicott and Family fonds, MG30-C130, vol. 20, file 402, 1.

${ }^{30}$ Huard, "The Canadian Peace Congress," 38.
} 
Despite an initial upsurge of opposition towards nuclear weapons following the nuclear bombings of Hiroshima and Nagasaki in August 1945, anti-nuclear sentiment was dormant in Canada between 1950 and 1959. ${ }^{31}$ Anti-nuclear efforts across the globe ebbed between 1950 and 1954, as nuclear arms became a central factor in the international rivalry of the Cold War and public complacency took hold. ${ }^{32}$ The decline in activism persisted longer in Canada, where there were no remarkable non-aligned nuclear disarmament movements to sustain public discussions about the threat of the Bomb. ${ }^{33}$ In Canada, as in most non-communist countries, the notoriety of the Communist-led WPC in the late 1940s and early 1950s greatly undermined efforts by disarmament activists to inspire the Canadian public to challenge the assumed need for nuclear deterrence in the tense international politics of the Cold War. ${ }^{34}$

The few who publicly spoke out against nuclear deterrence strategy in the 1950s "ran real risks," say the authors of one of the most important histories of Canada's Cold War. ${ }^{35}$ In the early 1950s, the term "peace" had become inseparable from communism in the Western mind. With the communist-led World Congress of Intellectuals for Peace in Wroclaw, Poland, in 1948, followed by the WPC's Stockholm Peace Appeal of 1950, and a history of Soviet promotion of the concept of "peaceful coexistence" in foreign policy

\footnotetext{
${ }^{31}$ Wittner, The Struggle Against the Bomb, vol. 2, 41.

${ }^{32}$ Wittner, The Struggle Against the Bomb, vol. 1, 335; Wittner, The Struggle Against the Bomb, vol. $2,1$.

${ }^{33}$ Sheila Young, "My Impressions of the First Canadian Peace Congress," 10 June 1949, University of British Columbia Rare Books and Special Collections (UBCRBSC), Women's International League for Peace and Freedom fonds, RBSC-ARC-1626, box 5, file 10, 1; Wittner, The Struggle Against the Bomb, vol. 1, 336; Socknat, Witness Against War, 289-290; Whitaker and Marcuse, Cold War Canada, 364.

${ }^{34}$ Wittner, The Struggle Against the Bomb, vol. 1, 338.

${ }^{35}$ Whitaker and Marcuse, Cold War Canada, 364.
} 
rhetoric, communist leaders had claimed "peace" for themselves. ${ }^{36}$ In this context, "peace" and "disarmament" became "dirty words.",37

Because of the association of peace with communism, peace and disarmament activists became a particular target of the Canadian Cold War security state. ${ }^{38}$ The Royal Canadian Mounted Police (RCMP) monitored peace and anti-nuclear organizations for subversive activities. ${ }^{39}$ Fear of public persecution, losing one's job, and alienating family members led many Canadians interested in disarmament to approach protests with caution. ${ }^{40}$ Even the WILPF felt the pressures brought by the "red scare." Membership lists and files were destroyed in the 1950 s to protect the anonymity of WILPF members. ${ }^{41}$ After the CPC presented its Stockholm Appeal petition signatures to the government and

\footnotetext{
${ }^{36}$ Geoffrey Roberts, The Soviet Union in World Politics: Coexistence, Revolution and Cold War, $1945-$ 1991 (London: Routledge, 1999), 4-5, 45; Timothy Johnston, "Peace or Pacifism? The Soviet 'Struggle for Peace in All the World, 1948-54," The Slavonic and East European Review 86(2) (April 2008): 259, 260; Nehring, Politics and Security, 160, 161; Moffatt, History of the Peace Movement, 25; Frances B. McCrea and Gerald E. Markle, Minutes to Midnight: Nuclear Weapons Protest in America (Newbury, Ca.: Sage Publications, 1989), 68; Whitaker and Marcuse, Cold War Canada, 365.

${ }^{37}$ Rabbi Abraham Feinberg, "The Threat of Nuclear War-Its Challenge to Canada," SOS Survival or Suicide 1 (September 1960), MUL, Canadian Peace Congress fonds, 47-1992, box 2, file: other peace organizations TO. Disarmament ctte., 1.

${ }^{38}$ Whitaker and Marcuse, Cold War Canada, 364.

${ }^{39}$ Whitaker and Marcuse, Cold War Canada, 364; Brookfield, Cold War Comforts, 77; Reg Whitaker, Gregory S. Kealey, and Andrew Parnaby, Secret Service: Political Policing in Canada from the Fenians to Fortress America (Toronto: University of Toronto Press, 2012), 180; Steve Hewitt, Spying 101: The RCMP's Secret Activities at Canadian Universities, 1917-1997 (Toronto: University of Toronto Press, 2002), 89; Steve Hewitt and Christabelle Sethna, "Sex Spying: The RCMP Framing of English Canadian Women's Liberation Groups during the Cold War," in Debating Dissent: Canada and the Sixties, eds. Lara Campbell, Dominique Clément, and Gregory S. Kealey (Toronto: University of Toronto Press, 2012), 139. ${ }^{40}$ Jules Pelletier to Kathleen Macpherson, 12 April 1965, LAC, Voice of Women fonds, MG28-I218, vol. 20, file: officials correspondence 1963-1965, 1; Helen Hall, "Montreal Peace Council," ca. 1951, LAC, James G. Endicott and Family fonds, MG30-C130, vol. 17, file: 337, 2; Floyd Williston, 7 July 1960, LAC, James G. Endicott and Family fonds, MG30-C130, vol. 8 file 129, 1; Jessie Storrie to Hon. Dana Porter, 2 August 1950, LAC, MG30-C130, vol. 63, file 1320, 1; "Statement of Sam Michnick," 26 August 1950, LAC, James G. Endicott and Family fonds, MG30-C130, vol. 63, file 1320, 1-2; Jessie Storrie, 27 August 1950, LAC, James G. Endicott and Family fonds, MG30-C130, vol. 63, file 1320, 1; Merrily Weisbord, The Strangest Dream: Canadian Communists, the Spy Trials, and the Cold War (Montreal: Véhicule Press, 1994); Whitaker and Marcuse, Cold War Canada, 4; Myrna Kostash, Long Way from Home: The Story of the Sixties Generation in Canada (Toronto: J. Lorimer, 1980), xxii-xxiii; Brookfield, Cold War Comforts, 78; Moffatt, History of the Peace Movement, 28.

${ }^{41}$ Brookfield, Cold War Comforts, 78.
} 
CPC chairman James Endicott visited the Soviet Union in the spring of 1950, the Canadian security state began to pay particular attention to the CPC, perhaps further accounting for the absence of notable disarmament activism in Canada during the early 1950 s. $^{42}$

That was not the case elsewhere. In March 1954, an American thermonuclear weapon test at Bikini Atoll resulted in serious illnesses among residents of the Marshall Islands and Japanese fishers. The "Castle Bravo" test was the largest nuclear weapon ever tested by the United States. At 15 megatons, the explosive yield of the bomb was two and a half times larger than expected and 1,000 times more powerful than the Hiroshima bomb. ${ }^{43}$ As historian of American disarmament activism Paul Boyer has explained, "it was Bikini, rather than Hiroshima and Nagasaki, that first brought the issue of radioactivity compellingly" to Western public consciousness. ${ }^{44}$

On 23 April 1957, in response to the Bikini fallout and Soviet tests in Siberia, Albert Schweitzer, a celebrated French humanitarian and Nobel Peace Prize winner, delivered his "Declaration of Conscience." Broadcast in 50 countries, it called for the cessation of nuclear weapons testing. The speech linked rising levels of nuclear radiation in the atmosphere from the testing of nuclear weapons to increases in birth defects and

\footnotetext{
${ }^{42}$ Huard, "The Canadian Peace Congress," 38; Whitaker and Marcuse, Cold War Canada, 372-373.

${ }^{43}$ Jeremi Suri, Power and Protest: Global Revolution and the Rise of Détente (Cambridge, Mass.: Harvard University Press, 2003), 9; Robert Divine, Blowing on the Wind: The Nuclear Test Ban Debate, 1954-1960 (New York: Oxford University Press, 1978), 6.

${ }^{44}$ Paul Boyer, By the Bomb's Early Light (Chapel Hill, NC: University of North Carolina Press, 1994), 90. See also: Wittner, The Struggle Against the Bomb, vol. 2, 2; "The Milk We Drink," Consumer Reports 24(3) (March 1959), 102; Daniel Heidt, "'I think that would be the end of Canada:' Howard Green, the Nuclear Test Ban, and Interest-Based Foreign Policy, 1946-1963," American Review of Canadian Studies 42(3) (September 2012): 348-349.
} 
cancers. ${ }^{45}$ Schweitzer's appeal drew increased public attention to nuclear weapons, influencing many to form and join anti-nuclear organizations in the late $1950 \mathrm{~s} .{ }^{46}$

The declaration had a particular influence on Canadian Mary Van Stolk. When her family moved to Edmonton in 1958, Van Stolk immediately set out to act upon Schweitzer's call to examine the threat that nuclear fallout posed to children. ${ }^{47}$ She started a mother's study group, which she called the Canadian Committee for the Control of Radiation Hazards (CCCRH). ${ }^{48}$ The committee initially focused on educating Canadians about the risks associated with radiation, but later transitioned into a disarmament organization. ${ }^{49}$ It became a national mixed-sex organization by January 1960 and organized an anti-nuclear petition a year later that garnered around 200,000 signatures. ${ }^{50}$ The organization adopted the name the Canadian Campaign for Nuclear Disarmament (CCND) in early 1962 in tribute to the popular British Campaign for Nuclear Disarmament. ${ }^{51}$

Around the same time as the CCCRH's formation, a collective of Montreal students from McGill University, Sir George Williams University, and the Université de Montréal started the Combined Universities Campaign for Nuclear Disarmament

\footnotetext{
${ }^{45}$ Wittner, The Struggle Against the Bomb, vol. 2, 31; Norman Cousins, ed., "The Schweitzer Declaration," Saturday Review, 18 May 1957, 17, 19.

${ }^{46}$ Olga Spuilles, ca. 1962, LAC, Voice of Women fonds, MG28-I218, vol. 1, file: correspondence Josephine Davis 1962, 1; McCrae and Markle, Minutes to Midnight, 70; Benjamin Ziemann, "The Code of Protest: Images of Peace in the West German Peace Movements, 1945-1990," Contemporary European History 17(2) (May 2008): 247.

${ }^{47}$ Mary Van Stolk to The Earl Russell, 28 October 1960, MUL, CCND fonds, SW571, box 4, file 1, 1; Mary Van Stolk to Albert Schweitzer, 28 October 1960, MUL, CCND fonds, SW571, box 4, file 1, 1. ${ }^{48}$ Wittner, The Struggle Against the Bomb, vol. 2, 197-198; Ball, "The History of the Voice of Women," 72 .

${ }^{49}$ Wittner, The Struggle Against the Bomb, vol. 2, 197.

${ }^{50}$ Research section, Ottawa, "National Committee for the Control of Radiation Hazards_-January 1962," 23 July 1977, LAC, CSIS files, RG146-738, vol. 1, (obtained under access to information), 14, 19; Wittner, The Struggle Against the Bomb, vol. 2, 197.

${ }^{51}$ Margaret Hanley to F. C. Hunnius, 20 February 1962, MUL, CCND fonds, SW571, box 1, file 2, 1; Helen Tucker to Mr. Thomson, 20 December 1961, MUL, CCND fonds, SW571, box 1, file 2, 1.
} 
(CUCND). ${ }^{52}$ On Christmas day 1959, eighty members of the new group marched through Ottawa in the first notable student political demonstration since $1945 .{ }^{53}$ By the summer of 1960, CUCND had become a national organization. ${ }^{54}$

The foundation of Van Stolk's study group and the CUCND followed several milestones in the defence and foreign policies of the Conservative government of John G. Diefenbaker that suggested the very real possibility of nuclear weapons on Canadian soil. The North American Air Defence Command (NORAD) agreement was completed in June $1958 .^{55}$ On 20 February 1959, Diefenbaker announced in the House of Commons that Canada would acquire Bomarc missiles, to be equipped with nuclear warheads. ${ }^{56}$ In May 1960, after an American U-2 spy plane was brought down in Soviet airspace, causing the cancellation of the East-West summit between Soviet Premier Nikita Khrushchev and American President Dwight Eisenhower, journalist Lotta Dempsey issued a well-received call in the Toronto Daily Star to women to speak out against the Cold War and nuclear arms. ${ }^{57}$ In response to Dempsey's column, a group of Toronto women formed the women's peace group, Voice of Women (VOW), in the

\footnotetext{
52 Patricia McMahon, Essence of Indecision: Diefenbaker's Nuclear Policy, 1957-1963 (Montreal: McGillQueen's University Press, 2009), 65.

${ }^{53}$ Bryan Palmer, Canada's 1960s: The Ironies of Identity in a Rebellious Era (Toronto: University of Toronto Press, 2009), 256-257; Dimitrios Roussopoulos, "Introduction," in The New Left in Canada, ed. Dimitrios Roussopoulos (Montreal: Our Generation Press-Black Rose Books, 1970), 8; Hewitt, Spying 101, 90; Arthur Pape, "Some thoughts on the peace effort in Canada," n.d., MUL, CCND fonds, box 9, file 4, 1; "Montreal Students Plan Ottawa March," The Globe and Mail, 23 December 1959, 2; McMahon, Essence of Indecision, 65; Palmer, Canada's 1960s, 257.

${ }^{54}$ Hewitt, Spying 101, 90.

${ }^{55}$ McMahon, Essence of Indecision, 12-13, 14; Sean Maloney, Learning to Love the Bomb: Canada's Nuclear Weapons During the Cold War (Washington: Potomac Books, 2007), 102, 122, 129-130; H. Basil Robinson, Diefenbaker's World: A Populist in Foreign Affairs (Toronto: University of Toronto Press, 1989), 19, 21.

${ }^{56}$ Canada, House of Commons Debates, vol. II (1959) (Ottawa: The Queen's Printer and Controller of Stationary, 1959), 1223.

${ }^{57}$ Dempsey, "Private Line," 21 May 1960, 62; Brookfield, Cold War Comforts, 82.
} 
summer of $1960 .{ }^{58}$ Within a year, the group counted over 4,000 registered members and 40 local branches. ${ }^{59}$

These national, secular peace organizations with an interest in nuclear disarmament emerged at a time when Canadian popular support for nuclear arms was unsettled. In the early 1960 s, public opinion polls consistently indicated mass endorsement of nuclear arms for Canadian forces. Yet, surveys also implied significant public support for disarmament and a nuclear test ban. ${ }^{60}$

To counter the notoriety and suspicion that had been associated with peace activism, in the $1960 \mathrm{~s}$, disarmament organizations recruited supporters among the ranks of the prominent and respected. Anti-nuclear advocates could be found in university faculties and administrations, the judiciary, business, the media, the public service, and government. ${ }^{61}$ For example, CCCRH members included Dr. Claude Bissell, president of the University of Toronto, retired justice of the Supreme Court of Canada Justice Ivan C. Rand, Saul Hayes, the executive vice-president of the Canadian Jewish Congress, Claude Jodoin, president of the Canadian Labour Congress, André Laurendeau, editor-in-chief of

\footnotetext{
${ }^{58}$ Brookfield, Cold War Comforts, 82-83. See for example: Helen M. Cree to Lotta Dempsey, 17 May 1960, LAC, Voice of Women fonds, MG28-I218, vol. 1, file: correspondence re. formation of VOW MayJune 1960, 1; Grace Jenlis to Miss Dempsey, 27 May 1960, LAC, Voice of Women fonds, MG28-I218, vol. 1, file: correspondence re. formation of VOW May-June 1960, 3-4; Hilkka O. Hormavirta to Lotta Dempsey, 30 May 1960, LAC, Voice of Women fonds, MG28-I218, vol. 1, file: correspondence re. formation of VOW May-June 1960, 1; Muriel Duggan to Lotta Dempsey, 30 May 1960, LAC, Voice of Women fonds, MG28-I218, vol. 1, file: correspondence re. formation of VOW May-June 1960, 1-2.

${ }^{59}$ Helen Tucker, "President's report, first annual meeting," 16 June 1961, LAC, Voice of Women fonds, MG28-I218, vol. 22, file: national annual meeting 1961, 4.

60 "Increase among those who say 'Ban the Bomb,"' in Gallup Report 1960-61 (Toronto: Canadian Institute of Public Opinion, 1961), 2; "Majority say army should be given nuclear weapons," in Gallup Report 196061, 2; "Belief in Disarmament has Risen Sharply in Six Years," in Gallup Report 1962 (Toronto: Canadian Institute of Public Opinion, 1962), 1; "Majority Say Our Forces Should Have Nuclear Arms," in Gallup Report 1962, 2; Norman Z. Alcock to the Hon. Lester B. Pearson, 15 January 1963, LAC, Lester B. Pearson fonds, MG26-N2, vol. 53, file 808, 2; Canadian Peace Research Institute, "C.P.R.I. Projects in Progress," Information Report (26 November 1962), LAC, Andrew Allan fonds, MG31-D56, vol. 39, file: Canadian Peace Research Institute n.d., 1962, 1964-1965, 1.

${ }^{61}$ McMahon, Essence of Indecision, 68-69.
} 
Le Devoir, and Oakley Dalgleish, editor of the Globe and Mail. ${ }^{62}$ It was publicly known that Maryon Pearson was a member of VOW before her husband, Liberal party leader

Lester B. Pearson, expressed his support for Canada's acquisition of nuclear weapons in January $1963 .{ }^{63}$ The opposition to nuclear arms of the Secretary of State for External Affairs from 1959 to 1963, Howard Green, was also well known, as was that of Norman Robertson, the department's undersecretary. ${ }^{64}$ The public association of such prominent figures with disarmament organizations indicates a shift in public perceptions of antinuclear activism by the early 1960s.

Though disarmers had overcome some of the public mistrust that had plagued the CPC, anti-nuclear efforts were not without their challenges between 1959 and 1963. Despite a shared disdain for nuclear arms and a common fear of the potential threat of nuclear annihilation, Canadian nuclear disarmers rarely saw eye to eye. The unity of Canadian anti-nuclear movements was fractured by difference and suspicion. ${ }^{65}$

\footnotetext{
62 "Prominent Canadians Form Committee on Radiation Hazards \& Nuclear Policy," 18 January 1960, MUL, CCND fonds, SW571, box 1, file 1, 5-6.

${ }^{63}$ Mrs. Lester B. Pearson, 30 July [1960], LAC, Voice of Women fonds, MG28-I218, vol. 1, file: correspondence members of parliament re. formation 1960-1963, 1; Irene Clark to Mrs. Lester B. Pearson, 6 June 1962, LAC, Lester B. Pearson fonds, MG26-N2, vol. 53, file 808, 1; Edmund Burke Society of Scarborough, "The Voice of Women, The Voice of What?," n.d., LAC, Voice of Women fonds, MG28I218, vol. 3, file: VOW National hate literature 1962-1966, 1; "Mrs. Pearson Resigns as VOW Sponsor," The Globe and Mail, 6 March 1963, 1.

${ }^{64}$ Hanna Newcombe to Mrs. Josephine Davis, 1 December 1962, LAC, Voice of Women fonds, MG28I218, vol. 1, file: correspondence Josephine Davis 1962, 1; Peggy Hope-Simpson to Josephine Davis, 24 November 1962, LAC, Voice of Women fonds, MG28-I218, vol. 1, file: correspondence Josephine Davis 1962, 1; Hugh Keenleyside to the Honourable Howard Green, 4 November 1960, LAC, Lester B. Pearson fonds, MG26-N2, vol. 49, file 806, 1; "Minutes of the Board of Directors' Meeting," 20-21 April 1963, MUL, CCND fonds, SW571, box 1, file 6, 7; "Exit Howard Green," The Toronto Daily Star, 10 April 1963, 6; Edwin Bolwell, "Why Green was Defeated," The Globe and Mail, 10 April 1963, 7; McMahon, Essence of Indecision, 51, 55; Robinson, Diefenbaker's World, 133, 97; Robert Bothwell, The Big Chill: Canada and the Cold War (Toronto: Canadian Institute of International Affairs, 1998), 65; George Ignatieff with Sonja Sinclair, The Making of a Peacemonger (Toronto: University of Toronto Press, 1985), 198.

${ }^{65}$ Dorothy Harrison to Dundas VOW, 12 November 1971, LAC, Voice of Women fonds, MG28-I218, vol. 21, file: Dundas correspondence 1965-1971, 1.
} 
Organizations diverged on politics and overall aims, and regularly acted independently out of concern that another anti-nuclear organization might derail their particular project.

The CPC struggled throughout with its "red" reputation. ${ }^{66}$ The CCCRH-CCND sought to keep the CPC at a distance because "it would be ruinous to the Canadian Campaign for Nuclear Disarmament if it should be associated with any communist group

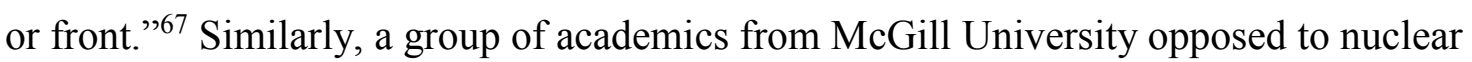
arms returned a donation from the CPC because "your organization can do us great harm. ${ }^{968}$ One university activist remembered being initially uninterested in joining VOW, despite feeling underappreciated as a woman in her university disarmament club, because of the way VOW members refused to engage with leading members of the CPC on the grounds that it would harm VOW's public image.${ }^{69} \mathrm{CPC}$ leaders were well aware of their unsavoury reputation among peace and disarmament groups, and often weighed the benefits to the greater cause against the costs of angering other groups when deciding when to participate publicly in joint disarmament events. ${ }^{70}$

In addition to difficult relationships with the $\mathrm{CPC}$, most Canadian peace organizations often elected to isolate themselves from other groups in an effort to preserve their distinct identities. When she established the CCCRH, Van Stolk envisioned

\footnotetext{
${ }^{66}$ Peter C. Newman, "Backstage With the Communists: Even Reds Spurring LPP," Maclean's Magazine (19 July 1958), LAC, James G. Endicott and Family fonds, MG30-C130, vol. 63, file 1323, 3; Edith Holtom to Mr. B. Malkin, 17 May 1961, LAC, James G. Endicott and Family fonds, MG30-C130, vol. 8, file 136, 1; Huard, "The Canadian Peace Congress," 26.

${ }^{67}$ J. T. Thorson to K. C. Woodsworth, 3 June 1963, MUL, CCND fonds, SW571, box 3, file 11, 1. See also: K. C. Woodsworth to J. T. Thorson, 7 June 1963, MUL, CCND fonds, SW571, box 3, file 11, 1-2. ${ }^{68}$ C. G. Gifford to Jacqueline Dineen, 29 August 1960, LAC, James G. Endicott and Family fonds, MG30C130, vol. 8, file 129, 1 .

${ }^{69}$ D. Gillian Thompson, interview with author, 12 November 2013.

${ }^{70}$ James Endicott to Jerome Davis, 7 September 1960, LAC, James G. Endicott and Family fonds, MG30C130, vol. 8 file 130, 1; Mary and James Endicott, "The Canadian Far Eastern Newsletter," 24 May 1961, LAC, James G. Endicott and Family fonds, MG30-C130, vol. 69, file 1412, 1.
} 
her committee as filling "a vacuum," becoming an "adult non-sectarian and secular group working on war/peace and social issues." She clearly placed her study group in opposition to the "communist" $\mathrm{CPC}$ and the religiously based efforts that had preceded it. ${ }^{71}$ And the CUCND was born out of a sense that young people, particularly students, had a special interest in and a unique role to play in keeping the world safe from nuclear disaster. ${ }^{72}$ VOW separated itself from other disarmament organizations with the premise that mothers were naturally suited to disarmament and peace work. ${ }^{73}$ These distinct identities prevented Canadian anti-nuclear organizations from ever coming together into a single unified movement. ${ }^{74}$

Despite their differences, Canadian disarmers still cooperated in the struggle against the Bomb. Many disarmers elected to be members of several organizations, which aided in the coordination of two significant national campaigns. ${ }^{75}$ Nearly all peace and disarmament groups in Canada participated in collecting signatures for the CCCRH's 1961 petition. ${ }^{76}$ And it was only with the fundraising of organizations such as VOW, CCCRH-CCND, and the Society of Friends, that physicist Norman Alcock was able to

${ }^{71}$ CCND Executive Committee, 13 April 1964, MUL, CCND fonds, SW571, box 1, file 15, 1. See also: Gilles B. Richard, Dimitrios Roussopoulos, and F. C. Hunnius, "Why the Canadian Campaign for Nuclear Disarmament must join the International Confederation for Disarmament and Peace," 20-21 July 1963, MUL, CCND fonds, SW571, box 2, file 1, 2 .

${ }^{72}$ Dimitrios Roussopoulos to Mary Van Stolk, 29 December 1960, MUL, CCND fonds, box 9, file 2, 1; "Resolutions and Reports of the Annual Conference Combined Universities Campaign for Nuclear Disarmament," February 1963, MUL, CUCND-SUPA fonds, box 7, file: early CUCND material, 1.

${ }^{73}$ Josephine Davis to Lester B. Pearson, 12 June 1960, LAC, Lester B. Pearson fonds, MG26-N2, vol. 91 , file: External Affairs Voice of Women 2, 9.

${ }^{74}$ Norman Pritchard, 2 November 1958, LAC, James G. Endicott and Family fonds, MG30-C130, vol. 7, file 113, 1; Jacqueline Dineen to R. G. Freeman, 26 July 1960, LAC, James G. Endicott and Family fonds, MG30-C130, vol. 8, file 129, 1; Jacqueline Dineen to Louise Harvey, 13 October 1959, LAC, James G. Endicott and Family fonds, MG30-C130, vol. 7, file 123, 1.

${ }^{75}$ Mabel Hanway to Jim and Jacky, 11 May 1962, LAC, James G. Endicott and Family fonds, MG30C130, vol. 8, file 143, 1; Lillian Marcus to executive Voice of Women, 30 November 1962, LAC, Voice of Women fonds, MG28-I218, vol. 1, file: correspondence Josephine Davis 1962, 2.

${ }^{76}$ CCCRH, "Memo to all branches," 28 June 1961, MUL, CCND fonds, SW574, box 19, file 13; "National organizations - names and addresses," 1961, MUL, CCND fonds, SW574, box 20, file 1, 1; Eva Sanderson to James S. Thomson, 3 October 1961, MUL, CCND fonds, SW573, box 17, file 4, 1. 
establish the Canadian Peace Research Institute in 1961, which served as a model for research institutes across the globe. ${ }^{77}$

All Canadian disarmament organizations envisioned the reduction and eradication of nuclear arms as only one piece in a larger project to realize a safer and more just and moral world ${ }^{78}$ As noble as their ultimate goals were, the movements were unable to sustain interest among protesters and to maintain activity when one important aim of disarmers was attained with the 1963 Limited Test Ban Treaty. The treaty drained disarmament efforts across the globe of the fear and urgency related to nuclear fallout, which had fuelled protest efforts in the early 1960 s. ${ }^{79}$ Furthermore, less than three months after the treaty came into effect, nuclear warheads were installed in Ontario and Quebec, crushing the morale of Canadian disarmament movements. ${ }^{80}$

\footnotetext{
77 [Gerry] Hunnius to James S. Thomson, 20 October 1961, MUL, CCND fonds, SW571, box 3, file 9; "Memo to Ray Silver from Marjorie McEnaney," 22 November 1961, Archives of Ontario (AO), Canadian Peace Research Institute fonds, F-883-1-2, container B297379, box 4, file: CAPRI correspondence 19611962; Basil Spurr, "Minutes of the Toronto Monthly Meeting of Friends," 20 March 1962, LAC, Society of Friends fonds, MG17-G1, reel M-3817, 1; Jessie Johnson and Margaret McHouther, "Meeting for Business," 7 June 1964, LAC, Society of Friends fonds, MG17-G1, reel M-3825, 2; Norman Hoyte to Norman Alcock, 8 January 1962, AO, Canadian Peace Research Institute fonds, F-883-1-2, container B297379, box 4, file: Hoyte and Jude; I. Zlotowski to Canadian Peace Research Institute, 10 August 1962, AO, Canadian Peace Research Institute fonds, F-883-1-2, container 297375, box 5, file: France; F. Wuesthoff to Norman Alcock, 17 October 1962, AO, Canadian Peace Research Institute fonds, F-883-1-2, container B297375, box 5, file: Germany; Victor Wallace to Norman Alcock, 18 July 1963, AO, Canadian Peace Research Institute fonds, F-883-1-2, container B297380, box 3, file: Australia.

${ }^{78}$ Kathleen Langston to Thérèse [Casgrain], 28 November 1962, LAC, Voice of Women fonds, MG28I218, vol. 1, file: correspondence Josephine Davis 1962, 1; W. H. S. Macklin to secretary CCCRH, 24 December 1961, MUL, CCND fonds, SW571, box 1, file 2, 1; "Resolutions and Reports of the Annual Conference Combined Universities Campaign for Nuclear Disarmament," February 1963, MUL, CUCNDSUPA fonds, box 7, file: early CUCND material Howard Adelman's file, 1.

${ }^{79}$ Chatfield, The American Peace Movement, 115; Wittner, The Struggle Against the Bomb, vol. 2, 443; Paul Boyer, "From Activism to Apathy: The American People and Nuclear Weapons, 1963-1980," Journal or American History 70 (March 1984): 824-835.

${ }^{80}$ Mabel Hanway, 26 August 1963, LAC, James G. Endicott and Family fonds, MG30-C130, vol. 8, file 160, 1; Jacqueline Dineen, “Annual Report," 25 March 1964, LAC, James G. Endicott and Family fonds, MG30-C130, vol. 10, file 178, 1; CUCND National Secretariat, "Special Mid-Summer Memo, Hiroshima Day," 6 August 1963, MUL, CUCND-SUPA fonds, box 3, file: interbranch memos Dec. 1962-Oct. 1963, 1; Wittner, The Struggle Against the Bomb, vol. 2, 443; David S. Churchill, "SUPA, Selma, and Stevenson: The Politics of Solidarity in mid-1960s Toronto," Journal of Canadian Studies 44(2) (Spring 2010): 34; Candace Loewen, "Mike Hears Voices: Voice of Women and Lester Pearson, 1960-1963," Atlantis 12(2)
} 
By the mid-1960s Canadian disarmament efforts had dissolved. VOW's agenda shifted to the war in Vietnam by the fall of 1963, and similarly, the CPC returned to its broader peace focus. ${ }^{81}$ By 1965 , most of the local branches of the CCND had folded, and the CUCND had transformed into a New Left student organization. ${ }^{82}$

The brief lives of Canadian disarmament organizations correspond to timelines laid out by scholars of social movements. Sociologists and disarmers Frances McCrea and Gerald Markle were left "pessimistic" by their study of the history of disarmament activism in the United States up to the late 1980s. What they found was a discouraging pattern of brief activity, followed by disintegration. ${ }^{83}$ Social movement scholars agree that movements will collapse if they are unable to develop a coherent identity ${ }^{84}$

Factionalism was very much an issue for Canadian disarmament efforts, which were dispersed across multiple organizations ${ }^{85}$ Social movement theorists also tend to concur that successful movements decline when the excitement and tension that created them is resolved by the achievement of the movement's goals. ${ }^{86}$ This was certainly the case for disarmament efforts, regardless of the limitations of the Limited Test Ban Treaty.

(Spring 1987): 29; Eva Sanderson to Miss Nancy Pocock, 22 April 1964, LAC, James G. Endicott and Family fonds, MG30-C130, vol. 10, file 179, 1; Roussopoulos, "Introduction," 8.

${ }^{81}$ Loewen, "Mike Hears Voices," 29; Eva Sanderson to Nancy Pocock, 22 April 1964, LAC, James Endicott and Family fonds, MG30-C130, vol. 10, file 179, 1; Bruce Mickleburgh, "Our Campaign Now: We the People vs. the UN deadlock," 22 November 1957, LAC, James Endicott and Family fonds, MG30C130, vol. 7, file 108, 1 .

82 Wittner, The Struggle Against the Bomb, vol. 2, 443.

${ }^{83} \mathrm{McCrea}$ and Markle, Minutes to Midnight, 164.

${ }^{84}$ Samuel Clark, "General Introduction," in Prophecy and Protest: Social Movements in Twentieth Century Canada, ed. by Samuel Clark, J. Paul Grayson, and Linda Grayson (Toronto: Gage Educational Publishing Limited, 1975), 30; Dan J. Wang and Sarah A. Soule, "Social Movement Organizational Collaboration: Networks of Learning and the Diffusion of Protest Tactics, 1960-1995," American Journal of Sociology 117(6) (May 2012): 1713, Håkan Thörn, Anti-Apartheid and the Emergence of a Global Civil Society (Basingstoke: Palgrave Macmillan, 2009), 69.

${ }^{85}$ R. R. Real to J. S. Thomson, 22 February 1962, MUL, CCND fonds, box 10, file 13.

${ }^{86}$ Clark, "General Introduction," 30; Sidney Tarrow, Power in Movement: Social Movements, Collective Action and Politics (Cambridge: Cambridge University Press, 1994), 5-6, 17-18; Robert D. Benford, "'You Could Be the Hundredth Monkey:' Collective Action Frames and Vocabularies of Motive Within the Nuclear Disarmament Movement," The Sociological Quarterly 34(2) (May 1993): 202; Thörn, Anti- 
As Lawrence Wittner, an optimistic historian of global anti-nuclear efforts, argued, the collapse of disarmament efforts around 1963 was nevertheless a success story. He asserted that disarmers created the environment of global concern over radiation hazards that made the Limited Test Ban Treaty possible in $1963 .{ }^{87}$ Historian of American peace activism Charles Chatfield agreed that anti-nuclear movements of the late 1950s and early 1960s should be recognized for making immense progress towards preventing nuclear war in a short period of time. Disarmers, according to Chatfield, educated the public about the dangers of nuclear fallout, forced Western governments to acknowledge those dangers, and forged a consensus against atmospheric testing. ${ }^{88}$

The moment of intense global anti-nuclear protest between 1959 and 1963 thus should not be dismissed because of its short lifespan. ${ }^{89}$ Furthermore, Canadian disarmament efforts should not be considered to have been ineffective because nuclear weapons were installed on Canadian soil. ${ }^{90}$ Such an assessment reduces the project of

Apartheid, 8-9. The author notes that this literature on social movements is dated. However, after an initial peak in interest in social movements in the mid-1970s, social movement theory was left untouched until the mid-1990s. On many of the questions of why social movements succeed or fail the literature from both periods are generally in agreement. Recent scholarship on "new social movements" still relies heavily on the theoretical frameworks presented in the 1990s, in particular Sidney Tarrow's work continues to be widely referenced (Benford, "'You Could Be the Hundredth Monkey,", 197; Wang and Soule, "Social Movement Organizational Collaboration," 1675; Christopher Rootes, "Global Visions: Global Civil Society and the Lessons of European Environmentalism," Voluntas: International Journal of Voluntary and Nonprofit Organizations 13(4) (December 2002): 413; David Meyer and Debra C. Minkoff, “Conceptualizing Political Opportunity," Social Forces 82(4) (June 2004): 1459; Nehring, Politics of Security, 6).

${ }^{87}$ Wittner, The Struggle Against the Bomb, vol. 2, 473.

${ }^{88}$ Chatfield, The American Peace Movement, 114.

${ }^{89}$ Chatfield, The American Peace Movement, 171; Charles DeBenedetti and Charles Chatfield, An American Ordeal: The Antiwar Movement of the Vietnam Era (Syracuse: Syracuse University Press, 1990), 81; Wittner, The Struggle Against the Bomb, vol. 2, 202.

${ }^{90}$ Jennifer Hunter argued in her 2004 Ph.D. dissertation that nuclear arms were installed in Canada because the Canadian anti-nuclear movement failed to arouse fear of nuclear arms in an indifferent Canadian public (Jennifer Hunter, "Wondering if It's Even Worthwhile Doing the Dishes: Canadians and the Nuclear Threat, 1945-1963" (Ph.D. diss., McGill University, 2004), 301). Through Patricia McMahon considered Canadian disarmers to have effectively dissuaded Prime Minister Diefenbaker from reaching an agreement to bring American nuclear warheads into Canada, she also concluded that Lester B. Pearson's finalization of an agreement in the fall of 1963 demonstrated the inability of disarmers to convince the Canadian public of the dangers of nuclear arms (McMahon, Essence of Indecision, xiv, xv). 
Canadian disarmers to the single goal of keeping Canada free from nuclear weapons, and fails to acknowledge the role that Canadian efforts played within larger international campaigns against nuclear arms.

\section{Peace and disarmament activism in Canadian historical analysis}

The Cold War efforts of Canadians opposed to nuclear arms have faded from public memory. ${ }^{91}$ This lack of a public consciousness about anti-nuclear activities has been reinforced by the fact that Canadian peace activism has been seriously understudied, especially in comparison to British and American movements. ${ }^{92}$ In 2007, historian of early twentieth century Canadian peace efforts Thomas Socknat warned that the legacies of Canadian peace activists were at risk of being forgotten entirely. ${ }^{93}$ Similarly, in their 2012 attack on what they considered to be the "toxic rebranding" of Canada into a "warrior nation," historian Ian McKay and journalist Jamie Swift argued that Canadians needed to understand "the complicated — and contested — history of Canadian attitudes towards war and peace." ${ }^{94}$ The relatively small number of peace movement activists and the general characterization of them as "quiet," explains perhaps the limited consideration Canadian historians have afforded pacifists. ${ }^{95}$ However, as sociologist S. D. Clark contended while looking back on Canadian social movements of

\footnotetext{
${ }^{91}$ Jim Harding, "Continuing On: Deepening the Anti-Nuclear Movement since the Sixties," in New World Coming: The Sixties and the Shaping of Global Consciousness, eds. Karen Dubinsky, et. al. (Toronto: Between the Lines, 2009), 388.

${ }^{92}$ Socknat, Witness Against War, 4, 5; Huard, "The Canadian Peace Congress," 25-26.

${ }^{93}$ Thomas Socknat, "Conscientious Objectors in the Context of Canadian Peace Movements," Journal of Mennonite Studies 25 (2007): 73.

${ }^{94}$ Ian McKay and Jamie Swift, Warrior Nation: Rebranding Canada in an Age of Anxiety (Toronto: Between the Lines, 2012), xi.

${ }^{95}$ Socknat, Witness Against War, 5; Brock and Young, Pacifism in the Twentieth Century, 249.
} 
the early twentieth century, "Although many of us would like to pretend otherwise, Canadians have not been a quiet people." 96

The dearth of scholarship on Canadian peace movements contrasts with the extensive work on Canada's Cold War. Recently, scholars have focused on demonstrating that Canada was affected by, and did in fact participate in, the Cold War on its own terms. ${ }^{97}$ While political scientists and historians such as Erika Simpson and Sean Maloney have explored how Canadian politicians and civil servants approached the Bomb, Canadian disarmers receive short shrift in Canadian historical analyses of the early Cold War. ${ }^{98}$ In fact, some general histories of Cold War Canadian social activism have omitted pacifists and anti-nuclear activists entirely. For example, the edited collections Creating Postwar Canada: Community, Diversity and Dissent and Debating Dissent: Canada and the 1960 s do not include a single essay on anti-nuclear protest. ${ }^{99}$ Often, peace and anti-nuclear activists are treated as merely one piece of a larger story in social histories of Canada's Cold War. In his work Canada's 1960s, Canadian social historian Brian Palmer considered Canadian disarmament activists to have provided a "significant challenge to the prospects of nuclear proliferation" and to have

\footnotetext{
${ }^{96}$ Clark, "General Introduction," 1.

${ }^{97}$ Brookfield, Cold War Comforts, 8-9; Bothwell, The Big Chill, xii; Palmer, Canada's 1960s, Kindle Loc 985; Robert Teigrob, Warming up to the Cold War: Canada and the United States' Coalition of the Willing, from Hiroshima to Korea (Toronto: University of Toronto Press, 2009), 21; Maloney, Learning to Love the Bomb, xx; Caralee Daigle, "A Challenge and a Danger: Canada and the Cuban Missile Crisis" (PhD diss., Queen's University, 2011); Hunter, "Wondering if It's Even Worthwhile Doing the Dishes."

${ }^{98}$ Erika Simpson, NATO and the Bomb: Canadian Defenders Confront Critics (Montreal: McGill-Queen's University Press, 2001), 5; Maloney, Learning to Love the Bomb, xviii. Other studies of Canada's acquisition of nuclear arms include: John Clearwater, Canadian Nuclear Weapons: The Untold Story of Canada's Cold War Arsenal (Toronto: Dundurn Press, 1998); Andrew Richter, Avoiding Armageddon: Canadian Military Strategy and Nuclear Weapons, 1950-63 (Vancouver: UBC Press, 2002); Howard H. Lentner, "Foreign Policy Decision Making: The Case of Canada and Nuclear Weapons," World Politics 29(1) (Oct. 1976); Don Munton, "Going Fission: Tales and Truths about Canada's Nuclear Weapons," International Journal 51(3) (Summer 1996).

${ }^{99}$ Magda Fahrni and Robert Rutherdale, eds., Creating Postwar Canada: Community, Diversity and Dissent, 1945-75 (Vancouver: UBC Press, 2008); Campbell, Clément, and Kealey, eds., Debating Dissent.
} 
had an important impact on Prime Minister Diefenbaker's thinking on the question of nuclear arms for Canada. ${ }^{100}$ Despite such a positive assessment of these groups, disarmers only appear sporadically throughout Palmer's work to provide brief examples of the "rebellious uniqueness" of Canada's 1960s that was the focus of his work. ${ }^{101}$

The women's peace organization, Voice of Women, figures significantly in a chapter of Tarah Brookfield's Cold War Comforts. In her analysis of Canadian women's Cold War child-welfare activism, Brookfield illustrated the large public mobilization of Canadian women for peace catalysed by the threat of nuclear war in the $1960 \mathrm{~s} .{ }^{102}$ Brookfield's focus on maternal feminism as a driver for women's activism highlighted the contributions of women to Canadian disarmament efforts. This dissertation will further Brookfield's project by emphasizing how VOW women's work contributed to broader Canadian campaigns against nuclear arms.

Patricia McMahon's monograph on Diefenbaker's nuclear policy did highlight some of the strategies used by the CCCRH, the CUCND, and VOW to sway the prime minister to reject nuclear weapons. However, because her work was focused on Diefenbaker's decision-making process on the question of nuclear arms in Canada, McMahon's work did not explore how anti-nuclear activists constructed their message, nor did it demonstrate how their campaigns were received outside of the Conservative cabinet. ${ }^{103}$

\footnotetext{
${ }^{100}$ Palmer, Canada's 1960s, Kindle Loc 1119-1146. See also his brief discussion of CUCND as a precursor to student New Left efforts (Palmer, Canada's 1960s, Kindle Loc 4893-4920).

${ }^{101}$ Palmer, Canada's 1960s, 21.

${ }^{102}$ Brookfield, Cold War Comforts, 3, 74.

${ }^{103}$ McMahon, Essence of Indecision, xiv.
} 
When historians have taken an interest in Canadian disarmament efforts, they generally have concentrated on the efforts of one group. The CPC and the CUCND have attracted some scholarly attention, likely because of the extent to which these two groups were targeted by the Canadian security state. ${ }^{104}$ The VOW in particular has the most substantial presence in the historiography of Canadian peace efforts, perhaps because of the importance of peace activism to women's history. ${ }^{105}$ VOW will likely continue to dominate the story of disarmament efforts because of its continued existence and the organization's new drive to promote its history following the celebration of its $50^{\text {th }}$ anniversary in 2010. ${ }^{106}$ Numerous biographies or autobiographies of former disarmament leaders have also contributed to an understanding of Canadian Cold War peace and disarmament efforts. Examples include Stephen Endicott's biography of his father, CPC leader James Endicott, and VOW president Kay Macpherson’s autobiography. ${ }^{107}$

\footnotetext{
${ }^{104}$ Whitaker, Kealey, and Parnaby, Secret Service, 344; Whitaker and Marcuse, Cold War Canada, 364365; Hewitt, Spying 101, 90, 94, 119; Michael Maurice Dufresne, “'Let's Not Be Cremated Equal:' The Combined Universities Campaign for Nuclear Disarmament 1959-1967," The Sixties in Canada: A Turbulent and Creative Decade, ed. M. Athena Palaeologu (Montreal: Black Rose Books, 2009); Huard, "The Canadian Peace Congress"; Bruce Douville, "Project La Macaza: A Study of Two Canadian Peace Protests in the 1960s," in Worth Fighting For: Canada's Tradition of War Resistance from 1812 to the War on Terror, eds. Lara Campbell, Michael Dawson, Catherine Gidney (Toronto: Between the Lines, 2015), Kindle ed.

${ }^{105}$ Kay Macpherson and Meg Sears, "Voice of Women: A History," in Women in the Canadian Mosaic, ed. Gwen Matheson (Toronto: Peter Martin Associates, 1976); Loewen, "Mike Hears Voices," 24-30; Ball, "The History of the Voice of Women"; Frances Early, "'A Grandly Subversive Time:' The Halifax Branch of the Voice of Women in the 1960s," in Mothers of the Municipality: Women, Work and Social Policy in Post-1945 Halifax, eds. Judith Fingard and Janet Guildford (Toronto: University of Toronto Press, 2005); Early, "Canadian Women and the International Arena in the Sixties;" Brookfield, Cold War Comforts; Marie Hammond-Callaghan, "Bridging and Breaching Cold War Divides: Transnational Peace Building, State Surveillance, and the Voice of Women," in Worth Fighting For: Canada's Tradition of War Resistance from 1812 to the War on Terror, eds. Lara Campbell, Michael Dawson, Catherine Gidney (Toronto: Between the Lines, 2015), Kindle ed.

${ }^{106}$ The Canadian Peace Congress is also still an active organization to this day, however it lacks the public presence and authority that Voice of Women has gathered as a an accredited non-governmental organization to the United Nations. Voice of Women, Building Peace Making History: 100 Years of Women's Peace Building in Canada (The VOW Peace Exhibit), Carleton University Department of History, Ottawa, February-March 2013; Janis Alton email to author, "Re: VOW History Project Meeting," 25 March 2015.

${ }^{107}$ Endicott, James G. Endicott; Kay Macpherson, When in Doubt, Do Both: The Times of My Life (Toronto: University of Toronto Press, 1994). See also: Kay Macpherson, "Persistent Voices: Twenty-Five
} 
Scholarly interest in North American Cold War peace and disarmament efforts increased between the 1980s and the early 2000s, as former youth activists emerged as established academics and sought to explain the rise and fall of the movements of which they were once a part. Beginning in the mid-1990s, this scholarship was aided by the declassification of certain government archives, for example federal cabinet records that are held private for 30 years. ${ }^{108}$ Gary Moffatt, a teacher and life-long social activist, wrote the only comprehensive survey of the efforts of Canadian Cold War disarmers in an attempt to educate anti-nuclear activists of the 1980s in the hope of preventing another movement collapse. ${ }^{109}$ The most detailed work on women's twentieth-century peace activism in Quebec, by feminist and peace activist Simone Monet-Chartrand, is part history and part memoire. ${ }^{110}$ Former student activists, such as CUCND founder Dimitrios Roussopoulos, have been responsible for much of the historiography on the CUCND. ${ }^{111}$

Years with the Voice of Women," Atlantis 12(2) (Spring 1987): 60-72; Marion Scott Kerans, Muriel Duckworth: A Very Active Pacifist: A Biography (Halifax: Fernwood, 1996); Mick Lowe, One Woman Army: The Life of Claire Culhane (Toronto: Macmillan Canada, 1992); Shirley Jane Endicott, China Diary: The Life of Mary Austin Endicott (Waterloo: Wilfrid Laurier University Press, 2003); Thérèse Casgrain, A Woman in a Man's World (Toronto: McClelland \& Stewart, 1972).

${ }^{108}$ Divine, Blowing on the Wind; Wittner, Rebels Against War; Boyer, "From Activism to Apathy," 821844; Milton Katz, Ban the Bomb: A History of SANE, the Committee for a Sane Nuclear Policy, 1957-1985 (Westport, Conn.: Greenwood Press, 1986); McCrea and Markle, Minutes to Midnight; DeBenedetti and Chatfield, An American Ordeal; Chatfield, The American Peace Movement; Amy Swerdlow, Women Strike for Peace: Traditional Motherhood and Radical Politics in the 1960s (Chicago and London: The University of Chicago Press, 1993); Allan M. Winkler, Life Under a Cloud: American Anxiety About the Atom (New York: Oxford University Press, 1993); Wittner, The Struggle Against the Bomb, vol. 1; Boyer, By the Bomb's Early Light; Wittner, The Struggle Against the Bomb, vol. 2; Brock and Young, Pacifism in the Twentieth Century; Robbie Lieberman, The Strangest Dream: Communism, Anticommunism, and the U.S. Peace Movement, 1945-1963 (Syracuse: Syracuse University Press, 2000); Lawrence S. Wittner, "Gender Roles and Nuclear Disarmament Activism, 1954-1965," Gender and History 12(1) (April 2000): 197-222.

${ }^{109}$ Moffatt, History of the Canadian Peace Movement, 1.

${ }^{110}$ Simonne Monet-Chartrand, Les Québécoises et le mouvement pacifiste (1939-1967) (Montreal: Les Éditions Écosociété, 1993), 13, 14. See also Sean Mills, The Empire Within: Postcolonial Thought and Political Activism in Sixties Montreal (Montreal: McGill-Queen's University Press, 2010), 48.

${ }^{111}$ Dimitrios Roussopoulos, ed. Our Generation Against Nuclear War (Montreal: Black Rose Books, 1996); Dimitrios Roussopoulos, ed. The New Left: Legacy and Continuity (Montreal; Black Rose Books, 2007); Dimitrios Roussopoulos, ed. The New Left in Canada (Montreal: Our Generation Press-Black Rose Books, 1970); Harding, "Continuing On." 
Those with a deep investment in the events, ideas, and organizations being discussed have produced most of the Canadian literature on Cold War peace and disarmament activities.

This pattern of activist domination of historical analyses is not solely a Canadian phenomenon. Scholars identifying as peace activists have produced most of the pivotal works in the history of Western peace and disarmament efforts. ${ }^{112}$ United States Department of State historian David S. Patterson has questioned whether activists can write about Cold War peace movements dispassionately and objectively. ${ }^{113}$ Patterson noted that scholars with different political views have presented peace movements much more critically, and have been quicker to characterize pacifists as naïve or misguided. ${ }^{114}$ Modern German historian Benjamin Ziemann has levelled the same criticism against European historian-activists and what he sees as the construction of a "heroic narrative of peace history" in Germany. ${ }^{115}$ For example, Wittner judged the CCCRH's 1961 "No Nuclear Weapons for Canada" petition to have successfully persuaded the Diefenbaker government against installing nuclear warheads on Canadian soil. Reliance on Wittner's assessment has led Canadian historians McMahon and Bruce Douville to overestimate

\footnotetext{
${ }^{112}$ Lawrence S. Wittner, "Combining Work as an Historian and Activist: A Personal Account," Peace \& Change 32(2) (April 2007): 128; Wittner, Rebels Against War, vii-viii; Rebecca Lowen, Review Resisting the Bomb: A History of the World Nuclear Disarmament Movement, 1954-1970 by Lawrence Wittner, Pacific Historical Review 69(1) (Feb. 2000): 139-140; David S. Meyer, Review Toward Nuclear Abolition: A History of the World Nuclear Disarmament Movement, 1971 to the Present by Lawrence S. Wittner, Political Science Quarterly 119(4) (Winter 2004/2005): 711-713; Powaski, Review The Struggle Against the Bomb, 1206-1207; Badash, Review The Struggle Against the Bomb, 539-540; Isserman, Review Resisting the Bomb, 527-528; Alonso, Peace as a Women's Issue, 4; Foster, Women for All Seasons, 2; Linda Gordon, "The Peaceful Sex? On Feminism and the Peace Movement," NWSA Journal 2(4) (Autumn 1990): 624; Swerdlow, Women Strike for Peace, 10-11; Boyer, By the Bomb's Early Light, xxii; Boyer, "From Activism to Apathy;" Chatfield, The American Peace Movement.

${ }^{113}$ David S. Patterson, “The Emergence of Peace History," Reviews in American History 23(1) (March 1995): 135.

${ }_{114}$ Patterson, "The Emergence of Peace History," 135.

${ }^{115}$ Ziemann, "The Code of Protest," 260-261.
} 
the impact of the petition. ${ }^{116}$ Nevertheless, current knowledge of Cold War peace and disarmament efforts is deeply indebted to the studies of those who could not "view the prospect of human extinction with scholarly detachment," as Paul Boyer put it the introduction to his history of American disarmament efforts. ${ }^{117}$

\section{Approach and methodology}

A variety of peace movements, community organizations, unions, and religious groups took up the cause of disarmament in the late 1950s and early 1960s. All of these various anti-nuclear expressions contributed to making Canadian disarmament efforts spirited, innovative, and complex. This study will focus nearly exclusively on four national disarmament organizations. While disarmament was only one of many concerns for community groups, unions, and religious organizations, the CCCRH, the CUCND, VOW, and the CPC prioritized nuclear disarmament from 1959 to 1963. Furthermore, many disarmers who were involved in smaller local organizations, or religiously based peace efforts, also became members of one or several of these major, national movements, making these bodies a fair representation of Canadian anti-nuclear activism. ${ }^{118}$ The values and actions of these groups were always as firmly grounded in the

\footnotetext{
${ }^{116}$ Wittner, The Struggle Against the Bomb, vol. 2, 201, 348-349, 389; Douville, "Project La Macaza," Kindle Loc 3064; McMahon, Essence of Indecision, 125, 175. For a challenge to this assessment see: Nicole Marion, ''I would rather be right:' Diefenbaker and Canadian Disarmament Movements," in Reassessing the Rogue Tory and His Times: New Perspectives on the Diefenbaker Era in Canadian Foreign Relations, eds. Janice Cavell and Ryan Touhey (Vancouver: University of British Columbia Press, forthcoming).

${ }_{117}$ Boyer, By the Bomb's Early Light, xxii.

${ }^{118}$ Palmer, Canada's 1960s, 257; Brookfield, Cold War Comforts, 71; Kerans, Muriel Duckworth, 85; Ball, "The History of the Voice of Women," 342; Voice of Women, "First Annual Meeting," 16-17 June 1961, LAC, Voice of Women fonds, MG28-I218, vol. 22, file: national annual meeting 1961 minutes background material, 2; "Canadian delegation to Congress on Disarmament and International Cooperation," 17 June 1958, LAC, James G. Endicott and Family fonds, MG30-C130, vol. 7, file 111; "Prominent Canadians Form Committee on Radiation Hazards \& Nuclear Policy," n.d., MUL, CCND fonds, SW571, box 1, file 1, 5,6 .
} 
past as they were committed to the future. ${ }^{119}$ For this reason, while the dissertation will be largely restricted to the most intense period of activity in Canada from 1959 to 1963, it will also discuss antecedents and epilogues.

Archival research and oral interviews form the foundation of the research for this dissertation. Archival holdings for the major Canadian disarmament organizations of interest to this study, as well as those for Canadian political parties and of prime ministers, were consulted to gain a comprehensive understanding of these organizations and their interactions with the Canadian public, Canadian governments, and with international disarmament efforts. The national offices of disarmament organizations kept the most regular and detailed records. Repositories were also most substantial for movements in large urban Ontario centres, in particular the Toronto and Ottawa branches. ${ }^{120}$ This means that the efforts of national executives and of large urban Ontario branches dominate the archive. Further research is needed on the experiences of disarmers outside of Ontario, and especially in Quebec, where disarmament movements became increasingly insular and disconnected from national efforts in the early 1960 s. $^{121}$ This bias in archival holdings is reinforced by the fact that the existing historiography on

\footnotetext{
${ }^{119}$ Historian of early twentieth century Canadian movements Thomas Socknat concludes that groups like the CPC, the CCND, and VOW were taking up the torch passed to them by the pre-Second World War generation of Canadian peace activists (Socknat, Witness Against War, 290-291).

${ }^{120}$ With a few exceptions, the national offices of disarmament organizations were in Toronto, explaining the dominance of Toronto branches in the archives. Voice of Women briefly moved its national offices to Montreal in 1962 while Thérèse Casgrain served as president, and the CUCND leadership often vacillated between Toronto and Montreal, where the organization's journal, Our Generation Against Nuclear War, was produced.

${ }^{121}$ James Endicott to Pierre St. Germaine, 8 January 1957, LAC, James G. Endicott and Family fonds, MG30-C130, vol. 6, file 105, 1; "Address of Jacques Larue-Langlois," 25 October 1963, MUL, CCND fonds, SW571, box 1, file 10, 1, 4-5; "Minutes of the Board of Directors' Meeting," 20-21 April 1963, MUL, SW571, box 1, file 6, 2; Marjorie Reid to Kay [Macpherson], 12 May 1965, LAC, Voice of Women fonds, MG28-I218, vol. 1, file: $5^{\text {th }}$ annual meeting reports to and lists $1965,1$.
} 
this subject has largely been written by or has been informed by the experiences and recollections of national leaders. ${ }^{122}$

Sociologist Håkan Thörn prioritized the voices and experiences of movement leaders, whom he called "key activists," in his study of British and Swedish antiapartheid movements from the early 1950s through to the 1990s. Thörn argued that "key activists" are central to an understanding of social movements because they act as "nodes in the information networks of the movements," and are important sources of information about the "crucial dynamics of the processes of identification, as well as to the informational, cognitive and spatial networks of a social movement." ${ }^{123}$ However, prioritizing the voices of organization leaders clouds an understanding of these movements by hiding the complexities of the experiences and motivations of individual Canadian men and women who chose to speak up against nuclear arms.

To reach beyond the perspectives of activist leaders, interviews were conducted with nine former rank-and-file members of the CUCND, the CCCRH, the CPC and VOW. The recollections of these participants both corroborated and disputed the written records that are dominated by the perspectives of organizational elites. The stories of participants in anti-nuclear protests were a valuable resource for uncovering how activists viewed themselves and their aims, as well as their capacity to convey this information to other Canadians. ${ }^{124}$ These interviews also played an important role in guiding research

\footnotetext{
${ }^{122}$ Casgrain, A Woman in a Man's World; Monet-Chartrand, Les Québécoises et le mouvement pacifiste; Macpherson, When in Doubt do Both; Macpherson, "Persistent Voices"; Roussopoulos, "Introduction;" James Harding, "The New Left in B.C.," in The New Left in Canada, ed. Dimitrios Roussopoulos (Montreal: Our Generation Press-Black Rose Books, 1970); Whitaker and Marcuse, Cold War Canada, 383.

${ }^{123}$ Thörn, Anti-Apartheid, 13-14, 31.

${ }^{124}$ My decision to conduct interviews with former activists and my approach to the interview process was directly guided by methodologies inspired by the work of Alessandro Portelli. My approach to interviews was particularly informed by Portelli's encouragement to allow the informant to lead the interview process
} 
into new directions and raised important questions about the legacies of Canadian

disarmament efforts, which helped to shape the organization of this study.

Several of the men and women who shared their experiences requested that their interviews remain anonymous. In a few instances that request emerged from a sense that they, as mere "followers" and "shadow members," were not worthy of attribution. They believed that their contributions were somehow less meaningful than the work performed by organization leaders. ${ }^{125}$ In a letter expressing her hope that she might be able to do something to support VOW in 1960, Georgenna Underwood Ferguson of Calgary identified herself and other housewives like her as "nobodies." ${ }^{126}$ Even Muriel Duckworth, a central leader of disarmament and peace activism in Halifax, confided to her biographer Marion Kerans Douglas in the 1980s that "she was just an ordinary woman and not a luminary in the peace movement."127 This sense of inadequacy may have been informed by the general exclusion of women from the leadership of Canadian activist efforts in the mid-twentieth century. ${ }^{128}$ However, male activists too shared the sentiment that their work was inconsequential relative to that of national disarmament

to and allow them the space to tell the story that they want to tell. Importantly, this approach allowed participants to define what they felt was most important for understanding their efforts, which did not always align with the assumptions I had reached following my reading of the written records. Alessandro Portelli, "The Peculiarities of Oral History," History Workshop 12 (Autumn 1981): 99-100; Jessica Squires, Building Sanctuary: The Movement to Support Vietnam War Resisters in Canada, 1965-73 (Vancouver: UBC Press, 2013), viii; Becki Ross, Burlesque West: Showgirls, Sex, and Sin in Postwar Vancouver (Toronto: University of Toronto Press, 2009), 23; Steven High, Industrial Sunset: The Making of North America's Rust Belt, 1969-1984 (Toronto: University of Toronto Press, 2003), 16.

${ }^{125}$ Anonymous, interview with author, 1 November 2013. Similar positions were expressed by: Anonymous, interview with author, 8 November 2013.

${ }^{126}$ Georgenna Underwood Ferguson to Mrs. Davis, 24 June 1960, LAC, Voice of Women fonds, MG28I218, vol. 1, file: correspondence re. formation of VOW June-Sept. 1960, 1.

${ }^{127}$ Kerans, Muriel Duckworth, 12.

${ }^{128}$ Wittner, "Gender Roles and Nuclear Disarmament Activism," 197-198; Holger Nehring, Politics of Security: British and West German Protest Movements and the Early Cold War, 1945-1970 (Oxford: Oxford University Press, 2013), 7-8; Bernice A. Carroll, "Feminism and Pacifism: Historical and Theoretical Connections," in Women and Peace: Theoretical, Historical and Practical Perspectives, eds. Ruth Roach Pierson, Joanne Thompson, Somer Bodribb and Paula Bourne (London, New York: Croom Helm, 1987), 2. 
leaders. ${ }^{129}$ Yet, the commitment, boldness, and leadership of organization executives upon which Canadian disarmament efforts were built would have been meaningless without the active participation of others.

For other interview subjects, the request for anonymity was related to a continuing fear that association with peace or disarmament activism would lead to persecution and could have an impact on their reputation. ${ }^{130}$ The archives of organizations like the CPC and VOW contain many letters from participants fearful of having their names used publicly in association with their peace work. ${ }^{131}$ To respect the privacy of all activists, the authors of written contributions that were found in various archives have not been identified in cases where the comments made could possibly prove to be embarrassing or hurtful to activists and their families.

This dissertation is the first scholarly investigation of anti-nuclear efforts in Canada in the late 1950s and early 1960s. It is also a necessary revision of the existing historiography on disarmament activism. The dissertation brings together approaches from a diverse literature on Canada's Sixties; Canada's Cold War; American, British, and Western European disarmament and peace movements; connected social movements such as the New Left, feminist movements, and environmental movements; and histories of children and childhood. Most significantly, this dissertation offers a reassessment of these movements and their importance to an understanding of Cold War social and

\footnotetext{
${ }^{129}$ Anonymous, interview with author, 8 November 2013.

${ }^{130}$ Anonymous, interview with author, 9 November 2013; Anonymous, interview with author, 6 November 2013. Concern was also expressed by Anonymous, interview with author, 1 November 2013.

${ }^{131}$ See for example: Anonymous to Mr. and Mrs. Endicott, 15 July 1964, LAC, James G. Endicott and Family fonds, MG30-C130, vol. 10, file 173, 2; Joyce Christie to Thérèse Casgrain, 27 November 1962, LAC, Voice of Women fonds, MG28-I218, vol. 1, file: correspondence Josephine Davis 1962, 1; Anonymous to Mr. Endicott, 28 January 1957, LAC, James G. Endicott and Family fonds, MG30-C130, vol. 2, file 21, 1; Ethel Neilson, 17 January 1949, LAC, James G. Endicott and Family fonds, MG30-C130, vol. 1 , file 1,1 .
} 
political dynamics in light of new theoretical work informing examinations of gender and transnational social movements.

Historical and sociological analyses of women's involvement in peace and disarmament activism in North America have relied extensively on gender theory. However, much of this research was based on what is now widely considered to be a dated understanding of feminism. ${ }^{132}$ This dissertation provides a re-evaluation of Canadian women's Cold War disarmament activism with assistance from recent challenges to understandings of historical women's movements as having occurred in "waves." 133 By avoiding the trap of trying to fit women's disarmament efforts into a continuum between first and second "wave" women's movements, this dissertation is better able to explore the complexities of Canadian women's relationships with feminism in the late 1950 s and early 1960 s.

Despite using gender analysis when studying women's activism and a spike in interest in historical constructions of masculinities beginning in the early 1990s, scholars

\footnotetext{
132 Jill Vickers, "The Intellectual Origins of the Women's Movement in Canada," in Challenging Times: The Women's Movement in Canada and the United States, eds. Constance Backhouse and David H. Flaherty (Montreal: McGill-Queen's University Press, 1992), 55; Ball, "The History of the Voice of Women," ii; Amy Swerdlow, "Ladies' Day at the Capitol: Women Strike for Peace versus HUAC," Feminist Studies 8(3) (Autumn 1982): 515; Swerdlow, Women Strike for Peace, 4-5, 8-9, 158, 238; Wittner, "Gender Roles and Nuclear Disarmament Activism," 197, 205.

${ }^{133}$ Brian T. Thorn, From Left to Right: Maternalism and Women's Political Activism in Postwar Canada (Vancouver: UBC Press, 2016), Kindle Loc 94; Vickers, "The Intellectual Origins of the Women's Movement in Canada," 39-40; Brookfield, Cold War Comforts, 6; Nancy Adamson, "Feminists, Libbers, Lefties, and Radicals: The Emergence of the Women's Liberation Movement," in A Diversity of Women: Ontario 1945-80, ed. Joy Parr (Toronto: Toronto University Press, 1995), 277; Joan Sangster, "Radical Ruptures: Feminism, Labor, and the Left in the Long Sixties in Canada," American Review of Canadian Studies 40(1) (March 2010): 2, 12; Kathleen A. Laughlin, et. al., "Is It Time to Jump Ship? Historians Rethink the Waves Metaphor," Feminist Formations 22(1) (Spring 2010): 76-77, 78, 87-88; Gail G. Campbell, "'Are we going to do the most important things?' Senator Muriel McQueen Fergusson, Feminist Identities, and the Royal Commission on the Status of Women," Acadiensis XXXVIII(2) (Summer/Autumn 2009): 76; Nancy A. Hewitt, "Feminist Frequencies: Regenerating the Wave Metaphor," Feminist Studies 38(3) (Fall 2012): 664-665; Ann Snitow, "A Gender Diary," in Feminism \& History, ed. Joan Wallach Scott (Oxford: Oxford University Press, 1996), 506, 518; Meg Luxton, "Feminism and Families: The Challenge of Neo-Conservatism," in Feminism and Families: Critical Policies and Changing Practices, ed. Meg Luxton (Halifax: Fernwood Publishing, 1997), 14.
} 
of peace and disarmament movements have rarely investigated gender when dealing with male activists. ${ }^{134}$ This dissertation addresses this shortfall by integrating historical analyses of Cold War constructions of masculinity with explorations of Canadian antinuclear activism. ${ }^{135}$ Engaging in gender analysis when investigating disarmament efforts acknowledges how performances of Cold War ideal masculinities informed the manner in which men expressed anti-nuclear positions.

Alongside gender theory, developments in sociological approaches to transnational social movements have allowed the dissertation to offer a new perspective on Cold War disarmament activism. Studies of the rise in global anti-nuclear protest in the late 1950s and early 1960s have tended to clump together all disarmament efforts by speaking of a single international anti-nuclear "movement."136 Recent approaches to transnationalism and social activism have emphasized that social movements, despite a focus on an international problem such as the Bomb, are always rooted in local, regional, and national contexts. ${ }^{137}$ The term "transnational advocacy network," proposed by political scientists Margaret E. Keck and Kathryn Sikkink, offers a valuable framework

\footnotetext{
${ }^{134}$ The Editorial Collective, "Why Gender and History?" Gender \& History 1 (1) (Spring 1989): 1-2; Karen Adler, Ross Balzaretti and Michele Mitchell, "Practicing Gender History," Gender \& History 20 (1) (April 2008): 2 .

135 Jean Bethke Elshtain, Women and War (New York: Basic Books, Inc., Publishers, 1987), 4; Tracy Xavia Karner, "Engendering Violent Men: Oral Histories of Military Masculinity," in Masculinities and Violence, ed. Lee H. Bowker (Thousand Oaks, California: SAGE Publications, Inc., 1998), 200; Christopher Dummitt, The Manly Modern: Masculinity in Postwar Canada (Vancouver: UBC Press, 2007), 3; Robert L. Griswold, Fatherhood in America: A History (New York: Basic Books, 1993), 186; Mona Gleason, "Disciplining Children, Disciplining Parents: The Nature and Meaning of Advice to Canadian Parents, 1945-1955," Histoire Sociale/Social History 29 (May 1996): 202; Robert Rutherdale, "New 'Faces' for Fathers: Memory, Life-Writing, and Fathers as Providers in the Postwar Consumer Era," in Creating Postwar Canada: Community, Diversity, and Dissent, 1945-75, eds. Magda Fahrni and Robert Rutherdale (Vancouver: UBC Press, 2008), 253; Herbert Sussman, Masculine Identities: The History and Meanings of Manliness (Santa Barbara, California: Praeger, 2012), 13-14.

${ }^{136}$ Holger Nehring, "National Internationalists: British and West German Protests Against Nuclear Weapons, the Politics of Transnational Communications and the Social History of the Cold War, 19571964," Contemporary European History 14(4) (2005): 560.

137 Tarrow, Power in Movement, 15; Thörn, Anti-Apartheid, 69; Nehring, "National Internationalists," 560.
} 
for explaining how independent, distinct national social movements interact with global

movements sharing similar concerns. Advocacy networks, according to Keck and

Sikkink, are loose and spontaneous societies formed when social movements share goals, resources, and people. ${ }^{138}$

Other relevant methodologies and scholarly literatures will be discussed in further detail within various chapters of the dissertation. In particular, scholarship on the idea of the child in human rights discourse and in Cold War politics was important to the analysis of the role that symbols of the child played in anti-nuclear rhetoric. ${ }^{139}$

Furthermore, historical analyses of the baby boom generation and of New Left politics in Canada, and sociological debates regarding radical protests, such as the practice of civil disobedience, have proven especially useful for examinations of youth activism and the radicalization of peace activism in Canada in the mid-Cold War. ${ }^{140}$

\section{Dissertation organization}

\footnotetext{
${ }^{138}$ Margaret E. Keck and Kathryn Sikkink, Activists Beyond Borders: Advocacy Networks in International Politics (Ithaca, N.Y.: Cornell University Press, 1998), 1-2.

${ }^{139}$ For example see: Karen Dubinsky, Babies Without Borders: Adoption and Migration across the Americas (Toronto: University of Toronto Press, 2010); Jacqueline Bhabha, "The Child: What Sort of Human," PMLA 121(5) (October 2006); Laura Briggs, "Mother, Child, Race, Nation: The Visual Iconography of Rescue and the Politics of Transnational and Transracial Adoption," Gender \& History 15(2) (August 2003); Emily S. Rosenberg, "Rescuing Women and Children," The Journal of American History 89(2) (September 2002).

${ }^{140}$ For example see: Doug Owram, Born at the Right Time: A History of the Baby Boom Generation (Toronto: University of Toronto Press, 1997); Cyril Levitt, Children of Privilege: Student Revolt in the Sixties (Toronto: University of Toronto Press, 1984); David S. Churchill, "SUPA, Selma, and Stevenson: The Politics of Solidarity in mid-1960s Toronto," Journal of Canadian Studies 44(2) (Spring 2010); Ian Milligan, Rebel Youth: 1960s Labour Unrest, Young Workers, and New Leftists in English Canada (Vancouver: UBC Press, 2014); Frank E. Myers, "Civil Disobedience and Organizational Change: The British Committee of 100," Political Science Quarterly 86(1) (March 1971): 111; Chatfield, The American Peace Movement, 102, 104; Roberta Lexier, "'The Backdrop Against Which Everything Happened:' English-Canadian Student Movements and Off-Campus Movements for Change," History of Intellectual Culture 7(1) (2007): 6; Frances B. McCrea and Gerald E. Markle, Minutes to Midnight: Nuclear Weapons Protest in America (Newbury, Ca.: Sage Publications, 1989), 23-24; Shragge, Eric, Ronald Babin and JeanGuy Vaillancourt, "Introduction," in Roots of Peace: The Movement Against Militarism in Canada, edited by Eric Shragge, Ronald Babin and Jean-Guy Vaillancourt, 9-15 (Toronto: Between the Lines, 1986), 9.
} 
In order to analyze the complex aims, methods, and motivations driving antinuclear efforts in Canada, the dissertation has been structured around the diverse relationships that disarmers had among themselves, with fellow disarmers across the globe, with the Canadian government, and with the Canadian public. Because this is a story of relationships, the dissertation has been organized thematically.

The first two chapters address the ways in which Cold War Western gender norms informed how activists understood and presented their anti-nuclear campaigns. Historians have wrongly pointed to an absence of female voices within early Cold War disarmament movements. ${ }^{141}$ As this dissertation will demonstrate, women did play a significant role in disarmament efforts, particularly through the women's group VOW.

The first chapter highlights the interactions between women's disarmament activism and diverse feminisms in Canada. Drawing on the current scholarly problematization of the idea that feminism can be analysed in terms of discrete "waves," this chapter challenges the accepted wisdom that early Cold War women's peace and anti-nuclear activism was a bridge between first and second "wave" feminisms. ${ }^{142}$ By rejecting the "waves" understanding of women's twentieth-century feminism, this chapter

\footnotetext{
${ }^{141}$ Nehring, Politics of Security, 7-8; Wittner, "Gender Roles and Nuclear Disarmament Activism," 197; Wittner, The Struggle Against the Bomb, vol. 2, 196-197; Bernice A. Carroll, "Feminism and Pacifism: Historical and Theoretical Connections," in Women and Peace: Theoretical, Historical and Practical Perspectives, eds. Ruth Roach Pierson, Joanne Thompson, Somer Bodribb and Paula Bourne (London, New York: Croom Helm, 1987), 2.

${ }^{142}$ Vickers, "The Intellectual Origins of the Women's Movement in Canada," 39-40, 55; Ball, "The History of the Voice of Women," ii, iii; Candace Loewen, "Making Ourselves Heard: 'Voice of Women' and the Peace Movement in the Early Sixties," in Framing Our Past: Canadian Women's History in the Twentieth Century, eds. Sharon Anne Cook, Lorna R. McLean, and Kate O'Rourke (Montreal: McGill-Queen's University Press, 2001), 284, 251; Hammond-Callaghan, "Bridging and Breaching Cold War Divides," Kindle Loc 2644; Swerdlow, "Ladies' Day at the Capitol," 515; Swerdlow, Women Strike for Peace, 4-5, 8-9, 158; Wittner, "Gender Roles and Nuclear Disarmament Activism," 197; Brookfield, Cold War Comforts, 6; Sangster, "Radical Ruptures," 2, 12; Laughlin, et. al., "Is It Time to Jump Ship?," 76-77, 78, 87-88; Hewitt, "Feminist Frequencies," 664-665.
} 
recognizes the vital importance that maternal feminism played in women's disarmament activism during the period under examination.

In a similar manner, the second chapter uses scholarship on masculinity to interrogate the manner in which Canadian men navigated the complicated terrain of normative ideas about masculinity. ${ }^{143}$ Male disarmers adhered to certain elements of gender norms, such as scientific rationalism, professional achievement, and fatherhood. By doing so, male disarmament activists were able to temper the degree to which the Canadian security state and the general public perceived their peace campaigns as a threat to the Cold War socio-political order.

Building upon the first two chapters, the third chapter further explores disarmers' compliance with Cold War gender norms through their prioritization of their identities as parents. Canadian disarmers framed their protests as being necessary for the protection of the world's children. By emphasizing their concern for the health and happiness of their own children as well as future generations of children, Canadian disarmers shared a common protest language with fellow disarmers across the West.

Young activists did not identify with this common positioning of activists as parent-citizens. Consequently, the priorities of young people were not always in line with those of the adult leaders of disarmament organizations. Envisioning themselves as having a special contribution to make to Cold War peace efforts, some young Canadians found meaningful space in which to work against war and nuclear arms within the

\footnotetext{
${ }^{143}$ Wittner, "Gender Roles and Nuclear Disarmament Activism," 214; Elshtain, Women and War, 4; Karner, "Engendering Violent Men," 200; Dummitt, The Manly Modern, 3; Griswold, Fatherhood in America, 186; Gleason, "Disciplining Children, Disciplining Parents," 202; Rutherdale, "New 'Faces' for Fathers," 253; Sussman, Masculine Identities, 13-14; R. W. Connell, Masculinities, second edition (Cambridge: Polity Press, 2005) 77; Erica Fraser, "Masculinity in the Personal Narratives of Soviet Nuclear Physicists," Aspasia 8 (2014): 48.
} 
CUCND. ${ }^{144}$ Chapter four highlights the autonomy and initiative of young Canadians involved with the CUCND and the manner in which Canadian youth disarmament campaigns stood apart in Canadian peace and disarmament efforts.

Chapter five examines the relationships that Canadian disarmers had with Canadian politicians. This chapter argues that disarmers failed in their efforts to keep nuclear arms out of Canada because of their preoccupation with political lobbying and their over-investment in relationships with disingenuous Canadian politicians. With their reliance on "traditional" protest methods, disarmers failed to attract the public attention needed to give anti-nuclear efforts the public weight necessary to influence policy decisions.

Finally, the sixth chapter explores the relationships that Canadian disarmers had with international disarmers. Connected by shared aims, anti-nuclear protest efforts on both sides of the Iron Curtain benefitted from exchanges of people, ideas, and educational resources across borders. While Canadian disarmament activists were active participants in international campaigns to ban the Bomb, their efforts were always grounded in national concerns. In this sense, Canadian anti-nuclear activists were "national internationalists," to adopt the phrase used by historian Holger Nehring to describe British and West German disarmament campaigns. ${ }^{145}$

This dissertation demonstrates that there were in fact complex, vigorous, and noisy expressions of anti-nuclear sentiment in Cold War Canada. Canadian disarmers may have been few in number, and may have been conservative in their protest methods,

\footnotetext{
144 "Resolutions and Reports of the Annual Conference Combined Universities Campaign for Nuclear Disarmament," February 1963, MUL, CUCND-SUPA fonds, box 7, file: early CUCND material, 1. ${ }^{145}$ Nehring, "National Internationalists," 561.
} 
but they nonetheless engaged in a remarkable struggle to protect humanity from the threat of nuclear war. They recognized that the most effective approach to the "tremendous task" 146 they were taking on was to "join together," 147 yet they never truly united to establish a concerted Canadian anti-nuclear movement. The responses of Canadian disarmers to the Cold War and to the threat of nuclear weapons were complicated by different experiences and understandings of the world around them.

\footnotetext{
${ }^{146}$ Fae E. Rose to Mrs. Davis, LAC, Voice of Women fonds, MG28-I218, vol. 1, file: correspondence re. formation of VOW May-June 1960, 3.

${ }^{147}$ Jacqueline Dineen to Catherine Fraser, 20 September 1960, LAC, James G. Endicott and Family fonds, MG30-C130, vol. 8, file 130, 1.
} 


\section{Chapter One \\ "Surely a mother has a right:" Canadian Feminism and Women's Disarmament Activism}

On 17 and 21 May 1960, Toronto Daily Star columnist Lotta Dempsey expressed

her outrage and fear after the cancellation of the East-West summit between Soviet

Premier Nikita Khrushchev and American President Dwight Eisenhower, following the downing of an American U-2 spy plane in Soviet airspace. ${ }^{148}$ Claiming that the world was closer than ever to complete destruction, Dempsey argued: "In some way women the world over must refuse to allow this thing to happen." 149 Dempsey's call for women to take action to prevent a nuclear holocaust received an immediate positive response from Canadian women, leading to the establishment of the women's peace group, Voice of Women (VOW) in the summer of $1960 .{ }^{150}$ Within six months, the Toronto-based organization had over 2,000 registered members nationally, demonstrating a desire among Canadian women to speak out and work against nuclear arms. ${ }^{151}$

Feminist scholars have described the participation of North American women in disarmament activism in the late 1950s and early 1960 s as a "bridge" between the first

\footnotetext{
148 Tarah Brookfield, Cold War Comforts: Canadian Women, Child Safety, and Global Insecurity, 19451975 (Waterloo: Wilfrid Laurier University Press, 2012), 82.

${ }^{149}$ Lotta Dempsey, "Private Line," Toronto Daily Star, 21 May 1960, 62.

${ }^{150}$ Brookfield, Cold War Comforts, 82-83. See for example: Helen M. Cree to Lotta Dempsey, 17 May 1960, Library and Archives Canada (LAC), Voice of Women fonds, MG28-I218, vol. 1, file: correspondence re. formation of VOW May-June 1960, 1; Grace Jenlis to Miss Dempsey, 27 May 1960, LAC, Voice of Women fonds, MG28-I218, vol. 1, file: correspondence re. formation of VOW May-June 1960, 3-4; Hilkka O. Hormavirta to Lotta Dempsey, 30 May 1960, LAC, Voice of Women fonds, MG28I218, vol. 1, file: correspondence re. formation of VOW May-June 1960, 1; Muriel Duggan to Lotta Dempsey, 30 May 1960, LAC, Voice of Women fonds, MG28-I218, vol. 1, file: correspondence re. formation of VOW May-June 1960, 1-2.

${ }^{151}$ Kay Macpherson, When in Doubt, Do Both: The Times of My Life (Toronto: University of Toronto Press, 1994), 141; Christine Ball, "The History of the Voice of Women/La Voix des Femmes: The Early Years, 1960-1963," (PhD diss., University of Toronto, 1994), 135, 436; Frances Early, "Canadian Women and the International Arena in the Sixties: The Voice of Women/La voix des femmes and the Opposition to the Vietnam War," in The Sixties: Passion, Politics and Style, ed. Dimitry Anastakis (Montreal: McGillQueen's University Press, 2008), 26.
} 
and second "waves" of Canadian feminism. ${ }^{152}$ Historian Christine Ball argued that VOW embodied the metamorphosis between “earlier Canadian women's movements for feminism, pacifism, and social justice" and "the modern Canadian feminist movement." 153 Candace Loewen echoed this understanding of VOW as an important site of transition for Canadian women from the respectable maternalism of the women's movements of the early nineteenth century to the vociferous political activism of the late 1960s women's liberation movements. ${ }^{154}$ Political scientist Jill Vickers also observed that VOW was "the main arena in which old and new feminists interacted," suggesting that the group was a "crucial link between generations of feminists." 155 Correspondingly, Monique Bégin, women's studies scholar and the executive secretary to the Royal Commission on the Status of Women, celebrated VOW as "the pioneer of the second wave of feminism." ${ }^{156}$ Most recently, historian Marie Hammond-Callaghan has argued that, after 1963, VOW began a "shift toward progressive, feminist, and New Left politics," again suggesting that "feminism" was previously absent from the organization's identity. $^{157}$

\footnotetext{
152 Jill Vickers, "The Intellectual Origins of the Women's Movement in Canada," in Challenging Times: The Women's Movement in Canada and the United States, eds. Constance Backhouse and David H. Flaherty (Montreal: McGill-Queen's University Press, 1992), 55; Ball, "The History of the Voice of Women," ii.

${ }^{153}$ Ball, "The History of the Voice of Women," iii.

${ }^{154}$ Candace Loewen, "Making Ourselves Heard: 'Voice of Women' and the Peace Movement in the Early Sixties," in Framing Our Past: Canadian Women's History in the Twentieth Century, eds. Sharon Anne Cook, Lorna R. McLean, and Kate O’Rourke (Montreal: McGill-Queen's University Press, 2001), 284, 251.

${ }^{155}$ Vickers, "The Intellectual Origins of the Women's Movement in Canada," 54, 55.

${ }^{156}$ Monique Bégin, "The Royal Commission on the Status of Women in Canada: Twenty Years Later," in Challenging Times: The Women's Movement in Canada and the United States, eds. Constance Backhouse and David H. Flaherty (Montreal: McGill-Queen's University Press, 1992), 24.

${ }^{157}$ Marie Hammond-Callaghan, "Bridging and Breaching Cold War Divides: Transnational Peace Building, State Surveillance, and the Voice of Women," in Worth Fighting For: Canada's Tradition of War Resistance from 1812 to the War on Terror, eds. Lara Campbell, Michael Dawson, Catherine Gidney (Toronto: Between the Lines, 2015), Kindle Loc 2644.
} 
American historians shared similar assessments of the role of women's disarmament activism in the development of feminist movements in the late 1960s and early 1970s. Activist and historian Amy Swerdlow argued that Women Strike for Peace (WSP) - the American equivalent to VOW, founded in 1961-lacked a feminist mentality in the 1960s, but that engaging in such political work led many members, herself included, to adopt feminist views by the 1970 s. ${ }^{158}$ Historian of international peace efforts Lawrence Wittner also tied North American women's disarmament activism to the collapse of 1950s conventional gender norms and the rise of the women's liberation movement in the late 1960 s. ${ }^{159}$

This consensus in the 1990s among feminist historians that disarmament activism served as a "bridge" between first and second "wave feminism" did effectively connect North American women's peace and disarmament activism to broader women's rights movements. However, this characterization of women's movements as separate "waves" failed to capture the complexities of the relationships that Canadian women disarmament activists had to feminism. Though it did not self-identify as a feminist organization, VOW became a vehicle for women to demand a greater say in national defence debates as women. Women's participation in anti-nuclear protest was more than just a steppingstone towards greater gender-consciousness and further liberationist projects, but was informed throughout by complementary and conflicting understandings of how women could and should contribute to a more peaceful world.

\footnotetext{
${ }^{158}$ Amy Swerdlow, "Ladies' Day at the Capitol: Women Strike for Peace versus HUAC," Feminist Studies 8(3) (Autumn 1982): 515; Amy Swerdlow, Women Strike for Peace: Traditional Motherhood and Radical Politics in the 1960s (Chicago and London: The University of Chicago Press, 1993), 4-5, 8-9, 158.

${ }^{159}$ Lawrence S. Wittner, "Gender Roles and Nuclear Disarmament Activism, 1954-1965," Gender and History 12(1) (April 2000): 197.
} 
In order to re-evaluate the relationship between feminism and women's disarmament activism, this chapter will first explore the evolution in the historiography of women's movements, paying particular attention to the critiques of the metaphor of women's movement "waves" which began in the 2000s. Drawing on this revisionary approach, it will be demonstrated how nineteenth-century understandings womanhood and motherhood and their innate link to passivism remained a persistent theme throughout women's participation in Cold War anti-nuclear activism. Acknowledging feminist critiques of this essentialist understanding of women, this chapter will then illustrate how the idea of motherhood served as a valuable political tool for ensuring the "respectability" and legitimacy of women's activism. Yet, motherhood was much more than a rhetorical weapon. The emotional and physical realities of motherhood and love for one's children played a significant role in Canadian women's the desire and ability to protest nuclear arms. Finally, although the "waves" metaphor has outlived its usefulness, it cannot be denied that participation in anti-nuclear activism certainly brought many women to question contemporary definitions of gender roles and the manner in which these ideas limited women's access to political, social, and legal opportunities.

\section{The women's movements "waves" metaphor}

The concept of women's movements that have risen and fallen in "waves" came under fire at the beginning of the twenty-first century. Both Canadian and American feminist scholars have argued against use of the metaphor, which perpetuates the misconception of women's activists in the late 1960s and 1970s that their "second wave movement" emerged spontaneously and without historical roots. Most critically, it 
hinders recognition of continuities between generations of women's movements. The "waves" concept has led to suggestions of inactivity and apathy between the "first wave" movement for civil and political rights of the mid-1800s to the 1920s (1940s in the case of Quebec where women's provincial voting rights were granted only in that decade) and the "second wave" of the late 1960s, when women began promoting the idea of formal gender equality. ${ }^{160}$

Furthermore, separating the movements in this way aggravates a long-standing ideological divide between maternal and equal rights feminists. In the "waves" version of women's rights history, the "second wave," led by feminists seeking to eradicate notions of gender difference, overtook the older "first wave" generation of women who emphasized gender difference and the special contributions that women could make to society. ${ }^{161}$ This understanding of feminist history assumes the demise of maternal feminism in the 1960s. ${ }^{162}$

As historian Gail Campbell has argued, such categorizations of feminists tend to imply "value judgments on some groups of feminists as compared to others." 163 Scholars

\footnotetext{
${ }^{160}$ Brian T. Thorn, From Left to Right: Maternalism and Women's Political Activism in Postwar Canada (Vancouver: UBC Press, 2016), Kindle Loc 94; Vickers, "The Intellectual Origins of the Women's Movement in Canada," 39-40; Brookfield, Cold War Comforts, 6; Nancy Adamson, "Feminists, Libbers, Lefties, and Radicals: The Emergence of the Women's Liberation Movement," in A Diversity of Women: Ontario 1945-80, ed. Joy Parr (Toronto: Toronto University Press, 1995), 277; Joan Sangster, "Radical Ruptures: Feminism, Labor, and the Left in the Long Sixties in Canada," American Review of Canadian Studies 40(1) (March 2010): 2, 12; Kathleen A. Laughlin, et. al., "Is It Time to Jump Ship? Historians Rethink the Waves Metaphor," Feminist Formations 22(1) (Spring 2010): 76-77, 78, 87-88; Gail G. Campbell, "'Are we going to do the most important things?' Senator Muriel McQueen Fergusson, Feminist Identities, and the Royal Commission on the Status of Women," Acadiensis XXXVIII(2) (Summer/Autumn 2009): 76; Nancy A. Hewitt, "Feminist Frequencies: Regenerating the Wave Metaphor," Feminist Studies 38(3) (Fall 2012): 664-665.

${ }_{161}$ Ann Snitow, "A Gender Diary," in Feminism \& History, ed. Joan Wallach Scott (Oxford: Oxford University Press, 1996), 506, 518.

${ }^{162}$ Meg Luxton, "Feminism and Families: The Challenge of Neo-Conservatism," in Feminism and Families: Critical Policies and Changing Practices, ed. Meg Luxton (Halifax: Fernwood Publishing, 1997), 14.

${ }^{163}$ Campbell, "'Are we going to do the most important things?," 56.
} 
of women's peace activism have disagreed about whether maternalism can be considered feminist. ${ }^{164}$ In the 1950s and 1960s, maternalist thinkers promoted the existence of "a uniquely female value system, based on care and nurturance," which implied a special collective responsibility for women to protect the children of the world. ${ }^{165}$ Swerdlow and Wittner have contended that WSP could not be considered to have been "feminist" in the 1960s, because of its members' promotion of maternalist values. ${ }^{166}$ For equal rights feminists and scholars in the 1980s and 1990s, maternalism was, in its promotion of the idea of "separate spheres," troublesome because it "is an explicit instrument for the subordination of women's lives to men's desires." ${ }^{167}$ Feminist scholars have also taken issue with the over-valorization of maternalism as an explanatory tool, since the standard of motherhood applied only to a privileged group of women, and even excluded those white, middle-class women who were not mothers, or who were not heterosexual. ${ }^{168}$

Other scholars, such as feminist historian Linda Gordon, have argued that it is possible to assert "the validity of a distinctive female view of certain social problems" and still to make politically subversive arguments for "women's integration on equal terms" into the political realm. ${ }^{169}$ According to Gordon's line of reasoning, women can profess a special interest in peace without putting aside their claims for equal

\footnotetext{
164 Snitow, “A Gender Diary,” 518, 522.

165 Thorn, From Left to Right, Kindle Loc 123.

${ }^{166}$ Swerdlow, Women Strike for Peace, 238; Swerdlow, "Ladies' Day at the Capitol," 515; Wittner, "Gender Roles and Nuclear Disarmament," 205.

${ }^{167}$ Sara Ruddick, "Thinking about Mothering and Putting Maternal Thinking to Use," Women's Studies Quarterly 11(4) (Winter 1983): 6, 4, Wittner, "Gender Roles and Nuclear Disarmament Activism," 205; Catherine Foster, Women for All Seasons: The Story of the Women's International League for Peace and Freedom (Athens, Georgia: University of Georgia Press, 1989), 40-41, 57.

${ }^{168}$ Linda Gordon, "The Peaceful Sex? On Feminism and the Peace Movement," NWSA Journal 2(4) (Autumn 1990): 628-629.

${ }^{169}$ Gordon, "The Peaceful Sex?," 632. See also: Snitow, "A Gender Diary," 522; Catherine Eschel, "Gender and the Subject of (Anti)Nuclear Politics: Revisiting Women's Campaigning against the Bomb," International Studies Quarterly 57 (2013): 714-715.
} 
participation in politics. Even as VOW women claimed to have no interest in undermining male-dominated political systems, they were also demanding a radical overhaul of Cold War politics and gender norms, when they stepped out in public as concerned mothers. ${ }^{170}$

The "waves" metaphor also created an artificial wall between liberal and liberationist feminists. Liberal feminists generally believed that it was possible to make change by working with the existing socio-political system, and thus tended to value the way they were perceived by government officials and the general public. Radical and liberationist movements, which emerged in the late-1960s, behaved according to the conviction that the system itself needed to be rebuilt in order for civil liberty and equality to become reality, and they used more attention-grabbing tactics to undermine the system. ${ }^{171}$ Scholars of women's movements have most often understood a unidirectional relationship in which liberal feminists evolved under the influence of radical feminists. ${ }^{172}$ However, as Stephanie Gilmore has argued in her analysis of 1970s women's activism in Memphis, Tennessee, "lived feminist activism happens somewhere between liberal and radical feminist ideology." ${ }^{173}$ In her defence of liberal feminism, feminist scholar Susan Wendell argued for greater recognition among scholars that the central political commitments of liberal feminism are not incompatible with the goals of socialist

\footnotetext{
${ }^{170}$ Frances Early, “'A Grandly Subversive Time:' The Halifax Branch of the Voice of Women in the 1960," in Mothers of the Municipality: Women, Work and Social Policy in Post-1945 Halifax, eds. Judith Fingard and Janet Guildford (Toronto: University of Toronto Press, 2005), 254.

${ }^{171}$ Adamson, "Feminists, Libbers, Lefties, and Radicals," 255; Meg Luxton, "Feminism as a Class Act: Working-Class Feminism and the Women's Movement in Canada," Labour/Le Travail 48 (Fall 2001): 14; Stephanie Gilmore, "The Dynamics of Second-Wave Feminist Activism in Memphis, 1971-1982: Rethinking the Liberal/Radical Divide," NWSA Journal 15(1) (Spring 2003): 95.

${ }^{172}$ Gilmore, "The Dynamics of Second-Wave Feminist Activism," 96; Susan Wendell, "A (Qualified) Defense of Liberal Feminism," Hypatia 2(2) (Summer 1987): 78.

${ }^{173}$ Gilmore, "The Dynamics of Second-Wave Feminist Activism," 96.
} 
and radical feminisms. All forms of feminism, she claimed, seek "the promotion of women's greater recognition and self-value as individuals," an equality of opportunity, the equality of legal rights, and an end to sex discrimination. ${ }^{174}$ In the Canadian context in particular, it is important to recognize the commonalities shared by different feminist ideologies. While radical movements were certainly influential in Canada in the 1970s, the growth of women's liberation movements in Canada was hampered by the persistence of a strong tradition of liberal feminism. ${ }^{175}$ The dominance of liberal feminist values in Canada was exemplified by the Royal Commission on the Status of Women, initiated in 1967, which explored ways for the federal government to ensure more equal opportunities for men and women in Canadian society. The Royal Commission was entirely built upon the expectation that change could be achieved through the mechanisms of the existing socio-political system. ${ }^{176}$

In light of these identified flaws in the metaphor of women's movement "waves," it is time that women's disarmament activism and its relationship to feminism be reconsidered. ${ }^{177}$ Attempts to fit women's anti-nuclear activism into a narrative of

\footnotetext{
${ }^{174}$ Wendell, "A (Qualified) Defense of Liberal Feminism," 66.

${ }^{175}$ Vickers, "The Intellectual Origins of the Women's Movement in Canada," 40-41, 52; Kimberly Speers, "The Royal Commission on the Status of Women in Canada, 1967-1970: Liberal Feminism and Its Radical Implications," in Framing Our Past: Canadian Women's History in the Twentieth Century, eds. Sharon Anne Cook, Lorna R. McLean, and Kate O'Rourke (Montreal: McGill-Queen's University Press, 2001), 253.

${ }^{176}$ Jessica Haynes, "Help for All Parents?: Child-Rearing Advice in English Canada in the 1960s and 1970s," Histoire Sociale/Social History 44(87) (May 2011): 57; Campbell, "'Are we going to do the most important things?," 53-54; Adamson, "Feminists, Libbers, Lefties, and Radicals," 253, 255.

${ }^{177}$ Scholars have also identified an innate bias towards middle-class, white feminists in the story of the birth of "second wave" feminism in the late 1960s. This tendency to prioritize the views and actions of this limited group has led to an omission of labour and ethnic or racial women's movements. Unfortunately, given the dominance of white, middle-class women in disarmament organizations, this chapter will not be able to acknowledge the racial and class diversity of mid-twentieth century North American women's movements. See: Dorothy Sue Cobble, The Other Women's Movement: Workplace Justice and Social Rights in Modern America (Princeton, New Jersey: Princeton University Press, 2004), 7; Sangster, "Radical Ruptures," 12; Luxton, "Feminism as a Class Act," 64; Becky Thompson, "Multiracial Feminism: Recasting the Chronology of Second Wave Feminism," Feminist Studies 28(2) (Summer 2002): 337; Swerdlow, Women Strike for Peace, 1-2; Ball, "The History of the Voice of Women," 188.
} 
progression from "first wave," liberal, maternal feminisms to "second wave," radical, equal rights feminisms do not allow for a full consideration of the dynamism in which feminism was lived and practiced by Canadian women.

\section{Women, mothers and peace activism}

There has been a long Western tradition of "culturally constructed and transmitted myths and memories" linking women to peace and men to war. ${ }^{178}$ The historic conflation of femininity with pacifism is thought to result from unequal power dynamics in patriarchal societies, in which women are portrayed as more sensitive, caring, compassionate and passive than men in order to justify their subordinate status. ${ }^{179}$ Though by the 1920s and 1930s peace activists had recognized that men had been socially conditioned towards violence, it remained an article of faith that women were biologically oriented towards peace. ${ }^{180}$ As late as the $1990 \mathrm{~s}$, feminist intellectuals had to encourage peace activists and scholars to dispute the apparent equation of pacifism with femininity. ${ }^{181}$

Inspired by the larger feminist project to highlight the social construction of gender, histories of women's peace activism since the 1990s have attempted to denaturalize the association of women with pacifism. ${ }^{182}$ Such studies have argued that the

\footnotetext{
178 Jean Bethke Elshtain, Women and War (New York: Basic Books, Inc., Publishers, 1987), 4.

${ }^{179}$ Rhodri Jeffreys-Jones, Changing Differences: Women and the Shaping of American Foreign Policy 1917-1994 (New Brunswick, New Jersey: Rutgers University Press, 1995), 10; Bernice A. Carroll, "Feminism and Pacifism: Historical and Theoretical Connections," in Women and Peace: Theoretical, Historical and Practical Perspectives, eds. Ruth Roach Pierson, Joanne Thompson, Somer Bodribb and Paula Bourne (London, New York: Croom Helm, 1987), 3; Harriet Hyman Alonso, Peace as a Women's Issue: A History of the U.S. Movement for World Peace and Women's Rights (Syracuse: Syracuse University Press, 1993), 11.

${ }^{180}$ Alonso, Peace as a Women's Issue, 263.

${ }^{181}$ Alonso, Peace as a Women's Issue, 11.

182 See for example: Swerdlow, Women Strike for Peace, 1, 10; Ruddick, "Thinking about Mothering," 6, 4; Snitow, “A Gender Diary,” 508; Jeffreys-Jones, Changing Differences, 5; Frances H. Early, "New
} 
acceptance of biologically essentialist rhetoric undermines the larger project for gender equality by reinforcing stereotypes embedded in patriarchal power structures.

Furthermore, they have regularly pointed out the absurdity of notions of women's innate pacifism, given that women have more often been defenders than critics of war. ${ }^{183}$

Nevertheless, political scientist Catherine Eschle recently reminded international relations scholars not to dismiss biologically essentialist rhetoric in explanations of women's peace activism, as these identities can still be mobilized to "have subversive political results." 184 Late nineteenth-century and early twentieth-century women's organizations in Canada shared this assumption that women were the more emotional and passive sex. But their promotion of these stereotypes also led to notions of women as the morally superior sex, which not only served to legitimize their calls to end violence but also their claims to political rights. ${ }^{185}$

While scholars have rightly challenged the assumption that there is a link between femininity and pacifism, many Canadian women viewed this association as natural in the early 1960s. In a letter to VOW co-founder Josephine Davis, Wilma McDonald of Edmonton wrote in June 1960 that such an organization was bound to gain support, for "[w]omen are almost universally opposed to the violence of war." 186 VOW supporter Ursula McLennon addressed the timelessness of women's peace work: "Security is women's business and has been since the beginning of time. The segment of society most

\footnotetext{
Historical Perspectives on Gendered Peace Studies," Women's Studies Quarterly 23(3/4) (Fall-Winter 1995): 23.

${ }^{183}$ Ruddick, "Thinking about Mothering," 6; Jeffreys-Jones, Changing Differences, 6; Early, "New Historical Perspectives," 23.

${ }^{184}$ Eschle, "Gender and the Subject of (Anti)Nuclear Politics," 715.

185 Thomas P. Socknat, Witness Against War: Pacifism in Canada, 1900-1945 (Toronto: University of Toronto Press, 1987), 34.

${ }^{186}$ Wilma McDonald to Mrs. Davis, 25 June 1960, LAC, Voice of Women fonds, MG28-I218, vol. 1, file: correspondence re. formation of VOW June-Sept. 1960, 1-2.
} 
affected by war is the home. The home revolves around women. [...] Women have always worked for peace. They know what war means. They know its implications." 187 By asserting that the home, the traditional realm of women, was most touched by war, McLennon claimed security, meaning peace, as the natural domain of women. In a reply to Lotta Dempsey’s 17 May 1960 “Private Line” column, Mavis Wiley explained the link between women and peace as having more to do with character than with spaces. She wrote that " $[\mathrm{m}]$ en seem to be too much concerned with economic considerations. Women have always been more concerned with people themselves." 188 Wiley's letter implied women naturally to be humanists, and, as such, connected womanhood to pacifism. At the VOW first anniversary meeting, President Helen Tucker emphasized that VOW had been created out of the belief that "women had a special contribution to make $[\ldots]$ to the preservation of peace or the creation of more trusting relationships among the peoples of the world," hinting at the idea of women as the more pacifist sex. ${ }^{189}$ Moreover, in 1966, when VOW was struggling, Joyce Knowles, a member from British Columbia, wondered why it was so hard to attract new members: "It seems to me somewhat ludicrous that we should have to cajole women into swelling our ranks. You would think peace and a better world would or should be a natural concern for all women." ${ }^{190}$ Echoing the sentiment of McDonald's letter, Knowles demonstrated an acceptance of the notion that women were innately drawn towards the fight for peace.

\footnotetext{
${ }^{187}$ Ursula McLennon to Voice of Women, n.d., LAC, Voice of Women fonds, MG28-I218, vol. 1, file: correspondence re. formation of VOW June-Sept. 1960, 1.

${ }^{188}$ Brookfield, Cold War Comforts, 82; Mavis Wiley to Lotta Dempsey, 17 May 1960, LAC, Voice of Women fonds, MG28-I218, vol. 1, file: correspondence re. formation of VOW June-Sept. 1960, 6.

189 “President's Report, First Annual Meeting," 1961, LAC, Voice of Women fonds, MG28-I218, vol. 1, file: $1^{\text {st }}$ annual meeting proceedings 1961,1 .

${ }^{190}$ Joyce Knowles to Kay Macpherson, 6 May 1966, LAC, Voice of Women fonds, MG28-I218, vol. 21, file: British Columbia correspondence 1965-1971, 2.
} 
Connected to the belief that there was something inherently pacifist about women was the assumption that it was motherhood in particular that drew women to desire peace. Nineteenth-century ideals of femininity, which persisted into the twentieth century, promoted the idea that maternal instincts provided women with a heightened sensibility to emotions. This was then taken for granted as giving them an advantage over men when it came to compassion and the ability to imagine peace. ${ }^{191}$ Historian of women's movements Harriet Hyman Alonso has found the role of women as life-givers to be a continuous theme running through every American women's rights and women's peace organization since the early nineteenth century. ${ }^{192}$

Similarly, Canadian women concerned with peace and the threat of nuclear war in the late 1950 s and early 1960 s often assumed that motherhood naturally led to a strong aversion to violence and war. Dempsey asserted in her 21 May 1960 column that she had never encountered "a woman anywhere who did not hate fighting and killing" and the resulting "terrible tragedy of children dead, maimed or left homeless and hungry." 193 Following Dempsey's lead, letters of support for VOW from Canadian women expressed the idea that women were particularly sensitive to the sufferings of children. Mrs. I. Lawton, a British immigrant living in Edmonton, found that her experience of living through air raids during the Second World War supported the idea that motherhood made women particularly keen to work for peace. As she wished the VOW organizers success, Lawton explained that in times of war "we women are the ones to suffer, seeing the terror

\footnotetext{
191 Alonso, Peace as a Women's Issue, 10-11.

192 Alonso, Peace as a Women's Issue, 263.

${ }^{193}$ Dempsey, "Private Line," 21 May 1960, 62.
} 
in little ones faces and not able to help." ${ }^{194}$ In the face of such violence, Lawton's letter implied, women were helpless to aid their children, making it in women's interest to ensure that wars did not happen at all.

In another response to Dempsey's May 1960 columns, Helen Wilks found fault with Canadian mothers who were oblivious to the realities of the international climate:

As a mother of three children, I have always marvelled at the great concern most Canadian mothers show in raising healthy children and giving them every possible advantage to grow up strong and free, only to ignore the warnings-from the most reputable sources - of the danger of life itself as a result of atomic testing and the greater danger of possible atomic war. ${ }^{195}$

While Wilks criticized Canadian mothers for not opening their eyes to the threats nuclear weapons posed to their children's health, Christine Sloan argued in a letter to the editors of the Toronto Daily Star that her "God-given" maternal instincts put her in a better position to sense the severity of the world situation. ${ }^{196}$ This instinct, argued Jeanette Orr, another VOW supporter, came from the fact that children "are the very purpose of our lives," and for that reason it was every mother's duty to "voice her protests against letting fanatics and lunatics kill her children." 197 In like manner, Ruth Harris suggested that the physical experience of motherhood — "the pain, sacrifice, anxiety, care and love in bearing and raising a family" - made it natural that women would want to protect that which they had "lived and worked for." 198 These VOW enthusiasts were regurgitating

\footnotetext{
${ }^{194}$ Mrs. I. Lawton, "Dear Madam,” n.d., LAC, Voice of Women fonds, MG28-I218, vol. 1, file: correspondence re. formation of VOW May-June 1960, 2-3.

${ }^{195}$ Helen Wilks, "Voice of the People: We Fret Over Child's Health But Ignore Atom Hazard," Toronto Daily Star, 3 June 1960, 6.

${ }^{196}$ Mrs. Christine Sloan to the editors of the Toronto Star, 18 June 1960, LAC, Voice of Women fonds, MG28-I218, vol. 1, file: correspondence re formation of VOW June-Sept. 1960, 1.

${ }^{197}$ Mrs. Jeanette Orr, 16 June 1960, LAC, Voice of Women fonds, MG28-I218, vol. 1, file: correspondence re formation of VOW May-June 1960, 1.

${ }^{198}$ Ruth Harris to Lotta Dempsey, 5 June 1960, LAC, Voice of Women fonds, MG28-I218, vol. 1, file: correspondence re. formation of VOW May-June 1960, 1.
} 
Cold War rhetoric that valorized the role of women as mothers. If a woman's duty in Cold War Canada was to act as "producer," then, certainly, women should demand that their offspring not be sacrificed to nuclear chaos. ${ }^{199}$

The assumption that motherhood was a common experience shared by all women was one of the central convictions underlying all of VOW's efforts. The first and second purposes of VOW, as declared in 1961, were to "unite women in concern for the future of the world" and "to help promote the mutual respect and cooperation among nations necessary for peaceful negotiation between world powers having differing ideological assumptions. ${ }^{.200}$ Maryon Pearson, wife of the Liberal Opposition leader, seized upon this international impetus when she accepted a position as honorary sponsor to the organization in July $1960 .{ }^{201}$ In her acceptance she stated:

If we women of the West could succeed in reaching the women on the other side of the 'curtain'-i.e. Russia and China - with no political overtones, but only as mothers of young children whose lives or well-being are at stake under this terrible threat of atomic fall-out, not to mention bombs, I think we could start a chain reaction toward peace instead of war. ${ }^{202}$

Maryon Pearson presented motherhood, an experience unique to women, as a means of overcoming Cold War divisions to make real progress towards peace. Similarly, in her acceptance of honorary sponsorship, Conservative Senator Olive Irvine focused on the universal sentiment to which VOW was appealing:

\footnotetext{
${ }^{199}$ Sean Mills, The Empire Within: Postcolonial Thought and Political Activism in Sixties Montreal (Montreal: McGill-Queen's University Press, 2010), 23.

${ }^{200}$ Voice of Women, "First Annual Meeting," 16-17 June 1961, LAC, Voice of Women fonds, MG28-I218, vol. 22, file: National Annual Meeting (1961) minutes and background material, 5.

${ }^{201}$ Honorary sponsorship was also requested of Conservative Prime Minister John G. Diefenbaker's wife Olive Diefenbaker, who declined as she thought her husband's political position could cause conflicts and put VOW in an awkward position (Olive Diefenbaker to Voice of Women, 8 August 1960, LAC, Voice of Women fonds, MG28-I218, vol. 1, file: correspondence - members of parliament re. formation 1960-1963, $1)$.

202 Mrs. Lester B. Pearson, 30 July ca. 1960, LAC, Voice of Women fonds, MG28-I218, vol. 1, file: correspondence - members of parliament re. formation 1960-1963, 1.
} 
As women and mothers we are naturally gravely concerned regarding the survival of our children and our homes. Women the world over share an abhorrence of nuclear war and in this new non-partisan organization I feel confident that a chord will be struck in the hearts of countless thousands of women of every race, creed and colour. We can, with joint effort, create a climate of understanding which will enable world powers to resolve their differences without war or threat of war. ${ }^{203}$

Much like Pearson, Irvine saw a mother's concern for her children as a global reality that was more powerful than any form of national, class or racial difference.

Three years later, after visiting ten European countries in 33 days as part of the United Nations' International Cooperation Year Travel Mission, VOW member Margaret Ashdown remained confident "that a real bond unites all women in their concern for the safety and future of the family of man. That this bond can transcend national boundaries appears to be definitely within the realm of possibility."204 The common worry that women held for the survival of humanity could serve as a bridge to reach across the boundaries that stood in the way of lasting peace. According to this line of thought, motherhood could cure all the ills of the Cold War.

Though unique as a national women's organization engaged in disarmament activism in Canada, VOW was not exceptional in its acceptance of the presumption of a natural link between motherhood and peace activism. The Canadian Peace Congress (CPC) Women's Committee's 1949 recruitment letter suggested that "mothers and potential mothers of sons" should be particularly worried about a future war. Ethel Neilson, chairman of the committee, prodded women to join the CPC, stating, "[t]o you, as a woman, the thought of another war must be intolerable. You, no doubt, are

\footnotetext{
${ }^{203}$ Senator Olive L. Irvine, 28 July 1960, LAC, Voice of Women fonds, MG28-I218, vol. 1, file: correspondence-members of parliament re. formation 1960-1963, 1.

${ }^{204}$ Margaret E. Ashdown, "International Cooperation Travel Mission June 10-July 14, 1963,” LAC, Voice of Women fonds, MG28-I218, vol. 2, file: International Cooperation Year Conference International Cooperation Travel Mission 1962-63, 1.
} 
wondering what you can do to prevent it." ${ }^{205}$ With her implication that women must find war abhorrent, Neilson and the CPC Women's Committee demonstrated an acceptance of the Western myth of women's inherent pacifism. Neilson's appeal for women's participation in peace activism, which identified a common ground for all women, would have been particularly important for attracting women to the CPC, whose membership often suffered because of the organization's (sometimes accurate) association with communism. $^{206}$

In the margins of her signed 1949 CPC Petition for Peace, Kay Carlin of Sudbury advised that " $[\mathrm{w}]$ omen of the world united and together could turn the tide from war to peace. They have the most to lose in case of war and the most to gain in time of peace." 207 Predicting the need for a women's group like VOW over a decade before its formation, Carlin's commentary on her petition card reflected an appreciation of the idea that women could make a special contribution to peace.

In a fundraising appeal, issued at a Mother's Day 1952 rally at Maple Leaf Gardens, CPC executive secretary Libbie C. Park reminded the audience that Mother's Day should be a day to think about peace. ${ }^{208}$ Park told a crowd of CPC supporters,

\footnotetext{
${ }^{205}$ Ethel Neilson, "Dear Friend of Peace," 17 January 1949, LAC, James G. Endicott and Family fonds, MG30-C130, vol. 1, file 1: origins and founding of the peace movement 1948-49, 1.

${ }^{206}$ S. H. Morrison to Hon L. B. Pearson, 3 May 1950, LAC, James Endicott and Family fonds, MG30C130, vol. 20, file 386, 1; Reg Whitaker and Gary Marcuse, Cold War Canada: The Making of a National Insecurity State, 1945-1957 (Toronto: University of Toronto Press, 1994), 372-373; Stephen Endicott, James G. Endicott: Rebel out of China (Toronto: University of Toronto Press, 1980), 271; Gary Moffatt, History of the Peace Movement in Canada (Ottawa: Grapevine Press, 1982), 18; Victor Huard, "The Canadian Peace Congress and the Challenge to Postwar Consensus, 1948-1953," Peace \& Change 19(1) (January 1994): 33-34.

${ }^{207}$ Kay Carlin, "Petition for Peace," 1949, LAC, James G. Endicott and Family fonds, MG30-C130, vol. 1, file 3.

${ }^{208}$ The official celebration of Mother's Day was first suggested in 1872 by Julia Ward Howe to be a day "devoted to the advocacy of peace." (Voice of Women "Third Annual Meeting, June 8-9, 1963, Winnipeg," LAC, Voice of Women fonds, MG28-I218, vol. 1, file: $3^{\text {rd }}$ Annual meeting minutes and proceedings 1963, 8.)
} 
"Today is Mothers [sic] Day. A day for greetings and messages of love and respect to mothers. There is not a mother in Canada...no, nor in the whole world who wants to see her sons and daughters go to war [...] Peace is the supreme gift for us to offer the mothers of this city." ${ }^{209}$ Implying that there was nothing that mothers wanted more than peace, Park's speech echoed the message that a mother's love for a child automatically conditioned women against war. Out of respect for the original intention of the holiday to be a day for the promotion of peace and as a symbol of their devotion to the cause by spending the day "separated from their families," Canadian women regularly staged peace vigils on Mother's Day into the 1960s. ${ }^{210}$

The perpetuation of these sorts of associations of femininity, motherhood and pacifism was underscored throughout the early 1960s in North America by public opinion polling that regularly suggested women were more interested in a world without war than were men. Wittner found "remarkable consistency" in American public opinion surveys regarding nuclear weapons that divided responses by sex. ${ }^{211}$ In a series of polls conducted between June 1961 and March 1962, Wittner noted a gender gap of between seven and 15 per cent, in which women expressed a greater fear of radioactive fallout, more worry over a potential nuclear war, and less approval of nuclear testing than did men. ${ }^{212}$

Though there were far fewer Canadian polls related to nuclear arms and war that were divided by sex, similar results can be found in Canadian examples. A 29 July 1961 survey found that 54 per cent of women were very or fairly worried about the possibility

\footnotetext{
${ }^{209}$ L.C. Park, "Maple Leaf Gardens, May 11 1952, Collections Appeal,” LAC, James Endicott and Family fonds, MG30-C130, vol. 16, file 311, 2.

210 "Manitoba Peace News," ca. summer 1962, LAC, James G. Endicott and Family fonds, MG30-C130, vol. 19 , file $362,1$.

${ }^{211}$ Wittner, "Gender Roles and Nuclear Disarmament Activism," 202.

${ }^{212}$ Wittner, "Gender Roles and Nuclear Disarmament Activism," 202-203.
} 
of another "all-out war," while 43 per cent of men expressed the same level of concern. ${ }^{213}$ When asked if the Canadian forces should be armed with nuclear weapons in November 1961, 54 per cent of women supported such a move, while 67 per cent of men approved. $^{214}$ With 11 and 13 per cent gender gaps, these two studies match Wittner's findings for American polls, supporting his contention that opinion surveys demonstrate a “disproportionately female concern about the Bomb," which likely flowed from “conventional assumptions about women's maternal nature."215

However, the last of the three Canadian Institute of Public Opinion surveys addressing the sentiments of men and women related to nuclear weapons was out of step with Wittner's conclusions. The December 1962 survey, which came on the heels of the October 1962 Cuban Missile Crisis, resulted in 55 per cent of women expressing support for nuclear arms for Canadian forces, a response consistent with the survey from the year before. Notably, approval among men dropped from 67 per cent to 54 per cent. ${ }^{216}$ Wittner would have been unable to locate such a change in American opinion, as the latest relevant survey he located was from March 1962, well before the tense 13-day confrontation in October between the United States and the Soviet Union over the deployment of Soviet ballistic missiles in Cuba. Regrettably, with no subsequent poll

\footnotetext{
213 "Majority see no threat of nuclear war just now: Optimism is down slightly from three years ago, but is still very high,” 29 July 1961, in Gallup Report 1960-61 (Toronto: Canadian Institute of Public Opinion, 1961), 2.

214 "Majority say army should be given nuclear weapons: This is verdict among those who know something about the controversy," 18 November 1961, in Gallup Report 1960-61 (Toronto: Canadian Institute of Public Opinion, 1961), 2.

${ }^{215}$ Wittner, "Gender Roles and Nuclear Disarmament Activism," 204.

216 "Majority Say Our Forces Should Have Nuclear Arms: The ratio is 5 in favor to 3 against the idea. Women approve more than men," 22 December 1962, in Gallup Report 1962 (Toronto: Canadian Institute of Public Opinion, 1962), 2.
} 
divided by sex to serve as a comparison, it is impossible to say whether the missile crisis had a significant long-term impact on this gap.

While this single poll calls into question Wittner's argument for a consistent gender gap in public opinion on nuclear weapons, it demonstrates continuity in the approaches of women towards nuclear arms and war. The gender gap was reduced not by a change in women's responses, but by a growing disapproval among Canadian men for the arming of Canadian forces with nuclear weapons. Polls then do appear to corroborate the assumption that there is something unique about the relationship between women and war.

\section{Motherhood as a political tool}

Since the 1990s feminist historians have argued that women were not necessarily acting for peace because they were mothers, but that they deliberately used their maternity to gain access to the political realm. According to this understanding of the naturalized association between women and pacifism, women peace activists are said to have chosen the rhetoric of motherhood as a conscious political tool. ${ }^{217}$ Emphasizing their status as mothers allowed women to express anger with the political system while maintaining credibility and the self-image of moral superiority that was the basis for many nineteenth- and early twentieth-century women's peace groups. ${ }^{218}$ Motherhood proved to be a powerful political identity in an environment where peace activists were

${ }^{217}$ Swerdlow, Women Strike for Peace, 1, 10; Alonso, Peace as a Women's Issue, 11-12; Helen Laville, "The Memorial Day Statement: Women's Organizations in the 'Peace Offensive," Intelligence and National Security 18(2) (June 2003): 207-208.

${ }^{218}$ Swerdlow, Women Strike for Peace, 3, 73, 235; Alonso, Peace as a Women's Issue, 264; Laville, "The Memorial Day Statement," 207-208. 
subject to "red tagging," which could have devastating effects on recruitment and on the public reception of anti-nuclear messages. ${ }^{219}$

Women Strike for Peace, which shared many of VOW's values, found that maternal language was easier for those outside peace movements and those in power to understand and accept, given women's assumed innate desire to save "the lives of their children and the children of the world." ${ }^{220}$ Furthermore, this was a female language, unlike the languages of political or civil rights, which had been the monopoly of men. ${ }^{221}$ The motherhood theme, then, made it possible for women to engage in highly political activity, and to access the traditionally masculine realms of national defence and foreign affairs, using a socially acceptable cover. ${ }^{222}$

Mary Endicott, the wife of James Endicott, the long-serving chairman of the CPC, was very aware of the political power of her motherhood. When writing a letter to Lester Pearson, an old friend, Endicott asked if he thought her to be a dangerous character. And if so, she replied: “I just can't understand how a person like yourself could come to that conclusion, but the risk is much less than to do nothing to save my children, and all children, from the nightmare of war."223 For Endicott, her position as a mother justified any and all action she took to promote peace.

The basis of the national efforts of the VOW was that "One of the greatest horrors of being a mother at this time is the certain knowledge that, if war comes, we are

\footnotetext{
${ }^{219}$ Laville, "The Memorial Day Statement," 207; Whitaker and Marcuse, Cold War Canada, 4.

${ }^{220}$ Laville, "The Memorial Day Statement," 207-208.

${ }^{221}$ Swerdlow, Women Strike for Peace, 235.

${ }^{222}$ Alonso, Peace as a Women's Issue, 11-12; Brookfield, Cold War Comforts, 7.

${ }^{223}$ Mary Endicott to L. B. Pearson, 20 April 1951, LAC, Lester B. Pearson fonds, MG26-N1, vol. 4, file: Pre 1958 Open Series Pearson, L.B., Endicott, Mrs James-1947-1951, 1.
} 
powerless to protect our children." 224 According to VOW, with the advent of the atomic bomb, mothers had to rely on governments to act in the interests of their children. As one mother expressed it in a letter to Pearson in January 1963, "surely a mother has a right and a strong say in the matter of whether her children live or die — when it is within our power to prevent their death." 225 In a world where the dangers exceeded the ability of mothers to protect their children, VOW women argued it was imperative that the government take into account the opinions of mothers when it came to foreign policy decisions, for the good of the country's future.

The theme of motherhood was important in the fight to attain respectability in a context where the term "peace" was widely associated with "communism." 226 In this environment, the majority of peace organizations, but most specifically VOW, prioritized a clean public image. In the 1960 s VOW members expressed concern that public demonstrations and marches would be perceived as "unladylike," and would undermine their reputation as non-threatening, civic-minded homemakers. For that reason, VOW organizers preferred silent vigils, scheduled meetings with politicians, reading groups, and guest lectures. ${ }^{227}$

VOW members also emphasized their identity as middle-class mothers to assuage fears of militancy. As demonstrated in Images 1 and 2, VOW women dressed appropriately for the occasion, wearing hats and gloves when meeting the prime minister.

\footnotetext{
${ }^{224}$ Josephine Davis to Lester B. Pearson, 12 June 1960, LAC, Lester B. Pearson fonds, MG26-N2, vol. 91, file: External Affairs Voice of Women 2, 9.

${ }^{225}$ Fran Hill, letter to Lester B. Pearson, January 31, 1963, LAC, Lester B. Pearson fonds, MG26-N2, vol. 50 , file 806.2 part $4,1-2$.

${ }^{226}$ Laville, "The Memorial Day Statement," 207.

${ }^{227}$ Kay Macpherson, "Persistent Voices: Twenty-Five Years with the Voice of Women," Atlantis 12(2) (Spring 1987): 71; Early, "Canadian Women and the International Arena," 26; Early, "'A Grandly Subversive Time,", 254.
} 
They also brought children in baby carriages to public demonstrations so that their status as mothers remained predominant. ${ }^{228}$ On one occasion, VOW women carried children with them as they waited patiently outside Prime Minister Diefenbaker's office for hours, hoping to say hello. ${ }^{229}$ RCMP surveillance notes confirm that VOW was successful in maintaining its desired image even during "unladylike” marches, as Cst. T. M. Quilley’s record of a November 1962 VOW march to Parliament Hill remarked several times that the women conducted themselves in an "orderly fashion" throughout the day. ${ }^{230}$ Their identification as mothers and "respectable" middle-class women in public presentations effectively illustrated that VOW members "had no desire to challenge the malecontrolled Canadian political system."231

Voice of Women attracted many women who had interests in peace activism, but who had been hesitant to join organizations like the CPC because of the taint of communism. As Mrs. E. F. Squires had exclaimed, "I am delighted that, at least, there are organizations in formation for peace which can no longer be smeared with the word 'Communism.' I believe that has held many people from taking a stand against war."232

\footnotetext{
${ }^{228}$ See Images 1 and 2. Simonne Monet-Chartrand, Les Québécoises et le mouvement pacifiste (1939-1967) (Montreal: Les Éditions Écosociété, 1993), 68; Ball, “The History of the Voice of Women," 75, 188; Early, "'A Grandly Subversive Time," 254; Macpherson, When in Doubt, Do Both, 105.

${ }^{229}$ J. Fisher, "Memo to the Prime Minister," 25 September 1961, University of Saskatchewan University Archives and Special Collections (USUASC), John G. Diefenbaker fonds, MG 01/XII/C/455, Diefenbaker centre row 9 , vol. $78,1,2$.

${ }^{230}$ Cst. T.M. Quilley, Royal Canadian Mounted Police Division “A,” Ottawa S.I.B., "Re: Voice of Women Canada," 5 November 1962, LAC, CSIS files, RG 146, vol. 2844, part 13, 1-2, (obtained under access to information). The same was noted of a 7 March 1962 VOW march to Parliament. (Cst. M.A. Yoblonski, Royal Canadian Mounted Police, Division “A," Ottawa S.I.B., "Re: Voice of Women - Canada," 12 March 1962, LAC, CSIS files, RG 146, volume 2844, part 7, 2 (obtained under access to information).)

${ }^{231}$ Early, "'A Grandly Subversive Time,"” 254.

${ }^{232}$ Mrs. E. F. Squires to Mrs. Davis, 21 June 1960, LAC, Voice of Women fonds, MG28-I218, vol. 1, file: correspondence re. formation of VOW June-Sept. 1960, 1. See also: Helen Borrell to Lotta Dempsey, 30 May 1960, LAC, Voice of Women fonds, MG28-I218, vol. 1, file: correspondence re. formation of VOW, May-June 1960, 2; Dorothy Tett to Lotta Dempsey, 23 June 1960, LAC, Voice of Women fonds, MG28I218, vol. 1, file: correspondence re. formation of VOW, June-Sept. 1960, 1-2.
} 
The maternal, middle-class persona put forward by VOW women forestalled attempts to label, and thus dismiss, the group as communist. Even on the few occasions after 1963 when VOW protests used more radical tactics, their political use of motherhood allowed VOW women to challenge their critics on the grounds that they were merely mothers serving the needs of children. ${ }^{233}$

Though WSP and VOW representatives were regularly in communication and shared ideas and methods, WSP generally took a more outwardly militant stance than did VOW. ${ }^{234}$ VOW women often spoke of mass demonstrations as inappropriate and celebrated their work as mothers. In comparison, WSP's signature action involved thousands of women refusing to engage in "women's work" in the home, declaring themselves "on strike" and engaging in large-scale public protests. ${ }^{235}$ In 1962, after only a year of activity, WSP was called before the House Un-American Activities Committee (HUAC), a House of Representatives investigative committee established to root out communists. WSP women led a national campaign of public protest against HUAC, which they brought into the hearing itself, undermining the authority of committee members with testimonies full of humour and defiance. ${ }^{236}$ By the end of the hearing WSP

\footnotetext{
${ }^{233}$ Brookfield, Cold War Comforts, 7; Cst. L.E.J. MacIsaac, Royal Canadian Mounted Police, Division "O," Toronto S.I.B., "Re: Voice of Women (Communist Activities Within) Toronto, Ontario," 29 May 1963, LAC, CSIS files, RG 146, vol. 2844, part 16, 1 (obtained under access to information).

${ }^{234}$ See for example: Unknown to Mrs. C. B. Macpherson, 12 December 1962, LAC, Voice of Women fonds, MG28-I218, vol. 1, file: correspondence re. meetings and conferences 1962, 1; "Report on Women's NATO Peace Conference, The Hague, Netherlands, May 12-14 1964," LAC, Voice of Women fonds, MG28-I218, vol. 1, file: $4^{\text {th }}$ Annual meeting minutes and proceedings 1964; Kay Macpherson to WSP, 8 Feb 1966, LAC, Voice of Women fonds, MG28-I218, vol. 20, file: telegrams Canadian and foreign 19651973.

${ }^{235}$ The first such strike occurred on 1 November 1961. Swerdlow, Women Strike for Peace, 1; "Women Strike for Peace!," 1 November 1961, LAC, James G. Endicott and Family fonds, MG30-C130, vol. 32, file $610,1$.

${ }^{236}$ Swerdlow, "Ladies' Day at the Capitol," 503-504.
} 
had captured "the sympathy and the support of large sections of the national media," marking "the beginning of the end of the committee's power." ${ }^{237}$

Though VOW leaders voiced their support of WSP and criticized HUAC's persecution of the organization, VOW generally did not seek to attract public attention with the same determination as its American cousin. ${ }^{238}$ While WSP gained great public popularity for its willingness to challenge the legitimacy of HUAC and by extension the American security state, VOW members were generally reluctant to take any position that could be seen as critical of the federal government and the existing political system. The VOW executive was so determined to maintain a collegial relationship with the Canadian government that it severed all formal ties to the Canadian Committee for the Control of Radiation Hazards (CCCRH) and its founder Mary Van Stolk over "Van Stolk's generally critical attitude towards the Canadian Government policy with regard to nuclear arms. ${ }^{239}$

While WSP's noisy approach helped the organization win the affections of some of the American press, VOW's quieter methods won it greater favour with Canadian legislative authorities. Once the tide of public opinion began to turn towards nuclear arms control in the early 1960s, American President John F. Kennedy spent many hours with Norman Cousins of the mixed-sex group, the National Committee for a Sane Nuclear Policy (SANE), but repeatedly refused to meet with anyone from WSP. Wittner has

\footnotetext{
${ }^{237}$ Swerdlow, "Ladies' Day at the Capitol," 501, 516. See also: Swerdlow, Women Strike for Peace, 97-98; Elaine Tyler May, Homeward Bound: American Families in the Cold War Era (New York: Basic Books, Inc., Publishers, 1988), 219; Eric Bentley, Thirty Years of Treason: Excerpts from Hearings Before the House Committee on Un-American Activities, 1938-1968 (New York: Viking Press, 1971), 951.

${ }^{238}$ Unknown to Mrs. C. B. Macpherson, 12 December 1962, 1.

${ }^{239}$ Cst. L. J. Mascotto, "Re: Voice of Women (Alberta Regional Division) \& alias. Communist Activities Within," 14 March 1962, LAC, CSIS files, RG 146, vol. 2844, part 7, 1 (obtained under access to information).
} 
argued that Kennedy's shunning of WSP was indicative of the group's failure to convince American political leaders that they, as women, deserved to be political "players." ${ }^{240}$ Yet, VOW very successfully created a space for women in the Canadian political sphere.

VOW had the best relationship with Canadian politicians of any anti-nuclear organization. The group had no trouble gaining access to Prime Minister Diefenbaker and received public praise from Liberal leader Pearson and Conservative Secretary of State for External Affairs Howard Green. ${ }^{241}$ The RCMP declared that there was no threat of communist infiltration in the VOW in 1961; nevertheless, surveillance of the organization continued for years after. ${ }^{242}$

By explaining their entry into the political realm on the basis of maternal concern, VOW organizers created an image that differentiated the organization from other disarmament groups and highlighted their position as a collective of women that had hitherto been too shy, nervous or uninspired to participate in disarmament or peace activism. VOW co-founder Davis, wife of the popular television personality Fred Davis, estimated that 80 per cent of the women who had joined VOW in its early days had never

\footnotetext{
${ }^{240}$ Wittner, "Gender Roles and Nuclear Disarmament Activism," 213.

${ }^{241}$ Whitaker and Marcuse, Cold War Canada, 364; Brookfield, Cold War Comforts, 77; Loewen, "Mike Hears Voices," 24. See also: Jacqueline Dineen to Rev. Willard Uphaus, March 26 1963, LAC, James G. Endicott and Family fonds, MG30-C130, vol. 8, file 157, 1; John G. Diefenbaker, "Memorandum, re. meeting with 'Voice of Women,"” 27 September 1961, USUASC, John G. Diefenbaker fonds, MG 01/XII/C/445, Diefenbaker centre row 9, vol. 78, 1; Lester B. Pearson to Mrs. Silver, 9 August 1960, LAC, Lester B. Pearson fonds, MG26-N2, vol. 3, file 100.1, 1; Lester B. Pearson to L. P. Ferg, 21 February 1962, LAC, Lester B. Pearson fonds, MG26-N2, vol. 91, file: external affairs Voice of Women 2, 1; Mrs. Davis to Howard Green, 22 June 1960, LAC, Voice of Women fonds, MG28-I218, vol. 1, file: correspondence members of parliament re. formation 1960-1963, 1.

${ }^{242}$ Insp. D. E. McLaren, "Re: Voice of Women, Cornwall, Ontario," 9 January 1961, LAC, CSIS files, RG 146, vol. 2843, part 2, 1 (obtained under access to information); Research Section, Ottawa, "Voice of Women: May 1960 to January 1962," 8 March 1962, LAC, CSIS files, RG 146, vol. 2844, part 7, 28 (obtained under access to information); Sgt. A. G. Lawrence, "Re: Voice of Women-Canada," 28 February 1963, LAC, CSIS files, RG 146, vol. 2844, part 15, 1 (obtained under access to information).
} 
before been members of any women's organization. ${ }^{243}$ The rush of these "non-joiners" to VOW, the majority of whom were housewives with young children, helped its numbers swell within its first six months of activity. ${ }^{244}$ For many of these "non-joiners," involvement with an organization like VOW was a significant risk. Many women, Davis included, participated against the wishes of their husbands. ${ }^{245}$ VOW had presented its purposes in such a way so as to convince women who were genuinely worried about global tensions and the development of nuclear weaponry that they "could change the world." 246 The presence of "non-joiners" in the organization not only benefitted VOW in terms of membership, but also furthered "an image of naiveté and political inexperience," which established a non-threatening identity, helping the organization to gain approval and support within the world of professional politics. ${ }^{247}$

\section{Realities of motherhood}

It would however be cynical to suggest that VOW women were only exploiting their status as mothers. Motherhood was a very real part of the individual identities of activists and guaranteeing a safe and happy future for their children was their primary objective. Alonso has argued that it was the birth of her own son that helped her to understand that motherhood was not just "a convenient political tool," but a "very real emotional condition," which motivated many women to speak out against war. ${ }^{248}$

\footnotetext{
${ }^{243}$ Josephine Davis to Hazen Argue, 11 February 1961, LAC, Voice of Women fonds, MG28-I218, vol. 1, file: correspondence - members of parliament re. formation 1960-1963, 2. See also: Macpherson When in Doubt, 90.

${ }^{244}$ Macpherson, When in Doubt, 141; Ball, "The History of the Voice of Women," 135, 436; Early, "Canadian Women and the International Arena in the Sixties," 26.

${ }^{245}$ Ball, "The History of Voice of Women," 226.

${ }^{246}$ Ball, "The History of Voice of Women," 226; Macpherson, When in Doubt, 89.

${ }^{247}$ Ball, "The History of Voice of Women," 208.

${ }^{248}$ Alonso, Peace as a Women's Issue, 12.
} 
Many of the women who were attracted to the concept of VOW presented their own children as the main cause of their anxiety over the potential for nuclear disaster. Women regularly began their letters by introducing their children. In a plea to Pearson to do something to end the arms race, Mrs. William Davies identified herself as "the mother of seven children, five of whom are boys," indicating the importance of her children to the development of her belief in the serious dangers of war and nuclear fall-out. ${ }^{249}$

It was also common for women to express their support for the idea of VOW by describing a feeling of intense anxiety and hopelessness. Bette McIlvenna, a 21-year-old mother of an eight-month-old daughter, wrote of thinking of her daughter's future in the nuclear age: "every time I think that she may not have the chance to grow up I could cry." ${ }^{, 250}$ Mrs. D. Shifflett, a mother of five children, similarly expressed a great sadness when thinking about the global situation, disclosing that she had "been deeply depressed for months about the threat to our very existence." 251 A mother of two, Mrs. A. Hicks, was "scared silly," and described watching her children play outside in the sun, only to then "imagine big planes zooming over, dropping bombs and destroying all that I can now see. ${ }^{252}$ Sandra Snetsinger also evoked the image of her children playing in the sun and the knowledge that it was impossible for her to "fully relax with the sword of a

\footnotetext{
${ }^{249}$ Mrs. Wm. Davies to Mr. Pearson, 8 August 1960, LAC, Lester B. Pearson fonds, MG26-N2, vol. 3, file $100.1,1$. Many other women specifically identified themselves as mothers in their correspondence to Pearson see for example: Margaret Cotgrave to Lester Pearson, 31 August 1960, LAC, Lester B. Pearson fonds, MG26-N2, vol. 3, file 100.1, 1; Esther Radosevic to Lester B. Pearson, 23 August 1960, LAC, Lester B. Pearson fonds, MG26-N2, vol. 3, file 100.1, 1; Jocelyn Lee to Lester B. Pearson, 19 August 1960, LAC, Lester B. Pearson fonds, MG26-N2, vol. 3, file 100.1, 1; Marion Bacon to Lester B. Pearson, 4 August 1960, LAC, Lester B. Pearson fonds, MG26-N2, vol. 3, file 100.1, 1.

${ }^{250}$ Bette McIlvenna to Lotta Dempsey, 30 May 1960, LAC, Voice of Women fonds, MG28-I218, vol. 1, file: correspondence re. formation of VOW May-June 1960, 1.

${ }^{251}$ Mrs. D. Shifflett to Mrs. F. Davis, 30 November 1960, LAC, Voice of Women fonds, MG28-I218, vol. 1, file: correspondence re. formation of VOW Oct 1960-Jan 1961, 1.

${ }^{252}$ Mrs. A. Hicks to Dempsey, 1960, LAC, Voice of Women fonds, MG28-I218, vol. 1, file: correspondence re. formation of VOW May-June 1960, 1-2.
} 
nuclear war hanging over their heads. ${ }^{253}$ Eleanor Thompson, a nineteen-year-old new mother, pleaded, "I want this fear to go, to completely disappear." 254 Writing of a "cold fear" coming over her every time she thought of a nuclear war and her two young children, Merle Keys recognized that this sense of terror and helplessness was likely shared by mothers in "Russia, China, America, or any place in the world." 255 For all of these women, the possibility of nuclear war seized them with anxiety and sadness, primarily because of what such a disaster would mean for their own children.

Many of these early letters of support for VOW did not just reveal the depth of mothers' anxieties for the futures of their children, but also tied this fear to a sincere conviction that it was time they did something to assuage their feelings of dread. In response to this common sense of helplessness among Canadian women, Dempsey proclaimed in her 21 May 1960 column, "But by God I'm not going down without a fight, and I know from the letters and telephone calls I have been getting from women $[\ldots]$ that you aren't going to either." ${ }^{256}$ Maryon Pearson identified the need for women to combat this fear: "I am sure many mothers (and grandmothers) in Canada feel helpless and horror-struck under the terrible threat that hangs over us, and would be anxious and enthusiastic to do what they could to stop it." ${ }^{257} \mathrm{VOW}$, she suggested, offered an outlet for women finally to take action to overcome this shared sense of powerlessness.

\footnotetext{
${ }^{253}$ Sandra Snetsinger to Pearson, 7 August 1960, LAC, Lester B. Pearson fonds, MG26-N2, vol. 3, file $100.1,1$.

${ }^{254}$ Eleanor Thompson to Mr. and Mrs. Davis, 24 June 1960, LAC, Voice of Women fonds, MG28-I218, vol. 1, file: correspondence re. formation of VOW June-Sept. 1960, 1.

${ }^{255}$ Merle Keys to Voice of Women, 6 July 1960, LAC, Voice of Women fonds, MG28-I218, vol. 1, file: correspondence re. formation of VOW June-Sept. 1960, 1.

${ }^{256}$ Dempsey, "Private Line," 21 May 1960, 62.

${ }^{257}$ Pearson, 30 July ca. 1960, 1.
} 
Florence Aymong saw VOW as a way for women to "do anything practical" to overcome the horrors they were feeling over the nuclear threat. ${ }^{258}$ For Muriel Duggan, who had previously been a "non-joiner," VOW gave her hope that change was possible: "Thank the good Lord that there are women who can and do make their voices heard for all of us who love our children and want the world to remain for them and who just don't know what to do. ${ }^{" 259}$ Fae E. Rose also wrote about her great excitement at the formation of VOW, an idea that "left me covered with goose-flesh!" 260 VOW answered a very intense determination among Canadian women that they could no longer go on sitting down and waiting for, as Esther Young wrote, "the threat of annihilation which is implicit in the mere existence of thermo-nuclear weapons. ${ }^{" 261}$ Many Canadian women who enthusiastically joined anti-nuclear organizations did so because they felt compelled to take real steps against the threat that nuclear arms posed to the well being of their own children.

Though motherhood proved to be a motivating factor for participation, as well as a political tool that served to legitimize action, the everyday realities of motherhood often created obstacles to women's full participation in anti-nuclear activism. The CPC sometimes had to recruit new executive secretaries or function without one as young mothers tried to balance the needs of their children with their determination to ensure a safe and happy future for those same children. ${ }^{262}$ Jacqueline Dineen, who served as CPC

\footnotetext{
${ }^{258}$ Florence Aymong to Mrs. Fred Davis, 18 June 1960, LAC, Voice of Women fonds, MG28-I218, vol. 1, file: correspondence re. formation of VOW June-Sept. 1960, 1-2.

${ }^{259}$ Duggan to Dempsey, 30 May 1960, 1.

${ }^{260}$ Mrs. Walter L. (Fae E.) Rose to Mrs. Davis, 17 June 1960, LAC, Voice of Women fonds, MG28-I218, vol. 1, file: correspondence re. formation of VOW May-June 1960, 1.

${ }^{261}$ Esther Young, 13 June 1960, LAC, Voice of Women fonds, MG28-I218, vol. 1, file: correspondence re. formation of VOW May-June 1960, 1.

262 Jacqueline Dineen to Mickey Stratford, 29 December 1960, LAC, James G. Endicott and Family fonds, MG30-C130, vol. 8, file 134, 1.
} 
national executive secretary through much of the early 1960s, gave birth to her third daughter in June 1961, but was back working two days a week in the CPC office within a month, having to rely on her older daughters and a cleaning lady to help her with childcare and housework. ${ }^{263}$ Betty Hood, another CPC member, was determined to be as effective as possible before giving birth, which she knew would limit her "usefulness." Hood requested CPC financial support to serve as a delegate to a women's peace conference in Havana in December 1962 while she was seven-months pregnant with her fifth child. ${ }^{264}$ Dineen advised against Hood's participation, arguing that it would be far too exhausting for a woman in Hood's "condition" and that she was shocked that her doctor had given his approval. ${ }^{265}$ Motherhood also frequently prevented women from wanting to attend international conferences. Another potential delegate to the AllAmerican Women's Congress in Havana declined the CPC's offer to fund her also to attend a second conference in Brazil, because she could not possibly be away from her children for more than the 16 days she had already planned for the Cuban meeting. ${ }^{266}$ It was difficult for women to take on peace work outside of the home, but there was still a good deal that they were able to do. Dineen, who was cognizant of the challenges of balancing responsibilities in the home with activism, praised the resourcefulness of female Canadian peace and disarmament activists. The telephone, she argued, was a potent weapon in the hands of women who could organize rallies and other

\footnotetext{
${ }^{263}$ Jacqueline Dineen to Mrs. Fazekas, 2 August 1961, LAC, James G. Endicott and Family fonds, MG30C130, vol. 8, file 137, 1; Jacqueline Dineen to Mabel Hanway, 21 September 1961, LAC, James G. Endicott and Family fonds, MG30-C130, vol. 8, file 139, 2.

${ }^{264}$ Betty Hood to Jacqueline Dineen, 8 December 1962, LAC, James G. Endicott and Family fonds, MG30C130, vol. 8, file 149, 1 .

${ }^{265}$ Jacqueline Dineen to Betty Hood, 11 December 1962, LAC, James G. Endicott and Family fonds, MG30-C130, vol. 8, file 149, 1.

${ }^{266}$ Betty Beeching to Jacqueline Dineen, 12 December 1962, LAC, James G. Endicott and Family fonds, MG30-C130, vol. 8, file 149, 1.
} 
group activities, and educate the public by calling in to "open line" radio shows, all while staying at home. ${ }^{267}$ Voice of Women also promoted the idea that all women could make a valuable contribution to the effort for peace, despite having little time or money. ${ }^{268}$

As the number of married women in the labour force grew to nearly 50 per cent in the 1960 s, free time for many Canadian women became increasingly scarce. ${ }^{269}$ By 1971 , VOW organizers had realized that the rise in the number of working women had significantly influenced the organization's ability to operate effectively because of a lack of volunteers. ${ }^{270}$ With a number of demands on their time, mothers eager to participate in peace and disarmament activism were in need of the assistance of family or friends who were able to shoulder some of the burdens of household duties.

The support of husbands was important to married women's participation in activism. In early 1957, the CPC in Windsor found that women were hesitant to go out canvassing without their husbands' backing, for fear that a wife's public activities could have repercussions for her husband's employment. ${ }^{271}$ In similar fashion, during the 28 July 1960 organizing meeting for VOW, married women were encouraged to seek their husbands' consent before associating themselves with VOW. ${ }^{272}$ Joyce Christie of Westmount, Quebec, wrote to Quebec VOW president Thérèse Casgrain apologizing for the inactivity caused by her desire to "avoid discord in my own family," while promising

\footnotetext{
${ }^{267}$ Jacqueline Dineen, “Our Women Act for Peace,” ca. 1965, LAC, James G. Endicott and Family fonds, MG30-C130, vol. 10, file 189, 1.

${ }^{268}$ Macpherson, When in Doubt, 141-142.

${ }^{269}$ Macpherson, When in Doubt, 143; Valerie Korinek, Roughing it in the Suburbs: Reading Chatelaine Magazine in the Fifties and Sixties (Toronto: University of Toronto Press, 2000), 6-7.

${ }^{270}$ Voice of Women Ontario Council, September 1971, LAC, Voice of Women fonds, MG28-I218, vol. 22, file: National Annual Meeting 1971, 1.

${ }^{271}$ Margaret Miller and Nora Rodd to James Endicott, 25 January 1957, LAC, James G. Endicott and Family fonds, MG30-C130, vol. 6, file 102, 1.

${ }^{272}$ Ball, "The History of Voice of Women," 188-189.
} 
to put in more effort toward public education now that she had her husband's "rather reluctant" permission to use her own name in letters to the press. ${ }^{273}$

Husbands of very active VOW members had to cope with regularly coming home from work to find the house in disarray, the children at the neighbours, and no sign of dinner. For women like Kathleen (Kay) Macpherson and Peggy Hope-Simpson, cooperative and like-minded husbands were central to managing home-life and activism. ${ }^{274}$ However, as Macpherson revealed in her memoirs, not all men could handle an "unconventional, independent type of wife," and this led to a number of separations. ${ }^{275}$ Davis, who had been a key member in VOW's formation, briefly stepped down to a "supportive" role in September 1961, because her work for VOW had "nearly destroyed" her and her family life. ${ }^{276}$ By requiring women to step outside of the traditional domain of the home, peace and disarmament activism had the potential to undermine the very homes and lifestyles these women sought to protect from nuclear destruction.

\section{Questioning women's subordination}

The importance of motherhood to the identities and political activities of these women should not be read as acquiescence to women's subordination in the domestic sphere. Many activist women came to resent having their political intelligence underestimated by male activists and political leaders. Despite the longstanding assumption that women were more inclined to pacifism than men, women often struggled

\footnotetext{
273 Joyce Christie to Thérèse [Casgrain], 27 November 1962, LAC, Voice of Women fonds, MG28-I218, vol. 1, file: correspondence Josephine Davis (vice-pres) 1962, 1.

${ }^{274}$ Macpherson, When in Doubt, 142; Peggy Hope-Simpson to Jo [Davis], 24 November 1962, LAC, Voice of Women fonds, MG28-I218, vol. 1, file: correspondence Josephine Davis (vice-pres) 1962, 2.

${ }^{275}$ Macpherson, When in Doubt, 142; Macpherson, "Persistent Voices," 61.

276 Josephine Davis to Madame Casgrain, 23 September 1961, LAC, Voice of Women fonds, MG28-I218, vol. 1, file: correspondence 1961 meetings, 1.
} 
to gain recognition and found themselves in the periphery of peace work when participating in mixed-sex organizations. Men were not only the lawmakers and opinionmarkers, but also dominated the leadership of mixed-sex disarmament organizations, reflecting the convention that international relations and defence policy were male domains. ${ }^{277}$ Of the forty-eight signatories to the New York Times advertisement that introduced SANE to Americans only three were from women. ${ }^{278}$ Following SANE's lead, the press release announcing the formation of the CCCRH included the names of 45 "prominent Canadians" who supported the committee. ${ }^{279}$ Of those 45 , none were women, a surprising omission given that the first two CCCRH branches to organize, Edmonton and Montreal, were founded and led by women. ${ }^{280}$ In fact, CCCRH founder Mary Van Stolk's name did not appear anywhere in the release, as leadership of the organization was given to Hugh Keenleyside, a former senior Canadian diplomat and chairman of the British Columbia Power Commission, when the committee launched its national campaign. $^{281}$

The invisibility and absence of women in the leadership of disarmament organizations was representative of a larger gendered division of labour within mixed-sex organizations. Scholars of American and European anti-nuclear activism have found that

\footnotetext{
${ }^{277}$ Wittner, "Gender Roles and Nuclear Disarmament Activism," 197-198; Holger Nehring, Politics of Security: British and West German Protest Movements and the Early Cold War, 1945-1970 (Oxford: Oxford University Press, 2013), 7-8; Carroll, "Feminism and Pacifism," 2.

${ }^{278}$ Wittner, "Gender Roles and Nuclear Disarmament Activism," 198.

${ }^{279}$ Lawrence S. Wittner, The Struggle Against the Bomb, Vol. 2 (Stanford: Stanford University Press, 1997), 196-197.

${ }^{280}$ Mary Van Stolk first established the CCCRH in Edmonton as a mother's reading group. Shortly after, Lillian Berkowitz and Ruth Tannenbaum set up a branch in Montreal. ("Prominent Canadians Form Committee on Radiation Hazards \& Nuclear Policy," 18 January 1960, MUL, CCND fonds, SW571, box 1, file 1, 1, 5-6; Wittner, The Struggle Against the Bomb, vol. 2, 196-197; Research Section, Ottawa, "National Committee for the Control of Radiation Hazards - January 1962," 23 July 1977, LAC, CSIS files, RG 146, vol. 2844, part 13, 1 (obtained under access to information).)

${ }^{281}$ Moffatt, History of the Peace, 27.
} 
women's work in mixed-sex organizations was largely "servant" work or "feminine" labour, such as cooking, household chores, and typing. ${ }^{282}$ D. Gillian Thompson, who was active in the University of British Columbia nuclear disarmament club from 1960 to 1964, discovered that women "were not treated equally" in mixed-sex groups, as most of the planning was done by men. ${ }^{283}$ Within many mixed-sex organizations, many seemingly enlightened men, who sought to educate the government and public on how to create a more just and safe world, did not acknowledge the political value of women's experiences and of women's voices. Given the persistent underestimation of the ability of women to contribute to national security debates, it is remarkable, Wittner notes, how often and determinedly women entered the debates over the Bomb. ${ }^{284}$

The limits placed on women's participation in peace and disarmament activism caused frustration and outrage. As women became active in organizations that did not represent their feelings and interests, and did not provide them with space for meaningful participation, they began to question the hegemony of male leadership in their campaigns. The experience of sexism within peace and disarmament organizations eventually led some women to seek out sex-segregated spaces. In doing so, a "specifically female discourse" on peace and security in Western Europe and North America was created in the early 1960s. ${ }^{285}$

Prior to the formation of VOW, there were few organizational options for Canadian women interested in working for peace and disarmament. By the mid-1950s,

\footnotetext{
${ }^{282}$ Carroll, "Feminism and Pacifism," 2; Nehring, Politics of Security, 8, 125, 212.

${ }^{283}$ D. Gillian Thompson, interview with author, 12 November 2013.

${ }^{284}$ Wittner, "Gender Roles and Nuclear Disarmament Activism," 198-199.

${ }^{285}$ Simon Hall, Rethinking the American Anti-War Movement (New York: Routledge, 2012), 108; Nehring, Politics of Security, 298.
} 
the Women's International League of Peace and Freedom (WILPF), an international women's peace organization first established in The Hague in 1915, had collapsed in Canada under the pressure of the post-Second World War red scare. ${ }^{286}$ The CPC, the largest and most active secular Canadian mixed-sex organization interested in peace and disarmament in the 1950s, was enthusiastically supported by women and had a designated women's committee. ${ }^{287}$ However, the CPC suffered greatly throughout the 1950s from consistent redbaiting, which likely deterred many women from participating. By 1956, in fact, the CPC was a shadow of its former self, its membership significantly reduced and many local offices closed. ${ }^{288}$

Women had formed mothers' anti-nuclear groups in Vancouver and Edmonton as early as 1958. While the Vancouver group remained locally based, the Edmonton club expanded to become the CCCRH under the leadership of Van Stolk. ${ }^{289}$ Though Edmonton's CCRH would establish a fruitful but brief link to VOW, becoming the VOWCRH in 1960, the CCCRH lost its original identity as a mother's study group on

\footnotetext{
${ }^{286}$ Membership lists and files were destroyed in the 1950s in order to protect the anonymity of WILPF members; however, it is clear the Canadian WILPF lost much of its membership to the state-sanctioned United Nations Association of Canada in the 1940s (Brookfield, Cold War Comforts, 78, 117; Ball, "The History of the Voice of Women," 64; Huard, "The Canadian Peace Congress," 28).

${ }^{287}$ Barbara Roberts, "Women's Peace Activism in Canada," in Beyond the Vote: Canadian Women and Politics, eds. Linda Kealey and Joan Sangster (Toronto: University of Toronto Press, 1989), 293; Eva Sanderson to Miss Lotta Dempsey, 4 June 1960, LAC, James G. Endicott and Family fonds, MG30-C130, vol. 8, file 133, 1; Ethel Neilson, "Dear Friend of Peace," 17 January 1949, LAC, James G. Endicott and Family fonds, MG30-C130, vol. 1, file 1, 1.

${ }^{288}$ Roberts, "Women's Peace Activism in Canada," 294-295.

${ }^{289}$ Roberts, "Women's Peace Activism in Canada," 296; Ball, "The History of the Voice of Women," 2, 72.
} 
radiation hazards when it was established as a national organization under Keenleyside's leadership. ${ }^{290}$

When it formed in the summer of 1960, VOW responded to a growing desire among women for a space of their own, one untainted by associations with communism or radicalism, to express and combat their fears of nuclear war. ${ }^{291}$ Voice of Women's message of maternalism and sisterhood appealed strongly to Canadian women. ${ }^{292}$ Within six months of its formation, VOW expanded to 2,000 members and 10,000 newsletter subscribers, an unprecedented growth for a Canadian peace organization, especially during the summer, when most Canadian groups were largely inactive. ${ }^{293}$ VOW filled a void in Canadian women's social life. For many women who had not previously engaged in disarmament and peace activism, VOW provided the first outlet through which they could express their fears over the possibility for nuclear war.

Though its members used the same maternal language as VOW, its American cousin WSP was much more explicitly founded out of frustration with male dominance in mixed-sex organizations like SANE. ${ }^{294}$ Nevertheless, the popularity of both VOW and WSP can be seen as signs of the desire among North American women to engage in peace and anti-nuclear activism on their own terms. Women engaged in disarmament activism both inside and outside of VOW emphasized men's responsibility for the current

\footnotetext{
290 Ball, "The History of the Voice of Women," 302.

${ }^{291}$ Lotta Dempsey, "Private Line," Toronto Daily Star, 17 May 1960, 52; Brookfield, Cold War Comforts, 82-83.

292 In his comparative history of Canadian women's right- and left-wing political activism in the 1940s and $1950 \mathrm{~s}$, Brian T. Thorn similarly found that maternalist rhetoric served as a potent recruiting tool for women's political organizations, by making women's political activism appear more "mainstream" and "respectable" (Thorn, From Left to Right, Kindle Loc 152, 1506, 1530).

${ }^{293}$ Ball, "The History of Voice of Women," 135; Wittner, "Gender Roles and Nuclear Disarmament Activism,” 204; Mrs. Fred Davis to Cairine Wilson, 2 September 1960, LAC, Voice of Women fonds, MG28-I218, vol. 1, file: correspondence-members of parliament re. formation 1960-1963, 1.

${ }^{294}$ Wittner, "Gender Roles and Nuclear Disarmament Activism," 204; Swerdlow, Women Strike for Peace, 50.
} 
world situation, and thus found another justification for women's entrance into the public domain of foreign and defence policy debates.

By implying that women had a unique abhorrence of war and could be the solution if they were to join together and raise their voices, VOW activists were suggesting that "men were the problem." 295 In a letter to Prime Minister Diefenbaker's wife Olive, Irene Rowcliffe of Moncton referred to all male political leaders, including the Prime Minister, as "silly little bullies" whose wives needed to stop from "poisoning the air with their damn fool bombs and even more stupid speeches.”296 Delphine Paré similarly wrote to Lester Pearson, arguing that it was time to let women take the lead in solving the world's ills. "First of all the world cannot be saved by men alone," she contended, "you have tried, in your own way, all of you; now we the women will try in our own way, and together, we will succeed."297 Men and women had different approaches, she suggested, and it had already been made clear that the ways of men had failed to bring about a better world.

This willingness to criticize men and the desire to form women's groups was not perceived by these women as an expression of feminism. The 1990s thesis that women's participation in disarmament activism served as a bridge between first and second "wave" women's movements was largely influenced by the reliance of groups, such as VOW and WSP, on maternalist rhetoric and the resistance of such women to the label of

\footnotetext{
295 Brookfield, Cold War Comforts, 84; Dempsey, "Private Line,” 21 May 1960, 62.

${ }^{296}$ Irene Rowcliffe to Mrs. John Diefenbaker, 22 September 1961, USUASC, John G. Diefenbaker fonds, MG 01/V/F/483, Diefenbaker Centre row 1, vol. 77, 1.

${ }^{297}$ Delphine Paré to Lester B. Pearson, 9 August 1960, LAC, Lester B. Pearson fonds, MG26-N2, vol. 3, file $100.1,1$.
} 
"feminists." ${ }^{298}$ Voice of Women's organizers explicitly chose not to define their group as feminist, as they associated the term with equal rights feminist ideologies, which sought to deconstruct gender differences and were at odds with their self-identification as mother-citizens. ${ }^{299}$

Voice of Women's maternalist rationale also served an important political purpose. Voice of Women organizers not only believed in the "separate spheres" conception of gender relations, in which men and women were each seen as having their own particular contribution to make to society, but they were also very conscious of the public's distaste for more egalitarian expressions of feminism. ${ }^{300}$ As author and biographer Marcus Van Steen explained to Ray Gardner of The Star Weekly in 1963, "it should be noted that this organization is not just another militant feminist group, prepared to go to any length to prove their equality with men." ${ }^{301}$ By continuing to adhere to maternal feminist traditions, VOW maintained a degree of social respectability, which allowed women to pursue their public project for peace and disarmament.

Nevertheless, VOW activities did lead some women to question socially constructed gender roles that limited women's access to politics. Many of the women who joined VOW in 1960 had never previously been exposed to political action and initially naively accepted "what we read in the press and what our politicians and officials told us." ${ }^{302}$ But they quickly gained a political education as they learned techniques to

\footnotetext{
${ }^{298}$ Ball, "The History of the Voice of Women," 8; Wittner, "Gender Roles and Nuclear Disarmament Activism," 197; Early, "Canadian Women and the International Arena," 26; Moffatt, History of the Peace Movement, 52.

${ }^{299}$ Early, "'A Grandly Subversive Time," 254.

${ }^{300}$ Brookfield, Cold War Comforts, 92.

${ }^{301}$ Marcus Van Steen to Ray Gardner, 23 August 1963, LAC, Voice of Women fonds, MG28-I218, vol. 2, file: International Cooperation Year Conference International Cooperation Travel Mission 1962-63, 1.

302 Macpherson, "Persistent Voices," 70-71.
} 
influence public opinion and to attract favourable press attention, along with the critical thinking skills necessary to become decision-makers themselves. As Dorothy Goldin Rosenberg explained, "Voice of Women was my university before I went to university." ${ }^{303}$ Women-only organizations provided women with intellectual and political training in a non-competitive all-female environment, and enhanced many women's individual understandings of their "political and personal worth." 304

In the summer and fall of VOW's first year, women argued that their voices should be given greater consideration in Canadian politics. Dempsey's column likely inspired such responses, writing as she did in protest to those who had told her that "it is naïve, childish, immature for women to think they might succeed where the heads of governments [...] have failed." ${ }^{305}$ Edna Chamberlain's letter in support of VOW reasoned that it was "time all women stood up and were counted." 306 Nineteen-year-old Betty May praised VOW for finally being a women's organization that "doesn't underestimate the intelligence of the average housewife and her interest in the world of today and tomorrow." May complained that too many women's groups functioned on the assumption that women's "main ambition is to gossip over the card table," and thus failed to take advantage of their full potential. ${ }^{307}$ Mrs. René St. Jacques wrote VOW organizers that Canadian women too often relied on their husbands when it came to political matters, and that an organization like VOW would finally allow women to develop their own

\footnotetext{
${ }^{303}$ Dorothy Goldin Rosenberg, interview with author, 30 November 2013.

${ }^{304}$ Swerdlow, Women Strike for Peace, 9; Macpherson, "Persistent Voices," 61; Mills, The Empire Within, 129-130.

${ }^{305}$ Dempsey, "Private Line," 21 May 1960, 62.

${ }^{306}$ Edna Chamberlain to Mrs. Davis, 24 June 1960, LAC, Voice of Women fonds, MG28-I218, vol. 1, file: correspondence re. formation of VOW June-Sept. 1960, 2.

${ }^{307}$ Betty May to Mrs. Davis, 24 June 1960, LAC, Voice of Women fonds, MG28-I218, vol. 1, file: correspondence re. formation of VOW June-Sept. 1960, 1-2.
} 
political intelligence. ${ }^{308}$ Pearl Ross insisted that for too long women had "kept to the back seats while our men proceeded to prepare for our total annihilation and that of our children," and that it was about time that women got over their reluctance to use their influence. ${ }^{309}$

Frustration with a lack of consideration for women's voices in political debates was a driving force for the formation of VOW. A 1958 study by the Motivational Research Institute, commissioned by Chatelaine, argued that Canadian women had a growing thirst for knowledge, which was helping them to develop increasing social, economic and psychological independence as women and as citizens. ${ }^{310}$ Therefore, as Frances Wilcox would argue in 1963 to a conservative subgroup of VOW, by the early 1960s Canadian women had recognized that "[p]olitics today is the stuff of life—or death." ${ }^{311}$ Women were eager to educate and train themselves so that they could effectively contribute their unique female perspective to political debates.

Involvement in intellectually stimulating and politically meaningful debates also led some women to question Cold War domestic ideology, which celebrated women's roles as mothers and homemakers. ${ }^{312}$ By the mid-1960s, many Canadian women who had engaged in political activism with organizations like VOW were asking "Is this all?," the question Betty Friedan had famously posed in her 1963 work, The Feminine Mystique. ${ }^{313}$

\footnotetext{
${ }^{308}$ Mrs. René St. Jacques to Mrs. Davis, LAC, Voice of Women fonds, MG28-I218, vol. 1, file: correspondence re. formation of VOW Oct. 1960, 1-2.

${ }^{309}$ Pearl Ross to Mrs. Fred Davis, 4 October 1960, LAC, Voice of Women fonds, MG28-I218, vol. 1, files: correspondence re. formation of VOW Oct. 1960, 1.

${ }^{310}$ Korinek, Roughing it in the Suburbs, 74-76.

${ }^{311}$ Frances Wilcox to the Emergency Resolutions Delegation, 26 May 1963, LAC, Voice of Women fonds, MG28-I218, vol. 29, file: Winnipeg meeting-emergency resolutions-correspondence p. 2 1963, 1.

312 Early, "'A Grandly Subversive Time,"” 272.

${ }^{313}$ While Friedan was not well received on her Canadian speaking tours, Canadian scholars have still found evidence that Friedan's argument held for many Canadian women in the 1950s and early 1960s. J. Paul Grayson, "The 'feminine mystique' and problems of a cohort of female Canadian university students in the early 1960s," The Sixties: A Journal of History, Politics and Culture 8(1) (2015): 55-56, 68-69; Betty
} 
Peace and disarmament organizations provided women with opportunities to be active outside the home, prompting recognition of a sense of dissatisfaction and deeply buried unhappiness with their home lives. ${ }^{314}$

In a letter to the VOW executive, one woman explained that it was only in encountering VOW that she had "come alive" for the first time. Her life at home was "insufficient to keep me content," she continued, and she was determined that a VOW branch in her hometown of Oshawa would satisfy her cravings for education and action. ${ }^{315}$ The contention that family life lacked the inspiration that disarmament groups offered to women was a common theme in informal correspondence between VOW women. Macpherson urged Chris Lane at the end of the summer of 1965 to get in touch with a woman who had spent the summer with her family and wanted "intellectual stimulation." "316 Another VOW woman suggested that it was only with her VOW friends that she could have serious conversations about the world's problems. As soon as she returned home to her "soul-less family," the only topic of interest was "what's for dinner?"317 For women who had become discontented with domestic life and who had begun to look for a new sense of purpose, VOW and other peace and disarmament groups

\footnotetext{
Friedan, The Feminine Mystique (New York: W.W. Norton \& Company, 1997), 57; Macpherson, "Persistent Voices," 61; Swerdlow, Women Strike for Peace, 12-13.

${ }^{314}$ Swerdlow, Women Strike for Peace, 12-13; Friedan, The Feminine Mystique, 57; Stephanie Coontz, A Strange Stirring: The Feminine Mystique and American Women at the Dawn of the 1960s (New York: Basic Books, 2011), 18.

315 Anonymous, 10 January 1968, LAC, Voice of Women fonds, MG28-I218, vol. 21, file: Ontario correspondence 1966-1971, 1.

${ }^{316}$ Kay Macpherson to Mrs. C. Lane, 27 August 1965, LAC, Voice of Women fonds, MG28-I218, vol. 21, file: Ontario correspondence 1966-1971, 1.

${ }^{317}$ Pat to Kay, 15 March 1966, LAC, Voice of Women fonds, MG28-I218, vol. 21, file: British Columbia correspondence 1965-1967, 1.
} 
offered an opportunity to find a community of people with whom they could investigate and challenge Cold War politics.

As Canadian women began to question women's relegation to the domestic sphere and discovered a newfound confidence in women's capacity to participate in political debates, the conservative approach VOW had taken in its protests came under fire. Beginning in late 1962, VOW experienced a devastating internal rift that saw a number of important members publicly resign. This resulted in membership falling by 1964 to half of its 1962 high of 6,000 members. ${ }^{318}$ Contradicting previous interpretations of the split, Ball argued that discord in the group was not caused by Lester Pearson's betrayal of January 1963, when he announced that a Liberal government would accept nuclear arms in Canada. Rather this external political event only aggravated an existing internal disagreement over how women should best participate in politics. ${ }^{319}$

One faction, led by Josephine Davis, wanted to see VOW continue to maintain its image of respectable mother-citizens by engaging in "positive" projects, such as support for the 1965 United Nations' International Cooperation Year and correspondence with politicians and women in other countries. A second group believed that their message would only be heard and taken seriously if they participated in public demonstrations and made their dissatisfaction with the socio-political system known by breaking the law through acts of civil disobedience. ${ }^{320}$ In the fall of 1964, this second group was modestly

\footnotetext{
${ }^{318}$ Ball, "The History of the Voice of Women," 4, 480-481; Cst. L.J. Mascotto, Royal Canadian Mounted Police, Division "K," Edmonton S.I.B., "Re: Voice of Women—Canada," 21 December 1962, LAC, CSIS files, RG 146, vol. 2844, part 14, 1 (obtained under access to information).

${ }^{319}$ Ball, "The History of the Voice of Women," 4; Loewen, "Mike Hears Voices," 27-28; Patrick Nicholson, Vision and Indecision (Don Mills, Ontario: Longmans Canada Limited, 1968), 214; Josephine Davis to Mrs. K. Macpherson, 30 March 1963, LAC, Voice of Women fonds, MG28-I218, vol. 1, file: correspondence Josephine Davis 1963.

${ }^{320}$ Ball, "The History of the Voice of Women," 475. For an example of the debate see: Joan Wright to the Emergency Resolutions Delegation, 25 May 1963, LAC, Voice of Women fonds, MG28-I218, vol. 39, file:
} 
victorious, as the VOW executive ruled that individual members were free to choose whether or not to participate in non-violent public demonstrations. ${ }^{321}$ In December 1964, two VOW presidents, Casgrain and Macpherson, were arrested in Paris for trespassing on North Atlantic Treaty Organization (NATO) property. The arrests pushed even more conservative women out of the organization, completing the exodus that began in early 1963. ${ }^{322}$ Disagreements between VOW members over the use of "radical" protest methods persisted well into the 1970s, challenging the "waves" thesis, in which argues that a more progressive second "wave" overtook the more conservative first "wave" in the late 1960 s. ${ }^{323}$

It is in this divide over protest methods that Ball saw signs of a transition within VOW from first to second "wave" feminism in Canada, as some VOW women became increasingly inspired by American civil rights movements and the rising Canadian New Left. ${ }^{324}$ By stepping away from the notion of women's movement "waves," it becomes clearer that this tension over protest methods was not a uniquely women's rights issue. Around 1963, the Combined Universities Campaign for Nuclear Disarmament (CUCND) and the successor to the $\mathrm{CCCRH}$, the Canadian Campaign for Nuclear Disarmament (CCND), both experienced significant debates over the use of more radical protest methods, particularly the use of civil disobedience, which was an important tactic for

\footnotetext{
Winnipeg meeting-Emergency Resolutions - correspondence pt. 2 1963, 1-2; Kathleen Langston to Thérèse [Casgrain], 28 November 1962, LAC, Voice of Women fonds, MG28-I218, vol. 1, file: correspondence Josephine Davis (vice-pres) 1962, 1; Susan Lamontagne to Mrs. Davis, 30 November 1962, LAC, Voice of Women fonds, MG28-I218, vol. 1, file: Correspondence Josephine Davis (vice-pres) $1962,1$.

${ }^{321}$ Voice of Women, "Minutes of Executive Meeting," 19 September 1964, LAC, Voice of Women fonds, MG28-I218, vol. 23, file: council meeting minutes 1962-1967, 1-2.

${ }^{322}$ Macpherson, "Persistent Voices," 67-68; Brookfield, Cold War Comforts, 91.

${ }^{323}$ Dorothy Harrison to Clare Agrunove, 24 January 1971, LAC, Voice of Women fonds, MG28-I218, vol. 41, file: McEwen, Charlotte-correspondence, 1968-1973, 1-2.

${ }^{324}$ Ball, "The History of the Voice of Women," 4, 475.
} 
American civil rights efforts. ${ }^{325}$ The VOW split over protest methods was not then a symptom of one "wave" of women's rights efforts overcoming an older "wave," but was indicative of a much larger transition in Canadian social movements. In the early 1960s, the inspiration of the American civil rights movements and the increasing influence of the growing New Left led Canadian peace activists to question the effectiveness of their liberal protest methods. ${ }^{326}$

Though VOW was hesitant to associate itself with feminism, and many of its members were uncomfortable with more radical methods of pursuing social and political change, the organization did actively participate in many of the central campaigns of the Canadian women's movements of the 1960s and 1970s. In 1964, VOW began to argue that the circulation of information about birth control and the sale of contraceptives should be made legal. ${ }^{327}$ VOW women also led some of the key liberal feminist organizations of the mid-twentieth century. Suffragist, social democrat, and former Quebec and national VOW president Casgrain founded the Fédération des femmes du Québec in 1966, the first mass-based liberal feminist organization in Quebec. ${ }^{328}$ That

\footnotetext{
${ }^{325}$ For further elaboration on this see the chapter on Youth Activism. Dimitrios Roussopoulos, Andre Cardinal and Dan Daniels, "Open letter to all concerned peaceniks," 28 May 1964, MUL, CUCND-SUPA fonds, box 10, file: Operation St. Jean Baptiste, 1; Peter Boothroyd to Andre Cardinal, Dan Daniels and Dimitri Roussopoulos, 9 June 1964, MUL, CUCND-SUPA fonds, box 10, file: Operation St. Jean Baptiste, 1; Dick Clements, "Report of the Programme Committee of the CUCND Federal Conference," 20-22 February 1963, MUL, CUCND-SUPA fonds, box 10, file: CUCND Conference, Feb. 1963, 3; Welland Campaign for Nuclear Disarmament, "Easter Peace Walk to the Peace Bridge," 1962, MUL, CCND fonds, SW573, box 18 , file 3,1 .

${ }^{326}$ See the chapter on traditional politics for elaboration on the liberal methods preferred by Canadian antinuclear protesters in the late 1950s and early 1960s.

${ }^{327}$ Kathleen Macpherson and Elsie Saumure, "Brief Submitted by the Voice of Women of Canada to the Standing Committee on Health and Welfare," 22 March 1966, LAC, Voice of Women fonds, MG28-I218, vol. 22, file: National annual meeting (1966) minutes and background material, 1; "Resolutions, Annual Meeting, May 1965," LAC, Voice of Women fonds, MG28-I218, vol. 1, file: $5^{\text {th }}$ annual meeting reports to and lists $1965,1$.

${ }^{328}$ Mills, The Empire Within, 48; Vickers, “The Intellectual Origins of the Women's Movement in Canada," 54.
} 
same year, VOW became a member of the Committee for the Equality of Women in Canada, which was vital to the establishment of the Royal Commission on the Status of Women in Canada. ${ }^{329}$ The Royal Commission served as a national political stage for Canadian women to present demands for pay equity, equal opportunity in the workplace, the recognition of women's unpaid work in the home, an end to sex discrimination, and women's control of their own sexuality and fertility, among other things. ${ }^{330}$ VOW was an active member of the National Ad Hoc Action Committee on the Status of Women (NAC), established in 1971 as a lobby group to ensure the implementation of the recommendations of the Royal Commission, and VOW president Macpherson served as NAC president from 1977 to $1979 .{ }^{331}$

As women's rights movements in Canada gained popularity and strength in the 1970s, VOW struggled to maintain a balance between its original aims and the interests that many of its members had in promoting women's rights. In a reply to Colleen Thatcher, who was looking for information on VOW's association to the "new feminist movement," Constance Gardner, speaking on behalf of the national executive, explained that VOW was in touch with women's liberation movements. Voice of Women had indeed sent some demonstrators to Queen's Park the day before to promote the addition of "sex discrimination" to the Ontario Human Rights Code. However, Gardner added, VOW's approach was distinct from those of women's liberation movements. VOW believed that "the best way for women to attain respect and fulfilment is to involve

\footnotetext{
${ }^{329}$ Mrs. C. B. [Kay] Macpherson to the Rt. Hon. L. B. Pearson, 30 November 1966, LAC, Voice of Women fonds, MG28-I218, vol. 20, file: government correspondence 1965-1969, 1.

${ }^{330}$ Haynes, "Help for All Parents?," 57; Campbell, "'Are we going to do the most important things," 5354; Mills, The Empire Within, 122-123.

${ }^{331}$ Voice of Women, "National Action Committee on the Status of Women Report," 9 September 1973, LAC, Voice of Women fonds, MG28-I218, vol. 17, file: Status of Women 1971-1973; Luxton, "Feminism as a Class Act," 80.
} 
themselves in the problems of their times." This meant putting their energies toward ending the war in Vietnam, opposing chemical and biological weapons research, strengthening the United Nations, and preserving ecological balance. ${ }^{332}$ For VOW, the fundamental issue was not gender equality in the workplace or women's reproductive rights, but the larger matter of the threat to peace and security globally.

Still, these broad and all encompassing goals were problematic for some members. In a letter to VOW leaders, Vancouver member Joan Wright lamented the lack of a cohesive purpose in the organization by 1971. As Wright noted, "Voice of Women was formed and grew because we felt that as women who had brought children into this world we had a great responsibility to see to it that there would in fact be a world for them to live in. We abhorred war, nuclear weapons testing, and the arms race. We all agreed." ${ }^{333}$ Wright's letter made it clear that women had come together under the banner of VOW to work for peace because they shared an undisputed responsibility to ensure the safety of their children. Wright was concerned that VOW had stretched itself too thin as it expanded into activities such as helping American draft resisters and promoting legalized access to contraception. In a response addressed to all VOW members, Macpherson explained that VOW efforts were inherently tied to the organization's initial and ultimate aim, which was "a peaceful, disarmed, and just world for our children and all children." ${ }^{334}$ By tying all social activism to the wish to create a better world for children, VOW's leadership continued to reinforce its original roots in maternal feminism into the

\footnotetext{
${ }^{332}$ Constance Gardner to Colleen Thatcher, 29 April 1970, LAC, Voice of Women fonds, MG28-I218, vol. 20, file: correspondence 'S' 1968-1971, 1.

333 Joan Wright to Kay and Muriel, 5 February 1971, LAC, Voice of Women fonds, MG28-I218, vol. 21, file: British Columbia correspondence 1965-1971, 1.

${ }^{334}$ Kay Macpherson, "Memo to various persons, particularly members concerned about VOW/VdF's multitudinous activities," 16 February 1971, LAC, Voice of Women fonds, MG28-I218, vol. 21, file: British Columbia correspondence 1965-1971, 1.
} 
1970s. Maternal rhetoric continued to be important for women engaged in anti-nuclear activism well into the end of the Cold War: the American group Mothers Embracing Nuclear Disarmament became an important voice for disarmament in the 1980s, relying exclusively on a language underlining the special "nurturing, healing quality" of mothers. ${ }^{335}$

\section{Conclusion}

Participation in disarmament activism, particularly within an all-female organization, inspired many women to challenge socially constructed gender roles and to demand greater rights for women. However, reliance on a narrative of progress that sees this protest activity as ushering in a new "wave" of women's movements misses the complexities of women's relationships with feminism. Despite conventional motives and rhetoric, anti-nuclear women left their homes and engaged with the overwhelmingly male domain of national security and foreign policy. Maternalism served to support women's claims to a right to participate in political debates on the grounds that women had a special interest in peace. It also provided a language that persuaded individual women who were worried about their children's future to join in a collective effort towards disarmament.

This emphasis on a more traditional maternal feminism by female disarmers, particularly those involved with VOW, was undeniably subversive, despite its conformity to orthodox gender norms. These women used their maternal status to demand a hearing by a national security state and national political system that was still reluctant to accept

\footnotetext{
${ }^{335}$ Hugh Mehan and John Wills, "Mend: A Nurturing Voice in the Nuclear Arms Debate," Social Problems 35(4) (Oct. 1988): 368, 371.
} 
the voices of women. As a group composed of individuals who had little access to, and thus little experience in, foreign affairs and defence politics, VOW women initially had limited potential to threaten the male-dominated Cold War political system. And yet, once they stepped into the public realm, VOW women challenged the established sociopolitical order by promoting a ban on nuclear weapons and demanding an end to sex discrimination.

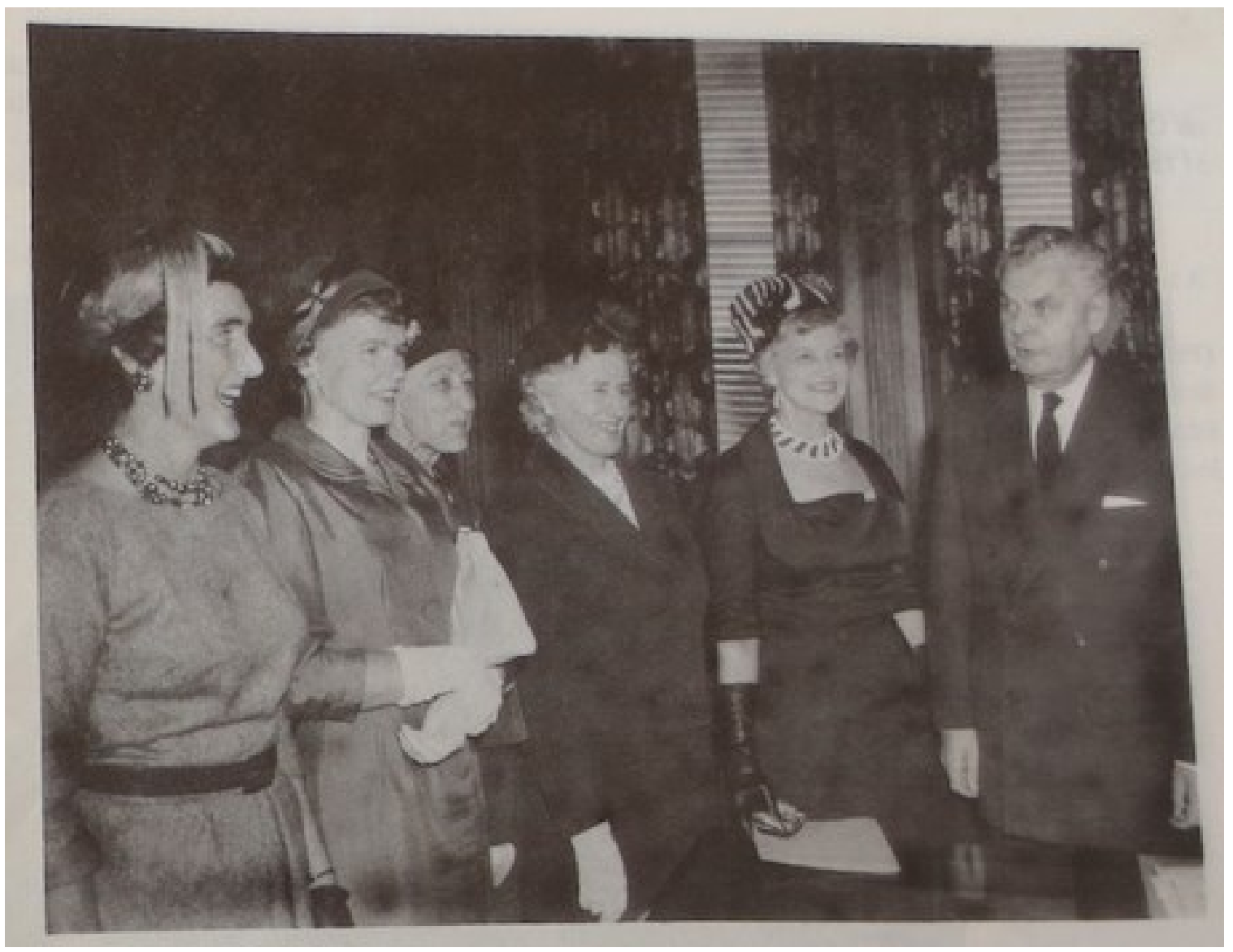

Image 1: Voice of Women executive meets with Prime Minister Diefenbaker, 26 September 1961. Photo credit: Champlain Marcil, Le Droit/Toronto Daily Star (26 September 1961), Amicus 7791748.

Voice of Women, number 14 (15 October 1961), Library and Archives Canada, Voice of Women fonds, MG28-I218, vol. 46, file: V.O.W. national newsletter 1960-1961, 9. 


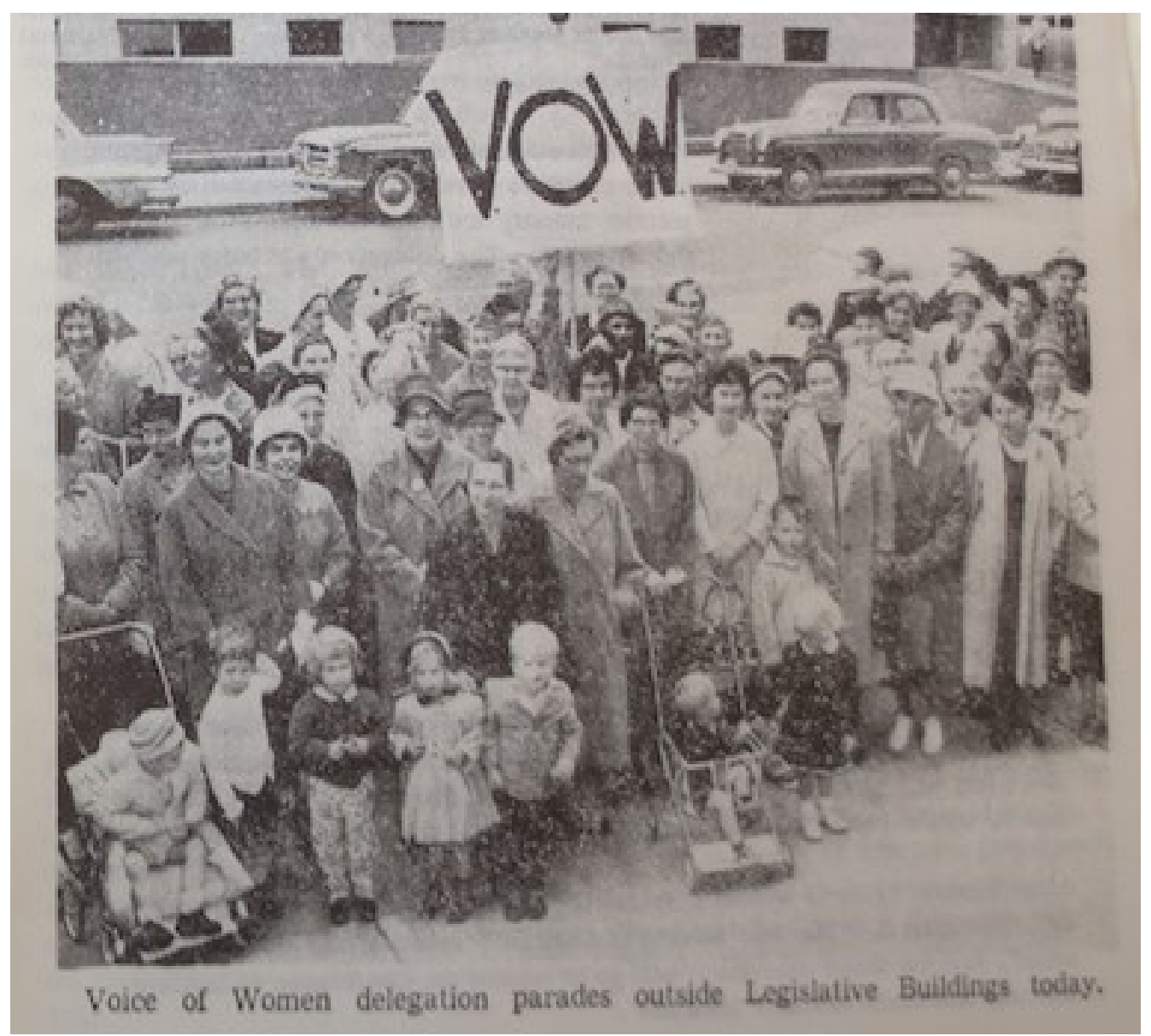

Image 2: VOW women and children outside the British Columbia legislative buildings, October 1961. Photo credit Victoria Daily Times.

Voice of Women, number 14, (15 October 1961), Library and Archives Canada, Voice of Women fonds, MG28-I218, vol. 46, file: V.O.W. national newsletter 1960-1961, 13. 


\section{Chapter Two \\ Rational, Professional Fathers: Masculinities and Disarmament Activism}

By the late 1950s, as information about advancing nuclear technology and the dangers of nuclear fallout became publicly known, it became increasingly clear to many Canadian men and women that there was "no longer any effective protection, for anyone, against today’s weapons of war." ${ }^{336}$ In a nuclear attack, women would be unable to protect children by caring for them in the home, and men could not ensure their families' safety through soldiering. ${ }^{337}$ Historian of international disarmament and peace

movements Lawrence Wittner has argued that the new realities of the nuclear age led to challenges to Cold War gender norms. ${ }^{338}$ Wittner has claimed that the menace of the Bomb turned "increasing numbers of women into political activists and of men into concerned parents." ${ }^{339}$ However, this assessment of anti-nuclear men as gender-benders was based on an out-dated and essentialist understanding of gender roles, which missed the importance of fatherhood to Cold War definitions of ideal masculinities.

The experiences of men active in anti-nuclear protests illustrate how complex and contradictory Cold War social constructions of masculinity were. Mixed-gender groups with a predominantly male presence embraced elements of "modern" masculinity through their emphasis on scientific rationalism, professional achievement, and fatherhood in their public statements. ${ }^{340}$ In the paranoid environment of the early Cold War, where

\footnotetext{
336 "Why is peace research important to you?," n.d., Library and Archives Canada (LAC), James G. Endicott and Family fonds, MG30-C130, vol. 8, file 140, 2.

${ }^{337}$ Jennifer Hunter, "Wondering if It's Even Worthwhile Doing the Dishes: Canadians and the Nuclear Threat, 1945-1963," (PhD diss. McGill University, 2000), i, 317.

${ }^{338}$ Lawrence Wittner, “Gender Roles and Nuclear Disarmament Activism, 1954-1965," Gender and History 12(1) (April 2000): 214.

339 Wittner, "Gender Roles and Nuclear Disarmament Activism,” 214.

340 Jean Bethke Elshtain, Women and War (New York: Basic Books, Inc., Publishers, 1987), 4; Tracy Xavia
} 
pacifism was discursively connected to communism, the allegiance of disarmament men to contemporary standards of hegemonic masculinity served to limit the perceived threat activists posed to the Cold War socio-political order.

Scholarly analysis of masculinities and anti-nuclear activism has been minimal, which seems surprising given the extensive literature on femininities, feminisms and women's disarmament activism. The scholarship examining "masculinity" in the late twentieth and early twenty-first centuries provides a valuable framework with which to understand the role that masculinities played in expressions of anti-nuclear protest by Canadian men. ${ }^{341}$ In the aggressively anti-communist climate of the Cold War, male disarmers were suspected of political, gender, and sexual deviance because of a Western cultural conflation of pacifism with communism and homosexuality. In order to combat this suspicion and legitimize their actions, Canadian men active in anti-nuclear organizations embraced certain aspects of Cold War hegemonic masculinity, presenting themselves as rational, informed professionals and fathers interested in establishing a more secure world.

\section{Masculinities}

Karner, "Engendering Violent Men: Oral Histories of Military Masculinity," in Masculinities and Violence, ed. Lee H. Bowker (Thousand Oaks, California: SAGE Publications, Inc., 1998), 200; Christopher Dummitt, The Manly Modern: Masculinity in Postwar Canada (Vancouver: UBC Press, 2007), 3; Robert L. Griswold, Fatherhood in America: A History (New York: Basic Books, 1993), 186; Mona Gleason, "Disciplining Children, Disciplining Parents: The Nature and Meaning of Advice to Canadian Parents, 1945-1955," Histoire Sociale/Social History 29 (May 1996): 202; Robert Rutherdale, "New 'Faces' for Fathers: Memory, Life-Writing, and Fathers as Providers in the Postwar Consumer Era," in Creating Postwar Canada: Community, Diversity, and Dissent, 1945-75, eds. Magda Fahrni and Robert Rutherdale (Vancouver: UBC Press, 2008), 253; Arlene S. Skolnick, Embattled Paradise: The American Family in an Age of Uncertainty (New York: Basic Books, 1993), 71; Herbert Sussman, Masculine Identities: The History and Meanings of Manliness (Santa Barbara, California: Praeger, 2012), 13-14.

${ }^{341}$ The Editorial Collective, "Why Gender and History?" Gender \& History 1(1) (Spring 1989): 1-2; Karen Adler, Ross Balzaretti and Michele Mitchell, "Practicing Gender History," Gender \& History 20(1) (April 2008): 2 . 
Sociologist R. W. Connell's definition of "hegemonic masculinity" has been widely accepted as the leading theory for understanding the nature and construction of masculine identities. ${ }^{342}$ Connell built off political theorist Antonio Gramsci's analysis of class relations, in which Gramsci referred to "hegemony" as the cultural dynamic by which one class establishes its moral, political, social and economic dominance over other classes. Gramscian "hegemony" is not established by force, or fear, but by mutual consent, and therefore, is weak, unstable, and always being resisted. 343 "Hegemonic" culture reproduces itself as a hybridization of appropriated and conflicting elements of subordinate cultures, allowing one group's dominance to persist throughout changing historical conditions. $^{344}$

In Connell's application of "hegemony" to gender relations, the mass media, the state and other cultural and social organizations, such as churches, promote certain models of ideal masculine conduct that are designed to maintain a patriarchal order. "Hegemonic masculinity" is not just "external" in that it serves to justify a patriarchal society; it is also "internal," explaining the social inferiority of certain other expressions of masculinity. ${ }^{345}$ Because "hegemony" is "relational," models of masculinity are always defined in contradistinction to socially constructed patterns of femininity. ${ }^{346}$ "Hegemonic

\footnotetext{
${ }^{342}$ Tony Jefferson, "Subordinating hegemonic masculinity," Theoretical Criminology 6(1) (2002): 65; Demetrakis Z. Demetriou, "Connell's Concept of Hegemonic Masculinity: A Critique," Theory and Society 30(3) (June 2001): 337; John Tosh, "Hegemonic Masculinity and the History of Gender," in Masculinities in Politics and War: Gendering Modern History, eds. Stefan Dudink, Karen Hagemann and John Tosh (Manchester: Manchester University Press, 2004), 42-43.

${ }^{343}$ R. W. Connell, Masculinities, second edition (Cambridge: Polity Press, 2005) 77; Walter L. Adamson, Hegemony and Revolution: A Study of Antonio Gramsci's Political and Cultural Theory (Berkeley: University of California Press, 1983), 174; Erica Fraser, "Masculinity in the Personal Narratives of Soviet Nuclear Physicists," Aspasia 8 (2014): 48.

${ }^{344}$ Demetriou, "Connell's Concept of Hegemonic Masculinity," 355; R. W. Connell and James W. Messerschmidt, "Hegemonic Masculinity: Rethinking the Concept," Gender and Society 19(6) (2005): 845.

${ }^{345}$ Connell and Messerschmidt, "Hegemonic Masculinity," 844.

${ }^{346}$ Connell and Messerschmidt, "Hegemonic Masculinity," 848.
} 
masculinity" does not represent a certain type of man, but is a way that men positioned themselves strategically, based on their own aspirations and needs; this makes it possible for men to transition between various classes of masculinity. ${ }^{347}$

Canadian men active in disarmament organizations often embodied many of the characteristics of Cold War "hegemonic masculinity." Despite the Canadian security state's distrust of peace activism, male disarmers were only rarely expelled from the brotherhood of "legitimate" men. The presence of Canadian activists in the realm of "acceptable" masculinities was made possible by the dynamic and contradictory models of masculinity presented to Cold War Canadians.

Women involved in twentieth-century peace and disarmament movements called upon the Western tradition that equated women with pacifism to naturalize their activism. Yet the flipside of this nineteenth-century tradition, which constructed men as warriors, proved problematic for men opposed to war and violence. ${ }^{348}$ As Jens Petter Kollhoj, a historian of Norwegian pacifism, has observed, "Throughout history interrelations between soldiering and notions of 'being a man' have been firm and persistent. Men who openly criticize the military and war have risked severe punishment and cultural stigmatization as 'cowards' and 'unmanly." ${ }^{, 349}$ By this understanding, violence was intrinsic to "man." 350

The characterization of masculinity as violent has become further entrenched for historians in the context of war, when nationalisms were often closely connected to a

\footnotetext{
${ }^{347}$ Connell and Messerschmidt, "Hegemonic Masculinity," 841.

${ }^{348}$ Elshtain, Women and War, 4.

349 Jens Petter Kollhoj, "Socialist Antimilitarist Manliness: Visual Representations and Normativity in Norway Circa 1914," Peace \& Change 34(2) (April 2009): 208.

${ }^{350}$ Elshtain, Women and War, 3-4.
} 
"hegemonic masculinity" defined by an equation of "man" with "soldier." In the case of First World War Britain, conscientious objectors were publicly condemned as shirkers, traitors, cowards, effeminates and sexual deviants. Despite the fact that only one-third of one per cent of all men recruited or conscripted into the British military refused to serve for reasons of conscience, these men "created more public bitterness and caused more governmental problems than any other single group. ${ }^{351}$ Similarly, in Canada and in the United States during and following the First World War, pacifists and conscientious objectors were labelled by the general public and the military establishment as effeminate and dishonourable for what was perceived as their unwillingness to face risk. ${ }^{352}$ Men anxious about the possibility of a third world war in the late 1950s and 1960s were working against an established assumption that a man who would not demonstrate courage and a willingness to sacrifice his life for his country was not really a man.

Wittner based his assessment of the gender non-conformity of American male disarmers on the understanding that to be an American man "was to show an unfailing readiness to fight and die for one's country." ${ }^{353}$ But this conception is at odds with other scholarly surveys of North American Cold War masculinities. The hypermasculinization

\footnotetext{
351 Thomas C. Kennedy, "Public Opinion and the Conscientious Objector, 1915-1919," The Journal of British Studies 12(2) (May 1973): 106. See also, John W. Chambers, "Introduction," in Conscription and Conscience: A History 1916-1919, by John W. Graham (New York, London: Garland Publishing, Inc., 1971), 5; Tosh, "Hegemonic Masculinity and the History of Gender," 49; Sonya O. Rose, "Temperate heroes: concepts of masculinity in Second World War Britain," in Masculinities in Politics and War: Gendering Modern History, eds. Stefan Dudink, Karen Hagemann and John Tosh (Manchester: Manchester University Press, 2004), 189; Deborah Cohler, "Sapphism and Sedition: Producing Female Homosexuality in Great War Britain," Journal of the History of Sexuality 16(1) (January 2007): 79; Samuel Hynes, A War Imagined: The First World War and English Culture (New York: Collier Books, 1990), 232.

${ }^{352}$ Elizabeth McKillen, "Pacifist Brawn and Silk-Stocking Militarism: Labor, Gender, and Antiwar Politics, 1914-1918," Peace \& Change 33(3) (July 2008): 391; Timothy Stewart-Winter, "Not a Soldier, Not a Slacker: Conscientious Objectors and Male Citizenship in the United States during the Second World War," Gender \& History 19(3) (November 2007): 519, 523; Dummitt, The Manly Modern, 35; Amy J. Shaw, Crisis of Conscience: Conscientious Objection in Canada During the First World War (Vancouver: UBC Press, 2009), 8.

${ }^{353}$ Wittner, "Gender and Nuclear Disarmament Activism," 206.
} 
of Nazi Germany, the experience of the Second World War, and the new uncertainties of the Cold War all led to revisions of definitions of masculinity beginning in the 1940s across the West. ${ }^{354}$ In the United States and Canada, the early decades of the Cold War were marked by a transition from "traditional" masculinity, which emphasized physical strength, aggression, and stoicism, to a "modern" masculinity that valued economic and professional achievement, risk management, rationalism, and nurturing fatherhood. ${ }^{355}$ In this age of transition, the ideology of the warrior male was often at odds with the value of the family man, with soldiering increasingly becoming a temporary duty as opposed to an essential identity. ${ }^{356}$

At the beginning of the Cold War, American and Canadian men found themselves facing what social scientist Michael Kimmel has called the "Goldilocks Dilemma," in which ideal masculinity was constructed as a delicate balance between strong, aggressive, daring hypermasculinity, and rational, responsible, sensitive hypomasculinity. ${ }^{357}$ To complicate the situation further, Canadian historian Christopher Dummitt has added that the "Goldilocks Dilemma" of the early Cold War also required men to straddle the line between conformity and rebellion in order to combat the emasculating boredom and uniformity of mid-twentieth-century corporate and suburban life. ${ }^{358}$ The murkiness of Cold War models of masculinity made it possible for men active in disarmament organizations to live within the bounds of socially "legitimate" masculinities, as they

\footnotetext{
${ }^{354}$ Rose, "Temperate heroes," 177; Gleason, "Disciplining Children," 202.

${ }^{355}$ Karner, "Engendering Violent Men," 200; Dummitt, The Manly Modern, 3; Griswold, Fatherhood in America, 186; Gleason, "Disciplining Children," 202; Rutherdale, "New 'Faces' for Fathers," 253.

${ }^{356}$ Skolnick, Embattled Paradise, 71; Sussman, Masculine Identities, 13-14.

${ }^{357}$ Michael Kimmel, Angry White Men: American Masculinity at the End of an Era (New York: Nation Books, 2013), 51; Dummitt, The Manly Modern, 97.

${ }^{358}$ Dummitt, The Manly Modern, 89. See also Michael Kimmel, Manhood in America: A Cultural History (New York and Oxford: Oxford University Press, 2012), 175.
} 
rebelled against the Cold War while prioritizing the qualities of rationalism,

professionalism, and concerned fatherhood.

\section{Peace activism, homosexuality, and communism}

The complicated nature of Cold War "hegemonic masculinity" created space for Canadian disarmers to participate in activism, while still behaving within the confines of “acceptable" masculinities. Still, their anti-nuclear stance brought them precariously close to "subordinate" behaviours. In all of the confusion of what it meant to be a man in Cold War North America, the only real certainty was what the ideal man was not. ${ }^{359}$ The ambiguity of "hegemonic masculinity" was clarified as it was firmly placed in opposition to the "dangerous" masculinities associated with homosexuals, communists and "irresponsible beatniks." 360 In Connell's theory of "hegemonic masculinity," homosexual masculinities are located "at the bottom of a gender hierarchy among men," because of associations of homosexuality with feminine behaviours. ${ }^{361}$ A long-standing Western presumption of women's biological inclination towards pacifism also attributed feminine qualities to pacifist men. ${ }^{362}$ Along these lines, pacifist men could also fall within the boundaries of "subordinate masculinities."

\footnotetext{
${ }^{359}$ It must be noted that this transition from "traditional" to "modern" masculinity swung towards "modern" masculinity much earlier for the middle-class than it did for working-class men who held onto "traditional" notions of masculinity longer. However, given the predominantly middle-class identity of anti-nuclear movements, this chapter will focus on understandings of middle-class masculinity in the early decades of the Cold War. See Karner, "Engendering Violent Men," 200; Nehring, The Politics of Security, 215-216.

${ }^{360}$ Kimmel, Manhood in America, 171, 175. See also: Mary Louise Adams, The Trouble with Normal: Postwar Youth and the Making of Heterosexuality (Toronto: University of Toronto Press), 9-10, 23.

${ }^{361}$ Connell, Masculinities, 78.

${ }^{362}$ Elshtain, Women and War, 4; Rhodri Jeffreys-Jones, Changing Differences: Women and the Shaping of American Foreign Policy 1917-1994 (New Brunswick, New Jersey: Rutgers University Press, 1995), 10; Bernice A. Carroll, "Feminism and Pacifism: Historical and Theoretical Connections," in Women and Peace: Theoretical, Historical and Practical Perspectives, eds. Ruth Roach Pierson, Joanne Thompson, Somer Bodribb and Paula Bourne (London, New York: Croom Helm, 1987), 3; Harriet Hyman Alonso,
} 
The masculinity of anti-nuclear men was most often deemed suspect because of the associations of peace activism with such "subordinate" masculinities as communism and homosexuality. During the First World War in Britain, "two home-front wars" against pacifists and homosexuals came together. ${ }^{363}$ A wartime cultural nexus of homosexual, pacifist artists, centred on musicologist Edward Dent at Cambridge University stood as proof for authorities of some inherent connection between homosexuality and pacifist beliefs. ${ }^{364}$ In this context, pacifist rhetoric and homosexuality were deemed to be equally offensive under the British First World War Defence of the Realm Act, instituted to prosecute activities perceived to be detrimental to the national war effort. ${ }^{365}$

While the affiliation of pacifism with homosexuality was not new, this discursive relationship took on new importance in the context of Cold War anti-communism. ${ }^{366}$ When the Soviet Union launched its "peace offensive" in 1953, proclaiming the principle of peaceful coexistence to be the cornerstone of Soviet foreign policy, the word "peace" became inseparable from "communism" in the Western world. ${ }^{367}$ By associating all who promoted the idea of peaceful coexistence and challenged the notion that security could

Peace as a Women's Issue: A History of the U.S. Movement for World Peace and Women's Rights (Syracuse: Syracuse University Press, 1993), 11.

${ }^{363}$ Hynes, A War Imagined, 232

${ }^{364}$ Karen Arrandale, "Artists' rifles and artistic licence: Edward Dent's war," First World War Studies 2(1) (March 2011): 8; Cohler, "Sapphism and Sedition," 79.

${ }^{365}$ Hynes, A War Imagined, 234.

${ }^{366}$ Tosh, "Hegemonic masculinity and the history of gender," 46.

${ }^{367}$ Reg Whitaker and Gary Marcuse, Cold War Canada: The Making of a National Insecurity State, 19451957 (Toronto: University of Toronto Press, 1994), 364, 365; Steve Hewitt, "Sunday Morning Subversion: The Canadian Security State and Organized Religion in the Cold War," in Love, Hate, and Fear in Canada's Cold War, ed. Richard Cavell (Toronto: University of Toronto Press, 2004), 67; Helen Laville, "The Memorial Day Statement: Women's Organizations in the 'Peace Offensive," Intelligence and National Security 18(2) (June 2003): 207. 
be guaranteed by nuclear deterrence with communism, Western governments "virtually silenced" opposition to the Cold War. ${ }^{368}$

Furthermore, Canadian government officials, medical experts and national security officials emphatically believed in a direct link between communism and "sexual depravity." 369 The logic was two-sided. Experts presumed that the weakness, instability and immorality attributed to homosexuals would make them vulnerable to blackmail and trickery by communists, and that communists, who were characterized as spineless, erratic, immoral dupes, would tend toward homosexuality. ${ }^{370}$ In the environment of Cold War paranoia, "queers and communists were seen as fellow travellers in right-wing Cold War discourse" for their joint transgression of "sexual, class, social and political boundaries." 371

Demonstrators in the United States connected to the Committee for a Sane Nuclear Policy (SANE) were regularly harassed as "commies" and "fags." 372 In Canada, anti-communist insults such as "commie stooge," "dead-head-red," and "red bastard" were regularly thrown at the Canadian Peace Congress (CPC), a national peace group established in 1949 that had ties to international communism. ${ }^{373}$ The Western Canadian

\footnotetext{
${ }^{368}$ Robbie Lieberman, The Strangest Dream: Communism, Anticommunism, and the U.S. Peace Movement, 1945-1963 (Syracuse: Syracuse University Press, 2000), xv-xvi.

${ }^{369}$ Gary Kinsman and Patrizia Gentile, The Canadian War on Queers: National Security as Sexual Regulation (Vancouver: UBC Press, 2010), 7; Steve Hewitt, Spying 101: The RCMP's Secret Activities at Canadian Universities, 1917-1997 (Toronto: University of Toronto Press, 2002), 53-54.

${ }^{370}$ Kinsman and Gentile, The Canadian War on Queers, 7; Hewitt, Spying 101, 53-54; Kimmel, Manhood in America, 171; Adams, The Trouble With Normal, 24-25.

${ }^{371}$ Kinsman and Gentile, The Canadian War on Queers, 8.

${ }^{372}$ Wittner, "Gender Roles and Nuclear Disarmament Activism," 207.

${ }^{373}$ Pat Walsh, "The Truth Will Out," The South End News, 14 December 1961, LAC, James G. Endicott and Family fonds, MG30-C130, vol. 64, file 1330, 4; "Prime Minister Heeds 'Ban-the-Bombers," The South End News, 29 November 1962, LAC, James G. Endicott and Family fonds, MG30-C130, vol. 64, file 1330, 1; "Joe 'Red' Commie, Pete 'I hate people' Mush, Dead-head-red," LAC, James G. Endicott and Family fonds, MG30-C130, vol. 16, file 322, 1; L.G. Arvay to James Endicott, 26 December 1964, LAC, James G. Endicott and Family fonds, MG30-C130, vol. 10, file 187, 1.
} 
executive of the student-run Combined Universities Campaign for Nuclear Disarmament (CUCND) found that one of the largest hurdles keeping young men from joining campus disarmament organizations was the fear that their friends would think they were "queers." 374 As one angry anti-communist threatened Toronto CPC members, "you jerks don't need protection from the Hydrogen Bomb but from the average 'Canadian,' which you definitely are not." ${ }^{375}$ Canadian disarmament men often found themselves treated as outsiders by those who remained devoted to the Cold War and nuclear deterrence.

Despite the public association of pacifism with homosexuality, American historian Simon Hall has found that there was little cooperation between gay liberation and antiwar movements in the United States in the 1960s. With both groups keen to maintain a "respectable" image, and both attracting their own communist controversies, they tended to keep a distance from one another. Gay activists interested in disarmament and peace activism also found that there was a serious issue with homophobia within the heterosexual peace movement. ${ }^{376}$ While such research has yet to be done for the Canadian context, it is clear that heterosexuality was an important identity marker for Canadian disarmament organizers, given how consistently they advertised their respect for the ideal of the Cold War nuclear family. ${ }^{377}$

In an era when gender failure was considered a threat to the democratic nation, the assumed masculine inadequacy of male disarmers served to justify state surveillance

\footnotetext{
374 “CUCND Western Consultation,” 28-29 September [ca. 1963], The William Ready Division of Archives and Research Collections, McMaster University Library (MUL), CCND fonds, box 9, file 13, 2. 375 "Dear Mr. M.P.," ca. March 1954, LAC, James G. Endicott and Family fonds, MG30-C130, vol. 18, file $339,1$.

${ }^{376}$ Simon Hall, Rethinking the American Anti-War Movement (New York: Routledge, 2012), 110-111.

${ }^{377}$ Nancy Christie, "'Look out for Leviathan': The Search for a Conservative Modernist Consensus," in Cultures of Citizenship in Post-War Canada, 1940-1955, eds. Nancy Christie and Michael Gauvreau (McGill-Queen's University Press, 2003), 65, 73; Magda Fahrni, Household Politics: Montreal Families and Postwar Reconstruction (Toronto: University of Toronto Press, 2005), 22-23.
} 
and to delegitimize their anti-nuclear endeavours. Into the 1960s, the state and the Royal Canadian Mounted Police (RCMP) considered communism to be the single most important threat to national security, leading the RCMP to track the activities of peace groups and individual peace activists. ${ }^{378}$ One CPC member remembered official visits by the RCMP to her home throughout the 1950s and early 1960s. She suspected that RCMP members were present at their Vancouver meetings and that the phones of CPC members were tapped. ${ }^{379}$ Police surveillance records do suggest that the telephones of suspected communists were in fact being monitored by the RCMP. ${ }^{380}$ Police officers did covertly attend "ban-the-bomb" marches and organization meetings. ${ }^{381}$ In order to identify potential new suspects or people who would be groomed into informants, officers tracked the finances and personal relationships of activists. Police officers would also covertly wait outside the homes of select activists, recording the license plate numbers and noting physical descriptions of people arriving for private functions. ${ }^{382}$

\footnotetext{
${ }^{378}$ Marcel Martel, “'They smell bad, have diseases, and are lazy': RCMP Officers Reporting on Hippies in the Late Sixties," The Canadian Historical Review 90(2) (June 2009): 245; Kimmel, Manhood in America, 171; Hewitt, Spying 101, 94; Whitaker and Marcuse, Cold War Canada, 4; Tarah Brookfield, Cold War Comforts: Canadian Women, Child Safety, and Global Insecurity, 1945-1975 (Waterloo: Wilfrid Laurier University Press, 2012), 77; Steve Hewitt and Christabelle Sethna, "Sex Spying: The RCMP Framing of English-Canadian Women's Liberation Groups during the Cold War," in Debating Dissent: Canada and the Sixties, ed. Lara Campbell, Dominique Clément and Gregory S. Kealey (Toronto: University of Toronto Press, 2012), 137; Reg Whitaker, Gregory S. Kealey and Andrew Parnaby, Secret Service: Political Policing in Canada from the Fenians to Fortress America (Toronto: University of Toronto Press: 2012), 180; Cpl. G. E. Woodley, "Re: Voice of Women-Communist Activities Within, Cornwall, Ontario," 11 June 1961, LAC, CSIS files, RG 146, vol. 2843, part 4, 3 (obtained under access to information). 379 Anonymous, interview with author, 9 November 2013.

${ }^{380}$ Cst. T. E. Linning, "Re: Communist Party of Canada Provincial Executive Committee, Alberta," 9 March 1961, LAC, CSIS files, RG 146, vol. 2843, part 3, file: Voice of Women Canada correspondence from 21-2-61 to 28-4-61, 13 (obtained under access to information).

${ }^{381}$ See Cst. T.M. Quilley, "Re: Voice of Women Canada," 5 November 1962, LAC, CSIS files, RG 146, vol. 2844, part 13 (obtained under access to information); Cpl. J. W. G. Boucher, "Re: The Canadian Committee for the Control of Radiation Hazards, Montreal, Quebec," 13 October 1959, LAC, CSIS files, RG 146-738, vol. 1 (obtained under access to information); Cst. R. L. Firby, "Re: Canadian Peace Congress-National Council—Canada," 15 December 1960, LAC, CSIS files, RG 146-723, vol. 2, file: Canadian Peace Congress correspondence from 4-3-58 to 19-12-60 (obtained under access to information). ${ }^{382} \mathrm{Cpl}$. A. F. Missler, "Re: Fellowship of Reconciliation-Vancouver, B.C., Surveillance Report," 18 November 1965, LAC, CSIS fonds, RG 146, vol. 2815, part 1, 2-3 (obtained under access to information); Cst. A. F. Missler, "Re: James Grimsby Foulks—Vancouver, B.C.," 29 July 1963, LAC, CSIS files, RG
} 
Canadian disarmers faced police harassment, and the possibility of arrest and abuse from the anti-communist public, and had reason to fear a loss of employment on account of their political views. ${ }^{383}$ In 1950 a number of CPC supporters were detained across the country for "disturbing the peace" while collecting signatures for a peace petition. ${ }^{384}$ However, Canadian disarmament protests were usually so small and insufficiently disruptive that police rarely bothered to arrest activists. ${ }^{385}$ Unlike in the United States, where the House Un-American Activities Committee (HUAC) had the power to investigate and arrest activists suspected of communist affiliations, and in Britain, where anti-nuclear Committee of 100 members were repeatedly jailed under the Defence of the Realm Act, there were relatively few arrests of disarmers in Canada. ${ }^{386}$

\footnotetext{
146, vol. 2844, part 17, 1 (obtained under access to information); Cst. P. T. Legare, "Re: Voice of Women communist activities within, Ottawa, Ontario," 21 February 1961, LAC, CSIS files, RG 146, vol. 2843, part 3, file: Voice of Women correspondence from 21-2-61 to 28-4-61, 3 (obtained under access to information); Cst. R E. Holloway, "Re: Communist Party of Canada, Ottawa," 5 July 1961, LAC, CSIS files, RG 146, vol. 2843, part 4, file: Voice of Women correspondence from 29-4-61 to 31-7-61, 11 (obtained under access to information); Woodley, "Re: Voice of Women," 11 June 1961, 2-3; Insp. J. T. J. Ouiment, "Re: Voice of Women — communist activities within, Cornwall, Ontario," 29 June 1961, LAC, CSIS files, RG 146, vol. 2843, part 4, file: Voice of Women correspondence from 29-4-61 to 31-7-61, 1 (obtained under access to information).

383 John Beeching, a Regina Peace Council Member, believes he was passed over for promotions because of his participation in activism (Beeching, email with author, 8 November 2013). See also: Jules Pelletier to Kathleen Macpherson, 12 April 1965, LAC, Voice of Women fonds, MG28-I218, vol. 20, file: officials correspondence 1963-1965, 1; Helen Hall, "Montreal Peace Council," ca. 1951, LAC, James G. Endicott and Family fonds, MG30-C130, vol. 17, file: 337, 2; Floyd Williston, 7 July 1960, LAC, James G. Endicott and Family fonds, MG30-C130, vol. 8 file 129, 1; Jessie Storrie to Hon. Dana Porter, 2 August 1950, LAC, MG30-C130, vol. 63, file 1320, 1; "Statement of Sam Michnick," 26 August 1950, LAC, James G. Endicott and Family fonds, MG30-C130, vol. 63, file 1320, 1-2; Jessie Storrie, 27 August 1950, LAC, James G. Endicott and Family fonds, MG30-C130, vol. 63, file 1320, 1; Merrily Weisbord, The Strangest Dream: Canadian Communists, the Spy Trials, and the Cold War (Montreal: Véhicule Press, 1994; Whitaker and Marcuse, Cold War Canada, 4; Myrna Kostash, Long Way from Home: The Story of the Sixties Generation in Canada (Toronto: J. Lorimer, 1980), xxii-xxiii; Moffatt, History of the Peace Movement, 28.

${ }^{384}$ Huard, "The Canadian Peace Congress," 26; "The Stockholm Appeal Campaign in Canada," Information Bulletin, Special Bulletin no. 2, 29 Aug. 1950, LAC, James G. Endicott and Family fonds, MG30-C130, vol. 20, file 402, 1; Jessie Storrie to Hon Dana Porter, 2 August 1950, LAC, James G. Endicott and Family fonds, MG30-C130, vol. 63, file: 1320, 1; Helen Hall, "Montreal Peace Council," 2. ${ }^{385}$ Moffatt, History of the Peace Movement, 63-64; Bruce Douville, "Project La Macaza: A Study of Two Canadian Peace Protests in the 1960s," in Worth Fighting For: Canada's Tradition of War Resistance from 1812 to the War on Terror, eds. Lara Campbell, Michael Dawson and Catherine Gidney (Toronto: Between the Lines, 2015), Kindle Loc 3170-3248.

${ }^{386}$ Amy Swerdlow, Women Strike for Peace: Traditional Motherhood and Radical Politics in the 1960s
} 
It is remarkable that the Canadian state did not combat anti-nuclear activists with the same bellicosity and determination as did the American and British security states. In fact, Canadian disarmament organizations, except for the CPC, were generally well received by Canadian politicians. Parliamentarians, including Liberal leader Lester B. Pearson, Conservative Secretary of State for External Affairs Howard Green, and Cooperative Commonwealth Federation leaders Hazen Argue and Tommy Douglas often praised the efforts of Canadian disarmers. ${ }^{387}$ It is possible that, by tying their protest messages to accepted standards of Cold War Canadian hegemonic masculinity, Canadian male disarmers minimized the concern that they posed a threat to the state.

\section{Masculinities in disarmament activism}

To counteract attempts to invalidate their work by associating peace activism with political, gender, and sexual deviance, male disarmers had to find ways to accentuate their masculinity. Women's organizations such as the Canadian Voice of Women (VOW) and the American Women Strike for Peace (WSP) used baby carriages to represent their

(Chicago and London: The University of Chicago Press, 1993), 97-98, 135; Alonso, Peace as a Women's Issue, 185; Lieberman, The Strangest Dream, 171; "Report of the Proceedings of the National Council of the Canadian Peace Congress," 3-4 December 1960, LAC, James G. Endicott and Family fonds, MG30C130, vol. 12, file 228, 1; Jacqueline Dineen to H. E. Raphael de la Colina, 21 February 1962, LAC, James G. Endicott and Family fonds, MG30-C130, vol. 2, file 32, 1; Holger Nehring, Politics of Security: British and West German Protest Movements and the Early Cold War, 1945-1970 (Oxford: Oxford University Press, 2013), 205.

${ }^{387}$ Lester B. Pearson to Mrs. Silver, 9 August 1960, LAC, Lester B. Pearson fonds, MG26-N2, vol. 3, file 100.1, 1; Lester B. Pearson to L. P. Ferg, 21 February 1962, LAC, Lester B. Pearson fonds, MG26-N2, vol. 91, file: external affairs Voice of Women 2, 1; Lester Pearson to Rabbi Feinberg, 25 May 1960, LAC, Lester B. Pearson fonds, MG26-N2, vol. 86, file: external affairs disarmament 1, 1; Lester B. Pearson to Mrs. Kallaur, 7 March 1962, LAC, Lester B. Pearson fonds, MG26-N2, vol. 53, file 808, 1; Josephine Davis to the Honourable Howard Green, 11 February 1961, LAC, Voice of Women fonds, MG28-I218, vol. 1, file: correspondence-members of parliament re. formation 1960-1963, 1; Hazen Argue,

"Disarmament and Common Sense," 4 November 1960, LAC, Voice of Women fonds, MG28-I218, vol. 1, file: correspondence - members of parliament re. formation 1960-1963, 2; James S. Thomson to Hazen Argue, 5 September 1961, MUL, CCND fonds, box 3, file 9, 1; James S. Thomson to Thomas C. Douglas, 5 September 1961, MUL, CCND fonds, box 3, file 9; Moffatt, History of the Peace Movement, 6-7. 
status as mother-citizens. ${ }^{388}$ Meanwhile, public activities involving mixed-sex organizations involved displays of the "modern" masculine qualities of self-control, emotional restraint, scientific rationality, professionalism, and nurturing fatherhood to symbolize adherence to the expectations of respectable male citizenship. ${ }^{389}$

The predominantly male leadership of the Canadian Committee for the Control of Radiation Hazards (CCCRH, renamed the Canadian Campaign for Nuclear Disarmament or CCND in 1962) strategized how best to present themselves publicly in order to be taken seriously. Major-General W. H. S. Macklin, a former army adjutant general, advised the CCCRH executive to avoid falling into the trap of sentiment. Acting out of emotion rather than from reason, he suggested, would be a clear sign of communist infiltration. ${ }^{390}$

In 1962, the CCND executive issued a manual for lobbyists, which laid out acceptable behaviour when approaching members of parliament. The guide instructed CCND representatives that politicians would not respond well to histrionics, and that speakers should express concern and be insistent, but avoid drama and aggression. ${ }^{391}$ Representatives declared the visit to Parliament for which the manual was created to have been a great success. They believed that their no-nonsense approach helped to dispel the image that members of parliament held of disarmers as being "negative non-rational

\footnotetext{
${ }^{388}$ Christine Ball, "The History of the Voice of Women/La Voix des Femmes: The Early Years, 19601963" (PhD diss., University of Toronto, 1994), 75; Swerdlow, Women Strike for Peace, 15.

${ }^{389}$ Janice Cavell, "Like Any Good Wife: Gender and Perceptions of Canadian Foreign Policy, 1945-75," International Journal (Spring 2008): 390; Nehring, Politics of Security, 211, 215-216; Wittner, "Gender Roles and Nuclear Disarmament Activism," 207.

${ }^{390}$ W.H.S. Macklin to secretary CCCRH, 24 December 1961, MUL, CCND fonds, SW571, box 1, file 2, 1; "National Members of the Canadian Campaign for Nuclear Disarmament," ca. 1962, MUL, CCND fonds, SW571, box 1, file 3, 1 .

${ }^{391}$ Canadian Campaign for Nuclear Disarmament, "Instructions for Lobbyists," 8-10 November 1962, MUL, CCND fonds, ACCN. 05-1989.102.F, box 24, file 5, 1.
} 
persons or fuzzy idealists or radical unilateralists," and had instead left an impression of "rational, level-headed, well-informed and moderate" individuals. ${ }^{392}$ To ensure a favourable reception from the public and from those in power, CCND's executive needed to exhibit the reasonable and restrained characteristics of "modern" masculinity, as Macklin had recommended.

To complement their calm, rational approach, male disarmers also drew on the "modern" masculine trait of scientific reason to justify their anti-nuclear position. The CPC regularly used the authority of science to steer their message away from excess emotionalism. ${ }^{393}$ Throughout the late 1950 s, when the CPC was the only major national organization with a significant anti-nuclear focus, its petitions, advertisements and briefs to government officials rooted appeals against nuclear weapons in scientific evidence. A 1957 advertisement announced that Professor R. E. Lapp, an American physicist who was involved in the Manhattan project, had calculated that, if thermonuclear weapons tests were not stopped, everyone in the world would reach their maximum permissible dose of radioactive strontium- 90 by $1962 .{ }^{394}$ A CPC petition circulated in 1958 found scientific support for the slightly less frightening contention that "[t]housands are likely to die because of tests already held. Many more will die if the tests continue. [...] You certainly have some poison in your bones now." Using the authority of "learned men of science," the CPC painted death as a certain outcome if nuclear tests were not brought to a halt. ${ }^{395}$ By connecting their fears of nuclear war to the authority of scientists, CPC

\footnotetext{
${ }^{392}$ Canadian Campaign for Nuclear Disarmament, "Report on the CCND Lobby of Members of Parliament," 8-10 Nov. 1962, MUL, CCND fonds, ACCN. 05-1089.102.F, box 24, file 5, 2.

${ }^{393}$ Whitaker and Marcuse, Cold War Canada, 366, 373; Huard, "The Canadian Peace Congress," 26.

394 "On June 10, Vote to Stop the Hydrogen Bomb Tests," LAC, James G. Endicott and Family fonds, MG30-C130, vol. 6, file 105.

${ }^{395}$ Canadian Peace Congress, "Peace petition 1958," LAC, James G. Endicott and Family fonds, MG30-

C130, vol. 2, file 24, 1. See also: "Canadian Peace Congress Brief Submitted to the Minister for External
} 
activists attempted to isolate their drive for peace from associations with the irrationality of communism.

In a demonstration of its belief in the potential of science to bring attention to and provide solutions for the threat of nuclear war, the CPC threw its full support behind the annual Pugwash Conferences of international scientists for peace and disarmament, which began in Pugwash, Nova Scotia, in 1957. In particular, the CPC promoted the conference's scholarly assessments that "unfounded faith in defensive measures may even contribute" to the outbreak of a war in which "most centres of civilization... would be totally destroyed." ${ }^{396}$ In addition to distributing the publications of Pugwash scientists widely, the CPC also circulated copies of a March 1959 Consumer Reports investigation, which tested milk samples from 48 American and Canadian cities and observed that levels of radioactive strontium-90 were increasing at twice the rate found by a similar study conducted by the United States Atomic Energy Commission. More frightening than the growing presence of this by-product of nuclear fallout in North American milk supplies, claimed the article, was that little was known about the actual effects of strontium-90 on human health. ${ }^{397}$ Canadian Peace Congress organizers shared scientific research to ground nightmares in fact.

While there were many examples of scientists' condemnations of nuclear arms from which CPC and other anti-nuclear groups could draw, there was also a great deal of

\footnotetext{
Affairs," 10 February 1959, LAC, James G. Endicott and Family fonds, MG30-C130, vol. 7, file 119, 1; "The purpose and program of the National Committee for a Sane Nuclear Policy," n.d., ca. 1957, LAC, James G. Endicott and Family fonds, MG30-C130, vol. 32, file 603, 3-4.

${ }^{396}$ Canadian Peace Congress, "World Scientists Have Warned Us, Report of the Third Pugwash Conference," LAC, James G. Endicott and Family fonds, MG30-C130, vol. 7, file 113, 3-4.

${ }^{397}$ Eva Sanderson to Dr. Dion, 4 June 1959, LAC, James G. Endicott and Family fonds, MG30-C130, vol. 7, file 124, 1; "The Milk We Drink," Consumer Reports 24(2) (March 1959), LAC, James G. Endicott and Family fonds, MG30-C130, vol. 7, file 119, 109-111.
} 
debate within the scientific community over the dangers of nuclear fallout. In April 1957, well-respected humanitarian and Nobel Peace Prize winner Dr. Albert Schweitzer issued an urgent appeal to end nuclear weapons testing because of the health threat posed by carcinogenic strontium-90. Schweitzer's "Declaration of Conscience" was broadcast internationally, but only received widespread publicity after United States Atomic Energy Commissioner Willard Libby questioned the legitimacy of Schweitzer's data, which Schweitzer had obtained through a group of professors at Washington University in St. Louis and from the Atomic Energy Commission. The squabble between Libby and Schweitzer sparked a lively debate among American scientists about the dangers of nuclear fallout. ${ }^{398}$

This confusion led the Saskatchewan Peace Council to condemn the Saskatchewan legislature for not engaging in further scientific study to determine the real threat posed by fallout by-products like strontium-90. The lack of available research "testifies to a completely cynical and calloused disregard for the consequences of atomic fall-out on the Canadian people," the Saskatchewan group claimed. ${ }^{399}$ In like manner, in his first chairman's address to the national CCCRH in June 1960, Hugh L. Keenleyside argued that with all of the scientific debate over the dangers, nuclear weapons tests must be stopped "unless it can be proven that they are essential for some over-riding national purpose." ${ }^{400}$ So long as there was any question among experts that the health costs might

\footnotetext{
${ }^{398}$ Milton Katz, Ban the Bomb: A History of SANE, the Committee for a Sane Nuclear Policy, 1957-1985 (Westport, Conn: Greenwood Press, 1986), 16-17; Allan M. Winkler, Life Under a Cloud: American Anxiety About the Atom (New York: Oxford University Press, 1993), 108; "The purpose and program of the National Committee for a Sane Nuclear Policy," 4.

399 "Submission to the Saskatchewan Peace Council to the members of the Saskatchewan Legislature," 13 March 1959, LAC, James G. Endicott and Family fonds, MG30-C130, vol. 7, file 119, 2.

${ }^{400}$ H. L. Keenleyside, "Why We are Here," 13 June 1960, LAC, James G. Endicott and Family fonds, MG30-C130, vol. 69, file 1412, 7.
} 
outweigh the security benefits of nuclear arms, an alternative should be developed, according to Keenleyside.

The Canadian Peace Research Institute (CPRI), which was established through fundraising led by VOW and the CCCRH-CCND, was founded to study scientifically the causes of war and through research uncover a cure for war and violence. The Institute was focused on maintaining the standard of masculine scientific rationalism. ${ }^{401} \mathrm{~A}$ funding pamphlet explaining the purposes of the CPRI explained that, since there was no effective protection against nuclear war, "science must be put to work stopping the rampage of war as it was put to work stopping the rampage of Polio." Furthermore, scientists were the ideal candidates to develop alternatives to war because they "approach a problem objectively ... unhampered by emotional pressures, political pressures, economic pressures. ${ }^{" 402}$ Scientists, by this logic, were clear representatives of hegemonic masculinity since they were rational, objective, and expert problem solvers.

In his article in support of the CPRI, journalist Pierre Berton explained that CPRI chairman and founder, Norman Z. Alcock, a physicist who had left a lucrative industrial position in 1961 to set up the Institute, was "so obviously" not a "crackpot." ${ }^{, 403}$ Alcock's warnings that there was a 50 per cent likelihood of nuclear annihilation by 1971 had to be taken seriously, Berton claimed, because Alcock's qualifications were "fairly impressive," as a scientist with expertise in both radar and nuclear fission. ${ }^{404}$ Alcock's authority was further reinforced by his equally impressive board of directors, which

${ }^{401}$ [Gerry] Hunnius to Dr. James S. Thomson, 20 October 1961, MUL, CCND fonds, SW571, box 3, file 9, 1; Moffatt, History of the Peace Movement in Canada, 59.

402 "Why is peace research important to you?," 2.

${ }^{403}$ Pierre Berton, "Dr. Norman Alcock Launches his Crash Program for Peace," 5 December 1961, Archives of Ontario (AO), Canadian Peace Research Institute fonds, F-883-1-2, container B297380, series A-2, box 3, file: Capri inauguration, 1 .

${ }^{404}$ Berton, "Dr. Norman Alcock," 1. 
included Dr. Brock Chisholm, the former director of the World Health Organization, and Dr. Franc Joubin, the geologist who uncovered uranium in Algoma, Ontario. ${ }^{405}$

The CPRI's band of scientists convinced Opposition leader Lester B. Pearson that there could not possibly be a "questionable nature" to Alcock's work. ${ }^{406}$ Officials in the Prime Minister's Office advised Prime Minister John G. Diefenbaker that there was no reason to be "unduly suspicious about the motives of the organizers which appear serious." ${ }^{\prime 407}$ Grassroots activists were equally impressed by the expertise of Alcock's institute. Mrs. L. H. Taylor of Red Deer, Alberta, requested a visit from Alcock in late 1961. She was not having much luck organizing a local CCCRH branch because of the "ultra-conservatism" of the community, but she believed that there might be more local support for "research." 408 As Berton had argued, a scientist of such prestige could not feasibly be considered a "crackpot," no matter how emphatically he resisted mass violence and war.

In addition to relying on the authority of science, male disarmers emphasized professional achievement, a central characteristic of "modern" masculinity, in their protest messages. The CCCRH publicly announced its formation as a national antinuclear organization in January 1960 with a press release listing the names of 45 notable Canadians who supported the committee. ${ }^{409}$ The release individually identified the

\footnotetext{
${ }^{405}$ Berton, "Dr. Norman Alcock," 3.

${ }^{406}$ Lester B. Pearson to Mrs. R. M. Bond, 7 March 1962, LAC, Lester B. Pearson fonds, MG26-N2, vol. 53 , file 808,1 .

${ }^{407}$ G. S. Murray to the under-secretary department of external affairs, 30 May 1962, University of Saskatchewan University Archives and Special Collections (USUASC), Rt. Hon John G. Diefenbaker papers, MG26M, PMO series, vol. 557, 424100 (obtained under access to information). See also: R. Harry Jay, "Memorandum: Canadian Peace Research Institute McGill Seminar June 11, 12, 13 1962," 18 June 1962, USUASC, Rt. Hon John G. Diefenbaker papers, MG26M, PMO series, vol. 557, 424096 (obtained under access to information).

${ }^{408}$ Mrs. L. H. Taylor to Mary Van Stolk, 15 December 1961, MUL, CCND fonds, SW572, box 8, file 9, 1. 409 The CCCRH executive released the press release following the success of a similar announcement of the formation of SANE in the United States (Lawrence S. Wittner, The Struggle Against the Bomb, Vol. 2
} 
important Canadian men by their professions, with the exception of John Drainie, a celebrated Canadian actor, and prominent Armenian-Canadian portrait photographer Yousuf Karsh, neither of whom needed an introduction. ${ }^{410}$ The remainder of the list was made up of university presidents and faculty, generally from medical or other science departments; lawyers and judges; newspaper publishers and editors; business executives; and leading labour, welfare and religious officials. ${ }^{411}$ The national executive elected Keenleyside to replace CCCRH founder Mary Van Stolk, a housewife from Edmonton, when the organization prepared to launch itself as a national campaign. Keenleyside was the former director general of the United Nations Technical Assistance Plan and was chairman of the British Columbia Power Commission. ${ }^{412}$ As a collective of men that easily met the "modern" masculine standard of professional achievement, this list served to illustrate the unquestionable masculinity of the organization and its respectful conformity to Cold War social expectations for men.

The identification of activists by their occupational success must have proven to be an effective tool, as it became standard practice for the CCCRH-CCND to associate activists with their professions. The 1962 CCND lobbyist manual instructed each representative to introduce himself with reference to his occupation. ${ }^{413}$ Professional identities were also important when the CCND board of directors debated how the organization might recover from the deeply pessimistic mood that took hold of the group

(Stanford: Stanford University Press, 1997), 196-197).

410 "Prominent Canadians Form Committee on Radiation Hazards \& Nuclear Policy," 18 January 1960, MUL, CCND fonds, SW571, box 1, file 1, 5-6.

411 "Prominent Canadians Form Committee," 5-6.

${ }^{412}$ Mary Van Stolk to Hugh Keenleyside, 4 November 1959, MUL, CCND fonds, SW571, box 4, file 1; Mary Van Stolk to Dr. H. L. Keenleyside, 2 June 1961, MUL, CCND fonds, SW571, box 2, file 13. 413 "Preliminary agreements concerning lobbying techniques," 17 October 1962, MUL, CCND fonds, ACCN. 05-1989.102.F, box 24, file 5, 1. 
in the spring of 1963 after the election of Pearson's pro-nuclear Liberals. It was determined that, if a delegation were to be assembled to persuade Prime Minister Pearson to change his mind on nuclear weapons, it would have to consist of CCND honorary president, Justice J. T. Thorson, and CCND chairman and former leader of the Cooperative Commonwealth Federation, M. J. Coldwell, along with other "prominent churchmen, trade union officials and industrialists. ${ }^{, 414}$ Not just any CCND member could approach the prime minister during this time of crisis; only those who had reached a certain degree of masculine respectability were deemed to be up to the task of convincing the government to reject nuclear arms in Canada.

Individual men also commonly referred to their education and employment when discussing their personal views about nuclear arms. In a letter welcoming the formation of VOW, Claude Laws offered that, as a chemist, he understood the deadly "mind of an atom. ${ }^{415}$ His opposition to the Bomb was intellectual, not emotional. When challenging Liberal leader Pearson's January 1963 announcement that his party would support nuclear arms in Canada, Lloyd Axworthy was sure to point out his training at Princeton University in international politics. As a young man pursuing a Masters' degree at a prestigious American Ivy League school, Axworthy presented his advanced education as a source of particular authority. ${ }^{416}$ A certified teacher from Rosemere, Quebec, R. C. Harris, wrote of his disappointment with Pearson's stance on nuclear arms, validating his opinion by presenting himself as "not an emotional 'ban the bomb' type but a serious

414 "Minutes of the Board of Directors' Meeting, Ottawa-April 20 \& 21, 1963," MUL, CCND fonds, SW571, box 1 , file 6,3 .

${ }^{415}$ Claude Laws to Voice of Women, 7 October [ca. 1960], LAC, Voice of Women fonds, MG28-I218, vol. 1, file: Correspondence re. formation of V.O.W. Oct 1960, 1.

${ }^{416}$ Lloyd Axworthy to Pearson, n.d., LAC, Lester B. Pearson fonds, MG26-N2, vol. 50, file 806.2 part 4, 1. 
‘student." ${ }^{417}$ In like manner, Frank G. Bass highlighted his five years of experience with the Royal Air Force to strengthen his advice to Pearson that the acquisition of nuclear arms by Canada would do nothing but take the country one step closer to "mass suicide. ${ } 418$

The all-female group VOW also sought to use the professional lives of its members to lend force to its work against war and nuclear arms. The organization celebrated the participation of prominent women, including Dr. Ursula Franklin of the University of Toronto physics department, psychologist Dr. Reva Gerstein, freelance journalists June Callwood and Dofy Skaith, Doris McCubben Anderson, editor of Chatelaine, and actress Toby Robins. ${ }^{419}$ However, more often than not, VOW, which was predominantly made up of middle-class housewives, identified women through their husbands. ${ }^{420}$ Janet Berton, a journalist herself, was identified in VOW publications simply as "Mrs. Pierre Berton." ${ }^{421}$ VOW co-founder Josephine Davis believed that the organization secured much positive publicity because of her husband Fred Davis' popular Canadian Broadcasting Corporation (CBC) television program, "Front Page Challenge. ${ }^{4422}$ While it was important for women activists to display professionalism and to use their socio-economic status to present "respectability," identification with an

\footnotetext{
${ }^{417}$ R. C. Harris to Lester B. Pearson, 14 January 1963, LAC, Lester B. Pearson fonds, MG26-N2, vol. 50, file 806.2 part 5,1 .

${ }^{418}$ Frank G. Bass to Pearson, 25 January 1963, LAC, Lester B. Pearson fonds, MG26-N2, vol. 50, file 806.2 part 4.

${ }^{419}$ Marcus Van Steen to Ray Gardner, 23 August 1963, LAC, Voice of Women fonds, MG28-I218, vol. 2, file: International Cooperation Year Conference International Cooperation Travel Mission 1962-63, 1; Carol Chapman, "How effective is the Voice of Women?," Chatelaine (June 1961), 116; Mrs. F. Davis to Lester B. Pearson, 12 June 1960, LAC, Voice of Women fonds, MG28-I218, vol. 1, file : correspondence members of parliament re. formation 1960-1963, 1.

${ }^{420}$ Jill Vickers, "The Intellectual Origins of the Women's Movement in Canada," in Challenging Times: The Women's Movement in Canada and the United States, eds. Constance Backhouse and David H. Flaherty (Montreal: McGill-Queen's University Press, 1992), 54.

${ }^{421}$ Chapman, "How effective is the Voice of Women?," 116; Mrs. F. Davis to Lester B. Pearson, 1.

${ }^{422}$ Chapman, "How effective is the Voice of Women?," 119.
} 
occupation was a much less significant tool for disarmament women, who more often than not identified primarily as mothers in their anti-nuclear campaigns.

Yet a rational and scientific approach to peace and anti-nuclear activism did not prevent men from alluding to fatherhood as a motivating factor for their activism.

Fatherhood in its many forms was a consistent feature in discussions of what it meant to be a man in the Cold War West. While "modern" masculinity emphasized economic and professional success, further reinforcing the principle of father as breadwinner, Cold War fatherhood was marked by an expectation that fathers would be increasingly involved in family domestic life. ${ }^{423}$

This "new" father was not a dramatic restructuring of gender roles; fathers were to be providers first and sensitive fathers second. The nurturing aspect of fatherhood was constrained by the continued persistence of "traditional" conceptions of masculinity well into the mid-twentieth century. ${ }^{424}$ Nevertheless, psychologists argued that fathers should take more interest in their children, and act as masculine role models, advisors, confidantes, disciplinarians, and entertaining playmates all at once. ${ }^{425}$ Cold War Canadian fathers were faced with Kimmel's "Goldilocks Dilemma." They could not be too hard or too soft and they could not be too career-focused. Nor could they become too engrossed by their children. ${ }^{426}$

\footnotetext{
${ }^{423}$ Mona Gleason, Normalizing the Ideal Psychology School and the Family in Postwar Canada (Toronto: University of Toronto Press, 1999), 67; Gleason, "Disciplining Children," 202; Chris Dummitt, "Finding a Place for Father: Selling the Barbecue in Postwar Canada," Journal of the Canadian Historical Association 9(1) (1998): 210.

${ }^{424}$ Griswold, Fatherhood in America, 2-3, 6, 8, 186; Elaine Tyler May, Homeward Bound: American Families in the Cold War Era (New York: Basic Books, Inc., Publishers, 1988), 142-149; Gleason, "Disciplining Children," 202; Dummitt, The Manly Modern, 78.

${ }^{425}$ Dummitt, The Manly Modern, 110; Gleason "Disciplining Children," 202; Dummitt, "Finding a Place for Father," 210; Jessica Haynes, "Help for All Parents?: Child-Rearing Advice in English Canada in the 1960s and 1970s," Histoire Sociale/Social History 44(87) (May 2011): 60.

${ }^{426}$ Kimmel, Angry White Men, 51.
} 
As confusing as the expectations were, one certainty was that fatherhood was not to be avoided. In Cold War North America, fatherhood stood as a sign of maturity, responsibility, virility, and patriotism. To be a proper male-citizen was to be a father. ${ }^{427}$ In the homophobic climate of Cold War Canada, it was not the overly domesticated or femininely passive fathers, but childless bachelors who were the most suspicious. ${ }^{428}$ For already disreputable peace and disarmament activists, fatherhood represented an important sign of conformity to Cold War standards of civic-masculinity.

The British Campaign for Nuclear Disarmament (CND), the British Committee of 100, and SANE, organizations with predominantly male leaderships and personas, all frequently drew on a father's love for his children as the focus of their advertisements. ${ }^{429}$ Canadian men too presented children as an important motivating factor for their antinuclear views. In his response to Lotta Dempsey’s May 1960 Toronto Daily Star columns exhorting women to fight together against nuclear arms, Edward Duncan of Calgary suggested that he would like to see a "Young Parents for Peace" group set up. ${ }^{430}$ Drawing on the middle-class ideal of family "togetherness," Duncan advised Dempsey that groups "would be all the stronger for having a complete family unit involved." 431 He did imply that men might be out of place in peace work, but also made it clear that husbands were

\footnotetext{
${ }^{427}$ Griswold, Fatherhood in America, 186; May, Homeward Bound, 98; Rutherdale, "New 'Faces' for Fathers," 253.

${ }^{428}$ Robert J. Corber, Homosexuality in Cold War America: Resistance and the Crisis of Masculinity (Durham and London: Duke University Press, 1997), 11-12; Griswold, Fatherhood in America, 189; Adams, The Trouble With Normal, 9-10, 25, 30.

${ }^{429}$ Wittner, "Gender Roles and Nuclear Disarmament Activism," 207-208.

${ }^{430}$ Edward D. Duncan to Miss Lotta Dempsey, 9 June 1960, LAC, Voice of Women fonds, MG28-I218, vol. 1, file: correspondence re. formation of V.O.W. n.d. May-June 1960, 1-2.

${ }^{431}$ Rutherdale, "New 'Faces' for Fathers," 241; Edward Duncan to Miss Lotta Dempsey, 2.
} 
"at least as enthusiastic as the wives" about the cause of "a happy and secure future for our children."432

James Endicott, who was considered "public enemy number one" by the anticommunist national security state, often referred to children when making emotional as opposed to scientific pleas for support. ${ }^{433}$ His 1958 annual CPC Christmas Appeal concluded with the request that readers do all they could for peace, "[i]n the name of my nine grand-children and all children everywhere." ${ }^{\circ 34}$ By projecting the role of concerned grandfather, Endicott proclaimed the rightness of his cause through his adoption and perpetuation of the Cold War standard of nurturing father.

The executive of the Manitoba branch of the CPC also used fatherhood as a means of encouraging members of the Manitoba legislature to speak out against nuclear arms. Praising Premier Dufferin Roblin's opposition to civil defence because underground shelters were ineffective, a Manitoba Peace Council brief to the legislature specifically identified Roblin as a "father of two children." The brief continued by encouraging the almost entirely male legislature to promote nuclear disarmament on the grounds that "the majority of the MLA's in this Legislature are married, with children and perhaps in some cases, grandchildren," and must therefore be "concerned about their

\footnotetext{
${ }^{432}$ Duncan to Dempsey, 2.

${ }^{433}$ Ian McKay and Jamie Swift, Warrior Nation: Rebranding Canada in an Age of Anxiety (Toronto: Between the Lines, 2012), 108; Whitaker and Marcuse, Cold War Canada, 372-373. For examples of annual Christmas Appeals referring to children see: James G. Endicott, "Christmas Appeal," 1962, LAC, James G. Endicott and Family fonds, MG30-C130, vol. 8, file 154, 1; James G. Endicott, "Christmas Appeal,” LAC, James G. Endicott and Family fonds, MG30-C130, vol. 10, file 182, 1.

${ }^{434}$ James Endicott, "Christmas Appeal," December 1958, LAC, James G. Endicott and Family fonds, MG30-C130, vol. 2, file 25, 1 . The reference to grandchildren resonated particularly with respondents, see for example: Ann Audreylio to Dr. Endicott, 18 December 1958, LAC, James G. Endicott and Family fonds, MG30-C130, vol. 2, file 25, 1.
} 
future." ${ }^{435}$ This CPC brief assumed that fatherhood would naturally lead men to oppose any use of nuclear arms.

Fatherhood was not an identity distinct from other aspects of "modern" masculinity. In a 1958 article for Weekend Magazine, Dr. J. Gordin Kaplan, a professor of physiology at Dalhousie University, presented his fatherhood and his professional expertise as connected. As a scientist, Kaplan argued that, despite the need for further research, it was undeniable that nuclear weapons tests posed a significant health risk. ${ }^{436}$ As a father, he pleaded for an end to nuclear weapons tests, because "I am very fond of this human race of ours, especially of my own family." ${ }^{437}$ To illustrate the dual identity that was informing his work against nuclear weapons testing, Weekend Magazine included a picture of Kaplan in his Dalhousie lab, supplemented by a photo of him with his two children (see Images 3 and 4). ${ }^{438}$ With Kaplan's smile matching that of his beaming four-year-old son, the photo, and Kaplan's closing words about his love for his family, made an emotional appeal against nuclear arms. ${ }^{439}$ As both a father and a scientist, Kaplan's authority on the matter was firmly established according to hegemonic standards of masculinity.

Reynold Rapp, elected the Progressive Conservative member of parliament for Humbolt-Melfort, Saskatchewan, in 1958, explained that his determination to rid the world of nuclear arms was informed by multiple aspects of his masculine identity. "As a Canadian citizen, as a father of a family and as one that saw the ravages of war and lived

\footnotetext{
${ }^{435}$ Floyd Williston, "Manitoba Peace Council Brief on Disarmament," 2 April 1962, LAC, James G. Endicott and Family fonds, MG30-C130, vol. 19, file 362, 1-2.

${ }^{436}$ Dr. J. Gordin Kaplan, "Nuclear Tests Must be Banned," Weekend Magazine 8(38) (1958), LAC, James

G. Endicott and Family fonds, MG30-C130, vol. 70, file 1425, 4.

${ }^{437}$ Kaplan, "Nuclear Tests Must be Banned," 41.

${ }^{438}$ Kaplan, "Nuclear Tests Must be Banned," 2, 4

${ }^{439}$ Kaplan, "Nuclear Tests Must be Banned," 4, 41.
} 
through the bloodiness of a revolution the world has never seen the like before-I can't but stand with you and others for Peace," he wrote to Mabel Hanway of the CPC. Born in Crimea, Rapp had witnessed the violence of the Russian Revolution and two world wars. As both "an M.P. responsible to his Country" and a father, Rapp vowed to support CPC in its campaign against war. ${ }^{440}$

This said, parenthood was not as important a tool for men as it was for women. Despite the valorization of fatherhood in Cold War constructions of masculinity, the symbolic value of fatherhood lacked the historic punch that motherhood held. As sociologists Hugh Mehan and John Wills argued in their study of the 1980s American women's group, Mothers Embracing Nuclear Disarmament, a father's arguments against nuclear weapons "do not carry the same social significance as motherist appeals." For such arguments to carry the same authority, men would have to establish that "their lives were shaped by their biological capacity to father," an argument that would have been out of step with principles of "modern" masculinity. ${ }^{441}$ For this reason, arguments presented by men against nuclear weapons more often relied on scientific rationalism and professional status than they did on fatherhood.

\section{Conclusion}

Wittner has emphasized that the difference between the gender radicalism of the disarmament efforts of women and men was that women were traditional in their motives and unorthodox in their methods, but men were progressive in their motives and

\footnotetext{
${ }^{440}$ Reynold Rapp to Mabel B. Hanway, 21 March 1958, LAC, James G. Endicott and Family fonds, MG30C130, vol. 7, file 109, 1.

${ }^{441}$ Hugh Mehan and John Wills, "Mend: A Nurturing Voice in the Nuclear Arms Debate," Social Problems 35(4) (Oct. 1988): 375.
} 
conventional in their methods. ${ }^{42}$ However, the ways in which Canadian anti-nuclear men presented themselves demonstrates a marked similarity between their rationales and evolving Cold War standards of masculinity. In their protest messages, male Canadian anti-nuclear activists embraced Cold War social norms in attempts to undermine Cold War defence and political principles.

Because of their symbolic proximity to subordinate masculinities, it was particularly important for Canadian disarmers to adopt and embody elements of hegemonic masculinity. In the anti-communist environment of the Cold War, where peace activism, homosexuality and communism were very closely associated, Canadian male disarmers maintained a level of "respectability" by emulating and perpetuating characteristics of Cold War ideal masculinity. Within the confines of the new "modern" masculinity of the Cold War era, an activism grounded in a father's love for his children was just as acceptable as a challenging of nuclear deterrence policy rooted in scientific research and professional expertise. For both male and female anti-nuclear advocates, parenthood proved to be an especially powerful stance from which their efforts to convince the public of the importance of bringing an end to the production and testing of nuclear arms.

${ }^{442}$ Wittner, "Gender Roles and Nuclear Disarmament Activism,” 206. 


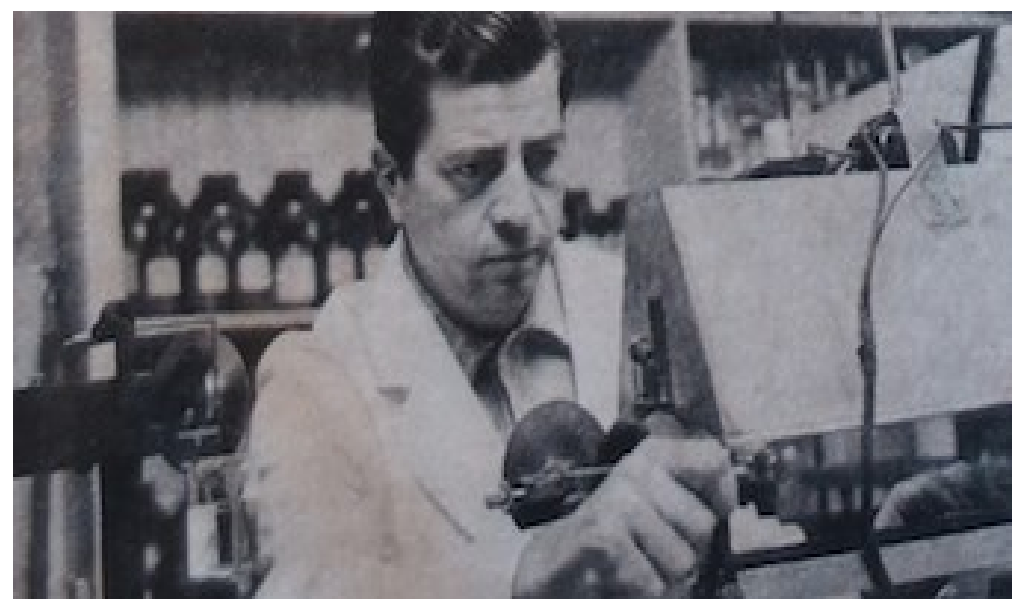

Image 3: Dr. J. Gordin Kaplan at his lab at Dalhousie University. Photo credit: Louis Jacques, Weekend Magazine, 1958, Amicus 121520.

Dr. J. Gordin Kaplan, "Nuclear Tests Must be Banned," Weekend Magazine 8(38) (1958), Library and Archives Canada, James G. Endicott and Family fonds, MG30-C130, vol. 70 , file 1425,4 .

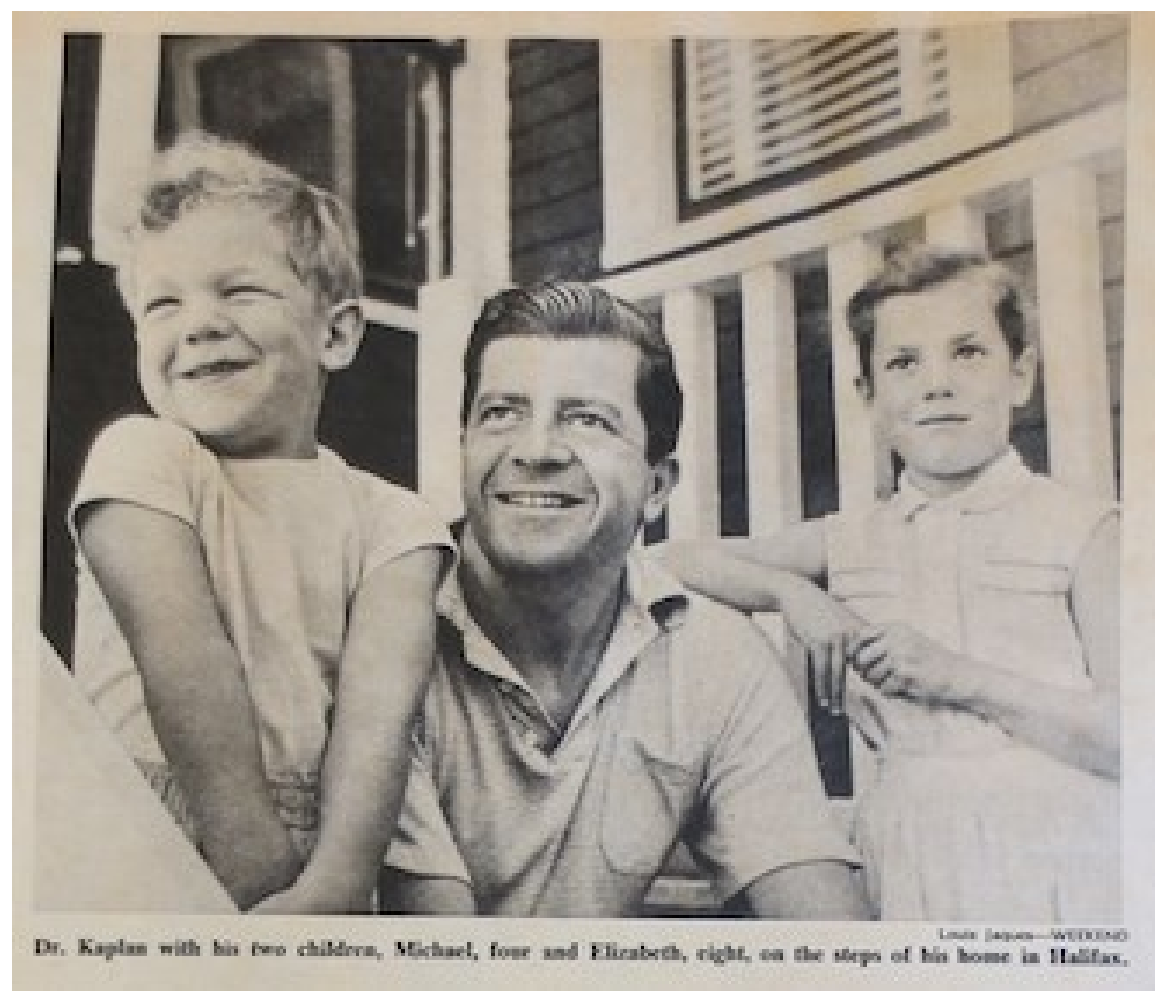

Image 4: "Dr. Kaplan with his two children, Michael, four and Elizabeth, eight, on the steps of his home in Halifax." Photo credit: Louis Jacques, Weekend Magazine, 1958, Amicus 121520.

Dr. J. Gordin Kaplan, "Nuclear Tests Must be Banned," Weekend Magazine 8(38) (1958), Library and Archives Canada, James G. Endicott and Family fonds, MG30-C130, vol. 70, file 1425, 4. 


\section{Chapter Three \\ "For the sake of our children:" "The Child" in Anti-Nuclear Activism}

“The world of the future doesn't even belong to us. It belongs to your nephew and your daughter and all the rest of the children who take for granted its limitless possibilities. We have no right to damage it," argued eminent Canadian physician Dr. Marion Hilliard in 1958. Using Hilliard's edict that the future must be preserved for its rightful owners, the Congress of Canadian Women appealed to Canadian parents to act to put a stop to nuclear weapons testing "for the sake of our children everywhere."443 Canadian disarmers often presented themselves as anxious mothers and fathers looking to protect their children. In doing so, Canadian anti-nuclear activists demonstrated their adherence to gender norms and spoke to the Cold War state's reverence for the family. Concentrating their protests on the theme of the rescue of children from an unfortunate or cataclysmic future allowed Canadian disarmament activists to present themselves as respectable Canadian parent-citizens.

A focus on the needs of children gave disparate anti-nuclear organizations a rhetoric that helped connect Canadian activists to fellow ban-the-bombers across the globe. Highlighting the threat that nuclear war posed to children was a useful tool in mobilizing people against nuclear arms, regardless of nationality, gender, class or politics. By emphasizing their identities as parents and as the protectors of children more generally, Canadian anti-nuclear activists participated in an international discussion on the dangers of nuclear weapons.

\footnotetext{
${ }^{443}$ Congress of Canadian Women, "Read what the late Dr. Marion Hilliard, eminent Canadian woman doctor of the Toronto Women's College Hospital had to say," 1958, Library and Archives Canada (LAC), James G. Endicott and Family fonds, MG30-C130, vol. 7, file 114, 2.
} 
In her work on Cold War Canadian women's child welfare campaigns, historian Tarah Brookfield argued that deploying their identities as mothers allowed "women a legitimate space in which to operate in the traditionally male realms of defence and diplomacy." ${ }^{444}$ Whether they were arguing for the promotion of civil defence strategies, the strengthening of the United Nations, international adoption or the prohibition of nuclear weapons testing, Brookfield described how Canadian Cold War women entered and were accepted into political debates on the grounds that they were defending the health and safety of children. ${ }^{445}$

While many of the Canadian women activists studied by Brookfield were acting out of concern for their own children, she noted that both children and the voices of children were usually omitted from activist rhetoric. In their child welfare work, Cold War Canadian women employed "emotionally driven" symbols of the child to attract the general public to their various campaigns. ${ }^{446}$ In this sense, it was the idea of the child that was important, not the child itself.

As Canadian historian Karen Dubinsky has observed, "the social category of 'child' is at once real and metaphorical—powerful as a cultural construct, but equally as forceful in flesh and blood." 447 Though "childhood" has a unique history and meaning in different cultures, the "symbolic child" carries importance across boundaries, as all nations and political ideologies imagine themselves through their children. ${ }^{448}$ Children, as

\footnotetext{
${ }^{444}$ Tarah Brookfield, Cold War Comforts: Canadian Women, Child Safety, and Global Insecurity, 19451975 (Waterloo: Wilfrid Laurier University Press, 2012), 3.

${ }^{445}$ Brookfield, Cold War Comforts, 3, 7.

${ }^{446}$ Brookfield, Cold War Comforts, 14.

${ }^{447}$ Karen Dubinsky, Babies Without Borders: Adoption and Migration across the Americas (Toronto: University of Toronto Press, 2010), 5.

${ }^{448}$ Dubinsky, Babies Without Borders, 14, 12.
} 
Hilliard argued, are the rightful owners of the future and its "limitless possibilities." 449 Imbued with the immense responsibility of realizing the nation's dreams for the future, "children carry enormous weight on their shoulders," according to Dubinsky. ${ }^{450}$

The "symbolic child" of the twentieth century was an exceptional "sort of human," in the words of scholar of human rights discourse Jacqueline Bhabha. ${ }^{451}$ Children, because of an assumption of their particular purity, vulnerability, and innocence, were considered to require special treatment and protection from adults. ${ }^{452}$ In her work on the iconography of children in adoption advertisements, historian of reproductive politics Laura Briggs has argued that, because of this special helplessness of children, certain types of images of children have evoked emotional and even physical responses from adults. ${ }^{453}$

The unique "vulnerable identity" of children has often left the idea of the child open to "intense forms of political manipulation." ${ }^{454}$ Political scientist Katrina Lee-Koo and German historian Benjamin Ziemann have found that various political actors have effectively mobilized images of the child in the promotion of war. Lee-Koo contended, for example, that "the child" was used to justify American military intervention in Afghanistan in the early twenty-first century. ${ }^{455}$ In striking contrast, Ziemann's work

\footnotetext{
${ }^{449}$ Congress of Canadian Women, "Read what the late Dr. Marion Hilliard," 1.

${ }^{450}$ Dubinsky, Babies Without Borders, 5.

${ }^{451}$ Jacqueline Bhabha, "The Child: What Sort of Human," PMLA 121(5) (October 2006): 1526.

452 Bhabha, "The Child," 1532-1533; Maureen Moynagh, "Human Rights, Child-Soldier Narratives, and the Problem of Form," Research in African Literatures 42(4) (Winter 2011): 39, 41, 47.

${ }^{453}$ Laura Briggs, "Mother, Child, Race, Nation: The Visual Iconography of Rescue and the Politics of Transnational and Transracial Adoption," Gender \& History 15(2) (August 2003): 185.

${ }^{454}$ Katrina Lee-Koo, "Not suitable for children: the politicization of conflict-affected children in post-2001 Afghanistan," Australian Journal of International Affairs 67(4) (2013): 487.

${ }^{455}$ Lee Koo, "Not suitable for children," 476, 485, 487.
} 
examined how West German peace activists used images of children to marshal support for their Cold War anti-war and anti-nuclear campaigns. ${ }^{456}$

Dubinsky has noted that, in Canada, the symbolic potency of the image of the child intensified during the insecurity and tension of the Cold War. Children became idealized and their distinct need for protection resulted in calls "for the construction of complex defence systems. ${ }^{257}$ It was vital that children be rescued from the potential trauma and violence of the Cold War.

Within the limited literature concentrated on the iconography of children in antinuclear protest, questions of gender dominate. Maternal feminism was the central exploratory lens for Brookfield's examination of women's disarmament activism. ${ }^{458}$ Similarly, Ziemann's investigation addressed the paternalist rhetoric behind the images of daughters and mothers found in the protest materials of West German disarmament organizations. ${ }^{459}$ Such a gendered analysis has led to the valuable discovery that the themes of the rescue of children and women emerged from "a social imaginary dominated by a masculinized national state that casts itself in a paternal role, saving those who are abused by rival men and nations. ${ }^{460}$ Scholars have exposed the manner in which activists consciously or subconsciously reinforced gender inequality through their acceptance of characterizations of state power as masculine performance. ${ }^{461}$

\footnotetext{
${ }^{456}$ Benjamin Ziemann, "The Code of Protest: Images of Peace in the West German Peace Movements, 1945-1990," Contemporary European History 17(2) (May 2008): 259.

${ }^{457}$ Dubinsky, Babies Without Borders, 12.

${ }^{458}$ Brookfield, Cold War Comforts, 6.

${ }^{459}$ Ziemann, "The Code of Protest," 244.

${ }^{460}$ Emily S. Rosenberg, "Rescuing Women and Children," The Journal of American History 89(2) (September 2002): 457.

${ }^{461}$ Rosenberg, "Rescuing Women and Children," 461, 462; Janice Cavell, "Like Any Good Wife: Gender and Perceptions of Canadian Foreign Policy, 1945-75," International Journal (Spring 2008): 387.
} 
However, because such an approach is rooted in a critique of paternalism, it often misses the fact that parenthood was a unifying identity that brought men and women together in their efforts to oppose the testing and proliferation of nuclear arms. This chapter will contribute to this discussion of the symbolic importance of children to social and political movements by demonstrating the ubiquity of the "symbolic child" in Canadian expressions of anti-nuclear opinion. The importance of "the child" to disarmament campaigns in Canada and across the West allowed anti-nuclear activists to make a place for themselves within international debates about the value of nuclear arms in the bipolar Cold War world.

\section{Children in Cold War Canada}

Reflecting the post-war emphasis on the family as the moral centre of modern citizenship, Canadian disarmers rested their claims to an authority on their status as parent-citizens. In the post-war welfare state, household issues and the family became important to Canadian politics in new ways. ${ }^{462}$ The family served as a safe haven in a chaotic world marked by the legacy of the Depression, the memory of the Second World War, and contemporary anxieties over nuclear weapons. ${ }^{463}$ As Elaine Tyler May argued with reference to the American experience, the aftermath of the Second World War and the continuing insecurity brought on by the Cold War meant that the family served as a

\footnotetext{
${ }^{462}$ Nancy Christie, "'Look out for Leviathan': The Search for a Conservative Modernist Consensus," in Cultures of Citizenship in Post-War Canada, 1940-1955, eds. Nancy Christie and Michael Gauvreau (McGill-Queen's University Press, 2003), 65, 73; Magda Fahrni, Household Politics: Montreal Families and Postwar Reconstruction (Toronto: University of Toronto Press, 2005), 22-23.

${ }^{463}$ Cara Spittal, "The Diefenbaker Moment" (PhD diss., University of Toronto, 2011), 224; Joanne Meyerowitz, "Introduction: Women and Gender in Postwar America, 1945-1960," in Not June Cleaver: Women and Gender in Postwar America, 1945-1960, ed. Joanne Meyerowitz (Philadelphia: Temple University Press, 1994), 3; Brookfield, Cold War Comforts, 10.
} 
place of safety and stability, where people could shape their own futures. ${ }^{464}$ In Canada too, fears of communism and nuclear war situated the family at the heart of efforts to defend morality, normalcy, democracy and capitalism. ${ }^{465}$ Children stood as proof of a successful marriage and family. For the Canadian postwar public and security state, babies were a sign of marital harmony, and of each parent's maturity, responsibility, patriotism, and complete and "normal" emotional and sexual development. ${ }^{466}$

The Canadian government thus participated in the intensification of the public valorization of "good old-fashioned family life."467 The growth of the post-war welfare state assigned public political importance to formerly domestic issues. Measures such as unemployment insurance, family allowances, veterans' benefits and improved old-age pensions were part of a redefinition of Canadian understandings of the role of the state and its relationship to the family. ${ }^{468}$ For example, family allowances signified that the "welfare and stability of the family unit" was a matter of national concern. ${ }^{469}$

The family, specifically children, took on particular importance after the mid1950s in Canada, as the post-war spike in births developed into a demographic revolution. In the mid-1930s, the Canadian birth rate sat at a low of 227,000 births per year. Following the Second World War, the birth rate climbed dramatically, reaching a

\footnotetext{
${ }^{464}$ Elaine Tyler May, Homeward Bound: American Families in the Cold War Era (New York: Basic Books, Inc., Publishers, 1988), 3, 24.

${ }^{465}$ Brookfield, Cold War Comforts, 10-11; Doug Owram, Born at the Right Time: A History of the Baby Boom Generation (Toronto: University of Toronto Press, 1996), 52-53, 253; Christie, “'Look out for Leviathan," 73; Mary Louise Adams, The Trouble With Normal: Postwar Youth and the Making of Heterosexuality (Toronto: University of Toronto Press, 1997), 38.

${ }^{466}$ Adams, The Trouble With Normal, 30, 32; May, Homeward Bound, 160.

${ }^{467}$ Mona Gleason, "Disciplining Children, Disciplining Parents: The Nature and Meaning of Advice to Canadian Parents, 1945-1955," Histoire Sociale/Social History 29 (May 1996): 193.

${ }^{468}$ Magda Fahrni and Robert Rutherdale, "Introduction," in Creating Postwar Canada: Community, Diversity, and Dissent, 1945-75, eds. Magda Fahrni and Robert Rutherdale (Vancouver: UBC Press, 2008), 4.

${ }^{469}$ Nancy Christie, Engendering the State: Family, Work, and Welfare in Canada (Toronto: University of Toronto Press, 2000), 13.
} 
peak of 479,000 by the late 1950s. Between 1945 and 1965, around 8.2 million Canadian babies were born. ${ }^{470}$ In 1961, nearly 42 per cent of the Canadian population was under the age of $20 .{ }^{471}$ The sheer size of the post-war baby boom generation provoked government officials to pay greater attention to the wellbeing of children. ${ }^{472}$ Innocent, vulnerable, malleable, and great in number, children required the protection of parents and the state. Their needs were prioritized over all others. ${ }^{473}$

Because children lacked a political voice, it fell to adults to safeguard their interests. ${ }^{474}$ Medical experts, psychologists and government officials presented children's mental and physical health as public concerns. ${ }^{475}$ These experts expected children to become the centre of their parents' universe. ${ }^{476}$ Born to parents whose childhood had been darkened by economic downturn and war, baby boom children were to be prized, pampered, coddled, and ensured the happy life their parents had been denied. ${ }^{477}$ Cold War Canadian suburban life was built around and for children. ${ }^{478}$ When Canadian disarmers spoke against nuclear arms "for the sake of our children," they were

\footnotetext{
470 "Generations in Canada," Statistics Canada, accessed 19 May 2016, https://www12.statcan.gc.ca/census-recensement/2011/as-sa/98-311-x/98-311-x2011003_2-eng.cfm; Owram, Born at the Right Time, ix; Ian Milligan, Rebel Youth: 1960s Labour Unrest, Young Workers, and New Leftists in English Canada (Vancouver: UBC Press, 2014), 14.

471 "Population growth and components (1851-2001 Censuses)," Statistics Canada, accessed 16 October 2015, http://www.statcan.gc.ca/tables-tableaux/sum-som/101/cst01/demo03-eng.htm; "Population, by age and sex, census dates, 1851 to 1976," Statistics Canada, accessed 27 November 2015, http://www.statcan.gc.ca/pub/11-516-x/sectiona/A78_93-eng.csv.

${ }^{472}$ Owram, Born at the Right Time, ix, 135.

${ }^{473}$ Robert Menzies, Robert Adamoski and Dorothy E. Chunn, "Rethinking the Citizen in Canadian Social History," Contesting Citizenship: Historical Readings, eds. Robert Adamoski, Dorothy E. Chunn and Robert Menzies (Peterborough, Ont.: Broadview Press, Ltd., 2002), 27; Christie, Engendering the State, 312; Fahrni, Household Politics, 143.

${ }^{474}$ Martha Minow and Richard Weissbourd, "Social Movements for Children," Daedalus 122(1) (Winter 1993): 14.

${ }^{475}$ Gleason, "Disciplining Children, Disciplining Parents," 189; Menzies, et. al., "Rethinking the Citizen," 27.

${ }^{476}$ Owram, Born at the Right Time, 51.

${ }^{477}$ Cyril Levitt, Children of Privilege: Student Revolt in the Sixties (Toronto: Macmillan Canada, 1992), 14-15.

${ }^{478}$ Owram, Born at the Right Time, 135.
} 
positioning themselves within an existing discourse about the value of the health and happiness of Canadian children.

While prevention was certainly the state's responsibility, in the event of a nuclear attack, the protection of children would fall on ill-equipped mothers and fathers. ${ }^{479} \mathrm{As}$ Andrew Burtch demonstrated in his history of civil defence planning in Canada, the Canadian government's Cold War civil defence plans, which evolved from self-help to evacuation plans and then to the building of private shelters, placed responsibility for survival on citizens ${ }^{480}$ All levels of government emphasized citizen responsibility for their own survival, even though citizens themselves expected the state to uphold its traditional responsibility as protector. ${ }^{481}$ For example, the Toronto Board of Education expected parents to pick up their children from school in the event of a nuclear attack; according to one parent, this was just a means for the education system to relieve itself of responsibility for children's safety. ${ }^{482}$

\section{Protest "for the children's sake"}

Canadian nuclear activists embraced the notion of parents' duty to ensure their children's safety. They defended their opposition to nuclear arms and their disdain for the Cold War animosities that were bringing the world closer to annihilation by declaring

\footnotetext{
${ }^{479}$ Lawrence Wittner, "Gender Roles and Nuclear Disarmament Activism, 1954-1965." Gender and History 12(1) (April 2000): 214.

${ }^{480}$ Andrew Burtch, Give Me Shelter: The Failure of Canada's Cold War Civil Defence (Vancouver: UBC Press, 2012), 1, 3, 4, 6-7.

${ }^{481}$ Janine Brodie, "Three Stories of Canadian Citizenship," in Contesting Citizenship: Historical Readings, eds. Robert Adamoski, Dorothy E. Chunn and Robert Menzies (Peterborough, Ont.: Broadview Press, Ltd., 2002), 44; Burtch Give Me Shelter, 6, 184.

482 "To the parents, from the Principal," 25 October 1962, The William Ready Division of Archives and Research Collections, McMaster University Library (MUL), CCND fonds, box 10, file 2, 1; Ruth Doehler to the Toronto Board of Education, 26 October 1962, MUL, CCND fonds, box 10, file 2, 1.
} 
themselves parents who were looking out for the interests of their children. Literature distributed by the communist-affiliated Canadian Peace Congress (CPC) often argued that the hydrogen bomb must be outlawed "for the children's sake." ${ }^{483}$ Mary Jennison of the $\mathrm{CPC}$ and the Toronto Association for Peace urged fellow CPC members across the country to work harder and to give more, all "in the name of these children." 484

Chairman James G. Endicott's 1964 Christmas Appeal reminded CPC supporters of the late American President John F. Kennedy's message to women that children "have no lobby in Washington.” As children had no voice in government, it was imperative, Endicott urged, that Canadian parents and grandparents act as the "Peace Lobby" for children. ${ }^{485}$ The non-partisan Canadian Campaign for Nuclear Disarmament (CCND) similarly defined its work as being driven by the desire and the right of parents to "have a say in decisions affecting the life and death" of their children. ${ }^{486}$ Toronto disarmament leader Rabbi Abraham Feinberg asserted in the fall of 1960 that "The attempt to arouse public opinion against nuclear armament is no more unpatriotic than the desire to save one's children from death." 487 Defining disarmament work as being "for the children's sake" was a means for anti-nuclear activists to transcend associations of pacifism with unpatriotic communism.

\footnotetext{
${ }^{483}$ Canadian Peace Congress, Saturday Night, 15 March 1958, LAC, James G. Endicott and Family fonds, MG30-C130, vol. 2, file 22, 51. See also: British Columbia Peace Council, "We must outlaw the Hydrogen Bomb," 1958, LAC, James G. Endicott and Family fonds, MG30-C130, vol. 7, file 114, 2.

${ }^{484}$ Mary Jennison to Mrs. L. Michaud, et. al., 9 July 1958, LAC, James G. Endicott and Family fonds, MG30-C130, vol. 7, file 116, 1.

${ }^{485}$ James G. Endicott, "Dear Friends" (Christmas Appeal), December 1964, LAC, James G. Endicott and Family fonds, MG30-C130, vol. 10, file 182, 1.

${ }^{486}$ CCND Ottawa Branch, "No Nuclear Arms for Canada," 1963, LAC, James G. Endicott and Family fonds, MG30-C130, vol. 2, file 34, 1.

${ }^{487}$ Rabbi Abraham Feinberg, "The Threat of Nuclear War-Its Challenge to Canada," SOS Survival or Suicide 1 (September 1960), MUL, Canadian Peace Congress fonds, 47-1992, box 2, file: other organizations TO. Disarmament ctte., 1.
} 
This emphasis on working for children was not unique to Canadian organizations. At the World Peace Council meeting in Berlin in the spring of 1957, the Council's bureau announced that an end to nuclear testing was required to allow the men and women of the organization to "save the lives of our children." 488 Given that it was the result of the efforts of a collective of Western and Eastern European communist parties, the World Council of Peace (of which the CPC was a member) had to be particularly careful to present its positions in a manner that was not too heavily marked by Cold War ideological divisions. ${ }^{489}$ The idea of the protection of children served to position the aims of the Council as outside communist politics.

The call to fight against nuclear arms "for the children's sake" carried with it an assumption that the desire to shield children from the possible horrors of war was universally held by adults. Members of the Saskatchewan Peace Council argued in 1955 that "every parent, every adult, has a responsibility to protect the wellbeing and safety of the younger generation. ${ }^{490}$ C. L. Morrison, a supporter of the Canadian women's peace organization Voice of Women (VOW), reasoned that all parents should want to defend their children against nuclear war. "How can any parent stay home and do nothing when the devils are going about as a roaring lion seeking whom they can devour," the Edmonton woman asked rhetorically in a letter to VOW co-founder Josephine Davis. ${ }^{491}$

\footnotetext{
${ }^{488}$ World Council of Peace, "Session of the Bureau of the World Council of Peace," 30 March-2 April 1957, LAC, James G. Endicott and Family fonds, MG30-C130, vol. 24, file 461, 2.

${ }^{489}$ Holger Nehring, Politics of Security: British and West German Protest Movements and the Early Cold War, 1945-1970 (Oxford: Oxford University Press, 2013), 160; Reg Whitaker and Gary Marcuse, Cold War Canada: The Making of a National Insecurity State, 1945-1957 (Toronto: University of Toronto Press, 1994), 372; Steve Hewitt, "Sunday Morning Subversion: The Canadian Security State and Organized Religion in the Cold War," in Love, Hate, and Fear in Canada's Cold War, ed. Richard Cavell (Toronto: University of Toronto Press, 2004), 67.

${ }^{490}$ Mabel Hanway and Dorothy Morrison, 2 January 1955, LAC, James G. Endicott and Family fonds, MG30-C130, vol. 19, file 367, 1.

${ }^{491}$ C. L. Morrison to Mrs. Fred Davis, 13 October 1960, LAC, Voice of Women fonds, MG28-I218, vol. 1, file: Correspondence re. formation of VOW Oct. 1960, 1.
} 
The protection of children was not only every parent's responsibility, but it was also absolutely necessary for the state to participate in the safeguarding of children, given Cold War demographics. In a 1963 brief to Judy LaMarsh, minister of National Health and Welfare, VOW executives emphasized that Canadians under 15 constituted one-third of the population. It was thus imperative that the government take action against nuclear weapons testing in order to protect the health of such an important segment of the population. ${ }^{492}$ In this way, VOW presented itself as the advocate for Canadian children who lacked the ability to speak to the government on their own behalf.

Canadian anti-nuclear organizations took on the role of national child advocates, a position that was particularly appealing to individual parents who feared for the future of their own children. A mother from Terrebonne, Quebec, Mrs. René Lajeunesse, understood the emotional power inherent in pleas against nuclear weapons based on a mother's concern for her children. Lajeunesse, who addressed her letter to Prime Minister John G. Diefenbaker's wife Olive, included a "sympathique" (cute) photo of one of her sons, which she stated was evidence of the importance of working for peace. ${ }^{493}$ Voice of Women published a picture of a member, Mrs. Bruce March, and her two sons Jeffrey and Kevin, in a 1961 national newsletter. The photograph of March with her two smiling boys on her lap plainly illustrated the caption, "This is the reason." ${ }^{494}$ Such images of

\footnotetext{
${ }^{492}$ Voice of Women, "Fallout Monitoring Brief to the Minister of National Health and Welfare," June 1963, LAC, Voice of Women fonds, MG28-I218, vol. 2, file: International Cooperation Year conference International Co-operation Travel Mission 1962-63, 4.

${ }^{493}$ Mde. René Lajeunesse to Madame John Diefenbaker, n.d., University of Saskatchewan Archives and Special Collections (USASC), John G. Diefenbaker fonds, MG01/V/F/483, Diefenbaker Centre row 1, vol. $77,1$.

${ }^{494}$ VOW, Voice of Women no. 6, 7, 8, 1 February 1961, LAC, Voice of Women fonds, MG28-I218, vol. 46, file: VOW national newsletter 1960-1961, 16.
} 
Canadian children served to put a face to the claims of activists that they were looking out for the best interests of "our children."

\section{Children's rights in anti-nuclear protest}

The historical moment that gave rise to the baby boom and the emerging Canadian welfare state also witnessed international acceptance of the notion of universal children's rights. ${ }^{495}$ Children have long held a special place in human rights discourse. The concept of human rights is rooted in a vision of the fundamental equality of human beings. ${ }^{496}$ Yet children are assumed to require special treatment and broader rights because of their vulnerability and innocence. ${ }^{497}$

Western child welfare advocates had been arguing that children required special protection, particularly from negligent parents, since the nineteenth century. The drive to establish legislative frameworks to take care of children gained urgency in the aftermath of the First World War. ${ }^{498}$ Sympathy for children who had suffered the effects of war became a powerful tool for encouraging international cooperation in peacetime, leading to the first international declaration of children's rights by the League of Nations in the 1920s. ${ }^{499}$

\footnotetext{
${ }^{495}$ Brookfield, Cold War Comforts, 12; Dominique Marshall, "The Construction of Children as an Object of International Relations: The Declaration of Children's Rights and the Child Welfare Committee of the League of Nations, 1900-1924," International Journal of Children's Rights 7 (1999): 103-104; Dominique Marshall, "The Cold War, Canada, and the United Nations Declaration of the Rights of the Child," in Canada and the Early Cold War 1943-1957, ed. Greg Donaghy, 183-212 (Ottawa: Department of Foreign Affairs and International Trade, 1998), 184.

${ }^{496}$ United Nations General Assembly, "Declaration of the Rights of the Child," A/RES/1386 (XIV), Declarations and Conventions Contained in GA Resolutions, accessed 22 July 2015, http://daccess-ddsny.un.org/doc/RESOLUTION/GEN/NR0/142/09/IMG/NR014209.pdf?OpenElement, 19.

${ }^{497}$ Bhabha, "The Child," 1532-1533; Moynagh, "Human Rights," 39, 41, 47.

${ }^{498}$ Marshall, "The Construction of Children as an Object of International Relations," 115, 133-134.

${ }^{499}$ Dominique Marshall, "Humanitarian Sympathy for Children in Times of War and the History of Children's Rights, 1919-1959," in Children and War: A Historical Anthology, ed. James Alan Marten (New York: New York University Press, 2002), 184.
} 
Initial efforts by post-war children's welfare activists to have the United Nations reconfirm the 1924 League of Nations Declaration of Children's Rights were met with disinterest. Many United Nations representatives assumed that the 1948 Universal Declaration of Human Rights rendered any specific statement for children unnecessary. ${ }^{500}$ However, by the late 1950s, the United Nations Human Rights Commission began to consider children's rights as a way to take action without aggravating the Cold War ideological divisions that had paralyzed the commission and its project to secure universal rights for adults. ${ }^{501}$ The United Nations General Assembly adopted the Declaration of the Rights of the Child in 1959, with the lofty premise that "mankind owes to the child the best it has to give" because every child deserves "a happy childhood." ${ }^{502}$ As a universally "cherished" but helpless human being, "the child" had a symbolic value that transcended Cold War conflict. ${ }^{503}$ Historian Dominique Marshall has suggested that children's rights had a strong appeal to Canadians who enthusiastically supported the 1959 declaration as well as the United Nations Children's Fund (UNICEF). ${ }^{504}$

Anti-nuclear activists adopted conceptions of universal human rights and stressed "the child's" innate purity and worth in their anti-nuclear campaign literature. The preamble to the 1959 Declaration of the Rights of the Child represented the declaration as being necessary for the child, who, "by reason of [their] physical and mental immaturity,

\footnotetext{
${ }^{500}$ Marshall, "Humanitarian Sympathy for Children," 196.

${ }^{501}$ Marshall, "The Cold War, Canada, and the United Nations Declaration of the Rights of the Child," 184185 .

${ }^{502}$ United Nations General Assembly, "Declaration of the Rights of the Child," 19.

${ }^{503}$ Marshall, "The Cold War, Canada, and the United Nations Declaration of the Rights of the Child," 194; Laura Briggs, Gladys McCormick and J. T. Way, "Transnationalism: A Category of Analysis," American Quarterly 60(3) (2008): 640; 299, 1532-1533.

${ }_{504}$ Marshall, "The Cold War, Canada, and the United Nations Declaration of the Rights of the Child," 194195.
} 
needs special safeguards and care. ${ }^{, 505}$ Pamphlets distributed by the CPC and the loosely affiliated Congress of Canadian Women argued that it would be unfair to expose children to the dangers of nuclear fallout and possible nuclear war because they were "innocent of politics" and "cannot act in their own defence." 506 By emphasizing the vulnerability of children, activists presented themselves as the defenders of children's right to life, health, and happiness.

Disarmers argued that the threat of extreme violence presented by nuclear arms was a betrayal of the helpless young by the old. Mrs. Charles Coulon, of Noranda, Quebec, wrote to Toronto Daily Star columnist Lotta Dempsey, arguing that children should be raised knowing that "they do not owe an adult world their lives." letter to Dempsey, Hilkka Hormavirta suggested that women needed to work to create a world where children would not have to "distrust the adult world for placing their innocent lives in jeopardy." ${ }^{508}$ A flyer announcing the $22^{\text {nd }}$ Annual Institute of International Relations meeting put on by the American Friends Service Committee and the Syracuse Peace Council, was illustrated with the hand-drawn image of two ragged adults, each carrying signs saying "I'd rather be red," and "I'd rather be dead." A child rode between them on a tricycle holding a placard simply stating "I'd rather be." The

\footnotetext{
${ }^{505}$ United Nations General Assembly, "Declaration of the Rights of the Child," 19.

${ }^{506}$ Peace Congress, "H-Tests Simply Insane, from the Star Weekly," ca. 1957, LAC, James G. Endicott and Family fonds, MG30-C130, vol. 6, file 106, 1; Congress of Canadian Women, "Read what the late Dr. Marion Hilliard," 2.

${ }^{507}$ Mrs. Charles Coulon to Lotta Dempsey, 6 June 1960, LAC, Voice of Women fonds, MG28-I218, vol. 1, file: Correspondence re. formation of VOW May-June 1960, 1.

${ }^{508}$ Hilkka O. Hormavirta to Lotta Dempsey, 30 May 1960, LAC, Voice of Women fonds, MG28-I218, vol. 1, file: Correspondence re. formation of VOW May-June 1960, 1.
} 
image implied that the ideological debates of the Cold War were of no interest to children and did not serve to protect their wellbeing. ${ }^{509}$

Peace and anti-nuclear activists also demonstrated an acceptance of the second article of the Declaration of the Rights of the Child, which stipulated that children had the right to "develop physically, mentally, morally, spiritually and socially in a healthy and normal manner." 510 "Normal" development, according to anti-nuclear weapons and peace activists associated with the CPC, required "peace on earth." ${ }^{11}$ CPC literature suggested that it would be unethical and unjust to subject children, who lacked the ability to defend themselves and were thus especially deserving of a peaceful world, to nuclear war.

A representative of the Canadian Committee for the Control of Radiation Hazards (CCCRH, which changed its name to CCND in 1962), James S. Thompson, also made moral arguments against nuclear weapons. On a Canadian Broadcasting Corporation (CBC) experts' panel on nuclear fallout, Thompson contended that the life of "one little child" was worth more than "all the insane folly of people who presume to act like statesmen." ${ }^{512}$ By this logic, the needs of children had to be prioritized over "insane" national defence considerations. Prioritizing children's interests was an idea present in the second and eighth articles of the Declaration of the Rights of the Child, which emphasized that "the best interests of the child shall be paramount," and that children shall be the first "to receive protection and relief." 513

\footnotetext{
${ }^{509}$ American Friends Service Committee, "Therefore choose life," 16-18 March 1962, MUL, CUCNDSUPA fonds, box 16, file: Correspondence-M. Rowan and D. Roussopoulos 1961-1962, 1. ${ }^{510}$ United Nations General Assembly, "Declaration of the Rights of the Child," 20.

${ }^{511}$ Alfred Schmidt, ca. 1959, LAC, James G. Endicott and Family fonds, MG30-C130, vol. 2, file 26, 1, 3. See also: Saskatchewan Peace Council, "We need your help," ca. 1958, LAC, James G. Endicott and Family fonds, MG30-C130, vol. 2, file 24, 2.

${ }^{512}$ Frank Freedman to Jacqueline Dineen, "The Invisible Rain," 18 January 1960, LAC, James G. Endicott and Family fonds, MG30-C130, vol. 70, file 1435, 2.

${ }^{513}$ United Nations General Assembly, "Declaration of the Rights of the Child," 20.
} 
Anti-nuclear and peace activism drew from the Declaration's demand that children be raised in an environment of "love and understanding," with "affection," and "moral and material security." "514 A pair of enthusiastic neighbours evoked this principle when they wrote to the VOW executive that given the vulnerability of children, it was cruel to raise them to believe that "a nuclear war is inevitable." ${ }^{515}$ Children should grow up carefree.

A Toronto parent, Ruth Doehler, wrote to her local board of education angry that emergency measures in schools trained children to fear nuclear war, but offered them no real sense of sanctuary or comfort. This deprived "children of their right to an untroubled childhood." ${ }^{516}$ In a letter to Progressive Conservative party leader Diefenbaker, Edna Markle implied that it was unfair for children to learn that "life is anything but sweet and lovely," and continued that children have the inalienable right to "the good things of this earth." ${ }^{517}$ These Canadian women were not simply arguing against nuclear weapons in the interest of children's physical security, but were also opposing the Cold War itself on the grounds that it was unjust to force children to grow up in fear. By adopting the language of children's rights, activists built their arguments against nuclear weapons upon internationally accepted standards for the appropriate treatment of children.

\section{The "symbolic child" in disarmament campaigns}

\footnotetext{
${ }^{514}$ United Nations General Assembly, "Declaration of the Rights of the Child," 20.

${ }^{515}$ Ruth E. Crowder and Frances Gallant to Voice of Women, 24 June 1960, LAC, Voice of Women fonds, MG28-I218, vol. 1, file: Correspondence re. formation of VOW June-Sept. 1960, 1.

${ }^{516}$ Ruth Doehler to the Toronto Board of Education, 26 October 1962, 1.

${ }^{517}$ Mrs. Edna E. Markle to the Hon. John G. Diefenbaker, 9 December 1965, USASC, John G. Diefenbaker fonds, MG01/IX/C/578, Diefenbaker Centre row 6, vol. 174, 1.
} 
While references to children were common in Canadian anti-nuclear literature, there was a notable absence of the voices of children in demands to ban nuclear weapons. The children used in disarmament protest materials were intended to stand in as representatives of all children. The individual experiences and wishes of the young were in many ways superfluous to disarmament campaigns. As Dubinsky and Brookfield have argued with respect to twentieth-century Canadian child welfare activism, the idea of the child carried as much social weight as any "flesh and blood" child. ${ }^{518}$ Because of the importance of the "social category" of "the child" in Western Cold War culture, disarmers were able to access a library of archetypes representing the vulnerability of children. ${ }^{519}$ By using culturally available motifs implying the need to rescue children, disarmers sought to illicit emotional and physical responses from the general public.

One of the most powerful images regularly used in anti-nuclear campaigns was that of an unaccompanied child. As Briggs has observed, the image of a child alone is a “disturbing picture," and one that has been regularly used to pull at the heartstrings of adults by various child welfare movements. ${ }^{520}$ The image of an unsupervised child, which became an increasingly common visual trope during the Second World War, created a longing among adults to "pick the child up and comfort it," according to Briggs. ${ }^{521}$ With its ability to foster an emotional and physical desire to act, the image of a solitary child became a useful tool for activists hoping to convince other parents of the importance of banning nuclear tests and weapons.

\footnotetext{
518 Dubinsky, Babies Without Borders, 5, 12; Brookfield, Cold War Comforts, 14.

519 On the cultural importance of "the child" see: Dubinsky, Babies Without Borders, 5, 12, 14; Bhabha, "The Child," 1526, 1532-1533; Briggs, "Mother, Child, Race, Nation," 185.

${ }^{520}$ Briggs, "Mother, Child, Race, Nation," 185.

${ }^{521}$ Briggs, "Mother, Child, Race, Nation," 185.
} 
Canadian Peace Congress leaders especially understood the value of this visual motif, since many of their public advertisements and petitions included images of unsupervised children. A CPC postcard advertising a 1958 rally at the Prince George Hotel in Toronto with guest Vincent Duncan-Jones, an English journalist, asked "Who will answer the cries of the remaining children? Over 100 million North Americans will be casualties during the first day of nuclear war." To highlight the argument that children would be left to suffer alone in the event of nuclear war, the postcard included the picture of a young blond boy crying, with open mouth and furrowed brow. ${ }^{522}$ Another 1958 CPC pamphlet, advertising a collection of anti-nuclear documentaries available for rent, used the photograph of a young girl, around 10 years of age, as the cover image for the pamphlet. ${ }^{523}$ The image of the girl had no direct relationship to any of the advertised films, but the implication was that all of the documentaries were expressions of fear for the wellbeing of children in the atomic age.

The CPC also used a reproduction of American artist Rockwell Kent's 1941 painting, Heavy Heavy Hangs Over Thy Head, to promote its 1960 rally. The painting depicts a sleeping infant at risk of being struck by a rifle hanging precariously above the child's head. ${ }^{524}$ Initially representative of the horrors of the Second World War, the painting's message remained relevant in the Cold War, when many parents still feared that negligence or chance could lead to nuclear annihilation.

\footnotetext{
${ }^{522}$ CPC Toronto, "Who will answer the cries," 1958, LAC, James G. Endicott and Family fonds, MG30C130, vol. 7, file 115, 1. Unfortunately, because of copyright the images discussed throughout this chapter could not be included in this dissertation.

${ }^{523}$ CPC, "No More War!," LAC, James G. Endicott and Family fonds, MG30-C130, vol. 7, file 115, 1. 524 "Rally for Peace and Disarmament," 7 February 1960, LAC, James G. Endicott and Family fonds, MG30-C130, vol. 2, file 27, 1.
} 
Since the children whose images were used in advertisements were intended to represent all children, even rudimentary drawings of infants could serve the same symbolic purpose as photographs. ${ }^{525}$ The CPC, the CCND, and the student-run Combined Universities Campaign for Nuclear Disarmament (CUCND) used very similar crude drawings of an infant sitting or standing directly under an H-bomb in their publications. The single curlicue on the centre of each baby's head and the similar placement of the bomb indicate that the image was likely borrowed from the American group the Committee for a Sane Nuclear Policy (SANE), which was credited for the image by the CCND. ${ }^{526}$ The use of virtually the same image by the CCND and the CUCND is not surprising given the official affiliation between the two organizations from 1962 to 1964 . What is notable is that a similar image was used by the CPC, an organization that rarely interacted with either campaign.

The image of the lone child was also popular among anti-nuclear weapons groups outside of Canada. The British Campaign for Nuclear Disarmament (CND) selected a hand drawing of a child, sitting alone in a pile of rubble, as the cover for its 1961 pamphlet for mothers concerned with the health effects of nuclear fallout on children. ${ }^{527}$ The emotional appeal of the booklet cover was achieved through its evocation of memories of Second World War bombing raids. In his work on the imagery used by Cold War West German peace movements, Ziemann discovered a similar use of visual images

\footnotetext{
${ }^{525}$ Brookfield, Cold War Comforts, 14.

${ }^{526}$ Unfortunately, for reasons of copyright, these images could not be reproduced in this dissertation. CPC, "No Nuclear Arms for Canada," ca. 1963, LAC, James G. Endicott and Family fonds, MG30-C130, vol. 9, file 164, 3; CUCND, "Support the Combined Universities Campaign for Nuclear Disarmament," n.d., MUL, CCND fonds, SW572, box 9, file 3, 1; CCND, Sanity 1(2) (February 1963), MUL, CCND fonds, ACCN. 05-1989.102.F, box 24, file 1, 6 .

527 “Tomorrow's Children: A Pamphlet of Women," third edition, 1961, MUL, CCND fonds, SW572, box 11, file $14,1$.
} 
reminiscent of the recent war. ${ }^{528}$ Such imagery brought a sense of urgency to anti-nuclear messages by implying that the destruction of Second World War bombing raids would be nothing compared to the devastation that a nuclear explosion would bring.

Ziemann also noted a common theme of illustrations of the beauty of childhood innocence in images used by the German anti-nuclear group Kampf dem Atomtod. ${ }^{529}$ Similarly, one cover of the monthly magazine of the New South Wales Peace Committee for International Cooperation and Disarmament emphasized the purity and vulnerability of childhood with a picture of three children, in knee-deep water, smiling into the camera. The image hinted at the joys of childhood, while at the same time calling to mind the physical defencelessness of children, as the smiling brood played in the surf without an adult in sight. ${ }^{530}$

The CPC's 1964 Christmas Appeal conjured up a similar image of childhood innocence with the hand-drawn illustration of three young children drawing a rendition of Pablo Picasso's peace dove. Calling attention to the children engaging in imaginative play, CPC chairman Endicott reminded CPC supporters that children were incapable of protecting themselves. ${ }^{531}$ Even as its project began to move away from a distinct focus on the nuclear question and towards a more general peace campaign following the signing of the 1963 Limited Test Ban Treaty, the CPC continued to use images of unaccompanied children in annual Christmas Appeals. Notably, the 1965 appeal, which included the sketch of a young girl with the peace dove at her feet, contained no explicit references to

\footnotetext{
528 Ziemann, "The Code of Protest," 242, 243.

529 Ziemann, "The Code of Protest," 246.

${ }^{530}$ N.S.W. Peace Committee for International Co-operation and Disarmament, Peace Action in Australia 6(1) (February 1964), MUL, CCND fonds, SW572, box 11, file 13, 1.

${ }^{531}$ Endicott, "Dear Friends," December 1964, 1.
} 
children in the text. Nevertheless, the image of the child and dove would have certainly reminded CPC supporters of the previous year's appeal, reinforcing the notion that all peace work was work for children. ${ }^{532}$

The image of the unaccompanied child was particularly important in the efforts of SANE. A 1961 pamphlet announcing the aims and key membership of the organization utilized the image of a child for its front cover. Much like the CPC postcard and pamphlet from 1958, the SANE leaflet used a picture of a single child's face, eyes looking up beseechingly. ${ }^{533}$ The picture of a solitary child became a standard feature of SANE campaigns. ${ }^{534}$

The Lyndon Johnson 1964 American presidential campaign hired SANE's advertising firm to produce the well-known "Daisy Girl" advertisement, attacking Johnson's Republican rival Barry Goldwater. Reminiscent of its SANE advertisements, the Doyle Dane Bernbach advertising firm centred the spot on an unaccompanied child. ${ }^{535}$ The black-and-white advertisement began with a three-year-old, freckled-faced girl, picking petals off a flower, and ended in nuclear explosion. ${ }^{536}$ One of the men instrumental in the creation of the commercial, Tony Schwartz, was well known for his belief in the importance of emotional appeals in advertising, as well as his atypical use of children's voices to intensify the heart-rendering effect. Though the advertisement only

\footnotetext{
532 Jacqueline Dineen, "Dear Friends" (Christmas Appeal), 19 October 1965, LAC, James G. Endicott and Family fonds, MG30-C130, vol. 10, file 189, 1.

${ }^{533}$ SANE, "Between a risk and a certainty a sane man does not hesitate," ca. 1961, MUL, CCND fonds, SW573, box 14, file 17, 1 .

${ }_{534}$ Wittner, "Gender Roles and Nuclear Disarmament Activism," 214.

${ }^{535}$ Wittner, "Gender Roles and Nuclear Disarmament Activism," 214; Paul Boyer, "From Activism to Apathy: The American People and Nuclear Weapons, 1963-1980," Journal of American History 70 (March 1984): 823.

${ }^{536}$ Democratic National Committee, "1964 Presidential Campaign Television Spot, 'Peace, Little Girl,' aka the 'Daisy Spot,"' Lyndon Baines Johnson Library and Museum Media Archives, accessed 15 June 2015, http://www.lbjlib.utexas.edu/johnson/media/daisyspot/.
} 
played once on national television, its impact was monumental. Many frightened viewers accused the Johnson campaign of going too far. For its "skilful manipulation of the fears residing in American viewers," the advertisement is of special significance in the history of political campaigning. ${ }^{537}$ The use of pictures of children away from the safety of adult supervision was by then a well-practiced method of creating an emotional appeal in efforts to ban the Bomb.

Another visual trope that was frequently evoked in anti-nuclear weapons activities was the image of the Madonna and child. The traditional Christian image, representing the importance of motherhood, the universality of maternal love, and the dependence of children on mothers, evolved throughout the twentieth-century as it was adopted for a number of political purposes. ${ }^{538}$ By the $1950 \mathrm{~s}$, Western uses of the motif had been broadened from the image of the mother and child to a more generalized image of the family, to highlight the role of fathers and mothers in the protection of children. ${ }^{539}$

As early as 1945, images reminiscent of the Madonna and child could be found in British and West German anti-nuclear protest literature, with the visual trope shifting more prominently towards representations of the nuclear family by $1955 .^{540}$ The Ottawa Committee for the Control of Radiation Hazards used the sketch of a family intertwined in an embrace, looking fearfully to the sky, for the cover of its 1962 booklet "Peace is our Only Shelter," protesting civil defence measures. The title and cover of the booklet hinted at both the importance and inadequacy of parental efforts to protect children in the atomic

\footnotetext{
${ }^{537}$ Robert Mann, "Daisy Petals and Mushroom Clouds," Campaign \& Elections 32(8) (Sept/Oct 2011): 33, 35 .

${ }^{538}$ Marita Sturken and Lisa Cartwright, Practices of Looking: An Introduction to Visual Culture (Oxford: Oxford University Press, 2001), 36.

539 Briggs, "Mother, Child, Race, Nation," 180, 186.

${ }^{540}$ Nehring, Politics of Security, 58-59 and Ziemann, "The Code of Protest," 244.
} 
age. ${ }^{541}$ Titled "Dr. Spock is worried," SANE's most famous advertisement, first published in April 1962 in the New York Times, featured the renowned pediatrician Dr. Benjamin Spock, gazing down at a young girl, with a hint of fatherly concern. Though Spock's physical distance from the child and the text itself made it clear that this was not his child, both his reputation as the ultimate parent and his protective stance above the child evoked the theme of parental guardianship common to the Madonna and child trope. This ad was reprinted in 700 newspapers around the world, and over 25,000 reprints were distributed throughout the United States and by the CCND in Canada. ${ }^{542}$ Western anti-nuclear protest materials involving children were almost without exception illustrated with white children. In their work on Irish humanitarian aid projects and anti-apartheid movements from the 1960s to the 1990s, Kevin O'Sullivan and Håkan Thörn found that appeals to a "common humanity" were most successful in the West when humanity is represented with a "local accent and a white face." ${ }^{, 43}$ According to their findings, people were more likely to engage in activism if they could see themselves or their own children in the images being presented. In the case of publications produced by Western anti-nuclear groups, the racially exclusive representation of children reflected the overwhelming "whiteness" of nuclear disarmament organizations. ${ }^{544}$ With the

\footnotetext{
${ }^{541}$ Ottawa Committee for the Control of Radiation Hazards, "Peace is our Only Shelter," MUL, CCND fonds, SW573, box 18, file 1, 1 .

${ }^{542}$ Benjamin Spock was extremely well received by Canadian parents. His 1946 work The Common Sense Book of Baby and Child Care sold 3,000 copies in Canada in six weeks (Jessica Haynes, "Help for All Parents?: Child-Rearing Advice in English Canada in the 1960s and 1970s," Histoire Sociale/Social History 44(87) (May 2011): 54). Wittner, "Gender Roles and Nuclear Disarmament Activism," 208; Dario Fazzi, "The Blame and the Shame: Kennedy's Choice to Resume Nuclear Tests in 1962," Peace and Change 39(1) (January 2014): 12; Herald of Health, "Dr. Spock is Worried," August 1962, LAC, James G. Endicott and Family fonds, MG30-C130, vol. 8, file 145, 1; F. C. Hunnius to the National Committee for a Sane Nuclear Policy, 6 July 1962, MUL, CCND fonds, box 14, file 21, 1.

${ }^{543}$ Kevin O'Sullivan, "Humanitarian encounters: Biafra, NGOs and imaginings of the Third World in Britain and Ireland, 1967-70," Journal of Genocide Research 16(2-3) (2014): 14; Håkan Thörn, Anti-Apartheid and the Emergence of a Global Civil Society (Basingstoke: Palgrave Macmillan, 2009), 74. ${ }^{544}$ Amy Swerdlow, Women Strike for Peace: Traditional Motherhood and Radical Politics in the 1960s
} 
obvious absence of non-white children in the visual imagery used in Canadian antinuclear activist publications, it is evident that both Canadian and other Western peace organizations consciously strove to draw attention to the dangers nuclear arms posed to "our" children.

"The child" was a potent tool in anti-nuclear campaigns. Because "childhood" had come to be imagined as a "space beyond conflict," the image of a threatened and helpless child could be psychologically and emotionally disturbing to adults. ${ }^{545}$ Disarmers across the West made use of culturally available symbols to illicit responses from the average citizen. The ubiquity of images of "the child" reflects a belief in the emotive potential of such visual representations and the ability of such images to speak to parents who held a variety of political allegiances.

\section{“The Milk We Drink"}

One domain where parents and activists spoke most emphatically on behalf of children was nuclear fallout from weapons testing and the resulting increase in radioisotopes in food supplies. The reality of nuclear fallout became a pressing public issue after an American thermonuclear weapon test at Bikini Atoll in March 1954 caused serious illness among residents of the Marshall Islands and some Japanese fishermen. ${ }^{546}$

(Chicago and London: The University of Chicago Press, 1993), 1-2, 5, 12-13, 90; Harriet Hyman Alonso, Peace as a Women's Issue: A History of the U.S. Movement for World Peace and Women's Rights (Syracuse: Syracuse University Press, 1993), 104-105, 228; Simon Hall, Rethinking the American Anti-War Movement (New York: Routledge, 2012), 95-96; Holger Nehring, "National Internationalists: British and West German Protests against Nuclear Weapons, the Politics of Transnational Communications and the Social History of the Cold War, 1957-1964," Contemporary European History 14(4) (2005): 566; Brookfield, Cold War Comforts, 15; Christine Ball, "The History of the Voice of Women/La Voix des Femmes: The Early Years, 1960-1963" (PhD diss., University of Toronto, 1994), 188.

${ }^{545}$ Dubinsky, Babies Without Borders, 131; Brookfield, Cold War Comforts, 73.

${ }^{546}$ Lawrence S. Wittner, The Struggle Against the Bomb, vol. 2 (Stanford: Stanford University Press, 1997), 2; Ralph H. Lutts, "Chemical Fallout: Rachel Carson's Silent Spring, Radioactive Fallout and the Environmental Movement," Environmental Review 9(3) (Autumn 1985): 213-214. 
Though scientists continued to disagree on the magnitude of the danger created by nuclear fallout, by late 1955 there was a consensus that the long-term genetic effects of strontium-90 - one of the more harmful radioactive by-products of a nuclear explosionwere concerning. ${ }^{547}$

The April 1957 global broadcast of humanitarian and Nobel Peace Prize winner Albert Schweitzer's "Declaration of Conscience," which criticized nuclear testing, drew further public attention to fallout. Schweitzer outlined recent findings about increased levels of nuclear radiation in the atmosphere resulting from American and Soviet hydrogen bomb tests, and explained that such radiation was linked to increases in birth defects and cancers. ${ }^{548}$ By the spring of 1959 , it was publicly known that elevated levels of strontium-90 were present in North American food and milk supplies from which it could be absorbed into the bones and teeth of children. ${ }^{549}$ In the United States, SANE took the lead in publicizing the dangers of fallout, and in 1959 in Edmonton, following consultation with SANE chairman Norman Cousins, Mary Van Stolk founded the Canadian Committee for the Control of Radiation Hazards, named for its initial singular focus on fallout. ${ }^{550}$

Parents were particularly receptive to arguments against nuclear weapons focused on the issue of fallout. Since the mid-1930s, the poison control movement, which became institutionalized in the formation of poison control centres in the $1950 \mathrm{~s}$, had engrained in

\footnotetext{
${ }^{547}$ Robert A. Divine, Blowing on the Wind: The Nuclear Test Ban Debate, 1954-1960 (New York: Oxford University Press, 1978), 47-48, 53, 78.

${ }^{548}$ Wittner, The Struggle Against the Bomb, vol. 2, 31; Norman Cousins, ed., "The Schweitzer Declaration," Saturday Review, 18 May 1957, 17, 19.

${ }^{549}$ Charles Chatfield, The American Peace Movement (New York: Twayne Publishers, 1992), 106; Lutts, "Chemical Fallout," 215.

${ }^{550}$ Chatfield, The American Peace Movement, 106; Wittner, The Struggle Against the Bomb, vol. 2, 197 198; Patricia McMahon, Essence of Indecision: Diefenbaker's Nuclear Policy, 1957-1963 (Montreal: McGill-Queen's University Press, 2009), 66, 127-128.
} 
North American parents the importance of protecting children from accidental household or environmental poisoning. ${ }^{551}$ Historian of medicine John C. Burnham has argued that North American environmental movements emerged out of this earlier movement. ${ }^{552}$ Similar connections can be drawn between fears of unseen household and environmental poisons and concerns about radioactive strontium-90. Environmental historian Ralph H. Lutts has argued that the popularity of Rachel Carson's Silent Spring and the capacity of the work to inspire a significant environmental movement benefitted from the groundwork laid by those raising public concern over nuclear fallout in the 1950s and early 1960s. By the time Carson's celebrated anti-pesticide book was published in 1962 , Americans had already been trained to fear toxins like strontium-90 and candy-flavoured aspirin. ${ }^{553}$ Since the 1930 s, North American parents had been conditioned by pediatricians to be wary of the insidious ways in which the child's environment was full of hazards. Strontium-90 resonated with this training, leading parents to pay special attention to claims that nuclear fallout could result in increased cases of cancer and genetic mutations in children. ${ }^{554}$

The association of strontium-90 with accidental poisonings was common in the publications of anti-nuclear organizations. As the public was still familiarizing itself with the realities of nuclear fallout, the CPC released an advertisement arguing that strontium90 can cause "fatal cancer of the blood." The advertisement urged Canadians to "vote to stop poisoning the earth" in the June 1957 federal election, by supporting only candidates

\footnotetext{
551 John C. Burnham, "How the Discovery of Accidental Childhood Poisoning Contributed to the Development of Environmentalism in the United States," Environmental History Review 19(3) (Autumn 1995): 58, 59, 72 .

552 Burnham, "How the Discovery of Accidental Childhood Poisoning," 58.

${ }^{553}$ Lutts, "Chemical Fallout," 212, 222; Burnham, "How the Discovery of Accidental Childhood Poisoning," 72.

${ }^{554}$ Burnham, "How the Discovery of Accidental Childhood Poisoning," 64.
} 
who had voiced opposition to hydrogen bomb tests. ${ }^{555}$ A British CND booklet, distributed to the CUCND, painted strontium-90 as a poisonous rain, falling on a group of young children. ${ }^{556}$ A CBC special broadcast on fallout, featuring a panel of leading disarmers including celebrated British peace activists Bertrand Russell and outspoken American chemist Dr. Linus Pauling, was given the title "The Invisible Rain." ${ }^{557}$ Carson similarly evoked the imagery of strontium-90 falling to the earth as poison rain in the introduction to Silent Spring ${ }^{558}$ Conceiving of fallout as "destruction...falling upon [the children] from the skies," as one Canadian mother put it, not only helped parents to make sense of this new phenomenon by relating it to a known experience, but also intensified fears. ${ }^{559}$ There was no way to stop the rain from falling, and no umbrella yet existed to protect children.

Discussions equating strontium-90 with toxic rain educated parents on the ecological food chain, leading to concerns that radioisotopes were present in food. ${ }^{560}$ Schweitzer's "Declaration of Conscience," which was a great source of inspiration for Western anti-nuclear groups, laid out the process through which radioactive fallout made its way into the bones of children. ${ }^{561}$ Grasses were absorbing radioactive elements in the soil, and were then being consumed by cows, whose meat and milk were fed to children,

${ }^{555}$ CPC, "On June 10, vote to stop the hydrogen bomb tests," LAC, James G. Endicott and Family fonds, MG30-C130, vol. 6, file 105.

${ }^{556}$ Campaign for Nuclear Disarmament, "In Ignorance Refrain!," MUL, CUCND-SUPA fonds, box 19, file: British Peace Movement Pamphlets, 1.

${ }^{557}$ Freedman, "The Invisible Rain," 1-2.

${ }^{558}$ Rachel Carson, Silent Spring (Boston: Houghton Mifflin, 2002), 6.

${ }_{559}$ Irene Rowcliffe to Mrs. Nina Khrushchev, 21 September 1961, USASC, John G. Diefenbaker fonds, MG01/V/F/483, Diefenbaker centre row 1, vol. 77, 1.

${ }^{560}$ Lutts, "Chemical Fallout," 216.

${ }^{561}$ Frances B. McCrea and Gerald E. Markle, Minutes to Midnight: Nuclear Weapons Protest in America (Newbury Ca.: Sage Publications, 1989), 70; Ziemann, "The Code of Protest," 247. 
Schweitzer explained. ${ }^{562}$ A November 1963 flyer acquired by the CCND, and produced by the Australian CND, used a comic strip based on the popular Mother Goose nursery rhyme "This is the house that Jack built," to illustrate the movement of radioactive isotopes through the food chain. The comic strip traced the progression from the bomb "that Jack built" to Jack's child, drinking the milk "that comes from the cow that eats the grass that absorbs the fallout that comes from the bomb that Jack built." ${ }^{.563}$ The nod to the nursery rhyme was not intended to make light of fallout, rather to set it up as a significant threat to the innocence and joy of childhood.

As the primary food of infants, milk became a powerful and emotional tool in discussions of nuclear fallout. ${ }^{564}$ In 1959 Consumer Reports released a scientific analysis of strontium-90 in various food products found across the United States, entitled "The Milk We Drink." Highlighting the insidious nature of fallout, the report contended, "fresh clean milk, which looks and tastes just as it always did, nevertheless contains (wherever you get it these days) an unseen contaminant." ${ }^{565}$ The report stated that strontium-90 levels in the milk sampled by Consumer Reports were at least double the estimates of the United States Atomic Energy Commission. Among the Canadian cities included in the survey sample, radioisotopes were found to be exceptionally high in Quebec City. ${ }^{566}$

"The Milk We Drink," which was read by millions in the United States and Canada, was

\footnotetext{
${ }^{562}$ Wittner, The Struggle Against the Bomb, vol. 2, 78; Ziemann, "The Code of Protest," 247; Cousins, "The Schweitzer Declaration," 19.

563 Australian Campaign for Nuclear Disarmament, "No French Tests, Questions to Consider in Federal Elections," November 1963, MUL, CCND fonds, SW572, box 11, file 13, 4.

${ }^{564}$ Lutts, "Chemical Fallout," 215; Wittner, "Gender Roles and Nuclear Disarmament Activism," 207.

${ }^{565}$ Consumer Reports, "The Milk We Drink," reprint by Consumers Union, March 1959, LAC, James G. Endicott and Family fonds, MG30-C130, vol. 7, file 119, 103.

566 Consumer Reports, "The Milk We Drink," 109-110.
} 
taken as scientific proof by many disarmers of the urgent need to cease nuclear weapons testing. ${ }^{567}$

The celebrated SANE "Dr. Spock is Worried" advertisement also referred to the dangers radioactive fallout posed for food supplies. The text of the advertisement opened with a message from Spock: "I am worried. Not so much about the effect of past tests, but at the prospect of endless future ones. As the tests multiply, so will the damage to children." 568 The text went on to inform readers that strontium-90 levels in children's bones would double in 1962 because of nuclear weapons tests. It also warned that cancercausing fallout was most present in milk, whole wheat, green leafy vegetables, and legumes. SANE discouraged the consumption of whole grain breads and cereals, and implied that milk could be dangerous, explaining that Great Britain was setting aside powdered milk for emergency use. ${ }^{569}$

Another popular SANE advertisement, that also made its way to Canada, featured a bottle of milk labelled as poisonous, with the mark of the skull and crossbones. The advertisement stressed the importance of milk, stating: "Milk is the most sacred of all foods. It is the food of infants and children. No one in the world has the right to contaminate it." The ad encouraged mothers and fathers to "raise hell." ${ }^{\text {"570 }}$ Because of milk's association with the health and development of infants, contaminated milk was a key concern to activists who wished to protect the next generation.

\footnotetext{
${ }^{567}$ Lutts, "Chemical Fallout," 215.

${ }^{568}$ Herald of Health, "Dr. Spock is Worried," 2.

${ }^{569}$ Herald of Health, "Dr. Spock is Worried," 3-4.

${ }^{570}$ SANE, "Is this what it's coming to?," LAC, James G. Endicott and Family fonds, MG30-C130, vol. 32, file 603, 1; Wittner, "Gender Roles and Nuclear Disarmament Activism," 207.
} 
The American women's group Women Strike for Peace (WSP) released a comparable advertisement. Using the image of a milk bottle, WSP advised parents that nuclear fallout caused cancer and deformities in children and that fresh milk should not be consumed for eight days after every nuclear weapon test. ${ }^{571}$ The slogan "Pure Milk Not Poison" was the most effective campaign waged by WSP and was central to WSP's successful recruiting efforts of 1962 and 1963, according to historian and WSP member Amy Swerdlow. ${ }^{572}$ WSP led boycotts of local dairies and milk delivery services, demanding more government-sponsored research into the health effects of the radioactive products of fallout and the installation of equipment capable of removing radioactive isotopes from milk. ${ }^{573}$ Fear of radioactive contamination of milk was also displayed by the women's group of the British CND in a mass march of several hundred women to the Soviet Embassy in London in the fall of $1961 .{ }^{574}$ The mixed-gender British CND and British Committee of 100 both produced copious literature and advertising related to the hazards of strontium-90 and the radioactive contamination of milk. ${ }^{575}$

Canadian activists shared the anxiety over milk. Petitions from the CPC released in 1958 stated that strontium-90 posed the greatest threat to children because of the way it replaced calcium in the bones of growing bodies ${ }^{576}$ One CPC petition warned that Canadian parents should be doubly concerned because children absorbed the radioisotope three times faster than adults, and because "Canada is among the countries where the

\footnotetext{
${ }^{571}$ Women Strike for Peace, "Nuclear tests cost lives," MUL, CCND fonds, box 15, file 12, 1.

${ }^{572}$ Swerdlow, Women Strike for Peace, 83.

${ }_{573}$ Alonso, Peace as a Women's Issue, 207.

${ }^{574}$ Nehring, Politics of Security, 222,

${ }^{575}$ Wittner, "Gender Roles and Nuclear Disarmament Activism," 207.

${ }^{576}$ Milton Katz, Ban the Bomb: A History of SANE, the Committee for a Sane Nuclear Policy, 1957-1985 (Westport, Conn: Greenwood Press, 1986), 16.
} 
fallout is heaviest." ${ }^{\text {577 }}$ Canada did receive more than the average doses of fallout. The manner in which wind currents focus radioactive debris around the poles and the high rainfall in temperate zones, combined with the fact that the majority of nuclear tests occurred in the northern hemisphere, meant that fallout was heavier in Northern countries like Canada. ${ }^{578}$

A plea sent to Toronto-based trade union organizations warned that millions "of children are carrying the bomb-bred seeds of their own and humanity's destruction. Your child may be next." ${ }^{579}$ Suggesting that it was almost too late, as strontium-90 was already hiding in the bodies of Canadian children, the petition to unionists urged parents to take immediate action against nuclear weapons tests. A Toronto Association for Peace (TAP) brief to Prime Minister Diefenbaker in the spring of 1959 explained that the "deadly poison" of strontium-90 had already tainted "every glass of milk we give to a child, every slice of bread we eat." Given the danger to children in particular, the TAP argued that it was "homicidal and suicidal" to continue testing nuclear weapons. ${ }^{580}$ The TAP also requested that local dairies begin taking measures to address the issue of contaminated milk. Eva Sanderson, the TAP president, argued that Canadian parents were in a very difficult position, because they had been encouraged for years to provide their children

${ }^{577}$ CPC Toronto, "Stop the Nuclear Tests Now," 1958, LAC, James G. Endicott and Family fonds, MG30C130, vol. 7, file 114, 3; Congress of Canadian Women, "Read What the Late Dr. Marion Hilliard," 2. ${ }^{578}$ Daniel Heidt, "'I think that would be the end of Canada:' Howard Green, the Nuclear Test Ban, and Interest-Based Foreign Policy, 1946-1963," American Review of Canadian Studies 42(3) (September 2012): 350-351; Saskatoon Committee for Control of Radiation Hazards, "Facts on Fallout," ca. 1959, LAC, James G. Endicott and Family fonds, MG30-C130, vol. 7, file 125, 1; "Fallout Monitoring in Canada Brief to the Minister of National Health and Welfare, by Voice of Women Canada," June 1963, LAC, Voice of Women fonds, MG28-I218, vol. 2, file: International Cooperation Year Conference International Cooperation Travel Mission 1962-63, 5 .

579 Toronto Committee for Peace, "To all Trade Union Organizations and all Trade Unionists," LAC, James G. Endicott and Family fonds, MG30-C130, vol. 7, file 114, 1.

${ }^{580}$ Toronto Association for Peace, "Toronto Association for Peace Submission to the Right Honourable John Diefenbaker," 4 May 1959, LAC, James G. Endicott and Family fonds, MG30-C130, vol. 7, file 124, 2. 
with milk, "one of nature's best well-balanced foods and so necessary for the building of young bones and teeth," but also knew milk to be tainted by radioactive fallout. ${ }^{581}$

The letters written in support of the formation of VOW in the spring and summer of 1960 made plain the challenges presented to parents by the realities of the nuclear age. One mother begged for the publication of medical research related to fallout, to teach mothers to "regard every glass of milk...with horror." ${ }^{582}$ In like manner, Irene Rowcliffe, of Moncton, wrote Olive Diefenbaker protesting nuclear weapons testing on the grounds that Canadian mothers were being forced to feed their "innocent babies" "Dirty Milk.",583 "Dirty milk" was everywhere, but there was no way to recognize it.

One of VOW's most successful campaigns was directly related to the issue of poisoned milk. The baby teeth campaign, which collected over 40,000 Canadian baby teeth from 1963 to 1965 , made great strides in efforts to get parents and children to think about the impact that nuclear fallout could have on children's bodies. ${ }^{584}$ Teeth collected by VOW were sent to dentist Dr. Murray Hunt and metallurgist Dr. Ursula Franklin at the University of Toronto. The study found that the levels of radioisotopes in children's teeth were highest in those from Calgary and lowest in those from Hamilton. But, Hunt assured Canadian parents in 1965, "none of the samples show activities that could be considered

\footnotetext{
${ }^{581}$ Eva Sanderson, "To the Dairies," 25 July 1959, LAC, James G. Endicott and Family fonds, MG30C130, vol. 18, file 349, 1 .

582 Sylvia Birchall to Lotta Dempsey, 30 May 1960, LAC, Voice of Women fonds, MG28-I218, vol. 1, file: Correspondence re. formation of VOW n.d. May-June 1960, 2.

${ }^{583}$ Mrs. Irene Rowcliffe to Mrs. John Diefenbaker, 22 September 1961, USASC, John G. Diefenbaker fonds, MG01.V.F.483, Diefenbaker Centre row 1, vol. 77, 1.

${ }^{584}$ Olga Spinks and Barbara Stewart, "Report of National Baby Tooth Coordination to National Annual Meeting," in "Voice of Women Annual Meeting 1965 Reports," May 1965, LAC, Voice of Women fonds, MG28-I218, vol. 1, file: $5^{\text {th }}$ annual meeting reports to and lists 1965, 6; Kay Macpherson, When in Doubt, Do Both: The Times of My Life (Toronto: University of Toronto Press, 1994), 139; Catherine Carstairs, "Food, Fear, and the Environment in the Long Sixties," in Debating Dissent: Canada and the Sixties, eds. Lara Campbell, Dominique Clément and Gregory S. Kealey (Toronto: University of Toronto Press, 2012), 34.
} 
to be dangerous. $" 585$ While the data did not reveal a reason to be concerned over fallout, it did provide an illustration of fallout patterns in Canada and demonstrated that strontium90 levels were lower in children who were breast-fed, according to Franklin. ${ }^{586}$

The VOW project did have a significant and lasting impact on Canadian parents and children. VOW's program convinced thousands of Canadian parents to collect and send in their children's teeth. The project's initial goal of collecting 2,000 teeth from the Toronto area was quickly exceeded. ${ }^{587}$ Between June 1963 and April 1964, Toronto area parents donated over 5,500 baby teeth. ${ }^{588}$ One VOW mother recalled that while she collected her children's baby teeth, she was also educating them about what it meant to live in the nuclear age. ${ }^{589}$ A child of disarmament activists, born in 1957 , remembered fifty-years later that he and all his siblings gave baby teeth to the "Tooth Fairy" project to document the effects of nuclear weapons tests. ${ }^{590}$ The project also received positive attention from the Globe and Mail. ${ }^{591}$ Minister of Health LaMarsh questioned the capacity of the study to reach any real conclusions from a "box full of teeth." VOW immediately responded to the criticism, defending the science behind the project in the press. Donations continued to pour in. ${ }^{592}$

\footnotetext{
${ }^{585}$ Spinks and Stewart, "Report on National Baby Tooth Cooperation," 6.

586 "VOW Defends Project Assailed by LaMarsh," The Globe and Mail, 5 December 1963, 14.

587 "Will You Help the Tooth Survey?," n.d., LAC, Voice of Women fonds, MG28-I218, vol. 5, file: radiation, baby teeth survey 1963, 2 .

588 Olga Spinks and Barbara Stewart, "Report of Toronto Baby Tooth Survey," May 1964, LAC, Voice of Women fonds, MG28-I218, vol. 22, file: National Annual Meeting (1964), 1.

${ }^{589}$ Anonymous, interview with author, 1 November 2013.

${ }^{590}$ Anonymous, email with author, 28 October 2013.

591 "New Program Launched," The Globe and Mail, 15 March 1963, 9; "Tooth Report Sought," The Globe and Mail, 25 July 1963, 14; "Molars Missing: Good Fairies Bite Science on Teeth," The Globe and Mail, 31 August 1963, 5; "1,200 Baby Teeth Collected for VOW," The Globe and Mail, 12 September 1963, 20; "Fallout Detection Tests Termed Inadequate," The Globe and Mail, 29 February 1964; "VOW Report: 12,000 Teeth Tested," The Globe and Mail, 1 June 1964.

592 "Teeth Check for Fallout Questioned," The Globe and Mail, 4 December 1963, 9; "VOW Defends Project Assailed by LaMarsh," The Globe and Mail, 5 December 1963, 14; Spinks and Stewart, "Report of Toronto Baby Tooth Survey," 1.
} 
VOW's successful consciousness-raising project was a spinoff of a campaign begun in 1959 by the St. Louis Citizens' Committee for Nuclear Information. The St. Louis project collected nearly 160,000 baby teeth between 1959 and 1964, sometimes at a rate of 750 teeth a week. The researchers found an increase of 300 per cent in strontium-90 in the teeth over the course of the study. ${ }^{593}$ The St. Louis project was inspired by biochemist Herman Kalckar's 1958 call for an international study of the accumulation of radioisotopes in baby teeth. While no such international study was ever undertaken, the coordinators of VOW's baby teeth project and the St. Louis survey organizers did work closely together, and handed out the same "I Gave My Tooth to Science" button to participating children. ${ }^{594}$

Both studies were remarkably successful at catching "the imagination of both the community at large" and that of the media. ${ }^{595}$ Baby teeth were the perfect means for establishing increasing levels of strontium-90 and other radioisotopes accumulating in human bodies because they were readily available and in continuous supply, could be collected without injury to the donor, and the donor's age could be precisely established ${ }^{596}$ Baby teeth also had an immense publicity value, which served to bring the issue of fallout close to home as parents gathered and sent in their own children's teeth. In an assessment of the VOW campaign, Royal Canadian Mounted Police Constable L. E. J. MacIsaac argued that the project would "undoubtedly" help VOW "regain any lost

\footnotetext{
${ }^{593}$ Lutts, "Chemical Fallout," 215-216; Wittner, "Gender Roles and Nuclear Disarmament Activism," 208; Carstairs, "Food, Fear, and the Environment in the Long Sixties," 33.

${ }^{594}$ Ethel Kesler, "Report of Ethel Kesler, Co-ordinator, Tooth Surveys, to National Annual Meeting of VOW," ca. 1964, LAC, Voice of Women fonds, MG28-I218, vol. 22, file: National Annual Meeting (1964), 1; Lutts, "Chemical Fallout," 216; The Spectator Weekend Magazine 13(43) (26 October 1963), LAC, Voice of Women fonds, MG28-I218, vol. 5, file: Radiation Baby Teeth Survey 1963, cover.

${ }^{595}$ Kesler, "Report," 1.

${ }^{596}$ Lutts, "Chemical Fallout," 215; Macpherson, When in Doubt, 139.
} 
respectability and to combat any future efforts on the part of anyone to discredit them." 597 As MacIsaac's assessment suggested, linking an anti-nuclear efforts to the health and future wellbeing of children was a means for activists to legitimize their campaigns.

The VOW pamphlet sent to Canadian parents soliciting baby teeth explicitly stated on two occasions that, because of the number of teeth collected and the manner in which they were studied, "it is impossible to give individual reports." 598 The inclusion of such a statement suggests that some parents were anxious to learn of the levels of radioisotopes accumulating in the bodies of their own children. VOW members and the mothers and fathers who sent their children's teeth to Toronto as part of the study often did so out of genuine concern for the dangers posed to the health of their children by strontium-90. Ethel Kesler, of Montreal, prompted Hunt and Franklin to begin the baby tooth campaign because she was worried about the presence of radioactive isotopes in the bodies of her three sons and could not find a Canadian lab doing such a study at the time..$^{599}$

While there was little agreement within the scientific community throughout the mid-1950s to early 1960s about the extent of the dangers of fallout, Canadian disarmers were quick to pick up on scientific research that pointed to significant increases in instances of childhood cancer and of children born with malformations as a result of continued nuclear weapons testing. ${ }^{600}$ One particular scientist-turned-activist often cited by Canadian activists was American Nobel Prize winning chemist Linus Pauling. Pauling

\footnotetext{
${ }^{597}$ Cst. L. E. J. MacIsaac, "Re. Voice of Women Communist Activities Within Canada," 23 October 1963, LAC, CSIS files, RG 146, vol. 2844, part 18, 2 (obtained under access to information).

598 "Will You Help the Tooth Survey," n.d., LAC, Voice of Women fonds, MG28-I218, vol. 5, file: Radiation baby teeth survey 1963, 2, 4 .

599 "Organizer in Town: Baby Teeth Given for Study," The Globe and Mail, 1 June 1963, 18.

${ }^{600}$ Divine, Blowing on the Wind, 50, 52-53, 122.
} 
became radicalized against nuclear weapons after being inspired by Schweitzer's 1957

"Declaration of Conscience." ${ }^{601}$ Despite being on a "look-out list" of foreign persons to be blocked from entering Canada for suspected communist affiliations, Pauling's message was effectively spread across Canada by the CPC and by guest appearances on the CBC. ${ }^{602}$ Pauling argued that nuclear weapons testing, as of November 1957, had already led to an increase of one per cent in both the number of children born with genetic mutations and in the number of deaths from leukemia and bone cancer across the globe. This meant an additional 15,000 "seriously defective" children born globally each year because of nuclear fallout. As the number of tests increased it was likely that at some point "the human race would no longer be recognisable as such to us, the number of defective, changed, mutated children being so great," Pauling claimed. ${ }^{603}$

Canadian parents took up Pauling's warnings about the impact of nuclear weapons tests. William Irvine anxiously wrote to Endicott that Pauling's findings made it clear that bomb tests needed to be stopped immediately and all existing weapons destroyed. Irvine took very seriously Pauling's estimates that " $1,250,000$ children will be born with gross physical and mental defects due to the carbon 14 fallout; that $1,400,000$ people now living will die of bone cancer and leukemia and 1,000,000 more will die of cancer of all kinds. ${ }^{604}$ Mary Jennison, on behalf of the Mid-Town Peace Association in

\footnotetext{
${ }^{601}$ Divine, Blowing on the Wind, 125-126; Chatfield, The American Peace Movement, 108.

${ }^{602}$ Whitaker and Marcuse, Cold War Canada, 372; James Endicott to the B.C. Peace Council, 18 March 1961, LAC, James G. Endicott and Family fonds, MG30-C130, vol. 8, file 136, 1; Jacqueline Dineen to All Peace Committees, 21 March 1961, LAC, James G. Endicott and Family fonds, MG30-C130, vol. 8, file 138, 1; CBC, Linus Pauling, "Our Special Speaker: The Dangers of Radioactivity," 24 November 1957, LAC, James G. Endicott and Family fonds, MG30-C130, vol. 70, file 1436; Freedman, "The Invisible Rain," 1-2.

${ }^{603}$ CBC, "Our Special Speaker," 1.

${ }^{604}$ William Irvine to Mr. Endicott, 3 February 1960, LAC, James G. Endicott and Family fonds, MG30C130, vol. 2, file 28, 1 .
} 
Toronto, evoked Pauling's name and findings when she wrote to her member of parliament opposing nuclear weapons testing on the grounds that nuclear fallout produces "idiot and abnormal" children. ${ }^{605}$

Fears over generations of children born with physical or mental disabilities because of nuclear fallout became a motivator for people to participate in anti-nuclear activism. As one woman explained to the VOW executive, Schweitzer's declaration that nuclear tests were "producing hundreds of thousands of deformed children" alerted her to the risks of nuclear testing and led to her involvement in VOW. ${ }^{606}$ A TAP delegation to Ottawa demanded that the federal government intervene to prevent the exposure of Canadians to strontium- 90 because the radioisotope caused cancer in children and could make unborn babies "physically or mentally abnormal."

Edith Holtom, one of the most active Ottawa members of the CPC, wrote to the editor of the Globe and Mail that the effects of nuclear fallout on the unborn were already known. In the case of survivors of the August 1945 atomic bombings of Hiroshima and Nagasaki, nearly one in six pregnancies resulted in stillborn or deformed offspring. Some children, she continued, were born "without brains, others lacked sexual organs, eyes or lips. ${ }^{9608}$ An early issue of the CUCND's journal Our Generation Against Nuclear War argued that the after-effects of the first two atomic bombings demonstrated the desperate need for disarmament. According to Our Generation 15 per cent of children born to the

\footnotetext{
${ }^{605}$ Mary Jennison to Charles Rea, 6 January 1957, LAC, James G. Endicott and Family fonds, MG30C130, vol. 18, file 348, 1 .

${ }^{606}$ Olga Spuiles, "Questionnaire," n.d., LAC, Voice of Women fonds, MG28-I218, vol. 1, file: Correspondence Josephine Davis (vice-pres) 1962, 1.

${ }^{607}$ Toronto Association for Peace, "Bomb tests endanger our health now, Ask Ottawa to safeguard our children!," 4 May 1959, LAC, James G. Endicott and Family fonds, MG30-C130, vol. 7, file 120, 1. ${ }^{608}$ Edith Holtom to the editor Globe and Mail, 20 Jan. 1959, LAC, James G. Endicott and Family fonds, MG30-C130, vol. 8, file 129, 1.
} 
survivors of these first two atomic bombings "showed abnormal signs." ${ }^{\circ 09}$ The British CND also referred to the 1945 atomic bombings in their pamphlet to educate women on the effects of nuclear fallout on children. Because of the cumulative effect of genetic mutations, the pamphlet argued, it would not be until the children born to the survivors of Hiroshima and Nagasaki had babies of their own that the true damage of nuclear weapons could be assessed. Nevertheless, the CND publication stated, it was unfair to run the risk of even one child "dying from cancer or coming into the world an idiot, blind, deformed or a weakling. ${ }^{\prime 610}$ For that reason, all tests needed to be stopped.

Several CPC publications called for an end to nuclear weapons testing because fallout resulting from the nuclear tests done by 1957 would increase infant mortality rates and the numbers of children born with genetic mutations or dying of cancer for 29 generations. ${ }^{611}$ And, because fallout could not be contained to the combatant nations in the event of war, the effects would be global. As one British Columbia Peace Council member argued in a letter to Prime Minister Diefenbaker in 1962, generations would be affected by disease and the births of "malformed children."

Fear of nuclear fallout commonly led to imagery of disfigured and mutant children. A popular advertisement developed by the Danish Campaign Against Nuclear Arms, and later circulated by other Scandinavian movements, featured a man standing behind his pregnant wife, with the caption "Is it a child or a misbegotten monster? Stop

\footnotetext{
${ }^{609}$ Combined Universities Campaign for Nuclear Disarmament, Our Generation Against Nuclear War, ca. 1960, MUL, CUCND-SUPA fonds, box 1, file CUCND Toronto Office 1960-1961, 2.

610 "Tomorrow's Children: A Pamphlet for Women," 1961, 4.

${ }^{611}$ CPC, "On June 10, vote to stop the hydrogen bomb tests," n.d., LAC, James G. Endicott and Family fonds, MG30-C130, vol. 6, file 105; CPC, "Peacegram," 24 May 1957, LAC, James G. Endicott and Family fonds, MG30-C130, vol. 7, file 107; Eva Sanderson, "Peacegram," n.d., LAC, James G. Endicott and Family fonds, MG30-C130, vol. 7, file 107.

${ }^{612}$ C. O. H. Pease to Hon. Prime Minister, 10 May 1962, USASC, John G. Diefenbaker fonds, MG01/VI/(154.1/U58), Diefenbaker Centre rows 2-4, vol. 52, 1.
} 
all nuclear weapons now!" ${ }^{613}$ Implying that their unborn child might not be recognizably human, the advertisement trusted its readers to imagine a radioactive-child for themselves. Hugh Keenleyside, chairman of the CCCRH, also used dramatic language to illustrate potential genetic mutations when he claimed in his June 1960 chairman's address to the CCCRH national committee that it would be to blame for not trying hard enough to stop the tests if their children or grandchildren were "born with two heads." Similarly, Ruth Harris from Aurora, Ontario, wrote to VOW leaders: "How can we...allow scientists and those in charge of nuclear armaments to put us in a position of worrying if in our old age we shall be asked by our freak grandchildren, 'Why did you allow this to happen to us?" ${ }^{615}$ According to Keenleyside and Harris, the responsibility to prevent generations of Canadian children from being born as "monsters" rested directly on parents.

Popular culture references abounded to provide Canadian parents with visual representations to help them imagine their world following a nuclear apocalypse. A wave of popular science fiction films released in the mid-1950s provided a variety of possible outcomes of radioactive fallout. The giant irradiated ants from 1954's Them!, the colossal spider of the 1955 film Tarantula, and the man who shrank to atomic size after radioactive exposure in 1957's The Incredible Shrinking Man all provided terrifying examples of radio-active side-effects. Added to science fiction was the thalidomide syndrome, which became a media story in 1962, providing real-life examples of

${ }^{613}$ Ziemann, "The Code of Protest," 245-246.

${ }^{614}$ H. L. Keenleyside, "Why We are Here," 13 June 1960, LAC, James G. Endicott and Family fonds, MG30-C130, vol. 8, file 129, 4.

${ }^{615}$ Ruth Harris to Lotta Dempsey, June 5, 1960, LAC, Voice of Women fonds, MG28-I218, vol. 1, file: Correspondence re. formation of VOW May-June 1960, 2. 
congenital malformations. Thalidomide had been promoted in the late 1950 s as a sedative and morning sickness treatment, before it was discovered that the drug caused defects in babies ranging from missing fingers to the absence of entire limbs. The drug was also found to cause damage to internal organs. ${ }^{616} \mathrm{With}$ such potent cultural examples readily available to parents, campaigns focused on the health effects of fallout highlighted the possibility of personal and global suffering for generations to come. References to fallout-induced genetic mutations made the argument that nuclear tests needed to be immediately halted.

\section{The "child" as justification for nuclear deterrence}

Just as the need to protect children had been used to argue against the use of violence, the need to guarantee children's safety had also served to vindicate military action. According to Lee-Koo, because of the real and metaphorical significance of children to any discussion of the future, political actors have often manipulated the image of the child in the interest of justifying war. ${ }^{617}$ In her analysis of the American combat mission in Afghanistan in the early twenty-first century, Lee-Koo explained that "the experiences of Afghan children [became] a moral currency" which belligerent parties used to demonize the enemy and to defend military intervention and retaliation. ${ }^{618}$

\footnotetext{
${ }^{616}$ Lutts, "Chemical Fallout," 212; Stefan Timmermans and Valerie Leiter, "The Redemption of Thalidomide: Standardizing the Risk of Birth Defects," Social Studies of Science 30(1) (February 2000): 41, 45; Jean F. Webb, "Canadian Thalidomide Experience," Canadian Medical Association Journal 89(19) (9 November 1963): 987-988, 989-990. Thalidomide syndrome was among one of the many side issues of interest to VOW in 1962 (Voice of Women, "President's Report," 16 September 1962, LAC, Voice of Women fonds, MG28-I218, vol. 22, file: National Annual Meeting (1962), 4).

${ }^{617}$ Lee-Koo, "Not suitable for children," 476, 485, 487.

${ }^{618}$ Lee-Koo, "Not suitable for children," 476.
} 
In a letter to CPC chairman Endicott's wife Mary, who was an old friend, Lester B. Pearson referred to Second World War fascist propaganda to illustrate how easily the idea of the child could be manipulated to benefit both sides of a conflict. "Do you not remember the flood of photographs of Hitler with children in his arms or handing him flowers," he asked. "And do you not remember also those sinister organizations, the Hitler-Jugend in Germany and the Ballilla in which Italian tots marched stridently singing Mussolini's hymns of war?" As he provided her with feedback on her pacifist booklet $M y$ Journey for Peace, Pearson cautioned Endicott that children may have a universal appeal, but "no one knows this better than the dictators." 619

While disarmers took advantage of the symbolic possibility that children presented for mobilizing opposition to nuclear arms in Canada and abroad, the "symbolic child" was also evoked by those who firmly believed in the principle of nuclear deterrence and who wanted Canada to acquire its own nuclear weapons. In her work on Cold War Canadian mothers' child welfare campaigns, Brookfield found that the desire to protect children served to motivate women to defend elements of Cold War politics. She demonstrated, for example, how the enthusiastic support of Canadian women's organizations, including the Local Council of Women, the Imperial Order Daughters of the Empire, and the Girl Guides, for civil defence measures indicated a tacit acceptance of Cold War nuclear deterrence policies. The vast majority of Canadian anti-nuclear organizations, on the other hand, argued that civil defence was a dangerous acquiescence in the inevitability of nuclear war. ${ }^{620}$ Inspired by the same desire as disarmers to make the

\footnotetext{
${ }^{619}$ Lester B. Pearson to Mary [Endicott], 19 May 1951, LAC, Lester B. Pearson fonds, MG26-N1, vol. 4, file: Pre 1958 open series Pearson, L.B. Endicott, Mrs. James 1947-1951, 2.

${ }^{620}$ Brookfield, Cold War Comforts, 6, 26, 33-34; Burtch, Give me Shelter, 66, 70, 184, 186-187; BC

CCRH, "Peace is the only safe shelter," ca. 1961, MUL, CCND fonds, SW571, box 5, file 17; National
} 
world a safer place for their children, women who eagerly volunteered their time to civil defence efforts did so without questioning war itself, but with a determination to ensure the survival of their children in the event of a nuclear conflict. ${ }^{621}$

Those who supported Canada's acquisition of nuclear arms presented themselves as representatives of children, in much the same way that disarmers portrayed themselves as child advocates. R. E. Buell, a former soldier, twisted the argument made by mothers like Harris that it was unjust for her generation to impose genetic malformations on the generations of the future. He argued, on the contrary, that his generation "had no right to condemn future generations" to life under communism. The only way to prevent the spread of communism to Canada, Buell suggested, would be in arming the nation to the fullest: this meant bringing nuclear weapons to Canada. ${ }^{622}$ Self-described mother of two Helen Cruickshank, from Lachine, Quebec, argued in a letter to Olive Diefenbaker that failing to arm Canada with nuclear weapons was like leaving valuables on the street to be stolen. While she found the thought of nuclear war to be horrific, Cruickshank implied that it was even more awful that "we do not seem to value our children enough to properly provide for our defence system." 623 The installation of nuclear weapons on Canadian soil and the training of Canadian forces in the use of the weapons was, according to Cruickshank, a sign of truly loving and cherishing children. Frank A.

Committee for a Sane Nuclear Policy, "Civil Defense," n.d., MUL, CCND fonds, box 14, file 17; Patricia Boulding to the editor of The Vancouver Sun, 26 February 1966, LAC, Voice of Women fonds, MG28I218, vol. 21, file: British Columbia correspondence 1965-1967; Voice of Women, "First Annual Meeting," 16-17 June 1961, LAC, Voice of Women fonds, MG28-I218, vol. 22, file: National Annual Meeting (1961), 8-9.

${ }^{621}$ Brookfield, Cold War Comforts, 28.

${ }^{622}$ R. E. Buell to Hon. Lester B. Pearson, 9 December 1961, LAC, Lester B. Pearson fonds, MG26-N2, vol. 3 , file $100.1,3$.

${ }^{623}$ Helen Cruickshank to Mrs. Diefenbaker, 20 August 1962, USASC, John G. Diefenbaker fonds, $\mathrm{MG} 01 / \mathrm{V} / \mathrm{F} / 483$, Diefenbaker centre row 1, vol. 77, 1. 
Rutherford, in a letter to Liberal Member of Parliament Paul Martin and to Pearson, also identified himself as a parent, whose six children were "made in Canada." Drawing on his parent-citizen status, Rutherford argued that Canada "should have nuclear defensive weapons immediately and indefinitely." ${ }^{, 624}$ Rutherford's letter emphasized that as a father he had a right to speak out to ensure that foreign and defence policy decisions were in the best interest of his Canadian children.

Child-centred rhetoric could support arguments in favour of and against nuclear proliferation. Yet nuclear proponents seldom used the images of children, and often steered away from making emotional appeals. When Liberal leader Pearson announced in Scarborough in January 1963 that his party would accept nuclear arms for Canada, he made no mention of how nuclear weapons would aid the wellbeing of Canadian children. In this speech to the York-Scarborough Liberal Association, Pearson explained that a Liberal government "would put Canada's armed services in the position to discharge fully commitments undertaken for Canada by its predecessor." This decision, he emphasized on several occasions, was based on a necessity to honour commitments made to Canadian allies by past governments. ${ }^{625}$ Pearson's speech distanced himself from responsibility for the decision and detached the question of nuclear arms for Canada from the emotional appeals that were common in the arguments presented by Canadian disarmers.

\footnotetext{
${ }^{624}$ Frank A. Rutherford to the Honourable Paul Martin, 18 February 1963, LAC, Lester B. Pearson fonds, MG26-N2, vol. 49, file 806.2 part 1, 1 .

625 "Text of an address by the Honourable Lester B. Pearson, Leader of the Liberal Party of Canada," 12 January 1963, LAC, Lester B. Pearson fonds, MG26-N2, vol. 114, file: National defence, Dept. of Nuclear weapons storage in Canada, 7, 3, 4, 5 .
} 
Liberal election strategists explicitly identified this rational approach to diplomacy as the best method for presenting their new nuclear policy to Canadians. Liberal party campaign strategist Tom Kent recommended that Liberal nuclear policy would be best received if presented as being a means of being good Canadians, for "good Canadianism means living on good terms with our friends in the free world." ${ }^{626} \mathrm{By}$ stressing the idea of good international citizenship, the 1963 Liberal party campaign strategy underlined the nuclear issue as a question of international relations, avoiding any significant discussion of what would happen if these weapons were used ${ }^{627}$ Many Conservative party officials similarly stressed the need to fulfil Canada's responsibilities as a member of the North Atlantic Treaty Organization (NATO) and of the North American Air Defence Command (NORAD). ${ }^{628}$

Political scientist Carol Cohn has observed a notable consistency in how defence analysts talk about nuclear arms. Cohn remarked that the techno-strategic jargon used when discussing nuclear weapons is a language that purposefully "shields us from the emotional reaction that would result if it were clear that one was talking about plans for mass murder. ${ }^{9629}$ In making the nuclear question an international relations issue, Canadian politicians attempted to separate the idea of acquiring nuclear weapons from the realities of nuclear war. Anti-nuclear organizations, on the other hand, relied on

\footnotetext{
${ }^{626}$ Tom Kent, "Strategy for Victory, 1963," 12 February 1963, LAC, Liberal Party of Canada fonds, MG28-IV3, vol. 689, file: National office general corr. Elections 1962-1963, 5.

${ }^{627}$ Liberal Party of Canada, "Press release: Statement by Hon. Lester B. Pearson on Nuclear Policy for Canada," 20 February 1963, LAC, Liberal Party of Canada fonds, MG28-IV3, vol. 689, file: National office general corr. elections 1962-1963, 1.

${ }^{628}$ Progressive Conservative Association of Canada, "Report of the Resolutions Committee Annual General Meeting," 16-18 March 1961, LAC, Progressive Conservative Party of Canada fonds, MG28-IV2, vol. 290, file: Resolutions 1961 annual meeting, E-1; E. A. Goodman to Rt. Hon. John G. Diefenbaker, 15 January 1963, LAC, Progressive Conservative Party of Canada fonds, MG28-IV2, vol. 292, file: Annual meeting 1963 resolutions, 1, 3-4.

${ }^{629}$ Carol Cohn, "'Clean Bombs' and Clean Language," in Women, Militarism and War, eds. Jean Bethke Elshtain and Sheila Tobias, 33-56 (Savage, Maryland: Rowman \& Littlefield Publishers, Inc., 1990), 34.
} 
emotional messages about what such a war would mean for the children of the world. When it came to the question of what was best for "the child," nuclear proponents and nuclear opponents were speaking entirely different languages.

\section{Conclusion}

The bodies, images and futures of children were omnipresent in emotional appeals against nuclear weapons. The idea of the child, imbued with parents' as well as the state's hopes for the future, was mobilized to condemn the acquisition of nuclear arms by Canada. Canadian anti-nuclear advocates relied on appeals based on the desire to protect the innocence of childhood to trigger an emotional response against the Bomb. The repetition of similar messages and visualizations across numerous Canadian anti-nuclear campaigns and in campaigns in the United States, Britain, and Western Europe indicates how much value activists placed upon the idea of protecting children in their propaganda. By evoking these kinds of themes, anti-nuclear activists around the world brought their individual concerns as parents into international discussions about the dangers of nuclear arms and the insanity of the Cold War.

Using a shared repertoire of visual imagery of suffering children, anti-nuclear activists shaped their campaigns in a manner that emphasized both the urgency and the respectability of their demands. With the baby boom giving rise to an increased public valorization of children and the family, and the emergence of a human rights discourse prioritizing children, nuclear disarmers were able to frame their messages within an existing social discussion about the importance of a safe and happy childhood. Disarmers called upon culturally meaningful visual tropes, such as that of the unaccompanied child, 
to create protest campaigns that spoke to the hopes and fears of parents everywhere. Disarmament campaigns harnessed parental concern for the health of children when they highlighted scientific data demonstrating the build-up of carcinogenic strontium-90 in children's bones.

By presenting themselves as parents, activists summoned experiences, desires, and needs that were commonly shared not just by activists within different organizations, but also across provincial, regional and national boundaries. Parents wanted to ensure a safe future for their children. Anti-nuclear activists argued that this future could only be assured by the abolition of nuclear arms. 


\section{Chapter Four \\ "We simply have too much at stake": The Combined Universities Campaign for Nuclear Disarmament and Canadian Youth Disarmament Activism}

As we have seen, Canadian nuclear disarmers often justified their opposition to nuclear arms testing and proliferation by claiming to act in the best interests of their children, and of all children. Yet while the idea of "the child" was central to many of the arguments put forward by Canadian anti-nuclear activists, the voices of the young were usually omitted in the activities of adult protesters. This prompted a few pre-teens to take the initiative to speak for themselves, as did Bob Abrams, a ninth-grade student at Malcolm High in Montreal, and 12-year-old Christine Beckett from Toronto, who wrote letters opposing nuclear arms to Liberal party leader Lester B. Pearson. ${ }^{630}$ As Beckett argued in her letter to Pearson,

If there is going to be a vote on the question of nuclear arms it should be the children's decision - it's our world - and I strongly urge you to restrict the polls to children under the age of $\underline{18}$. We know what we want our world to be, but the adults don't seem to care very much any more, do they? ${ }^{631}$

This sense that adults did not seem to understand the severity of the threat posed by nuclear arms led many Canadian young people to seek out a space of their own.

Established in 1959, the student-led Combined Universities Campaign for Nuclear Disarmament (CUCND) was a unique expression of anti-nuclear opinion in Canada during the early 1960s. ${ }^{632}$ As an organization for Canadian young people, the CUCND

\footnotetext{
${ }^{630}$ Bob Abrams to Lester B. Pearson, 17 January 1963, Library and Archives Canada (LAC), Lester B. Pearson fonds, MG26-N2, vol. 50, file 806.2 part 5, 1; Christine Beckett to Mr. Pearson, ca. January 1963, LAC, Lester B. Pearson fonds, MG26-N2, vol. 50, file 806.2 part 5, 1.

${ }^{631}$ Beckett to Pearson, ca. January 1963, 1.

${ }^{632}$ Roberta Lexier, "To Struggle Together or Fracture Apart: The Sixties Student Movements at EnglishCanadian Universities," in Debating Dissent: Canada and the Sixties, eds. Lara Campbell, Dominique Clément and Gregory S. Kealey (Toronto: University of Toronto Press, 2012), 93; Karine Hébert, "Between the Future and the Present: Montreal University Student Youth and the Post-war Years, 1945 -
} 
promoted aims and methods that set it apart from the major "adult" Canadian anti-nuclear organizations. CUCND members recognized the interconnectedness of social problems, such as poverty, racism, and violence, and the dangerous Cold War state of affairs. But, the organization also struggled throughout its short life with student apathy, low membership, and accusations of radicalism. Nevertheless, in less than a decade, the CUCND would evolve into "the single most important New Left organization in Canada." 633

The importance of the CUCND to 1960s politics is undisputed and well documented in histories concerned with student movements of the 1960s and the Canadian left. ${ }^{634}$ Because historians have focused on the role the CUCND played in the development of the Canadian New Left, the significance of the CUCND as an independent disarmament organization has been overlooked. ${ }^{635}$ For example, Bryan Palmer's discussion of the CUCND in his work on Canadian identity formation during the 1960s implies that the CUCND and the "adult" Canadian Campaign for Nuclear

1960," in Cultures of Citizenship in Post-War Canada, 1940-1955, eds. Nancy Christie and Michael Gauvreau (McGill-Queen's University Press, 2003), 185.

${ }^{633}$ Doug Owram, Born at the Right Time: A History of the Baby Boom Generation (Toronto: University of Toronto Press, 1997), 221. See also: Cyril Levitt, Children of Privilege: Student Revolt in the Sixties (Toronto: University of Toronto Press, 1984), 42.

${ }^{634}$ David S. Churchill, "SUPA, Selma, and Stevenson: The Politics of Solidarity in mid-1960s Toronto," Journal of Canadian Studies 44(2) (Spring 2010): 33; Owram, Born at the Right Time, 220-221; Catherine Gidney, "Poisoning the Student Mind?: The Student Christian Movement at the University of Toronto, 1920-1965," Journal of the Canadian Historical Association 8(1) (1997): 159; Myrna Kostash, Long Way from Home: The Story of the Sixties Generation in Canada (Toronto, J. Lorimer, 1980), xxiv-xxv; Levitt, Children of Privilege, 42; Dimitrios Roussopoulos, "Introduction," in The New Left in Canada, ed.

Dimitrios Roussopoulos (Montreal: Our Generation Press-Black Rose Books, 1970), 9-10.

${ }^{635}$ All of the sources below do little more than give a cursory glance at the CUCND: Lawrence S. Wittner, The Struggle Against the Bomb, vol. 2 (Stanford: Stanford University Press, 1997), 443, 457; Steve Hewitt, Spying 101: The RCMP's Secret Activities at Canadian Universities, 1917-1997 (Toronto: University of Toronto Press, 2002), 94; Richard Harris, Democracy in Kingston: A Social Movement in Urban Politics, 1965-1970 (Montreal, Kingston: McGill-Queen's University Press, 1988), 54; Catherine Gidney, Long Eclipse: The Liberal Protestant Establishment and the Canadian University, 1920-1970 (Montreal, Kingston: McGill-Queen's University Press, 2004), 61. 
Disarmament (CCND) were one organization. ${ }^{636}$ Despite his contention that the CUCND has not been properly appreciated as an independent organization, CUCND scholar Michael Maurice Dufresne also reduced the CUCND to the "student component" of the CCND. ${ }^{637}$

In her recollection and examination of 1960s Canadian student movements, journalist Myrna Kostash began her discussion of the CUCND with its end, when it became the Student Union for Peace Action (SUPA), the forerunner to the Canadian New Left Committee, in early 1965. She devoted fewer than two pages to her exploration of the CUCND's disarmament efforts. ${ }^{638}$ Similarly, historian Ian Milligan's Rebel Youth highlighted the formation of SUPA and glossed over the CUCND's history as a disarmament organization. ${ }^{639}$ The CUCND “deserve[s] far more attention from Canadian scholars," Dimitry Anastakis argued in his introduction to the edited collection The Sixties: Passion, Politics and Style, ironically the only reference in the entire collection to the CUCND. ${ }^{640}$ The current scholarly treatment of the CUCND fails to properly acknowledge the autonomy and initiative of Canadian university students, and to

\footnotetext{
${ }^{636}$ Bryan Palmer, Canada's 1960s: The Ironies of Identity in a Rebellious Era (Toronto: University of Toronto Press, 2009), 256. See also Levitt, Children of Privilege, 40 and Michael Maurice Dufresne, "'Let's Not be Cremated Equal:' The Combined Universities Campaign for Nuclear Disarmament, 19591967," in The Sixties in Canada: A Turbulent and Creative Decade, ed. M. Athena Palaeologu (Montreal: Black Rose Books, 2009), 9.

${ }^{637}$ Michael Maurice Dufresne, “'Let's Not Be Cremated Equal:' The Combined Universities Campaign for Nuclear Disarmament 1959-1967," The Sixties in Canada: A Turbulent and Creative Decade, ed. M. Athena Palaeologu (Montreal: Black Rose Books, 2009), 13, 9-10.

${ }^{638}$ Kostash, Long Way from Home, 3-5. Doug Owram's treatment of CUCND similarly moves very quickly into SUPA, with a limited discussion of CUCND and anti-nuclear activism (Owram, Born at the Right Time, 218-220).

${ }^{639}$ Ian Milligan, Rebel Youth: 1960s Labour Unrest, Young Workers, and New Leftists in English Canada (Vancouver: UBC Press, 2014), 72.

${ }^{640}$ Dimitry Anastakis, "Introduction," in The Sixties: Passion, Politics and Style, ed. Dimitry Anastakis (Montreal and Kingston: McGill-Queen's University Press, 2008), 7.
} 
recognize the singular nature of Canadian youth approaches in anti-nuclear activism in the early 1960s.

The CUCND was born in late 1959 through the coming together of two separate student organizations. In November 1959, students from McGill University, Sir George Williams University, and the Université de Montréal organized in opposition to nuclear arms. They assembled in response to Canadian Prime Minister John G. Diefenbaker's announcement that Canada would acquire Bomarc-B missiles and in anticipation of the planned spring 1960 East-West summit meeting between Soviet Premier Nikita Khrushchev and American President Dwight D. Eisenhower. ${ }^{641}$ On Christmas day of that year, eighty members of the new group marched through Ottawa, and laid a wreath and held a silent vigil at the National War Memorial. ${ }^{642}$ This march was the first significant public student political demonstration since the end of the Second World War. ${ }^{643}$ Just days before a group of students and faculty from the University of Toronto had presented Diefenbaker with an anti-nuclear petition carrying 3,000 signatures. ${ }^{644}$

News coverage of the Christmas march immediately identified a budding studentled effort against the bomb. While there was no connection between the two student-led actions, press reports associated the Christmas march with the University of Toronto

${ }^{641}$ Dufresne, “'Let's Not Be Cremated Equal,” 15; Patricia McMahon, Essence of Indecision: Diefenbaker's Nuclear Policy, 1957-1963 (Montreal: McGill-Queen's University Press, 2009), 66; Hewitt, Spying 101, 90.

${ }^{642}$ Palmer, Canada's 1960s, 256-257; Roussopoulos, "Introduction," 8; Hewitt, Spying 101, 90; Arthur Pape, "Some thoughts on the peace effort in Canada," n.d., The William Ready Division of Archives and Research Collections, McMaster University Library (MUL), CCND fonds, box 9, file 4, 1; "Montreal Students Plan Ottawa March," The Globe and Mail, 23 December 1959, 2.

${ }^{643}$ McMahon, Essence of Indecision, 65; Palmer, Canada's 1960s, 257; Roussopoulos, "Introduction," 8. ${ }^{644}$ Wittner, The Struggle Against the Bomb, vol. 2, 348; Douglas Kay Campbell, A History of the Ban-TheBomb Movement, Toronto 1959-1961, Part 1 (Toronto, 1961), MUL, CUCND-SUPA fonds, box 1, file: CUCND Toronto office 1960-1961, 5; "Canada and Disarmament," The Globe and Mail, 16 December 1959, 6; "Bomb Ban Petition Grows," The Globe and Mail, 19 December 1959, 8. 
petition. ${ }^{645}$ By June 1960, these separate student efforts had merged, when students from Toronto, Montreal, and Ottawa gathered to protest the Bomarc missile base in North Bay, Ontario as the CUCND. ${ }^{646}$ The CUCND's membership approached 4,000 by the fall of 1961, with groups located in at least 17 universities across the country. ${ }^{647}$ Between 1962 and 1965, the CUCND was formally associated with the CCND. ${ }^{648}$ But the CUCND rarely towed the line and always behaved as a distinct organization. ${ }^{649}$

In early 1963, CUCND leaders determined that the organization's "bombcentric" campaign was too limited, and began pursing an ambitious program of comprehensive social reform. ${ }^{650}$ To reflect the new purpose of the organization, its leaders adopted the name SUPA in 1965, before finally transitioning into the New Left Committee in $1967 .^{651}$ The redefinition of the organization's objectives allowed Canadian student activists to stave off the fate that awaited most middle-class anti-nuclear organizations in the mid-1960s, as public interest in disarmament withered. ${ }^{652}$

\footnotetext{
645 "Bomb Ban Petition Grows," 8; "Montreal Students Plan Ottawa March," 2.

${ }^{646}$ Hewitt, Spying 101, 90.

${ }^{647}$ I. Turnbull, “Open Letter to All Supporters of Nuclear Disarmament and World Peace,” n.d., LAC, James G. Endicott and Family fonds, MG30-C130, vol. 19, file 361, 1; Dimitrios Roussopoulos to Mary Van Stolk, 29 December 1960, MUL, CCND fonds, box 9, file 2, 1; Federal Secretariat CUCND, "Interbranch memo," 15 September 1961, MUL, CUCND-SUPA fonds, box 1, file: CUCND Toronto office 1960-1961, 2; "Names and Addresses of CUCND executive members in Canada," spring 1960, MUL, CUCND-SUPA fonds, box 1, file: CUCND Toronto office 1960-1961, 1.

648 "Minutes of CCND Board of Directors Meeting," 20 February 1965, MUL, CCND fonds, SW571, box 1 , file 8,2 .

${ }^{649}$ David Maxwell to J. S. Thomson, 14 February 1962, MUL, CCND fonds, box 9, file 1, 1; Arthur Schafer to James S. Thomson, 25 February 1962, MUL, CCND fonds, box 9, file 1, 1; "What is the Canadian Campaign for Nuclear Disarmament," ca. 1963, MUL, CCND fonds, box 1, file 1, 2.

${ }^{650}$ Jim Harding, "Continuing On: Deepening the Anti-Nuclear Movement since the Sixties," in New World Coming: The Sixties and the Shaping of Global Consciousness, eds. Karen Dubinsky, et. al. (Toronto: Between the Lines, 2009), 397.

${ }^{651}$ Churchill, "SUPA, Selma, and Stevenson," 38; Palmer, Canada's 1960s, 258, 261; "Report of SUPA National Conference, Reprinted from SANITY," Winter 1965, MUL, CUCND-SUPA fonds, box 7, file: policy and council documents, 1.

${ }^{652}$ For example, most CCND branches were inactive by 1965. Kostash, Long Way from Home, xxiv; Saskatoon branch, "Policy Working Paper," 1963, MUL, CUCND-SUPA fonds, box 7, file: CUCND Declaration Feb. 1963, 3.
} 
Born in great numbers, in an age of affluence, with the threat of nuclear war looming, the Canadian baby boom generation offered a distinct articulation of antinuclear sentiment in Canada. CUCNDers' self-identification as distinct from adult disarmers resulted in the pursuit of objectives and the use of methods that were exceptional among Canadian disarmament organizations. Nonetheless, public understandings of the young as vulnerable to corruption and an association of peace advocates with the hippie movement were persistent problems for youth disarmament organizations whose efforts were publicly linked to radical politics. In addition, in an age when nearly 90 per cent of young adults still chose work over university education, the CUCND was not terribly representative of Canadian young people. ${ }^{653}$ Furthermore, the CUCND was a heavily masculine organization. The CUCND, like all mixed-sex Canadian peace and disarmament organizations of the time, regularly failed to make meaningful space for women's participation. Nevertheless, by learning from the examples of others and engaging international partners in its anti-nuclear projects, the CUCND established itself as a dynamic and internationally recognized peace organization.

\section{Young people in Cold War Canada}

The formation and premises of the CUCND reflected the experiences and values of Canadians born in affluence and uncertainty during the early Cold War. The post Second World War generation of Canadians was influential because of its size. From a low point in the mid-1930s of 227,000 live births, the number of Canadians born each

${ }^{653}$ Milligan, Rebel Youth, 3, 4, 12-13. 
year more than doubled to a peak of 479,000 by the late 1950 s; between 1946 and 1955 , around 3.9 million Canadian babies were born. ${ }^{654}$ This population explosion meant that by 1961, nearly 42 per cent of the Canadian population of just over 18 million was under the age of $20 .{ }^{655}$ Sheer numbers prompted greater public interest in the wellbeing of these children, who would become known as the baby boomers, since the family assumed new importance to the political agenda of the postwar welfare state. ${ }^{656}$

This generation also grew up during a period of sustained economic prosperity. As a result, the baby boomers "became the best-fed, best-educated, and healthiest generation in Canadian history." ${ }^{657}$ In the late 1950 s, more young Canadians were completing high school. By 1960 a noteworthy two-thirds of Canadian young people finished high school on time. ${ }^{658}$ More young people also had the opportunity to attend university than ever before. Although only 6 per cent of youth aged 18 to 24 attended college or university during the 1955-1956 academic year, that number had increased to 13 per cent ten years later. ${ }^{659}$ That said the vast majority of young people went directly into the work force after high school.

Young people were also affected by a new cultural, political, and intellectual climate. The principles of self-determination and the right to social and economic

${ }^{654}$ Owram, Born at the Right Time, ix; Milligan, Rebel Youth, 14.

655 "Population growth and components (1851-2001 Censuses)," Statistics Canada, accessed 16 October 2015, http://www.statcan.gc.ca/tables-tableaux/sum-som/101/cst01/demo03-eng.htm; "Population, by age and sex, census dates, 1851 to 1976," Statistics Canada, accessed 27 November 2015, http://www.statcan.gc.ca/pub/11-516-x/sectiona/A78_93-eng.csv.

${ }^{656}$ Nancy Christie, “'Look out for Leviathan': The Search for a Conservative Modernist Consensus," in Cultures of Citizenship in Post-War Canada, 1940-1955, eds. Nancy Christie and Michael Gauvreau (McGill-Queen's University Press, 2003), 65, 73; Magda Fahrni, Household Politics: Montreal Families and Postwar Reconstruction (Toronto: University of Toronto Press, 2005), 22-23; Owram, Born at the Right Time, ix, 135.

${ }^{657}$ Owram, Born at the Right Time, $\mathrm{x}$.

${ }^{658}$ Milligan, Rebel Youth, 15.

${ }^{659}$ Milligan, Rebel Youth, 18. 
equality were impressed upon North American children by their parents and by the political and social world around them. ${ }^{660}$ The post-war revolution in child psychology emphasized permissiveness in child rearing. According to child psychologists, such as the influential Erik H. Erikson, it was important for adolescents' development that they be free to form their own identities. ${ }^{661}$ Young people were generally provided with "greater freedom than their parents had had." ${ }^{662}$ They were able to keep pocket money as wages, dated without chaperons, drove cars, and chose their own courses at school. ${ }^{663}$

Postwar suburbs were constructed to prioritize the needs of children and to emphasize family life. New toys, clothing styles, music, magazines, television programs and films were all produced in response to the desires of young people. ${ }^{664}$ As historian Doug Owram has argued in his work on the baby boom generation, Canadian society was “designed" for these children, and they knew it. ${ }^{665}$

The young people born just before the boom began, who because of their age and experience tended to lead most youth movements, similarly grew up with a sense that they were different. These "wartime babies" also experienced a childhood distinct from that of preceding generations. They were the first to experience the intensive commercialization of youth that marked the postwar period; they spent more time in school; and they benefited from technological expansion, particularly the increasing

\footnotetext{
${ }^{660}$ Levitt, Children of Privilege, 15; Roberta Lexier, “'The Backdrop Against Which Everything Happened:' English-Canadian Student Movements and Off-Campus Movements for Change," History of Intellectual Culture 7(1) (2007): 5; Milligan, Rebel Youth, 14.

${ }^{661}$ Palmer, Canada's 1960s, 184; Erik H. Erikson, Identity and the Life Cycle (New York: W. W. Norton and Company, 1994), 119.

${ }^{662}$ Mary Louise Adams, The Trouble With Normal: Postwar Youth and the Making of Heterosexuality (Toronto: University of Toronto Press, 1997), 51.

${ }^{663}$ Adams, The Trouble With Normal, 51.

${ }^{664}$ Owram, Born at the Right Time, 135; Adams, The Trouble with Normal, 42.

${ }^{665}$ Owram, Born at the Right Time, 135.
} 
accessibility of the automobile. ${ }^{666}$ "For wartime babies and baby boomers, everything began with a sense of difference," historian Ian Milligan has claimed. ${ }^{667}$

While these young people were raised with greater personal and economic freedom, their independence was restricted by psychological understandings of human maturation. One of the distinct features of postwar North American life was the prolonging of childhood. ${ }^{668}$ Young people were not expected to be capable of making significant decisions on their own and the choices they did make for themselves were “contingent upon adult approval." 669

In the postwar years, psychological experts defined adolescents as "bodies in midpassage," individuals in a critical, "anxiety-ridden stage" of identity formation. They were perceived to be in need of appropriate examples of successful adulthood that would lead them to choose the liberal, democratic, heterosexual, and capitalist North American standard for themselves. ${ }^{670}$ It was vital that the young be presented with ideal examples of successful maturation, because the teenager was understood to be dangerously "vulnerable to disruption." ${ }^{671}$ In a world that was "designed" for them, Canadian young people had very little say.

As they neared adulthood, many Canadian baby boomers came to the realization that the world they were inheriting was not the world they had been promised as

\footnotetext{
${ }^{666}$ Adams, The Trouble with Normal, 42.

${ }^{667}$ Milligan. Rebel Youth, 13-14.

668 Adams, The Trouble with Normal, 51.

${ }^{669}$ Adams, The Trouble with Normal, 51. See also Owram, Born at the Right Time, 157.

${ }^{670}$ Palmer, Canada's 1960s, 184; Michael Kimmel, Manhood in America: A Cultural History (New York and Oxford: Oxford University Press, 2012), 171; Elaine Tyler May, Homeward Bound: American Families in the Cold War Era (New York: Basic Books, 1988), 109; Robert L. Griswold, Fatherhood in America: A History (New York, Basic Books, 1993), 186; Adams, The Trouble with Normal, 45-46.

${ }^{671}$ Mona Gleason, "Disciplining Children, Disciplining Parents: The Nature and Meaning of Advice to Canadian Parents, 1945-1955," Histoire Sociale/Social History 29 (May 1999): 189; Palmer, Canada's 1960s, 184-185.
} 
children. ${ }^{672}$ Students learned that a university degree did not mean immediate access to the intellectual and social elite, and young skilled workers faced unemployment. ${ }^{673}$ Young university students and workers were pained to discover once they were out on their own, that they had no more freedom than they had under their parents' roofs. They also questioned the Western promises that both capitalist mass consumption and democracy would create a "richer, more equitable place to live." ${ }^{674}$ As historian Jeremi Suri stated in his analysis of 1960s global protest movements, "Youthful citizens expected too much in a world still dominated by nuclear dangers, Cold War divisions, and large bureaucratic institutions. ${ }^{" 675}$ In this environment the message that young people were special clashed with understandings of young people as dependent and weak, and thus led to disillusionment and frustration among many young people. ${ }^{676}$ Disappointed with the lack of access to the political decision-making structures of the "adult" world, CUCND youths came together to demand their right to express their own desires for a nuclear-free world.

For many young Canadian disarmers, it was important that the opinions of young people, the leaders of the future, be taken into greater consideration by politicians. 18year-old Carol Robertson asked the leaders of the Canadian Committee for the Control of Radiation Hazards (CCCRH) to take note of the number of signatures she had gathered

\footnotetext{
${ }^{672}$ Owram, Born at the Right Time, 280; Samuel Clark, "General Introduction," in Prophecy and Protest: Social Movements in Twentieth Century Canada, ed. Samuel Clark, J. Paul Grayson and Linda Grayson (Toronto: Gage Educational Publishing Limited, 1975), 8.

${ }^{673}$ James Harding, "The New Left in B.C.," in The New Left in Canada, ed. Dimitrios Roussopoulos (Montreal: Our Generation Press-Black Rose Books, 1970), 27; Levitt, Children of Privilege, 133.

${ }^{674}$ Milligan, Rebel Youth, 31, 34-35; Levitt, Children of Privilege, 8, 16, 71.

${ }^{675}$ Jeremi Suri, Power and Protest: Global Revolution and the Rise of Détente (Cambridge, Massachusetts: Harvard University Press, 2003), 260.

${ }^{676}$ Levitt, Children of Privilege, 73-74; "The Declaration of the Combined Universities Campaign for Nuclear Disarmament (CUCND)," February 1963, MUL, CUCND-SUPA fonds, box 7, file: CUCND Declaration Feb. 1963, 12.
} 
from young people for the CCCRH's 1961 nation-wide anti-nuclear petition to Prime Minister Diefenbaker. Robertson argued that the signatures would

impress our government since most of us will be voting by the next elections, and so they will have to start understanding us, the generation brought up in the shadow of two terrible wars and fully aware that they may face one far more shattering one which would end our lives not just ruin them. ${ }^{677}$

Just as Beckett had demanded in her letter to Pearson that Canadians under the age of 18 be consulted on the question of nuclear arms for Canada, Robertson emphasized the need for the government to start listening to those who were nearly eligible to vote. ${ }^{678}$ Sixteenyear-old Terry Davey reminded the organizers of the women's peace organization Voice of Women (VOW) that "We youth of today are the adults of tomorrow's world."679 It was imperative for the future of the country that the positions of young Canadians be given further consideration by those in power.

More importantly, argued young activist Daniel P. Kelly, omitting the voices of young people from defence and foreign policy decision-making processes also meant overlooking "the fighting public" — those who would "actually do the fighting when the time comes." ${ }^{680}$ A 1958 funding request from the Canadian Peace Congress (CPC) included a brief excerpt from a letter written by an 11-year-old boy, in which he pleaded: 'I want to die of old age, not roasted or blasted, or become a 'war-veteran.' Please help me and all the other children of our earth to grow up to a venerable age." ${ }^{\prime 61}$ As the potential soldiers of the future, these young Canadians demanded a right to be heard.

\footnotetext{
${ }^{677}$ Carol Robertson, n.d., MUL, CCND fonds, SWS74, box 20, file 11, 1.

${ }^{678}$ Beckett to Pearson, ca. January 1963, 1.

679 Terry Davey, 1 July 1960, LAC, Voice of Women, MG28-I218, vol. 1, file: correspondence re. formation of VOW June-Sept. 1960, 1.

${ }^{680}$ Daniel P. Kelly to Mrs. Fred Davis, 11 July 1960, LAC, Voice of Women fonds, MG28-I218, vol. 1, file: correspondence re. formation of VOW June-Sept. 1960, 1.

${ }^{681}$ James G. Endicott, "To all Friends and Supporters of the Canadian Peace Congress," 3 July 1958, LAC, James G. Endicott and Family fonds, MG30-C130, vol. 7, file 116, 1.
} 
For many young Canadians, there was a feeling that adults did not understand just how much the fear of a nuclear war affected their lives. ${ }^{62}$ Beckett's comment that the "the adults don't seem to care very much any more" reflected a common impression held by young disarmers. ${ }^{683}$ Many young activists assumed that most adults, who had already lived full lives, shared the belief expressed by one discouraged CPC supporter in 1959 that "I suppose I shouldn't worry as I am over 40." ${ }^{\prime 64}$ As CUCND chairman Dimitrios Roussopoulos complained to CCCRH founder Mary Van Stolk in 1960, CUCND members were becoming frustrated with divisions caused by "egotistic and pretentious personalities" within the CCCRH. He continued, "I can say for CUCND which stands for the younger generation that we cannot tolerate splits or disagreements because we simply have too much at stake!" ${ }^{685}$ In his article on a Christmas 1960 CUCND rally on Parliament Hill, which was not attended by a single member of Parliament, Roger Appleton of the Ottawa Citizen reported that student disarmers were not visibly disappointed by the lack of adult response to their protest. "They' re used to public apathy," he explained. ${ }^{686}$ The efforts of many young disarmers were informed by an understanding that the young had more to lose than their elders in a nuclear war.

Young disarmers struggled to have their perspectives taken seriously by "adult" leaders. As Dick Flacks and Tom Hayden, two leaders of the American student activist group Students for a Democratic Society (SDS) recalled, "the vast majority of students internalized the messages of their elders that they were too young, too inexperienced, too

\footnotetext{
682 Robertson, n.d., 1-2.

${ }^{683}$ Beckett to Pearson, ca. January 1963, 1.

${ }^{684}$ A. Beazer, 23 December 1959, LAC, James G. Endicott and Family fonds, MG30-C130, vol. 2, file 26, 1. See for example: Eleanor Thomson to Mr. Davis, 24 June 1960, LAC, Voice of Women fonds, MG28I218, vol. 1, file: correspondence re. formation of VOW June-Sept. 1960, 2.

${ }^{685}$ Roussopoulos to Van Stolk, 29 December 1960, 1.

${ }^{686}$ Roger Appleton, "Silent Hill Greets Anti H-Bomb Rally,” Ottawa Citizen, 27 December 1960, 13.
} 
unqualified to make a difference." ${ }^{687}$ In September 1963, leaders from Western Canadian CUCND branches complained that they were having difficulty attracting and keeping members because of an assumption "that the politicians know better" than students. ${ }^{68}$ For example, the Member of Parliament for Leeds, John R. Matheson, defended the Liberal government's position on nuclear arms for Canada in November 1963, suggesting that CUCND students do more research before settling on any position on nuclear weapons. Matheson argued that his war experiences and status as a parent gave him greater authority to determine what defence policy for Canada would be most “contributory to peace." He advised CUCND federal chairman Arthur (Art) Pape that students needed to trust the government's approach to nuclear arms, as "it would be erroneous to believe that fresh young men and women who have never seen bombings, shellfire and stinking death care more about peace than some of us who have." ${ }^{689}$ These kinds of claims that students were too inexperienced to understand the world that they wished to change angered some young people, spurring them to action, but also had the effect of deterring students from even trying. ${ }^{690}$

Brewster Keen, youth secretary of the American branch of the international peace organization the Fellowship of Reconciliation, explained to the CUCND executive in November 1963 that there was a mood of "fatalism or profound cynicism" among

\footnotetext{
${ }^{687}$ David Flacks and Tom Hayden, “The Port Huron Statement at 40,” The Nation, 5 August 2002, accessed 8 October 2015, http://www.thenation.com/article/port-huron-statement-40/, 18.

688 "CUCND Western Consultation," 28-29 September [1963], MUL, CUCND-SUPA fonds, box 1, file: correspondence - executive secretary Toronto office 1962-1963, 1.

${ }^{689}$ John R. Matheson to Arthur Pape, 6 November 1963, MUL, CUCND-SUPA fonds, box 17, file: brief to Parliament Ottawa Oct. 9-Nov 1963, 1-2.

${ }^{690}$ Flacks and Hayden, "The Port Huron Statement," 18; "Report of SUPA National Conference," 2.
} 
students. ${ }^{691}$ Student pessimism was validated by the response the CUCND received from parliamentarians when they presented a brief two days later. Afterwards, Pape revealed in a letter to Pearson the CUCND delegation's bitter disappointment over the attitude of members of Parliament that "political parties or Parliament are [not] the correct institutions to deal with the problem as basic as the peace one." Moreover, Pape continued, federal politicians seemed to be in complete denial that the world was anything but "rosy," making it nearly impossible for real change to occur. Witnessing complacency on the part of their elected leaders fuelled the "seed[s] of resentment among many young people today," according to Pape. ${ }^{692}$

\section{The CUCND and youth activism}

Young workers' and university students' access to leadership positions in "adult" organizations, such as VOW, the CPC and the CCCRH-CCND, was limited. ${ }^{693}$ The CUCND was born out of a sense that the voices of young people were not being properly considered by the "adult" world, which was a problem given young people's belief in their aptitude for critically examining and challenging foreign relations and defence policies that had led to a world where nuclear annihilation was a possibility. ${ }^{694}$ As the CUCND statement of purpose proclaimed: "students have a special role to play in the

\footnotetext{
${ }^{691}$ Brewster Keen, “The University Community Today," CUCND Federal Conference Report Nov. 1963, 9-12 November 1963, MUL, CUCND-SUPA fonds, box 11, file: CUCND federal conference report Nov. $1963,6$.

${ }^{692}$ Arthur Pape to L. B. Pearson, 19 November 1963, MUL, CUCND-SUPA fonds, box 17, file: brief to Parliament Ottawa Oct. 9-Nov. 1963, 1-2. See also: Arthur Pape to T. C. Douglas, 20 November 1963, MUL, CUCND-SUPA fonds, box 17, file: brief to Parliament Ottawa Oct. 9-Nov. 1963, 1-2.

${ }^{693}$ Roussopoulos, "Introduction," 8; Lexier, “'The Backdrop Against Which Everything Happened," 3; Palmer, Canada's 1960s, 257; Levitt, Children of Privilege, 40.

${ }^{694}$ Arthur Pape, "Dear fellow peaceniks," 1 May 1962, MUL, CUCND-SUPA fonds, box 3, file:

Interbranch memos Dec. 1962-Oct. 1963, 1.
} 
struggle to eliminate war as a method of settling international disputes, and that the university community should take the lead in the mobilization of social forces internationally for the achievement of world peace."695 The CUCND's program and methods reflected the mentality that Canadian students were in a privileged position to make the changes needed to bring about a safer world.

By the spring of 1960, there were 16 CUCND branches in Quebec, Ontario, Manitoba, Saskatchewan, and Alberta. ${ }^{69}$ To form a national campaign against nuclear arms with dedicated support from Canadian post-secondary institutions, official CUCND branches were required to have at least 10 student members and financing from the university's student government. If students were unable to gather enough support, their club was deemed a "nuclear studies group," with only a semi-official status in the CUCND. ${ }^{697}$ The CUCND executive emphasized both public education and direct action to challenge "every assertion made on behalf of the nuclear stalemate" and in favour of nuclear weapons for Canada. ${ }^{698}$

The name finally chosen for the national organizing body for Canadian university disarmament organizations, CUCND, was a deliberate nod to the British Campaign for Nuclear Disarmament (CND) ${ }^{699}$ While engaged in graduate studies at the London School of Economics in the late 1950s, CUCND co-founder Roussopoulos had worked with the

\footnotetext{
695 "Resolutions and Reports of the Annual Conference Combined Universities Campaign for Nuclear Disarmament," February 1963, MUL, CUCND-SUPA fonds, box 7, file: early CUCND material, 1. 696 "Names and addresses of CUCND executive members," Spring 1960, MUL, CUCND-SUPA fonds, box 1, file: CUCND Toronto office 1960-1961.

697 “The Charter," ca. 1963, MUL, CUCND-SUPA fonds, box 1, file: CUCND Toronto office 1960-1961, 6.

698 "Important notice to all CUCND members," n.d., MUL, CUCND-SUPA fonds, box 1, file: CUCND Toronto office 1960-1961, 1.

${ }^{699}$ Campbell, A History of the Ban-the-Bomb Movement, 5; "The Charter," 3; Holger Nehring, "National Internationalists: British and West German Protests against Nuclear Weapons, the Politics of Transnational Communications and the Social History of the Cold War, 1957-1964," Contemporary European History 14(4) (2005): 563.
} 
CND and its university campaign. When he returned to Montreal in October 1959, Roussopoulos "brought back with him the latest ideas and techniques ... to make a successful campaign." ${ }^{700}$ Borrowing its name, aims, and methods from the British CND, the CUCND was self-consciously a "continuation and expansion" of the British CND movement. ${ }^{701}$ As Roussopoulos recalled, young Canadians drew courage from the boldness and fearlessness of British activists who responded to beatings and arrests with "smiles, with songs, and with non-violence."702

Demonstrating their solidarity with the British CND, the CUCND immediately adopted the CND's position in favour of "unilateral abandonment of nuclear weapons no matter what any other power may do." ${ }^{.703}$ A primary aim of all Canadian anti-nuclear organizations was to achieve complete multilateral disarmament. While "adult" antinuclear organizations in Canada, such as the CCCRH-CCND, the CPC, and VOW, all participated in a mass campaign promoting "no nuclear arms for Canada," the CUCND stood apart by its explicit calls for Canada unilaterally to refuse nuclear arms. ${ }^{704}$ CUCND executive members consistently defended their position by insisting that they were by no means calling for independent disarmament by the West. But their persistent use of the term "unilateral" led to the assumption that they were not opposed to Soviet maintenance

\footnotetext{
700 Olig to Michael Rowan, 13 September 1960, MUL, CUCND-SUPA fonds, box 1, file: CUCND Toronto correspondence 1960-1961, 1. See also: Dufresne, “'Let's Not Be Cremated Equal,"” 15.

${ }^{701}$ Douglas Kay Campbell, A History of the Ban-The-Bomb Movement, Toronto 1959-1961, Part 1

(Toronto, 1961), MUL, CUCND-SUPA fonds, box 1, file: CUCND Toronto Office 1960-1961

correspondence, 1. See also: Olig to Rowan, 13 September 1960, 1.

${ }^{702}$ Roussopoulos, "Introduction," 8.

703 "Policy Statement," Autumn 1960, MUL, CUCND-SUPA fonds, box 7, file: early CUCND material, 2.

${ }^{704}$ CCND Ottawa, "No Nuclear Arms for Canada," 1963, LAC, James G. Endicott and Family fonds, MG30-C130, vol. 2, file 34; CPC, "No Nuclear Arms for Canada," April 1963, LAC, James G. Endicott and Family fonds, MG30-C130, vol. 2, file 34; "Voice of Women President's Report," 16 September 1962, LAC, Voice of Women fonds, MG28-I218, vol. 22, file: national annual meeting (1962), 4; "Resolutions and Reports of the Annual Conference Combined Universities Campaign for Nuclear Disarmament Toronto," February 1963, 1.
} 
of a nuclear arsenal, thus complicating the CUCND's relationships with other Canadian organizations. $^{705}$

The CUCND's use of the words "independent" and "unilateral" proved jarring to Canadians both inside and outside of anti-nuclear movements. Hugh Keenleyside, chairman of the CCCRH-CCND, declined a CUCND request to act as a sponsor of the group on the grounds that he was "not prepared to support a programme of unilateral disarmament."706 The CCCRH-CCND executive did not wish to be tied to "unilateralist" efforts: it advised members about the importance of correcting misconceptions that disarmament activists were "non-rational persons or fuzzy idealists or radical unilateralists." 707 The affiliation of CUCND with CCND was delayed for years over the issue of unilateralism. ${ }^{708}$ The CUCND's promotion of unilateralism was even too much for many fellow students. An October 1961 poll by the University of Toronto Varsity student newspaper indicated that two-thirds of the university's students rejected the CUCND because of its calls for Canada's unilateral renunciation of nuclear weapons. ${ }^{709}$ The adoption of another central feature of the CND's work in Britain had more positive results for the CUCND in Canada. The CND's signature protest, the annual 85kilometer march from the Aldermaston atomic weapons research centre to Trafalgar Square in central London over Easter weekend, inspired the early organizers of CUCND

\footnotetext{
${ }^{705}$ F. C. Hunnius to James S. Thomson, 14 September 1961, MUL, CCND fonds, SW571, box 3, file 9, 1; F. C. Hunnius to Dr. H. L. Keenleyside, 8 November 1961, MUL, CCND fonds, SW572, box 9, file 2, 1.

${ }^{706}$ H. Keenleyside to F. C. Hunnius, 20 October 1961, MUL, CCND fonds, SW572, box 9, file 2, 1.

${ }^{707}$ CCND, "Instructions for Lobbyists," 8-10 November 1962, MUL, CCND fonds, ACCN. 05-1989. 102.F, box 24, file 5, 1; CCND, "Report on the CCND Lobby of Members of Parliament," 8-10 November 1962, MUL, CCND fonds, ACCN. 05-1989. 102.F, box 24, file 5, 2.

${ }^{708}$ H. Keenleyside to Dr. Jules Gilbert, 24 April 1961, MUL, CCND fonds, SW571, box 2, file 13, 1; H. Keenleyside to Mrs. Van Stolk, 27 January 1961, MUL, CCND fonds, SW571, box 4, file 3, 1. 709 "Varsity Students Reject CUCND Favour Canadian Nuclear Arms," The Varsity, vol. LXXXI(17), 30 October 1961, MUL, CCND fonds, SW572, box 9, file 3, 1, 3.
} 
and served as a persistent reference point for the ideal form of protest. ${ }^{710}$ At its most well attended rally in 1960, the Aldermaston March attracted nearly 100,000 participants. ${ }^{711}$ The CUCND, the CCCRH-CCND, VOW, and the CPC all recognized the significance and popularity of the Aldermaston marches by holding annual Easter marches. Beginning in 1962, the organizations collaborated to stage united anti-nuclear Easter marches across the country. ${ }^{712}$

In 1959 and 1960 CUCND organized "our Aldermaston,” as the national secretariat called it, over Christmas. ${ }^{713}$ CUCND's executive explained that it had used the same criteria to select Christmas for their march as the CND did when it scheduled its first Aldermaston march over Easter weekend 1958. By giving up time with their families, marchers would demonstrate the depth of their conviction, according to CND and CUCND organizers. ${ }^{714}$ Furthermore, "if in fact Christmas means the birth of the prince of peace what we should be doing is advocating peace in the most outspoken way and not sitting at home opening gifts and eating Xmas pudding," the CUCND secretariat argued. ${ }^{715}$ Holding protests over holidays was particularly meaningful for young activists.

\footnotetext{
${ }^{710}$ Nehring, "National Internationalists," 563; 100, 65; Campbell, A History of the Ban-the-Bomb Movement, 5; "We March on Christmas Day," Our Generation Against Nuclear War, fall 1960, MUL, CUCND-SUPA fonds, box 1, file CUCND Toronto office 1960-1961, 1; "Report on the Ottawa Motorcade," December 1960, MUL, CUCND-SUPA fonds, box 1, file: CUCND Toronto office 19601961, 3; National Secretariat, "Re: Ottawa Protest Motorcade," MUL, CUCND-SUPA fonds, box 1, file: CUCND Toronto office 1960-1961, 1.

${ }^{711}$ Holger Nehring, The Politics of Security: British and West German Protest Movements and the Early Cold War, 1945-1970 (Oxford: Oxford University Press, 2013), 4, 135, 198; Nehring, "National Internationalists," 578.

712 "Canadian Peace Congress Submission to the Right Honourable John Diefenbaker," 15 May 1961, LAC, James G. Endicott and Family fonds, MG30-C130, vol. 8, file 139, 2; "Nous voulons la paix non des bombes," 21 April 1962, MUL, CCND fonds, SW573, box 18, file 3; Ellen to F. C. Hunnius, 2 April 1962, MUL, CCND fonds, SW573, box 18, file 3, 1; Floyd to James Endicott, 4 April 1962, LAC, James G. Endicott and Family fonds, MG30-C130, vol. 8, file 139, 1.

${ }^{713}$ National secretariat, "Re. Ottawa Protest Motorcade," n.d., 1.

${ }^{714}$ Howard Adelman, "To whom it may concern," n.d., MUL, CUCND-SUPA fonds, box 1, file: CUCND executive meeting minutes Jan. 27 1961, 1.

${ }^{715}$ National secretariat, "Re. Ottawa Protest Motorcade," n.d., 1.
} 
Many students acted against the wishes of their parents when they chose to participate in marches over holidays. By making their public statement on days that had been set aside as time for "family togetherness," they thumbed their noses at their parents and the very notion of family, a mainstay of Western Cold War values. ${ }^{716}$

The selection of Christmas over Easter also served a very practical purpose for CUCND organizers. The Easter weekend often conflicted with university exam schedules. On the other hand, students were always off by Christmas Eve. ${ }^{717}$ But that did not mean that students were willing or able to make their way to Ottawa during such a significant family holiday. Though approximately 430 students sacrificed their holiday to stand in the cold on Parliament Hill in December 1960, the CUCND's report on the event determined that the numbers needed to be larger to garner the attention required to create change. ${ }^{718}$ The report's author argued, "the significance of Christmas as the day of peace is insignificant compared to the number of people prevented from going on that day." $" 719$ From then on, CUCND branches participated in local Easter marches, joining in protest with thousands of other activists across the country and the world. ${ }^{720}$ In 1962 and 1963 , “Aldermaston" Easter marches were held simultaneously in nations such as Britain, Greece, Denmark, Switzerland, Australia, and the United States. ${ }^{721}$

\footnotetext{
${ }^{716}$ Gary Moffatt, History of the Peace Movement in Canada (Ottawa: Grapevine Press, 1982), 41; Tarah Brookfield, Cold War Comforts: Canadian Women, Child Safety, and Global Insecurity, 1945-1975 (Waterloo: Wilfrid Laurier University Press, 2012), 10-11; "Canada and Disarmament," 6; "Bomb Ban Petition Grows," 8; "Montreal Students Plan Ottawa March," 2; Roussopoulos to Van Stolk, 29 December 1960, 1; Owram, Born at the Right Time, 52-53, 253; Christie, "'Look out for Leviathan," 73; May, Homeward Bound, 3, 24.

${ }^{717}$ Eilert Frerichs to Howard Edelman, 9 December 1960, MUL, CUCND-SUPA fonds, box 1, file: CUCND Toronto correspondence 1960-1961, 1.

718 "Report on the Ottawa Motorcade," 2-3.

719 "Report on the Ottawa Motorcade," 3.

720 "Report on the Ottawa Motorcade," 4.

721 "The Easter Demonstrators," The Globe and Mail, 24 April 1962, 6; Peace Action in Australia vol. 4(4) (May 1963), MUL, CCND fonds, SW572, box 11, file 13; Peace Information Bulletin vol. 1 (April 1963), MUL, CUCND-SUPA fonds, box 5, file: Peace Information Bulletin April 1963-Oct. 1964, 8, 10, 11.
} 
The transition to a common Easter march was important for the CUCND after the disappointment of its Christmas 1960 march. Students from at least 15 universities, some of who walked 200 kilometres from Montreal to Ottawa over the course of five days, attended the rally. Nevertheless, press coverage described the event as a resounding failure. ${ }^{722}$ Reporters for the Globe and Mail, Toronto Daily Star, and Ottawa Citizen all focused on the fact that there was not a single politician on Parliament Hill to receive the students. ${ }^{723}$ "Despite their numbers, the students raised hardly a ripple on the tranquil surface of Christmas Day in Ottawa," wrote Appleton in the Ottawa Citizen. ${ }^{724}$

The CUCND had experienced a similarly disappointing response during its spring 1960 event in North Bay. Carrying placards reading "Nuclear bases in Canada invite atomic bombardment," nearly 100 students from the University of Toronto, Carleton University, the University of Ottawa, Université de Montréal, McGill University, Université Laval, and Sir George Williams University picketed the construction site for a proposed Bomarc base. ${ }^{725}$ The community, which stood to benefit financially from the construction of the base, largely ignored the students' placards. ${ }^{726}$

The North Bay protest suffered from many of the same weaknesses as the Ottawa Christmas march. There were too few students present to make enough of a scene to attract the attention of political leaders and the public. As the anonymous author of the report on the Christmas 1960 march concluded, a protest "must have conflict. There must

\footnotetext{
${ }^{722}$ Roussopoulos to Van Stolk, 29 December 1960, 1.

${ }^{723}$ Walter Gray, "Only Carillon Yule Hymns Hail 400 Peace Marchers," The Globe and Mail, 26 December 1960, 1; “450 'Ban-The-Bomb’ Marchers Fail to Rouse Ottawa,” The Toronto Daily Star, 27 December 1960, 16; Roger Appleton, "Silent Hill Greets Anti H-Bomb Rally,” Ottawa Citizen, 27 December 1960, 13.

${ }^{724}$ Appleton, "Silent Hill," 13.

${ }^{725}$ Photo North Bay 1960, MUL, CUCND-SUPA fonds, box 18, file: demonstrations, marches, etc. photographs 1960-1964; Dufresne, "'Let's Not Be Cremated Equal,"” 25.

${ }^{726}$ McMahon, Essence of Indecision, 77.
} 
be an actual confrontation with the opposition" if CUCND protests were ever to lead to change. ${ }^{727}$ In other words, CUCND efforts in 1960 were too tame and too small to be taken seriously.

The CUCND's next major national activity was a 73-hour vigil on Parliament Hill over Thanksgiving weekend in October 1961, co-sponsored by VOW. ${ }^{728}$ While the event coincided with the presentation of 141,000 signatures against nuclear arms collected by various Canadian disarmament organizations and submitted to Prime Minister Diefenbaker by the CCCRH, the CUCND's protest was singled out in press coverage. ${ }^{729}$ What made this particular effort different from previous actions was that CUCND numbers were buttressed by the joint participation of VOW women, and that Prime Minister Diefenbaker was present to witness the CUCND's picket when he received the CCCRH petition. Globe and Mail reporter Walter Gray deemed the CUCND demonstration to have been "quiet" and "orderly," a complimentary description for a protest in $1961 . .^{730}$

Throughout their planning of national protest activities, CUCND event organizers strove to maintain a reputation for "orderly" behaviour. To curb youthful rambunctiousness and keep student campaigns professional in appearance, CUCND leaders banned the consumption of alcohol during protests. This rule was not always

\footnotetext{
727 "Report on the Ottawa Motorcade," 4.

728 "72 hours picket of House of Commons, Ottawa," Fall 1961, MUL, CUCND-SUPA fonds, box 18, file: demonstrations, marches, etc., photographs 1960-1964.

${ }^{729}$ Walter Gray, "Cleric Says PM Vows No A-Arms in Peace," The Globe and Mail, October 7, 1961, 1; William MacEachern, "500 'Ban Bombers' At Ottawa," The Toronto Daily Star, 7 October 1961, 1; "Minutes of the Meeting of the Third Annual Conference of the Canadian Committee for the Control of Radiation Hazards," February 26-27, 1962, MUL, CCND fonds, box 18, file 1, 6; McMahon, Essence of Indecision, 125.

${ }^{730}$ Gray, "Cleric Says PM Vows," 1. See for example of the prizing of "orderly" behavior by disarmament groups: Welland Campaign for Nuclear Disarmament, "Easter Peace Walk to the Peace Bridge," ca. 1962, MUL, CCND fonds, SW573, box 18, file 3, 1.
} 
respected. During the Christmas 1960 Ottawa march, conflict arose between "those who wanted to sleep and others who preferred to "live it up.",731

The federal executive reiterated in 1963 that demonstrations had to be sanctioned by the national executive and be thoroughly organized in advance so that extensive preparation could temper reactionary urges and ensure that demonstrators were not there to "let off justified emotional steam." "732 Still, youthful passion did get CUCND into trouble with political leaders in November 1963, when politically inflammatory statements accusing Canadian political parties of approaching the world's problems with "a callous and flippant attitude" were attributed to CUCND leaders. ${ }^{733}$ As Pape explained in his apology to Prime Minister Pearson and New Democratic Party (NDP) leader T. C. Douglas, "political naiveté" on the part of the students was to blame for comments made to the press out of "frustration and anger." 734 Recognizing the inexperience of students in addressing their concerns to high-level government officials and the possibility that young people gathering together in protest might also want to "live it up," CUCND leaders emphasized as early as the fall of 1960 the importance of student activists presenting "the façade of 'adult' seriousness before the public.",735

In its early years, the CUCND relied on petitions, marches, vigils, public lectures, and briefs to politicians to mobilize their peace program. ${ }^{736}$ The CUCND, and other

\footnotetext{
731 "Report on the Ottawa Motorcade," 1-2.

${ }^{732}$ Dick Clements, "Report of the Programme Committee of the CUCND Federal Conference," 20-22 February 1963, MUL, CUCND-SUPA fonds, box 10, file: CUCND conference, Feb. 1963, 3.

733 "Student Group Upset Following Peace Pitch to Pearson for Funds," The Globe and Mail, 14 November 1963, 1.

${ }^{734}$ Pape to Pearson, 19 November 1963, 1; Pape to Douglas, 20 November 1963, 1; T. C. Douglas to Arthur Pape, 27 November 1963, MUL, CUCND-SUPA fonds, box 17, file: brief to Parliament Oct. 9Nov. 1963, 1.

${ }^{735}$ Olig to Rowan, 13 September 1960, 1.

736 "Important notice to all CUCND members," 1.
} 
Canadian Cold War disarmament organizations, drew such conservative activist methods from the example of the religiously based Canadian pacifist and social reform traditions of the early twentieth century. ${ }^{737}$ The efforts of the CUCND were particularly informed by the experiences of students who had engaged with the Student Christian Movement (SCM) ${ }^{738}$ Founded in 1920, the SCM was an influential religious force on Canadian university campuses. Established out of student discontent with traditional religious institutions, the SCM brought together social gospel, social reform, and student advocacy on Canadian campuses. ${ }^{739}$ By the early 1930s, the SCM began denouncing war, which led naturally into anti-nuclear activism by the end of the Second World War. ${ }^{740}$ Still active when the CUCND was established, the SCM became a supporter of and collaborator with nuclear disarmament movements. ${ }^{741}$

As students moved from the SCM to the CUCND, they took with them the Christian sense of duty that had been central to the SCM's program. ${ }^{742}$ The CUCND's charter declared: "In faith and in reason, we affirm our conviction that nuclear arms are wholly evil...and that, in the event of war, nations which condone their use will be committing suicide and will be guilty of the murder of the rest of mankind." ${ }^{743}$ Furthermore, as the CUCND executive reiterated in February 1963, "The CUCND believes that the nature of the arms race is such that it inevitably erodes all the human,

\footnotetext{
${ }^{737}$ Moffatt, History of the Peace Movement in Canada, 51; Thomas Socknat, Witness Against War: Pacifism in Canada, 1900-1945 (Toronto: University of Toronto Press, 1987), 10, 14, 290-291; Dorothy Harrison, 12 November 1971, LAC, Voice of Women fonds, MG28-I218, vol. 21, file: Dundas, Ontario, correspondence 1965-1971, 1-2.

${ }^{738}$ Owram, Born at the Right Time, 219; Marion Douglas Kerans, Muriel Duckworth: A Very Active Pacifist, A Biography (Halifax: Fernwood, 1996), 30.

${ }^{739}$ Gidney, "Poisoning the Student Mind," 148-149.

${ }^{740}$ Gidney, "Poisoning the Student Mind," 153.

${ }^{741}$ Gidney, "Poisoning the Student Mind," 159.

${ }^{742}$ Owram, Born at the Right Time, 219; Palmer, Canada's 1960s, 257.

${ }^{743}$ CUCND, "End the Arms Race or End the Human Race," MUL, CUCND-SUPA fonds, box 7, file: early CUCND material, charter, brochures, 2.
} 
moral and cultural values of civilization. ${ }^{\$ 44}$ The CUCND charter clearly aligned the organization's campaign against the Bomb with a larger project of social reform rooted in Christian moralism. Confirming the importance of Christian values to their efforts, CUCND's Christmas 1960 march on Parliament Hill was preceded by a religious service and the distribution of literature on nuclear disarmament to Ottawa churches. ${ }^{745}$

By 1963, the CUCND had expanded its analysis about the dangers posed by nuclear weapons to include a critique that Cold War politics were corrupting society. A November 1963 brief to Parliament criticized Canadians for abandoning the values of "charity, respect for all men as equals, human community, justice and freedom" through their acceptance of the Cold War and of nuclear deterrence. ${ }^{746}$ With this brief, the CUCND approached Canadian political leaders not with a program of "next steps for disarmament," but with the demand for the establishment of a society "based on the worth and dignity of the individual, which recognizes equality and self-government as the rights and needs of all men." ${ }^{.747}$ The 1963 brief was symbolic of the CUCND's transition from a single-issue disarmament campaign into a broader student-led effort for significant social, political, and economic change for the betterment of humanity. ${ }^{748}$ Increasing student interest in American civil rights movements largely influenced the CUCND's shift to individual rights. While existing literature tends to suggest that Canadian student movements and anti-war efforts were defined by a degree of anti-

\footnotetext{
744 "Resolutions and reports of the annual conference Combined Universities Campaign for Nuclear Disarmament," February 1963, 1.

745 "Students Have Ottawa Date Christmas Day," The Globe and Mail, 24 December 1960, 5.

${ }^{746}$ Combined Universities Campaign for Nuclear Disarmament, "A Brief to Members of Parliament," 13 November 1963, MUL, CUCND-SUPA fonds, box 11, file: CUCND federal conference report Nov. 1963 2.

${ }^{747}$ Combined Universities Campaign for Nuclear Disarmament, “A Brief to Members of Parliament," 13 November 1963, 1 .

${ }^{748}$ Owram, Born at the Right Time, 220.
} 
Americanism, it is important to stipulate that CUCND organizers did not display any outward distaste for the United States until later in the 1960s, by which point American involvement in the Vietnam War had begun to intensify. ${ }^{749}$ The anti-nuclear group at the University of Toronto that would eventually become one of the first CUCND branches initially named itself after the Chicago Student Peace Union. ${ }^{750}$ The growing American New Left and the efforts of American youth groups such as the SDS and the Student Nonviolent Coordinating Committee (SNCC) to combat poverty, racism, and discrimination inspired CUCND students in the early 1960s. ${ }^{751}$ In 1963, CUCND organizers modelled their Peace Research and Education Project, aimed at bringing peace research into high school and university curricula, after an SDS education program. ${ }^{752}$ The CUCND also actively cooperated with American groups, with members participating in events like the Committee for Nonviolent Action's Quebec-Washington-Guantanamo walk, and received regular correspondence and visits from SDS leaders Hayden and Todd Gitlin. $^{753}$

At the CUCND federal conference in February 1963, the executive produced a declaration announcing a new organization in response to "our growing experience and

\footnotetext{
${ }^{749}$ Churchill, "SUPA, Selma, and Stevenson," 34; Owram, Born at the Right Time, 300-301; Erika Simpson, "New Ways of Thinking about Nuclear Weapons and Canada's Defence Policy," in The Diefenbaker Legacy: Canadian Politics, Law and Society Since 1957, ed. Donald C. Story and R. Bruce Shepard (Regina: Canadian Plains Research Center, 1998), 29; Simon Hall, Rethinking the American AntiWar Movement (New York: Routledge, 2012), 11.

${ }^{750}$ Campbell, A History of the Ban-the-Bomb Movement, 5.

751 "Report of SUPA National Conference," 1; David S. Churchill, "Draft Resisters, Left Nationalism and the Politics of Anti-Imperialism," The Canadian Historical Review 93(2) (June 2012): 258; Churchill, "SUPA, Selma, and Stevenson," 34; Palmer, Canada's 1960s, 261.

${ }^{752}$ CUCND Secretariat, 16 June 1963, MUL, CUCND-SUPA fonds, box 1, file: CUCND secretariat meeting minutes, 2 .

${ }^{753}$ Committee for Nonviolent Action, "Quebec-Washington-Guantanamo Walk for Peace," MUL, CUCND-SUPA fonds, box 5, file: Quebec-Washington-Guantanamo Walk, 1; Palmer, Canada's 1960s, $261,269$.
} 
changing times."754 The SDS's 1962 "Port Huron Statement," the founding manifesto of the American New Left, directly informed the CUCND's declaration. ${ }^{755}$ The Port Huron document represented the insistence of a generation of disillusioned young people on their right to self-determination. The manifesto critiqued postwar Western society, particularly anti-communism, and emphasized participatory democracy, individual rights, and anti-colonialism. Historian Michael Kazin has described the statement as "the most ambitious, the most specific, and the most eloquent manifesto in the history of the American left." It put forward, Kazin contended, "an entire agenda for a generation."”56 "We were giving voice to a new generation of rebels," Port Huron authors Flacks and Hayden claimed forty years later. ${ }^{757}$ The statement became the most widely distributed document of the American New Left. ${ }^{758}$ In a chronology of the evolution of the CUCND into SUPA, the foundation of the SDS and the "Port Huron Statement" were listed as key events in the history of Canadian student movements. ${ }^{759}$

The "Port Huron Statement" had so successfully expressed the values of a generation that there was no attempt or need for CUCND organizers to acknowledge their use of the words of the American student proclamation. Borrowing directly from the

\footnotetext{
754 "The Declaration of the Combined Universities Campaign for Nuclear Disarmament (CUCND)," February 1963, MUL, CUCND-SUPA fonds, box 7, file: CUCND Declaration, 1.

755 "Appendix: The Port Huron Statement," in Democracy is in the Streets: From Port Huron to the Siege of Chicago, by James Miller (Cambridge, Mass.: Harvard University Press, 2004), 334; Michael Kazin, "The Port Huron Statement at Fifty," Dissent 59(2) (Spring 2012): 83; Tony Hyde, Student Union for Peace Action: An Analysis; Something Old, Something New, Something Borrowed, Something Blue (Toronto: Research, Information and Publications Project of the New Left Committee, September 1967), MUL, CUCND-SUPA fonds, box 16A, file 10, 3; Flacks and Hayden, "The Port Huron Statement at 40," 18; James Miller, Democracy is in the Streets: From Port Huron to the Siege of Chicago (Cambridge, Mass.: Harvard University Press, 2004), 13, 18.

${ }^{756}$ Kazin, "The Port Huron Statement at Fifty," 83.

${ }^{757}$ Flacks and Hayden, "The Port Huron Statement at 40," 18.

${ }^{758}$ Kirkpatrick Sale, SDS (Students for a Democratic Society) (New York: Vintage, 1974), 69; Flacks and Hayden, "The Port Huron Statement at 40," 18.

759 "SUPA chronology," MUL, CUCND-SUPA fonds, box 16A, file 15, 1.
} 
SDS's statement, in February 1963 CUCND students professed themselves to be "breaking the crust of apathy and overcoming the inner alienation that remain the defining characteristics of" university life. ${ }^{760}$ The CUCND's declaration was a call to action, and it criticized Canadian students for their impassivity. "There is not much willingness to take risks..., no setting of dangerous goals, no real conception of personal identity except one manufactured in the image of others, no real urge for personal fulfilment except to be almost as successful as the very successful person," the declaration charged ${ }^{761}$ Reaching well beyond the CUCND's initial impetus as a disarmament organization, the CUCND's executive urged students to organize into a movement for radical structural change, in early 1963 . World peace would only be one part of the equation. ${ }^{762}$

The CUCND's devotion to the principles of the SDS and the "Port Huron Statement" was further reflected in its November 1963 brief to Parliament. In addition to its promotion of individual rights, the CUCND's critique of Canadian society's failure to do more than "pay lip-service" to the values of equality and fairness was reproduced from the SDS's statement. ${ }^{763}$ With its embrace of "Port Huron," the CUCND began its transition into a much more self-consciously student-led campaign to address the

\footnotetext{
760 "The Declaration of the Combined Universities Campaign for Nuclear Disarmament," 11; “Appendix: The Port Huron Statement," 334.

761 "The Declaration of the Combined Universities Campaign for Nuclear Disarmament," 11.

762 "The Declaration of the Combined Universities Campaign for Nuclear Disarmament," 13

${ }^{763}$ Combined Universities Campaign for Nuclear Disarmament, "A Brief to Members of Parliament," 13 November 1963," 2; “Appendix: The Port Huron Statement," 334; Hyde, Student Union for Peace Action, 3.
} 
institutional and systemic causes of violence and war, including poverty and discrimination. ${ }^{764}$

The 1963 shift served pre-emptively to prepare the organization to survive the decline in public interest in disarmament in late 1963. Disarmament began to fade from public view after the fall 1963 signing of the Limited Test Ban treaty, which prohibited the testing of nuclear arms in the atmosphere, under water, and in outer space, and the arrival of nuclear warheads on Canadian soil at the end of the year. ${ }^{765}$ Having already recognized that questions of war and peace must be expanded to consider "the institutions and systems that create them," the CUCND was able to persevere at a moment when banthe-bomb activism had become "irrelevant." ${ }^{, 766}$ As Montreal member Stan Gray predicted, shortly after the April 1963 federal election, "people might very well interpret the last election as the final decision re nuclear arms, and the whole matter closed." 767 The victory of Pearson's pro-nuclear Liberals hurt the morale of the CUCND, as it had with respect to other Canadian anti-nuclear organizations. ${ }^{768}$ Because CUCND had

\footnotetext{
764 "CUCND National Membership Conference Regina," 28 December-1 January [1964], MUL, CUCNDSUPA fonds, box 11, file: Regina conference 1964, 1; "Report of SUPA National Conference," 1; Owram, Born at the Right Time, 220; Palmer, Canada's 1960s, 258.

${ }^{765}$ Arthur Pape and Peter Boothroyd, 11 January 1963, MUL, CUCND-SUPA fonds, box 1, file: correspondence - executive secretary Toronto office 1962-1963, 1; CUCND National Secretariat, "Special Mid-Summer Memo, Hiroshima Day August 6 1963," MUL, CUCND-SUPA fonds, box 3, file: Interbranch memos Dec. 1962-Oct. 1963, 1; Hyde, Student Union for Peace Action, 5; Owram, Born at the Right Time, 220; Churchill, "SUPA, Selma, and Stevenson," 38-39; Wittner, The Struggle Against the Bomb, vol. 2, 202; Manitoba Conference for a Non-Nuclear Canada, "Only Disarmament Guarantees Survival! Brief presented to members of Manitoba Provincial Legislature," 16 March 1964, LAC, James G. Endicott and Family fonds, MG30-C130, vol. 19, file 362, 2; Charles Chatfield, The American Peace Movement (New York: Twayne Publishers, 1992), 115; Wittner, The Struggle Against the Bomb, vol. 2, 443.

${ }^{766}$ Kostash, Long Way from Home, xxiv-xxv; Hyde, Student Union for Peace Action, 5.

${ }^{767}$ Stan Gray to Art [Pape], 27 May 1963, MUL, CCND fonds, box 9, file 9, 1.

768 "Dear CUCNDer," ca. 1964, MUL, CUCND-SUPA fonds, box 2, file: Toronto office correspondence 1964-1965, 1; Arthur Pape to Stan Gray, 23 August 1963, MUL, CCND fonds, box 9, file 9, 1-2; Wittner, The Struggle Against the Bomb, vol. 2, 443; Churchill, "SUPA, Selma, and Stevenson," 34; Candace Loewen, "Mike Hears Voices: Voice of Women and Lester Pearson, 1960-1963," Atlantis 12(2) (Spring 1987): 29; Eva Sanderson to Miss Nancy Pocock, April 22, 1964, LAC, James G. Endicott and Family fonds, MG30-C130, vol. 10, file 179, 1.
} 
already diversified its goals, however, it successfully avoided having the nuclear issue become "the final seal in our coffin.",769

The refocusing and broadening of CUCND's aims throughout 1963 brought a radicalization of positions and methods. Following the April 1963 federal election, the CUCND officially began to promote Canadian neutrality. Liberal party promises that a Liberal government would accept nuclear arms for Canada to honour existing defence commitments prompted the CUCND to demand the Canadian withdrawal from all military alliances in early $1963 .{ }^{770}$ The CUCND executive became convinced that Canadian unilateral disarmament was impossible so long as Canada remained a member of the North Atlantic Treaty Organization (NATO). ${ }^{771}$ This position was not only a break with past approaches for CUCND, but pulled the organization yet another step away from organizations like the CCND and VOW. ${ }^{772}$ In July 1963, important "adult" disarmers F. R. Scott, dean of the McGill Faculty of Law, and CCND chairman Keenleyside, both refused to support the CUCND because the organization had begun to branch out "into attitudes on foreign affairs that have nothing to do with nuclear disarmament."773 The CUCND ended its formal association with CCND over the 1964-1965 New Year's holiday when the organization confirmed its move beyond a single-issue disarmament organization by changing its name to SUPA. ${ }^{774}$

\footnotetext{
${ }^{769}$ Gray to [Pape], 27 May 1963, 1.

770 "Text of an address by the Honourable Lester B. Pearson," 12 January 1963, LAC, Lester B. Pearson fonds, MG26-N2, vol. 50, file 806.2 part 3, 7.

${ }^{771}$ CUCND, "Federal Conference Report Nov. 1963," 9-12 November 1963, MUL, CUCND-SUPA fonds, box 11, file: CUCND federal conference report-Nov. 1963, 1.

${ }^{772}$ CUCND, "Federal Conference Report Nov. 1963," 1; Arthur Pape, "Some thoughts on the peace effort in Canada," MUL, CCND fonds, box 9, file 4, 4.

${ }^{773}$ F. R. Scott to Arthur Pape, 31 July 1963, MUL, CUCND-SUPA fonds, box 3, file: sponsors' file correspondence July-Sept. 1963 and June 1964, 1. See also: H. L. Keenleyside to Arthur Pape, 23 July 1963, MUL, CUCND-SUPA fonds, box 3, file: sponsors' file correspondence July-Sept. 1963 and June $1964,1$.

774 "Report of SUPA National Conference," 1.
} 
Beginning in the summer of 1963, CUCND leaders also began to consider altering the CUCND's policy on civil disobedience. ${ }^{775}$ While preparing for the 73 -hour picket in Ottawa in October 1961, the CUCND federal secretariat made it clear that it would not endorse any acts of civil disobedience, as such activities "could leave us wide open to large-scale imprisonment thus fatally crippling the movement itself." ${ }^{776}$ In June 1962, members of the University of British Columbia group were so worried that that they would be arrested for spending the night in a public park during a 48-hour fast that they did not bring tents, leaving them without shelter when it rained on the second night. ${ }^{777}$ Conversely, in June 1963, CUCND leaders determined that their past actions had not been dramatic enough, and proposed "our conviction would be shown in the fact that we were willing to go to jail.".778

Following the lead of their British CND mentors, the CUCND began explicitly practicing civil disobedience in 1964, to the discomfort of some. With instances of civil disobedience in Britain leading to high profile arrests, some CUCND students, and members of other Canadian anti-nuclear organizations believed that the action went too far. ${ }^{779}$ At the CUCND-initiated June 1964 protest at the La Macaza military base in Quebec, only 17 of approximately 100 protestors chose to practice civil disobedience by blocking the entry gate. Even though air force guards removed protestors from the gate

\footnotetext{
${ }^{775}$ CUCND secretariat, 16 June 1963, MUL, CUCND-SUPA fonds, box 1, file: CUCND secretariat meeting minutes Dec. 1962-Feb. 1964, 3.

${ }^{776}$ Federal secretariat CUCND, "Inter-branch memo," 15 September 1961, MUL, CUCND-SUPA fonds, box 1, file: CUCND Toronto office 1960-1961 correspondence, 2.

${ }_{777}$ Peter Light, 14 June 1962, MUL, CCND fonds, box 9, file 2, 1-2.

${ }^{778}$ CUCND secretariat, 16 June 1963, 3.

779 Dimitrios Roussopoulos, Andre Cardinal and Dan Daniels, "Open letter to all concerned peaceniks," 28 May 1964, MUL, CUCND-SUPA fonds, box 10, file: Operation St. Jean Baptiste, 1; Peter Boothroyd to Andre Cardinal, Dan Daniels and Dimitri Roussopoulos, 9 June 1964, MUL, CUCND-SUPA fonds, box 10, file: Operation St. Jean Baptiste, 1; Nehring, The Politics of Security, 205; Margaret Haines to Kay Macpherson, 12 March 1966, LAC, Voice of Women fonds, MG28-I218, vol. 21, file: British Columbia correspondence 1965-1971.
} 
area, relations between protestors and military personnel remained relatively cordial, especially compared to the "considerably rougher" treatment that a group of nearly 50 practitioners of civil disobedience received during the larger September 1964 protest at the base. Contrary to many fears, there were no notable injuries during either event, nor were any protesters arrested. ${ }^{780}$ At La Macaza the CUCND moved to the forefront of Canadian peace organizations willing to experiment with more dramatic forms of protest. Even the relatively conservative VOW began permitting individual activists to practice civil disobedience by the fall of $1964 .^{781}$

In the summer of 1964, the CUCND put its adoption of American civil rights values and methods into action, imitating SDS and SNCC community-based initiatives. CUCND sent students to Halifax, Kingston, and to several First Nations reserves, with the aim of empowering communities to confront poverty, racism, and discrimination. ${ }^{782}$ Still committed to disarmament, ten CUCND students spent that summer in North Bay, in a failed attempt to organize the community against the nuclear warheads that had arrived at the Bomarc base on New Year's Eve $1963 .^{783}$

While the CUCND re-invented itself in 1963, its most successful independent endeavour, the Montreal-based journal Our Generation Against Nuclear War, remained

\footnotetext{
${ }^{780}$ George Johnston to Lester B. Pearson, 16 September 1964, LAC, Lester B. Pearson fonds, MG26-N3, vol. 25, file 135.1, 1; S. Malanchuk to Lester B. Pearson, 21 September 1964, LAC, Lester B. Pearson fonds, MG26-N3, vol. 35, file 135.1, 1; Bruce Douville, "Project La Macaza: A Study of Two Canadian Peace Protests in the 1960s," in Worth Fighting For: Canada's Tradition of War Resistance from 1812 to the War on Terror, eds. Lara Campbell, Michael Dawson and Catherine Gidney (Toronto: Between the Lines, 2015), Kindle Loc 3170-3248.

${ }^{781}$ Voice of Women, "Minutes of Executive Meeting," 19 September 1964, LAC, Voice of Women fonds, MG28-I218, vol. 23, file: council meeting minutes 1962-1967, 1-2.

782 "Report of SUPA National Conference," 1; Churchill, "Draft Resisters, Left Nationalism and the Politics of Anti-Imperialism," 258; Churchill, "SUPA, Selma, and Stevenson," 34; Palmer, Canada's 1960s, 261.

${ }^{783}$ Harris, Democracy in Kingston, 56; John Clearwater, Canadian Nuclear Weapons: The Untold Story of Canada's Cold War Arsenal (Toronto: Dundurn Press, 1998), 55.
} 
central to the organization's identity. The journal continued publication until 1994, after evolving into an anarchist periodical in $1966 .{ }^{784}$ Founded in 1961 by CUCND leader Roussopoulos, the CUCND executive envisioned the journal as a space to facilitate an international dialogue about peace, in hopes of creating a truly global peace movement. ${ }^{785}$ In less than a year the journal had 1,333 subscribers across Canada and in another 22 countries, such as West Germany, Mexico, Ghana, Iran, and Japan. ${ }^{786}$ By 1962 the journal had the backing of the British CUCND and Youth CND, and of the Student branch of the Committee for a Sane Nuclear Policy (SANE), the Student Peace Union, the Committee for Non-Violent Action, the War Resisters International, and the American Friends Service Committee in the United States. ${ }^{787}$ In December 1963, the editors of the British CND's quarterly, War and Peace, asked to merge with Our Generation, demonstrating the esteem in which the publication was held internationally. ${ }^{788}$

Our Generation's editorial staff prided themselves on the quarterly's identification as a peace research journal and actively recruited peace scholars to maintain the quarterly's intellectual tenor. The November 1961 inaugural issue of the

\footnotetext{
${ }^{784}$ Moffatt, History of the Peace Movement in Canada, 28.

785 "To all associate editors and correspondence editors," 15 December 1961, MUL, CUCND-SUPA fonds, box 16, file: correspondence M. Rowan and D. Roussopoulos 1961-1962, 1; F. C. Hunnius, "Report to the Editorial Board of 'Our Generation Against Nuclear War,"' 19 September 1962, MUL, CCND fonds, SW574, box 22, 7; F. C. Hunnius to Onee Khanna, 1 October 1962, MUL, CCND fonds, box 9, file 17, 1; Sean Mills, The Empire Within: Postcolonial Thought and Political Activism in Sixties Montreal (Montreal: McGill-Queen's University Press, 2010), 49; Harris, Democracy in Kingston, 54.

${ }^{786}$ Our Generation Against Nuclear War, "Memo to all editors," October 1962, MUL, CUCND-SUPA fonds, box 17, file: Ottawa Mike Rowan 1962-1963, 1.

787 "To all associate editors and corresponding editors," 15 December 1961, 1; Gerry [Hunnius] to Dimitri Roussopoulos, 2 February 1962, MUL, CUCND-SUPA fonds, box 16, file: correspondence M. Rowan and D. Roussopoulos, 1-4.

${ }^{788}$ Dimitrios Roussopoulos to Arthur Pape, 1 December 1963, MUL, CUCND-SUPA fonds, box 3, file: CUCND correspondence Arthur Pape, 1; OGAWN Bulletin, 15 December 1963, MUL, CCND fonds, ACCN. 05-1989.102.f, box 25, file 21, 1.
} 
quarterly featured celebrity contributions from CND leader Bertrand Russell, Canadian author Farley Mowat, and Dr. Norman Alcock, whose Canadian Peace Research Institute was founded in the same month. ${ }^{789}$ In 1961-1962 the editorial team included Stuart Hall, a Rhodes Scholar from Jamaica, an Oxford University graduate, and CND publications chairman, who became one of the founding members of the influential Birmingham School of Cultural Studies; Adam Roberts, editor of Peace News, who became Montague Burton Professor of International Relations at Oxford University; and Devi Prasad, a disciple of Mahatma Gandhi's. ${ }^{790}$ Indian Prime Minister Jawaharlal Nehru wrote the preface for the 1963 Winter-Spring issue to demonstrate his enthusiastic support for the journal and its goals, according to Our Generation's Indian editor. ${ }^{791}$

The internationalist drive behind Our Generation was characteristic of youth movements of the 1960s. An international political youth culture emerged during the 1960s. As a result youth movements across the globe demonstrated a "consistency or homogeneity in goals and means."792 Our Generation's international editorial board and readership was made possible by evolving technology that made communication and travel easier and more accessible for Canadian young people. ${ }^{793}$ Participating in the postwar cultural phenomenon of European backpacking, CUCND leaders such as

\footnotetext{
${ }^{789}$ Moffatt, History of the Peace Movement in Canada, 28; Our Generation Against Nuclear War 1(1) (Fall 1961), accessed 19 November 2015, http://s3.amazonaws.com/xlsuite_production/assets/9271675/Vol_1_part_1.pdf.

790 "To all associate editors and corresponding editors," 1; Our Generation Against Nuclear War, "Memo to all editors," 2.

791 Jawaharlal Nehru, "Preface to the Sixth Issue," Our Generation Against Nuclear War 2(2) (Winter/Spring 1963), accessed 19 November 2015, http://s3.amazonaws.com/xlsuite_production/assets/9272955/Vol_2_no_2.pdf, 3; Our Generation Against Nuclear War, "Memo to all editors," October 1962, 2.

792 Richard G. Braungart, "Historical Generations and Generation Units: A Global Pattern of Youth Movements," Journal of Political and Military Sociology 12 (Spring 1984): 128.

${ }^{793}$ Richard Ivan Jobs, "Youth Movements: Travel, Protest, and Europe in 1968," The American Historical Review 114(2) (April 2009): 378, 380.
} 
Roussopoulos and F. C. (Gerry) Hunnius, made personal connections with disarmament and peace organizations across Europe. ${ }^{794}$ In addition to selling Our Generation abroad, annual European trips by Roussopoulos also helped to arrange for coordinated protests against the Canadian acquisition of nuclear weapons at Canadian diplomatic missions in Britain, Denmark, Sweden, Norway, Italy, and Belgium in the spring of $1963 .{ }^{795}$

Though run by a semi-autonomous editorial board, Our Generation's leadership was dominated by CUCND members and was financially dependent on the CUCND. ${ }^{796}$ Financial troubles caused significant tension between the CUCND and the editorial board of Our Generation. CUCND regularly failed to provide necessary financial support to the organization, leading Our Generation editors to release a satirical request in November 1963 for a "sugar daddy." 797 While a lack of occupational responsibilities provided students with greater freedom to express themselves, it also meant that they had little spare income to put towards CUCND's educational efforts. In a mass plea for funds to Canadian peace and disarmament organizations, the CUCND executive explained: "We have no regular income except from the pockets of young people at schools and universities. These young people are already giving as much as they can to the cause that

\footnotetext{
${ }^{794}$ Owram, Born at the Right Time, 206; "Combined Universities Campaign for Nuclear Disarmament," n.d., MUL, CUCND-SUPA fonds, box 1, file: CUCND Toronto office 1960-1961 correspondence, 2; Hunnius to Khanna, 1 October 1962, 1; F. C. Hunnius to Fredy Aeberli, 4 June 1962, MUL, CCND fonds, SW571, box 2, file 12, 1 .

${ }^{795}$ Dimitri Roussopoulos to Ian Gentles, 15 January 1963, MUL, CUCND-SUPA fonds, box 1, file: Toronto office correspondence with D. Roussopoulos Nov. 1962-Jan. 1964, 1; H. H. Moats to K. C. Woodsworth, 8 February 1963, MUL, CCND fonds, SW571, box 6, file 14, 1.

${ }^{796}$ Elka Cohen to Peter Boothroyd, 19 March 1964, MUL, CUCND-SUPA fonds, box 16, file: correspondence re. OGANW and memos 1963-1964, 1; Peter Boothroyd to Elka Cohen, 22 March 1964, MUL, CUCND-SUPA fonds, box 16, file: correspondence re. OGANW and memos 1963-1964, 1-2. ${ }^{797}$ Our Generation Against Nuclear War, "Wanted: Sugar Daddy," 29 November 1963, MUL, CUCNDSUPA fonds, box 17, file: memos 1963-1965, 1; Cohen to Boothroyd, 19 March 1964, 1; Boothroyd to Cohen, 22 March 1964, 1-2; "Report of Committees on Organization and International Editorial Coordination of Our Generation Against Nuclear War," 29 September 1963, MUL, CUCND-SUPA fonds, box 17, file: organization file Fall 1963, 1.
} 
they so passionately believe in. This is money they can ill afford." ${ }^{\text {798 }}$ Identifying as a distinct student community therefore presented both benefits and challenges for CUCND. Yet financial challenges were not unique to the CUCND. Both the CCCRH-CCND and the CPC claimed to be near bankruptcy several times during the late 1950 s and early 1960s. ${ }^{799}$

Despite financial constraints, Our Generation, and by association the CUCND, was internationally recognized to a degree unmatched by any other Canadian peace organization. CUCND leader Peter Boothroyd apologized to Our Generation's editorial board for CUCND's failure to pay its dues, recognizing that "CUCND is lucky enough to be listed as publisher of [Our Generation]. I agree with you that this carries prestige, (not 'some,' a lot) and that it gives outsiders the impression of a tremendous university movement." 800 Our Generation's prominence conferred on Canadian student disarmament efforts an importance that could not be reached with their national campaigns alone. Canadian scholars have claimed that Our Generation had "a profound effect on opinion, especially in the Western Hemisphere," as Russell had hoped for in his preface to the first issue of Our Generation. ${ }^{801}$ While Canadian "adult" anti-nuclear

\footnotetext{
798 Turnbull, "Open letter to all supporters of nuclear disarmament and world peace," 1.

799 To the Windsor Peace Council, 8 October 1959, LAC, James G. Endicott and Family fonds, MG30C130, vol. 7, file: 122, 1; Jacqueline Dineen to All Peace Committees and Supporting Organizations, 9 August 1961, LAC, James G. Endicott and Family fonds, MG30-C130, vol. 8, file 139, 1; Jacqueline Dineen to K. Shukurova, 7 February 1963, LAC, James G. Endicott and Family fonds, MG30-C130, vol. 8, file 156, 1; James S. Thomson to Hazen Argue, 5 September 1961, MUL, CCND fonds, SW571, box 3, file 9, 1; Mary Needler to John, 19 September 1961, MUL, CCND fonds, SW573, box 17, file 4, 1.

${ }^{800}$ Boothroyd to Cohen, 22 March 1964, 1.

${ }^{801}$ Bertrand Russell, "Preface to First Issue," Our Generation Against Nuclear War 1(1) (Fall 1961), accessed 19 November 2015, http://s3.amazonaws.com/xlsuite_production/assets/9271675/Vol_1_part_1.pdf, 3. See: Bryan Palmer, "New Left Liberations: The Poetics, Praxis and Politics of Youth Radicalism," The Sixties in Canada: A Turbulent and Creative Decade, ed. M. Athena Palaeologu (Montreal: Black Rose Books, 2009), 133; Palmer, Canada's 1960s, 516; Harris, Democracy in Kingston, 54; Mills, The Empire Within, 50; Ian McKay, Rebels, Reds, Radicals: Rethinking Canada's Left History (Toronto: Between the Lines, 2005),
} 
groups preached the values of an internationalist outlook, it was student activists who acted upon their internationalism in the CUCND through their journal.

Alongside its international prestige, the CUCND brought "new dynamism and strength," 21 new branches, and 7,000 members to the "adult" CCND, when the two organizations became formally affiliated in $1962 .{ }^{802}$ During its three-year alignment with the CCND, CUCND was far from subservient to the adult organization. The student campaign continued to pursue aims and methods that eclipsed the accepted positions of the CCND, including unilateral disarmament, Canadian withdrawal from NATO, and civil disobedience. Furthermore, CUCND leaders such as Roussopoulos, Hunnius and Pape all played central roles in the executive management of the CCND. ${ }^{803}$ CUCND students had successfully made a space of authority for themselves within Canadian antinuclear movements. CUCND was by no means a "junior" organization.

\section{“Beard with business suit:" student activism and radicalism}

Despite the successes of the CUCND as an independent student voice against nuclear arms, the organization was regularly troubled by accusations of radicalism. The CUCND generation was born in a time of relative peace and prosperity, to parents who knew little else but war and economic depression and were determined to give their children everything they had been denied when they were young. ${ }^{804}$ Postwar young

\footnotetext{
184; Spencer Metta, Review of Our Generation Against Nuclear War by Dimitrios Roussopoulos, The Canadian Journal of Sociology 10(3) (Summer 1985): 350.

${ }^{802}$ Wittner, The Struggle Against the Bomb, vol. 2, 198.

803 "Two memos regarding the international confederation for disarmament and peace," 19 July 1963, MUL, CCND fonds, SW571, box 2, file 3, 1, 2; Gilles B. Richard, Dimitrios Roussopoulos, F. C. Hunnius, "Why the Canadian Campaign for Nuclear Disarmament Must Join the International Confederation for Disarmament and Peace," 20-21 July 1963, MUL, CCND fonds, SW571, box 2, file 1, 3; Dufresne, "Let's Not Be Cremated Equal," 27.

${ }^{804}$ Roussopoulos, "Introduction," 7; Levitt, Children of Privilege, 15, 34.
} 
people "represented the investment in the future" made by their parents and the state. ${ }^{805}$ After several difficult decades, the idea of baby boom children represented a promise for a better future. But lofty expectations also led to great anxiety. ${ }^{806}$ Sociologist Mary Louise Adams has observed that in Cold War Canada, "youth operated as a metaphor for the development of the society as a whole." ${ }^{807}$ The successful maturation of baby boomers was a requirement if the nation was to flourish. ${ }^{808}$ "Potentially delinquent or unruly youth" posed a significant risk to the nation. ${ }^{809}$ As not-yet-complete adults, still in an insecure stage of identity formation, government officials and psychologists feared that young people were especially vulnerable to dangerous influences, particularly communism. ${ }^{810}$ In the context of Cold War ideological tensions, according to Adams, the "potential for trouble slipped easily into the category of being trouble." 811

Moreover, large in numbers, the postwar generation "threatened to eclipse the adult world." ${ }^{\prime 12}$ Many Canadians interpreted youthful music, entertainment, and dress as a rejection of the values of established Canadian "adult" society. ${ }^{813}$ With the help of the Canadian media, it became publicly accepted that "to be a student in 1960s was to be a radical." ${ }^{" 14}$ Similarly, historian of SANE Milton Katz found that the American public automatically associated peace activism with radicalism (meaning communism) and

\footnotetext{
805 Adams, The Trouble With Normal, 51.

${ }^{806}$ Adams, The Trouble With Normal, 40.

${ }^{807}$ Adams, The Trouble With Normal, 40-41.

${ }^{808}$ Adams, The Trouble With Normal, 168.

${ }^{809}$ Adams, The Trouble With Normal, 42. See also: Gleason, "Disciplining Children, Disciplining Parents," 184-185.

${ }^{810}$ Adams, The Trouble with Normal, 50; Palmer, Canada's 1960s, 184; Kimmel, Manhood in America, 171; May, Homeward Bound, 109; Griswold, Fatherhood in America, 186.

811 Adams, The Trouble With Normal, 48.

${ }^{812}$ Owram, Born at the Right Time, 186-187.

813 Adams, The Trouble With Normal, 41.

${ }^{814}$ Owram, Born at the Right Time, 217.
} 
radicalism with sporting beards and sandals. ${ }^{815}$ Marcel Martel also indicated in his history of Royal Canadian Mounted Police (RCMP) suspicion of "hippie" culture that associations of radicalism with long, unkempt hair were common in 1960 s Canada. ${ }^{816}$

Walter Gray's report for the Globe and Mail on CUCND's 1960 Christmas march derisively referred to "bearded" protesters or "the beard" on several occasions. ${ }^{817}$ Such characterizations connecting the CUCND with countercultural expressions followed the organization throughout the early 1960s. At a September 1963 gathering of Western Canadian branches, CUCND leaders argued that the organization was struggling to attract and keep members because of an assumption "that we are beatniks." ${ }^{818}$ As early as 1961 , the CUCND executive recognized that this association needed to be overcome. It proposed "a series of visits by a clean-scrubbed, sincere, responsible youth should clear up these problems." 819 The CUCND's programme committee advised students at the 1963 federal conference that male protesters should wear a "white shirt and tie" and instructed women to wear "skirts not leotards." ${ }^{\text {" }} 20$ Attire was clearly viewed as being much a sign of radicalism as excessive facial hair.

Students had "set off alarm bells in the security service" when they started to mobilize as a group against the Cold War in $1959 .{ }^{821}$ According to historian Steve

${ }^{815}$ Milton Katz, Ban the Bomb: A History of SANE, the Committee for a Sane Nuclear Policy, 1957-1985 (Westport, Conn.: Greenwood Press, 1986), 94.

${ }^{816}$ Marcel Martel, "'They smell bad, have diseases, and are lazy:' RCMP Officers Reporting on Hippies in the Late Sixties," The Canadian Historical Review 90(2) (June 2009): 218, 223, 227. See also: Owram, Born at the Right Time, 216.

${ }^{817}$ Gray, "Only Carillon Yule Hymns Hail 400 Peace Marchers," 1.

818 "CUCND Western Consultation," 28-29 September [1963], 1.

819 "Prospectus for CUCND," n.d., MUL, CUCND-SUPA fonds, box 1, file: CUCND Toronto office 1960$1961,2$.

${ }^{820}$ Clements, "Report of the Programme Committee of the CUCND Federal Conference," 3.

${ }^{821}$ Reg Whitaker, Gregory S. Kealey, and Andrew Parnaby, Secret Service: Political Policing in Canada from the Fenians to Fortress America (Toronto: University of Toronto Press: 2012), 344. See also: Hewitt, Spying 101, 94. 
Hewitt, the CUCND functioned as a "symbolic bridge across the 1960s" for the Canadian security state. Student disarmers were part of a transition in which threats to the nationstate expanded from communism to include the New Left, Red Power, Black Power, Maoists, and Quebec separatists by the early 1970s. ${ }^{822}$ The RCMP had a presence on Canadian campuses for most of the twentieth century for the purposes of protecting "universities and students from 'undue influence' on the part of Communists, other radicals, and enemy intelligence agents." ${ }{ }^{23}$ Students were perceived not just as "passive recipients of propaganda," but also were paradoxically understood to be "active initiators of change," given their status as future elites ${ }^{824}$ RCMP commissioner Clifford Harvison feared in 1961 that students with a strong sense of morality might see communism as a potential cure for some of Western society's ills. ${ }^{825}$

RCMP countersubversion on university campuses ranged from recruiting students as informants to the placement of undercover police officers in suspected organizations. ${ }^{826}$ RCMP agents were secretly present at the CUCND's North Bay picket in the summer of $1960 .{ }^{827}$ The McMaster University branch of the CUCND was fully aware of RCMP surveillance of their branch. John Steele complained to Toronto-based CUCND leader Mike Rowan in December 1960 that the McMaster branch was unable to sustain membership and action because "the RCMP has held us back considerably." $\$ 28$

\footnotetext{
${ }^{822}$ Hewitt, Spying 101, 119.

${ }^{823}$ Hewitt, Spying 101, 5.

${ }^{824}$ Hewitt, Spying 101, 89.

${ }^{825}$ Hewitt, Spying 101, 100.

${ }^{826}$ Hewitt, Spying 101, 93, 101.

${ }^{827}$ Hewitt, Spying 101, 90.

${ }^{828}$ John Steele to Mike Rowan, 5 December 1960, MUL, CUCND-SUPA fonds, box 1, file: CUCND

Toronto correspondence 1960-1961, 1.
} 
RCMP activities on Canadian campuses resulted in significant embarrassment for the force in the spring of 1961, when Université Laval CUCND students publicized RCMP attempts to persuade students to inform on one another. For the first time, the RCMP's countersubversion operations were open to public scrutiny. ${ }^{829}$ Minister of Justice Davie Fulton defended the force on 9 June 1961, reminding the House of Commons of the "need for a security and intelligence service to protect the interests of Canada and Canadians against the efforts of those who are our opponents." ${ }^{830}$ But he privately ordered a halt to all investigations on campuses. ${ }^{831}$

The force did not fully cease its countersubversion operations on Canadian campuses. ${ }^{832}$ Surveillance continued even after RCMP commissioner Harvison informed Fulton in 1961 that the CUCND was not a communist front, nor was it organized by communists. ${ }^{833}$ In November 1963, the Pearson government and the RCMP reached an informal agreement, which was publicly understood to represent the government's disapproval of RCMP security investigations on university campuses ${ }^{834}$ Despite public objections to RCMP interventions in Canadians student life, members of Parliament such as Liberal member Gabriel Roberge and NDP representative Herbert Wilfred Herridge, did not challenge the need for the state to keep a close eye on student activities. ${ }^{835}$

\footnotetext{
${ }^{829}$ Hewitt, Spying 101, 93-94; Whitaker, Kealey and Parnaby, Secret Service, 344.

${ }^{830}$ Canada, House of Commons Debates, vol. 6, 1960-61 (Ottawa: Roger Duhamel, Queen's Printer and Controller of Stationary, 1961), 6113. See also: Bruce Macdonald, "RCMP Uses Spies on Campus: MP," The Globe and Mail, 12 June 1961, 17.

${ }^{831}$ Hewitt, Spying 101, 94.

${ }^{832}$ Hewitt, Spying 101, 100-101.

${ }^{833}$ Hewitt, Spying 101, 94.

${ }^{834}$ Hewitt, Spying 101, 101.

${ }^{835}$ Canada, House of Commons Debates, vol. 6, 1960-61, (Ottawa: Roger Duhamel, Queen's Printer and Controller of Stationary, 1961), 6113-6114; "Fulton Defends RCMP On Security Detail," The Globe and Mail, 10 June 1961, 4; Hewitt, Spying 101, 101.
} 
There was a historic tendency for peace and anti-nuclear activists to be situated on the political left, and the New Left movement, which grew out of CUCND, did embrace certain Marxist ideologies. ${ }^{836}$ Most notably, the attempt by Toronto high school students and young workers to create a Youth Campaign for Disarmament collapsed because of an increasingly assertive Trotskyist element, eventually causing all non-Trotskyists to resign. ${ }^{837}$ As D. Gillian Thompson recalled of her time with the University of British Columbia nuclear disarmament club from 1960 to 1964, the executive's leftist, and faintly Trotskyist, agenda briefly derailed the university's nuclear disarmament club in $1961 . .^{838}$

CUCND organizers recognized the need to keep the organization free of communist influences, but stopped short of banning the participation of communists in their efforts, as SANE did in the United States. ${ }^{839}$ The interest of declared communists in disarmament efforts proved difficult for the McGill University CUCND group. "The CUCND has ... been open recently in Montreal to well based attacks that McGill CUCND was a 'front,"” Roussopoulos reported to Rowan in February $1961 .{ }^{840}$ The University of British Columbia student government rejected a proposal for a student peace council on the grounds that it could become a communist front, and University of Toronto students voted against establishing campus CUCND chapters. ${ }^{841}$ Students at the

\footnotetext{
${ }^{836}$ Lawrence Wittner, Rebels Against War: The American Peace Movement, 1933-1983 (Philadelphia: Temple University Press), 304; Thomas P. Socknat, Witness Against War: Pacifism in Canada, 1900-1945 (Toronto: University of Toronto Press, 1987), 289; Levitt, Children of Privilege, 8.

${ }_{837}^{837}$ Moffatt, History of the Peace Movement in Canada, 48.

${ }^{838}$ D. Gillian Thompson, interview with author, 12 November 2013.

${ }^{839}$ Chatfield, The American Peace Movement, 108; Paul Boyer, "From Activism to Apathy: The American People and Nuclear Weapons, 1963-1980," Journal of American History 70 (March 1984): 839-840.

${ }^{840}$ Dimitrios Roussopoulos to Mike Rowan, 13 February 1961, MUL, CUCND-SUPA fonds, box 1, file: CUCND Toronto correspondence 1960-1961, 1.

${ }^{841}$ Hewitt, Spying 101, 75; "Varsity Students Reject CUCND," 1.
} 
University of Manitoba, concerned about their future employment prospects, refused to be publicly associated with a campus peace group. ${ }^{842}$ Such apprehensiveness about peace and disarmament activism was a consistent problem for CUCND in the recruitment of new members.

In one instance, the president of the Carleton University CUCND branch resigned and the entire branch threatened to withdraw from CUCND because of the "communist dominated Toronto branch" and "their wishy washy fellow travelling policy on nuclear tests. ${ }^{~} 843$ The University of Toronto branch firmly denied the allegations, assuring CUCND chairman Roussopoulos that "we are really a good clean bunch of kids. No one in CUCND even has a beard (which is not as much as you can say for the Secretariat), we're all nice, blond, blue-eyed kids without a tinge of red in us." ${ }^{844}$ The Toronto branch's contention that they were "cleaner" than the national secretariat is noteworthy, given the criticism that national executive members later levelled against the average CUCND student for a lack of political radicalism. In the 1967 founding documents of the Canadian New Left Committee, CUCND leaders, such as Roussopoulos, Stan Gray, and Tony Hyde, lambasted CUCND and SUPA members' combined failure to "to go beyond the confines of liberalism" and to "transcend their middle-class origins." $" 845$

\footnotetext{
${ }^{842}$ Hewitt, Spying 101, 75.

${ }^{843}$ Dimitrios Roussopoulos to Judith L. Clavir, 10 November 1961, MUL, CUCND-SUPA fonds, box 1, file: CUCND Toronto office 1960-1961, 1. See also Dorothy Thompson to U of T CUCND, 13 November 1961, MUL, CUCND-SUPA fonds, box 1, file: CUCND Toronto Office 1960-1961, 1.

${ }^{844}$ CUCND Toronto to Dimitrios Roussopoulos, 20 November 1961, MUL, CUCND-SUPA fonds, box 1, file: CUCND Toronto Office 1960-1961, 1.

${ }^{845}$ Stan Gray, "The Statement of the New Left Committee," 10 September 1967, MUL, CUCND-SUPA fonds, box 7, file: New Left Committee minutes, 4, 3; Roussopoulos, "Introduction," 9; Harvey Shepherd, "SUPA Dissolved; New Left Comm. Formed," New Left Committee Bulletin 1(1) (October 1967), MUL, CUCND-SUPA fonds, box 16A, file 8, 1; Hyde, Student Union for Peace Action, 1, 14. As early as 1964, Roussopoulos expressed frustration over student refusal to do more than "try out" leftist politics (Dimitrios Roussopoulos, "The Student Syndrome," 28 December 1964, MUL, CUCND-SUPA fonds, box 22, file 3, $10)$.
} 
Notwithstanding the frustration of CUCND leaders with the organization's overall "conservatism," the CUCND as a national organization made significant efforts to keep student disarmament efforts free from radicalism. ${ }^{846}$ No figures exist indicating the percentage of Canadian university students who held "radical" left political outlooks and therefore could have brought radical politics into the CUCND ${ }^{847}$ However, that RCMP leadership had determined in 1961 that the CUCND was not a communist front suggests that the organization did successfully keep itself free of any significant communist intrusions.

Looking back on 1960s Canadian student activism, Roussopoulos suggested that the lack of serious radicalism among students could be explained by the fact that Canada produced "no outspoken persons of commanding intellectual and moral stature from whom we could draw inspiration," such as American biochemist and peace activist Linus Pauling, civil rights leader Martin Luther King Jr., or Bertrand Russell. ${ }^{848}$ The CUCND's radicalism was exaggerated, as was the majority of student disarmers' engagement with countercultural and specifically communist activities. In this sense, the CUCND had much in common with "adult" disarmament organizations in Canada.

\section{CUCND elitism}

Just as radicalism within the CUCND was overstated by the Canadian police state, claims by the organization that it was representative of the feelings and desires of a

\footnotetext{
846 "The Declaration of the Combined Universities Campaign for Nuclear Disarmament," 15.

${ }^{847}$ J. Paul Grayson, "'Talkin' 'Bout My Generation': Political Orientations and Activities of a Cohort of Canadian University Students in the Mid-Sixties," Journal of Historical Sociology 26(2) (June 2013): 202, 208.

${ }^{848}$ Roussopoulos, “Introduction,” 9.
} 
generation of Canadian young people were also overdone. ${ }^{849}$ The CUCND was in fact an elite organization. University students, the main source of CUCND membership, "led a relatively privileged existence." ${ }^{950}$

The CUCND's explicit identity as a "university student and faculty campaign" effectively excluded the 87 per cent of young Canadians who moved immediately into the workforce out of high school. ${ }^{851}$ In the fall of 1960, the CUCND executive determined that non-university students should be allowed to participate in CUCND activities, but as "non-voting" associates ${ }^{852}$ During the Christmas 1960 march on Ottawa, the group from Toronto consisted of 65 high school students and non-students and only 45 university students. ${ }^{853}$ Yet these non-university students had no official voice in the policies and positions of the CUCND. As early as September 1960, there was talk among CUCND national leaders of creating a Youth Campaign for Nuclear Disarmament (YCND) for working youths and high school students. ${ }^{854}$ However, YCNDs established in Canada were never officially affiliated to the CUCND. A YCND was established in Toronto in 1963, but had nearly collapsed by April 1964, after a Trotskyist take-over. ${ }^{855}$

\footnotetext{
${ }^{849}$ On several occasions briefs and correspondence from CUCND leaders purported to express the feelings of all Canadian young people. See for example: Information Bulletin vol. 1(11) (27 September 1961), MUL, CUCND-SUPA fonds, box 7, file: early CUCND material, 1; Pape to Pearson, 19 November 1963, 2; Hyde, Student Union for Peace Action, 3.

${ }^{850}$ Levitt, Children of Privilege, 33.

851 "Combined Universities Campaign for Nuclear Disarmament," n.d., 1. See also: Milligan, Rebel Youth, 18; "Resolutions and Reports of the Annual Conference Combined Universities Campaign for Nuclear Disarmament," February 1963, 1, 2.

${ }^{852}$ Mike Rowan to Gilles Richard, 1 September 1960, MUL, CUCND-SUPA fonds, box 1, file: CUCND Toronto correspondence 1960-1961, 1-2.

853 "Report of the Ottawa Motorcade," 1960, 1.

${ }^{854}$ Olig to Rowan, 13 September 1960, 1.

${ }^{855}$ Turnbull, "Open letter to all supporters of nuclear disarmament and world peace," 1; Youth Campaign for Nuclear Disarmament, "Policy Statement," 1963, LAC, James G. Endicott and Family fonds, MG30C130, vol. 8, file 140, 1; Peter Boothroyd to Harry Mister, 27 April 1964, MUL, CUCND-SUPA fonds, box 3, file: miscellaneous correspondence Dec. 1962-Jan. 1964, 1; Moffatt, History of the Peace Movement in Canada, 48.
} 
As former participant Gary Moffatt indicated in his history of Canadian antinuclear efforts, it was odd that the CUCND made so little effort to include these young people, given “its members' own recent experience in high schools and its philosophy of linking with disinherited sectors of the population. ${ }^{" 856}$ Furthermore, the CUCND recognized in its proposal for the Peace Education Project that "high schools represent the educational terminal point" for the majority of Canadians, making it imperative that secondary school students be introduced to a variety of opinions on conflict resolution. ${ }^{857}$ If CUCND was to be successful in attracting undergraduate students to the cause of disarmament, it was vital that Canada's young people be inspired in high school to seize the "power to control their world" and guide it towards peace. ${ }^{858}$

Furthermore, many conditions of student life presented hurdles to participation in protest efforts for the relatively small group of young people who did attend university and were thus eligible for full CUCND membership. Few students were willing or able to take part in protests during exam periods, and many experienced students ultimately withdrew from the CUCND to focus on their studies. ${ }^{859}$ The McGill University CUCND, one of the founding branches of the organization, was near collapse in October 1964.

\footnotetext{
${ }^{856}$ Moffatt, History of the Peace Movement in Canada, 49.

857 “Prospectus-Peace Education Project," n.d., MUL, CUCND-SUPA fonds, box 10, file: CUCND conference Nov. 1963, 1.

${ }^{858}$ Bob Davis, "Schools and the Peace Movement," 28 December 1964, MUL, CUCND-SUPA fonds, box 22, file 3, 1,9 .

${ }^{859}$ Moffatt, History of the Peace Movement in Canada, 28; John Steele to Mike [Rowan], 5 December 1960, MUL, CUCND-SUPA fonds, box 1, file: CUCND Toronto correspondence 1960-1061, 3; William Webster to Arthur Pape, 3 November 1964, MUL, CUCND-SUPA fonds, box 10, file: Remembrance Week 1964, 1.
} 
Most of its seasoned and enthusiastic members ceased participation in CUCND "for academic reasons." 860

Leadership within the national organization then became restricted to a select group who prioritized activism over other responsibilities. SUPA leader Hyde determined that both CUCND and SUPA collapsed because members were unable or unwilling to assert themselves because of a dominating leadership core. ${ }^{861}$ Eight individuals commanded the CUCND and carried through to SUPA. Their personal interests "rapidly translated into rhetoric and programme" for the organizations. According to Hyde, one could write a complete and accurate history of CUCND with the biographies of these men. ${ }^{862}$ While Hyde did not reveal the names of those key individuals, within the CUCND archives Roussopoulos, Pape, Boothroyd, and Rowan, a group based out of Montreal, Toronto, and Ottawa, dominate the authorship of correspondence and official documents. ${ }^{863}$ CUCND leaders all either had graduate training and/or were part of the pre-boom generation, further separating them from the average CUCND member, who was usually a first-year undergraduate student. ${ }^{864}$

CUCND secretary Dick Clements urged branch leaders in 1963 to get to the "average" "rusty thinking" "College Jo," "before the cretins of various political and religious persuasions can infect the innocent frosh with the non-peace intellectual

\footnotetext{
${ }^{860}$ Dale Brown to Arthur Pape, 8 October 1964, MUL, CUCND-SUPA fonds, box 10, file: Remembrance Week 1964, 1.

${ }^{861}$ Hyde, Student Union for Peace Action, 14.

${ }^{862}$ Hyde, Student Union for Peace Action, 5.

${ }^{863}$ Palmer and Dufresne both identified the overwhelming dominance of the authority of Roussopoulos and Pape (Palmer, "New Left Liberations," 133; Dufresne, "'Let's Not Be Cremated Equal,"” 15, 19).

${ }^{864}$ Steele to Rowan, 5 December 1960, 3.
} 
rubbish." 865 The participation of the average "beer-drinking sot" undergraduate student needed to be balanced with the involvement of "a good graduate student core" and "faculty personnel," according to Clements, to elevate the level of "thinking" and "maturity" in the organization. ${ }^{866}$ Such a disparaging assessment of undergraduate students underlined the frustration and disappointment of CUCND leaders with the intellectual divide that they believed separated them from the remainder of CUCND members. ${ }^{867}$ The CUCND executive considered intellectualism to be important for establishing a reputation for sophisticated problem solving, but it ultimately detracted from the organization's ability to appeal to the wider student body. ${ }^{868}$

\section{Women in student activism}

In addition to its intellectual elitism, the CUCND was an overwhelmingly masculine organization. While the exclusion of women from leadership roles was not at all uncommon in mixed-sex disarmament and peace organizations, the absence of meaningful opportunities for women's participation is striking in an organization that prided itself on its devotion to the principle of "respect for all men as equals." 869 Scholars of European and North American student movements have observed that from the 1930s to the 1970 s the term "youth" almost always referred to "men" when used in a political

\footnotetext{
${ }^{865}$ Clements, "Report of the Programme Committee of the CUCND Federal Conference, of Feb. 20-22, 1963," 4. See also: "The Declaration of the Combined Universities Campaign for Nuclear Disarmament," 11.

${ }^{866}$ Clements, "Report of the Programme Committee," 4, 6, 7-8.

867 "Report of SUPA National Conference," 1965, 2.

${ }^{868}$ Clements, "Report of the Programme Committee," 6; "CUCND Western Consultation," 4.

${ }^{869}$ Combined Universities Campaign for Nuclear Disarmament, "A Brief to Members of Parliament," 13 November 1963, 2.
} 
context. ${ }^{870}$ When it came to youth disarmament activism in Canada, there was certainly a male bias.

Thompson complained that women were not included in event planning decisions in the University of British Columbia nuclear disarmament club. For her, this meant "my participation was different from men's and also less than it could [or] should have been." As a young woman, eager to participate in disarmament activism, Thompson "was constantly frustrated because it was so hard to be heard by the predominantly male establishment." 871

References to women in CUCND event planning documents and educational literature were often misogynistic. One manual for an unidentified CUCND campaign explained that all press releases related to the event should include pictures of "pretty girls behind the booths," because the daily papers "will print any picture of pretty girls." 872 A CUCND newsletter produced by the Carleton University branch in March 1963 included a cartoon of two women at the lunch line with the caption "What are you counting now — calories or Strontium 90?"873 The caption was likely intended to highlight the developing fear in Canada over the growing presence of strontium-90, a radioactive by-product of nuclear fallout, in foods such as whole grains and milk. However, the subtext of the cartoon was an assumption that women would be dieting, presumably so that they could be "pretty" for promotional photographs.

\footnotetext{
${ }^{870}$ Susan B. Whitney, Mobilizing Youth: Communists and Catholics in Interwar France (Durham and London: Duke University Press, 2009), 9; Adams, The Trouble With Normal, 40.

${ }^{871}$ Thompson, interview with author, 12 November 2013.

872 "Manual for a CUCND Campaign," n.d., MUL, CCND fonds, SW572, box 9, file 1, 2.

${ }^{873}$ Carleton CUCND Newsletter 1(3) (27 March 1963), MUL, CUCND-SUPA fonds, box 4, file: Carleton 1962-1964, 2.
} 
The 1962 "Port Huron Statement" "had nothing to say about three groups that would become major factors in American politics and culture by the end of the decade: environmentalists, feminists, and the New Right." ${ }^{874}$ CUCND's own "Port Huron Statement," its 1963 brief to Canadian Parliament, criticized the hypocrisy of Canadian society, all the while leaving women out of their demands for respect, equality, justice, and freedom. ${ }^{875}$ Given this absence of feminist voices in the key documents for the transition from CUCND to SUPA and broader student-led leftist movements in Canada, it is not surprising that historians have noted "endemic sexism" in Canada's New Left movement of the late 1960s ${ }^{876}$ Milligan, Nancy Adamson, and Joan Sangster have all argued that the exclusion of women from the leadership of New Left efforts helped to foster the emergence of the women's liberation movement in Canada in the late 1960s. ${ }^{877}$

\section{Conclusion}

The CUCND failed to speak for most Canadian young people, excluding nonuniversity students, women, and even most university student members from significant decision-making in the organization. Nevertheless, the organization remains a special case in the history of disarmament activism in Cold War Canada. The CUCND deserves consideration for its accomplishments as a disarmament organization, and not just as a forerunner of Canada's New Left. The CUCND was an organization apart in Canadian disarmament efforts with its promotion of unilateral disarmament, civil disobedience and

\footnotetext{
${ }^{874}$ Kazin, "The Port Huron Statement at Fifty," 88.

${ }^{875}$ Combined Universities Campaign for Nuclear Disarmament, "A Brief to Members of Parliament," 13 November 1963, 2; Hyde, Student Union for Peace Action, 3.

${ }^{876}$ Milligan, Rebel Youth, 10.

${ }^{877}$ Milligan, Rebel Youth, 10; Nancy Adamson, "Feminists, Libbers, Lefties, and Radicals: The Emergency of the Women's Liberation Movement," in A Diversity of Women: Ontario 1945-80, ed. Joy Parr (Toronto: Toronto University Press, 1995), 253, 256; Joan Sangster, "Radical Ruptures: Feminism, Labor, and the Left in the Long Sixties in Canada," American Review of Canadian Studies 40(1) (March 2010): 7-8.
} 
Canadian withdrawal from military alliances, its religious roots in the SCM, and its adoption of the values of American civil rights and student movements. Furthermore, with the success of its journal Our Generation Against Nuclear War, the CUCND represented all Canadian anti-nuclear efforts internationally.

The CUCND's independent existence became more pronounced in 1963, when CUCND students embraced the SDS's "Port Huron Statement," and initiated the organization's transition away from disarmament activism. By the time the public had begun to lose interest in disarmament in late 1963, CUCND students had already revised the organization's "obsolete" bombcentric focus. ${ }^{878}$ The CUCND executive connected its single-issue campaign against the Bomb to a wide range of social ills including poverty and racism. This expanded program to address the structural causes of war allowed Canadian student anti-nuclear movements to evolve more effectively than those of their adult colleagues, as the nuclear issue faded from the public agenda in the mid-1960s. ${ }^{879}$

\footnotetext{
${ }^{878}$ Owram, Born at the Right Time, 220; Harding, "Continuing On," 397; Dufresne, "'Let's Not Be Cremated Equal,"” 29.

${ }^{879}$ Kostash, Long Way from Home, xxiv.
} 


\section{Chapter Five \\ Canadian Disarmers and the End of "Proper Politics"}

With the April 1963 election of a pro-nuclear Liberal federal minority

government, it seemed certain that nuclear warheads would be stationed on Canadian

soil. Disarmers became anxious that the average Canadian might consider the debate over

nuclear arms in Canada to be "closed." 880 "We need a dramatic and different type of

protest," the Combined Universities Campaign for Nuclear Disarmament (CUCND)

secretariat proclaimed in June $1963 .{ }^{881}$ By the summer of that year, Canadian anti-nuclear

activists had determined a need to revisit and amplify their protest methods if they were

ever to cause a "breakthrough" in the way that Canadians conceived of nuclear arms. ${ }^{882}$

Up until 1963, Canadian peace and disarmament organizations rarely questioned

the effectiveness of their preferred conservative protest methods. ${ }^{883}$ As they strove to

maintain an image of "respectability," to stave off accusations of radicalism and

communist affiliation, Canadian disarmament organizations built upon the traditions of

${ }^{880}$ Stan Gray to Art [Pape], 27 May 1963, The William Ready Division of Archives and Research Collections, McMaster University Library (MUL), CCND fonds, SW572, box 9, file 9, 1. See also: John Alan Lee to Arthur Pape, 8 November 1963, MUL, CCND fonds, SW571, box 3, file 2, 1; Bruce Underhill to K. C. Woodsworth, 2 February 1963, MUL, CCND fonds, SW571, box 5, file 21; Charlotte McEwen to Jo [Davis], 3 June 1963, Library and Archives Canada (LAC), Voice of Women fonds, MG28-I218, vol. 39, file: Winnipeg Meeting Emergency Resolutions correspondence pt. 1 1963, 1; Bertrand Russell to James Endicott, 3 June 1963, LAC, James G. Endicott and Family fonds, MG30-C130, vol. 8, file 160, 1; Floyd [Williston] to James Endicott, 30 August 1963, LAC, James G. Endicott and Family fonds, MG30C130, vol. 8, file 160, 1.

${ }^{881}$ CUCND Secretariat, 16 June 1963, MUL, CUCND-SUPA fonds, box 1, file: CUCND secretariat meeting minutes Dec. 1962-Feb. 1964, 3.

${ }_{882}$ Peggy Hope-Simpson to Joe [Davis], 24 November 1962, LAC, Voice of Women fonds, MG28-I218, vol. 1, file: correspondence Josephine Davis (vice-pres) 1962, 2. See also: Joan Wright to the Emergency Resolutions Delegation, 25 May 1963, LAC, Voice of Women fonds, MG28-I218, vol. 39, file: Winnipeg Meeting Emergency Resolutions correspondence pt. 2, 1963, 2; "Minutes of the Board of Directors' Meeting," 20-21 April 1963, MUL, CCND fonds, SW571, box 1, file 6, 4; Arthur Pape to Prof. Keyfitz, 8 August 1963, MUL, CCND fonds, SW571, box 4, file 8, 1.

${ }^{883}$ Gary Moffatt, History of the Peace Movement in Canada (Ottawa, ON: Grapevine Press, 1982), 51; Thomas Socknat, Witness Against War: Pacifism in Canada, 1900-1945 (Toronto: University of Toronto Press, 1987), 10, 14, 290-291. 
early twentieth century religiously based peace efforts. ${ }^{884}$ Disarmers, like their

predecessors, focused on public education, whether through petitions, marches, vigils, newspaper advertisements, and letters to the editor. ${ }^{885}$ But, the initial educational drive of groups like the Canadian Campaign for Nuclear Disarmament (CCND) and the women's peace group Voice of Women (VOW) quickly became of lesser importance as activists prioritized political lobbying, another tactic borrowed from the pacifist past. ${ }^{886}$ Unlike the British Campaign for Nuclear Disarmament (CND), which served as a model for Canadian groups and initially focused solely on the Labour Party, no Canadian disarmament group associated itself with any one political party. All national Canadian anti-nuclear organizations explicitly proclaimed themselves to be non-partisan. ${ }^{887}$

Throughout the period of their greatest strength from 1959 to 1963, Canadian disarmers consciously avoided any form of protest that was associated with radicalism, specifically civil disobedience. ${ }^{888}$ Like their colleagues in the British CND, Canadian

\footnotetext{
${ }^{884}$ Dorothy Harrison, 12 November 1971, LAC, Voice of Women fonds, MG 28 I 218, vol. 21, file: Dundas, Ontario, correspondence 1965-1971, 1-2; Moffatt, History of the Peace Movement in Canada, 51. ${ }^{885}$ CUCND secretariat, 3 December 1962, MUL, CUCND-SUPA fonds, box 1, file: CUCND secretariat meeting minutes Dec. 1962-Feb. 1964, 4.

886 "Policy Statement," autumn 1960, MUL, CUCND-SUPA fonds, box 7, file: Early CUCND material, 23; "What is the Canadian Campaign for Nuclear Disarmament,?" ca. 1963, MUL, CCND fonds, SW571, box 1, file 1, 1-2; Mary Jennison, "The Growth of the Peace Movement in Canada," ca. 1949, LAC, James G. Endicott and Family fonds, MG30-C130, vol. 1, file 1, 3-4; "Brief concerning the: 1) motivation 2) purpose 3) methods of implementation 4) organization of a proposed, new international movement to be known as 'Voice of Women,"' 12 June 1960, LAC, Voice of Women fonds, MG28-I218, vol. 7, file: Development of Brief - Organization of VOW, 1961, 2; Mrs. F. Davis to Hon. Lester B. Pearson, 22 June 1960, LAC, Voice of Women fonds, MG28-I218, vol. 1, file: Correspondence-members of parliament re. formation 1960-1963, 1; Socknat, Witness Against War, 10, 14, 290-291.

${ }^{887}$ Holger Nehring, Politics of Security: British and West German Protest Movements and the Early Cold War, 1945-1970 (Oxford: Oxford University Press, 2013), 129-130; "Policy Statement," autumn 1960, 3; "What is the Canadian Campaign for Nuclear Disarmament?," ca. 1963, 2; "The Provisional Committee for a Canadian National Peace Congress, Statement of Purpose," n.d., LAC, James G. Endicott and Family fonds, MG30-C130, vol. 1, file 1, 1; Pamela Sachs, "Press Release," 6 March 1963, LAC, Voice of Women fonds, MG28-I218, vol. 2, file: Council Meetings, Minutes, 1964, 1.

${ }^{888}$ Holger Nehring, "National Internationalists: British and West German Protests against Nuclear Weapons, the Politics of Transnational Communications and the Social History of the Cold War, 19571964," Contemporary European History 14(4) (2005): 580-581; Margaret Haines to Kay Macpherson, 12 March 1966, LAC, Voice of Women fonds, MG28-I218, vol. 21, file: British Columbia correspondence
} 
disarmers were committed to the "proper politics" of civil extraparliamentary protest. ${ }^{889}$ Canadian activists were confident that the most effective means of convincing the public to reject the idea of nuclear deterrence was to limit public demonstrations, which might be perceived as militant, and focus on educating political leaders. Disarmers operated under the assumption that, if the government was adequately informed about the dangers of nuclear radiation and war, it would "do the right thing" and Canadian public opinion would follow. ${ }^{890}$

Because of their preoccupation with political lobbying and maintaining "respectable" public images, in spite of their best efforts Canadian disarmers failed to have a significant impact on Canadian defence and foreign policy decision-making related to nuclear arms. Their methods of "orderly" protest were insufficient to convince Canadian politicians that there would be significant electoral consequences if nuclear weapons were acquired by Canada. ${ }^{891}$ In the context of the 1960 s_ an era of passion and change - traditional politics were an out-dated and inadequate response to the dangers of the Cold War arms race. ${ }^{892}$

1965-1971, 2-3; "Why a Committee of 100," Survival 1(1) (November 1961), LAC, James G. Endicott and Family fonds, MG30-C130, vol. 19, file 376, 1.

${ }^{889}$ Nehring, "National Internationalists," 580.

${ }^{890}$ Marion Douglas Kerans, Muriel Duckworth: A Very Active Pacifist, A Biography (Halifax: Fernwood, 1996), 88. See also: Canadian Campaign for Nuclear Disarmament, "Instructions for Lobbyists," 8-10 November 1962, MUL, CCND fonds, ACCN. 05-1989.102.F, box 24, file 5, 2; Jean Birch to Mrs. Macpherson, 5 June 1963, LAC, Voice of Women fonds, MG28-I218, vol. 29, file: Winnipeg meeting Emergency Resolutions correspondence pt. 1 1963, 1; Carole Chapman, "How effective is The Voice of Women?," Chatelaine (June 1961), 188.

${ }^{891}$ See for example of the obsession with "orderly" behavior in disarmament groups: Welland Campaign for Nuclear Disarmament, "Easter Peace Walk to the Peace Bridge," ca. 1962, MUL, CCND fonds, SW573, box 18, file 3,1 .

${ }^{892}$ Dimitry Anastakis, "Introduction," in The Sixties: Passion, Politics and Style, ed. Dimitry Anastakis (Montreal: McGill-Queen's University Press, 2008), 9; Nehring, The Politics of Security, 47-48; Bryan Palmer, Canada's 1960s: The Ironies of Identity in a Rebellious Era (Toronto: University of Toronto Press, 2009), Kindle Loc 139; Lara Campbell and Dominique Clément, "Introduction: Time, Age, Myth: Towards a History of the Sixties," in Debating Dissent: Canada and the Sixties, edited by Lara Campbell, Dominique Clément and Gregory S. Kealey (Toronto: University of Toronto Press, 2012), 6; Doug Owram, 
Canadian disarmers were convinced that the use of "proper politics" would eventually be successful because of the cordial relationships that most organizations had with all three of the major Canadian political parties in the early 1960s. Disarmament organizations generally received warm welcomes when visiting Ottawa and left their meetings with politicians feeling heard and validated. However, Canadian anti-nuclear activists saw courtesy as a sign of progress towards an anti-nuclear perspective. In reality, no conversions took place.

Conservative leader John G. Diefenbaker had no sympathy for disarmers, and was not overly fearful of their potential strength. Instead he used disarmers as an excuse to justify his drawn-out negotiations with the United States government to determine the conditions for the acquisition and storage of defensive nuclear weapons in Canada. Liberal leader Lester B. Pearson, a public supporter of Canadian anti-nuclear efforts, betrayed disarmers in January 1963, when he began promoting the installation of nuclear warheads in Canada. The Cooperative Commonwealth Federation (CCF) and its successor the New Democratic Party (NDP) had a surprisingly rocky relationship with disarmers, as the party strove throughout the 1950s to avoid any hint of association with communism. Once the party renewed its support for peace efforts in the 1960 s, it was the disarmers who rejected the party. With their reluctance to embrace publicly the CCFNDP, and their reliance on Diefenbaker's hollow friendship and Pearson's temporary support, Canadian disarmers placed all their hopes in empty promises.

\section{Diefenbaker and the disarmers}

Born at the Right Time: A History of the Baby Boom Generation (Toronto: University of Toronto Press Incorporated, 1996), x, 308. 
Though disarmers were "thank[ing] heaven" for Diefenbaker and his approach to the nuclear arms question by the time of the 1963 election, Diefenbaker was no patron of Canadian anti-nuclear activists. ${ }^{893}$ Throughout much of his time in power, Diefenbaker demonstrated ambivalence towards Canadian disarmers. He sometimes treated disarmers with respect and congeniality, and at other times ignored them and spoke of them with derision. However, he regularly referred to Canadian disarmament efforts and public opposition to nuclear weapons when explaining his ambiguous position on nuclear weapons. During the election of 1963, Diefenbaker positioned himself as an ally of disarmers, not because he had become a true believer in their cause, or because he feared their potential political strength, but because he had decided that resistance to American nuclear designs would have the greatest public appeal.

As early as 1954, the Canadian government, under the leadership of Louis St. Laurent's Liberals, had tacitly supported the nuclearization of Canada's defence when the North Atlantic Treaty Organization (NATO) shifted its strategic defence priorities from conventional armaments to nuclear weapons. ${ }^{894}$ However, American legislation prevented any arrangements for the deployment of American nuclear weapons outside of the United States before $1957 .{ }^{895}$ Negotiations related to the conditions for stationing American nuclear arms in Canada finally began at the NATO summit meeting in December 1957 seven months after Diefenbaker's Conservatives defeated the Liberals in the June 1957

\footnotetext{
${ }^{893}$ Edward Andrew, "Voice of the People: Taste of Irony," Toronto Daily Star, 6 February 1963, 4.

${ }^{894}$ Robert Bothwell, The Big Chill: Canada and the Cold War (Toronto: Canadian Institute of International Affairs, 1998), 58; Nehring, Politics of Security, 43-44, David Bercuson, Review of Essence of Indecision: Diefenbaker's Nuclear Policy, 1957-1963 by Patricia McMahon, Canadian Historical Review 91(1) (March 2010): 175.

${ }^{895}$ Sean M. Maloney, Learning to Love the Bomb: Canada's Nuclear Weapons During the Cold War (Washington, D.C.: Potomac Books, 2007), 76.
} 
federal election. ${ }^{896}$ Canadian-American nuclear talks involved four separate issues: the acquisition of nuclear warheads for Canadian forces on Canadian soil; the acquisition of nuclear warheads for Canadian forces in Europe; the storage of anti-submarine weapons for American and Canadian forces at Argentia, Newfoundland; and the storage of nuclear arms for American forces at Goose Bay, Labrador, and Harmon Air Force base in Newfoundland. ${ }^{897}$ The questions of nuclear arms on Canadian soil, either under the control of Canadian or American forces, proved the most problematic, and negotiations faced a number of starts and stops. By early 1963 Canadian-American relations and confidence in Diefenbaker's leadership both within and without the Conservative party had brought the Diefenbaker government to the point of collapse. ${ }^{898}$

The inability of the Diefenbaker government to reach an agreement for the installation of on nuclear arms in Canada has led many scholars to accuse Diefenbaker of "hesitation" and "indecision" on the nuclear question. ${ }^{899}$ Such assessments are unduly

896 "Extract from Cabinet Conclusions," 15 January 1960, Documents on Canadian External Relations (DCER), vol. 27, ed. Janice Cavell (Ottawa: Foreign Affairs and International Trade Canada, 2007), doc. 262.

${ }^{897}$ Basil H. Robinson, Diefenbaker's World: A Populist in Foreign Affairs (Toronto: University of Toronto Press, 2009), 107; Erika Simpson, NATO and the Bomb: Canadian Defenders Confront Critics (Montreal: McGill-Queen's University Press, 2001), 106; Doug Munton, “Going Fission: Tales and Truths about Canada's Nuclear Weapons," International Journal 51(3) (Summer 1996), 520.

${ }^{898}$ Douglas S. Harkness, "Tense days led to a showdown," Calgary Herald, 19 October 1977, A3; "Telegram from the Embassy in Canada," Foreign Relations of the United States (FRUS), 1961-1963, vol. XIII (Washington: Unites States Government Printing Office, 1994), doc. 445; Asa McKercher, "Diefenbaker's World: One Canada and the History of Canadian-American Relations, 1961-63," The Historian 75(1) (2013): 114; Robinson, Diefenbaker's World, 318-319; Maloney, Learning to Love the Bomb, 261; Simpson, NATO and the Bomb, 121.

${ }^{899}$ Patricia McMahon, Essence of Indecision: Diefenbaker's Nuclear Policy, 1957-1963 (Montreal: McGill-Queen's University Press, 2009), xv-xvi; Jocelyn Maynard Ghent, "Did He Fall or Was He Pushed? The Kennedy Administration and the Collapse of the Diefenbaker Government," The International History Review 1(2) (April 1979): 172-173; Denis Smith, Rogue Tory: The Life and Legend of John G. Diefenbaker (Toronto: University of Toronto Press, 1987), 328; Andrew Richter, Avoiding Armageddon: Canadian Military Strategy and Nuclear Weapons, 1950-63 (Vancouver: UBC Press, 2002), 102; Peter C. Newman, Renegade in Power: The Diefenbaker Years (Toronto: McClelland and Stewart Limited, 1973), xxiii, 333; Robert Bothwell, “The Canadian Isolationist Tradition," International Journal 54(1) (Winter 1998/1999): 84. 
harsh. Nuclear warheads would not have even been ready for Canada before the fall of 1962. ${ }^{900}$ Nevertheless, nuclear negotiations were far from smooth and efficient under Diefenbaker's leadership.

Contemporary observers and historians alike have made numerous attempts to understand why Diefenbaker held so firmly to what would become a fatal strategy for his government. The Diefenbaker prime ministerial papers reveal little about his rationale. ${ }^{901}$ Moreover, his memoirs represent a combination of "selective recollection" and "inattentiveness to factual detail."902 There is no consensus among scholars seeking to explain Diefenbaker's delays.

Many, like political scientist Denis Smith and journalist Peter Newman, have argued that the hesitation was caused by the prime minister's flawed character, particularly his indecisiveness, insecurity, paranoia, and inability to deal effectively with antagonism. ${ }^{903}$ Political scientists Brian Bow and Erika Simpson and historian Sean Maloney emphasized the impact that pro-disarmament elements in the Department of External Affairs had on negotiations. ${ }^{904}$ Political scientist Andrew Richter has suggested

900 "Extract from Cabinet Conclusions," 4 July 1960, DCER, vol. 27, doc. 272; Richter, Avoiding Armageddon, 92; John Clearwater, Canadian Nuclear Weapons: The Untold Story of Canada's Cold War Arsenal (Toronto: Dundurn Press, 1998), 20.

${ }^{901}$ Daniel Macfarlane, "Courting War over a Rubber Stamp: Canada and the 1961 Berlin Wall Crisis," International Journal 63(3) (Summer 2008), 752.

902 Donald C. Story, Review of One Canada: Memoirs of the Right Honourable John G. Diefenbaker: The Crusading Years, 1875-1956, eds. John H. Archer and John A. Munro, Canadian Journal of Political Science/Revue canadienne de science politique 1(1) (March 1977), 181.

${ }^{903}$ Smith, Rogue Tory, 328, 553, 578; Newman, Renegade in Power, xx-xxi, xxiii, 333, 341; Bothwell, The Big Chill, 65; J. L. Granatstein, A Man of Influence: Norman A. Robertson and Canadian Statecraft 192968 (Ottawa: Deneau Publishers \& Company Ltd., 1981), 356; Paul H. Robinson, Jr., interview by Willis Armstrong, 1989, "Frontline Diplomacy," Library of Congress, accessed May 27, 2015, http://lcweb2.loc.gov/service/mss/mfdip/2004/2004rob03/2004rob03.pdf, 7.

${ }_{904}$ Brian Bow, "Parties and Partisanship in Canadian Defence Policy," International Journal 64(1) (Winter 2008/2009), 81; Maloney, Learning to Love the Bomb, 226-227, 230, 259-260; Erika Simpson, "New Ways of Thinking about Nuclear Weapons and Canada's Defence Policy," in The Diefenbaker Legacy: Canadian Politics, Law and Society Since 1957, eds. Donald C. Story and R. Bruce Shepard (Regina: Canadian Plains Research Centre, 1998), 40. 
that negotiations were hampered by a combination of factors, including the prime minister's political style, American interference, domestic opposition to nuclear arms, animosity between Diefenbaker and American President John F. Kennedy, the political threat posed by Liberal leader Pearson, and the influence of an anti-nuclear cohort in External Affairs. ${ }^{905}$ All of these theories imply that there was no driving force in Diefenbaker's approach to nuclear arms for Canada and that the prime minister was struggling throughout to make up his own mind on the matter, leaving him susceptible to his own anxieties or to outside influences.

Historian Patricia McMahon and journalist Patrick Nicholson contended that growing anti-nuclear movements in Canada caused Diefenbaker to dither because he was worried about domestic political trouble. ${ }^{906}$ However, the prime minister's approach to nuclear weapons did not change when anti-nuclear organizations made their greatest demonstration of strength, presenting Diefenbaker with 141,000 signatures against nuclear arms in Canada in October 1961. ${ }^{907}$ John Hilliker and Donald Barry have also argued that Diefenbaker tailored his approach to nuclear weapons based on his understanding of Canadian public opinion. Hilliker and Barry attributed greater calculation behind Diefenbaker's actions, helping better to explain why he continued to pursue the possibility of nuclear arms in Canada after the fall of 1961. They have

\footnotetext{
${ }^{905}$ Richter, Avoiding Armageddon, 87.

${ }^{906}$ McMahon, Essence of Indecision, x-xii; Patrick Nicholson, Vision and Indecision (Don Mills, ON: Longmans Canada Limited, 1968), 207-208.

907 "Minutes of the Meeting of the Third Annual Conference of the Canadian Committee for the Control of Radiation Hazards," 26-27 February 1962, MUL, CCND fonds, box 18, file 1, 6; Research section, Ottawa, "National Committee for the Control of Radiation Hazards_-January 1962," July 23, 1977, LAC, CSIS files, RG146-738, vol. 1, (obtained under access to information), 14, 19; Lawrence S. Wittner, The Struggle Against the Bomb, vol. 2 (Stanford: Stanford University Press, 1997), 197.
} 
maintained that Diefenbaker sought to appear to support both sides of the nuclear debate, purposefully keeping “everybody off-base." 908

Such an understanding is supported by the assessment of H. Basil Robinson, who worked as Diefenbaker's External Affairs liaison officer. Diefenbaker, according to Robinson, carefully weighed the political consequences of any decision and had a tendency to proceed cautiously when faced with potentially controversial decisions. ${ }^{909}$ Diefenbaker had also, as Cara Spittal has demonstrated, achieved the largest majority government in Canadian history in 1958 on the basis of his ability to "play up to the whims of the strategically calculated mass audience." 910 It is not unthinkable that Diefenbaker's approach to nuclear weapons for Canada would follow the same pattern of accommodation of public opinion, at a time when popular sentiment towards nuclear arms was unclear. From 1961 to 1963, polls consistently showed more support for nuclear arms in Canada than opposition, but at the same time implied increasing public support for disarmament and a nuclear test ban. ${ }^{911}$

Yet, Diefenbaker began to drift closer towards a non-nuclear option for Canada in January 1963, when public opinion polls indicated that the majority of Canadians wanted to see Canadian forces armed with nuclear weapons. ${ }^{912}$ At this point, one can no longer

\footnotetext{
${ }^{908}$ John F. Hilliker and Donald Barry, "The PM and the SSEA in Canada's foreign policy: sharing the territory, 1946-1968," International Journal 50(1) (Winter 1994-1995), 179; John F. Hilliker, "The Politician and the 'Pearsonalities': The Diefenbaker Government and the Conduct of Canadian External Relations," Historical Papers/Communications historiques 19(1) (1984), 166.

909 Robinson, Diefenbaker's World, 319.

${ }^{910}$ Cara Spittal, "The Diefenbaker Moment" (Ph.D. diss., University of Toronto, 2011), 142-143.

911 "Increase among those who say 'Ban the Bomb,"” in Gallup Report 1960-61 (Toronto: Canadian Institute of Public Opinion, 1961), 2; "Majority say army should be given nuclear weapons," in Gallup Report 1960-61, 2; "Belief in Disarmament has Risen Sharply in Six Years," in Gallup Report 1962 (Toronto: Canadian Institute of Public Opinion, 1962), 1; "Majority Say Our Forces Should Have Nuclear Arms," in Gallup Report 1962, 2.

${ }^{912}$ Norman Z. Alcock to the Hon. Lester B. Pearson, 15 January 1963, LAC, Lester B. Pearson fonds, MG26-N2, vol. 53, file 808, 2; "Majority Say Our Forces Should Have Nuclear Arms," 2.
} 
explain Diefenbaker's stance on nuclear arms solely with reference to cautious

consideration of public opinion. In early 1963, the prime minister's paranoia and concern for his personal popularity began to influence his thinking on nuclear negotiations. ${ }^{913}$ Diefenbaker became an ally of nuclear disarmers when worsening relations with the United States resulted in public embarrassment for himself and when Pearson took a pronuclear stance. Driven by both ego and legitimate discomfort with American nuclear policy, Diefenbaker moved towards a re-assessment of the requirement for nuclear weapons and had become an ally of Canadian disarmers by the election of April 1963.

In the early years of the Diefenbaker government, there were few signs that the demands of disarmament activists would find friendly ears within the ruling party. From 1957 to 1959, Diefenbaker clearly favoured Canada's acquisition of nuclear weapons, and took several steps towards arming Canadian troops in Canada and Europe with nuclear arms. During this time the Diefenbaker government accepted Canadian participation in the North American Air Defence Command (NORAD), ordered BomarcB missiles for installation on Canadian soil, accepted a strike-reconnaissance role for Canadian forces in Europe, and purchased CF-104 aircraft with very little resistance from the collection of Canadian peace groups that was beginning to coalesce around the issue of nuclear arms. ${ }^{914}$

When Diefenbaker announced on 20 February 1959 that Canada would acquire Bomarc missiles, he emphasized that defensive nuclear weapons were necessary, given

\footnotetext{
${ }^{913}$ Newman, Renegade in Power, xx-xxi; Smith, Rogue Tory, 553.

${ }^{914}$ Bothwell, The Big Chill, 58; Simpson, "New Ways of Thinking about Nuclear Weapons," 31; Greg Donaghy, Tolerant Allies: Canada \& The United States 1963-1968 (Montreal: McGill-Queen's University Press, 2002), 6; Robinson, Diefenbaker's World, 107; Howard H. Lentner, "Foreign Policy Decision Making: The Case of Canada and Nuclear Weapons," World Politics 29(1) (October 1976): 43.
} 
the improbability that the United Nations would develop a successful disarmament agreement. He observed that the full potential of the Bomarc "is achieved only when they are armed with nuclear warheads." With this, Diefenbaker revealed that the Canadian government was beginning to explore with the United States government the conditions for Canada's acquisition of nuclear arms. ${ }^{915}$

As would become his pattern, Diefenbaker softened his announcement, emphasizing that Canada would "continue to support effective measures for disarmament" and that the Bomarc decision was taken only after "much soulsearching." ${ }^{916}$ Cloaking what was largely a pro-nuclear statement with support for disarmament, Diefenbaker revealed his desire to come to a decision that, "in the light of the expectations of the future, will be considered right. ${ }^{" 917}$ When it came to nuclear arms, Diefenbaker wanted to take the most publicly-favoured option. This speech, which Diefenbaker would quote repeatedly when asked to clarify his position on nuclear weapons, set the stage for his approach to the issue for the remainder of his time as prime minister. $^{918}$

Despite the careful wording, Diefenbaker's statement helped catalyzed growing Canadian anti-nuclear movements. His speech coincided with rising international concerns over radioactive fallout. This international environment coupled with the Bomarc announcement served to revitalize the decade-old Canadian Peace Congress

${ }^{915}$ Canada, House of Commons Debates, vol. II (1959) (Ottawa: The Queen's Printer and Controller of Stationary, 1959), 1223.

${ }_{916}$ Canada, House of Commons Debates, vol. II (1959), 1223.

${ }^{917}$ Canada, House of Commons Debates, vol. II (1959), 1224.

918 "Extract from Cabinet Conclusions," July 4, 1960, DCER, vol. 27, doc. 272; Canada, House of Commons Debates, vol. I (1960) (Ottawa: The Queen's Printer and Controller of Stationary, 1960), 73; "Extract from Cabinet Conclusions," February 14, 1961, DCER, vol. 28, ed. Janice Cavell (Ottawa: Foreign Affairs and International Trade Canada, 2009), doc. 331; Canada, House of Commons Debates, vol. I (1963) (Ottawa: Roger Duhamel, 1963), 124. 
(CPC), and inspired the formation of two organizations that would quickly develop national support. In April 1959, Mary Van Stolk started the Canadian Committee for the Control of Radiation Hazards (CCCRH), which would later become the CCND, and a collective of Montreal university students formed the CUCND in November of that year. ${ }^{919}$

As Canadian disarmament efforts were beginning to organize, Diefenbaker provided activists with reason to believe him sympathetic. Canadian Peace Congress members were certain that the Diefenbaker government shared their desire for a nuclear weapons test ban. Despite her organization's reputation as a communist-dominated organization, CPC secretary Eva Sanderson had received polite assurances from Diefenbaker's private secretary that the Canadian delegation at the United Nations was doing all that it could to reach a disarmament agreement and a nuclear test ban. ${ }^{920}$ In May 1959, the CPC-affiliated Toronto Association for Peace (TAP) submitted a brief to Diefenbaker that expressed confidence he would act to put a stop to nuclear weapons testing, because "your government has told us on other occasions that you too are concerned with this matter." ${ }^{, 921}$ Politicians generally reserved only 30 to 45 minutes for visits from anti-nuclear lobbies, but in December 1959 the prime minister spent an exceptional hour and a half with an anti-nuclear delegation from the University of

\footnotetext{
919 Tarah Brookfield, Cold War Comforts: Canadian Women, Child Safety, and Global Insecurity, $1945-$ 1975 (Waterloo: Wilfrid Laurier University Press, 2012), 72; Wittner, The Struggle Against the Bomb, vol. 2, 2, 31, 78; Jacqueline Dineen to Louise Harvey, December 8, 1959, LAC, James G. Endicott and Family fonds, MG30-C130, vol. 7, file 123, 1; McMahon, Essence of Indecision, 66; "Bomb Ban Petition Grows," Globe and Mail, 19 December 1959, 8; Palmer, Canada's 1960s, 257.

${ }^{920}$ Derek Bedson to Eva Sanderson, 6 November 1957, LAC, James G. Endicott and Family fonds, MG30C130, vol. 6, file 104, 1. On the CPC and communism see: Reg Whitaker and Gary Marcuse, Cold War Canada: The Making of a National Insecurity State, 1945-1957 (Toronto: University of Toronto Press, 1994), 366, 373; Victor Huard, "The Canadian Peace Congress and the Challenge to Postwar Consensus, 1948-1953," Peace and Change 19(1) (January 1994): 26.

921 Toronto Association for Peace, "Submission to the Right Honourable John Diefenbaker," 4 May 1959, LAC, James G. Endicott and Family fonds, MG30-C130, vol. 7, file 124, 2, 3.
} 
Toronto, during which he assured the group of students and faculty that disarmament was his main diplomatic priority. ${ }^{922}$ The government's expressions of support for nuclear disarmament and a test ban gave these groups reason to believe that they would at the very least be heard when they approached the prime minister.

Disarmament groups in Canada became even more convinced that Diefenbaker could eventually be brought on side when he named Harold Green to the position of secretary of state for External Affairs in June 1959. While his predecessor, Sidney Smith, had been convinced that Canada's contribution to American deterrence was necessary to combat the Soviet threat, Green was a sincere advocate of disarmament and an opponent of nuclear weapons testing. ${ }^{923}$ Though Diefenbaker did not appoint him on policy grounds, but because of his position within Diefenbaker's very tight circle of trust, Green's influence on Canadian nuclear policy from 1959 to 1963 was considerable. ${ }^{924}$ With Green's appointment, the Diefenbaker cabinet became seriously divided on nuclear arms, with ministers of National Defence George Pearkes and Douglas Harkness leading the pro-nuclear group. ${ }^{925}$ These divisions were apparent to disarmament advocates, who found Harkness to be particularly abrasive towards them. ${ }^{926}$ Instead of

\footnotetext{
922 Wittner, The Struggle Against the Bomb, vol. 2, 348; Douglas Kay Campbell, A History of the Ban-TheBomb Movement, Toronto 1959-1961, Part 1 (Toronto, 1961), MUL, CUCND-SUPA fonds, box 1, file: CUCND Toronto office 1960-1961, 5; "Canada and Disarmament," Globe and Mail, 16 December 1959, 6. ${ }_{923}$ McMahon, Essence of Indecision, 40, 51; Robinson, Diefenbaker's World, 133, 97; Bothwell, The Big Chill, 65; Donaghy, Tolerant Allies, 6-7; Willis C. Armstrong, interview by Charles Stuart Kennedy, 29 November 1988, "Frontline Diplomacy: The Foreign Affairs Oral History Collection of the Association for Diplomatic Studies and Training," Library of Congress, accessed 27 May 2015, http://lcweb2.loc.gov/service/mss/mfdip/2004/2004arm03/2004arm03.pdf, 19.

${ }_{924}$ McMahon, Essence of Indecision, 51, 54; Lentner, "Foreign Policy Decision Making," 52, 75; John G. Diefenbaker, One Canada: Memoirs of the Right Honourable John G. Diefenbaker, The Tumultuous Years, 1962-1967 (Toronto: Macmillan of Canada, 1977), 75; Robinson, Diefenbaker's World, 97; Maloney, Learning to Love the Bomb, 367; George Ignatieff, with Sonja Sinclair, The Making of a Peacemonger (Toronto: University of Toronto Press, 1985), 197-198.

${ }_{925}$ Maloney, Learning to Love the Bomb, 259; Simpson, NATO and the Bomb, 111.

${ }^{926}$ Josephine Davis to the Honourable Howard Green, 11 February 1961, LAC, Voice of Women fonds, MG28-I218, vol. 1, file: correspondence-Members of Parliament re. formation 1960-1963, 1; Hon. D.S.
} 
proselytizing to the unfriendly elements of the cabinet, activists stuck to their traditionally "quiet" approach by focusing their efforts on the already converted Green. ${ }^{927}$ In December 1962, VOW member Hanna Newcombe reminded the organization how important it was to "stay on friendly terms" with the government, especially Green. ${ }^{928}$ Disarmers regularly praised Green's work for disarmament at the United Nations, with VOW member Peggy Hope-Simpson describing him as "a grand person, with more than a touch of greatness." ${ }^{929}$ Yet, while disarmers took the presence of Green in the Diefenbaker cabinet as proof that the Conservative government was prioritizing nuclear disarmament, Diefenbaker was continuing to pursue nuclear negotiations with the United States.

On 12 January 1960, the prime minister introduced the notion of joint CanadianAmerican control of nuclear arms to negotiations for Canada's acquisition from the Americans of nuclear warheads, a condition that was legally extremely difficult for the Americans to meet. ${ }^{930}$ Diefenbaker reiterated to cabinet three days later that, in order to address public concerns, "he had to be able to say that, in so far as defensive weapons for Canada's forces were concerned, the government had the right of joint custody and the ultimate decision as to their use. ${ }^{" 931}$ He justified this new position on the grounds that

\footnotetext{
Harkness to Mr. Arthur Pape, 7 June 1963, MUL, CCND fonds, SW574, box 19, file 7, 1; Hazen Argue to Mrs. Fred Davis, 15 February 1961, LAC, Voice of Women fonds, MG28-I218, vol. 1, file: correspondence-Members of Parliament re. formation 1960-1963, 1.

${ }^{927}$ Peter Brock and Nigel Young, Pacifism in the Twentieth Century (Syracuse: Syracuse University Press, 1999), 249.

${ }_{928}$ Hanna Newcombe to Mrs. Josephine Davis, 1 December 1962, LAC, Voice of Women fonds, MG28I218, vol. 1, file: correspondence Josephine Davis (vice-pres) 1962, 1.

${ }_{929}$ Peggy Hope-Simpson to Josephine Davis, 24 November 1962, LAC, Voice of Women fonds, MG28I218, vol. 1, file: correspondence Josephine Davis (vice-pres) 1962, 1. See also: Hugh Keenleyside to the Honourable Howard Green, 4 November 1960, LAC, Lester B. Pearson fonds, MG26-N2, vol. 49, file 806, 1.

930 “Aide-Mémoire by Embassy of United States," 17 January 1960, DCER, vol. 27, document 265.

931 "Extract from Cabinet Conclusions," 15 January 1960, DCER, vol. 27, document 262.
} 
Canadian sovereignty needed to be reinforced in the face of demands in Canada for disarmament, which "could not be overlooked." 932 CUCND had organized the first student demonstration since the end of the Second World War a month before. A delegation from the University of Toronto presented the prime minister with 3,000 signatures against nuclear arms and 80 CUCND students marched through Ottawa on Christmas day 1959. However, the principle of "joint custody" was an illogical response to public support for disarmament. It flew in the face of the students' demands to ban the spread of nuclear arms. ${ }^{933}$

The prime minister and the public had concerns about American nuclear policy, which was defined by the principles of nuclear overkill and preventive attack. ${ }^{934} \mathrm{In}$ addition to tying his request for "joint control" to anti-nuclear sentiment in Canada, Diefenbaker advised cabinet that Canadians were opposed to the presence of offensive nuclear weapons in Canada, for fear that "the U.S. might launch a war from Canadian bases." 935 This emphasis on "joint custody" was based on a legitimate desire to ensure that no pre-emptive nuclear attack on the Soviet Union could be initiated by the United States from Canadian soil without the permission of the Canadian government. The reference to disarmers was unnecessary for the purposes of explaining the need for Canadian "joint control." By including disarmers in his justification, Diefenbaker

\footnotetext{
932 "Extract from Cabinet Conclusions," document 262.

${ }^{933}$ Campbell, A History of the Ban-The-Bomb Movement, 5; "Canada and Disarmament," 6; "Bomb Ban Petition Grows," 8; Palmer, Canada's 1960s, 257.

${ }^{934}$ David McDonough, "Nuclear Superiority or Mutually Assured Deterrence: The Development of the US Nuclear Deterrent," International Journal 60(3) (Summer 2005): 814; David Alan Rosenberg, "The Origins of Overkill: Nuclear Weapons and American Strategy, 1945-1960," International Security 7(4) (Spring 1983), 6, 66.

935 "Extract from Cabinet Conclusions," 15 January 1960, DCER, vol. 27, document 262.
} 
attributed to Canadian anti-nuclear movements a political strength and public appeal that they did not have.

As he had already begun to reference disarmers in explaining his rationale towards a cautious approach to nuclear arms in Canada, it is not surprising that VOW found Diefenbaker to be supportive of their efforts in their first meeting with him in June 1960. ${ }^{936}$ Conservative Senator Olive Irvine told the group that Diefenbaker appreciated their "magnificent work." 937 Even though the prime minister's wife declined the VOW's invitation to become an honorary sponsor of the group - an offer that Maryon Pearson, wife of Liberal leader Pearson, enthusiastically accepted — VOW was convinced that Olive Diefenbaker was "in sympathy" with the purposes of their organization. ${ }^{938}$ Later, the Edmonton Security and Intelligence branch of the Royal Canadian Mounted Police (RCMP) reported that members of VOW were claiming that the organization had "the official backing of the Conservative Government." 939 This was an exaggeration.

The language used by the prime minister in his correspondence with disarmament groups often gave off the impression of his support for their work. While Diefenbaker acknowledged differences on certain questions of national security, the prime minister conceded in his July 1960 letter to the leader of the Toronto Committee for Disarmament, Rabbi Abraham Feinberg, that the group and his government were working "towards the

\footnotetext{
${ }^{936}$ Mrs. F. Davis to the Right Hon. John G. Diefenbaker, 22 June 1960, LAC, Voice of Women fonds, MG28-I218, vol. 1, file: correspondence-Members of Parliament re. formation 1960-1963, 1.

${ }^{937}$ Senator Olive L. Irvine to Voice of Women, 28 July 1960, LAC, Voice of Women fonds, MG28-I218, vol. 1, file: correspondence-Members of Parliament re. formation 1960-1963, 1.

938 Olive Diefenbaker to Voice of Women, 8 August 1960, LAC, Voice of Women fonds, MG28-I218, vol. 1, file: correspondence-Members of Parliament re. formation 1960-1963, 1; Mrs. Lester B. Pearson to Voice of Women, 30 July ca. 1960, LAC, Voice of Women fonds, MG28-I218, vol. 1, file: correspondence-Members of Parliament re. formation 1960-1963, 1; Mrs. F. Davis to Mrs. John Diefenbaker, 3 September 1960, LAC, Voice of Women fonds, MG28-I218, vol. 1, file: correspondenceMembers of Parliament re. formation 1960-1963, 1.

939 Cst. W. A. Woods, "Re: Communist Party of Canada, Provincial Executive Committee, Alberta," 9 March 1961, LAC, CSIS files, RG146, vol. 2843, part 3, 4 (obtained under access to information).
} 
same ends." Furthermore, Diefenbaker stated that he found the interest shown by this group of "serious-minded Canadians" on the important question of disarmament to be "greatly encouraging." $" 940$ With words of support offered in correspondence and in person, disarmament organizers were misled into believing that they had the prime minister's ear when it came to the question of nuclear weapons.

Outside of his correspondence with disarmers, there were few signs that Diefenbaker considered activists to be "serious-minded" citizens. On 1 December 1960, he complained to Norman Robertson, the under secretary of state for External Affairs, about the "long-hairs talking in favour of there being no nuclear defences." "941 In addition to dismissing Canadian anti-nuclear activists as "hippies," Diefenbaker again expressed his lukewarm sentiment towards disarmament. In a 6 December cabinet meeting, he argued that, while disarmament was "a laudable purpose," he was reluctant to see the Conservative party "dubbed the disarmament party." 942

Though he expressed little sympathy for Canadian anti-nuclear activists and disarmament efforts generally, at his meeting with John F. Kennedy in May 1961, Diefenbaker demonstrated a preoccupation with Canadian anti-nuclear opinion. ${ }^{943}$ During the meeting in Ottawa with the American president, he explained that his mail was "running very heavy in letters against" nuclear arms. ${ }^{944}$ Because of "very widespread public opinion against all nuclear weapons," particularly among "respectable" Canadians,

\footnotetext{
940 John Diefenbaker to Rabbi Feinberg, 29 July 1960, LAC, Abraham Feinberg fonds, MG31-F9, vol. 3, file: Toronto Committee for Disarmament May 17-Sep 1 1960, 1-2.

${ }^{941}$ N. A. Robertson to Prime Minister, "The Irish Resolution on the Prevention of the Further Spread of Nuclear Weapons," 1 December 1960, DCER, vol. 27, document 107; J. G. Diefenbaker, "Disarmament," 3 December 1960, DCER, vol. 27, document 110; “Extract from Cabinet Conclusions,” DCER, vol. 27, document 111.

942 "Extract from Cabinet Conclusions," DCER, vol. 27, document 111.

943 Robinson, Diefenbaker's World, 144.

944 Ivan B. White, "Memorandum of Conversation," 17 May 1961, FRUS, 1961-1963, vol. XIII, doc. 423.
} 
Diefenbaker advised a dubious Kennedy that the storage of nuclear arms on Canadian soil was politically impossible. ${ }^{945}$

But Diefenbaker continued to prefer Canadian participation in deterrence. Diefenbaker and his cabinet responded favourably to a telegram from Kennedy on 3 August 1961 calling for nuclear talks to be resumed "with vigor," formal negotiations of agreements for Canada's acquisition of nuclear warheads having been suspended since the spring of 1960 for the presidential election. ${ }^{946}$ Kennedy's request came in the midst of rising tension in Europe. Soviet Premier Nikita Khrushchev renewed threats to cut off Western access to West Berlin in the spring and the Berlin Wall was erected in the summer. The Berlin crisis importantly led the Kennedy administration to consider the need to strengthen conventional NATO forces, an appraisal which Diefenbaker supported by sending an additional 1,106 soldiers to the brigade in Germany ${ }^{947}$ But this did not change cabinet's focus on national surveys that suggested a majority of Canadians were in favour of nuclear warheads. Robinson was certain that Diefenbaker was considering "a generally more tolerant stance towards nuclear weapons" in the summer of $1961 .{ }^{948}$

Furthermore, Diefenbaker's behaviour towards disarmers did not reflect apprehensiveness about anti-nuclear opinion. On 25 September 1961, a delegation of VOW members presented a brief to the prime minister. Diefenbaker's memorandum regarding his reception of the leaders of the delegation indicated indifference towards their requests, and centred instead on their displeasure with his revelation that Russian

\footnotetext{
${ }^{945}$ Ivan B. White, "Memorandum of Conversation," 17 May 1961, FRUS, 1961-1963, vol. XIII, doc. 425.

946 "Telegram from the Department of State to the Embassy in Canada," 3 August 1961, FRUS, 1961-1963, vol. XIII, doc. 426; "Extract from Cabinet Conclusions," 22 August 1961, DCER, vol. 28, doc. 354.

${ }^{947}$ Isabel Campbell, Unlikely Diplomats: The Canadian Brigade in Germany, 1951-64 (Vancouver: UBC Press, 2013), 173-174.

948 "Extract from Cabinet Conclusions," 23 August 1961, DCER, vol. 28, doc. 355; Robinson, Diefenbaker's World, 229.
} 
women were now using the VOW name. ${ }^{949}$ Moreover, Diefenbaker ignored the over 100 VOW women and their children who stood waiting in the corridor hoping to meet him. ${ }^{950}$ A little over a week before the meeting with VOW, Diefenbaker had written to his brother Elmer that opposition to nuclear defence was an opinion held by the uninformed and that was "most beneficial to the Communists." 951

Diefenbaker had implicitly used VOW as his excuse for delay when he advised Kennedy in May 1961 that a "woman's committee" was stirring up hostility to nuclear arms in Canada. ${ }^{952}$ Yet the prime minister's lukewarm reception of VOW in September and his dismissal of disarmament efforts as pro-communist prove that disarmers had not convinced him of the validity of their cause. Diefenbaker's expressions of concern over Canadian public opinion were used to defend his cautious approach to nuclear negotiations. In fact, Diefenbaker might have anticipated that Kennedy would understand the argument, since he was facing significant public resistance to the dissemination and testing of nuclear arms. ${ }^{953}$

Historians have identified the fall of 1961 as the turning point when Diefenbaker began to lean more towards disarmament. ${ }^{954}$ First, on 26 September 1961, Kennedy made a statement to the United Nations General Assembly, during which he proclaimed the need for success in disarmament negotiations and implied that the transfer of control over

\footnotetext{
949 John Diefenbaker, "Memorandum re. Meeting with 'Voice of Women' delegation September 25, 1961," 27 September 1961, University of Saskatchewan University Archives and Special Collections (USUASC), John G. Diefenbaker fonds, MG-01/XII/C/445, Diefenbaker Centre row 9, vol. 78, 1.

950 J. Fisher, "Memo to the Prime Minister," 25 September 1961, USUASC, Diefenbaker fonds, MG01/XII/C/445, Diefenbaker Centre row 9, vol. 78, 1.

951 John Diefenbaker to Elmer, 14 September 1961, in Personal Letters of a Public Man: The Family Letters of John G. Diefenbaker, ed. by Thad McIlroy (Toronto: Doubleday Canada Ltd., 1985), 107.

952 White, doc. 425.

${ }^{953}$ Dario Fazzi, "The Blame and the Shame: Kennedy’s Choice to Resume Nuclear Tests in 1962," Peace and Change 39, 1 (January 2014), 3, 13.

954 Wittner, The Struggle Against the Bomb, vol. 2, 348, 389; McMahon, Essence of Indecision, 175;

Robinson, Diefenbaker's World, 231-232.
} 
nuclear weapons needed to be blocked for disarmament to become reality. ${ }^{955}$ As was part of a larger pattern of the Kennedy administration, the pronouncement was made with little consideration for the impact it would have on American allies. ${ }^{956}$ The Canadian press interpreted Kennedy's address as preventing any possibility for "joint control," and "killed nuclear weapons in Canada" in the prime minister's mind, according to Robinson. $^{957}$

Then, on Thanksgiving weekend in October, the CCCRH presented the prime minister with 141,000 signatures against nuclear arms for Canada. The petition, which eventually accumulated over 200,000 signatures, was the most widely publicized and successful action by nuclear disarmers in Canada. ${ }^{958}$ It was representative of a growing discomfort towards nuclear arms. Many Canadians had become increasingly concerned with the dangers of nuclear fallout since it had become public in 1954 that American thermonuclear weapons tests at Bikini Atoll had resulted in serious illnesses. ${ }^{959}$ Notably, disarmament organizations were multiplying and steadily expanding; the Saskatchewan and British Columbia legislatures had passed unanimous resolutions in opposition to the production and testing of nuclear weapons; and a Gallup poll from the summer of 1961

\footnotetext{
955 "Text of President Kennedy's Address to the United Nations General Assembly," Globe and Mail, 26 September 1961, 14.

${ }^{956}$ Frank Costigliola, "The Pursuit of Atlantic Community: Nuclear Arms, Dollars, and Berlin," In Kennedy's Quest for Victory: American Foreign Policy, 1961-1963, ed. Thomas G. Paterson (Oxford: Oxford University Press, 1989), 24-25, 28, 51.

${ }^{957}$ Walter Gray, "Government Policy Unchanged: Ottawa in the Eye of a Nuclear Hurricane," Globe and Mail, 3 October 1961, 7; H. B. Robinson, "Nuclear Weapons Policy," 6 October 1961, DCER, vol. 28, doc. 359.

${ }^{958}$ Research section, Ottawa, "National Committee for the Control of Radiation Hazards," 14, 19; Wittner, The Struggle Against the Bomb, vol. 2, 197.

${ }^{959}$ Women's International League for Peace and Freedom Vancouver branch, "Brief submitted to Rt. Hon. Louis St. Laurent re. recent H-bomb explosions," 12 April 1954, University of British Columbia Rare Books and Special Collections (UBCRBSC), RBSC-ARC-1626, box 3, file 8, 1; Brookfield, Cold War Comforts, 72; Wittner, The Struggle Against the Bomb, vol. 2, 2, 31, 78.
} 
hinted that 80 per cent of Canadians supported a nuclear test ban. ${ }^{960}$ Historians Lawrence Wittner, Bruce Douville, and Patricia McMahon have suggested that it was the petition that caused nuclear negotiations to stall out almost as soon as they had been revived in the fall of $1961 .{ }^{961}$

Even though Diefenbaker had told Kennedy that anti-nuclear sentiment in Canada needed to be taken seriously, his actual response to the petition demonstrated continued indifference towards the disarmers. ${ }^{962}$ In the press, the CCCRH delegation emphasized Diefenbaker's promise that there would be no nuclear weapons in Canada during peacetime.${ }^{963}$ Yet, in their private report on the event, CCCRH leaders revealed that the prime minister "hardly expressed sympathy with our point of view." 964 The petition did attract much media attention, but this did not immediately translate into mass opposition to nuclear weapons. ${ }^{965} \mathrm{~A}$ month after the petition was delivered to the prime minister, a

\footnotetext{
${ }^{960}$ F. C. Hunnius to James Thomson, 22 September 1961, MUL, CCND fonds, box 3, file 9, 1; Federal Secretariat CUCND, "Inter-branch memo," 15 September 1961, MUL, CUCND-SUPA fonds, box 1, file: CUCND Toronto office 1960-1961, 2; Christine Ball, "The History of the Voice of Women/La Voix des Femmes: The Early Years, 1960-1963" (PhD diss., University of Toronto, 1994), 135, 436; "Report of the Proceedings of the National Council of the Canadian Peace Congress," 3-4 December 1960, LAC, Endicott fonds, MG30-C130, vol. 8, file 134, 7; "Submission of the Saskatchewan Peace Council to the members of the Saskatchewan Legislature," 13 March 1959, LAC, Endicott fonds, MG30-C130, vol. 7, file 119; Hugh Keenleyside to J. G. Diefenbaker, 30 March 1961, MUL, CCND fonds, box 2, file 13, 1; "The Vast Majority Want Nuclear Tests Stopped," in Gallup Report 1960-61, 1.

${ }^{961}$ Wittner, The Struggle Against the Bomb, vol. 2, 348, 389; Bruce Douville, "Project La Macaza: A Study of Two Canadian Peace Protests in the 1960s," in Worth Fighting For: Canada's Tradition of War Resistance from 1812 to the War on Terror, eds. Lara Campbell, Michael Dawson, Catherine Gidney (Toronto: Between the Lines, 2015), Kindle Loc 3064; McMahon, Essence of Indecision, 175.

962 White, "Memorandum of Conversation," FRUS, 1961-1963, vol. XIII, document 423.

${ }^{963}$ Walter Gray, "Cleric Says PM Vows No A-Arms in Peace," Globe and Mail, 7 October 1961, 1; "Public Statements by Members of the Government Regarding the Acquisition and Storage of Nuclear Weapons (Outside the House of Commons), As of March 1, 1962," LAC, Progressive Conservative Party of Canada fonds, MG28IV-2, vol. 421, file: Nuclear weapons 1962, 2.

964 "Minutes of the Meeting of the Third Annual Conference of the Canadian Committee for the Control of Radiation Hazards," 26-27 February 1962, MUL, CCND fonds, box 18, file 1, 6.

${ }^{965}$ McMahon, Essence and Indecision, 140.
} 
Gallup poll found that 61 per cent of Canadians remained in favour of arming Canadian forces with nuclear weapons. ${ }^{966}$

In November, Diefenbaker advised American Ambassador Livingston Merchant that cabinet would be shortly reviewing the nuclear question. He also explained that Canadian-American nuclear talks had become "paralyzed" in the fall because of a press leak in September revealing the American president's 3 August personal telegram to Diefenbaker on the subject. Diefenbaker informed Merchant that any suggestion that Canada was "acting under pressure from Washington" made progress on negotiations impossible ${ }^{967}$ Following the leak, personal communications ceased between Kennedy and Diefenbaker, which the president attributed to the embarrassment it had caused the prime minister. ${ }^{968}$ Kennedy's intervention in the nuclear debate had influenced Diefenbaker's thinking on nuclear arms for Canada to a greater extent than considerations of public opposition to the Bomb.

However, the interruption in nuclear negotiations in the fall of 1961 left Canadian disarmers with confidence in their methods. In March 1962, VOW members from Montreal took a "Peace Train" to Ottawa and presented the prime minister with a brief promising that they would "continue to come from time to time, and in increasing numbers, as do women in other countries who seek from their leaders similar positive steps to peace." ${ }^{969}$ Satisfied with the friendly reception their delegation received from Diefenbaker and other parliamentarians, VOW women returned to their "Peace Train"

\footnotetext{
966 "Majority say army should be given nuclear weapons," 2.

967 "Telegram from the Embassy in Canada to the Department of State," 27 November 1961, FRUS, 19611963, vol. XIII, doc. 427; "Just What Was Said," Globe and Mail, 20 September 1961, 7.

${ }^{968}$ A.D.P. Heeney, “Ambassador in United States to Prime Minister," 3 November 1961, DCER, vol. 28, doc. 317.

${ }^{969}$ Voice of Women, "A Brief to the Prime Minister of Canada to be presented Wednesday March $7^{\text {th }}$, 1962,” USUASC, John G. Diefenbaker fonds, MG 01/VII/A/742, Diefenbaker Centre row 4, volume 83, 4.
} 
with newfound certainty that their civil appeals to Parliament were effective lobbying methods. ${ }^{970}$ In the summer of 1962, Helen Tucker, one of the founding members of VOW, boasted in the CUCND periodical Our Generation Against Nuclear War, that the combination of VOW telegrams, letters, and petitions to the prime minister "played no small part in keeping Canada free...from nuclear weapons." 971 This would prove to be dangerous and false self-assurance.

As they concentrated almost single-mindedly on lobbying Canadian politicians during the 1962 election campaign, disarmers were unsuccessful in their attempts to make nuclear policy a campaign issue. ${ }^{972}$ Shortly after the June 1962 election, a Gallup poll found that the vast majority of Canadians were preoccupied with unemployment, with only eight per cent feeling that nuclear arms were the most significant problem facing the country. ${ }^{973}$ Failing to learn their lesson after the election, disarmers were equally ineffective in influencing public sentiment against nuclear arms when a political opportunity was presented to them in the fall of that year.

In October 1962, a 13-day confrontation between the United States and the Soviet Union over the deployment of Soviet ballistic missiles in Cuba heightened Canadian fears of a nuclear war. ${ }^{974}$ During the Cuban Missile Crisis, Diefenbaker's circumspection was revealed when it took the prime minister three days to declare his support for the

\footnotetext{
${ }^{970}$ Simonne Monet-Chartrand, Les Québécoises et le mouvement pacifiste (1939-1967) (Montreal: Les Éditions Écosociété, 1993), 69.

${ }^{971}$ Helen Tucker, "Voice of Women and the Conference for International Cooperation Year," Our Generation Against Nuclear War 1(4) (Summer 1962): 27.

972 "President's Report," 16 September 1962, LAC, Voice of Women fonds, MG28-I218, vol. 22, file: National Annual Meeting 1962, 2; Richard F. Brown, "Statement and Questionnaire to all candidates for Parliament," MUL, CCND fonds, SW573, box 18, file 17; McMahon, Essence of Indecision, 139, 141.

973 "One-Half the Nation Thinks Jobless our Greatest Worry," in Gallup Report 1962, 2.

${ }^{974}$ See for example Howard Green's statements on his reaction to the crisis on 24 January 1963 (Canada, House of Commons Debates, vol. III (1962) (Ottawa: Roger Duhamel, 1963), 3068).
} 
American military blockade of Cuba, established to prevent the delivery of additional Soviet weapons. ${ }^{975}$ As he defended his response to the crisis to his cabinet, Diefenbaker referred again to his mailbag, overflowing with anti-nuclear letters. ${ }^{976}$

Public opinion was conflicted on the question of nuclear weapons in the fall of 1962. A November survey performed on behalf of the Canadian Peace Research Institute (CPRI) found that 94 per cent of Canadians supported general disarmament. ${ }^{977}$ Yet a Gallup poll report released a month later emphasized that "while the government hesitates ... the general public reports five to three in favour" of arming Canadian forces with nuclear weapons. ${ }^{978}$ While general disarmament and the question of Canada's acquisition of nuclear arms were inseparable for disarmers, for the general public and for officials in Canada's Department of National Defence these were independent issues so long as disarmament discussions at the United Nations remained fruitless. ${ }^{979}$

Instead of using the Cuban crisis as evidence to convince the public of "the real danger of a nuclear war breaking out," anti-nuclear weapons groups continued to centre

\footnotetext{
${ }^{975}$ Diefenbaker had been informed by Green that the legality of the blockade, which Kennedy referred to as a "quarantine," was "by no means clear," justifying Diefenbaker's delayed response (H.C. Green, "United States Quarantine Against Cuba," 23 October 1962, DCER, vol. 29, ed. Janice Cavell (Ottawa: Foreign Affairs, Trade and Development Canada, 2013), doc. 660). See also: John Bird, "Dief indecisive on Canada's role in crisis," Toronto Daily Star, 25 October 1962, 7; "Canada's Stand on Cuba Criticized by Truman," Globe and Mail, 26 October 1962, 1; "Ottawa Wishy-Washy, Young PCs Charge," Globe and Mail, 26 October 1962, 1.

976 Patrick Nicholson states that on one day of the crisis, Diefenbaker received 433 letters urging for Canadian neutrality, whereas he only received 15 endorsing President Kennedy's action (Nicholson, Vision and Indecision, 159).

977 Canadian Peace Research Institute, "Information Report," 26 November 1962, LAC, James G. Endicott and Family fonds, MG30-C130, vol. 8, file 149, 1.

978 "Majority Say Our Forces Should Have Nuclear Arms," 2; Jacqueline Dineen to Mel Doig, 15 November 1962, LAC, Endicott fonds, MG30-C130, vol. 8, file 148, 1; Kay Macpherson, When in Doubt, Do Both: The Times of My Life (Toronto: University of Toronto Press, 1994), 98.

${ }^{979}$ Daniel Heidt, "'I think that would be the end of Canada:' Howard Green, the Nuclear Test Ban, and Interest-Based Foreign Policy, 1946-1963," American Review of Canadian Studies 42(3) (September 2012): 361; Canadian Peace Congress, "Peace Group Goes to Ottawa," 7 September 1963, LAC, James G. Endicott and Family fonds, MG30-C130, vol. 2, file 33; Albert Legault and Michel Fortmann, A Diplomacy of Hope: Canada and Disarmament, 1945-1988 (Montreal: McGill-Queen's University Press, 1992), 171, 178,185 .
} 
their attention on Parliament. ${ }^{980}$ In their late-October 1962 brief to the prime minister, VOW recognized that Canadians were much more conscious of the need to take measures to "assure human survival," but turned to the prime minister for further action, instead of seeking to persuade the public. ${ }^{981}$ Introducing the brief, VOW president Thérèse Casgrain wrote to Diefenbaker, "in your position as Prime Minister of our country we have faith you can give world leadership in finding new ways of adjusting the conflicting needs of nations." 982 As a representative of thousands of Canadian women, Casgrain made it clear that VOW was relying on the prime minister to make the right decision. ${ }^{983}$ In their tepid response to the Cuban crisis, influenced by their confidence in their use of "proper politics," the post-crisis VOW brief illustrated disarmers' false assumption that, once they won him over, Diefenbaker would bring the country alongside.

Diefenbaker's response to the crisis tested the public's patience with the Conservative government's obfuscation of the nuclear question and concern about relations with the United States. ${ }^{984}$ Diefenbaker agreed to revive negotiations with the United States in November. He selected the more detached Gordon Churchill, minister of Veterans' Affairs, as the tiebreaker to join Harkness and Green on the negotiating team. ${ }^{985}$ Progress was made on an agreement for the provision of nuclear arms for Canada's forces in Europe, but no workable solution was reached on the Canadian

\footnotetext{
${ }^{980}$ Youth Campaign for Nuclear Disarmament, "Policy Statement,” June 1963, LAC, James G. Endicott and Family fonds, MG30-C130, vol. 8, file 140, 1; McMahon, Essence of Indecision, 153.

981 Thérèse Casgrain to Hon. John Diefenbaker, 29 October 1962, LAC, Voice of Women fonds, MG28I218, vol. 1, file: correspondence re. meetings and conferences 1962, 1.

${ }^{982}$ Casgrain to Diefenbaker, 29 October 1962, 1.

${ }^{983}$ Smith, Rogue Tory, 328.

984 "Majority Say Our Forces Should Have Nuclear Arms," 2; "Nuclear Weapons are Wanted by Nearly Half of Canadians," Gallup Report 1963 (Toronto: Canadian Institute of Public Opinion, 1963), 1; Newman, Renegade in Power, 333; Ghent, "Did He Fall or Was He Pushed?," 247; Nicholson, Vision and Indecision, 176; Simpson, NATO and the Bomb, 121; Maloney, Learning to Love the Bomb, 367. 985 "Extract from Cabinet Conclusions," 30 October 1962, DCER, vol. 29, doc. 231, 391; Harkness, "Tense days led to a showdown," A3.
} 
proposal that a "missing piece" of the weapons be stored out of the country until an emergency, so that it could still be claimed there were "no operational nuclear weapons on Canadian soil." 986 The negotiation was put on hold until a NATO ministerial meeting in May 1963..$^{987}$

In January 1963, two external interventions finally forced Diefenbaker to clarify his position on nuclear arms in Canada. General Lauris Norstad, the retiring NATO Supreme Allied Commander, Europe, publicly revealed in Ottawa on 3 January 1963 that Canada had to accept nuclear weapons if it was to fulfil its NATO commitments. Diefenbaker was humiliated. Norstad's comments undermined the prime minister's political credibility. ${ }^{988}$ Then, on 12 January, Pearson announced that a Liberal government would accept nuclear arms in Canada. ${ }^{989}$ Harkness saw this shift in Liberal policy as an opportunity to settle the nuclear question once and for all and complete negotiations with the United States free of criticism, but Diefenbaker would not "follow" Pearson. ${ }^{990}$ With Norstad's and Pearson's statements, emotions pushed him closer to an anti-nuclear position.

\footnotetext{
${ }^{986}$ Michael D. Stevenson, “'Tossing a Match into Dry Hay:' Nuclear Weapons and the Crisis in U.S.Canadian Relations, 1962-1963," Journal of Cold War Studies 16(4) (Fall 2014), 13; U.S. Senate, Committee on Foreign Relations, Subcommittee on Canadian Affairs, "Supplying of Nuclear Arms to the Canadian Forces," 4 February 1963, Executive Sessions of the Senate Foreign Relations Committee, vol. XV (1963), accessed 10 December 2015, http://babel.hathitrust.org/cgi/pt?id=mdp.39015039034460;view=1up;seq=1, 131.

${ }^{987}$ An Anglo-American meeting in December in Nassau prompted Diefenbaker to shelve a decision until the May 1963 NATO ministerial meeting. Diefenbaker interpreted the discussions in Nassau of a possible NATO multilateral nuclear-armed submarine force as demanding a re-evaluation of the necessity for Canada's acquisition of nuclear warheads (Stevenson, "'Tossing a Match into Dry Hay," 18.)

988 "Norstad View Finds Ottawa Off Guard," Globe and Mail, 5 January 1963, 1; "General Norstad's Reminder," Globe and Mail, 5 January 1963, 6; Harkness, "Tense days led to a showdown," A3; Maloney, Learning to Love the Bomb, 295-296.

989 "Text of an address by the Honourable Lester B. Pearson," 12 January 1963, LAC, Pearson fonds, MG26-N2, vol. 50, file 806.2 part 3, 7.

${ }^{990}$ Harkness, "Tense days led to a showdown," A3; Robinson, Diefenbaker's World, 318-319.
} 
A week following Pearson's announcement, Diefenbaker intervened to prevent the Progressive Conservative Association of Canada from adopting a resolution supporting nuclear weapons for Canada at its annual general meeting. ${ }^{991}$ In the House of Commons on 25 January, Diefenbaker emphasized that Canada was not required to accept nuclear arms and would "not be a pawn or be pushed around by other nations," but instead would be "a useful and ever-ready agent for peace." 992 The speech was interpreted as a rejection of nuclear warheads for Canada, to the shock and disappointment of Harkness. After all, cabinet — including Green — agreed that Canada had made the commitments to which Norstad had referred. ${ }^{993}$

The 25 January statement greatly upset the United States, leading the Department of State to issue a press release that challenged the veracity of Diefenbaker's statements, precipitating a revolt within Diefenbaker's cabinet and the collapse of his government. ${ }^{994}$ The Americans had finally had enough of Diefenbaker's "foot dragging," "irresponsible nonsense," and "neurotic Canadian view of world." With the press release, its architect, William Butterworth, the American ambassador to Canada, consciously aided in the

\footnotetext{
${ }^{991}$ Harkness, "Tense days led to a showdown," A3; Progressive Conservative Association of Canada, "Draft Report of the Resolutions Committee Annual General Meeting," 17-19 January 1963, LAC, Progressive Conservative Party of Canada fonds, MG28IV-2, vol. 292, file: kits - annual meeting 1963, 11. 992 Canada, House of Commons Debates, vol. III (1962), 3126.

993 "Nuclear policy muddied by Dief; Harkness upset," The Citizen, 24 October 1977, 37; "Under Pearson Fire, Diefenbaker Denies Nuclear Reneging," Globe and Mail, 26 January 1963, 9; Smith, Rogue Tory, 471; McMahon, Essence of Indecision, 164.

994 "Memorandum from the Assistant Secretary of State for European Affairs to the Under Secretary of State," 29 January 1963, FRUS, 1961-1963, vol. XIII, doc. 443; "Department of State Press Release No. 59," 30 January 1963, FRUS, 1961-1963, vol. XIII, doc. 444; "Telegram from the Embassy in Canada to the Department of State," 3 February 1963, FRUS, 1961-1963, vol. XIII, doc. 445; U.S. Senate, "Supplying of Nuclear Arms," 134; Hon. Douglas S. Harkness, "Resignation delayed under cabinet pressure," Calgary Herald, 20 October 1977, F1; George Bain, "Not Satellite of U.S., PM says; Nuclear Debate Forced on PCs," Globe and Mail, 1 February 1963, 1-2; Hon Douglas S. Harkness, "A foolish move," The Citizen, 25 October 1977, 61; Hon. Douglas S. Harkness, "No hope of reconciliation Harkness tells Diefenbaker," The Calgary Herald, 22 October 1977, D2; McKercher, "Diefenbaker's World," 114; Ghent, "Did He Fall or War He Pushed?," 268-269.
} 
destabilization of Diefenbaker's government, leaving the fate of nuclear negotiations in the hands of the Canadian people. ${ }^{995}$

From the day his government fell, Diefenbaker moved closer to a non-nuclear stance. Insisting that he would not be forced by a foreign government to accept nuclear arms in Canada, Diefenbaker attempted to use anti-American sentiment as a means of holding onto power. ${ }^{996}$ Disarmers read Diefenbaker's election campaign as a sign that "Diefenbaker now champions the cause" against nuclear weapons. ${ }^{997}$ Correspondence from disarmament activists characterized Diefenbaker as "the only Canadian Prime Minister since Sir John A. with any guts" for his stance on nuclear weapons. ${ }^{998}$ In a demonstration of support for Diefenbaker, the CPC took out an ad in the Globe and Mail, calling for Canadians to demand "no nuclear arms for Canada." ${ }^{\text {"999 }}$ British and Australian anti-nuclear groups commended Diefenbaker's resistance to “tremendous U.S. pressure to accept U.S. Nuclear weapons in Canada." ${ }^{1000}$ Letters to Pearson assured him that the Liberal party's position on nuclear weapons was sending former supporters running to the Conservatives. ${ }^{1001}$ During the 1963 election, disarmers were convinced that Diefenbaker

\footnotetext{
995 "Telegram from the Embassy in Canada," FRUS, 1961-1963, vol. XIII, doc. 445.

${ }^{996}$ Canada, House of Commons Debates, vol. III (1963) (Ottawa: Roger Duhamel, 1963), 3440; A.D. P. Heeney, "Memorandum of Conversations with the Prime Ministers in Ottawa, Tuesday, 30 August 1960, and Wednesday, 31 August 1960," DCER, vol. 27, doc. 228; U.S. Senate, "Supplying of Nuclear Arms," 137; Simpson, NATO and the Bomb, 124; McKercher, "Diefenbaker's World," 94.

${ }^{997}$ K. C. Woodsworth to the editor Globe and Mail, 13 January 1963, MUL, CCND fonds, box 2, file 4, 1. ${ }_{998}$ Marie Moreau to Mrs. Diefenbaker, 6 February 1963, USUASC, John G. Diefenbaker fonds, MG 01/V/F/483, Diefenbaker Centre row 1, vol. 77, 1.

999 Jacqueline Dineen, “Annual Report,” 25 March 1964, LAC, James G. Endicott and Family fonds, MG30-C130, vol. 10, file 178, 1; "Display ad 14: 'No Nuclear Arms for Canada,"” Globe and Mail, 16 January 1963, 9.

${ }^{1000}$ Campaign for Nuclear Disarmament Sydney, "The Fall of the Diefenbaker Government in Canada," C.N.D. Newsletter, 3 (February 1963), MUL, CCND fonds, box 11, file 13, 2; Mike Warwood, 22 March 1963, MUL, CCND fonds, box 12, file 4, 1.

${ }^{1001}$ Charlotte McEwen to Lester Pearson, 28 January 1963, LAC, Pearson fonds, MG26-N2, vol. 50, file 806.2 part 3,1 .
} 
could be trusted to put "Canadian interests first" by keeping the nation free of nuclear arms. $^{1002}$

A little over a week from the election, Diefenbaker's delay on nuclear arms for Canada was validated by the publication of American Secretary of Defense Robert McNamara's claim that the "Bomarc is no good," because the weapon was costly and vulnerable to enemy attack. ${ }^{1003}$ McNamara's revelation raised Diefenbaker's spirits immensely. The remainder of his campaign rested on the argument that nuclear arms on Canadian soil would make the country a "decoy duck."1004

It had been only in January of 1963, when Canadian-American relations had degraded resulting in public embarrassment for Diefenbaker and after Pearson declared himself in support of nuclear arms in Canada, that the prime minister's approach shifted towards more complete support for disarmament. His spotty relationship with Canadian anti-nuclear organizations suggests that Diefenbaker's concern for disarmament was no more than a means of justifying a cautious and protracted consideration of the question of nuclear arms in Canada. Disarmers did not pose a real political threat to Diefenbaker, but they did serve as a useful excuse. Diefenbaker had waited too long to see which position on nuclear weapons for Canada would be remembered as being "right."1005

\section{Pearson, man of peace and traitor}

\footnotetext{
${ }^{1002}$ Fred M. Swaine to Lester Pearson, 1 February 1963, LAC, Pearson fonds, MG26-N2, vol. 50, file 806.2 part 4,1 . 
The transformation of Diefenbaker from disingenuous opportunist to unexpected ally by the election of 1963 would not have occurred had it not been for Pearson's betrayal of disarmers. Since 1959, Pearson had been a public cheerleader for Canadian anti-nuclear efforts. ${ }^{1006}$ As a Nobel Peace Prize winner, disarmers intuitively gravitated towards Pearson, assuming that he would consistently advocate for world peace.

Pearson's revision of the Liberal party's defence policy in January 1963, supporting Canada's acquisition of nuclear arms, shocked Canadian disarmers and left anti-nuclear organizations struggling to cope with the loss of a hero.

In the eyes of disarmament activists, Pearson was "Canada's man of peace."1007 This reputation was intimately tied to the Nobel Peace Prize awarded to Pearson for his part in resolving the conflict when Britain and France invaded Egypt after the Egyptian government nationalized the Anglo-French Suez Canal. ${ }^{1008}$ Disarmers' correspondence regularly contended that it was only natural that "a Nobel Peace Prize winner be among the first leading Canadian citizens to advocate the only sane and realistic policy open to Canada. ${ }^{" 1009}$ Past accomplishments set the expectation among disarmers that he could be trusted to advocate a non-nuclear position for Canada.

Disarmers did not seem to notice that Pearson had supported the use of tactical nuclear weapons by Canada in July 1959, and instead relied on the anti-nuclear stance he

\footnotetext{
${ }^{1006}$ Jacqueline Dineen, CPC national secretary, once described groups like the CUCND as being "respectable" in comparison to the CPC. Jacqueline Dineen to Mabel Hanway, 13 January 1960, LAC, James G. Endicott and Family fonds, MG30-C130, vol. 7, file 126, 1. 1007 Janice Cavell, "Like Any Good Wife: Gender and Perceptions of Canadian Foreign Policy, 1945-75," International Journal (Spring 2008): 395; Charlotte McEwen to the Hon. L. B. Pearson, 14 January 196[3], LAC, Lester B. Pearson fonds, MG26-N2, vol. 50, file: 806.2 part 3, 1.

${ }^{1008}$ Bothwell, "The Canadian Isolationist Tradition," 81; Cavell, "Like Any Good Wife," 386.

${ }^{1009}$ Marc Boulard to L.B. Pearson, 8 August 1960, LAC, Lester B. Pearson fonds, MG26-N2, vol. 3, file 100.1, 1. See also Victor Sifton to Mike [Pearson], 21 March 1960, LAC, Lester B. Pearson fonds, MG26N2, vol. 86, file: external affairs disarmament 1, 1-2; Margaret Cotgrave to Lester Pearson, 31 August 1960, LAC, Lester B. Pearson fonds, MG26-N2, vol. 3, file 100.1, 1;
} 
promoted from 1960 to $1963 .{ }^{1010}$ Disarmers clung to his statements that "I do not believe that Canada should accept nuclear arms under national control by herself or by the U.S.A.," and his promises as that as prime minister "I would do my very best, not only to outlaw nuclear testing, but to outlaw nuclear warfare as a step in outlawing every kind of warfare."1011 Pearson's generally “dovish" approach to nuclear weapons through to the 1963 election campaign fuelled the faith disarmers had in him. ${ }^{1012}$

Pearson and his wife Maryon had been public supporters and defenders of groups like VOW and the CCCRH-CCND from their inception. ${ }^{1013}$ Pearson regularly replied to concerned citizens that he saw no signs of communist subversion in VOW, the Toronto Committee for Disarmament, or the CPRI. ${ }^{1014}$ VOW members were confident during the group's first two years of activity that Pearson was “backing us with everything he's got." 1015

${ }^{1010}$ Canada, House of Commons Debates, vol. 1 (1963), 126; Nicholson, Vision and Indecision, 212-214; Lentner, "Foreign Policy Decision Making," 33.

${ }^{1011}$ Lester B. Pearson to Mr. and Mrs. Good, 6 April 1962, LAC, Lester B. Pearson fonds, MG26-N2, vol. 50, file 806.2 part 2, 1; "Memorandum to the Members of the Liberal Caucus, re. Foreign and Defence Policy," 12 November 1962, LAC, Liberal Party of Canada fonds, MG28-IV3, vol. 689, file: national office general correspondence elections 1962-63, 1; Lester B. Pearson to Mrs. G. Ferguson, 12 November 1962, LAC, Lester B. Pearson fonds, MG26-N2, vol. 53, file 807.3, 2. See also Lester B. Pearson to Mrs. D. W. Hanford, 27 November 1961, LAC, Lester B. Pearson fonds, MG26-N2, vol. 91, file: external affairs Voice of Women 2, 1; Lester B. Pearson to George Wilkins, 9 November 1962, LAC, Lester B. Pearson fonds, MG26-N2, vol. 50, file 806.2 part 2, 1; Esther Radosevic to Lester B. Pearson, 23 August 1960, LAC, Lester B. Pearson fonds, MG26-N2, vol. 3, file 100.1, 1; Jocelyn Lee to Lester B. Pearson, 19 August 1960, LAC, Lester B. Pearson fonds, MG26-N2, vol. 3, file 100.1, 1; Mrs. Wm. Davies to Mr. Pearson, 8 August 1960, LAC, Lester B. Pearson fonds, MG26-N2, file 100.1, 1.

1012 Nicholson, Vision and Indecision, 212-213.

1013 Candace Loewen, "Mike Hears Voices: Voice of Women and Lester Pearson, 1960-1963," Atlantis 12(2) (Spring 1987): 25; Lester B. Pearson to Dr. Keenleyside, 17 March 1961, LAC, Lester B. Pearson fonds, MG26-N2, vol. 22, file 313.30, 1.

${ }^{1014}$ Lester B. Pearson to Mrs. Silver, 9 August 1960, LAC, Lester B. Pearson fonds, MG26-N2, vol. 3, file 100.1, 1; Lester B. Pearson to L. P. Ferg, 21 February 1962, LAC, Lester B. Pearson fonds, MG26-N2, vol. 91, file: external affairs Voice of Women 2, 1; Lester Pearson to Rabbi Feinberg, 25 May 1960, LAC, Lester B. Pearson fonds, MG26-N2, vol. 86, file: external affairs disarmament 1, 1; Lester B. Pearson to Mrs. Kallaur, 7 March 1962, LAC, Lester B. Pearson fonds, MG26-N2, vol. 53, file 808, 1; Lester B. Pearson to R. M. Bond, 7 March 1962, LAC, Lester B. Pearson fonds, MG26-N2, vol. 53, file 808, 1. 1015 Loewen, "Mike Hears Voices," 25; Josephine Davis to Therese Casgrain, 23 September 1961, LAC, Voice of Women fonds, MG28-I218, vol. 1, file: correspondence 1961 2; Mrs. Fred Davis to Lester B. Pearson, 5 April 1962, LAC, Lester B. Pearson fonds, MG26-N2, vol. 53, file 808, 2. 
Pearson's announcement in Scarborough that a Liberal government would fulfil commitments already made regarding nuclear weapons was influenced by a number of factors. ${ }^{1016}$ As late as mid-November 1962, he had promised CCND leaders that "he was not in favour of Canada acquiring nuclear weapons for any purpose." ${ }^{1017}$ That same month, Liberal defence critic Paul Hellyer returned from a NATO parliamentarians' meeting and pleaded with Pearson to repair "the hopeless position of Canada's forces in Europe," who were suffering from low morale because of inadequate equipment. Pearson had already been questioning Canada's defence arrangements following the Cuban missile crisis, leaving him open to Hellyer's argument that Canadian forces needed to be given the proper "means" for doing their jobs. ${ }^{1018}$

It is also very likely that Pearson was swayed by opinion polls, which indicated majority support in Canada for the acquisition of nuclear arms. ${ }^{1019}$ There was a political strategy underlining Pearson's decision. His announcement came days after Norstad's revelation about Canadian defence commitments. The clarification of Canada's responsibilities to NATO allowed Pearson to claim that the Conservative government's approach to nuclear negotiations was an embarrassment and that the new Liberal position was the only "honourable course."1020

${ }^{1016}$ LBP, "Nuclear Weapons and Defence Policy," 21 February 1963, LAC, Lester B. Pearson fonds, MG26-N2, vol. 114, File: nuclear weapons storage in Canada, 3.

1017 Woodsworth to the editor Globe and Mail, 13 January 1963, 1.

${ }^{1018}$ Lester Pearson, Mike: The Memoirs of the Right Honourable Lester B. Pearson, vol. 3, edited by J.A. Munro and A.I. Inglis (Toronto: University of Toronto Press, 1972-1975), 70, 116. See also: McMahon, Essence of Indecision, 160; Lentner, "Foreign Policy Decision Making," 36, 64.

1019 "Majority Say Our Forces Should Have Nuclear Arms"; Alcock to Pearson, 15 January 1963, 2; McMahon, Essence of Indecision, 160; Lentner, "Foreign Policy Decision Making," 49; Nicholson, Vision and Indecision, 214.

1020 "Statement by Hon. Lester B. Pearson on Nuclear Policy for Canada," 20 February 1963, LAC, Lester B. Pearson fonds, MG26-N2, vol. 114, file: nuclear weapons storage in Canada, 2; "Text of an address by the Honourable Lester B. Pearson," 12 January 1963, LAC, Lester B. Pearson fonds, MG26-N2, vol. 50, file 806.2 part 3,7 . 
Pearson's revision of his position was a blow to disarmament groups. Canadian disarmers perceived Pearson's approach to nuclear weapons throughout the election campaign as a deep betrayal by a trusted mentor. ${ }^{1021}$ From the time of his Scarborough speech, Pearson received a string of letters lamenting the disappearance of "the old Mike Pearson."1022 Correspondence from nuclear opponents described Pearson as a "traitor" and an opportunist, and demanded that he return his Nobel Peace Prize. ${ }^{1023}$ John E. Ball, on behalf of the Hamilton chapter of the United Electrical, Radio and Machine Workers of America, wrote the Nobel Prize Committee requesting that Pearson's peace prize be rescinded, because his Scarborough speech had "dealt a heavy blow to all workers for peace in the world over." ${ }^{\text {"1024 }}$ An immediate postcard campaign was put together, with at least 1,400 postcards from Alberta and Quebec expressing opposition to nuclear arms in Canada making their way to the Liberal leader's office before the end of January. ${ }^{1025}$ However, with polls indicating that anywhere between 41 and 54 per cent of Canadians wanted nuclear weapons for the Canadian forces, Pearson was able to ignore the opposition of anti-nuclear activists throughout the election campaign. ${ }^{1026}$

\footnotetext{
${ }^{1021}$ Loewen, "Mike Hears Voices," 28; Charlotte McEwen to the Hon. L. B. Pearson, 14 January 196[3], 1. 1022 Donald A. Cameron to Hon. Lester B. Pearson, 15 January 1963, LAC, Lester B. Pearson fonds, MG26-N2, vol. 49, file 806.2, 3; Mrs. R. A. Johnson to Mr. Ray Perrault, cc'd to Lester Pearson, 14 January 1963, LAC, Lester B. Pearson fonds, MG26-N2, vol. 50, file: 806.2 part 4, 1. ${ }^{1023}$ Marie Moreau to Mrs. Diefenbaker, 6 February 1963, USUASC, John G. Diefenbaker fonds, MG 01/V/F/483, Diefenbaker Centre row 1, vol. 77, 1; V. Bjarnasen to Hon Lester B. Pearson, 13 January 196[3], LAC, Lester B. Pearson fonds, MG26-N2, vol. 50, file 806.2 part 5, 3; Doris Thomson to Mr. Lester Pearson, 10 March 1963, LAC, Lester B. Pearson fonds, MG26-N2, vol. 49, file 806.2 part 1, 1; Oakville Voice of Women to Mr. Pearson, 14 January 1963, LAC, Lester B. Pearson fonds, MG26-N2, vol. 51, file 806.2 part 6, 1; Jacques Fortier to M. Lester B. Pearson, 30 January 1963, LAC, Lester B. Pearson fonds, MG26-N2, vol. 49, file 806.2 part 1, 1; Peter Light to Lester Pearson, 19 January 1963, LAC, Lester B. Pearson fonds, MG26-N2, vol. 50, file 806.2 part 4, 1.

1024 John E. Ball to the Nobel Peace Prize Committee, cc'd to Lester B. Pearson, 21 January 1963, LAC, Lester B. Pearson fonds, MG26-N2, vol. 50, file 806.2 part 4, 2.

${ }^{1025}$ LAC, Lester B. Pearson fonds, MG26-N2, vol. 51, file 806.2 part 7; LAC, Lester B. Pearson fonds, MG26-N2, vol. 51, file 806.2 part 8; LAC, Lester B. Pearson fonds, MG26-N2, vol. 51, file 806.2 part 9; LAC, Lester B. Pearson fonds, MG26-N2, vol. 51, file 806.2 part 10.

${ }^{1026}$ Alcock to Pearson, 15 January 1963, 2; "Majority Say Our Forces Should Have Nuclear Weapons," 2.
} 
Voice of Women's image suffered especially, as Pearson's shifting policy resulted in the public resignation of his wife as an honorary sponsor of VOW. Though Maryon Pearson publicly placed the blame on internal issues within the VOW, it was widely accepted by VOW supporters that her resignation was entirely political. ${ }^{1027}$ The shock of Pearson's volte-face was so powerful that it has led many historians to interpret it as the cause of ruptures within VOW that damaged the organization and its credibility in $1963 .{ }^{1028}$ The need to take a political position and publicly oppose their former ally did put intense strain on the organization, which was already struggling with significant internal division as a result of a push by some members to adopt more radical methods and a disagreement over the importance of disarmament to VOW's overall peace project. $^{1029}$

From 12 January 1963 onward, Pearson would never again be Canada's "man of peace" for disarmament activists. The day following Pearson's Scarborough speech, CCND chairman K. C. Woodsworth wrote to the editor of the Globe and Mail explaining that, with the Liberal leader's "tragic betrayal," Diefenbaker had become the best ally for

\footnotetext{
${ }^{1027}$ Maryon Pearson, 14 January 1963, LAC, Lester B. Pearson fonds, MG26-N2, vol. 91, file: external affairs Voice of Women 2, 1; Maryon Pearson to Mrs. Gordon Konantz, n.d., LAC, Lester B. Pearson fonds, MG26-N2, vol. 91, file: external affairs Voice of Women 1; Mrs. C. Jorgensen to Lester Pearson, 16 January 1963, LAC, Lester B. Pearson fonds, MG26-N2, vol. 50, file 806.2 part 4, 2; E.E. Bent to L. B. Pearson, 18 January 1963, LAC, Lester B. Pearson fonds, MG26-N2, vol. 50, file 806.2 part 5; Doris Thomson to Lester Pearson, 10 March 1963, LAC, Lester B. Pearson fonds, MG26-N2, vol. 49, file 806.2 part 1, 1; "Pearson's Wife Quits Peace Group," Toronto Daily Star, 5 March 1963, 1; Lotta Dempsey, "The Woman Behind Lester Pearson," Toronto Daily Star, 11 March 1963, 37; La Voix des Femmes, "Minutes," 6 March 1963, LAC, Voice of Women fonds, MG28-I218, vol. 23, file: council meetings (various) minutes 1962-1967, 3; Loewen, "Mike Hears Voices," 29; Moffatt, History of the Peace Movement in Canada, 53. ${ }^{1028}$ Brookfield, Cold War, 91; Frances Early, "Canadian Women and the International Arena in the Sixties: The Voice of Women/La voix des femmes and the Opposition to the Vietnam War," in The Sixties: Passion, Politics and Style, ed. Dimitry Anastakis (Montreal: McGill-Queen's University Press, 2008), 26; Macpherson, When in Doubt, 102-103.

${ }^{1029}$ Ball, "The History of the Voice of Women," 4; Josephine Davis to Mrs. K. Macpherson, 30 March 1963, LAC, Voice of Women fonds, MG28-I218, vol. 1, file: correspondence Josephine Davis 1963.
} 
opponents of nuclear weapons. ${ }^{1030}$ Pearson's clear and strong position on fulfilling Canada's existing defence commitments served to create an environment which encouraged Canadian anti-nuclear activists to lean on Diefenbaker.

\section{Disarmers reject the CCF-NDP}

Given the general tendency for peace and anti-nuclear activists to come from the political left, an alliance with a "prairie Conservative" and staunch anti-Communist like Diefenbaker was improbable. ${ }^{1031}$ However, the relationship between the leftist CCF-NDP and Canadian disarmers was difficult from the start. The CCF spurned anti-nuclear efforts through the 1950s as part of a larger anti-communist crusade. Then, once the party returned to its peace-activist roots in the 1960s, disarmers kept their distance from the CCF-NDP.

The CCF was founded as a socialist party with a base in rural agricultural communities and very strong tendencies towards pacifism. ${ }^{1032}$ The party's pacifist principles were tested by fascist aggression during the late 1930s. The party's founder, J. S. Woodsworth, was alone among CCF members of parliament in opposing Canada's entry into war in September 1939. ${ }^{1033}$ From that point forward, the CCF had a complicated relationship with anti-war activism. When the CPC was founded in 1948, CCF leader M. J. Coldwell encouraged his members to attend CPC leader James Endicott's public lectures. This loose support for the CPC quickly turned to a complete

\footnotetext{
${ }^{1030}$ Woodsworth to the editor Globe and Mail, 13 January 1963, 1.

${ }^{1031}$ Lawrence Wittner, Rebels Against War: The American Peace Movement, 1933-1983 (Philadelphia: Temple University Press), 304; Socknat, Witness Against War, 289; Bothwell, The Big Chill, 55.

1032 Moffat, History of the Peace Movement in Canada, 5; Socknat, Witness Against War, 137; Meg Luxton, "Feminism as a Class Act: Working-Class Feminism and the Women's Movement in Canada," Labour/Le Travail 48 (Fall 2001): 83.

1033 Socknat, Witness Against War, 194.
} 
anti-communist campaign, when in preparation for the 1949 federal election, Coldwell warned CCF members to stay away from the CPC to avoid any possible association of the party with "Red" sympathizers. ${ }^{1034}$ A January 1949 article in the party's journal, $C C F$ Across Canada, declared that peace councils were communist fronts. ${ }^{1035}$ Though many party supporters criticized the journal, pointing out that such censuring of peace groups went against Woodsworth's "greatest principle" of peace, the party stood by the article. ${ }^{1036}$ The CCF had chosen its side in the Cold War, adopting the standard North American association of peace activism with the enemy - communism. ${ }^{1037}$

While the CCF was silent on peace issues in the 1958 election, very shortly after, at the initiative of Saskatchewan Premier T. C. (Tommy) Douglas and his provincial party, the CCF began to return to its peace-activist origins. ${ }^{1038}$ Saskatchewan was the first legislature in the Commonwealth to issue an anti-nuclear statement in April 1958, with a unanimous resolution sent to the United Nations protesting nuclear weapons tests. ${ }^{1039}$ In a

\footnotetext{
1034 Huard, "The Canadian Peace Congress," 33-34.

1035 “New 'Peace Councils' Communist-Inspired," CCF Across Canada 3(1) (January 1949), LAC, Cooperative Commonwealth Federation and New Democratic Party fonds, MG28-IV1, vol. 363, file: Canadian Peace Congress and Councils 1936-56, 4.

${ }^{1036}$ Florence E. Rice to the editor "Across Canada," 14 February 1949, LAC, Co-operative Commonwealth Federation and New Democratic Party fonds, MG28-IV1, vol. 363, file: Canadian Peace Congress and Councils 1936-1956, 2; E. M. Van Blaricom, 12 February 1949, LAC, Co-operative Commonwealth Federation and New Democratic Party fonds, MG28-IV1, vol. 363, file: Canadian Peace Congress and Councils 1936-1956, 1; David Lewis to E. M. Van Blaricom, 14 March 1949, LAC, Co-operative Commonwealth Federation and New Democratic Party fonds, MG28-IV1, vol. 363, file: Canadian Peace Congress and Councils 1936-1956.

1037 William Irvine to Lorne Ingle, 8 December 1951, LAC, Co-operative Commonwealth Federation and New Democratic Party fonds, MG28-IV1, vol. 363, file: Canadian Peace Congress and Councils 1936-56, 1; Benjamin Isitt, "Confronting the Cold War: The 1950 Vancouver Convention of the Co-operative Commonwealth Federation," The Canadian Historical Review 91(3) (September 2010): 501; Myrna Kostash, Long Way from Home: The Story of the Sixties Generation in Canada (Toronto: J. Lorimer, 1980), xxiii-xxiv; Stephen Endicott, James G. Endicott: Rebel out of China (Toronto: University of Toronto Press, 1980), 270; Whitaker and Marcuse, Cold War Canada, 375.

1038 "Is Peace an Issue in March 31 Election?," The Workers Vanguard 3(4) (March 1958), LAC, James G. Endicott and Family fonds, MG30-C130, vol. 7, file 109, 1-2.

1039 "Report of the Proceedings of the National Council of the Canadian Peace Congress," 3-4 December 1960, LAC, James G. Endicott and Family fonds, MG30-C130, vol. 8, file 134, 7; "Submission of the Saskatchewan Peace Council to the members of the Saskatchewan Legislature," 13 March 1959, LAC, James G. Endicott and Family fonds, MG30-C130, vol. 7, file 119.
} 
speech made in Kayville, Saskatchewan, on 4 November 1960, CCF federal leader Hazen Argue took up the banner of Canadian disarmers. He argued, "Neither Mr. Diefenbaker nor Mr. Harkness sees the absurdity of actually preparing to fight a nuclear war. Why prepare for suicide? Would it not be more sensible to prepare for peace?" ${ }^{1040}$ Calling on the Conservative government to keep nuclear weapons away from Canadian soil, Argue marked the federal CCF's newfound acceptance of Canadian anti-nuclear efforts.

In April 1961, at a rally in Regina, Douglas praised the CCCRH for "seeking to arouse the Canadian people to the dangers which confront them." Without recognition of the irony of his statement, he advised them not to become discouraged. They would certainly be "misunderstood and misrepresented." 1041 By the summer of 1961, when the CCF and the Canadian Labour Congress merged to become the NDP with Douglas as leader, the party established a clear stance against nuclear weapons for Canada. ${ }^{1042}$ From 1961 to 1963, the NDP offered its support to Canadian disarmers and took a clear stand as a party against nuclear weapons, making it the most obvious potential political partner for anti-nuclear groups. ${ }^{1043}$

However, as one VOW member observed in the winter of 1962, anti-nuclear groups did not reward the one party whose policy on nuclear arms was closest to their

\footnotetext{
${ }^{1040}$ Hazen Argue, "Disarmament and Common Sense," 4 November 1960, LAC, Voice of Women fonds, MG28-I218, vol. 1, file: correspondence-Members of Parliament re. formation 1960-1963, 2.

1041 "Premier T.C. Douglas Speaks on Disarmament, April 1 19t 1961 , Regina, Saskatchewan," LAC, Cooperative Commonwealth Federation and New Democratic Party fonds, MG28-IV1, vol. 546, file: T.C. Douglas on disarmament, 7, 3 .

1042 "The Federal Program of the New Democratic Party, Adopted by its founding convention, Ottawa July 31-August 4, 1961," LAC, Co-operative Commonwealth Federation and New Democratic Party fonds, MG28-IV1, vol. 538, file: New Democratic Party program 1961, 27.

${ }^{1043}$ Argue to Davis, 15 February 1961, 1; James S. Thomson to Hazen Argue, 5 September 1961, MUL, CCND fonds, box 3, file 9, 1; James S. Thomson to Thomas C. Douglas, 5 September 1961, MUL, CCND fonds, box 3, file 9; Moffatt, History of the Peace Movement in Canada, 6-7.
} 
own. ${ }^{1044}$ Anti-nuclear leaders took for granted that all NDP members would support their disarmament briefs, and groups were not disappointed when Douglas was unavailable for meetings. ${ }^{1045}$ Organization leaders were hesitant to endorse the NDP for its nuclear policy, because "to endorse a party for one plant in its platform ... implies active support for that party in preference to any other." 1046 While it was acceptable to celebrate individual politicians, such as Green, Diefenbaker, and Pearson, for their positions on nuclear arms, championing an entire party went against the non-partisan identities of the CCCRH-CCND, the CUCND, the CPC, and VOW. Non-partisanship was central to their attempts to ensure "respectability."

Ignoring warnings from advisors that an over-emphasis on opposition to nuclear arms in Canada might be harmful in an election, the NDP embraced its identity as the only political party to take an unequivocal stand against nuclear arms in the 1963 election campaign. ${ }^{1047}$ In response to Pearson's reversal of Liberal policy, Douglas set the stage for the NDP election campaign with his 24 January 1963 House of Commons speech. Asserting that the NDP believed that "all Canada's energies should be directed towards

\footnotetext{
${ }^{1044}$ Marjorie Ball to Mrs. Josephine Davis, 28 November 1962, LAC, Voice of Women fonds, MG28-I218, vol. 1, file: correspondence Josephine Davis (vice-pres) 1962, 1.

1045 David Lewis to F. C. Hunnius, 19 October 1962, MUL, CCND fonds, SW574, box 19, file 3, 1; "Report on the CCND Lobby of Members of Parliament," 8-10 November 1962, MUL, CCND fonds, ACCN. 05-1989.102.F, box 24, file 5, 1; Arthur Pape to T.C. Douglas, 20 November 1963, MUL, CUCND-SUPA fonds, box 17, file Brief to Parliament Ottawa Oct. 9-Nov. 1963, 1; McMahon, Essence of Indecision, 140.

1046 Toronto Campaign for Nuclear Disarmament, "Our Part in the Election," Newsletter 11(4) (15 March 1963), MUL, CCND fonds, SW571, box 6, file 12, 1.

${ }^{1047}$ Kenneth Bryden to T. C. Douglas, 19 February 1963, LAC, Co-operative Commonwealth Federation and New Democratic Party fonds, MG28-IV1, vol. 412, file: T.C. Douglas correspondence, 1-2; Stanley Knowles, ca. 1963, LAC, Co-operative Commonwealth Federation and New Democratic Party fonds, MG28-IV1, vol. 410, file: Correspondence Candidates 1962, 1; Denis J. Fletcher, 24 February 1963, LAC, Co-operative Commonwealth Federation and New Democratic Party fonds, MG28-IV1, vol. 412, file: miscellaneous correspondence, 1 . NDP officials and supporters were apparently unaware of the opposition of the Communist Party of Canada and of the Quebec Social Credit to nuclear weapons for Canadian forces (McMahon, Essence of Indecision, 140; Toronto Campaign for Nuclear Disarmament, "Our Part in the Election," 1).
} 
preventing a nuclear holocaust" by "refusing to acquire nuclear weapons for Canada's forces either at home or abroad," Douglas firmly placed the NDP in the anti-nuclear camp. ${ }^{1048}$ The NDP even sought to bring in celebrated American anti-nuclear leader Norman Cousins and Canadian Brock Chisholm, former director of the World Health Organization and member of the CPRI board of directors, to enliven their campaign and provide a boost for "the nuclear theme." 1049

Yet disarmament organizations largely held back from proclaiming public support for the NDP. Casgrain was forced to resign as VOW president and from the organization when she ran as an NDP candidate in the 1963 election. ${ }^{1050}$ During the campaign, the Globe and Mail drew attention to the public assumption that the VOW had "scorned" the NDP, with an editorial cartoon depicting a sad Douglas, holding wilted flowers, rejected by VOW women. ${ }^{1051}$ The Toronto CCND refused to endorse the party, because that would mean committing the organization to all NDP policies, distracting the CCND from its central project. ${ }^{1052}$ The Vancouver branch of the Women's International League for Peace and Freedom (WILPF) also refused to endorse the NDP, arguing that the party's anti-nuclear stance did not go far enough, since it did not demand Canada's withdrawal from NATO — the source of its nuclear commitments. ${ }^{1053}$ The only exception was the

\footnotetext{
1048 "Stand of New Democratic Party on Nuclear Weapons for Canada, Speech of T. C. Douglas, M.P. for Burnaby-Coquitlam, Leader of the New Democratic Party, Delivered in the House of Commons on January 24, 1963," House of Commons Debates (Roger Duhamel, Queen's Printer and Controller of Stationary, Ottawa, 1963), LAC, Co-operative Commonwealth Federation and New Democratic Party fonds, MG28IV1, vol. 562, file 14, 3-4.

${ }^{1049}$ Ray Woollam to Terry [Grier], 20 March 1963, LAC, Co-operative Commonwealth Federation and New Democratic Party fonds, MG28-IV1, vol. 412, file: miscellaneous correspondence, 1.

1050 Pamela Sachs, "Press Release," 6 March 1963, LAC, Voice of Women fonds, MG28-I218, vol. 2, file: council meetings, minutes 1963, 1.

1051 "The Silent Voice," Globe and Mail, 1 March 1963, 6; "NDP Refused Official Backing by VOW Heads," Globe and Mail, 28 February 1963, 9.

${ }^{1052}$ Toronto Campaign for Nuclear Disarmament, "Our Part in the Election," 1.

${ }^{1053}$ Sheila Young to T. Douglas, 4 May 1963, UBCRBSC, Women's International League for Peace and Freedom fonds, RBSC-ARC-1626, box 3, folder 9, 1 .
} 
francophone element of the Montreal CCND, which suspended peace activities to work for the NDP during the election. ${ }^{1054}$ However, this group had already begun to pursue a more radical approach than the remainder of the anglophone CCND. ${ }^{1055}$

The relationship between disarmers and the CCF-NDP had long been complicated by caution on both sides. First, the CCF feared association with anti-nuclear groups and accusations of communist leanings. Then, when the CCF rediscovered its peace-activist roots, disarmers were so focused on "respectability" and the need to avoid any suggestion of partisanship that they evaded any relationships with the party. In the election of 1963, when the two groups could have benefitted from an alliance, the disarmers put their weight behind Diefenbaker and the Conservatives. Since there was no faith that the NDP could win the election, the divided Conservatives presented the best alternative to the pro-nuclear Liberals for those whose main concern in 1963 was the nuclear question. ${ }^{1056}$

\section{Losing the "nuclear election"}

While the 1963 election did involve questions of the economy and Diefenbaker's leadership, it was "one of the few Canadian foreign policy elections par excellence," this time when Canada's nuclear policy was a central concern. ${ }^{1057}$ The extent to which the election of a minority government for Pearson was based on nuclear policy is unclear. Green, who had been celebrated by disarmers for his fight against nuclear arms, lost his

\footnotetext{
1054 "Minutes of the Board of Directors' Meeting, Ottawa, April 20 \& 21 1963," MUL, CCND fonds, SW571, box 1, file 6, 1-2.

1055 “Address of Jacques Larue-Langlois," 25 October 1963, MUL, CCND fonds, SW571, box 1, file 10, 1, 4-5; "Minutes of the Board of Directors' Meeting," 20-21 April 1963, MUL, SW571, box 1, file 6, 2.

${ }^{1056}$ Donald A. Cameron to Lester B. Pearson, 15 January 1963, LAC, Lester B. Pearson fonds, MG26-N2, vol. 49, file 806.2 part 1, 1; International Peace Bureau, "Peace Action Projects," Peace Information Bulletin 1 (April 1963), MUL, CUCND-SUPA fonds, box 5, file: Peace Information Bulletin April 1963Oct. 1964, 11; Toronto Campaign for Nuclear Disarmament, "Our Part in the Election," 1.

${ }^{1057}$ Bothwell, The Big Chill, 66; CPC, "No Nuclear Arms for Canada," ca. 1963, LAC, Endicott fonds, MG30-C130, vol. 9, file 164, 1.
} 
seat, while Harkness, who had split with Diefenbaker over his indecision on nuclear weapons, was re-elected. ${ }^{1058}$ Harkness claimed that the Conservatives "probably would have won the election," and could have won a majority, if Diefenbaker had clearly supported nuclear warheads for Canada. ${ }^{1059}$ Both the NDP and Social Credit, whose Quebec section had taken an anti-nuclear stance, lost a handful of seats. ${ }^{1060}$ Yet, Tom Kent, advisor to and speechwriter for Pearson, theorized that the Liberals would have won a majority had Pearson not changed the party's defence policy. ${ }^{1061}$ Pearson's turnaround also cost him the support of a growing left-leaning francophone element in the Liberal party (including Pierre Elliott Trudeau) and many Anglophone academics. ${ }^{1062}$ Hilliker and Barry noted that, even though it lost, the Conservative party's "fortunes revived considerably during the campaign," suggesting that there was some benefit to Diefenbaker's approach to the nuclear issue during the campaign. ${ }^{1063}$ Conversely, Newman found Diefenbaker's final anti-American push in the last week of the campaign, when he "built up the McNamara statement into a hysterical condemnation of the Liberals," to have been "ugly," illogical, and ultimately harmful. ${ }^{1064}$ Columnists for the Globe and Mail and the Toronto Daily Star argued that the results of the election had little to do with the nuclear question, but that the Conservative loss was related to

\footnotetext{
1058 McMahon, Essence of Indecision, 169.

1059 "PCs Viewed as Winner If A-Arms Backed," Globe and Mail, April 10, 1963, 10.

1060 Toronto Campaign for Nuclear Disarmament, "Our Part in the Election," 1; McMahon, Essence of Indecision, 169; Maloney, Learning to Love the Bomb, 270;

1061 Tom Kent, A Public Purpose (Montreal: McGill-Queen's Press, 1988), 193, 195.

1062 Maloney, Learning to Love the Bomb, 299; John English, The Life of Lester Pearson, vol. 2 (Toronto: Lester \& Orpen Dennys, 1992), 263; Gérard Rancourt to Lester B. Pearson, 7 May 1963, LAC, Lester B. Pearson fonds, MG26-N3, vol. 31, file 109.11 part 2, 1; CPC, "A Memorandum to the North Atlantic Treaty Organization Council Meeting," May 1963, LAC, James G. Endicott and Family fonds, MG30C130, vol. 9, file 166, 2.

1063 Hilliker and Barry, "The PM and the SSEA," 180; Kent, A Public Purpose, 195.

1064 Newman, Renegade in Power, 391-392, 400.
} 
"general disenchantment with the PC Government" and a sense that the Conservatives were incapable to addressing the recession and unemployment. ${ }^{1065}$

Regardless of the cause for the outcome, anti-nuclear weapons groups took solace in their reading of the election results as a vote against nuclear weapons. Opponents of nuclear arms wrote Pearson in the spring and summer of 1963 reminding him that he did not have a mandate to bring nuclear arms onto Canadian soil. The Calgary Labour Council urged Pearson to remember that, since less than 50 per cent of Canadians voted for the Liberals in the April election, "If you continue with your avowed policy, you will be disregarding the true wishes of the majority of the Citizens of this Country."1066 The CPC advised the NATO Council that the Canadian public had not approved nuclear weapons for Canada. ${ }^{1067}$ Anti-nuclear groups and peace organizations in Canada and abroad, such as the World Peace Council, claimed that disarmers had in fact won the election. ${ }^{1068}$

Nevertheless, the Liberal victory sapped morale within the movements. Disarmers struggled after the election to devise an appropriate and effective effort to keep Pearson from acquiring nuclear arms for Canada. The CCND board of directors overwhelmingly dismissed a proposal put forward by John Lee that a delegation made up of prominent members be put together to approach Pearson with alternatives to nuclear arms. Stig Harvor and student leaders Dimitrios Roussopoulos and Arthur Pape argued that such an

\footnotetext{
${ }^{1065}$ Edwin Bolwell, "Why Green was Defeated," Globe and Mail, 10 April 1963, 7; "The Reason Why," Toronto Daily Star, 10 April 1963, 6.

1066 W. Y. Paterson to the Honourable Lester B. Pearson, 16 May 1963, LAC, Lester B. Pearson fonds, Prime Minister's Office correspondence 1963-1965, MG26-N3, vol. 31, file 109.11 part 1, 1.

${ }^{1067}$ Canadian Peace Congress, "A Memorandum to the North Atlantic Treaty Organization Council Meeting," May 1963, LAC, James G. Endicott and Family fonds, MG30-C130, vol. 9, file 166, 2. 1068 J. D. Bernal to the CPC and Toronto Association for Peace, 7 May 1963, LAC, James G. Endicott and Family fonds, MG30-C130, vol. 8, file 159, 1.
} 
effort would be a waste of time because Pearson was immune to the pleas of disarmers. Coldwell, the former CCF leader, demonstrated his pessimism when he asserted that solicitations by grass-roots activists "had never succeeded in the House [of Commons]."1069 Many disarmament organizers expressed distrust of the sincerity of Pearson's assurances that he would seek to amend Canada's commitments to NATO. ${ }^{1070}$ But not all had lost faith in their traditional political methods. K. C. Woodsworth suggested that their best option was to approach the opposition, for "there is a possibility of producing an organized force within parliament." Diefenbaker had apparently convinced disarmers that he was sincerely opposed to nuclear arms. ${ }^{1071}$

Disarmers' disappointment with Pearson was equalled by their satisfaction with Diefenbaker. Following the election, anti-nuclear advocates praised Diefenbaker and his party for their efforts. Reporting on the election results to the WILPF in Zurich, Sheila Young of the Vancouver branch of the League explained that her group was very pleased that the Conservatives "fought very hard for disarmament."1072 Young wrote Diefenbaker in gratitude for his stand on nuclear weapons and to express regret over the election results, particularly the fact that Green, a man of "high principles" and courage, had lost his seat. ${ }^{1073}$ Along with the WILPF, the CPC and the CCND expressed gratitude for Diefenbaker's stand against nuclear arms. ${ }^{1074}$ Fifty years later, two former activists

\footnotetext{
1069 "Minutes of the Board of Directors' Meeting, Ottawa, April 20 \& 21, 1962," 3-4, 5.

1070 Pearson, Mike, 71, 116; Mabel Hanway, "Dear Friends of peace," 26 August 1963, LAC, James G. Endicott and Family fonds, MG30-C130, vol. 8, file 160, 1; CCND Board of Directors, "Minutes of the Board of Directors' Meeting, Ottawa,” 20-21 April 1963, MUL, CCND fonds, SW571, box 1, file 6, 3. 1071 "Minutes of the Board of Directors' Meeting, Ottawa, April 20 \& 21, 1962," 1.

1072 Sheila Young to Dr. Gertrude Worker, 13 April 1964, UBCRBSC, Women's International League for Peace and Freedom fonds, RBSC-ARC-1626, box 3, folder 9, 1.

1073 Sheila Young to Rt. Hon John Diefenbaker, 4 May 1963, UBCRBSC, Women's International League for Peace and Freedom fonds, RBSC-ARC-1626, box 3, folder 9, 1.

1074 Dineen, “Annual Report," 1; "Minutes of the Board of Directors' Meeting, Ottawa-April 20 \& 21 , 1963,” MUL, CCND fonds, box 1, file 6, 7.
} 
recalled Diefenbaker as having been one who was "always careful to oppose any more nuclearization of Canada."1075 Through the election campaign Diefenbaker had, aided by Pearson's change of mind, convinced anti-nuclear organizations that he was their man.

\section{Conclusion}

While they grew in popularity between 1959 and 1960, and had demonstrated their great noise-making capacity in 1961, by the end of 1963 there was little for politicians to fear from the disarmers. As in the United States and Britain, the popularity of disarmament movements began to falter in response to the Limited Test Ban Treaty. ${ }^{1076}$ Moreover, just as Canadian anti-nuclear activists were attempting to regain their footing and plan for the next phase of their project, they were dealt a second and more serious blow. Canadian disarmers' optimism faded and then collapsed when nuclear weapons were stationed in Ontario on New Year's Eve 1963, a date chosen, disarmers assumed, so that the government would not have to face the shame of their actions when Canadians were distracted by the holidays. ${ }^{1077}$ With this, Canadian anti-nuclear organizations had to reconsider their purpose and lost much of their membership. ${ }^{1078}$

\footnotetext{
1075 Anonymous, interview with author, 8 November 2013; D. Gillian Thompson, interview with author, 12 November 2013.

${ }^{1076}$ Charles Chatfield, The American Peace Movement (New York: Twayne Publishers, 1992), 115; Wittner, The Struggle Against the Bomb, vol. 2, 443.

1077 Wittner, The Struggle Against the Bomb, vol. 2, 202; Manitoba Conference for a Non-Nuclear Canada, "Only Disarmament Guarantees Survival! Brief presented to members of Manitoba Provincial Legislature," 16 March 1964, LAC, James G. Endicott and Family fonds, MG30-C130, vol. 19, file 362, 2.

1078 CUCND National Secretariat, "Special Mid-Summer Memo, Hiroshima Day," 6 August 1963, MUL, CUCND-SUPA fonds, box 3, file: interbranch memos Dec. 1962-Oct. 1963, 1; Wittner, The Struggle Against the Bomb, vol. 2, 443; David S. Churchill, "SUPA, Selma, and Stevenson: The Politics of Solidarity in mid-1960s Toronto," Journal of Canadian Studies 44(2) (Spring 2010): 34; Loewen, "Mike Hears Voices," 29; Eva Sanderson to Miss Nancy Pocock, 22 April 1964, LAC, James G. Endicott and Family fonds, MG30-C130, vol. 10, file 179, 1; Dimitrios Roussopoulos, "Introduction," in The New Left in Canada, ed. Dimitrios Roussopoulos (Montreal: Our Generation Press-Black Rose Books, 1970), 8.
} 
Though Diefenbaker had made himself into an ally for disarmers by the election of 1963, he was never a sincere supporter of disarmament efforts. He had used Canadian disarmers as an excuse for his overlong consideration of the issue of nuclear arms in Canada. Pearson, though a public supporter until 1963, broke off relations with disarmers when he revised the Liberal defence policy for political gain. While the CCF-NDP made the most natural political partner for Canadian anti-nuclear movements, their relationship was fraught throughout by the need to remain "respectable" in the face of the Cold War "red scare."

For years, Canadian disarmers had attempted to remain "orderly" in the face of "ugly Cold War accusations that they were 'commie' sympathizers or worse." 1079 However, by prioritizing the conversion of politicians, Canadian disarmers failed to affect a major shift in Canadian public opinion against nuclear weapons as a deterrence strategy. ${ }^{1080}$ Canadian Committee for the Control of Radiation Hazards chairman Hugh Keenleyside had promised Green in November 1960 that there would "be a violent reaction in Canada against the Government" if nuclear arms were acquired, but an outburst of opposition never materialized. ${ }^{1081}$

As VOW member Dorothy Goldin Rosenberg noted, "most of the time we were already speaking to the people who had similar ideas." ${ }^{1082}$ So focused on not offending the average Canadian with large and loud public demonstrations, disarmers failed to

\footnotetext{
1079 Palmer, Canada's 1960s, 258.

1080 "One in Ten Very Worried on Chance of Nuclear War," in Gallup Report 1963 (Toronto: Canadian Institute of Public Opinion, 1963), 1; "Nuclear Weapons are Wanted by Nearly Half of Canadians," 2.

${ }^{1081}$ H. Keenleyside to the Honourable Howard Green, 4 November 1960, LAC, Lester B. Pearson fonds, MG26-N2, vol. 49, file 806, 2.

1082 Dorothy Goldin Rosenberg, interview with author, 30 November 2013.
} 
rouse significant public opposition to the Bomb. ${ }^{1083}$ Respectable "proper politics" had proved to be inadequate in the Cold War 1960s.

Coming out of the difficult year that was 1963, many disarmers recognized that the only way for Canadian anti-nuclear movements to regain "their balance" and to ignite any significant opposition to the presence of nuclear arms in Canada was to turn to "more militant activity." 1084 As early as June 1963, CUCND leaders proposed that acts of civil disobedience would serve to dramatize their efforts, as "our conviction would be shown in the fact that we were willing to go to jail." ${ }^{\prime 085}$ At a time when Canadians and humanity in general were "so close to the Zero Hour," Canadian disarmers needed to look beyond traditional politics if they were ever to "liberate mankind from the insanity of war."1086

\footnotetext{
${ }^{1083}$ Arthur Pape to Viv Nelles, 29 May 1963, MUL, CCND fonds, SW571, box 5, file 8, 1; Mary Dales to Mme Casgrain, 6 January 1963, LAC, Voice of Women fonds, MG28-I218, vol. 1, file: correspondence Josephine Davis 1963, 1-2; Betty Drew to Mrs. Macpherson, 31 May 1963, LAC, Voice of Women fonds, MG28-I218, vol. 39, file: Winnipeg meeting emergency resolutions correspondence pt. 1 1963, 1; Shirley McNaughton to Mme Casgrain, 15 January 1963, LAC, Voice of Women fonds, MG28-I218, vol. 1, file: correspondence Josephine Davis 1963, 2; Welland Campaign for Nuclear Disarmament, "Easter Peace Walk to the Peace Bridge," 1.

${ }^{1084}$ Floyd Williston to CPC, 4 January 196[4], LAC, James G. Endicott and Family fonds, MG30-C130, vol. 10 , file $169,1$.

${ }^{1085}$ CUCND secretariat, 16 June 1963, 3.

1086 "Why a Committee of 100?," Survival 1(1) (November 1961), LAC, James G. Endicott and Family fonds, MG30-C130, vol. 19, file 376, 1.
} 


\section{Chapter Six \\ Finding Meaning Through International Cooperation: "National Internationalist" Canadians and Transnational Disarmament Advocacy Networks}

All "human life is in imminent danger," declared celebrated British peace activist Bertrand Russell in his message to Canadian Peace Congress (CPC) supporters at their 1962 disarmament rally. "Nuclear war is a matter of statistical near certainty, unless the peoples of the world join in a movement of mass resistance, an international movement capable of systemically obstructing the entire technology of extermination," he continued. ${ }^{1087}$ Calling on Canadian disarmers to add their voices to an international campaign to ban the Bomb, Russell highlighted the need for activists to work beyond their national campaigns if they were to have an impact on international politics.

Because of the global nature of the dangers of nuclear warfare, anti-nuclear efforts naturally reached beyond national borders. Connected by shared goals, antinuclear protest campaigns exchanged people and ideas across boundaries. However, as much as interactions between disarmers across the globe rose above nationalisms and the Cold War ideological struggle, protest efforts were also "embedded firmly in their respective political systems and their national political traditions," as historian of British and West German disarmament efforts Holger Nehring has pointed out. ${ }^{1088}$

Canadian activists, like their peers across the globe, observed successful protest methods abroad and adapt them to fit their local needs. Canadian disarmers were active participants in an international conversation about the dangers of the Bomb, sharing their

\footnotetext{
1087 The Earl Russell to Eva Sanderson, 22 March 1962, Library and Archives Canada (LAC), James G. Endicott and Family fonds, MG30-C130, vol. 2, file 32, 1.

1088 Holger Nehring, "National Internationalists: British and West German Protests Against Nuclear Weapons, the Politics of Transnational Communications and the Social History of the Cold War, 19571964," Contemporary European History 14(4) (2005): 560.
} 
national experiences, protest ideas, and educational materials with others. Canadian

movements were the product of and a response to international efforts to ban the Bomb and bring about lasting peace.

Historians of peace and disarmament activism Lawrence Wittner and Charles Chatfield have argued that the combined efforts of disarmers across the globe in the late 1950s and early 1960s successfully drew public attention to the dangers of nuclear fallout. In this way, disarmers created a climate of global insecurity over nuclear radiation, which made the 1963 Partial Test Ban Treaty possible, according to Wittner and Chatfield. ${ }^{1089}$ Signed in the fall of 1963 , the Test Ban Treaty was a promise by all existing and potential nuclear powers - except China, France, and North Korea - to cease the testing of nuclear arms in the atmosphere, in outer space, and under water. ${ }^{1090}$ This treaty was not only an acknowledgement that the dangers of nuclear fallout outweighed the benefits of testing new nuclear weapons technologies, but was also understood by disarmers to be the first step towards ridding the world of such powerful weapons. $^{1091}$

\footnotetext{
${ }^{1089}$ Lawrence Wittner, The Struggle Against the Bomb, vol. 2 (Stanford: Stanford University Press, 1997), 473; Charles Chatfield, The American Peace Movement (New York: Twayne Publishers, 1992), 114. Such a position is also argued in the following: Amy Swerdlow, Women Strike for Peace: Traditional Motherhood and Radical Politics in the 1960s (Chicago: The University of Chicago Press, 1993), 12-13; Catherine Foster, Women for All Seasons: The Story of the Women's International League for Peace and Freedom (Athens, Georgia: University of Georgia Press, 1989), 28; David S. Churchill, "SUPA, Selma, and Stevenson: The Politics of Solidarity in mid-1960s Toronto," Journal of Canadian Studies 44(2) (Spring 2010): 37; France Early, "Canadian Women and the International Arena in the Sixties: The Voice of Women/La voix des femmes and the Opposition to the Vietnam War," in The Sixties: Passion, Politics and Style, ed. Dimitry Anastakis (Montreal: McGill-Queen's University Press, 2008): 25; Milton Katz, Ban the Bomb: A History of SANE, the Committee for a Sane Nuclear Policy, 1957-1985 (Westport, Conn.: Greenwood Press, 1986), xii-xiii; Allan M. Winkler, Life Under a Cloud: American Anxiety About the Atom (New York: Oxford University Press, 1993), 4.

${ }^{1090}$ Wittner, The Struggle Against the Bomb, vol. 2, 415; Early, "Canadian Women and the International Arena in the Sixties," 28; "Two Memos Regarding the International Confederation for Disarmament and Peace," 19 July 1963, The William Ready Division of Archives and Research Collections, McMaster University Library (MUL), CCND fonds, SW571, box 2, file 3, 3.

${ }^{1091}$ K. C. Woodsworth, "No Nuclear Arms for Canada," n.d., MUL, CCND fonds, SW573, box 13, file 10, 3; "Statement on the Test Ban Treaty," 30 July 1963, LAC, James G. Endicott and Family fonds, MG30-
} 
In highlighting the Test Ban Treaty as evidence of the success of disarmament efforts of the 1950s and 1960s and because of the global threat of the Bomb, Cold War historians have often illustrated anti-nuclear weapons movements of this period as a "single global actor." 1092 The notion of one overarching disarmament movement, while creating a powerful image of global unity against the Bomb, fails to acknowledge the extent to which national contexts and concerns created many very distinct movements. ${ }^{1093}$ Furthermore, though Canadian disarmament efforts celebrated the Test Ban Treaty alongside fellow anti-nuclear and peace activists in the United States, Britain, and West Germany, there were very few examples of formal international campaigns organized in support of a test ban. ${ }^{1094}$

Canadian efforts were instead part of a "transnational advocacy network." As proposed by political scientists Margaret E. Keck and Kathryn Sikkink, advocacy networks form when independent social movements share similar goals, information, and resources, including educational and protest materials as well as individuals. ${ }^{1095}$ Blurring

C130, vol. 2, file 34, 1; Canadian Peace Congress, "Peace Group Goes to Ottawa," 7 September 1963 , LAC, James G. Endicott and Family fonds, MG30-C130, vol. 2, file 33, 1; Joseph and Marjorie Reid to Mr. Pearson, 9 August 1963, LAC, Lester B. Pearson fonds, MG26-N3, vol. 31, file 109.11 part 3, 1. 1092 Nehring, "National Internationalists," 560.

${ }^{1093}$ Holger Nehring, "Pacifism," in The Palgrave Dictionary of Transnational History, ed. Akira Iriye and Pierre-Yves Saunier (Basingstoke and New York: Palgrave Macmillan, 2009), 805; Holger Nehring, Politics of Security: British and West German Protest Movements and the Early Cold War, 1945-1970 (Oxford: Oxford University Press, 2013), 299.

${ }^{1094}$ Nehring, Politics of Security, 232; Swerdlow, Women Strike for Peace, 81; Chatfield, The American Peace Movement, 106; Paul Boyer, "From Activism to Apathy: The American People and Nuclear Weapons, 1963-1980," Journal of American History 70 (March 1984): 839.

1095 Margaret E. Keck and Kathryn Sikkink, Activists Beyond Borders: Advocacy Networks in International Politics (Ithaca, N.Y.: Cornell University Press, 1998), 1-2. This term has been widely informed by the influential theoretical work of sociologist Sidney Tarrow (Sidney Tarrow, Power in Movement: Social Movements, Collective Action and Politics (Cambridge: Cambridge University Press, 1994), 15). Canadian historian David S. Churchill similarly uses the term "network" to describe the interconnectedness of Canadian, American and British anti-nuclear campaigns in the early 1960s (Churchill, "SUPA, Selma, and Stevenson," 37). Though not using the same language, Håkan Thörn's study of anti-apartheid movements shares a similar definition of transnational social movements (Håkan Thörn, Anti-Apartheid and the Emergence of a Global Civil Society (Basingstoke: Palgrave Macmillan, 2009), 69). 
national boundaries, transnational advocacy networks can effect changes in world politics, according to Keck and Sikkink, as disarmers did with the 1963 test ban. ${ }^{1096}$ These groups, which Keck and Sikkink described as being part of an "international society," simultaneously challenge both domestic and international politics. ${ }^{1097}$ The loose and spontaneous nature of these "networks" or "societies" allows organizations to customize protest methods that have been successful elsewhere to meet local concerns. ${ }^{1098}$ Nehring has used the term "national internationalists" to emphasize the extent to which disarmament efforts approached the international problem of nuclear arms from individual, local, regional, and national perspectives. ${ }^{1099}$ Thus, as Nehring argued, it is important not to adopt a transnational approach at the expense of considering the national contexts of these social movements. ${ }^{1100}$

Nevertheless, the inclusion of the word "internationalists" is a flaw in Nehring's concept of "national internationalists." Political scientists and historians have often associated twentieth-century peace and disarmament activism with the ideology of “internationalism.” Regularly used without definition, scholars of peace activism generally understand "internationalism" to mean a belief that establishing greater understanding, cooperation, and respect among states is the key to lasting peace. ${ }^{1101}$

\footnotetext{
1096 Keck and Sikkink, Activists Beyond Borders, 2.

1097 Keck and Sikkink, Activists Beyond Borders, 4.

1098 Nehring, "Pacifism," 805.

1099 Nehring, "National Internationalists," 561.

${ }^{1100}$ Nehring, "National Internationalists," 560-561.

1101 Nigel Young, "The Peace Movement: A Comparative and Analytical Survey," Alternatives XI (1986):

190-191; Richard L. Harris, "Cuban Internationalism, Che Guevara, and the Survival of Cuba's Socialist Regime," Latin American Perspectives 36(3) (May 2009): 28; David Cortright, Peace: A History of Movements and Ideas (Cambridge: Cambridge University Press, 2008), 8; Jean Bethke Elshtain, Women and War (New York: Basic Books Inc., 1987), 234; Chatfield, The American Peace Movement, 48; Thomas Socknat, Witness Against War: Pacifism in Canada, 1900-1945 (Toronto: University of Toronto Press, 1987), 21; Bernice A. Carroll, "Feminism and Pacifism: Historical and Theoretical Connections," in Women and Peace: Theoretical, Historical, and Practical Perspectives, eds. Ruth Roach Pierson, with Joanne Thompson, Somer Bodribb, and Paula Bourne (London: Croom Helm, 1987), 3; Nehring, "National
} 
However, within this broad definition, "internationalism" exists in many different forms, to the extent that the term has nearly lost all meaning. ${ }^{1102}$

It is important to deconstruct the concept to understand fully the various manifestations of international cooperation in the projects of Cold War peace and disarmament activists. ${ }^{1103}$ These differences not only shaped the responses of disarmers to the Cold War and to the threat of nuclear war, but also defined the ways they cooperated with one another. Furthermore, distinct understandings of the value of international cooperation played an important role in determining the ability of disarmament organizations to marry local and national concerns to the broader project of international peace.

The efforts of Canadian anti-nuclear activists were shaped by their assumptions about the nature of Canada and its rightful place in the world. The "No Nuclear Weapons for Canada" campaign was the only program that united all Canadian disarmament organizations in the early 1960s. By advocating an anti-nuclear option as the most Canadian approach to the Cold War, disarmers rooted their campaigns in a vision of Canada as a moral nation devoted to being a leader in the maintenance of world peace. All nuclear disarmers agreed that the stationing of nuclear warheads on Canadian soil would bring the world closer to nuclear disaster. Canada's acquisition of nuclear arms in

\footnotetext{
Internationalists," 581; Tarah Brookfield, Cold War Comforts: Canadian Women, Child Safety, and Global Insecurity, 1945-1975 (Waterloo: Wilfrid Laurier University Press, 2012), 74.

${ }^{1102}$ Ian Tyrell, "American Exceptionalism in an Age of International History," The American Historical Review 96(4) (October 1991): 1050; Cornelia Navari, Internationalism and the state in the twentieth century (London: Routledge, 2000), 361.

${ }^{1103}$ Harris, "Cuban Internationalism," 28; Kalevi J. Holsti, "From Khartoum to Quebec: internationalism and nationalism within the multi-community state," in Nationalism and Internationalism in the Post-Cold War Era, eds. Kjell Goldman, Ulf Hannerz, and Charles Westin (London: Routledge, 2000), 144, 146; Navari, Internationalism and the state, 360.
} 
the winter of 1963-1964 was, then, deeply demoralizing for Canadian disarmament efforts. ${ }^{1104}$

All disarmament groups responded to the demise of this campaign in their own ways, but it was those organizations that were formed upon a principle of promoting international cooperation that fared better in the mid-1960s. The loosely communist CPC was driven by socialist understandings of the universality of exploitation, which predisposed the organization to support resistance to oppression, particularly in the case of anti-colonial struggles. ${ }^{1105}$ For non-partisan organizations such as the Canadian Committee for the Control of Radiation Hazards (CCCRH) and the Combined Universities Campaign for Nuclear Disarmament (CUCND) international cooperation had more practical ends. These organizations saw interactions with foreign peace and disarmament organizations as critical for strengthening their own national projects, as well as allowing Canadian movements to contribute meaningfully to international campaigns against nuclear arms. Like the CPC, the purposes of the women's peace organization Voice of Women (VOW) promoted international cooperation. Voice of Women was formed under the principle that women had a special interest in the maintenance of peace and the organization was envisioned as an organizing body for an international society of women seeking to bring about a safer world. ${ }^{1106}$

\footnotetext{
${ }^{1104}$ Wittner, The Struggle Against the Bomb, vol. 2, 202; Manitoba Conference for a Non-Nuclear Canada, "Only Disarmament Guarantees Survival! Brief presented to members of Manitoba Provincial Legislature," 16 March 1964, Library and Archives Canada (LAC), James G. Endicott and Family fonds, MG30-C130, vol. 19 , file $362,2$.

${ }^{1105}$ Navari, Internationalism and the state, 360.

${ }^{1106}$ Wilma McDonald to Mrs. Davis, 25 June 1960, LAC, Voice of Women fonds, MG28-I218, vol. 1, file: correspondence re. formation of VOW June-Sept. 1960, 1-2; "President's Report, First Annual Meeting," 1961, LAC, Voice of Women fonds, MG28-I218, vol. 1, file: $1^{\text {st }}$ annual meeting proceedings 1961, 1; Voice of Women, "First Annual Meeting," 16-17 June 1961, LAC, Voice of Women fonds, MG28-I218, vol. 22, file: National Annual Meeting (1961) minutes and background material, 5.
} 


\section{"No Nuclear Weapons for Canada"}

Understanding a need to address the interests and values of a Canadian audience, anti-nuclear organizations sculpted their campaigns to meet local realities. ${ }^{1107}$ Disarmament leaders found that Canadians were much more interested in a campaign opposing the installation of nuclear arms in Canada than any discussion of civil rights, liberties for minority groups, or anti-colonial struggles. ${ }^{1108}$ As Jacqueline Dineen, executive secretary for the CPC, advised leading American pacifist preacher Willard Uphaus, Canadian disarmament organizations "like to stick to domestic issues like 'No Nuclear Arms for Canada.",1109

Following the Conservative victory in the June 1957 federal election, the government of Prime Minister John G. Diefenbaker took measures setting the groundwork for the installation of nuclear arms on Canadian soil. From 1958 to 1959 Canada accepted the North American Air Defence Command (NORAD) agreement, ordered Bomarc-B missiles, agreed to a strike reconnaissance role for armed forces in Europe, and purchased CF-104 fighter-bomber aircraft. ${ }^{1110}$ When Diefenbaker announced on 20 February 1959 that Canada was purchasing the Bomarcs, he revealed that the

\footnotetext{
${ }^{1107}$ Margaret E. Keck and Kathryn Sikkink, "Transnational advocacy networks in international and regional politics," International Social Science Journal 51(159) (March 1999): 90.

1108 James Endicott, "World Peace Council Problems," 23 March 1959, LAC, James G. Endicott and Family fonds, MG30-C130, vol. 7, file 124, 2-3; F. C. Hunnius, to Bayard Rustin, 7 September 1961, MUL, CCND fonds, box 15, file 11, 1 .

${ }^{1109}$ Jacqueline Dineen to Willard Uphaus, 26 March 1963, LAC, James G. Endicott and Family fonds, MG30-C130, vol. 8, file 157, 1 .

${ }^{1110}$ Greg Donaghy, Tolerant Allies: Canada \& The United States 1963-1968 (Montreal: McGill-Queen's University Press, 2002), 6; Howard H. Lentner, "Foreign Policy Decision Making: The Case of Canada and Nuclear Weapons," World Politics 29(1) (October 1976): 43.
} 
Canadian government was beginning to explore with the United States government Canada's acquisition of nuclear arms. ${ }^{1111}$

Diefenbaker and his government failed to reach an agreement regarding the installation of nuclear arms in Canada. At issue in Canadian-American nuclear talks were questions of the conditions for Canada's acquisition of nuclear warheads, as well as for the storage of weapons for American forces on Canadian soil. ${ }^{1112}$ Years of uncertainty about the issue under the Diefenbaker government were finally brought to a conclusion in the spring 1963 federal election, when the Liberal party, which had come out in favour of nuclear arms for Canada in early 1963, achieved a minority government. The government of Lester B. Pearson finalized negotiations with the United States government in August 1963, the same month in which the Limited Test Ban Treaty was signed. On New Year's Eve 1963, nuclear warheads arrived at North Bay, Ontario. ${ }^{113}$

From 1959 through to 1963 , Canadian disarmers were engaged in a concerted struggle opposing the installation of nuclear arms in Canada. In the spring of 1961, Canadian anti-nuclear activists initiated their most united campaign with the "No Nuclear

${ }^{1111}$ Canada, House of Commons Debates, vol. II (1959) (Ottawa: The Queen's Printer and Controller of Stationary, 1959), 1223.

1112 Basil H. Robinson, Diefenbaker's World: A Populist in Foreign Affairs (Toronto: University of Toronto Press, 2009), 107; Erika Simpson, NATO and the Bomb: Canadian Defenders Confront Critics (Montreal: McGill-Queen's University Press, 2001), 106; Doug Munton, "Going Fission: Tales and Truths about Canada's Nuclear Weapons," International Journal 51(3) (Summer 1996): 520; Nicole Marion, "'I would rather be right:' Diefenbaker and Canadian Disarmament Movements," in Reassessing the Rogue Tory and His Times: New Perspectives on the Diefenbaker Era in Canadian Foreign Relations, eds. Janice Cavell and Ryan Touhey (Vancouver: University of British Columbia Press, forthcoming).

${ }^{1113}$ Denis Smith, Rogue Tory: The Life and Legend of John G. Diefenbaker (Toronto: Macfarlane Walter \& Ross, 1995), 328, 578; Robert Bothwell, "The Canadian Isolationist Tradition," International Journal 54(1) (Winter 1998/1999): 84; Patrick Nicholson, Vision and Indecision (Don Mills, Ontario: Longmans Canada Limited, 1968), 169, 176; Janice Cavell, "Like Any Good Wife: Gender and Perceptions of Canadian Foreign Policy, 1945-75," International Journal (Spring 2008): 396; Robert Bothwell, The Big Chill: Canada and the Cold War (Toronto: Canadian Institute of International Affairs, 1998), 66; CPC, "No Nuclear Arms for Canada," ca. 1963, LAC, James G. Endicott and Family fonds, MG30-C130, vol. 9, file 164, 1; John Clearwater, Canadian Nuclear Weapons: The Untold Story of Canada's Cold War Arsenal (Toronto: Dundurn Press, 1998), 27, 48, . 
Weapons for Canada" petition organized by the CCCRH. The petition was circulated by the CCCRH, the CPC, VOW, the Fellowship of Reconciliation, the Canadian Friends Service Committee, the Canadian Labour Congress, the Young Men’s Christian Association (YMCA), the Ontario Cancer Institute, as well as other peace groups, unions, churches and religious organizations. ${ }^{1114}$ When CCCRH leadership delivered the petition to Prime Minister Diefenbaker on Thanksgiving weekend in October 1961, the groups had gathered over 141,000 signatures, and by the end of the year the petition had over 200,000 supporters. ${ }^{1115}$ Fifteen years later, the Ottawa research section of the Royal Canadian Mounted Police (RCMP) concluded that the petition was the most widely publicized and successful action by nuclear disarmers in Canada. ${ }^{116}$

Arguing that, "the spread of nuclear weapons to more nations would increase the danger of nuclear war breaking out and would make disarmament harder to negotiate," the petition appealed to Canadians to ask the federal government "to reject nuclear weapons for the armed forces of Canada and to prohibit their installation on Canadian soil." 1117 The wording of the petition avoided any discussion of the East-West ideological divide or reference to military alliances. With its clear national focus, the campaign was constructed upon a specific understanding of Canada.

\footnotetext{
${ }^{1114}$ CCCRH, "Memo to all branches," 28 June 1961, MUL, CCND fonds, SW574, box 19, file 13; "National organizations - names and addresses," 1961, MUL, CCND fonds, SW574, box 20, file 1, 1; Eva Sanderson to James S. Thomson, 3 October 1961, MUL, CCND fonds, SW573, box 17, file 4, 1. 1115 "Statement of the Executive of the Canadian Committee for the Control of Radiation Hazards (on the occasion of the presentation of 141,000 signatures to the Prime Minister)," n.d., MUL, CCND fonds, SW572, box 8, file 3, 1; Walter Gray, "Cleric Says PM Vows No A-Arms in Peace," The Globe and Mail, 7 October 1961, 1; Wittner, The Struggle Against the Bomb, vol. 2, 197.

1116 Research section, Ottawa, "National Committee for the Control of Radiation Hazards_January 1962," 23 July 1977, LAC, CSIS files, RG 146-738, vol. 1, 14, 19 (obtained under access to information).

1117 “No Nuclear Weapons for Canada!," 1961, MUL, CCND fonds SW573, box 10, file 11, 1.
} 
In addition to the 1961 petition, disarmers regularly used the slogan "No Nuclear Weapons for Canada," to demonstrate that the acquisition of nuclear arms and participation in a Cold War system that created the need for such weapons was unCanadian. ${ }^{1118}$ By promoting a vision of Canada as a peacemaker and moral leader, Canadian disarmers claimed that it was only natural for Canada to remain unburdened by nuclear arms.

Building off of historian and political scientist Benedict Anderson's Imagined Communities, in which he posited that nationalisms are historical and cultural artefacts whose meanings change over time and across different groups of people, Canadian historians have offered many understandings of Cold War Canadian nationalisms. ${ }^{1119}$ As historians Norman Hillmer and Adam Chapnick have argued, Canadians' "opinions about identity and destiny were divided," making it impossible to identify a "single or static twentieth-century Canadian nationalist ideology." ${ }^{1120}$ In their campaigns, disarmers relied on a specific conception of Canada, which fit both their hopes for Canada and their dreams of world peace.

\footnotetext{
${ }^{1118}$ No Nuclear Weapons for Canada, "Open Letter to Prime Minister Diefenbaker," July 1960, LAC, James G. Endicott and Family fonds, MG30-C130, vol. 8, file 133; C. G. Gifford and J. Arthur Boorman, "No Nuclear Weapons for Canada Appeal," n.d., LAC, James G. Endicott and Family fonds, MG30-C130, vol. 8, file 129; Lod Gardner to Jim Endicott, 21 February 1961, LAC, James G. Endicott and Family fonds, MG30-C130, vol. 8, file 136, 1; F. C. Hunnius to H. L. Keenleyside, 8 November 1961, MUL, CCND fonds, SW572, box 9, file 2, 1; "What is the Canadian Campaign for Nuclear Disarmament?," ca. 1963, MUL, CCND fonds, SW571, box 1, file 1, 1; Welland Campaign for Nuclear Disarmament, "Easter Peace Walk to the Peace Bridge," 1962, MUL, CCND fonds, SW573, box 18, file 3, 1.

1119 Benedict Anderson, Imagined Communities: Reflections on the Origin and Spread of Nationalism (New York: Verso, 2006), 4, 6. See for example: José Eduardo Igartua, The Other Quiet Revolution: National Identities in English Canada 1945-71 (Vancouver: UBC Press, 2006), 5, 115, 165; Bryan Palmer, Canada's 1960s: The Ironies of Identity in a Rebellious Era (Toronto: University of Toronto Press, 2009), Kindle Loc 474-499; Robert Teigrob, Warming Up to the Cold War: Canada and the United States' Coalition of the Willing, from Hiroshima to Korea (Toronto: University of Toronto Press, 2009), 17-18, 21. ${ }^{1120}$ Norman Hillmer and Adam Chapnick, "Introduction: An Abundance of Nationalisms," in Canada's of the Mind: The Making and Unmaking of Canadian Nationalisms in the Twentieth Century, eds. Norman Hillmer and Adam Chapnick (Montreal and Kingston: McGill-Queen's University Press, 2007), 5.
} 
Disarmers and peace activists commonly referred to Canada as a "peaceable" nation. This conception of Canada was a readily available motif, which had long been promoted by Canadians interested in seeing the state play a larger role in encouraging more friendly and respectful cooperation among nations. At the high point of peace activism in Canada during the 1920s and 1930s, peace groups had imagined Canada as a "peaceful kingdom," a nation tolerant of dissent, with respect for the individual, and committed to social justice. ${ }^{1121}$ Canadian Cold War peace activists paired this notion with a popularly accepted understanding of Canada as a leading "middle power." This idea was built on an assumption that Canada held a position in global politics just outside the circle of the major powers, which had become poisoned by ill will and distrust. In this space, Canada, according to promoters of Canada as a "middle power," could perform a valuable role as a mediator in the bi-polar Cold War world. ${ }^{1122}$ Furthermore, as a "middle"-sized power, Canada should serve as a mentor for "smaller" powers. ${ }^{1123}$ Cold War disarmers proudly promoted the idea of Canada as a "peacekeeping" nation. The resolution of the Suez crisis of 1956 stood as a primary example for Canadian peace activists of the country's capacity to improve relations among states through mediation and conciliation. When the Egyptian government nationalized the AngloFrench Suez Canal, and Britain and France invaded Egypt to recover their lost property, Canadian Secretary of State for External Affairs Lester B. Pearson assisted in launching

${ }^{1121}$ Robert Bothwell, Ian Drummond and John English, Canada Since 1945: Power, Politics and Provincialism (Toronto: University of Toronto Press, 1989), 4-5; Socknat, Witness Against War, 291. ${ }_{1122}$ Palmer, Canada's 1960s, 51; Brookfield, Cold War Comforts, 74.

${ }^{1123}$ Rabbi Abraham Feinberg, "The Threat of Nuclear War-Its Challenge To Canada," SOS Survival or Suicide, vol. 1, September 1960, LAC, James G. Endicott and Family fonds, MG30-C130, vol. 20, file 390, 1. 
the first large-scale United Nations peacekeeping force to monitor a cease-fire agreement. This earned Pearson the Nobel Peace Prize. ${ }^{1124}$

Many historians argue that the notion of Canada as "peacekeeper" has been more rhetoric than practice in the history of Canadian foreign policy. ${ }^{1125}$ Nevertheless, this mythology has given Canadians a sense of international importance and moral superiority. ${ }^{1126}$ Furthermore, as Sean Maloney has argued, the "myth of Canadian peacekeeping" has fuelled other assumptions about Canada: that it is an unmilitary nation, with no colonial past, and home to "nice, inoffensive, altruistic people."1127

Though more legend than reality, the idea of Canada as a peace-making middle power was very important to the project pursued by Canadian disarmament activists. Disarmers repeated the refrain that Canada's position as a "peacemaker" should determine how the nation interacted with other countries. ${ }^{1128}$ The charter of the student disarmament organization, the CUCND, argued that Canada was well placed to provide "leadership in international questions," because, as a nation that "has never held sovereign control over an alien people," "its credentials are sound."1129 The Toronto

\footnotetext{
${ }^{1124}$ Bothwell, "The Canadian Isolationist Tradition," 81; Hector Mackenzie, "Canada's Nationalist Internationalism: From the League of Nations to the United Nations," in Canada's of the Mind: The Making and Unmaking of Canadian Nationalisms in the Twentieth Century, eds. Norman Hillmer and Adam Chapnick (Montreal and Kingston: McGill-Queen's University Press, 2007), 105; Cavell, "Like Any Good Wife," 386.

${ }^{1125}$ Mackenzie, "Canada's Nationalist Internationalism,” 105.

${ }^{1126}$ Mackenzie, "Canada's Nationalist Internationalism," 90.

${ }^{1127}$ Sean M. Maloney, Canada and UN Peacekeeping: Cold War by Other Means, 1945-1970 (St. Catherines: Vanwell Publishing Limited, 2002), 2.

${ }^{1128}$ Sheila [Young] to Eva Sanderson, 8 May 1957, MUL, Canadian Peace Congress fonds, 47-1992, box 2, file: correspondence-Women's International League for Peace and Freedom 1956-57, 1; Marion Bacon to Lester B. Pearson, 4 August 1960, LAC, Lester B. Pearson fonds, MG26-N2, vol. 3, file: 100.1, 1; "Monsieur Pearson," 1963, LAC, Lester B. Pearson fonds, MG26-N2, vol. 51, file 806.2 part 7; M. Shipley to Lester B. Pearson, 9 February 1966, LAC, Voice of Women fonds, MG28-I218, vol. 20, file: letters to the Prime Minister regarding Vietnam 1966, 1; Simonne Monet-Chartrand, Les Québécoises et le movement pacifiste (1939-1967) (Montreal: Les Éditions Écosociété, 1993), 45; Feinberg, "The Threat of Nuclear War," 1.

${ }^{1129}$ Montreal CUCND, “The Charter," ca. 1963, MUL, CUCND-SUPA fonds, box 1, file: CUCND Toronto office 1960-1961, 3.
} 
Committee for Disarmament also emphasized that Canada's "relative freedom from the historical burden of colonialism" put it in a unique position to "boldly advance the cause of peace." ${ }^{1130}$

It was not only Canada's "innocent" past that disarmers latched onto as evidence for encouraging a leading position for Canada in international conflict resolution. As one disarmer wrote to Prime Minister Diefenbaker's wife Olive, "as the oldest self-governing dominion of the Commonwealth, [Canada] has a clear duty to set an example to the younger members." ${ }^{1131}$ In this sense, Canada was conceived of as the elder sibling, responsible for teaching its newly independent and nearly independent Commonwealth siblings how to play nicely with others.

Disarmers warned that it would undermine Canada's position of moral superiority in international politics to accept nuclear weapons. The CUCND contended that in denunciating nuclear arms, Canada would be able to "assume the leadership of the middle powers having demonstrated its sincerity" to serve peace. ${ }^{1132}$ Flipping the argument to the negative, K. C. Woodsworth, chairman of the CCND, argued that acceptance of American nuclear warheads on Canadian soil would "tie Canada more tightly to the military-political line of the Pentagon," making it increasingly difficult for the nation to pursue an "independent peace-making role." 1133 In much the same way, the women-only peace organization VOW claimed in its 1963 brief to Prime Minister Pearson that the acquisition of nuclear arms by Canada would cripple "Canada's ability to play an

\footnotetext{
1130 "Tomorrow may be never, the only alternative to peace is not war; it is death," March 1960, LAC, Lester B. Pearson fonds, MG26-N2, vol. 86, file: external affairs, disarmament (1), 6.

${ }^{1131}$ Anne Dorian to Mrs. Diefenbaker, 23 March 1963, University of Saskatchewan Archives and Special Collections (UOS), John G. Diefenbaker fonds, MG/01/V/F/483, Diefenbaker centre row 1, vol. 77, 3.

1132 "Combined Universities Campaign for Nuclear Disarmament," n.d., MUL, CUCND-SUPA fonds, box 1, file: CUCND Toronto Office 1960-1961, 1.

${ }^{1133}$ Woodsworth, "No Nuclear Arms for Canada," n.d., 3.
} 
effective part in resolving world tensions." 1134 Similarly, the Vancouver branch of the Women's International League for Peace and Freedom (WILPF) argued that the acquisition of nuclear arms by Canada would weaken "its position in the United Nations and world public opinion." 1135

Nuclear arms were seen as particularly harmful to Canada's moral influence upon smaller nations because, the Manitoba Peace Council emphasized to the Manitoba legislature, Canada was "in a sense the founding member of the non-nuclear club." Disarmers were proud of the fact that Canada had the capacity to build its own nuclear weapons, but had chosen not to do so. ${ }^{1136}$ As such, it would be a significant betrayal of years of moral leadership for Canada to accept nuclear arms. Disarmers' investment in this image of the nation required activists to selectively overlook Canadian foreign policy decisions that called into question Canada's moral superiority. When the first atomic bomb was detonated over Hiroshima, Japan, on 6 August 1945, Canadian newspapers celebrated the fact that Canadian scientists and uranium made the development of such a weapon possible. ${ }^{1137}$ Yet Canadian disarmers made no mention of Canadian complicity when criticizing the atomic bombings of Hiroshima and Nagasaki. ${ }^{1138}$

\footnotetext{
1134 "Brief Presented to the Prime Minister by Voice of Women-Canada-La Voix des Femmes," 23 May 1963, LAC, Voice of Women fonds, MG28-I218, vol. 2, file: International Cooperation Year Conference International Cooperation Travel Mission 1962-63, 1.

${ }^{1135}$ Sheila Young to John Diefenbaker, 12 January 1963, University of British Columbia Rare Books and Special Collections (UBC), Women's International League for Peace and Freedom fonds, RBSC-ARC1626, box 3, file 9,1 .

1136 "Only Disarmament Guarantees Survival!," 16 March 1964, LAC, James G. Endicott and Family fonds, MG30-C130, vol. 19, file 362, 2.

${ }^{1137}$ Teigrob, Warming up to the Cold War, 23; C. R. Blackburn, “Atomic Bomb Rocks Japan,” The Globe and Mail, 7 August 1945, 1.

${ }^{1138}$ Setsuko Thurlow, interview with author, 30 October 2013; "Remember Hiroshima!," SOS Survival or Suicide, vol. 1, September 1960, MUL, Canadian Peace Congress fonds, 47-1992, box 2, file: other organizations circulars and printed To. Disarmament ctte. 1960-1961, 2; Pierre Berton, "Dr. Norman Alcock Launches his Crash Program for Peace," Toronto Daily Star, 5 December 1961, Archives of Ontario (AO), Canadian Peace Research Institute fonds, F-883-1-2, container B297380, box 3, file: Capri inauguration, 3; Teigrob, Warming Up to the Cold War, 25, 49, 50; Sean M. Maloney, Learning to Love the
} 
In January 1963 Liberal leader Pearson announced that his government would abide by the commitments Canada had made to its military allies, suggesting support for the installation of nuclear arms in Canada. ${ }^{1139}$ Pearson's speech identified the hypocrisy of refusing nuclear weapons for Canada on moral grounds, while the Canadian government benefitted from the sale of uranium for the production of such arms. ${ }^{1140}$ It was only after this time that disarmers began protesting the sale of Canadian uranium to foreign governments for the production of nuclear weapons. ${ }^{1141}$

The shift in Liberal policy towards nuclear arms had further implications the ways disarmers framed their message opposing nuclear arms for Canada. Liberal strategist and speechwriter Tom Kent contended that the party must be prepared to address any accusations of "being poor Canadians" when publicizing the new Liberal policy. To do so, Kent advised, "We should insist that good Canadianism means living on good terms with our friends in the free world. ${ }^{1142}$ In order to sell Canadians on the idea of acquiring nuclear arms, Kent argued, Liberals had to redefine what it meant to be Canadian. As Pearson's announcement emphasized, Canada could not stand for moral superiority and

Bomb: Canada's Nuclear Weapons During the Cold War (Washington: Potomac Books, 2007), 2; Bothwell, The Big Chill, 214.

1139 "Text of an address by the Honourable Lester B. Pearson," 12 January 1963, LAC, Lester B. Pearson fonds, MG26-N2, vol. 50, file 806.2 part 3, 7.

1140 "Text of an address by the Honourable Lester B. Pearson," 12 January 1963, 3, 4.

${ }^{1141}$ Charlotte McEwen to L. B. Pearson, 14 January 196[3], LAC, Lester B. Pearson fonds, MG26-N2, vol. 50, file 806.2 part 3, 1; Mrs. W. Walsh to Mr. Pearson, 31 January 1963, LAC, Lester B. Pearson fonds, MG26-N2, vol. 50, file 806.2 part 3, 2; "Resolutions and Reports of the Annual Conference Combined Universities Campaign for Nuclear Disarmament," February 1963, MUL, CUCND-SUPA fonds, box 7, file: early CUCND material, 2; Youth Campaign for Disarmament, "Policy Statement," June 1963, LAC, James G. Endicott and Family fonds, MG30-C130, vol. 8, file 140, 2; Ulrich Leo to Lester B. Pearson, 11 June 1963, LAC, Lester B. Pearson fonds, MG26-N2, vol. 50, file 806.2 part 3, 1; Eva Sanderson to Lester B. Pearson, 22 January 1964, LAC, James G. Endicott and Family fonds, vol. 18, file 353, 1; Jules Pelletier to Mary Rea Bain, 23 January 1963, LAC, Voice of Women fonds, MG28-I218, vol. 20, file: Officials correspondence 1963-1965, 1.

1142 Tom Kent, "Strategy for Victory," 12 February 1963, LAC, Liberal Party of Canada fonds, MG28-IV3, vol. 689, file: national office general correspondence elections 1962-1963 (2), 5. 
"middle power" leadership as disarmers had claimed. Instead, it should be about being a good friend, and in this case in particular, a good friend to the United States and to other members of the North Atlantic Treaty Organization (NATO). ${ }^{1143}$

Disarmers countered arguments about the importance of loyalty and good allyship by highlighting the risks of relying on relationships with the United States and NATO. Journalist James Minifie's 1960 bestseller, Peacemaker or Powder-Monkey, provided anti-nuclear activists with the language necessary to challenge the new Liberal position. Minifie described Canada as a peaceful community, without a history of territorial ambitions, and having proven its peacemaking talents during the Suez crisis and by choosing not to develop its own nuclear warheads. ${ }^{1144}$ However, Minifie argued, such qualities were "cancelled out by the fact that Canada is still walking with the Devil," referring to the United States. ${ }^{145}$ Minifie was particularly concerned that Canada was increasingly becoming a "puppet" of the United States. ${ }^{1146}$ His insistence that Canada withdraw from NATO and NORAD and reinvest in the United Nations for the sake of preserving Canadian sovereignty was picked up and disseminated by Canadian disarmers. ${ }^{1147}$

\footnotetext{
1143 "Text of an address by the Honourable Lester B. Pearson," 12 January 1963, 2, 3, 4, 5.

1144 James M. Minifie, Peacemaker or Powder-Monkey: Canada's Role in a Revolutionary World (Toronto: McClelland \& Stewart Limited, 1960), 2-3, 28.

${ }_{1145}$ Minifie, Peacemaker or Powder-Monkey, 3.

${ }_{1146}$ Minifie, Peacemaker or Powder-Monkey, 11.

${ }_{1147}$ Minifie, Peacemaker or Powder-Monkey, 3, 20, 172; James Minifie, "Midweek Review," 22 October 1958, LAC, James G. Endicott and Family fonds, MG30-C130, vol. 68, file 1396, 2; Young to Diefenbaker, 12 January 1963, 2; CUCND, "Federal Conference Report Nov. 1963," 9-12 November 1963, MUL, CUCND-SUPA fonds, box 11, file: CUCND federal conference report-Nov. 1963, 1; "Address of Jacques Larue-Langlois," 25 October 1963, MUL, CCND fonds, SW571, box 1, file 10, 5; United Electrical Radio and Machine Workers of America to John Diefenbaker, 4 May 1960, LAC, James. G. Endicott and Family fonds, MG30-C130, vol. 8, file 128, 1; Committee on Nuclear Disarmament at the University of Toronto, "Brief to the Prime Minister of Canada," 2 June 1960, UOS, John G. Diefenbaker fonds, MG01/VII/A/671, Diefenbaker centre row 4, vol. 79, 16; Hugh Keenleyside to J. G. Diefenbaker, 30 March 1961, MUL, CCND fonds, SW571, box 2, file 13, 1-2.
} 
While Minifie's ideas had influenced Canadian disarmament efforts since his book was released in 1960, it was not until after Pearson's January 1963 speech that antiAmericanism began to intensify in anti-nuclear protests. Soon after the announcement of the Liberal stance on nuclear arms, the Montreal CPC argued that Canadians would be bowing "in humiliation to the arrogant U.S.A. demand" if American nuclear warheads were installed on Canadian soil. ${ }^{148}$ Following the victory of the pro-nuclear Liberals in the April 1963 federal election, the CPC distributed advertisements and press releases proclaiming that Canada was merely "tagging along" with Washington if the government accepted nuclear arms, making the nation "a nuclear dump." 1149 The Winnipeg Peace Council wrote to the editor of the Winnipeg Free Press that the Pearson government "has signed away our sovereignty and our future" when negotiations with the United States for the placement of American nuclear weapons on Canadian soil were completed. ${ }^{150}$ The Quebec Mouvement pour le désarmement nucléaire (MDN) similarly argued that the Liberal government had "so cheaply sold part of Canada's sovereignty." 1151 One member of the Manitoba CPC, Floyd Williston, compared Canada's condition following Pearson's acceptance of nuclear arms for Canada to the experience of African-American slaves. Williston contended that, "Just as many, many years ago the rights of a people were sold on the auction block by traders in human bodies, so has the Pearson

\footnotetext{
${ }^{1148}$ Montreal Peace Council, "To the Members of the Quebec Provincial Legislature," January 1963, LAC, James G. Endicott and Family fonds, MG30-C130, vol. 8, file 155, 1.

1149 "Mr. Pearson: Please be right again!/M. Pearson, Ayez raison encore une fois, S.V.P.!," October 1963, LAC, James G. Endicott and Family fonds, MG30-C130, vol. 2, file 34; "Peace Group Goes to Ottawa," 7 September 1963, LAC, James G. Endicott and Family fonds, MG30-C130, vol. 2, file 33.

1150 "Sample Letters to Editor and Sample Resolutions," n.d., LAC, James G. Endicott and Family fonds, MG30-C130, vol. 9, file 161, 1. On the bilateral nuclear weapons agreement see Clearwater, Canadian Nuclear Weapons, 42-43.

1151 "Address of Jacques Larue-Langlois," 5.
} 
government, by its nuclear agreement with the USA sold our birthright and sovereignty as a nation." 1152

In spite of the united effort by disarmers to define nuclear arms as contrary to the national interest, anti-nuclear groups were unable to keep nuclear warheads out of Canada. Morale among disarmers collapsed after the stationing of nuclear warheads on Canadian soil on New Year's Eve 1963. Many of the arguments made by disarmers about Canada's special potential to be a leader for peace crumbled as it was demonstrated that Canada held no real moral high ground. The break down of the "No Nuclear Weapons for Canada" campaign left disarmament organizations to re-evaluate their purpose as membership numbers began to fall dramatically. ${ }^{153}$

Though Canadian disarmament organizations found both success and disappointment in their nationally focused "No Nuclear Weapons for Canada" campaign, their efforts were not solely defined by the relationships of anti-nuclear organizations with Canadians. In the years before and after Canadian anti-nuclear groups came together with the 1961 petition, disarmers learned of the value of cooperation as they engaged with transnational disarmament activist networks. While all Canadian disarmament efforts benefitted from international cooperation, the concept meant various things and served diverse purposes for different organizations.

\section{The CPC and socialist internationalism}

\footnotetext{
${ }^{1152}$ Floyd Williston, "Stop the Nuclear Agreement," 5 September 1963, LAC, James G. Endicott and Family fonds, MG30-C130, vol. 9, file 161, 1.

${ }^{1153}$ Wittner, The Struggle Against the Bomb, vol. 2, 202; Manitoba Conference for a Non-Nuclear Canada, "Only Disarmament Guarantees Survival!," 2; "Council Meeting," 15-16 February 1964, LAC, Voice of Women fonds, MG28-I218, vol. 2, file: council meetings minutes 1964, 6.
} 
The CPC was founded in 1949, as the result of a visit to Toronto by a prominent American pacifist professor emeritus of the New York Union Theological College, Harry Ward, who was enthralled by communist-led efforts in Europe to create an international peace organization. During the trip, Ward encouraged two former students to establish a peace council modelled on the European example. The two Canadian United Church ministers then invited fellow minister James G. Endicott to lead a new peace organization headquartered in Toronto. ${ }^{1154}$

A month prior to the establishment of the CPC in May 1949, Endicott attended the World Congress of Partisans of Peace in Paris, which formally launched the international communist-directed peace campaign that would become known as the World Peace Council (WPC). ${ }^{1155}$ The CPC immediately tied itself to the WPC. To illustrate its association with the WPC, the CPC used a dove as its symbol. WPC supporter Pablo Picasso had designed the simple, graphic-line drawing of a dove carrying an olive branch for the 1949 Paris peace congress. ${ }^{1156}$ The Picasso dove, despite its association with communism, was the main internationally-recognized symbol of peace activism until the late-1950s. ${ }^{1157}$

\footnotetext{
${ }^{1154}$ Toronto Provisional Committee to Establish a Peace Council, 26 November 1948, LAC, James G. Endicott and Family fonds, MG30-C130, vol. 1, file 1, 1; Socknat, Witness Against War, 289-290; Gary Moffatt, History of the Peace Movement in Canada (Ottawa, ON: Grapevine Press, 1982), 18; Victor Huard, "The Canadian Peace Congress and the Challenge to Postwar Consensus, 1948-1953," Peace \& Change 19(1) (January 1994): 30; Lawrence S. Wittner, The Struggle Against the Bomb, vol. 1 (Stanford: Stanford University Press, 1993), 211.

${ }^{1155}$ The name World Peace Council and World Council of Peace appear to have been used interchangeably by organization leaders and members. "Carte de delegue," 1949, LAC, James G. Endicott and Family fonds, MG30-C130, vol. 20, file 396; Wittner, The Struggle Against the Bomb, vol. 1, 175.

1156 James G. Endicott, “Christmas Appeal,” December 1964, LAC, James G. Endicott and Family fonds, MG30-C130, vol. 10, file 182, 1; National Labor Conference for Peace, "Peace or War," n.d., LAC, James G. Endicott and Family fonds, MG30-C130, vol. 31, file 595, 1; Wittner, Struggle Against the Bomb, vol. 1, 178.

${ }^{1157}$ Nehring, Politics of Security, 209.
} 
Though free to pursue campaigns that reflected Canadian national interests, the CPC's efforts were inextricably tied to the programme of the WPC. ${ }^{1158}$ The connection allowed the Canadian organization to benefit from the stability and strength of a mass, organized network, with sister organizations in over 70 countries. ${ }^{1159}$ Both the WPC and CPC were intended to act as an "international movement for peace, cutting across every boundary of country, race or creed" through mutual understanding and respect. ${ }^{1160}$ WPC leaders and $\mathrm{CPC}$ organizers regularly referred to their organizations as "the peace movement," giving the impression that the WPC held a monopoly on peace activities across the globe. ${ }^{1161}$

For much of the twentieth century, "peace" was an important self-description of Soviet foreign policy. The Bolsheviks promoted an image of the Soviet Union as a peacemaker following the March 1918 Treaty of Brest-Litovsk, which ended Soviet entanglement in the First World War. ${ }^{1162}$ In the 1920 s, Soviet leaders pursued a policy of "peaceful coexistence" in hopes of establishing friendly relations with capitalist nations

\footnotetext{
1158 James Endicott, "Dear Friends of Peace," December 1957, LAC, James G. Endicott and Family fonds, MG30-C130, vol. 7, file 108, 2; F. Vigne to Canadian Peace Congress, 24 February 1959, LAC, James G. Endicott and Family fonds, MG30-C130, vol. 7, file 119, 1.

${ }^{1159}$ Wittner, The Struggle Against the Bomb, vol. 1, 184.

1160 "The Nature and Purpose of the Canadian Peace Congress," 1 March 1960, LAC, James G. Endicott and Family fonds, MG30-C130, vol. 1, file 6, 1; World Council of Peace, "10 ${ }^{\text {th }}$ Anniversary Declaration," 13 May 1959, LAC, James G. Endicott and Family fonds, MG30-C130, vol. 26, file 486, 1; Congress for Disarmament and International Cooperation, "Statement by Sponsors," 16-22 July 1958, LAC, James G. Endicott and Family fonds, MG30-C130, vol. 7, file 111, 1.

${ }^{1161}$ The Provisional Committee for a Canadian National Peace Congress, "Statement of Purpose," n.d., LAC, James G. Endicott and Family fonds, MG30-C130, vol. 1, file 1, 1; "The Nature and Purpose of the Canadian Peace Congress," 1950, LAC, James G. Endicott and Family fonds, MG30-C130, vol. 1, file 6, 1; Mary Jennison, "The Growth of the Peace Movement in Canada," n.d., LAC, James G. Endicott and Family fonds, MG30-C130, vol. 1, file 1, 1-2; James G. Endicott, "Christmas Appeal," 1956, LAC, James G. Endicott and Family fonds, MG30-C130, vol. 2, file 21, 1; Vigne to Canadian Peace Congress, 24 February 1959, 1; World Council of Peace, "Session of the Bureau of the World Council of Peace," 30 March-2 April 1957, LAC, James G. Endicott and Family fonds, MG30-C130, vol. 24, file 461, 3; World Council of Peace, " $10^{\text {th }}$ Anniversary Declaration," 1.

${ }_{1162}$ Timothy Johnston, "Peace or Pacifism? The Soviet 'Struggle for Peace in All the World, 1948-54," The Slavonic and East European Review 86(2) (April 2008): 260.
} 
to protect their young communist revolution: only under peaceful conditions could socialism grow in world politics. ${ }^{1163}$ By the late 1940 s, the dictums of "peaceful coexistence" and "peace in all the world," were central themes in Soviet foreign policy rhetoric. ${ }^{1164}$ With this history of Soviet promotion of "peace" and the communist-led WPC's claims to be "the" world peace movement, the term "peace" became entangled with "communism" in the early 1950s. ${ }^{1165}$ As Endicott wrote of the decade, "Peaceful coexistence' was almost a swear word to most NATO block apologists." "1166

One of the primary goals of the WPC network was the outlawing of nuclear arms, because such weapons "endanger the world's population." ${ }^{1167}$ This emphasis on the dangers of nuclear arms further supported assumptions about the organization's subservience to Soviet foreign policy. Until the Soviet Union launched both the world's first intercontinental ballistic missile and earth-orbiting satellite in 1957, North Americans believed that the nuclear deterrent forces of the United States were superior to those of the Soviets. ${ }^{1168}$ As CPC organizers said in 1950, "The Peace Movement has been severely criticised because it seemed to be only concerned about atomic weapons and it is claimed that this puts the U.S. at a disadvantage."1169 The anti-communist press and CPC

\footnotetext{
1163 Geoffrey Roberts, The Soviet Union in World Politics: Coexistence, Revolution and Cold War, 1945 1991 (London: Routledge, 1999), 4.

1164 Johnston, "Peace or Pacifism?," 259, 260; Roberts, The Soviet Union in World Politics, 4-5, 45.

${ }^{1165}$ Nehring, Politics and Security, 160, 161; Moffatt, History of the Peace Movement, 25; Frances B.

McCrea and Gerald E. Markle, Minutes to Midnight: Nuclear Weapons Protest in America (Newbury, Ca.: Sage Publications, 1989), 68; Reg Whitaker and Gary Marcuse, Cold War Canada: The Making of a National Insecurity State, 1945-1957 (Toronto: University of Toronto Press, 1994), 365.

1166 James G. Endicott, "The Nature and Purpose of the Canadian Peace Congress," n.d., LAC, James G. Endicott and Family fonds, MG30-C130, vol. 1, file 6, 1.

1167 James Endicott to Howard Green, 10 July 1962, LAC, James G. Endicott and Family fonds, MG30C130, vol. 8, file 152, 1. See also: "The Nature and Purpose of the Canadian Peace Congress," 1950, LAC, James G. Endicott and Family fonds, MG30-C130, vol. 1, file 6, 1; World Council of Peace, "10 $0^{\text {th }}$ Anniversary Declaration," 1.

${ }^{1168}$ Christopher A. Preble, “'Who Ever Believed in the 'Missile Gap'?': John F. Kennedy and the Politics of National Security," Presidential Studies Quarterly 33(4) (December 2003): 802-803.

1169 "The Nature and Purpose of the Canadian Peace Congress," 1950, 1.
} 
opponents in Canada regularly condemned the organization for being overly critical of the United States and too sympathetic to the Soviet Union. ${ }^{1170}$

The most successful action taken by the CPC, which became one of the most significant expressions of anti-nuclear activism in Canada, was the circulation of the Stockholm Appeal in 1950. Over 500 million people from 79 countries signed the WPCsponsored petition, which called for the "unconditional" banning of nuclear weapons. Among those signatures were 300,000 collected by the CPC — one hundred thousand more signatures than the 200,000 collected for the 1961 "No Nuclear Weapons for Canada" petition. ${ }^{1171}$ The support received for the Stockholm Appeal was remarkable given the association of peace activism, and especially the CPC, with communism, the intensity of anti-communism at the time, and the fact that several petition collectors were arrested. $^{1172}$

In addition to its participation in a mass, international, organized campaign, as a member of the WPC family, CPC had regular access to foreign peace organizations. ${ }^{1173}$ CPC officials engaged in regular correspondence with WPC-affiliated organizations in the Soviet Union, Japan, and the Federal Republic of Germany, among others. Still, the

\footnotetext{
${ }^{1170}$ Marjorie Lamb, "The Canadian Peace Congress and the World Peace Movement," The Alert Service, Spring 1958, LAC, James G. Endicott and Family fonds, MG30-C130, vol. 63, file 1321, 1; Solon E. Low to Eva Sanderson, 16 January 1958, LAC, James G. Endicott and Family fonds, MG30-C130, vol. 7, file 109, 1; James Endicott to Rev. Norman McNairn, 18 January 1963, LAC, James G. Endicott and Family fonds, MG30-C130, vol. 9, file 164, 1.

1171 "Statements on the nature and purpose of the Peace Congress," n.d., LAC, James G. Endicott and Family fonds, MG30-C130, vol. 1, file 6, 1; Regina Peace Council, "Peace is Everyone's Business," 1989, MUL, Canadian Peace Congress fonds, 27ld, box 59, file: Peace Congress History, 3-4; "Petitions for peace," 1949, LAC, James G. Endicott and Family fonds, MG30-C130, vol. 1, file 3, 1; "Press Release," 8 August 1950, LAC, James G. Endicott and Family fonds, MG30-C130, vol. 20, file 402, 1; Wittner, The Struggle Against the Bomb, vol. 1, 183; Wittner, The Struggle Against the Bomb, vol. 2, 197.

1172 Huard, "The Canadian Peace Congress," 26; "The Stockholm Appeal Campaign in Canada," Information Bulletin, Special Bulletin no. 2, 29 August 1950, LAC, James G. Endicott and Family fonds, MG30-C130, vol. 20, file 402, 1.

1173 James Endicott, "Canadian Peace Congress," n.d., LAC, James G. Endicott and Family fonds, MG30C130, vol. 7, file 114, 1 .
} 
CPC's efforts were undermined by the paucity of foreign-language speakers in the Toronto national office. In 1957, the CPC's administrative secretary sent apologies to several WPC affiliates that there was no one in the office who could read Polish, Russian, or even French. ${ }^{1174}$

Through their correspondence with other peace councils, the executive members of the CPC learned how fortunate they were to be Canadians. There was no organized, state-sanctioned effort to destroy peace movements in Canada. ${ }^{1175}$ On behalf of the CPC's national executive, secretary Eva Sanderson wrote to the Argentinian ambassador to express solidarity with the Argentine Peace Council that had been banned by its government in the spring of $1959 .{ }^{1176}$ The CPC also spoke out in support of the German Peace Council, after the Federal Republic of Germany closed down its offices, confiscated its funds, and tried the council's leaders for "activities contrary to the constitutional order." "1177 The CPC national executive contributed to the defence fund for

\footnotetext{
${ }^{1174}$ Soviet Peace Committee, 4 November 1955, LAC, James G. Endicott and Family fonds, MG30-C130, vol. 1, file 19; Kenjuro Yanagita, 28 October 1955, LAC, James G. Endicott and Family fonds, MG30C130, vol. 1, file 19, 1; CPC administrative secretary to Kierunki, 27 March 1957, LAC, James G. Endicott and Family fonds, MG30-C130, vol. 6, file 106; CPC administrative secretary to New Korea, 27 March 1957, LAC, James G. Endicott and Family fonds, MG30-C130, vol. 6, file 106; CPC administrative secretary to Bratiski Vesnik, 27 March 1957, LAC, James G. Endicott and Family fonds, MG30-C130, vol. 6, file 106; CPC administrative secretary to La Roumani Nouvelle, 22 April 1957, LAC, James G. Endicott and Family fonds, MG30-C130, vol. 6, file 106.

${ }_{1175}$ Robbie Lieberman, The Strangest Dream: Communism, Anticommunism, and the U.S. Peace Movement, 1945-1963 (Syracuse: Syracuse University Press, 2000), 171, 180; Swerdlow, Women Strike for Peace, 101; Harriet Hyman Alonso, Peace as a Women's Issue: A History of the U.S. Movement for World Peace and Women's Rights (Syracuse: Syracuse University Press, 1993), 159; Steve Hewitt, "Sunday Morning Subversion: The Canadian Security State and Organized Religion in the Cold War," in Love, Hate, and Fear in Canada's Cold War, ed. Richard Cavell (Toronto: University of Toronto Press, 2004), 67; Steve Hewitt and Christabelle Sethna, "Sex Spying: The RCMP Framing of English-Canadian Women's Liberation Groups during the Cold War," in Debating Dissent: Canada and the Sixties, edited by Lara Campbell, Dominique Clément and Gregory S. Kealey (Toronto: University of Toronto Press, 2012), 139; Whitaker and Marcuse, Cold War Canada, 4;

${ }^{1176}$ Eva Sanderson to the Argentinian Ambassador, 26 May 1959, LAC, James G. Endicott and Family fonds, MG30-C130, vol. 7, file 124, 1.

${ }_{1177}$ Jacqueline Dineen to the German Peace Council, 12 November 1959, LAC, James G. Endicott and Family fonds, MG30-C130, vol. 7, file 125, 1-2.
} 
Dr. William Uphaus, an American Methodist preacher and pacifist, who served a year in jail for refusing to provide the names of those who had attended a peace conference to a New Hampshire state legislative committee investigating "subversives." ${ }^{1178}$ CPC members also served as middlemen, assisting American activists to obtain visas to attend conferences in communist countries, such as China. This was necessary because the American security state paid much closer attention to suspicious mail than did the Canadian government. ${ }^{1179} \mathrm{CPC}$ officials recognized the privilege that accrued to them as citizens of a country with a relatively moderate approach to communism.

Alongside the benefits of a large international organization, the association with the communist-led WPC did have significant ramifications for the CPC's reputation in Canada. Vocal anti-communists referred to the CPC as a "tool of Soviet imperialism"1180 and "Moscow's agents in Canada," 1181 and described Endicott as "Stalin's remittance man,"1182 "an old-time Communist agent,"1183 and "the no. 1 Commie stooge in Canada." 1184 Secretary of state for External Affairs Lester B. Pearson led a personal

1178 "Report of the Proceedings of the National Council of the Canadian Peace Congress," 3-4 December 1960, LAC, James G. Endicott and Family fonds, MG30-C130, vol. 12, file 228, 1; Jacqueline Dineen to H. E. Raphael de la Colina, 21 February 1962, LAC, James G. Endicott and Family fonds, MG30-C130, vol. 2, file 32, 1; Willard Uphaus to Eva Sanderson, 20 February 1960, MUL, Canadian Peace Congress fonds, 47-1992, box 1, file: activists Willard Uphaus 1956-61, 1.

${ }^{1179}$ Florence Luscomb to Mary Endicott, 22 May 1962, LAC, James G. Endicott and Family fonds, MG30C130, vol. 8, file 143, 1 .

${ }^{1180}$ Rev. Gordon C. Smyth on CKEY radio, "The Red Vulture in Toronto," 25 May 1952, James G.

Endicott and Family fonds, MG30-C130, vol. 63, file 1321, 2.

${ }^{1181}$ United Canadian Committee, "Freedom for All Individuals and Nations," April 1951, LAC, James G. Endicott and Family fonds, MG30-C130, vol. 63, file 1321, 1.

1182 Ukrainian Association of Victims of Russian Communist Terror, "To the Citizens of Canada," 31 January 1954, LAC, James G. Endicott and Family fonds, MG30-C130, vol. 63, file 1321, 2.

${ }^{1183}$ Pat Walsh, "The Truth Will Out," The South End News, 30 November 1961, LAC, James G. Endicott and Family fonds, MG30-C130, vol. 64, file 1330, 4.

${ }^{1184}$ Pat Walsh, "The Truth Will Out," The South End News, 14 December 1961, LAC, James G. Endicott and Family fonds, MG30-C130, vol. 64, file 1330, 4. 
crusade against the CPC in the early 1950s, making numerous public speeches

condemning the organization for its connections to communism. ${ }^{1185}$

CPC branches were blocked from renting spaces for meetings by school boards

and church councils, and in Quebec, the province's notorious "Padlock Law" prevented

CPC meetings with its power to close any facility used for the dissemination of

communist propaganda. ${ }^{1186}$ Endicott and other CPC members faced regular persecution

by the RCMP when returning from international peace conferences. Endicott complained

of unnecessary luggage searches and the seizing of papers and photographs by the RCMP

every time he returned to Canada between 1951 and 1958. ${ }^{1187}$ RCMP surveillance notes

on CPC activities indicate intense suspicion of and a strong degree of hostility towards

the $\mathrm{CPC}$, suggesting that the body was unlikely to receive sympathetic treatment from

police. ${ }^{1188}$

${ }_{1185}$ Mary Endicott to Lester B. Pearson, 22 May 1951, LAC, Lester B. Pearson fonds, MG26-N1, vol. 4, file: Pearson, L.B. Endicott, Mrs. James-1947-1951, 1; Stephen Endicott, James G. Endicott: Rebel Out of China (Toronto: University of Toronto Press, 1980), 275, 277; Whitaker and Marcuse, Cold War Canada, 372-373.

${ }^{1186}$ Edith Holtom to J. Houlahan, 6 December 1949, LAC, Edith Ellen Holtom fonds, MG31-I1, vol. 2, file: general disarmament 1948-1970, 1; Edith Holtom to H. Pullen, 5 February 1951, LAC, Edith Ellen Holtom fonds, MG31-I1, vol. 2, file: general disarmament 1948-1970, 1; Mickey Stratford to Jackie [Dineen], 9 October 1962, LAC, James G. Endicott and Family fonds, MG30-C130, vol. 8, file 147, 2; Hellen Hall, "Montreal Peace Council," ca. 1951, LAC, James G. Endicott and Family fonds, MG30-C130, vol. 17, file 337, 1; Whitaker and Marcuse, Cold War Canada, 378.

${ }^{1187}$ James Endicott, “A statement on searches of my baggage and person by RCMP officers," n.d., LAC, James G. Endicott and Family fonds, MG30-C130, vol. 63, file 1322, 1-2; James Endicott to E. D. Fulton, 25 January 1958, LAC, James G. Endicott and Family fonds, MG30-C130, vol. 63, file 1322, 1; Lucile Barash to Officier-Commandant Division 'C' Gendarmerie Royale du Canada, 29 novembre 1952, LAC, James G. Endicott and Family fonds, MG30-C130, vol. 20, file 395, 1.

${ }^{1188}$ Royal Canadian Mounted Police, Division 'O,' Toronto S.I.B., "Re: Canadian Peace Congress, National Conference," 15 November 1960, LAC, CSIS files, RG 146-723, vol. 2, file: Canadian Peace Congress correspondence from 4-3-58 to 19-12-60, 1 (obtained under access to information); Inspector D. E. McLaren to the officers commanding RCMP 'A,' 'C,' 'D,' ' $F$,' ' $H$,' and ' $K$ ' divisions, 17 November 1960, LAC, CSIS files, RG 146-723, vol. 2, file: Canadian Peace Congress correspondence from 4-5-58 to 19-12-60, 1 (obtained under access to information); Cst. W. G. Elkeer, "Re: Canadian Peace Congress (National Council) Canada," 1 February 1962, LAC, CSIS files, RG 146-723, vol. 4, file: Canadian Peace Congress correspondence from 22-4-61 to 12-12-69, 3-4 (obtained under access to information); Cpl. W. H. Dustan, "Re: Communist Party of Canada Provincial Executive Committee, Ontario," 12 April 1969, LAC, CSIS files, RG 146-723, vol. 4, file: Canadian Peace Congress correspondence from 2-4-61 to 12-1269,3 (obtained under access to information). 
The Canadian government issued a "look-out list" of persons to be banned from entering Canada for political reasons, which, in the early 1950s, featured most of the executive of the WPC, including Picasso, French philosopher Jean-Paul Sartre, Chilean poet Pablo Neruda, American chemist Linus Pauling, and German playwright Bertolt Brecht. ${ }^{1189}$ Two CPC events in 1952 and 1953 were compromised when the keynote speakers, American civil rights activist W. E. B. DuBois and British feminist social activist Monica Felton, were prevented from entering Canada. ${ }^{1190}$

The worst abuses faced by CPC members were instances of violence from anticommunists. One former member of the Regina Peace Council recalled being greeted at the door by a man with a hunting rifle and an elderly member being pushed down a flight of stairs while they were canvassing for signatures for a peace petition in the early 1950s. ${ }^{191}$ CPC gatherings were marred by incidents of threatening verbal assaults and disruptive acts, such as the throwing of tomatoes at one $1953 \mathrm{CPC}$ assembly at Massey Hall in Toronto. ${ }^{1192 ~ " I n c e n d i a r y ~ d e v i c e s " ~ w e r e ~ s e t ~ o f f ~ a t ~ t w o ~ e n t r a n c e s ~ t o ~ t h e ~ E n d i c o t t ~}$ home while Endicott's wife Mary was hosting a group of 40 women. ${ }^{1193}$

James Endicott attempted to keep the organization isolated from formal communist politics in Canada, and was not personally associated with the Communist

\footnotetext{
${ }^{1189}$ Whitaker and Marcuse, Cold War Canada, 372.

${ }^{1190}$ L. C. Park, 11 May 1962, LAC, James G. Endicott and Family fonds, MG30-C130, vol. 16, file 311, 1; E. M. Alpin to Walter Harris, 30 April 1953, LAC, James G. Endicott and Family fonds, MG30-C130, vol. 17 , file 330,1 .

${ }^{1191}$ John Beeching, email to author, 8 November 2013.

1192 Toronto Peace Council, "Memorandum to Individuals and Organizations in Toronto," 2 October 1953, LAC, James G. Endicott and Family fonds, MG30-C130, vol. 17, file 329, 2.

${ }^{1193}$ The Toronto Daily Star's report of the event describes the incident as only involving a "stink bomb," however the archives and historians Reg Whitaker and Gary Marcuse all agree that there was in fact a fire and that people could have been seriously injured. "Memorandum to Individuals and Organizations in Toronto from the Toronto Peace Council," 2 October 1953, LAC, James G. Endicott and Family fonds, MG30-C130, vol. 63, file 1321, 1-2; “40 Endicott Guests Flee 'Stink Bombs,” Toronto Daily Star, 1 October 1953, 2; Endicott, James G. Endicott, 285-286; Whitaker Marcuse, Cold War Canada, 377.
} 
Party of Canada. ${ }^{1194}$ At an early meeting of the provisional committee to establish a peace council in Canada, organizers, including Mary Endicott, agreed that the founding principles of the Canadian Peace Congress must emphasize "that we are not trying to deal with the foreign policy of Soviet Russia and we are not trying to organize any attack on Canadian foreign policy. We are going to urge that all questions of international dispute shall be settled by discussion and compromise." ${ }^{1195}$ In this way, the organizers sought from the Congress' beginnings to disassociate their peace efforts from Cold War politics. But, because of the clear communist domination of the WPC and the fact that a large percentage of CPC supporters were members of the Communist Party of Canada, attempts to disassociate the CPC from communism were futile. ${ }^{196}$

In spite of James Endicott's protests against characterizations of him as a "bigname Red," the CPC's programme was in fact firmly grounded in the socialist internationalism of the WPC. ${ }^{1197}$ Socialists generally accepted that war was caused by problems of economic injustice and political repression. ${ }^{1198}$ Socialist internationalism represented a largely working-class struggle against capitalism, seeking to address exploitation across the globe. ${ }^{1199}$ Eventually, with the elimination of capitalism and the oppression that comes with it, lasting peace, in theory, could be obtained. ${ }^{1200}$ While this

${ }^{1194}$ S. H. Morrison to Hon L. B. Pearson, 3 May 1950, LAC, James Endicott and Family fonds, MG30C130, vol. 20, file 386, 1; James Endicott, “Mailbag," Maclean's Magazine, 30 August 1958, LAC, James G. Endicott and Family fonds, MG30-C130, vol. 63, file 1323, 4; Whitaker and Marcuse, Cold War Canada, 372-373; Endicott, James G. Endicott, 271; Moffatt, History of the Peace Movement, 18; Huard, "The Canadian Peace Congress," 33-34.

1195 "Toronto Provisional Committee to Establish a Peace Council," 26 November 1948, LAC, James G. Endicott and Family fonds, MG30-C130, vol. 1, file 1, 2.

${ }^{1196}$ Endicott, James G. Endicott, 270; Whitaker and Marcuse, Cold War Canada, 366.

1197 James Endicott to the Editor Maclean's, 11 July 1958, LAC, James G. Endicott and Family fonds, MG30-C130, vol. 63, file 1323, 1.

${ }^{1198}$ Young, "The Peace Movement," 194.

${ }^{1199}$ Harris, "Cuban Internationalism," 28-29; Joachim C. Häberlen, "Between global aspirations and local realities: the global dimensions of interwar communism," Journal of Global History 7 (2012): 415.

${ }^{1200}$ Johnston, "Peace or Pacifism?," 261. 
belief served as the driving principle behind many socialist pacifist movements, by no means did it lead all socialists to pacifism. ${ }^{1201}$

The purposes of the CPC and the founding philosophies of the WPC demonstrated an acceptance of socialist internationalism. The CPC was formed with the belief that a "selfish drive for profit...lies behind all aggression." 202 The principles of the WPC, as emphasized at its tenth anniversary session, included a demand for the "establishment of normal commercial relations based on mutual advantage." ${ }^{1203}$ Both organizations critiqued capitalism as an economic system that bred exploitation and oppression for the benefit of the few.

For the $\mathrm{CPC}$ and the WPC, in addition to more equitable economic relations, the "elimination of all forms of colonialism and racial discrimination" and the recognition of "the right of people to their sovereignty and independence" were considered necessary for the establishment of peace. ${ }^{1204}$ Anti-imperialism was intrinsic to the socialist internationalism practiced by the WPC. ${ }^{1205}$ From as early as the 1920 s, the colonial world played an important role in Soviet foreign policy, as the "labouring masses" of the colonies were seen to represent a potent "auxiliary force" for the world socialist revolution. ${ }^{1206}$ However, it was the understanding that capitalist imperialism propagated

\footnotetext{
${ }^{1201}$ Fanny Coulomb and Renaud Bellais, "The Marxist Analysis of War and Military Expenditures, Between Certainty and Uncertainty," Defence and Peace Economics 19(5) (October 2008): 351-352; Young, "The Peace Movement," 194; Susan B. Whitney, Mobilizing Youth: Communists and Catholics in Interwar France (Durham and London: Duke University Press, 2009), 36; Johnston, "Peace or Pacifism?," 333.

1202 "Draft resolution to the Canadian Peace Congress, 1948-1948," LAC, James G. Endicott and Family fonds, MG30-C130, vol. 1, file 1, 1.

${ }^{1203}$ World Council of Peace, " $10^{\text {th }}$ Anniversary Declaration," 1.

${ }^{1204}$ World Council of Peace, " $10^{\text {th }}$ Anniversary Declaration," 1.

${ }^{1205}$ Harris, "Cuban Internationalism," 29; Andrée Lévesque, "Anniversaires et manifestations des camarades: la culture international et l'identitaire communists au Canada pendant l'entre-deux-guerres," Labour/Le Travail 49 (Spring 2002): 84-85.

${ }^{1206}$ Häberlen, "Between global aspirations and local realities," 421.
} 
war that more importantly drove the anti-colonialism of the WPC and of many socialist peace activists. $^{1207}$

CPC members recognized that the fight against colonialism could not be separated from the battle against war. At the June 1957 WPC meeting at Colombo, Sri Lanka, WPC members released a statement declaring that "real peace cannot exist so long as the desires of the peoples for independence are restrained by force."1208 The Windsor branch of the CPC announced that, so long as "vast numbers of our fellowmen" were denied "the good things of earth," peace and security were impossible. ${ }^{1209}$ WPC and CPC members were reiterating the principles of the April 1955 Bandung Conference, which had brought together representatives from 29 independent and nearly-independent Asian and African states. The final communiqué of the conference concluded that "respect for human rights, state sovereignty and territorial integrity, racial equality, and the promotion of economic and cultural cooperation" would help enhance security in the face of the prospect of complete annihilation in nuclear war. ${ }^{1210}$

While Endicott recognized the legitimacy and importance of anti-colonial struggles in the Global South, he argued that the question of colonialism was dangerously

\footnotetext{
${ }^{1207}$ Roscoe Rodd to the CPC, 8 April 1959, LAC, James G. Endicott and Family fonds, MG30-C130, vol. 7, file 124, 1; Günter Wernicke, "The Communist-Led World Peace Council and the Western Peace Movements: The Fetters of Bipolarity and Some Attempts to Break Them in the Fifties and Early Sixties," Peace \& Change 26(3) (July 2001): 267.

1208 "The Colombo Appeal to All Governments for the Immediate Ending of Nuclear Tests," June 1957, LAC, James G. Endicott and Family fonds, MG30-C130, vol. 7, file 107, 2.

${ }^{1209}$ Roscoe Rodd to the CPC, 8 April 1959, LAC, James G. Endicott and Family fonds, MG30-C130, vol. 7, file 124, 1. See also: "Statements on the nature and purpose of the Peace Congress," n.d., 1; Bruce Mickleburgh, 5 July 1957, LAC, James G. Endicott and Family fonds, MG30-C130, vol. 7, file 107; Mary Jennison, "The Growth of the Peace Movement in Canada," n.d., LAC, James G. Endicott and Family fonds, MG30-C130, vol. 1, file 1, 3 .

${ }^{1210}$ Christopher J. Lee, "At the Rendezvous of Decolonization: the Final Communiqué of the Asian-African Conference, Bandung, Indonesia, 18-24 April 1955," Interventions 11(1) (March 2009): 87; Naoko Shimazu, "Diplomacy as Theatre: Staging the Bandung Conference of 1955," Modern Asian Studies 48(1) (January 2014): 226.
} 
dividing the WPC. He contended in March 1959 that the issue of atomic warfare and the risks of nuclear fallout were paramount to Canadians, but these problems were remote for WPC representatives from Latin America, Asia, and Africa, who were more intent on encouraging the redistribution of wealth to bring about peace. ${ }^{1211}$ Nevertheless, the CPC followed the lead of the WPC, and increasingly shifted its attention away from nuclear arms in the early 1960 s to anti-colonial struggles and to the promotion of national selfdetermination. $^{1212}$

Led by Endicott, who spent nearly two decades working as a Methodist missionary in China, the CPC regularly spoke in opposition to the exclusion of China from the United Nations and any intervention in Chinese politics by the international community. ${ }^{1213}$ The CPC initiated a campaign protesting American interference in Cuban politics, which attracted the interest of many American socialists and peace activists. ${ }^{1214}$ The national council of the $\mathrm{CPC}$ also publicly supported Congolese anti-colonial efforts

\footnotetext{
${ }^{1211}$ Endicott, "World Peace Council Problems," 2-3.

1212 "The Nature and Purpose of the Canadian Peace Congress," 1950, 1; James Endicott, "Report on Cuba and World Peace," 19 January 1961, LAC, James G. Endicott and Family fonds, MG30-C130, vol. 8, file 138, 1; Eleanor Stevenson, 2 February 1963, LAC, James G. Endicott and Family fonds, MG30-C130, vol. 8, file 156, 1; "Report of the Proceedings of the National Council of the Canadian Peace Congress," 3-4 December 1960, LAC, James G. Endicott and Family fonds, MG30-C130, vol. 12, file 228, 2; Peter Simon, 22 October 1964, LAC, James G. Endicott and Family fonds, MG30-C130, vol. 10, file 175, 1.

1213 "Its Your Life Don't Let Chiang Kai-shek or Foster Dulles End It," 1958, LAC, James G. Endicott and Family fonds, MG30-C130, vol. 7, file 114, 1; "Resolutions National Council Canadian Peace Congress," 10 November 1958, LAC, James G. Endicott and Family fonds, MG30-C130, vol. 7, file 118, 1; British Columbia Peace Council, "Petition to the Canadian Government," 6 February 1959, LAC, James G. Endicott and Family fonds, MG30-C130, vol. 7, file 124, 1; "Submission of the Saskatchewan Peace Council to the members of the Saskatchewan Legislature," 13 March 1959, LAC, James G. Endicott and Family fonds, MG30-C130, vol. 7, file 119, 2; Gardner to Endicott, 21 February 1961, 1; "Statement on the Test Ban Treaty," 30 July 1963, LAC, James G. Endicott and Family fonds, MG30-C130, vol. 2, file 34, 1. ${ }^{1214}$ James Endicott, "Report on Cuba and World Peace," 19 January 1961, LAC, James G. Endicott and Family fonds, MG30-C130, vol. 8, file 138, 1; James G. Endicott, "A Canadian Letter to President Kennedy," n.d., LAC, James G. Endicott and Family fonds, MG30-C130, vol. 8, file 139, 1; "Canadian Peace Congress Submission to the Right Honorable John Diefenbaker," 15 May 1961, LAC, James G. Endicott and Family fonds, vol. 8, file 139, 3; George J. Meyer to the CPC, 2 April 1962, LAC, James G. Endicott and Family fonds, MG30-C130, vol. 8, file 142, 1; Norman McNairn to James Endicott, 16 January 1963, LAC, James G. Endicott and Family fonds, MG30-C130, vol. 9, file 164, 1; Jacqueline Dineen, "Annual Report," 25 March 1964, LAC, James G. Endicott and Family fonds, MG30-C130, vol. 10 , file $178,1$.
} 
in $1960 .{ }^{1215}$ By 1965 , the CPC's main campaign was centred on opposition to the war in Vietnam. ${ }^{1216}$

At the December 1960 national council meeting of the CPC, Endicott admitted that "the white man's oppression of Africa must end," and that Africans "have the right to revolt, civil war or any other kind of violence that they wish to use... because generally speaking they have no other way to get their wrongs righted." ${ }^{1217}$ In announcing his approval of violence in the case of anti-colonial struggles, Endicott embroiled the CPC in one of the awkward tensions common to socialist peace movements. ${ }^{1218}$ As national liberation movements rose up in the Global South, the CPC, like much of the socialist pacifist world, struggled to balance peace activism with communist conceptions of "revolutionary" wars waged by oppressed peoples against capitalist powers as "just wars." 1219

The questions of "legitimate" wars of liberation and the right of peoples to selfdetermination served to exacerbate strains within the CPC between members with varying devotions to pacifism. In the end, these divisions, particularly Endicott's stance that China was justified in refusing to sign the Limited Test Ban Treaty because of the potential threat of American imperialism and his support for China in instances of

\footnotetext{
1215 "Report of the Proceedings of the National Council of the Canadian Peace Congress," 3-4 December 1960, LAC, James G. Endicott and Family fonds, MG30-C130, vol. 12, file 228, 2.

1216 J. M. Beeching, "Dear Friend," 16 June 1965, LAC, James G. Endicott and Family fonds, MG30-C130, vol. 18, file 360, 1; James Endicott, "Christmas Appeal," December 1965, LAC, James G. Endicott and Family fonds, MG30-C130, vol. 10, file 189, 1; “Accelerate Peace for Vietnam!," 24 January 1966, LAC, James G. Endicott and Family fonds, MG30-C130, vol. 18, file 360, 1; Manitoba Peace Council, "Newsletter," May 1966, LAC, James G. Endicott and Family fonds, MG30-C130, vol. 19, file 363, 1. 1217 "Report of the Proceedings of the National Council of the Canadian Peace Congress," 3-4 December $1960,7,4$.

${ }^{1218}$ Endicott, "World Peace Council Problems," 2-3.

${ }^{1219}$ Endicott, "The Nature and Purpose of the Peace Congress," n.d., 1; Whitney, Mobilizing Youth, 36; Günter Wernicke, "The Unity of Peace and Socialism? The World Peace Council on a Cold War Tightrope Between the Peace Struggle and Intrasystemic Communist Conflicts," Peace \& Change 26(3) (July 2001): 333.
} 
conflict with the Soviet Union, led the CPC to separate ties from its long-time leader. ${ }^{1220}$ Still, this broader concentration on the interrelation of imperialism and war did have the benefit of providing the $\mathrm{CPC}$ with a continued purpose after nuclear disarmament began to fade from public attention in late $1963 .^{1221}$

\section{Inspiration, imitation, and initiative: the CCCRH, the CUCND, and international cooperation}

International cooperation for the CPC was ideologically-based and guided every campaign the organization pursued. For genuinely non-partisan organizations, such as the CCCRH and the CUCND, international cooperation served more utilitarian purposes. Some Canadian groups were spurred to action by successful external protest efforts, particularly those in Britain and the United States, and sought to emulate their international colleagues. Like the $\mathrm{CPC}$, the creation of the $\mathrm{CCCRH}$ was inspired by activist efforts abroad. In January 1959, Mary Van Stolk of Edmonton started a mother's study group on nuclear radiation hazards, which quickly became a national organization after she sought guidance from leaders of the American group the National Committee for a Sane Nuclear Policy (SANE). SANE was the core of American opposition to nuclear weapons testing, and Homer Jack of SANE had helped get the internationally influential British Campaign for Nuclear Disarmament (CND) off the ground in January

\footnotetext{
${ }^{1220}$ Mel Doig to CPC, 11 August 1963, LAC, James G. Endicott and Family fonds, MG30-C130, vol. 8, file 1690, 2-3; Jacqueline Dineen to Mel Doig, 5 September 1963, LAC, James G. Endicott and Family fonds, MG30-C130, vol. 8, file 160, 1-2; "Minutes of the National Executive Meeting," 4 September 1963, LAC, James G. Endicott and Family fonds, MG30-C130, vol. 12, file 234; "Statement on the Test Ban Treaty," 30 July 1963, 1; Moffatt, History of the Peace Movement, 22-23; Donn Downey, "Obituary: James Gareth Endicott," The Globe and Mail, 29 November 1993, C5.

${ }^{1221}$ Endicott, James G. Endicott, 329.
} 
1958, following Britain's first hydrogen bomb test. ${ }^{1222}$ By selecting SANE leaders as her mentors in organizing anti-nuclear protests, Van Stolk was drawing on the experience of a group of men who had already had success. After visits to New York and Los Angeles to discuss issues of organization and policy, Van Stolk kept up regular correspondence with SANE executive members as she prepared to unveil the national CCCRH. ${ }^{1223}$ Following the example set by SANE and the CND, Van Stolk publicly introduced the CCCRH with a long list of high-profile supporters to shore up the credibility of her organization. $^{1224}$

Though it was the connections with SANE that helped bring the CCCRH to life, members felt more closely aligned with the CND, electing to change the organization's name to the CCND in February $1962 .{ }^{1225}$ The change of name was widely supported by members because of the familiarity that Canadians had with the popular and vocal British CND; there was a sense that the two organizations were "kindred" spirits because of longstanding connections between Canada and Great Britain. ${ }^{1226}$ In addition to adopting the name of their British colleagues, the CCCRH-CCND adopted the CND's logo, the

\footnotetext{
${ }^{1222}$ Katz, Ban the Bomb, 35; Chatfield, The American Peace Movement, 104; Nehring, Politics of Security, 570 .

${ }^{1223}$ Mary Van Stolk, "Report of the National Executive Secretary," 20-21 March 1961, MUL, CCND fonds, SW571, box 4, file 3, 2-3; Donald Keys to Mary Van Stolk, 26 April 1959, MUL, CCND fonds, SW571, box 4, file 1; Donald Keys to Mary Van Stolk, 5 August 1959, MUL, CCND fonds, SW571, box 4, file 1, 1; Christine Ball, "The History of the Voice of Women/La Voix des Femmes: The Early Years, 1960-1963” (Ph.D. diss., University of Toronto, 1994), 72.

1224 "Prominent Canadians Form Committee on Radiation Hazards \& Nuclear Policy," 18 January 1960, MUL, CCND fonds, SW571, box 1, file 1, 1, 5-6; Patricia McMahon, Essence of Indecision: Diefenbaker's Nuclear Policy, 1957-1963 (Montreal: McGill-Queen's University Press, 2009), 67; Wittner, The Struggle Against the Bomb, vol. 2, 196-197.

${ }^{1225}$ Margaret Hanley to F. C. Hunnius, 20 February 1962, MUL, CCND fonds, SW571, box 1, file 2, 1; Helen Tucker to Mr. Thomson, 20 December 1961, MUL, CCND fonds, SW571, box 1, file 2, 1.

${ }^{1226}$ K.C. Woodsworth to J. T. Thorson, 7 June 1963, MUL, CCND fonds, SW571, box 3, file 11, 2. See also: Janet Brown, 27 March 1962, MUL, CCND fonds, SW571, box 6, file 5, 1; Eugene Forsey to F. C. Hunnius, 12 December 1961, MUL, CCND fonds, SW571, box 1, file 2, 1; McMahon, Essence of Indecision, 67, 80; Moffatt, History of the Peace Movement, 28.
} 
semaphore symbols for ' $\mathrm{N}$ ' and ' $\mathrm{D}$ ' signifying nuclear disarmament. This symbol eventually overtook Picasso's dove as the international symbol of peace activism, and is still recognized as the peace symbol. ${ }^{1227}$ The Canadian university disarmament organization, the CUCND, also paid homage to the CND with its name choice and immediate adoption of the 'ND' emblem. ${ }^{1228}$

In addition to tying themselves symbolically to well known international organizations, Canadian disarmers took advantage of the experience of established organizations by leaning on them for guidance on questions of policy and method. Bertha Cowen, of the CCND's committee on publications, reached out to at least 45 organizations from 17 countries, of all political leanings, for information on how organizations delivered information to the public, how their executive committees were structured, what books members read, and whether any information publications could be shared. ${ }^{1229}$ American organizations such as SANE, the Student Peace Union, Turn Towards Peace, and Women Strike for Peace, and European organizations like the West German Ostermarsch der Atomwaffengegner, supplied the CCCRH-CCND and CUCND with updated policy statements to assist the Canadians with policy positions. ${ }^{1230}$

\footnotetext{
${ }^{1227}$ Gilles B. Richard, Dimitrios Roussopoulos, F. C. Hunnius, "Why the Canadian Campaign for Nuclear Disarmament Must Join the International Confederation for Disarmament and Peace," 20-21 July 1963, MUL, CCND fonds, SW571, box 2, file 1, 3; Nehring, Politics of Security, 209; Moffatt, History of the Peace Movement, 28; Benjamin Ziemann, "The Code of Protest: Images of Peace in the West German Peace Movements, 1945-1990," Contemporary European History 17(2) (May 2008): 248.

${ }^{1228}$ Douglas Kay Campbell, A History of the Ban-the-Bomb Movement, Toronto 1959-1961, Part 1 (Toronto, 1961), MUL, CUCND-SUPA fonds, box 1, file: CUCND Toronto office 1960-1961, 5; "The Charter," ca. 1963, MUL, CUCND-SUPA fonds, box 1, file: CUCND Toronto office 1960-1961, 3; Nehring, "National Internationalists," 563.

${ }^{1229}$ Bertha Cowan, "Dear Friends," 19 February 1962, MUL, CCND fonds, ACCN. 05-1989.102f, box 23, file 2 .

${ }^{1230}$ Steve Allen to Mary Van Stolk, 28 December 1960, MUL, CCND fonds, SW571, box 4, file 1, 2; Mirianna Newton to Steve Allen, 8 December 1959, MUL, CCND fonds, SW571, box 4, file 1, 1; Arthur Pape to National Committee for a Sane Nuclear Policy, 25 July 1963, MUL, CCND fonds, box 14, file 23, 1; Homer Jack, 4 October 1963, MUL, CCND fonds, box 14, file 20, 1; Student Peace Union to the Canadian Campaign for Nuclear Disarmament, 12 July 1962, MUL, CCND fonds, box 15, file 4, 1; Liora
} 
A black button with a silver 'ND' symbol on it, produced by the Swedish Kampanjen Mot Atomvapen, caught the eye of CCND officials, who requested large quantities of the pins to sell to Canadians. ${ }^{1231}$ According to disarmament activist Gary Moffatt, some employers took issue with activists who wore the buttons to work. ${ }^{1232}$ Canadian activists also sought to borrow larger statements from foreign organizations, such as the Seattle Peace Information Center's Hiroshima Exhibit, which the CCND toured across Canada. ${ }^{1233}$

Canadian organizations did not merely reproduce successful protest materials used by other organizations, but adapted them to their own needs. University of Manitoba professor of physics F. M. Kelly re-wrote the Greater St. Louis Citizen's Committee for Nuclear Information's "Nuclear War in St. Louis" article to fit Canadian conditions for the Winnipeg Committee for Disarmament. The St. Louis piece presented the fictional story of life in St. Louis following a nuclear bombing, based on scientific research about the consequences of nuclear fallout provided by the Joint U.S. Congressional Committee on Atomic Energy. Kelly extrapolated the American data to create a realistic account of what life would be like in Winnipeg for survivors of a nuclear attack. ${ }^{1234}$

Of all the borrowing by Canadian movements, the most important was their imitation of the British CND's Aldermaston March. The annual 85-kilometre protestmarch from the Aldermaston atomic weapons research centre to central London on Easter

Proctor to Bob Gilmore, 28 September 1964, MUL, CCND fonds, ACCN 05-1989.102.f, box 23, file 7, 1; F. C. Hunnius to Jeanne S. Bagby, 4 June 1962, MUL, CCND fonds, box 15, file 12, 1; Dr. Andreas Buro to Canadian CND, 10 April 1962, MUL, CCND fonds, box 14, file 7, 1.

${ }^{1231}$ F. C. Hunnius to Bertil Svahnstrom, 27 November 1962, MUL, CCND fonds, box 15, file 5, 1.

${ }^{1232}$ Moffatt, History of the Peace Movement, 28.

${ }^{1233}$ Barbara Mark to K. C. Woodsworth, 15 May 1963, MUL, CCND fonds, box 15, file 1, 1.

${ }^{1234}$ F. C. Hunnius to Judith S. Miller, 22 June 1962, MUL, CCND fonds, ACCN. 05-1989.102.f, box 25, file 11, 1; F. M. Kelly, "Nuclear War in Winnipeg: One Year Later, A Story Based Upon Facts," SOS 6 (February 1961), LAC, James G. Endicott and Family fonds, MG30-C130, vol. 20, file 390, 1. 
weekend was a signature event of the British CND. At its largest rally in 1960, the Aldermaston March attracted nearly 100,000 participants to London's Trafalgar Square. ${ }^{1235}$ For the CCND, the CUCND, and the CPC, the Aldermaston March functioned as a paradigm for protest. The first CUCND march through downtown Ottawa on Christmas Day 1959 was inspired by the Aldermaston March. ${ }^{1236}$ All of the major Canadian disarmament organizations organized a variety of marches in attempts to recreate the spirit, enthusiasm and pubic appeal of Aldermaston. ${ }^{1237}$ Although the marches were impressive by Canadian standards, attracting as many as several hundred protesters, they paled beside the British original. ${ }^{1238}$ The American SANE and the West German Campaign Against Atomic Death also emulated Aldermaston. ${ }^{1239}$ The march was so popular among disarmers globally, that many activists travelled to participate in the London march themselves. Beginning at the second annual march in 1959, foreign disarmers, including Canadians, had their own sections in the march. ${ }^{1240}$

The Aldermaston March was rooted in Mohandas Gandhi's approach to nonviolent resistance. However, so prominent were the British Aldermaston marches in the

\footnotetext{
${ }^{1235}$ Nehring, Politics of Security, 4, 135, 198; Nehring, "National Internationalists," 578.

${ }^{1236}$ Arthur Pape, "Some thoughts on the peace effort in Canada," n.d., MUL, CCND fonds, SW572, box 9, file 4, 1; "Montreal Students Plan Ottawa March," The Globe and Mail, 23 December 1959, 2; "Motorcade to North Bay, May 9-10-11," ca. April 1960, LAC, James G. Endicott and Family fonds, MG30-C130, vol. 8, file 128, 1, 4; Palmer, Canada's 1960s; Steve Hewitt, Spying 101: The RCMP's Secret Activities at Canadian Universities, 1917-1997 (Toronto: University of Toronto Press, 2002), 90; Churchill, "SUPA, Selma, and Stevenson," 36; Moffat, History of the Peace Movement, 28.

1237 "Canadian Peace Congress Submission to the Right Honourable John Diefenbaker," 15 May 1961, LAC, James G. Endicott and Family fonds, MG30-C130, vol. 8, file 139, 2; "Nous voulons la paix non des bombes," 21 April 1962, MUL, CCND fonds, SW573, box 18, file 3; Ellen to F. C. Hunnius, 2 April 1962, MUL, CCND fonds, SW573, box 18, file 3, 1; Floyd to James Endicott, 4 April 1962, LAC, James G. Endicott and Family fonds, MG30-C130, vol. 8, file 139, 1.

${ }^{1238}$ Patricia Wiley, "To the Editor," Toronto Daily Star, 8 April 1959, LAC, James G. Endicott and Family fonds, MG30-C130, vol. 18, file 349, 1; Moffatt, History of the Peace Movement, 28.

${ }^{1239}$ Katz, Ban the Bomb, 37, 66; Nehring, Politics of Security, 198.

${ }^{1240}$ Marion Feld to Mary Van Stolk, February 1961, MUL, CCND fonds, SW571, box 4, file 1, 1.
} 
minds of activists that they did not think of the endeavour's Indian roots. ${ }^{1241}$ The CUCND did bring on one of Gandhi's disciples, Devi Prasad, as an editor of their journal Our Generation Against Nuclear War. Still, the organization did not connect their use of non-violence to Ghandi's teachings, nor did any of the other Canadian organizations that sought to emulate the Aldermaston March. ${ }^{1242}$

Despite their failure to acknowledge Ghandi's contribution to global peace protests, Canadian activists did look to international disarmament and peace leaders, as there were no major Canadian celebrities for disarmers to rally behind. ${ }^{1243}$ On 23 April 1957, in response to illnesses caused by American hydrogen bomb tests at Bikini Atoll and Soviet tests in Siberia, Albert Schweitzer, a celebrated French humanitarian and Nobel Peace Prize winner, delivered his anti-nuclear "Declaration of Conscience" broadcast in 50 countries. His speech outlined recent findings about increased levels of nuclear radiation in the atmosphere resulting from the testing of nuclear weapons and explained that such radiation was linked to increased cases of birth defects and cancers. ${ }^{1244}$ Schweitzer's appeal proved a catalyst for international disarmament efforts. ${ }^{1245}$ In Canada the declaration was immediately made available to those who had

\footnotetext{
${ }^{1241}$ Nehring, Politics of Security, 198-199; Mark Kurlansky, "Preface," in Gandhi on Non-Violence, ed. Thomas Merton (New York: New Directions Publishing Corporation, 2007), xiv.

1242 Our Generation Against Nuclear War, "Memo to all editors," October 1962, MUL, CUCND-SUPA fonds, box 17, file: Ottawa Mike Rowan 1962-1963, 2; "Prospectus, Peace Education Project," n.d., MUL, CUCND-SUPA fonds, box 10, file: CUCND conference, Nov. 1963, 1; John A. Lee, "To Those who take PEACE personally and seriously," 18 October 1963, MUL, CCND fonds, ACCN. 05-1989.102.f, box 23, file 13, 1-3; Voice of Women, "Minutes of Executive Meeting," 19 September 1964, LAC, Voice of Women fonds, MG28-I218, vol. 23, file: Council Meetings minutes 1962-1967, 1.

${ }^{1243}$ Dimitrios Roussopoulos, "Introduction," in The New Left in Canada, ed. Dimitrios Roussopoulos (Montreal: Our Generation Press-Black Rose Books, 1970), 9.

${ }^{1244}$ Wittner, The Struggle Against the Bomb, vol. 2, 31; Norman Cousins, ed., "The Schweitzer Declaration," Saturday Review, 18 May 1957, 17, 19.

${ }^{1245}$ For example, one Canadian woman explained to VOW organizers that she first saw the need to speak out against nuclear arms after hearing Schweitzer's broadcast "expressing horror that we would be producing hundreds of thousands of deformed children for future generations, through damage to the genetic pool by fallout" (Olga Spuilles, ca. 1962, LAC, Voice of Women fonds, MG28-I218, vol. 1, file:
} 
missed the broadcast. It was published in the American magazine Saturday Review and copies were distributed by the CPC. ${ }^{1246}$

The declaration particularly affected Van Stolk. Van Stolk's husband Jan had worked with Schweitzer in Lambaréné, Gabon, when the humanitarian composed his “Declaration of Conscience." When the Van Stolks moved to Canada in 1958, Mary Van Stolk immediately set out to act upon Schweitzer's call to examine the threat that nuclear fallout posed to children. ${ }^{1247}$ In return, Schweitzer was a vocal supporter of the efforts of the CCCRH-CCND. ${ }^{1248}$

Bertrand Russell, an influential British philosopher, historian, mathematician, and social critic, was also an important mentor for CCCRH-CCND organizers. Russell dedicated much of his life to peace activism and had become a hero to pacifists and conscientious objectors when he was imprisoned in 1918 for writing an anti-war essay. His peace activism intensified when the atomic bomb heightened war's destructiveness. He penned the anti-nuclear Russell-Einstein Manifesto with Albert Einstein in 1955. In September 1961, at the age of 89, Russell was again imprisoned for his peace activism. ${ }^{1249}$ This history of personal sacrifice in the name of peace made Russell a global icon for anti-nuclear weapons efforts. ${ }^{1250}$

\footnotetext{
correspondence Josephine Davis 1962, 1). McCrae and Markle, Minutes to Midnight, 70; Ziemann, "The Code of Protest," 247.

${ }^{1246}$ Mary Endicott to Mr. and Mrs. Wm. Green, 10 June 1957, LAC, James G. Endicott and Family fonds, MG30-C130, vol. 6, file 103, 1.

${ }^{1247}$ Mary van Stolk to The Earl Russel, 28 October 1960, MUL, CCND fonds, SW571, box 4, file 1, 1; Mary Van Stolk to Albert Schweitzer, 28 October 1960, MUL, CCND fonds, SW571, box 4, file 1, 1. ${ }^{1248}$ Mary Van Stolk to H. L. Keenleyside, 7 December 1960, MUL, CCND fonds, SW571, box 4, file 3, 1. 1249 Ray Perkins Jr., "Introduction," in Yours Faithfully, Bertrand Russell: A Lifelong Fight for Peace, Justice and Truth in Letters to the Editor, by Bertrand Russell, ed. Ray Perkins Jr. (Chicago: Open Court, 2002), 1, 7, 10; Nehring, Politics of Security, 205.

${ }^{1250}$ Nehring, "National Internationalists," 577.
} 
Canadian organizations regularly sought out approval and public acknowledgment from Russell. ${ }^{1251}$ Combined Universities Campaign for Nuclear Disarmament officials engaged in regular correspondence with Russell, who agreed to serve as the organization's honorary president in November $1960 .{ }^{1252}$ Russell also wrote the preface for the first issue of the CUCND's Our Generation Against Nuclear War. ${ }^{1253}$ For one Regina-based activist, serving as a Canadian representative at Russell's $90^{\text {th }}$ birthday celebration at Royal Festival Hall in London was a highlight of his time with the CCND. ${ }^{1254}$

Several American disarmament leaders were also important to Canadian efforts. American chemist Linus Pauling played a central role in developing an international antinuclear campaign among scientists. The distribution of Pauling's anti-nuclear petition allowed the CPC to maintain its public presence when more mainstream organizations, such as the CCCRH-CCND and VOW, were gaining popularity in the early 1960s. ${ }^{1255}$ Norman Cousins, the leader of SANE, who had convinced Schweitzer to publicize his concerns about nuclear arms, was also a source of inspiration for Canadian activists,

\footnotetext{
${ }^{1251}$ Van Stolk to Keenleyside, 7 December 1960, 1; Mrs. R. A. Johnson to Ralph Shoennan, 11 May 1962, MUL, CCND fonds, SW574, box 20, file 20, 1; Bertrand Russell to James Endicott, 19 June 1963, LAC, James G. Endicott and Family fonds, MG30-C130, vol. 8, file 160, 1.

1252 Bertrand Russell to Elka Cohen, 25 November 1960, MUL, Bertrand Russell Archives, RA1, box 11.16, document 00000005. See also: Dick Clements to Bertrand Russell, 22 July 1961, MUL, Bertrand Russell Archives, RA2, box 10.33, document 141612; Bertrand Russell to Dick Clements, 16 August 1961, MUL, Bertrand Russell Archives, RA2, box. 10.33, document 141613; Olga Rapoport to Bertrand Russell, 18 December 1961, MUL, Bertrand Russell Archives, RA 1, box. 1.50, document 000000; Bertrand Russell to Elvin Shapiro, 25 March 1962, MUL, Bertrand Russell Archives, RA 1, box 6.20, document 000000.

${ }^{1253}$ Bertrand Russell, "Preface to First Issue," Our Generation Against Nuclear War 1(1) (Fall 1961), accessed 19 November 2015, http://s3.amazonaws.com/xlsuite_production/assets/9271675/Vol_1_part_1.pdf, 3 .

${ }^{1254}$ Anonymous, interview with author, 6 November 2013.

${ }^{1255}$ Jacqueline Dineen, “To All Peace Committees,” 21 March 1961, LAC, James G. Endicott and Family fonds, MG30-C130, vol. 8, file 139, 1; Chatfield, The American Peace Movement, 108.
} 
particularly those in CCCRH-CCND, who were always aware of the role Cousins had played in the establishment of their organization. ${ }^{1256}$

Dr. Benjamin Spock, a leading American paediatrician who became the public face of SANE with the New York Times advertisement "Dr. Spock is Worried," had significant appeal in Canada. ${ }^{1257}$ Spock's teachings on permissive child rearing were popular with post-war Canadian parents, and his celebrity status helped to draw unusually large crowds to his speeches. ${ }^{1258}$ Because of this popularity, CCND reprinted "Dr. Spock is Worried" for distribution in Canada, and attempted to organize a very expensive Canadian Spock speaking tour, which far exceeded their financial capabilities. ${ }^{1259}$ By tying themselves to such recognizable American and European peace leaders, Canadian organizers connected themselves to a global effort to ban the Bomb and attracted more casual supporters to their organizations.

While international disarmament efforts and their leaders were important to Canadian disarmament organizations, Canadian anti-nuclear efforts were not creatures of more developed movements in the United States and Europe. Canadian disarmers were engaged in mutually beneficial collaboration with disarmers across the globe. For

\footnotetext{
${ }^{1256}$ Cousins, ed., "The Schweitzer Declaration," 13-14; Mary Van Stolk to Norman Cousins, 16 June 1961, MUL, CCND fonds, SW571, box 4, file 1, 1; McCrea and Markle, Minutes to Midnight, 70.

${ }^{1257}$ Lawrence S. Wittner, "Gender Roles and Nuclear Disarmament Activism, 1954-1965," Gender and History 12(1) (April 2000): 208; Swerdlow, Women Strike for Peace, 2; Charles DeBenedetti and Charles Chatfield, An American Ordeal: The Antiwar Movement of the Vietnam Era (Syracuse: Syracuse University Press, 1990), 57; Herald of Health, "Dr. Spock is Worried," August 1962, LAC, James G. Endicott and Family fonds, MG30-C130, vol. 8, file 145, 1.

${ }_{1258}$ Jessica Haynes, "Help for All Parents?: Child-Rearing Advice in English Canada in the 1960s and 1970s," Histoire Sociale/Social History 44(87) (May 2011): 54; Doug Owram, Born at the Right Time: A History of the Baby Boom Generation (Toronto: University of Toronto Press, 1997), 135; Ian Milligan, Rebel Youth: 1960s Labour Unrest, Young Workers, and New Leftists in English Canada (Vancouver: UBC Press, 2014), 14.

${ }^{1259}$ F. C. Hunnius to the National Committee for a Sane Nuclear Policy, 6 July 1962, MUL, CCND fonds, SW573, box 14, file 23, 1; Arthur Pape to Homer Jack, 20 November 1963, MUL, CCND fonds, box 14, file $23,1$.
} 
example, the CCCRH-CCND's mass petition and article by chairman K. C. Woodsworth that made up the group's "No Nuclear Weapons for Canada" campaign were requested and translated by foreign organizations. ${ }^{1260}$

The CUCND saw itself as part of a broader international effort for peace, opening up communications with protest groups in the United States, the Soviet Union, Sweden, Australia, India, and Japan, among other nations, primarily through the publication of its journal, Our Generation Against Nuclear War. ${ }^{1261}$ An international collective of student peace movements voted the journal, which had subscribers in at least 23 countries outside of Canada, to be the international journal of student peace activism in the early 1960s. Our Generation then reached a significant "adult" membership once it merged with the British CND's quarterly in $1963 .{ }^{1262}$

The Canadian Peace Research Institute (CPRI), founded in 1961 by nuclear physicist Norman Alcock, also helped to give Canadian anti-nuclear efforts a global reach. Alcock left a lucrative consulting job to establish his institute with the help of fundraising from disarmament organizations such as VOW, the CCCRH-CCND, and the Society of Friends. ${ }^{1263}$ Alcock's booklet The Bridge of Reason, which laid out his belief

\footnotetext{
${ }^{1260}$ Jarold F. Lyke to CCCRH, 22 June 1961, MUL, CCND fonds, box 14, file 18, 22 June 1961, 1; K. Ogoshi to K. C. Woodsworth, 18 April 1963, MUL, CCND fonds, box 13, SW573, file 10, 1; J. D. Bernal to CPC, 7 May 1963, LAC, James G. Endicott and Family fonds, MG30-C130, vol. 8, file 159, 1. ${ }^{1261}$ Our Generation Against Nuclear War, "Memo to all editors," 1, 2; Campbell, A History of the Ban-TheBomb Movement, 5; Churchill, "SUPA, Selma, and Stevenson," 37; McMahon, Essence of Indecision, 64; Wittner, The Struggle Against the Bomb, vol. 2, 298.

1262 Our Generation Against Nuclear War, "Memo to all editors," 1-2; "Major Expansion," 15 December 1963, MUL, CCND fonds, ACCN. 05-1989.102.f, box 25, file 21, 1; Wittner, Struggle Against the Bomb, vol. 2, 298.

1263 [Gerry] Hunnius to James S. Thomson, 20 October 1961, MUL, CCND fonds, SW571, box 3, file 9; "Memo to Ray Silver from Marjorie McEnaney," 22 November 1961, AO, Canadian Peace Research Institute fonds, F-883-1-2, container B297379, box 4, file: CAPRI correspondence 1961-1962; Basil Spurr, "Minutes of the Toronto Monthly Meeting of Friends," 20 March 1962, LAC, Society of Friends fonds, MG17-G1, reel M-3817, 1; Jessie Johnson and Margaret McHouther, "Meeting for Business," 7 June 1964, LAC, Society of Friends fonds, MG17-G1, reel M-3825, 2.
} 
in the potential for scientific research to realize peace, was translated by foreign peace organizations into several languages, including Spanish and German. ${ }^{1264}$ The CPRI inspired the growth of similar research institutes across Europe, and provided financial support necessary for the establishment of a German institute. ${ }^{1265}$

Canadian campaigns contributed to international disarmament efforts as a member of organized international efforts against nuclear arms. In the spring of 1963, CCND and CUCND were being courted to join the newly established International Confederation for Disarmament and Peace (ICDP). In response to tense relations between communist-WPC members and Western organizations, the Confederation was founded to rise above Cold War ideological conflict as a network of non-aligned peace organizations. ${ }^{1266}$ CUCND leaders Dimitrios Roussopoulos, F. C. (Gerry) Hunnius, Arthur Pape, and Peter Boothroyd pushed for the CCND and the CUCND to join the ICDP on the grounds that individual, disjointed, national organizations lacked the strength to prevent nuclear war. ${ }^{1267}$ As Roussopoulos, Hunnius and Professor Gilles B. Richard explained to the CCND board of directors in July 1963, "the CCND efforts at

\footnotetext{
${ }^{1264}$ Moffat, The History of the Peace Movement, 59; Julian Griggs to Mr. and Mrs. Robert C. Jones, 29 April 1963, AO, Canadian Peace Research Institute fonds, F-883-1-2, container B297376, box 8, file: Mexico, 1; Dr. F. Wuesthoff to Dr. Norman Alcock, 18 December 1962, AO, Canadian Peace Research Institute fonds, F-883-1-2, container B297375, box 5, file: Germany.

1265 Norman Hoyte to Norman Alcock, 8 January 1962, AO, Canadian Peace Research Institute fonds, F883-1-2, container B297379, box 4, file: Hoyte and Jude; [Francis] Jude to Norman [Alcock], 9 January 1962, AO, Canadian Peace Research Institute fonds, F-883-1-3, container B297379, box 4, file: Hoyte and Jude; Norman Alcock to Norman Hoyte, 7 August 1962, AO, Canadian Peace Research Institute fonds, F883-1-2, container B297379, box 4, file: Hoyte and Jude; I. Zlotowski to the Canadian Peace Research Institute, 10 August 1962, AO, Canadian Peace Research Institute fonds, F-883-1-2, container B297375, box 5, file: France; F. Wuesthoff to Norman Alcock, 17 October 1962, AO, Canadian Peace Research Institute fonds, F-883-1-2, container B297375, box 5, file: Germany; Julian Griggs to F. Wuesthoff, 16 May 1963, AO, Canadian Peace Research Institute fonds, F-883-1-2, container B297375, box 5, file: Germany; Ilse Korte to the Canadian Peace Research Institute, 4 April 1963, AO, Canadian Peace Research Institute fonds, F-833-1-2, container B297375, box 5, file: Germany; Canadian Peace Research Institute, Information Report, 26 November 1962, LAC, Andrew Allan fonds, MG31-D56, vol. 39, file: Canadian Peace Research Institute, 3.

${ }^{1266}$ Wittner, Struggle Against the Bomb, vol. 2, 303-304; Richard, Roussopoulos and Hunnius, "Why," 1. 1267 "Two memos," 1, 2.
} 
world disarmament are less meaningful if they are not expressed within a (sic) international framework in co-operation with other like-minded organizations throughout the world." ${ }^{1268}$ By this logic, participation in a formal network of international disarmament groups would imbue Canadian efforts with greater significance and would supply the motivation needed to continue their efforts at a time when anti-nuclear efforts were beginning to lose steam in Canada. However, despite arguments that there was strength in international unity, the CCND board of directors procrastinated when it came to formally joining the ICDP.

The CCND executive approved membership to the ICDP in February 1963, but had still not formally joined the Confederation by the summer, to the frustration of CUCND leadership. ${ }^{1269}$ CCND chairman Woodsworth argued against ICDP membership out of fear that an international umbrella like ICDP would value international agreement at the expense of allowing individual members the freedom to respond to national concerns. Woodsworth contended that, while networking with other organizations was certainly beneficial, this could be done through existing informal and flexible transnational advocacy channels of correspondence and conferences. ${ }^{1270}$

CCND did eventually sign-on to the ICDP, but its lack of enthusiasm was notable given the large role Roussopoulos and Hunnius played in the formation of the Confederation. Roussopoulos left his position as editor-in-chief of Our Generation Against Nuclear War to organize the first international conference of the ICDP in

\footnotetext{
1268 Richard, Roussopoulos and Hunnius, "Why," 1.

1269 "Two memos," 1, 2.

1270 "Two memos," 4.
} 
Sweden in January 1964. Hunnius moved to London, England, to work as the general secretary of the ICDP. ${ }^{1271}$

The CCND's hesitation in joining this established advocacy network was emblematic of the organization's superficial devotion to the goal of international cooperation. When disarmament began to lose urgency at the end of 1963 with the installation of nuclear arms in Canada and the signing of the Limited Test Ban Treaty, both the CCND and the CUCND struggled to redefine their purposes. ${ }^{1272}$ By 1965 most of the local branches of the CCND had collapsed, and the CUCND had been reborn as a student New Left organization. ${ }^{1273}$ When CUCND leaders reinvented the organization as the Student Union for Peace Action in 1965 they purposely saturated the organization's programme with influences of socialist internationalism, making "human liberation," including anti-colonialism and anti-racism, central to their campaigns as the fight against war. ${ }^{1274}$

\section{VOW: women as a global force}

1271 "Report to our readers," Our Generation Against Nuclear War 2(4) (December 1963): 1-2; Arthur Pape, "Report to the CCND and CUCND," 9-13 January 1964, MUL, CCND fonds, SW571, box 3, file 4, 4.

1272 "CCND consultation," 18-20 September 1964, MUL, CCND fonds, SW571, box 1, file 11, 1; Stanley Rands to Art [Pape], 4 December 1963, MUL, CCND fonds, SW571, box 6, file 4; CUCND National Secretariat, "Special Mid-Summer Memo, Hiroshima Day," 6 August 1963, MUL, CUCND-SUPA fonds, box 3, file: interbranch memos Dec. 1962-Oct. 1963, 1; Arthur Pape, "Report to the CCND and CUCND," January 1964, MUL, CCND fonds, SW571, box 3, file 4, 1; Wittner, The Struggle Against the Bomb, vol. 2, 443; Chatfield, The American Peace Movement, 115; Boyer, "From Activism to Apathy," 824-835. ${ }^{1273}$ Wittner, The Struggle Against the Bomb, vol. 2, 443.

1274 Joan Sangster, "Radical Ruptures: Feminism, Labor, and the Left in the Long Sixties in Canada," American Review of Canadian Studies 40(1) (March 2010): 8; Jim Harding, "Continuing On: Deepening the Anti-Nuclear Movement since the Sixties," in New World Coming: The Sixties and the Shaping of Global Consciousness, eds. Karen Dubinsky, et. al. (Toronto: Between the Lines, 2009), 397; "Outline of Manifesto Table of Contents," 2 January 1967, MUL, CUCND-SUPA fonds, box 7, file: SUPA Manifesto Papers Spring 1967, 1. 
As a non-partisan and women-only organization, $\mathrm{VOW}$, founded in Toronto in the summer of 1960, did not benefit from international cooperation through a mass umbrella organization such as the WPC, nor did it have foreign sister organizations to learn from, as did the Canadian campaigns for nuclear disarmament. ${ }^{1275}$ VOW engaged in no regular communications with foreign peace organizations in the early 1960s. ${ }^{1276}$ In fact, VOW organizers devoted much more time to relationships with Canadian political leaders than to interactions with related transnational advocacy networks. ${ }^{1277}$ In the end, VOW formed its own advocacy network of likeminded women's movements.

VOW, though founded in response to fears about nuclear war and the health hazards posed by nuclear fallout, always presented its project as larger than disarmament. VOW founders described their organization as primarily an international peace effort, within which nuclear weapons were seen to be symptomatic of a larger issue. ${ }^{1278}$ VOW's program was built upon the assumption that women inherently shared a desire for peace

\footnotetext{
1275 The organization with the objectives and structure closest to VOW was the American organization Women Strike for Peace, which was not initiated until late 1961 (Swerdlow, Women Strike for Peace, 1-2). 1276 "Report on Women's NATO Peace Conference," 12-14 May 1964, LAC, Voice of Women fonds, MG28-I218, vol. 1, file: $4^{\text {th }}$ annual meeting minutes and proceedings 1964. VOW's closest relationship to a foreign organization - Women Strike for Peace — did not fully develop until the mid-1960s (Dagmar Wilson to Kay Macpherson, 31 March 1965, LAC, Voice of Women fonds, MG28-I218, vol. 22, file: national annual meeting 1962; Kay Macpherson, "Dear WSPers," 23 January 1967, LAC, Voice of Women fonds, MG28-I218, vo. 18, file: Vietnam visits and visas; Muriel Duckworth to WSP Washington, 9 May 1970, LAC, Voice of Women fonds, MG28-I218, vol. 20, file: telegrams Canadian and foreign 1965-1973). ${ }_{1277}$ Mrs. F. Davis to Lester B. Pearson, 22 June 1960, LAC, Voice of Women fonds, MG28-I218, vol. 1, file: correspondence members of parliament re. formation 1960-1963, 1; Mrs. F. Davis to John G. Diefenbaker, 22 June 1960, LAC, Voice of Women fonds, MG28-I218, vol. 1, file: correspondence members of parliament re. formation 1960-1963, 1; Josephine Davis to Howard Green, 11 February 1961, LAC, Voice of Women fonds, MG28-I218, vol. 1, file: correspondence members of parliament re. formation 1960-1963, 1; “Annual Meeting Reports," 16-17 September 1962, LAC, Voice of Women, MG28-I218, vol. 22, file: national annual meeting 1962, 1; Thérèse Casgrain to John Diefenbaker, 29 October 1962, LAC, Voice of Women fonds, MG28-I218, vol. 1, file: correspondence re. meetings and conference 1962, 1; Voice of Women, "Brief to the Prime Minister," 1 November 1962, LAC, Voice of Women, MG28-I218, vol. 1, file: annual meeting minutes and proceedings 1962, 1; Voice of Women, "President's Reports, First Annual Meeting," 16 June 1961, LAC, Voice of Women, MG28-I218, vol. 22, file: national annual meeting 1961, 3-4.

1278 "Brief Concerning Voice of Women," 16 February 1961, LAC, Voice of Women fonds, MG28-I218, vol. 1, file: correspondence members of parliament re. formation 1960-1963, 2-3.
} 
and that grassroots interaction between women of different cultures could lead to world peace through the establishment of mutual respect and understanding. ${ }^{1279}$

To put the organization's philosophy of the power of united womanhood into action, VOW coordinated efforts to help Canadian women create personal bonds with women from other nations. VOW began by setting up a pen pal system to allow women to share and compare living conditions in other nations, with an emphasis on children's education. Some women with knowledge of French, Ukrainian, and Spanish were immediately paired with women in France, Ukraine, and Latin America. Training in Esperanto — a language created in 1887 as a politically neutral universal language — then allowed for the expansion of the pen pal program further into the Soviet Union and into Japan, Czechoslovakia, Hungary, Poland, and other Eastern European nations. The expansion of communication into the Soviet bloc was vital to VOW's goal of establishing peace through understanding in the context of the Cold War. ${ }^{1280}$ Letter writing was a way for women, who were unable to travel to international women's conferences, to feel like active participants in the fight for peace. ${ }^{1281}$

\footnotetext{
${ }^{1279}$ Voice of Women, "First Annual Meeting," 16-17 June 1961, LAC, Voice of Women fonds, MG28I218, vol. 22, file: National Annual Meeting (1961) minutes and background material, 5; Isabel Batcheller, "First Annual Meeting," 16-17 June 1961, LAC, Voice of Women fonds, MG28-I218, vol. 1, file: $1^{\text {st }}$ annual meeting, proceedings, 1961, 5; "President's Report," 16 September 1962, LAC, Voice of Women fonds, MG28-I128, vol. 22, file: national annual meeting 1962, 1.

${ }^{1280}$ Marjorie Reid, "Committee on International Relations, Report to the Annual Conference," May 1964, LAC, Voice of Women fonds, MG28-I218, vol. 1, file: reports to annual meeting 1964, 1; Moffatt, History of the Peace Movement, 51; Brookfield, Cold War Comforts, 89; Leslie A. Freeman to the Principal, 15 September 1966, LAC, Voice of Women fonds, MG28-I218, vol. 1, file: correspondence general 19611967, 1; Takako Taketomi to Helen Tucker, n.d., LAC, Voice of Women fonds, MG28-I218, vol. 2, file: International Cooperation Year Conference International Co-operation Travel Mission 1962-1963, 1. ${ }^{1281}$ Dawn Watson to Lotta Dempsey, 21 May 1960, LAC, Voice of Women fonds, MG28-I218, vol. 1, file: correspondence re. formation of V.O.W., 1; Kay Macpherson, "Memo to various persons," 16 February 1971, LAC, Voice of Women fonds, MG28-I218, vol. 21, file: British Columbia correspondence 1965$1971,1$.
} 
To further facilitate women's grassroots interactions, VOW sponsored Grethe Dahl to serve as a volunteer nurse in Ceylon as part of the Canadian Overseas Volunteers program, and arranged for exchanges with Soviet and Vietnamese women. ${ }^{1282}$ VOW also established branches in the United States and Pakistan. ${ }^{1283}$ The Canadian VOW initiated a petition to the United Nations for the establishment of a World Peace Year, which was eventually held as International Cooperation Year in 1965, with sustained participation from VOW Canada. ${ }^{1284}$ With its facilitation of relationships between women of different nations, VOW created its own advocacy network.

VOW was established as an outlet for Canadian women to encourage international cooperation, but it was immediately implicated in the anti-nuclear fervour that swept through Canadian peace organizations in the early 1960s. ${ }^{1285}$ This became particularly troublesome for VOW in early 1963, when the organization nearly broke apart over a divide between those who wanted to see the organization re-devote itself to

\footnotetext{
1282 O.G. Schmidt to Mrs. W. D. Tucker, 5 March 1962, LAC, Voice of Women fonds, MG28-I218, vol. 1, file: correspondence general 1961-1967, 1; Helen Tucker, "President's Reports, First Annual Meeting," 16 June 1961, LAC, Voice of Women fonds, MG28-I218, vol. 22, file: National Annual Meeting 1961, 3-4; Kathleen Macpherson to Ivan Petukhov, 4 September 1964, LAC, Voice of Women fonds, MG28-I218, vol. 5, file: U.S.S.R. visit 1964; Lorraine Bates, "Memo," 6 October 1964, LAC, Voice of Women, MG28I218, vol. 5, file: U.S.S.R. visit 1964; Phan Thi An to Kay Macpherson, 21 November 1967, LAC, Voice of Women fonds, MG28-I218, vol. 20, file: Vietnam visit correspondence 1967-1968; Claire to Kay, 25 June 1969, LAC, Voice of Women fonds, MG28-I218, vol. 43, file: security re. Vietnamese visit 1969. 1283 "Minutes of Board of Directors Meeting," 17 July 1961, LAC, Voice of Women fonds, MG28-I218, vol. 22, file: National Annual Meeting 1961, 3-4.

1284 Josephine Davis to John G. Diefenbaker, 22 September 1961, LAC, Voice of Women fonds, MG28I218, vol. 1, file: correspondence 1961, 2; Josephine Davis to Thérèse Casgrain, 11 September 1961, LAC, Voice of Women fonds, MG28-I218, vol. 1, file: correspondence 1961, 1; "Report to Voice of Women, Canada, from WILC for ICY," 8-9 June 1963, LAC, Voice of Women fonds, MG28-I218, vol. 13, file: International Cooperation Year correspondence 1962-1966; "International Co-Operation Year 1965, Presentation to the ICY Medal," ca. 1965, LAC, Voice of Women fonds, MG28-I218, vol. 1, file: $5^{\text {th }}$ Annual Meeting reports to and lists, 1; Marcus Van Steen to Ray Gardner, 23 August 1963, LAC, Voice of Women fonds, MG28-I218, vol. 2, file: International Cooperation Year Conference International Cooperation Travel Mission, 1.

${ }^{1285}$ Merle Keys, 6 July 1960, LAC, Voice of Women fonds, MG28-I218, vol. 1, file: correspondence re. formation of V.O.W., 1-2; Ivy Stoetzer, 12 October 1960, LAC, Voice of Women fonds, MG28-I218, vol. 1, file: correspondence re. formation of V.O.W., 1; "President's Report," 16 September 1962, LAC, Voice of Women fonds, MG28-I218, vol. 22, file: National Annual Meeting 1962, 1.
} 
its original focus on international cooperation and those who joined the organization because of their concern over the Bomb and nuclear fallout. ${ }^{1286}$ Co-founder Josephine Davis pointed out in her letter of resignation from the organization in March 1963 that she believed that Canada should not accept nuclear arms, but that was not the reason for VOW's formation: "I could have joined the Toronto Committee for Disarmament in June 1960, and saved myself a lot of trouble." ${ }^{1287}$ Because of the prominence of anti-nuclear campaigning to peace advocacy in the early 1960s, VOW struggled to establish a public image separate from other Canadian disarmament organizations. ${ }^{1288}$

With the decline in anti-nuclear efforts in 1963, VOW executives became determined to move the organization's efforts towards the international sphere. ${ }^{1289}$ In the mid-1960s, VOW threw its efforts behind International Cooperation Year and, as American involvement in the war in Vietnam intensified, the organization increasingly turned its attention to the women and children of Vietnam. ${ }^{1290}$ In the late 1960 s, VOW

\footnotetext{
${ }^{1286}$ Blanche Gorsky to Thérèse Casgrain, 28 November 1962, LAC, Voice of Women fonds, vol. 1, file: correspondence Josephine Davis 1962, 2; Joan Wright to Emergency Resolutions Delegation, 25 May 1963, LAC, Voice of Women fonds, MG28-I218, vol. 39, file: Winnipeg meeting Emergency Resolutions correspondence pt. 2, 2.

1287 Josephine Davis to Kay Macpherson, 30 March 1963, LAC, Voice of Women fonds, MG28-I218, vol. 1, file: correspondence Josephine Davis 1963, 1.

${ }^{1288}$ Carol Chapman, "How effective is the Voice of Women?," Chatelaine, June 1961, 117.

1289 Mabel Hanway, 26 August 1963, LAC, James G. Endicott and Family fonds, MG30-C130, vol. 8, file 160, 1; Jacqueline Dineen, “Annual Report," 25 March 1964, LAC, James G. Endicott and Family fonds, MG30-C130, vol. 10, file 178, 1; CUCND National Secretariat, "Special Mid-Summer Memo, Hiroshima Day," 6 August 1963, MUL, CUCND-SUPA fonds, box 3, file: interbranch memos Dec. 1962-Oct. 1963, 1; Wittner, The Struggle Against the Bomb, vol. 2, 443; Churchill, "SUPA, Selma, and Stevenson," 34; Candace Loewen, "Mike Hears Voices: Voice of Women and Lester Pearson, 1960-1963," Atlantis 12(2) (Spring 1987): 24, 29; Eva Sanderson to Miss Nancy Pocock, 22 April 1964, LAC, James G. Endicott and Family fonds, MG30-C130, vol. 10, file 179, 1; Roussopoulos, "Introduction," 8; Ball, "The History of the Voice of Women," 203.

${ }^{1290}$ WILC for ICY, "Report to Voice of Women, Canada," 8-9 June 1963, LAC, Voice of Women fonds, MG28-I218, vol. 13, file: International Cooperation Year correspondence printed materials; "Voice of Women and the Communist Smear," January 1965, LAC, Voice of Women fonds, MG28-I218, vol. 2, file: President's reports 1965, 2; Patricia Boulding to Kathleen Langston, 5 May 1965, LAC, Voice of Women fonds, MG28-I218, vol. 21, file: British Columbia correspondence 1965-1967; Dorothy Anwell to Lester B. Pearson, 18 January 1966, LAC, Voice of Women fonds, MG28-I218, vol. 20, file: letters to the Prime Minister regarding Vietnam 1965-1966; "Voice of Women," May 1965, LAC, Voice of Women fonds, MG28-I218, vol. 3, file: Church Organizations 1965-1966; Constance Gardner to Colleen Thatcher, 29
} 
women organized a highly successful knitting campaign in which over 15,000 women knit dark-coloured clothing for Vietnamese children. The clothes were intended to camouflage the children, with the dark colours hiding them from searchlights, and raise awareness of their plight. ${ }^{1291}$

VOW's programme throughout the 1960s was driven by the belief that interactions among women of different cultures could bring about greater understanding and cooperation among states. This conception of the necessary recipe for world peace led VOW organizers to pursue campaigns aimed at relieving all forms of suffering across the globe. The expansion of the aims of the organization and its distinct objective of providing a space for women to make meaningful contributions towards peace has allowed the VOW to persist to this day. ${ }^{1292}$

\section{Conclusion}

In the fall of 1963, Canada became one of over 100 states to sign the Treaty Banning Nuclear Weapon Tests in the Atmosphere, in Outer Space and Under Water, also known as the Limited Test Ban Treaty. ${ }^{1293}$ After only a few years of aggressive lobbying, the efforts of Canadian disarmers and anti-nuclear protesters across the globe

\footnotetext{
April 1970, LAC, Voice of Women fonds, MG28-I218, vol. 20, file: correspondence 'S' 1968-1971; Kay Macpherson, "Memo to various persons, particularly members concerned about VOW/VdF's multitudinous activities," 16 February 1971, LAC, Voice of Women fonds, MG28-I218, vol. 21, file: British Columbia correspondence 1965-1971, 1.

${ }^{1291}$ Joyce White, "To council members and provincial membership chairmen," 24 November 1969, LAC, Voice of Women fonds, MG28-I218, vol. 23, file: memorandum from the national office 1962-1974, 1; Mick Lowe, One Woman Army: The Life of Claire Culhane (Toronto: Macmillan Canada, 1992), 184-185; Brookfield, Cold War Comforts, 164, 181; Carol Chesto to Lil Greene, 10 June 1969, LAC, Voice of Women fonds, MG28-I218, vol. 42, file: U.S. delegates replies 1969; Early, "Canadian Women and the International Arena," 34.

1292 "About," Canadian Voice of Women, accessed 9 September 2016, http://vowpeace.org/about/. ${ }^{1293}$ Wittner, The Struggle Against the Bomb, vol. 2, 415; Early, "Canadian Women and the International Arena in the Sixties," 28; "Two Memos," 3.
} 
were validated with what they perceived to be an important step towards a world without war. ${ }^{1294}$ With their voices combined, in the early 1960 s disarmers drew public attention to the hazards of nuclear radiation, helping to bring about an international consensus against atmospheric testing. ${ }^{1295}$ For disarmers a test ban and multilateral nuclear disarmament were interrelated. Public opposition to nuclear weapons tests did not, however, lead to mass support for a ban on the arms themselves. This disconnect proved troublesome for the efforts of Canadian disarmers in particular.

Canadian disarmers discovered both the value and the weakness of a strictly national campaign with their "No Nuclear Weapons for Canada" program. Canadian antinuclear activists were "national internationalists," in the sense that their participation in an international effort to save humanity from nuclear annihilation was intimately connected to national concerns. To present their campaign in a language that made sense and appealed to Canadians, disarmers framed their anti-nuclear efforts in a certain understanding of ideal "Canadianism.” By putting forth an image of Canada as a kind and moral world leader, devoted to both protecting the dignity of the individual and promoting international cooperation, Canadian disarmers sought to convince the public that the acquisition of nuclear arms by Canada was un-Canadian.

The campaign served to bring together diverse anti-nuclear organizations, but it failed to keep Canada free of nuclear weapons. With the arrival of nuclear weapons in North Bay, Ontario, and La Macaza, Quebec, Canadian disarmers struggled to

\footnotetext{
${ }^{1294}$ Woodsworth, "No Nuclear Arms for Canada," 3; "Statement on the Test Ban Treaty," 30 July 1963, 1; Canadian Peace Congress, "Peace Group Goes to Ottawa," 1; Joseph and Marjorie Reid to Pearson, 9 August 1963, 1.

${ }^{1295}$ Wittner, The Struggle Against the Bomb, vol. 2, 473; Chatfield, The American Peace Movement, 114; Swerdlow, Women Strike for Peace, 12-13; Foster, Women for All Seasons, 28; Churchill, "SUPA, Selma, and Stevenson," 37; Early, "Canadian Women and the International Arena in the Sixties," 25; Katz, Ban the Bomb, xii-xiii; Winkler, Life Under a Cloud, 4.
} 
reinvigorate and reframe their anti-nuclear campaigns. In the end, it was the organizations that explicitly tied their efforts to the global struggle for peace and enthusiastically embraced their membership in transnational peace and disarmament advocacy networks that were best equipped to extend their work beyond "No Nuclear Weapons for Canada."

The work of the CPC and its parent-organization the communist-led WPC was ideologically rooted in socialist internationalism and an acceptance of the universality of exploitation under capitalism. This philosophy inspired a consistent critique of colonialism and a championing of national self-determination by CPC supporters, providing the organization with a persistent purpose long after the signing of the test ban treaty. ${ }^{1296}$ Though driven by very different politics, VOW's approach to international cooperation was similarly grounded in a notion of universal experience. Despite the organization's self-imposed isolation from existing advocacy networks, VOW established its own distinct network of women across the globe grounded in the assumption that women shared a special capacity to encourage lasting peace. The belief that grassroots interactions among women could spread into greater respect and understanding at the level of international politics helped VOW to expand its priorities outside of nuclear disarmament.

Some groups such as the CCCRH-CCND and the CUCND were more utilitarian in their approach to international cooperation. These organizations took advantage of exchanges of resources and individuals among peace and disarmament groups as a central

\footnotetext{
1296 "Main Resolution," Documents of Extraordinary Renewal Convention, 25 October 2005, Canadian Peace Congress, accessed 28 August 2016, http://www.canadianpeacecongress.ca/statementscpcon/documents-of-extraordinary-renewal-convention-october-25-2008.
} 
strategy for strengthening disarmament efforts. This lack of deeper investment in an international outlook was particularly detrimental for the CCND and the CUCND. In distinct ways, Canadian disarmers integrated themselves in a mass international effort against nuclear arms through the exchange of ideas, methods, and people across borders. Learning from the experiences of larger, foreign disarmament efforts, Canadian anti-nuclear activists formed movements that reflected the distinct objectives of individual organizations, national contexts, and the broader global threat presented by the Bomb. Whether through informal advocacy networks or formal international organizations, Canadian disarmers discovered, as Roussopoulos, Hunnius, and Richard argued, that cooperation with like-minded people across the globe gave their efforts strength not possible for national campaigns alone. ${ }^{1297}$ By overcoming difference and identifying shared values and desires, Canadian anti-nuclear activists learned that their message carried much greater weight when their voices were added to an international chorus.

${ }^{1297}$ Richard, Roussopoulos and Hunnius, "Why," 1. 


\section{Conclusion}

In historical analyses of early Cold War disarmament movements, Canadian antinuclear efforts have been undervalued, being dismissed as "quiet" and "minimal."1298 It is true that low key protest methods were consciously prioritized by disarmament groups. Disarmers understood "proper politics" to be the approach that the Canadian public would be most likely to support in light of Cold War associations of peace activism with communism. ${ }^{1299}$ They were fewer in number than their counterparts in the United States and Great Britain. Yet they waged a vigorous and complicated battle against nuclear arms between 1959 and 1963. Canadian disarmament movements also had their successes, most notably with the gathering of over 200,000 signatures against the installation of nuclear arms in Canada in 1961 and the collection of over 40,000 children's teeth, drawing public attention to the dangers of nuclear fallout. The characterization of these movements as "quiet" does not properly capture the drive, idealism, anxiety, and passion that animated Canadian disarmament efforts.

Canadian disarmers responded to the Cold War and the threat of nuclear weapons in diverse ways. Disarmers were women, men, parents, professionals, students, and

\footnotetext{
${ }^{1298}$ Peter Brock and Nigel Young, Pacifism in the Twentieth Century (Syracuse: Syracuse University Press, 1999), 249; Lawrence S. Wittner, The Struggle Against the Bomb, vol. 1 (Stanford: Stanford University Press, 1993), 99.

${ }^{1299}$ Holger Nehring, "National Internationalists: british and West German Protests Against Nuclear Weapons, the Politics of Transnational Communications and the Social History of the Cold war, 19571964," Contemporary European History 14(4) (2005): 580; Marion Douglas Kerans, Muriel Duckworth: A Very Active Pacifist, A Biography (Halifax: Fernwood, 1996), 88; Canadian Campaign for Nuclear Disarmament, "Instructions for Lobbyists," 8-10 November 1962, MUL, CCND fonds, ACCN. 051989.102.F, box 24, file 5, 2; Jean Birch to Mrs. Macpherson, 5 June 1963, LAC, Voice of Women fonds, MG28-I218, vol. 29, file: Winnipeg meeting Emergency Resolutions correspondence pt. 1 1963, 1; Carole Chapman, "How effective is The Voice of Women?," Chatelaine (June 1961), 188.
} 
young people, all of various political persuasions. Their efforts in opposition to the Bomb were informed by their different experiences and understandings of their world.

Canadian women engaged in anti-nuclear protest had complex relationships with feminism. Women's disarmament activism was informed by complementary and conflicting understandings of women's potential to bring about a more peaceful world. Women's early Cold War activism challenged socially constructed gender roles and was a stepping-stone towards greater gender-consciousness and liberationist projects. However, it was also intimately tied to nineteenth-century understandings that equated womanhood to motherhood, and suggested women's childbearing ability naturally lent to passivism. ${ }^{1300}$ Maternal rhetoric provided women with a language to express their right to participate in political debates at a time when the national political system was indisposed to listening to the voices of women. The reliance on more "traditional" maternal feminism by female disarmers, particularly those involved with Voice of Women, was subversive. ${ }^{1301}$ Women involved in disarmament activism demanded access to the public realm and in doing so challenged the established patriarchal socio-political order.

The participation of men in disarmament activism similarly conformed to and resisted Cold War ideal gender norms. The experiences of disarmament men demonstrate the complexities of Cold War constructions of masculinity. By adhering to elements of

\footnotetext{
${ }^{1300}$ Thomas P. Socknat, Witness Against War: Pacifism in Canada, 1900-1945 (Toronto: University of Toronto Press, 1987), 34; Sara Ruddick, "Thinking about Mothering: and Putting Maternal Thinking to Use,” Women's Studies Quarterly 11(4) (Winter 1983): 6; Rhodri Jeffreys-Jones, Changing Differences: Women and the Shaping of American Foreign Policy 1917-1994 (New Brunswick, New Jersey: Rutgers University Press, 1995), 6; Frances Early, "New Historical Perspectives on Gendered Peace Studies," Women's Studies Quarterly 23(3/4) (Fall-Winter 1995): 23.

${ }^{1301}$ Catherine Eschle, "Gender and the Subject of (Anti)Nuclear Politics: Revisiting Women's Campaigning against the Bomb," International Studies Quarterly 57 (2013): 715; Lawrence S. Wittner, "Gender Roles and Nuclear Disarmament Activism, 1954-1965," Gender and History 12(1) (April 2000): 197.
} 
"modern" ideal masculinity, Canadian disarmers responded to public suspicions of

political, gender, and sexual deviance that were connected to a Western cultural

conflation of pacifism with communism and homosexuality. ${ }^{1302}$ To legitimize their

actions, Canadian men active in anti-nuclear organizations presented themselves as

rational, informed professionals and fathers interested in establishing a more secure

world. Within the confines of the "modern" masculinity of the Cold War era, activism

grounded in a father's love for his children was as respectable as challenges to nuclear

deterrence policy rooted in scientific research and professional expertise. ${ }^{1303}$

For all anti-nuclear advocates, parenthood was an especially powerful position in

efforts to convince the public of the importance of banning the testing and production of

nuclear weapons. Canadian disarmers presented themselves as reasonable parent-citizens

when they prioritized the rescue of children from a cataclysmic future in their campaigns.

${ }^{1302}$ Michael Kimmel, Manhood in America: A Cultural History (New York and Oxford: Oxford University Press, 2012), 171, 175. See also: Mary Louise Adams, The Trouble with Normal: Postwar Youth and the Making of Heterosexuality (Toronto: University of Toronto Press), 9-10, 23; Jean Bethke Elshtain, Women and War (New York: Basic Books, Inc., Publishers, 1987), 4; Jeffreys-Jones, Changing Differences, 10; Bernice A. Carroll, "Feminism and Pacifism: Historical and Theoretical Connections," in Women and Peace: Theoretical, Historical and Practical Perspectives, eds. Ruth Roach Pierson, Joanne Thompson, Somer Bodribb and Paula Bourne (London, New York: Croom Helm, 1987), 3; Harriet Hyman Alonso, Peace as a Women's Issue: A History of the U.S. Movement for World Peace and Women's Rights (Syracuse: Syracuse University Press, 1993), 11; Samuel Hynes, $A$ War Imagined: The First World War and English Culture (New York: Collier Books, 1990), 232; Gary Kinsman and Patrizia Gentile, The Canadian War on Queers: National Security as Sexual Regulation (Vancouver: UBC Press, 2010), 7; Steve Hewitt, Spying 101: The RCMP's Secret Activities at Canadian Universities, 1917-1997 (Toronto: University of Toronto Press, 2002), 53-54.

${ }^{1303}$ Elshtain, Women and War, 4; Tracy Xavia Karner, "Engendering Violent Men: Oral Histories of Military Masculinity," in Masculinities and Violence, ed. Lee H. Bowker (Thousand Oaks, California: SAGE Publications, Inc., 1998), 200; Christopher Dummitt, The Manly Modern: Masculinity in Postwar Canada (Vancouver: UBC Press, 2007), 3; Robert L. Griswold, Fatherhood in America: A History (New York: Basic Books, 1993), 186; Mona Gleason, "Disciplining Children, Disciplining Parents: The Nature and Meaning of Advice to Canadian Parents, 1945-1955," Histoire Sociale/Social History 29 (May 1996): 202; Robert Rutherdale, "New 'Faces' for Fathers: Memory, Life-Writing, and Fathers as Providers in the Postwar Consumer Era," in Creating Postwar Canada: Community, Diversity, and Dissent, 1945-75, eds. Magda Fahrni and Robert Rutherdale (Vancouver: UBC Press, 2008), 253; Arlene S. Skolnick, Embattled Paradise: The American Family in an Age of Uncertainty (New York: Basic Books, 1993), 71; Herbert Sussman, Masculine Identities: The History and Meanings of Manliness (Santa Barbara, California: Praeger, 2012), 13-14. 
The post-war baby boom had resulted in a public valorization of children and the family.

An accompanying rise in human rights discourse prioritizing children allowed disarmers to frame their protest messages within an accepted social dialogue about the significance of a safe and happy childhood. ${ }^{1304}$ Discussions of the threat that nuclear war and nuclear fallout posed to children affected people emotionally and activists sought to mobilize around this. Disarmers utilized culturally meaningful visual tropes, such as the unaccompanied child, to create protest campaigns that were designed to speak to the hopes and fears of parents everywhere. The needs of children provided a common language that helped connect Canadian activists to fellow disarmers across the globe. Despite the emphasis on the need to protect future generations from the dangers of nuclear weapons technology in disarmament campaigns, young activists often found their perspectives were not reflected in the programs of "adult" organizations. ${ }^{1305}$ The omission of the opinions of young Canadians galvanized the development of expressions of a distinct youth perspective on nuclear arms. ${ }^{1306}$ With its self-conscious identity as a

\footnotetext{
${ }^{1304}$ Doug Owram, Born at the Right Time: A History of the Baby Boom Generation (Toronto: University of Toronto Press, 1997), ix, 135; Robert Menzies, Robert Adamoski and Dorothy E. Chunn, "Rethinking the Citizen in Canadian Social History," Contesting Citizenship: Historical Readings, eds. Robert Adamoski, Dorothy E. Chunn and Robert Menzies (Peterborough, Ont.: Broadview Press, Ltd., 2002), 27; Nancy Christie, Engendering the State: Family, Work, and Welfare in Canada (Toronto: University of Toronto Press, 2000), 312; Magdalena Fahrni, Household Politics: Montreal Families and Postwar Reconstruction (Toronto: University of Toronto Press, 2005), 143; Martha Minow and Richard Weissbourd, "Social Movements for Children," Daedalus 122(1) (Winter 1993): 14; Tarah Brookfield, Cold War Comforts: Canadian Women, Child Safety, and Global Insecurity, 1945-1975 (Waterloo: Wilfrid Laurier University Press, 2012), 12; Dominique Marshall, "The Construction of Children as an Object of International Relations: The Declaration of Children's Rights and the Child Welfare Committee of the League of Nations, 1900-1924," International Journal of Children's Rights 7 (1999): 103-104; Dominique Marshall, "The Cold War, Canada, and the United Nations Declaration of the Rights of the Child," in Canada and the Early Cold War 1943-1957, ed. Greg Donaghy, 183-212 (Ottawa: Department of Foreign Affairs and International Trade, 1998), 184; Jacqueline Bhabha, "The Child: What Sort of Human?," PMLA 121(5) (October 2006): 1532-1533; Maureen Moynagh, "Human Rights, Child-Soldier Narratives, and the Problem of Form," Research in African Literatures 42(4) (Winter 2011): 39, 41, 47.

${ }^{1305}$ Brookfield, Cold War Comforts, 14.

${ }^{1306}$ Roberta Lexier, "To Struggle Together or Fracture Apart: The Sixties Student Movements at EnglishCanadian Universities," in Debating Dissent: Canada and the Sixties, eds. Lara Campbell, Dominique Clément and Gregory S. Kealey (Toronto: University of Toronto Press, 2012), 93; Karine Hébert,
} 
youth organization, the Combined Universities Campaign for Nuclear Disarmament (CUCND) pursued objectives and used methods that were exceptional among Canadian anti-nuclear efforts, particularly with its early promotion of the use of non-violent civil disobedience. The CUCND was thus an organization apart in Canadian disarmament activities. $^{1307}$

From 1959 to 1963, the majority of Canadian disarmers purposely avoided any form of protest that was publicly linked to radicalism, specifically civil disobedience. ${ }^{1308}$ Until 1963, Canadian peace and disarmament organizations emphasized political lobbying as a protest tactic, and rarely doubted the effectiveness of their conservative methods. ${ }^{1309}$ Canadian activists assumed that, if Canadian politicians were sufficiently informed about the dangers of nuclear fallout and nuclear war, the federal government would lead the Canadian public in a widespread denunciation of nuclear technology. ${ }^{1310}$

\footnotetext{
"Between the Future and the Present: Montreal University Student Youth and the Post-war Years, 19451960," in Cultures of Citizenship in Post-War Canada, 1940-1955, eds. Nancy Christie and Michael Gauvreau (McGill-Queen's University Press, 2003), 185.

${ }^{1307}$ CUCND secretariat, 16 June 1963, William Ready Division of Archives and Research Collections, McMaster University Library (MUL), CUCND-SUPA fonds, box 1, file: CUCND secretariat meeting minutes Dec. 1962-Feb. 1964, 3; Federal secretariat CUCND, "Inter-branch memo," 15 September 1961, MUL, CUCND-SUPA fonds, box 1, file: CUCND Toronto office 1960-1961 correspondence, 2; Peter Light, 14 June 1962, MUL, CCND fonds, box 9, file 2, 1-2.

${ }^{1308}$ Nehring, "National Internationalists," 580-581; Margaret Haines to Kay Macpherson, 12 March 1966, Library and Archives Canada (LAC), Voice of Women fonds, MG28-I218, vol. 21, file: British Columbia correspondence 1965-1971, 2-3; "Why a Committee of 100," Survival 1(1) (November 1961), LAC, James G. Endicott and Family fonds, MG30-C130, vol. 19, file 376, 1.

${ }^{1309}$ Gary Moffatt, History of the Peace Movement in Canada (Ottawa, ON: Grapevine Press, 1982), 51; Socknat, Witness Against War, 10, 14, 290-291; "Policy Statement," autumn 1960, MUL, CUCND-SUPA fonds, box 7, file: Early CUCND material, 2-3; "What is the Canadian Campaign for Nuclear Disarmament,?" ca. 1963, MUL, CCND fonds, SW571, box 1, file 1, 1-2; Mary Jennison, "The Growth of the Peace Movement in Canada," ca. 1949, LAC, James G. Endicott and Family fonds, MG30-C130, vol. 1, file 1, 3-4; "Brief concerning the: 1) motivation 2) purpose 3) methods of implementation 4) organization of a proposed, new international movement to be known as 'Voice of Women," 12 June 1960, LAC, Voice of Women fonds, MG28-I218, vol. 7, file: Development of Brief-Organization of VOW, 1961, 2; Mrs. F. Davis to Hon. Lester B. Pearson, 22 June 1960, LAC, Voice of Women fonds, MG28-I218, vol. 1, file: Correspondence - members of parliament re. formation 1960-1963, 1.

${ }^{1310}$ Marion Douglas Kerans, Muriel Duckworth: A Very Active Pacifist, A Biography (Halifax: Fernwood, 1996), 88; Canadian Campaign for Nuclear Disarmament, "Instructions for Lobbyists," 8-10 November 1962, MUL, CCND fonds, ACCN. 05-1989.102.F, box 24, file 5, 2; Jean Birch to Mrs. Macpherson, 5 June
} 
But disarmers' methods of "orderly" protest failed to convince Canadian politicians of the threat of the Bomb. In spite of their best efforts, Canadian anti-nuclear organizations failed to influence Canadian foreign and defence policy decision-making or promote meaningful public opposition to nuclear arms. The traditional politics of Canadian disarmers were an inadequate response to the dangers of the Cold War arms race. ${ }^{1311}$

There is no consensus among scholars of social movements and practitioners as to the effectiveness of civil disobedience compared to conventional legal protest methods. Frances Wilcox, a VOW member, argued in May 1963 that "namby-pamby" legal means of protest had long proven to be useless:

The Negroes tried legal means for one hundred years, and where did it get them? The right to the worst jobs after the whites had theirs. Not the right to get off the bus and go to the toilet when the bus stopped at a 'rest' place for the whites. Not the right to drink at a white drinking fountain. The legal right to vote, denied them in practice. ${ }^{1312}$

The suffragettes, on the other hand, with their many "forceful demonstrations" had won women the right to vote, Wilcox observed. ${ }^{1313}$ Supporters of civil disobedience and dramatic non-violent mass actions have argued that militant protests, such as the sit-ins and freedom rides used in the United States by the Student Nonviolent Coordinating

\footnotetext{
1963, LAC, Voice of Women fonds, MG28-I218, vol. 29, file: Winnipeg meeting Emergency Resolutions correspondence pt. 1 1963, 1.

${ }^{1311}$ Dimitry Anastakis, "Introduction," in The Sixties: Passion, Politics and Style, ed. Dimitry Anastakis (Montreal: McGill-Queen's University Press, 2008), 9; Holger Nehring, The Politics of Security: British and West German Protest Movements and the Early Cold War, 1945-1970 (Oxford: Oxford University Press, 2013), 47-48; Bryan Palmer, Canada's 1960s: The Ironies of Identity in a Rebellious Era (Toronto: University of Toronto Press, 2009), Kindle Loc 139; Lara Campbell and Dominique Clément, "Introduction: Time, Age, Myth: Towards a History of the Sixties," in Debating Dissent: Canada and the Sixties, edited by Lara Campbell, Dominique Clément and Gregory S. Kealey (Toronto: University of Toronto Press, 2012), 6; Owram, Born at the Right Time, x, 308.

${ }^{1312}$ Frances Wilcox to Emergency Resolutions Delegation, 26 May 1963, LAC, Voice of Women fonds, MG28-I218, vol. 39, file: Winnipeg meeting Emergency Resolutions correspondence pt. 2 1963, 1.

${ }^{1313}$ Wilcox, 26 May 1963, 1. The Committee for 100 used the same example of civil disobedience in Canada's past ("Why a Committee of 100?," Survival 1(1) (November 1961), LAC, James G. Endicott and Family fonds, MG30-C130, vol. 19, file 376, 1).
} 
Committee in their fight for racial equality, attracted greater public attention and raised greater opposition, leading to more constructive discussions of the issues. ${ }^{1314}$ The practice of civil disobedience indeed proved to be effective in attracting media attention in the nuclear weapons freeze campaigns of the 1980s across the West. ${ }^{1315}$ However, other scholars point out that, because of the threat of imprisonment, groups practicing civil disobedience rarely last long and struggle to maintain membership. ${ }^{1316}$

As the Canadian Committee of 100 declared in their call for greater use of civil disobedience in anti-nuclear efforts in 1961, it is clear that "normal means of persuasion" had only had limited success in Canada. ${ }^{1317}$ The "No Nuclear Arms for Canada" campaign waged by Canadian disarmers faced "unmitigated defeat" with the arrival of nuclear arms in Canada on New Year's Eve 1963. ${ }^{1318}$ The traditional protest methods of Canadian disarmers did not produce the public uproar necessary to keep nuclear arms out of Canada. ${ }^{1319}$

${ }^{1314}$ Frank E. Myers, "Civil Disobedience and Organizational Change: The British Committee of 100," Political Science Quarterly 86(1) (March 1971): 111; Chatfield, The American Peace Movement, 102, 104; Roberta Lexier, “'The Backdrop Against Which Everything Happened:' English-Canadian Student Movements and Off-Campus Movements for Change," History of Intellectual Culture 7(1) (2007): 6; Frances B. McCrea and Gerald E. Markle, Minutes to Midnight: Nuclear Weapons Protest in America (Newbury, Ca.: Sage Publications, 1989), 23-24; "Join the Committee of 100 and work for peace," n.d., LAC, James G. Endicott and Family fonds, MG30-C130, vol. 33, file 625, 3; "Why a Committee of 100?," 1.

${ }^{1315}$ Chatfield, The American Peace Movement, 154-155; Shragge, Eric, Ronald Babin and Jean-Guy Vaillancourt, "Introduction," in Roots of Peace: The Movement Against Militarism in Canada, edited by Eric Shragge, Ronald Babin and Jean-Guy Vaillancourt, 9-15 (Toronto: Between the Lines, 1986), 9; Nigel Young, "The Peace Movement: A Comparative and Analytical Survey," Alternatives XI (1986): 203.

${ }^{1316}$ McCrea and Markle, Minutes to Midnight, 162; Moffatt, History of the Peace Movement in Canada, 1; Myers, "Civil Disobedience and Organizational Change," 111; Nehring, "National Internationalists," 580581.

1317 "Why a Committee of $100 ?$, , 1.

1318 "Dear CUCNDer," ca. 1964, MUL, CUCND-SUPA fonds, box 2, file: Toronto office correspondence 1964-1965, 1.

${ }^{1319}$ Mabel Hanway to Jacqueline Dineen, 26 August 1963, LAC, James G. Endicott and Family fonds, MG30-C130, vol. 8, file 160, 1; "Sample Letters to Editor and Sample Resolutions," n.d., LAC, James G. Endicott and Family fonds, MG30-C130, vol. 9, file 161, 1; Manitoba Conference for a Non-Nuclear Canada, "Only Disarmament Guarantees Survival," 16 March 1964, LAC, James G. Endicott and Family fonds, MG30-C130, vol. 19, file 362, 1-2; Jack Duckworth to Alex D. MacDonald, 21 August 1964, MUL, CCND fonds, SW572, box 7, file 7, 1 . 
While they were unsuccessful in challenging assumptions of the value of nuclear deterrence as a defence strategy, Canadian disarmers, working in tandem with antinuclear organizations across the globe, had helped to create the environment of public concern over radioactive nuclear fallout that made the Limited Test Ban Treaty of 1963 possible. ${ }^{1320}$ Canadian disarmament campaigns were always rooted in domestic political concerns and set in national political and historical contexts. Nevertheless, anti-nuclear activists learned that international cooperation among like-minded individuals provided social movements with a weight that was unobtainable for national efforts alone. ${ }^{1321}$ Because of the global nature of the threat posed by the Bomb, anti-nuclear efforts naturally extended over national borders. Within transnational disarmament advocacy networks, Canadian activists, like their peers across the globe, observed successful protest methods abroad and altered them to fit local needs. Canadian movements were then a product and an adaptation of international efforts to ban nuclear weapons.

Canadian disarmers drew public attention to the hazards of nuclear fallout, and contributed to an international consensus opposing the atmospheric testing of nuclear

\footnotetext{
${ }^{1320}$ Lawrence Wittner, The Struggle Against the Bomb, vol. 2 (Stanford: Stanford University Press, 1997), 473; Charles Chatfield, The American Peace Movement (New York: Twayne Publishers, 1992), 114; Amy Swerdlow, Women Strike for Peace: Traditional Motherhood and Radical Politics in the 1960s (Chicago and London: The University of Chicago Press, 1993), 12-13; Catherine Foster, Women for All Seasons: The Story of the Women's International League for Peace and Freedom (Athens, Georgia: University of Georgia Press, 1989), 28; David Churchill, "SUPA, Selma, and Stevenson: The Politics of Solidarity in mid-1960s Toronto," Journal of Canadian Studies 44(2) (Spring 2010): 37; Frances Early, "Canadian Women and the International Arena in the Sixties: The Voice of Women/La voix des femmes and the Opposition to the Vietnam War," in The Sixties: Passion, Politics and Style, ed. Dimitry Anastakis (Montreal: McGill-Queen's University Press, 2008), 25; Milton Katz, Ban the Bomb: The History of SANE, the Committee for a Sane Nuclear Policy, 1957-1985 (Westport, Conn.: Greenwood Press, 1986), xii-xiii; Allan M. Winkler, Life Under a Cloud: American Anxiety About the Atom (New York: Oxford University Press, 1993), 4.

${ }^{1321}$ Gilles B. Richard, Dimitrios Roussopoulos, F. C. Hunnius, "Why the Canadian Campaign for Nuclear Disarmament Must Join the International Confederation for Disarmament and Peace," 20-21 July 1963, MUL, CCND fonds, SW571, box 2, file 1, 1.
} 
arms. ${ }^{1322}$ "Our survival, physical and moral, has resulted from the activities of those men and women who worked to free humanity from the menace of nuclear annihilation," historian of global disarmament efforts Lawrence Wittner has argued. ${ }^{1323}$ In like manner, former CUCND member Jim Harding has claimed that the efforts of disarmers proved "that collective, non-violent, extraparliamentary activism makes a difference — and probably even helped to keep us alive."1324

Anti-nuclear activists across the globe recognized that the 1963 Limited Test Ban Treaty, while a significant accomplishment in the fight for nuclear disarmament, also "ended the sense of urgency" that had once been associated with the Bomb. ${ }^{1325}$ Increasing public complacency over nuclear weapons resulted in significant decreases in Canadian participation in disarmament organizations, with most either collapsing or turning their attention to different social and political concerns by the mid-1960s. ${ }^{1326}$ This decline in

1322 Wittner, The Struggle Against the Bomb, vol. 2, 473; Chatfield, The American Peace Movement, 114; Swerdlow, Women Strike for Peace, 12-13; Foster, Women for All Seasons, 28; Churchill, "SUPA, Selma, and Stevenson," 37; Early, "Canadian Women and the International Arena in the Sixties," 25; Katz, Ban the Bomb, xii-xiii; Winkler, Life Under a Cloud, 4.

${ }^{1323}$ Wittner, The Struggle Against the Bomb, vol. 2, 473.

1324 Jim Harding, "Continuing On: Deepening the Anti-Nuclear Movement since the Sixties," in New World Coming: The Sixties and the Shaping of Global Consciousness, eds. Karen Dubinsky, et. al. (Toronto: Between the Lines, 2009), 398.

1325 Arthur Pape, "Report to the CCND and CUCND," 9-13 January 1964, MUL, CCND fonds, SW571, box 3, file 4, 1. See also: Canadian Peace Congress, 7 September 1963, LAC, James G. Endicott and Family fonds, MG30-C130, vol. 2, file 33, 1; Stan Gray to Art Pape, 25 August 1963, MUL, CUCNDSUPA fonds, box 4, file: McGill University 1962-1964, 1, 2; "Dear CUCNDer," n.d., MUL, CUCNDSUPA fonds, box 2, file: Toronto office correspondence 1964-1965, 1; Chatfield, The American Peace Movement, 114, 115; Wittner, The Struggle Against the Bomb, vol. 2, 443, 451; Paul Boyer, "From Activism to Apathy: The American People and Nuclear Weapons, 1963-1980," Journal or American History 70 (March 1984): 824-835.

1326 "Minutes of CCND Board of Directors Meeting," 20 February 1965, MUL, CCND fonds, SW 571, box 1, file 8, 1; Floyd Williston to the Executive of the Canadian Peace Congress, 13 September 1967, LAC, James G. Endicott and Family fonds, MG30-C130, vol. 19, file 363, 1; Anne Van Heteren to Voices, 8 February 1971, LAC, Voice of Women fonds, MG28-I218, vol. 21, file: Calgary correspondence 19661971; Eva Sanderson to Nancy Pocock, 22 April 1964, LAC, James Endicott and Family fonds, MG30C130, vol. 10, file 179, 1; Bruce Mickleburgh, "Our Campaign Now: We the People vs. the UN deadlock," 22 November 1957, LAC, James Endicott and Family fonds, MG30-C130, vol. 7, file 108, 1; Wittner, The Struggle Against the Bomb, vol. 2, 443; Candace Loewen, "Mike Hears Voices: Voice of Women and Lester Pearson, 1960-1963," Atlantis 12(2) (Spring 1987): 29. 
enthusiasm for anti-nuclear efforts was further aggravated in Canada when the government acquired nuclear arms at the end of 1963. In 1964, representatives of the Canadian Peace Congress (CPC), the Canadian Campaign for Nuclear Disarmament (CCND) and the CUCND judged Canada's disarmament efforts as having failed. ${ }^{1327}$ CUCND leader Arthur Pape declared in August 1963, "the first phase of a long war has clearly been lost." 1328

Yet as the CPC executive concluded in 1992, looking back on nearly a halfcentury of activity, "we would be fooling ourselves to think our work is [ever] done."1329 For Canadian disarmers the struggle for the eradication of nuclear weapons was only one step in a larger project to bring about a safer and more just world. ${ }^{1330}$ Once disarmament became a lesser concern, Canadian anti-nuclear activists broadened their efforts. By 1964, Voice of Women (VOW) and the CPC, along with peace organizations across the globe, organized protests against increasing American military intervention in Vietnam. ${ }^{1331}$ By the 1970s many Canadian disarmers had become environmentalists, questioning the wisdom and safety of nuclear power. ${ }^{1332}$ Former Canadian disarmers also

\footnotetext{
${ }^{1327}$ Floyd Williston to CPC, 4 January 196[4], LAC, James G. Endicott and Family fonds, MG30-C130, vol. 10, file 169, 1; Bruce Robinson to Murray [Thompson], 22 April 1964, MUL, CCND fonds, SW571, box 6, file 3; Jack Duckworth to Alex D. MacDonald, 21 August 1964, MUL, CCND fonds, SW572, box 7, file 7, 1; "Dear CUCNDer," 1.

${ }^{1328}$ Arthur Pape to Stan Gray, 23 August 1963, MUL, CCND fonds, SW572, box 9, file 9, 2.

${ }^{1329}$ Canadian Peace Congress, "Canadian Peace Congress Annual Christmas Appeal," Peace Newsletter 1(1) (November 1992), MUL, Canadian Peace Congress fonds, box 59, file: Christmas Appeal 1991-1992, 1.

${ }^{1330}$ Kathleen Langston to Thérèse [Casgrain], 28 November 1962, LAC, Voice of Women fonds, MG28I218, vol. 1, file: correspondence Josephine Davis 1962, 1; W. H. S. Macklin to secretary CCCRH, 24 December 1961, MUL, CCND fonds, SW571, box 1, file 2, 1; "Resolutions and Reports of the Annual Conference Combined Universities Campaign for Nuclear Disarmament," February 1963, MUL, CUCNDSUPA fonds, box 7, file: early CUCND material Howard Adelman's file, 1.

${ }^{1331}$ Brookfield, Cold War Comforts, 165; Boyer, "From Activism to Apathy," 835-836; Eva Sanderson to Nancy Pocock, April 22, 1964, LAC, James Endicott and Family fonds, MG30-C130, vol. 10, file 179, 1. 1332 "Proposals for a revised Voice of Women," 1970, LAC, Voice of Women fonds, MG28-I218, vol. 22, file: national annual meeting 1970, 1; Kay Macpherson, When in Doubt, Do Both: The Times of My Life (Toronto: University of Toronto Press, 1994), 137; Hugh L. Keenleyside, Memoirs of Hugh L. Keenleyside: On the Bridge of Time (Toronto: McClelland and Stewart Limited, 1982), 560-561; Mark Leeming, "The
} 
began to frame their activism around the recognition that violence against women,

poverty, racial discrimination, environmental degradation, violations of democratic rights, militarism, and war were all interrelated. ${ }^{1333}$ Building on the political education that they had gained in disarmament movements, Canadian disarmament activists continued their fight for a better world. ${ }^{1334}$

"The only person who can look back at the end of their life and say that they have not failed, is the person who did not reach high enough," argued long-serving CPC chairman James Endicott. ${ }^{1335}$ Several former disarmers agreed that it was not the individual accomplishments that mattered when measuring the legacy of disarmament activism. One former CCND member contended that compelling people to think about the issues of war and peace was almost as important as changing people's minds. By increasing awareness, "we made a dent," he said. ${ }^{1336}$ The energy and determination that accompanied disarmament activism inspired many Canadians to continue to push for change. ${ }^{1337}$ D. Gillian Thompson, who had been an active disarmer while in university, looked back on her activism with fondness and pride. "I treasure most the memory of my

Creation of Radicalism: Anti-Nuclear Activism in Nova Scotia, c. 1972-1979," The Canadian Historical Review 95(2) (June 2014): 218, 240; Harding, "Continuing On," 390-391.

1333 "CUCND National Membership Conference Regina," 28 December-1 January [1964], MUL, CUCNDSUPA fonds, box 11, file: Regina Conference 1964, 1; "Report of SUPA National Conference, Reprinted from SANITY," Winter 1965, MUL, CUCND-SUPA fonds, box 7, file: Policy and council documents, 1; Beatrice Ferneyhough to Muriel Duckworth, 8 September 1971, LAC, Voice of Women, MG28-I218, vol. 1, file: correspondence general 1967-1973, 7; Owram, Born at the Right Time, 220; Macpherson, When in Doubt, Do Both, 137-138.

${ }^{1334}$ For example, Murray Thompson, who had rung the death knell for the CCND in 1965, went on to found the Canadian peace organization Project Ploughshares in 1976. The organization continues to promote peaceful alternatives to conflict resolution to this day ("CCND Executive Meeting," 26 January 1965, MUL, CCND fonds, SW571, box 1, file 15, 2; "History," Project Ploughshares, accessed 16 September 2016, http://ploughshares.ca/about-us/history/.)

1335 James Endicott as cited in Reg Whitaker and Gary Marcuse, Cold War Canada: The Making of a National Insecurity State, 1945-1957 (Toronto: University of Toronto Press, 1994), 383.

${ }^{1336}$ Anonymous, interview with author, 6 November 2013.

1337 Dorothy Goldin Rosenberg, interview with author, 30 November 2013; Anonymous, interview with author, 9 November 2013. 
younger, hopeful self, and the dream of building a better, more equal society, worldwide." 1338

${ }^{1338}$ D. Gillian Thompson, interview with author, 12 November 2013. 


\section{Bibliography}

\section{Primary Sources}

$\underline{\text { Interviews and related communications }}$

Alton, Janis. "Re: VOW History Project Meeting," email to author. 25 March 2015. Anonymous. Email with author. 28 October 2013.

Anonymous. Interview with author. 1 November 2013. Anonymous. Interview with author. 6 November 2013. Anonymous. Interview with author. 8 November 2013. Anonymous. Interview with author. 9 November 2013.

Anonymous to VOW. "Re. Banning the Bomb: your help with research," email forwarded to author. 30 October 2013.

Beeching, John. Email to author. 8 November 2013.

Goldin Rosenberg, Dorothy. Interview with author. 30 November 2013.

Thompson, D. Gillian. Interview with author. 12 November 2013.

Thurlow, Setsuko. Interview with author. 30 October 2013.

\section{Archival Sources}

Archives of Ontario. Canadian Peace Research Institute fonds. F-883-1-2.

Library and Archives Canada. Abraham Feinberg fonds. MG31-F9.

Library and Archives Canada. Andrew Allan fonds. MG31-D56.

Library and Archives Canada. Co-operative Commonwealth Federation and New

Democratic Party fonds. MG28-IV1.

Library and Archives Canada. CSIS files. RG146. (Obtained under access to information).

Library and Archives Canada. CSIS files. RG146-723. (Obtained under access to information).

Library and Archives Canada. CSIS files. RG146-738. (Obtained under access to information).

Library and Archives Canada. Edith Ellen Holtom fonds. MG31-I1.

Library and Archives Canada. James G. Endicott and Family fonds. MG30-C130.

Library and Archives Canada. Lester B. Pearson fonds, Leader of the Opposition correspondence. MG26-N2.

Library and Archives Canada. Lester B. Pearson fonds, Pre-1958 correspondence. MG26N1.

Library and Archives Canada. Lester B. Pearson fonds, Prime Minister's Office correspondence. MG26-N3.

Library and Archives Canada. Liberal Party of Canada fonds. MG28-IV3.

Library and Archives Canada. Progressive Conservative Party of Canada fonds. MG28IV2.

Library and Archives Canada. Society of Friends fonds. MG17-G1.

Library and Archives Canada. United Nations Association in Canada fonds. MG28-I202. 
Library and Archives Canada. Voice of Women fonds. MG28-I218.

University of British Columbia Rare Books and Special Collections. Mildred Fahrni fonds. RBSC-ARC-1183.

University of British Columbia Rare Books and Special Collections. Women's International League for Peace and Freedom fonds. RBSC-ARC-1626.

University of Saskatchewan University Archives and Special Collections. John G. Diefenbaker fonds.

The William Ready Division of Archives and Research Collections, McMaster University Library. Bertrand Russell archives.

The William Ready Division of Archives and Research Collections, McMaster University Library. Canadian Peace Congress fonds.

The William Ready Division of Archives and Research Collections, McMaster University Library. CCND fonds.

The William Ready Division of Archives and Research Collections, McMaster University Library. CUCND-SUPA fonds.

Newspapers and Magazines

The Calgary Herald.

Chatelaine.

Consumer Reports.

The Globe and Mail.

Ottawa Citizen.

Our Generation Against Nuclear War.

Saturday Review.

The Toronto Daily Star.

\section{$\underline{\text { Memoirs }}$}

Casgrain, Thérèse F. A Woman in a Man's World. Toronto: McClelland \& Stewart, 1972. Diefenbaker, John G. One Canada: Memoirs of the Right Honourable John G. Diefenbaker, The Tumultuous Years, 1962-1967. Toronto: Macmillan of Canada, 1977.

Ignatieff, George, with Sonja Sinclair. The Making of a Peacemonger. Toronto: University of Toronto Press, 1985.

Keenleyside, Hugh L. Memoirs of Hugh L. Keenleyside: On the Bridge of Time. Toronto: McClelland and Stewart Limited, 1982.

Kent, Tom. A Public Purpose. Montreal: McGill-Queen's Press, 1988.

Macpherson, Kay. When in Doubt, Do Both: The Times of My Life. Toronto: University of Toronto Press, 1994.

Pearson, Lester. Mike: The Memoirs of the Right Honourable Lester B. Pearson, vol. 3, edited by J.A. Munro and A.I. Inglis. Toronto: University of Toronto Press, 19721975 .

$\underline{\text { Published Sources }}$ 
Canada. House of Commons Debates, vol. II (1959). Ottawa: The Queen's Printer and Controller of Stationary, 1959.

Canada. House of Commons Debates, vol. I (1960). Ottawa: The Queen's Printer and Controller of Stationary, 1960.

Canada. House of Commons Debates, vol. VI (1960-61). Ottawa: Roger Duhamel, 1961.

Canada. House of Commons Debates, vol. III (1962). Ottawa: Roger Duhamel, 1963.

Canada. House of Commons Debates, vol. I (1963). Ottawa: Roger Duhamel, 1963.

Canada. House of Commons Debates, vol. III (1963). Ottawa: Roger Duhamel, 1963.

Cavell, Janice, ed. Documents on Canadian External Relations, vol. 27. Ottawa: Foreign Affairs and International Trade Canada, 2007.

Cavell, Janice, ed. Documents on Canadian External Relations, vol. 28. Ottawa: Foreign Affairs and International Trade Canada, 2009.

Cavell, Janice, ed. Documents on Canadian External Relations, vol. 29. Ottawa: Foreign Affairs, Trade and Development Canada, 2013.

Foreign Relations of the United States, 1961-1963, vol. XIII. Washington: Unites States Government Printing Office, 1994.

Gallup Report 1960-61. Toronto: Canadian Institute of Public Opinion, 1961.

Gallup Report 1962. Toronto: Canadian Institute of Public Opinion, 1962.

Gallup Report 1963. Toronto: Canadian Institute of Public Opinion, 1963.

Mcllroy, Thad, ed. Personal Letters of a Public Man: The Family Letters of John G. Diefenbaker. Toronto: Doubleday Canada Ltd., 1985.

Minifie, James M. Peacemaker or Powder-Monkey: Canada's Role in a Revolutionary World. Toronto: McClelland \& Stewart Limited, 1960.

\section{$\underline{\text { Internet Sources }}$}

“About." Canadian Voice of Women. Accessed 9 September 2016, http://vowpeace.org/about/.

Armstrong, Willis C. Interview by Charles Stuart Kennedy. 29 November 1988.

"Frontline Diplomacy: The Foreign Affairs Oral History Collection of the Association for Diplomatic Studies and Training." Library of Congress. Accessed 27 May 2015, http://lcweb2.loc.gov/service/mss/mfdip/2004/2004arm03/2004arm03.pdf.

Democratic National Committee. "1964 Presidential Campaign Television Spot, 'Peace, Little Girl,' aka the 'Daisy Spot.”' Lyndon Baines Johnson Library and Museum Media Archives. Accessed 15 June 2015, http://www.lbjlib.utexas.edu/johnson/media/daisyspot/.

"Generations in Canada." Statistics Canada. Accessed 19 May 2016, https://www12.statcan.gc.ca/census-recensement/2011/as-sa/98-311-x/98-311x2011003_2-eng.cfm.

"History." Project Ploughshares. Accessed 16 September 2016, http://ploughshares.ca/about-us/history/.

"Main Resolution." Documents of Extraordinary Renewal Convention, 25 October 2005. 
Canadian Peace Congress. Accessed 28 August 2016, http://www.canadianpeacecongress.ca/statements-cpcon/documents-ofextraordinary-renewal-convention-october-25-2008.

"Population, by age and sex, census dates, 1851 to 1976." Statistics Canada. Accessed

27 November 2015, http://www.statcan.gc.ca/pub/11-516-x/sectiona/A78_93eng.csv.

"Population growth and components (1851-2001 Censuses)." Statistics Canada. Accessed 16 October 2015, http://www.statcan.gc.ca/tables-tableaux/sumsom/101/cst01/demo03-eng.htm.

Robinson, Jr., Paul H. Interview by Willis Armstrong. 1989. "Frontline Diplomacy." Library of Congress. Accessed May 27, 2015, http://lcweb2.loc.gov/service/mss/mfdip/2004/2004rob03/2004rob03.pdf.

United Nations General Assembly. "Declaration of the Rights of the Child," A/RES/1386 (XIV). Declarations and Conventions Contained in GA Resolutions. Accessed 22 July 2015, http://daccess-ddsny.un.org/doc/RESOLUTION/GEN/NR0/142/09/IMG/NR014209.pdf?OpenElem ent.

U.S. Senate, Committee on Foreign Relations, Subcommittee on Canadian Affairs. "Supplying of Nuclear Arms to the Canadian Forces." 4 February 1963. Executive Sessions of the Senate Foreign Relations Committee, vol. XV (1963). Accessed December 10, 2015, http://babel.hathitrust.org/cgi/pt?id=mdp.39015039034460;view=1up;seq=1.

\section{Other Sources}

Voice of Women. Building Peace Making History: 100 Years of Women's Peace Building in Canada (The VOW Peace Exhibit). Carleton University Department of History, Ottawa. February-March 2013.

\section{Secondary Sources}

Adamoski, Robert, Dorothy E. Chunn and Robert Menzies. Contesting Canadian Citizenship: Historical Readings. Peterborough, Ontario: Broadview Press, Ltd., 2002.

Adams, Mary Louise. The Trouble With Normal: Postwar Youth and the Making of Heterosexuality. Toronto: University of Toronto Press, 1997.

Adamson, Walter L. Hegemony and Revolution: A Study of Antonio Gramsci's Political and Cultural Theory. Berkeley: University of California Press, 1983.

Adler, Karen, Ross Balzaretti and Michele Mitchell, "Practicing Gender History," Gender \& History 20 (1) (April 2008): 1-7.

Alonso, Harriet Hyman. Peace as a Women's Issue: A History of the U.S. Movement for World Peace and Women's Rights. Syracuse: Syracuse University Press, 1993.

Anastakis, Dimitry, ed. The Sixties: Passion, Politics and Style. Montreal: McGillQueen's University Press, 2008.

Anderson, Benedict. Imagined Communities: Reflections on the Origin and Spread of 
Nationalism. New York: Verso, 2006.

Anderson, Kay. Vancouver's Chinatown: Racial Discourse in Canada, 1875-1980. Montreal: McGill-Queen's University Press, 1991.

Arrandale, Karen. "Artists' rifles and artistic licence: Edward Dent's war." First World War Studies 2(1) (March 2011): 7-16.

Badash, Lawrence. Review The Struggle Against the Bomb, Volume 2, Resisting the Bomb: A History of the World Nuclear Disarmament Movement, 1954-1970 by Lawrence S. Wittner. Isis 93(3) (September 2002): 539-540.

Backhouse, Constance and David H. Flaherty, eds. Challenging Times: The Women's Movement in Canada and the United States. Montreal: McGill-Queen's University Press, 1992.

Ball, Christine. "The History of the Voice of Women/La Voix des Femmes: The Early Years, 1960-1963.” PhD diss., University of Toronto, 1994.

Benford, Robert D. "'You Could Be the Hundredth Monkey': Collective Action Frames and Vocabularies of Motive within the Nuclear Disarmament Movement." The Sociological Quarterly 34(2) (May 1993): 195-216.

Bentley, Eric. Thirty Years of Treason: Excerpts from Hearings Before the House Committee on Un-American Activities, 1938-1968. New York: Viking Press, 1971.

Bercuson, David. Review of Essence of Indecision: Diefenbaker's Nuclear Policy, 19571963 by Patricia McMahon. Canadian Historical Review 91(1) (March 2010): 174-176.

Bhabha, Jacqueline. “The Child: What Sort of Human?" PMLA 121(5) (October 2006): 1526-1535.

Bothwell, Robert. The Big Chill: Canada and the Cold War. Toronto: Canadian Institute of International Affairs, 1998.

Bothwell, Robert. "The Canadian Isolationist Tradition." International Journal 54(1) (Winter 1998/1999): 76-87.

Bothwell, Robert, Ian Drummond and John English. Canada since 1945: Power, Politics and Provincialism, rev. ed. Toronto: University of Toronto Press, 1989.

Bow, Brian. "Parties and Partisanship in Canadian Defence Policy." International Journal 64(1) (Winter 2008/2009): 67-88.

Bowker, Lee H., ed. Masculinities and Violence. Thousand Oaks, California: SAGE Publications, Inc., 1998.

Boyer, Paul. By the Bomb's Early Light. Chapel Hill, NC: University of North Carolina Press, 1994.

Boyer, Paul. "From Activism to Apathy: The American People and Nuclear Weapons, 1963-1980." Journal of American History 70 (March 1984): 821-844.

Braungart, Richard G. "Historical Generations and Generation Units: A Global Pattern of Youth Movements." Journal of Political and Military Sociology 12 (Spring 1984): 113-135.

Briggs, Laura. "Mother, Child, Race, Nation: The Visual Iconography of Rescue and the Politics of Transnational and Transracial Adoption." Gender \& History 15(2) (August 2003): 179-200.

Briggs, Laura, Gladys McCormick and J. T. Way. "Transnationalism: A Category of Analysis." American Quarterly 60(3) (2008): 625-648. 
Brock, Peter and Nigel Young. Pacifism in the Twentieth Century. Syracuse: Syracuse University Press, 1999.

Brookfield, Tarah. Cold War Comforts: Canadian Women, Child Safety, and Global Insecurity, 1945-1975. Waterloo: Wilfrid Laurier University Press, 2012.

Burnham, John C. "How the Discovery of Accidental Childhood Poisoning Contributed to the Development of Environmentalism in the United States." Environmental History Review 19(3) (Autumn 1995): 57-81.

Burtch, Andrew. Give Me Shelter: The Failure of Canada's Cold War Civil Defence. Vancouver: UBC Press, 2012.

Campbell, Gail G. "'Are we going to do the most important things?' Senator Muriel McQueen Fergusson, Feminist Identities, and the Royal Commission on the Status of Women." Acadiensis XXXVIII(2) (Summer/Autumn 2009): 52-77.

Campbell, Isabel. Unlikely Diplomats: The Canadian Brigade in Germany, 1951-64. Vancouver: UBC Press, 2013.

Campbell, Lara, Dominique Clément and Greg Kealey, eds. Debating Dissent: Canada and the 1960s. Toronto: University of Toronto Press, 2012.

Campbell, Lara, Michael Dawson, Catherine Gidney, eds. Worth Fighting For: Canada's Tradition of War Resistance from 1812 to the War on Terror. Toronto: Between the Lines, 2015. Kindle ed.

Carson, Rachel. Silent Spring. Boston: Houghton Mifflin, 2002.

Cavell, Janice. "Like Any Good Wife: Gender and Perceptions of Canadian Foreign Policy, 1945-75." International Journal (Spring 2008): 385-403.

Chambers, John W. "Introduction." In Conscription and Conscience: A History 19161919, edited by John W. Graham. New York, London: Garland Publishing, Inc., 1971.

Chatfield, Charles. The American Peace Movement. New York: Twayne Publishers, 1992.

Christie, Nancy. Engendering the State: Family, Work, and Welfare in Canada, 19401955. Montreal: McGill-Queen's University Press, 2003.

Christie, Nancy and Michael Gauvreau, eds. Cultures of Citizenship in Post-War Canada, 1940-1955. McGill-Queen's University Press, 2003.

Churchill, David S. "Draft Resisters, Left Nationalism and the Politics of AntiImperialism." The Canadian Historical Review 93(2) (June 2012): 227-260.

Churchill, David S. "SUPA, Selma, and Stevenson: The Politics of Solidarity in mid1960s Toronto." Journal of Canadian Studies 44(2) (Spring 2010): 32-69.

Clark, Samuel, J. Paul Grayson and Linda Grayson, eds. Prophecy and Protest: Social Movements in Twentieth Century Canada. Toronto: Gage Educational Publishing Limited, 1975.

Clearwater, John. Canadian Nuclear Weapons: The Untold Story of Canada's Cold War Arsenal. Toronto: Dundurn Press, 1998.

Cobble, Dorothy Sue. The Other Women's Movement: Workplace Justice and Social Rights in Modern America. Princeton, New Jersey: Princeton University Press, 2004.

Cohler, Deborah. "Sapphism and Sedition: Producing Female Homosexuality in Great War Britain." Journal of the History of Sexuality 16(1) (January 2007): 68-94.

Cohn, Carol. "Clean Bombs' and Clean Language." In Women, Militarism and War, 
edited by Jean Bethke Elshtain and Sheila Tobias. Savage, Maryland: Rowman \& Littlefield Publishers, Inc., 1990.

Connell, R. W. Masculinities, second edition. Cambridge: Polity Press, 2005.

Connell, R. W. and James W. Messerschmidt. "Hegemonic Masculinity: Rethinking the Concept." Gender and Society 19(6) (2005): 829-859.

Cook, Sharon Anne, Lorna R. McLean, and Kate O'Rourke, eds. Framing Our Past: Canadian Women's History in the Twentieth Century. Montreal: McGill-Queen's University Press, 2001.

Coontz, Stephanie. A Strange Stirring: The Feminine Mystique and American Women at the Dawn of the 1960s. New York: Basic Books, 2011.

Corber, Robert J. Homosexuality in Cold War America: Resistance and the Crisis of Masculinity. Durham and London: Duke University Press, 1997.

Cortright, David. Peace: A History of Movements and Ideas. Cambridge: Cambridge University Press, 2008.

Coulomb, Fanny, and Renaud Bellais. "The Marxist Analysis of War and Military Expenditures, Between Certainty and Uncertainty." Defence and Peace Economics 19(5) (October 2008): 351-359.

Daigle, Caralee. "A Challenge and a Danger: Canada and the Cuban Missile Crisis." $\mathrm{PhD}$ diss., Queen's University, 2011.

DeBenedetti, Charles and Charles Chatfield. An American Ordeal: The Antiwar Movement of the Vietnam Era. Syracuse: Syracuse University Press, 1990.

Demetriou, Demetrakis Z. "Connell's Concept of Hegemonic Masculinity: A Critique." Theory and Society 30(3) (June 2001): 337-361.

Divine, Robert A. Blowing on the Wind: The Nuclear Test Ban Debate, 1954-1960. New York: Oxford University Press, 1978.

Donaghy, Greg. Tolerant Allies: Canada \& The United States 1963-1968. Montreal: McGill-Queen's University Press, 2002.

Dubinsky, Karen. Babies Without Borders: Adoption and Migration across the Americas. Toronto: University of Toronto Press, 2010.

Dubinsky, Karen, Catherine Krull, Susan Lord, Sean Mills and Scott Rutherford, eds. New World Coming: The Sixties and the Shaping of Global Consciousness. Toronto: Between the Lines, 2009.

Dudink, Stefan, Karen Hagemann and John Tosh, eds. Masculinities in Politics and War: Gendering Modern History. Manchester: Manchester University Press, 2004.

Dummitt, Chris. "Finding a Place for Father: Selling the Barbecue in Postwar Canada." Journal of the Canadian Historical Association 9(1) (1998): 209-223.

Dummitt, Christopher. The Manly Modern: Masculinity in Postwar Canada. Vancouver: UBC Press, 2007.

Early, Frances H. "New Historical Perspectives on Gendered Peace Studies." Women's Studies Quarterly 23(3/4) (Fall-Winter 1995): 22-31.

The Editorial Collective. "Why Gender and History?" Gender \& History 1(1) (Spring 1989): 1-6.

Elshtain, Jean Bethke. Women and War. New York: Basic Books, Inc., Publishers, 1987.

Endicott, Shirley Jane. China Diary: The Life of Mary Austin Endicott. Waterloo: Wilfrid Laurier University Press, 2003.

Endicott, Stephen. James G. Endicott: Rebel out of China. Toronto: University of 
Toronto Press, 1980.

English, John. The Life of Lester Pearson, vol. 2. Toronto: Lester \& Orpen Dennys, 1989, 1992.

Erikson, Erik H. Identity and the Life Cycle. New York: W. W. Norton and Company, 1994.

Eschle, Catherine. "Gender and the Subject of (Anti)Nuclear Politics: Revisiting Women's Campaigning against the Bomb.” International Studies Quarterly 57 (2013): 713-724.

Fahrni, Magda. Household Politics: Montreal Families and Postwar Reconstruction. Toronto: University of Toronto Press, 2005.

Fahrni, Magda and Robert Rutherdale, eds. Creating Postwar Canada: Community, Diversity, and Dissent, 1945-75. Vancouver: UBC Press, 2008.

Fazzi, Dario. "The Blame and the Shame: Kennedy's Choice to Resume Nuclear Tests in 1962." Peace and Change 39(1) (January 2014): 1-22.

Fingard, Judith and Janet Guildford, eds. Mothers of the Municipality: Women, Work and Social Policy in Post-1945 Halifax. Toronto: University of Toronto Press, 2005.

Flacks, David and Tom Hayden. "The Port Huron Statement at 40." The Nation. 5 August 2002. Accessed 8 October 2015, http://www.thenation.com/article/port-huronstatement-40/.

Foster, Catherine. Women for All Seasons: The Story of the Women's International League for Peace and Freedom. Athens, Georgia: University of Georgia Press, 1989.

Fraser, Erica. "Masculinity in the Personal Narratives of Soviet Nuclear Physicists," Aspasia 8 (2014): 45-63.

Friedan, Betty. The Feminine Mystique. New York: W.W. Norton \& Company, 1997.

Fujiwara, Aya. Ethnic Elites and Canadian Identity: Japanese, Ukrainians, and Scots, 1919-1971. Winnipeg: University of Manitoba Press, 2012.

Ghent, Jocelyn. "Canada, the United States and the Cuban Missile Crisis." Pacific Historical Review 48(2) (1979): 159-184.

Ghent, Jocelyn Maynard. "Did He Fall or Was He Pushed? The Kennedy Administration and the Collapse of the Diefenbaker Government." The International History Review 1(2) (April 1979): 246-270.

Gidney, Catherine. Long Eclipse: The Liberal Protestant Establishment and the Canadian University, 1920-1970. Montreal, Kingston: McGill-Queen's University Press, 2004.

Gidney, Catherine. "Poisoning the Student Mind?: The Student Christian Movement at the University of Toronto, 1920-1965." Journal of the Canadian Historical Association 8(1) (1997): 147-163.

Gilmore, Stephanie. "The Dynamics of Second-Wave Feminist Activism in Memphis, 1971-1982: Rethinking the Liberal/Radical Divide." NWSA Journal 15(1) (Spring 2003): 94-117.

Gleason, Mona. "Disciplining Children, Disciplining Parents: The Nature and Meaning of Advice to Canadian Parents, 1945-1955." Histoire Sociale/Social History 29 (May 1996): 187-209.

Gleason, Mona. Normalizing the Ideal Psychology, Schooling and the Family in Postwar Canada. Toronto: University of Toronto Press, 1999. 
Goldman, Kjell, Ulf Hannerz, and Charles Westin, eds. Nationalism and Internationalism in the Post-Cold War Era. London: Routledge, 2000.

Gordon, Linda. "The Peaceful Sex? On Feminism and the Peace Movement." NWSA Journal 2(4) (Autumn 1990): 624-634.

Granatstein, J. L. A Man Of Influence: Norman A. Robertson and Canadian Statecraft 1929-68. Ottawa: Deneau Publishers \& Company Ltd., 1981.

Grayson, J. Paul. “'Talkin' 'Bout My Generation': Political Orientations and Activities of a Cohort of Canadian University Students in the Mid-Sixties." Journal of Historical Sociology 26(2) (June 2013): 200-233.

Grayson, J. Paul. "The 'feminine mystique' and problems of a cohort of female Canadian university students in the early 1960s." The Sixties: A Journal of History, Politics and Culture 8(1) (2015): 50-74.

Griswold, Robert L. Fatherhood in America: A History. New York: Basic Books, 1993.

Häberlen, Joachim C. "Between global aspirations and local realities: the global dimensions of interwar communism." Journal of Global History 7 (2012): 415437.

Hall, Simon. Rethinking the American Anti-War Movement. New York: Routledge, 2012.

Harris, Richard. Democracy in Kingston: A Social Movement in Urban Politics, $1965-$ 1970. Montreal, Kingston: McGill-Queen's University Press, 1988.

Harris, Richard L. "Cuban Internationalism, Che Guevara, and the Survival of Cuba's Socialist Regime." Latin American Perspectives 36(3) (May 2009): 27-42.

Haynes, Jessica. "Help for All Parents?: Child-Rearing Advice in English Canada in the 1960s and 1970s." Histoire Sociale/Social History 44(87) (May 2011): 53-82.

Heidt, Daniel. "I think that would be the end of Canada:' Howard Green, the Nuclear Test Ban, and Interest-Based Foreign Policy, 1946-1963." American Review of Canadian Studies 42(3) (September 2012): 343-369.

Hensley, Melissa Anne. "Feminine Virtue and Feminist Fervor: The Impact of the Women's International League for Peace and Freedom in the 1930s." Affilia: Journal of Women and Social Work 21(2) (Summer 2006): 146-157.

Hewitt, Nancy A. "Feminist Frequencies: Regenerating the Wave Metaphor." Feminist Studies 38(3) (Fall 2012): 658-680.

Hewitt, Steve. Spying 101: The RCMP's Secret Activities at Canadian Universities, 1917-1997. Toronto: University of Toronto Press, 2002.

Hewitt, Steve. "Sunday Morning Subversion: The Canadian Security State and Organized Religion in the Cold War." In Love, Hate, and Fear in Canada's Cold War, edited by Richard Cavell. Toronto: University of Toronto Press, 2004.

High, Steven. Industrial Sunset: The Making of North America's Rust Belt, 1969-1984. Toronto: University of Toronto Press, 2003.

Hilliker, John and Donald Barry, "The PM and the SSEA in Canada's foreign policy: sharing the territory, 1946-1968." International Journal 50(1) (Winter 19941995): 163-188.

Hillmer, Norman and Adam Chapnick, eds. Canada's of the Mind: The Making and Unmaking of Canadian Nationalisms in the Twentieth Century. Montreal and Kingston: McGill-Queen's University Press, 2007.

Hunter, Jennifer. "Wondering if It's Even Worthwhile Doing the Dishes: Canadians and the Nuclear Threat, 1945-1963." PhD diss., McGill University, 2004. 
Huard, Victor. "The Canadian Peace Congress and the Challenge to Postwar Consensus, 1948-1953." Peace \& Change 19(1) (January 1994): 25-49.

Hynes, Samuel. A War Imagined: The First World War and English Culture. New York: Collier Books, 1990.

Iacovetta, Franca. Gatekeepers: Reshaping Immigrant Lives in Cold War Canada. Toronto: Between the Lines, 2006.

Igartua, José Eduardo. The Other Quiet Revolution: National Identities in English Canada, 1945-71. Vancouver: UBC Press, 2006.

Ignatieff, George, with Sonja Sinclair. The Making of a Peacemonger. Toronto: University of Toronto Press, 1985.

Iriye, Akira and Pierre-Yves Saunier, eds. The Palgrave Dictionary of Transnational History. Basingstoke; New York: Palgrave Macmillan, 2009.

Isitt, Benjamin. "Confronting the Cold War: The 1950 Vancouver Convention of the Cooperative Commonwealth Federation." The Canadian Historical Review 91(3) (September 2010): 465-501.

Isserman, Maurice. Review Resisting the Bomb: A History of the World Nuclear Disarmament Movement, 1954-1970 by Lawrence S. Wittner. Political Science Quarterly 114(3) (Autumn 1999): 527-528.

Jefferson, Tony. "Subordinating hegemonic masculinity." Theoretical Criminology 6(1) (2002): 63-88.

Jeffreys-Jones, Rhodri. Changing Differences: Women and the Shaping of American Foreign Policy 1917-1994. New Brunswick, New Jersey: Rutgers University Press, 1995.

Jobs, Richard Ivan. "Youth Movements: Travel, Protest, and Europe in 1968." The American Historical Review 114(2) (April 2009): 376-404.

Johnston, Timothy. "Peace or Pacifism? The Soviet 'Struggle for Peace in All the World,' 1948-54.” The Slavonic and East European Review 86(2) (April 2008): 259-282.

Katz, Milton. Ban the Bomb: A History of SANE, the Committee for a Sane Nuclear Policy, 1957-1985. Westport, Conn: Greenwood Press, 1986.

Kazin, Michael. “The Port Huron Statement at Fifty.” Dissent 59(2) (Spring 2012): 8389.

Kealey, Linda and Joan Sangster, eds. Beyond the Vote: Canadian Women and Politics. Toronto: University of Toronto Press, 1989.

Keck, Margaret E. and Kathryn Sikkink. Activists Beyond Borders: Advocacy Networks in International Politics. Ithaca, N.Y.: Cornell University Press, 1998.

Keck, Margaret E. and Kathryn Sikkink. "Transnational advocacy networks in international and regional politics.” International Social Science Journal 51(159) (March 1999): 89-101.

Kennedy, Thomas C. "Public Opinion and the Conscientious Objector, 1915-1919." The Journal of British Studies 12(2) (May 1973): 105-119.

Kerans, Marion Douglas. Muriel Duckworth: A Very Active Pacifist, A Biography. Halifax: Fernwood, 1996.

Kimmel, Michael. Angry White Men: American Masculinity at the End of an Era. New York: Nation Books, 2013.

Kimmel, Michael. Manhood in America: A Cultural History. New York and Oxford: 
Oxford University Press, 2012.

Kinsman, Gary and Patrizia Gentile. The Canadian War on Queers: National Security as Sexual Regulation. Vancouver: UBC Press, 2010.

Kollhoj, Jens Petter. "Socialist Antimilitarist Manliness: Visual Representations and Normativity in Norway Circa 1914." Peace \& Change 34(2) (April 2009): 208231.

Korinek, Valerie. Roughing it in the Suburbs: Reading Chatelaine Magazine in the Fifties and Sixties. Toronto: University of Toronto Press, 2000.

Kostash, Myrna. Long Way from Home: The Story of the Sixties Generation in Canada. Toronto: J. Lorimer, 1980.

Kurlansky, Mark. "Preface." In Gandhi on Non-Violence, edited by Thomas Merton. New York: New Directions Publishing Corporation, 2007.

Laughlin, Kathleen A., Julie Gallagher, Dorothy Sue Cobble, Eileen Boris, Premilla Nadasen, Stephanie Gilmore and Leandra Zarnow. "Is It Time to Jump Ship? Historians Rethink the Waves Metaphor." Feminist Formations 22(1) (Spring 2010): 76-135.

Laville, Helen. “The Memorial Day Statement: Women's Organizations in the 'Peace Offensive."” Intelligence and National Security 18(2) (June 2003): 192-210.

Lee, Christopher J. "At the Redezvous of Decolonization: the Final Communiqué of the Asian-African Conference, Bandung, Indonesia, 18-24 April 1955.” Interventions 11(1) (March 2009): 81-93.

Lee-Koo, Katrina. "Not suitable for children: the politicization of conflict-affected children in post-2001 Afghanistan." Australian Journal of International Affairs 67(4) (2013): 475-490.

Leeming, Mark. "The Creation of Radicalism: Anti-Nuclear Activism in Nova Scotia, c. 1972-1979." The Canadian Historical Review 95(2) (June 2014): 217-241.

Legault, Albert and Michel Fortmann. A Diplomacy of Hope: Canada and Disarmament, 1945-1988. Montreal: McGill-Queen's University Press, 1992.

Lentner, Howard H. "Foreign Policy Decision Making: The Case of Canada and Nuclear Weapons." World Politics 29(1) (Oct. 1976): 29-66.

Lévesque, Andrée. "Anniversaires et manifestations des camarades: la culture international et l'identitaire communists au Canada pendant l'entre-deux-guerres." Labour/Le Travail 49 (Spring 2002): 83-92.

Levitt, Cyril. Children of Privilege: Student Revolt in the Sixties. Toronto: University of Toronto Press, 1984.

Lexier, Roberta. “'The Backdrop Against Which Everything Happened:' EnglishCanadian Student Movements and Off-Campus Movements for Change." History of Intellectual Culture 7(1) (2007): 1-18.

Lieberman, Robbie. The Strangest Dream: Communism, Anticommunism, and the U.S. Peace Movement, 1945-1963. Syracuse: Syracuse University Press, 2000.

Loewen, Candace. "Mike Hears Voices: Voice of Women and Lester Pearson, 19601963." Atlantis 12(2) (Spring 1987): 24-30.

Lowe, Mick. One Woman Army: The Life of Claire Culhane. Toronto: Macmillan Canada, 1992.

Lowen, Rebecca. Review Resisting the Bomb: A History of the World Nuclear Disarmament Movement, 1954-1970 by Lawrence Wittner. Pacific Historical 
Review 69(1) (Feb. 2000): 139-140.

Lutts, Ralph H. "Chemical Fallout: Rachel Carson's Silent Spring, Radioactive Fallout and the Environmental Movement." Environmental Review 9(3) (Autumn 1985): 210-225.

Luxton, Meg. "Feminism as a Class Act: Working-Class Feminism and the Women's Movement in Canada." Labour/Le Travail 48 (Fall 2001): 63-88.

Luxton, Meg, ed. Feminism and Families: Critical Policies and Changing Practices. Halifax: Fernwood Publishing, 1997.

Macfarlane, Daniel. "Courting War over a Rubber Stamp: Canada and the 1961 Berlin Wall Crisis," International Journal 63(3) (Summer 2008): 751-768.

Macpherson, Kay. "Persistent Voices: Twenty-Five Years with the Voice of Women." Atlantis 12(2) (Spring 1987): 60-72.

Maloney, Sean M. Canada and UN Peacekeeping: Cold War by Other Means, $1945-$ 1970. St. Catherines: Vanwell Publishing Limited, 2002.

Maloney, Sean M. Learning to Love the Bomb: Canada's Nuclear Weapons During the Cold War. Washington: Potomac Books, 2007.

Mann, Robert. "Daisy Petals and Mushroom Clouds." Campaign \& Elections 32(8) (Sept/Oct 2011): 29-35.

Marion, Nicole. "'I would rather be right:' Diefenbaker and Canadian Disarmament Movements." In Reassessing the Rogue Tory and His Times: New Perspectives on the Diefenbaker Era in Canadian Foreign Relations, edited by Janice Cavell and Ryan Touhey. Vancouver: University of British Columbia Press, forthcoming.

Marshall, Dominique. "Humanitarian Sympathy for Children in Times of War and the History of Children's Rights, 1919-1959." In Children and War: A Historical Anthology, edited by James Alan Marten. New York: New York University Press, 2002.

Marshall, Dominique. "The Cold War, Canada, and the United Nations Declaration of the Rights of the Child." In Canada and the Early Cold War 1943-1957, edited by Greg Donaghy, Ottawa: Department of Foreign Affairs and International Trade, 1998.

Marshall, Dominique. "The Construction of Children as an Object of International Relations: The Declaration of Children's Rights and the Child Welfare Committee of the League of Nations, 1900-1924." International Journal of Children's Rights 7 (1999): 103-147.

Martel, Marcel. "'They smell bad, have diseases, and are lazy': RCMP Officers Reporting on Hippies in the Late Sixties.” The Canadian Historical Review 90 (2) (June 2009): 215-245.

Matheson, Gwen, ed. Women in the Canadian Mosaic. Toronto: Peter Marlin Associates, 1976.

May, Elaine Tyler. Homeward Bound: American Families in the Cold War Era. New York: Basic Books, Inc., Publishers, 1988.

McCrea, Frances B. and Gerald E. Markle. Minutes to Midnight: Nuclear Weapons Protest in America. Newbury, Ca.: Sage Publications, 1989.

McDonough, David. "Nuclear Superiority or Mutually Assured Deterrence: The Development of the US Nuclear Deterrent." International Journal 60(3) (Summer 2005): 811-823. 
McKay, Ian. Rebels, Reds, Radicals: Rethinking Canada's Left History. Toronto: Between the Lines, 2005.

McKay, Ian and Jamie Swift. Warrior Nation: Rebranding Canada in an Age of Anxiety. Toronto: Between the Lines, 2012.

McKercher, Asa. "Diefenbaker's World: One Canada and the History of CanadianAmerican Relations, 1961-63." The Historian 75(1) (2013): 94-120.

McKillen, Elizabeth. "Pacifist Brawn and Silk-Stocking Militarism: Labor, Gender, and Antiwar Politics, 1914-1918." Peace \& Change 33(3) (July 2008): 388-425.

McMahon, Patricia. Essence of Indecision: Diefenbaker's Nuclear Policy, 1957-1963. Montreal: McGill-Queen's University Press, 2009.

Mehan, Hugh and John Wills. "Mend: A Nurturing Voice in the Nuclear Arms Debate." Social Problems 35(4) (Oct. 1988): 363-383.

Metta, Spencer. Review of Our Generation Against Nuclear War by Dimitrios Roussopoulos. The Canadian Journal of Sociology 10(3) (Summer 1985): 350.

Meyer, David S. Review Toward Nuclear Abolition: A History of the World Nuclear Disarmament Movement, 1971 to the Present by Lawrence S. Wittner. Political Science Quarterly 119(4) (Winter 2004/2005): 711-713.

Meyer, David S. and Debra C. Minkoff. "Conceptualizing Political Opportunity." Social Forces 82(4) (June 2004): 1457-1492.

Meyerowitz, Joanne. "Introduction: Women and Gender in Postwar America, 19451960." In Not June Cleaver: Women and Gender in Postwar America, 1945-1960, edited by Meyerowitz, Joanne. Philadelphia: Temple University Press, 1994.

Miller, James. Democracy is in the Streets: From Port Huron to the Siege of Chicago. Cambridge, Mass.: Harvard University Press, 2004.

Milligan, Ian. Rebel Youth: 1960s Labour Unrest, Young Workers, and New Leftists in English Canada. Vancouver: UBC Press, 2014.

Mills, Sean. The Empire Within: Postcolonial Thought and Political Activism in Sixties Montreal. Montreal: McGill-Queen's University Press, 2010.

Minow, Martha and Richard Weissbourd. "Social Movements for Children." Daedalus 122(1) (Winter 1993): 1-29.

Moffatt, Gary. History of the Peace Movement in Canada. Ottawa, ON: Grapevine Press, 1982.

Monet-Chartrand, Simonne. Les Québécoises et le mouvement pacifiste (1939-1967). Montreal: Les Éditions Écosociété, 1993.

Moynagh, Maureen. "Human Rights, Child-Soldier Narratives, and the Problem of Form." Research in African Literatures 42(4) (Winter 2011): 39-59.

Munton, Don. "Going Fission: Tales and Truths about Canada's Nuclear Weapons." International Journal 51(3) (Summer 1996): 506-528.

Myers, Frank E. "Civil Disobedience and Organizational Change: The British Committee of 100." Political Science Quarterly 86(1) (Mar. 1971): 92-112.

Navari, Cornelia. Internationalism and the state in the twentieth century. London: Routledge, 2000.

Nehring, Holger. "National Internationalists: British and West German Protests against Nuclear Weapons, the Politics of Transnational Communications and the Social History of the Cold War, 1957-1964." Contemporary European History 14(4) (2005): 559-582. 
Nehring, Holger. Politics of Security: British and West German Protest Movements and the Early Cold War, 1945-1970. Oxford: Oxford University Press, 2013.

Newman, Peter C. Renegade in Power: The Diefenbaker Years. Toronto: McClelland and Stewart Limited, 1973.

Nicholson, Patrick. Vision and Indecision. Don Mills, Ontario: Longmans Canada Limited, 1968.

O'Sullivan, Kevin. "Humanitarian encounters: Biafra, NGOs and imaginings of the Third World in Britain and Ireland, 1967-70." Journal of Genocide Research 16(2-3) (2014): 1-14.

Owram, Doug. Born at the Right Time: A History of the Baby Boom Generation. Toronto: University of Toronto Press, 1996.

Palaeologu, M. Athena, ed. The Sixties in Canada: A Turbulent and Creative Decade. Montreal: Black Rose Books, 2009.

Palmer, Bryan. Canada's 1960s: The Ironies of Identity in a Rebellious Era. Toronto: University of Toronto Press, 2009.

Parr, Joy, ed. A Diversity of Women: Ontario 1945-80. Toronto: Toronto University Press, 1995.

Paterson, Thomas G., ed. Kennedy's Quest for Victory: American Foreign Policy, 1961 1963. Oxford: Oxford University Press, 1989.

Patterson, David S. "The Emergence of Peace History." Reviews in American History 23(1) (March 1995): 129-136.

Perkins, Ray, Jr. "Introduction." In Yours Faithfully, Bertrand Russell: A Lifelong Fight for Peace, Justice and Truth in Letters to the Editor, by Bertrand Russell, edited by Ray Perkins Jr. Chicago: Open Court, 2002.

Pierson, Ruth Roach, with Joanne Thompson, Somer Brodribb and Paula Bourne, eds. Women and Peace: Theoretical, Historical and Practical Perspectives. London, New York: Croom Helm, 1987.

Portelli, Alessandro. "The Peculiarities of Oral History." History Workshop 12 (Autumn 1981): 96-107.

Powaski, Ronald E. Review The Struggle Against the Bomb, Volume 3, A History of the World Disarmament Movement, 1971 to the Present by Lawrence S. Wittner. The American Historical Review 109(4) (October 2004): 1206-1207.

Preble, Christopher A. "'Who Ever Believed in the 'Missile Gap'?': John F. Kennedy and the Politics of National Security." Presidential Studies Quarterly 33(4) (December 2003): 801-826.

Richter, Andrew. Avoiding Armageddon: Canadian Military Strategy and Nuclear Weapons, 1950-63. Vancouver: UBC Press, 2002.

Roberts, Geoffrey. The Soviet Union in World Politics: Coexistence, Revolution and Cold War, 1945-1991. London: Routledge, 1999.

Robinson, H. Basil. Diefenbaker's World: A Populist in Foreign Affairs. Toronto: University of Toronto Press, 1989.

Rootes, Christopher. "Global Visions: Global Civil Society and the Lessons of European Environmentalism." Voluntas: International Journal of Voluntary and Nonprofit Organizations 13(4) (Dec. 2002): 411-429.

Rosenberg, David Alan. "The Origins of Overkill: Nuclear Weapons and American Strategy, 1945-1960.” International Security 7(4) (Spring 1983): 3-71. 
Rosenberg, Emily S. "Rescuing Women and Children." The Journal of American History 89(2) (September 2002): 4456-465.

Ross, Becki. Burlesque West: Showgirls, Sex, and Sin in Postwar Vancouver. Toronto:

University of Toronto Press, 2009.

Roussopoulos, Dimitrios, ed. Our Generation Against Nuclear War. Montreal: Black Rose Books, 1996.

Roussopoulos, Dimitrios, ed. The New Left: Legacy and Continuity. Montreal; Black Rose Books, 2007.

Roussopoulos, Dimitrios J., ed. The New Left in Canada. Montreal: Our Generation Press-Black Rose Books, 1970.

Ruddick, Sara. "Thinking about Mothering and Putting Maternal Thinking to Use." Women's Studies Quarterly 11(4) (Winter 1983): 1-19.

Sale, Kirkpatrick. SDS (Students for a Democratic Society). New York: Vintage, 1974.

Sangster, Joan. "Radical Ruptures: Feminism, Labor, and the Left in the Long Sixties in Canada." American Review of Canadian Studies 40(1) (March 2010): 1-21.

Sasikumar, Karthika. "Documenting Disarmament," review Confronting the Bomb: A Short History of the World Nuclear Disarmament Movement by Lawrence S. Wittner. Peace and Conflict 17 (2011): 104-106.

Scott, Joan Wallach, ed. Feminism \& History. Oxford: Oxford University Press, 1996.

Shaw, Amy J. Crisis of Conscience: Conscientious Objection in Canada During the First World War. Vancouver: UBC Press, 2009.

Shimazu, Naoko. "Diplomacy as Theatre: Staging the Bandung Conference of 1955." Modern Asian Studies 48(1) (January 2014): 225-252.

Shragge, Eric, Ronald Babin and Jean-Guy Vaillancourt, eds. Roots of Peace: The Movement Against Militarism in Canada. Toronto: Between the Lines, 1986.

Simpson, Erika. NATO and the Bomb: Canadian Defenders Confront Critics. Montreal: McGill-Queen's University Press, 2001.

Skolnick, Arlene S. Embattled Paradise: The American Family in an Age of Uncertainty. New York: Basic Books, 1993.

Smith, Denis. Rogue Tory: The Life and Legend of John G. Diefenbaker. Toronto: Macfarlane Walter \& Ross, 1995.

Socknat, Thomas. "Conscientious Objectors in the Context of Canadian Peace Movements." Journal of Mennonite Studies 25 (2007): 61-74.

Socknat, Thomas P. Witness against War: Pacifism in Canada, 1900-1945. Toronto: University of Toronto Press, 1987.

Spittal, Cara. "The Diefenbaker Moment." PhD diss., University of Toronto, 2011.

Squires, Jessica. Building Sanctuary: The Movement to Support Vietnam War Resisters in Canada, 1965-73. Vancouver: UBC Press, 2013.

Stevenson, Michael D. "'Tossing a Match into Dry Hay:' Nuclear Weapons and the Crisis in U.S.-Canadian Relations, 1962-1963." Journal of Cold War Studies 16(4) (Fall 2014): 5-34.

Stewart-Winter, Timothy. "Not a Soldier, Not a Slacker: Conscientious Objectors and Male Citizenship in the United States during the Second World War." Gender \& History 19(3) (November 2007): 519-542.

Story, Donald C. Review of One Canada: Memoirs of the Right Honourable John G. 
Diefenbaker: The Crusading Years, 1875-1956, eds. John H. Archer and John A. Munro. Canadian Journal of Political Science/Revue canadienne de science politique 1(1) (March 1977): 181-182.

Story, Donald C. and R. Bruce Shepard, eds. The Diefenbaker Legacy: Canadian Politics, Law and Society Since 1957. Regina: Canadian Plains Research Center, 1998.

Sturken, Marita and Lisa Cartwright. Practices of Looking: An Introduction to Visual Culture. Oxford: Oxford University Press, 2001.

Suri, Jeremi. Power and Protest: Global Revolution and the Rise of Détente. Cambridge, Massachusetts: Harvard University Press, 2003.

Sussman, Herbert. Masculine Identities: The History and Meanings of Manliness. Santa Barbara, California: Praeger, 2012.

Swerdlow, Amy. "Ladies' Day at the Capitol: Women Strike for Peace versus HUAC." Feminist Studies 8(3) (Autumn 1982): 493-520.

Swerdlow, Amy. Women Strike for Peace: Traditional Motherhood and Radical Politics in the 1960s. Chicago and London: The University of Chicago Press, 1993.

Tarrow, Sidney. Power in Movement: Social Movements, Collective Action and Politics. Cambridge: Cambridge University Press, 1994.

Teigrob, Robert. Warming up to the Cold War: Canada and the United States' Coalition of the Willing, from Hiroshima to Korea. Toronto: University of Toronto Press, 2009.

Thompson, Becky. "Multiracial Feminism: Recasting the Chronology of Second Wave Feminism." Feminist Studies 28(2) (Summer 2002): 336-360.

Thorn, Brian T. From Left to Right: Maternalism and Women's Political Activism in Postwar Canada. Vancouver: UBC Press, 2016. Kindle edition.

Thörn, Håkan. Anti-Apartheid and the Emergence of a Global Civil Society. Basingstoke: Palgrave Macmillan, 2009.

Timmermans, Stefan and Valerie Leiter. "The Redemption of Thalidomide: Standardizing the Risk of Birth Defects." Social Studies of Science 30(1) (February 2000): 41-71.

Tyrell, Ian. "American Exceptionalism in an Age of International History." The American Historical Review 96(4) (Oct. 1991): 1031-1055.

Wang, Dan J. and Sarah A. Soule. "Social Movement Organizational Collaboration: Networks of Learning and the Diffusion of Protest Tactics, 1960-1995." American Journal of Sociology 117(6) (May 2012): 1674-1722.

Webb, Jean F. "Canadian Thalidomide Experience." Canadian Medical Association Journal 89(19) (9 November 1963): 987-992.

Weisbord, Merrily. The Strangest Dream: Canadian Communists, the Spy Trials, and the Cold War. Montreal: Véhicule Press, 1994.

Wendell, Susan. "A (Qualified) Defense of Liberal Feminism." Hypatia 2(2) (Summer 1987): 65-93.

Wernicke, Günter. "The Communist-Led World Peace Council and the Western Peace Movements: The Fetters of Bipolarity and Some Attempts to Break Them in the Fifties and Early Sixties." Peace \& Change 23(3) (July 1998): 265-311.

Wernicke, Günter. "The Unity of Peace and Socialism? The World Peace Council on a 
Cold War Tightrope Between the Peace Struggle and Intrasystemic Communist Conflicts." Peace \& Change 26(3) (July 2001): 332-351.

Whitaker, Reg and Gary Marcuse. Cold War Canada: The Making of a National Insecurity State, 1945-1957. Toronto: University of Toronto Press, 1994.

Whitaker, Reg, Gregory S. Kealey and Andrew Parnaby. Secret Service: Political Policing in Canada from the Fenians to Fortress America. Toronto: University of Toronto Press: 2012.

Whitney, Susan B. Mobilizing Youth: Communists and Catholics in Interwar France. Durham and London: Duke University Press, 2009.

Winkler, Allan M. Life Under a Cloud: American Anxiety About the Atom. New York: Oxford University Press, 1993.

Wittner, Lawrence S. "Combining Work as an Historian and Activist: A Personal Account." Peace \& Change 32(2) (April 2007): 128-133.

Wittner, Lawrence S. "Gender Roles and Nuclear Disarmament Activism, 1954-1965." Gender and History 12(1) (April 2000): 197-222.

Wittner, Lawrence S. Rebels Against War: The American Peace Movement, 1933-1983. Philadelphia: Temple University Press, 1984.

Wittner, Lawrence S. The Struggle Against the Bomb, vol. 1. Stanford: Stanford University Press, 1993.

Wittner, Lawrence S. The Struggle Against the Bomb, vol. 2. Stanford: Stanford University Press, 1997.

Young, Nigel. "The Peace Movement: A Comparative and Analytical Survey." Alternatives XI (1986): 185-217.

Ziemann, Benjamin. "The Code of Protest: Images of Peace in the West German Peace Movements, 1945-1990." Contemporary European History 17(2) (May 2008): 237-261. 


\section{Appendix}

\section{Ethics Clearance Form}

\section{Carleton \\ Canada's Capital University}

Carleton University Research Ethics Office Research Ethics Board

511 Tory, 1125 Colonel By Drive Ottawa, ON K1S 5B6 Canada Tel: 613-520-2517, ethics@carleton.ca

\section{Ethics Clearance Form - Clearance Renewal}

This is to certify that the Carleton University Research Ethics Board has examined the application for ethical clearance. The REB found the research project to meet appropriate ethical standards as outlined in the Tri-Council Policy Statement: Ethical Conduct for Research Involving Human, 2nd edition, and the Carleton University Policies and Procedures for the Ethical Conduct of Research.

Original Date of Clearance: June 26, 2013

Renewal Date of Clearance: May 01, 2015

Researcher: Nicole Marion (Student Research: Ph.D. Student)

Department: Faculty of Arts and Social ScienceslHistory (Department of)

University: Carleton University

Research Supervisor (if applicable): Norman Hillmer

Project Number: 13371

Alternate File Number (if applicable): 14-0262

Project Title: Banning the Bomb: Canadian Anti-Nuclear Activism, 1957-1963 (working title)

Funder (if applicable):

Clearance Expires: May 31, 2016

\section{All researchers are governed by the following conditions:}

Annual Status Report: You are required to submit an Annual Status Report to either renew clearance or close the file. Failure to submit the Annual Status Report will result in the immediate suspension of the project. Funded projects will have accounts suspended until the report is submitted and approved.

Changes to the project: Any changes to the project must be submitted to the Carleton University Research Ethics Board for approval. All changes must be approved prior to the continuance of the research.

Adverse events: Should a participant suffer adversely from their participation in the project you are required to report the matter to the Carleton University Research Ethics Board. You must submit a written record of the event and indicate what steps you have taken to resolve the situation.

Suspension or termination of clearance: Failure to conduct the research in accordance with the principles of the Tri-Council Policy Statement: Ethical Conduct for Research Involving Humans, 2nd edition and the Carleton University Policies and Procedures for the Ethical Conduct of Research may result in the suspension or termination of the research project.

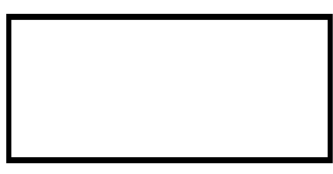

Louise Heslop

Chair, Carleton University Research Ethics Board

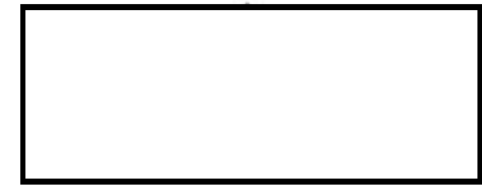

Andy Adler

Vice-Chair, Carleton University Research Ethics Board 